\title{
Regional Forest Governance
}

\author{
Forstliche Potentiale und politische Kräfte \\ in der integrierten ländlichen Entwicklung
}

r.t. orstuirtschaft in kanmar. desantcoxicrten Ansatzas daralt hin, dass no nicht systematisch analysiert welche $\mathrm{f}$ für welche orstak elineser Nutzen realisierbar welche politischen Kräfte die integriente mulising auf übergeordneten politischen Ebenen als auch iminitiative "WAD "Sowie das Bundesmodellvorhaben " betrachtet, Regelförde rertentändicheirs "Agrarstruktur und Küstenschutz" (GAK) und ,regionale Wirtschaftsstruktur" ( ) ), sowie die zwei und der "Europäische Landwirtschaftsfonds für die Entwicklung des ländlichen Rau seil der Programmdokumente, Exper waskionen in

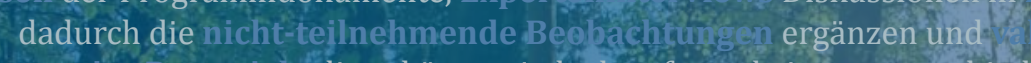
Timovat fue Potentiale diese können jedoch aufgrund eines unterschiedlichen te und analysierte Ressourcen sowie unterschiedlicher Gover fance-Proy durch den Regional Governance-Ansatz erlangen stagulitgé
und Formulierung von Programmen auf zentraler Ebene als auch deren

Inter stehs skaini onen geprägt kann der Regional Governance-Ansatz leicht durch whentalis: wurden und deren ins ektoren tragen zur Hemmung des intersektoralen Ansatzes bei unter die Rathmentedg gungen der sektoralen Formulierung bei der zunehmender sich voraussichtlich auch auf regionaler Ebene Regional Governance beinhaltet deren Jegistenz gegen die Integration und den E. als auch in der tonse yang der Programme mindern daher die Governance Bund innovatigje ermöglicht, die sowohl für die individuelle

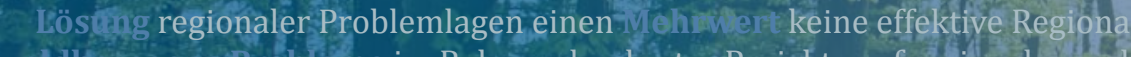

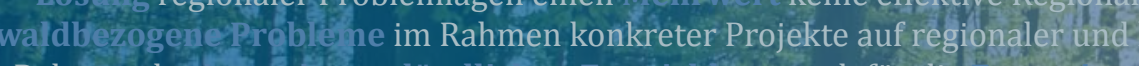

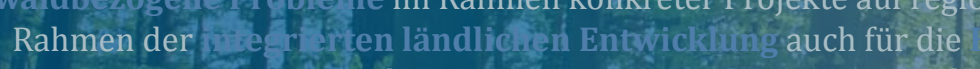
partizipativen Steuerungskonzept einer loutet die Ansatzes darauf hin, dass hier polfosche k älu wirken, die in der Regional Governance nicht vona die erhobenen Dater nimmt mana ußerdên Sekum därdatenahalysen Potentiale eine Kooperation im Rahmen der integrierten ländlichêr
sierbar welche politischen Kräfte die integrierte sierbar welche politischen Kräfte die integrierte
Ebenen als auch im regoll vorhaben "Regionein Alstiv" betrachtet. Regelförderung werden die gionale Wirtschaftsstruktur" (CLW), sowie die zwei wichtigsten EU-Strukturfonds ( die Entwicklung des ländlichen Raums" (EIDR) analysiert und ausführliche

Diskussionen in Folsgrupp nimmt man außerdem ergänzen und valiodieren die erhobenen Daten die Forstwirtschaft eines unterschiedlichen Informatio s nol zu den Programmen bestehende licher Anreivwirtungen nicht von allen Forstakteuren gleichermaßen realisiert Regionale mit demoliratisch legitimierten Government-Institutionen und -Akteuren in staatliche Akteure höherer politischer Ebenen Einfluss auf regionaler Ebene und Ebene als auch deren regionale Uimscizuig stark vom Interesse der Initiatoren und deren

Governance-Ansatz leicht durch starke Aliteure und deren Interessenskoalitionen Anspruch der Förderprogramme wird nicht durchgängig erfüllt und daher adressierten Ansatzes bei sektorübergreifende Integration somit lediglich im regionalen Vollzug und unter die Formulierung bei der zunehmender Professionalis eswing und Institutionalisierung werden sich voraussichtlich auch auf reg integ xationshemmende Bedingungen einstellen so birgt die derzeitige politische Ebenen und starke Akteure die Machtstrategie der adressierten der Regional Governance beinhaltet deren

twurden und deren instersektor tragen zur Hemmung des intersektora und den Erhalt sektoraler Politikinstrumente werden Blockadct sowohl in der Formulierung als auch in der

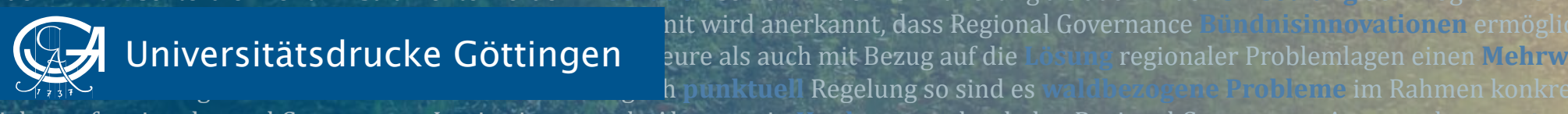





\section{Lukas Giessen \\ Regional Forest Governance}

This work is licensed under the Creative Commons License 3.0 "by-nd", allowing you to download, distribute and print the document in a few copies for private or educational use, given that the document stays unchanged and the creator is mentioned. You are not allowed to sell copies of the free version. 
erschienen in der Reihe der Universitätsdrucke

im Universitätsverlag Göttingen 2010 
Lukas Giessen

\section{Regional Forest Governance}

Forstliche Potentiale

und politische Kräfte

in der integrierten ländlichen Entwicklung

Potentials for forestry

and political drivers in integrated

rural development policy

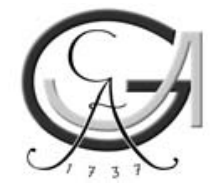

Universitätsverlag Göttingen

2010 


\section{Bibliographische Information der Deutschen Nationalbibliothek}

Die Deutsche Nationalbibliothek verzeichnet diese Publikation in der Deutschen Nationalbibliographie; detaillierte bibliographische Daten sind im Internet über <http://dnb.ddb.de> abrufbar

Global Forest Decimal Classification: GFDC 901, 903

\section{Anschrift des Autors}

Lukas Giessen

e-mail: lgiesse@uni-goettingen.de

Lukas Giessen

Georg-August-Universität Göttingen

Professur für Forst und Naturschutzpolitik

Büsgenweg 3

37077 Göttingen / Germany

Kumulative Dissertation zur Erlangung des akademischen Grades Doctor of Philosophy (PhD) der Fakultät für Forstwissenschaften und Waldökologie der Georg-August-Universität Göttingen.

1. Gutachterin / 1. Gutachter: Prof. Dr. Max Krott

2. Gutachterin / 2. Gutachter: Prof. Dr. Renate Bürger-Arndt

3. Gutachterin / 3. Gutachter: Prof. Dr. Norbert Weber

Tag der mündlichen Prüfung: 27.11.2009

Dieses Buch ist auch als freie Onlineversion über die Homepage des Verlags sowie über den OPAC der Niedersächsischen Staats- und Universitätsbibliothek (http://www.sub.uni-goettingen.de) erreichbar und darf gelesen, heruntergeladen sowie als Privatkopie ausgedruckt werden Es gelten die Lizenzbestimmungen der Onlineversion. Es ist nicht gestattet, Kopien oder gedruckte Fassungen der freien Onlineversion zu veräußern.

Satz und Layout: Lena Runge Umschlaggestaltung: Margo Bargheer

(C) 2010 Universitätsverlag Göttingen http:/ / univerlag.uni-goettingen.de ISBN: 978-3-941875-73-9 


\section{Dank}

Ich möchte Herrn Prof. Dr. Max Krott danken, der mir mit seinen Arbeitsweisen geholfen hat, den Blick für Wesentliches zu schärfen. Die vielfältigen Möglichkeiten zur selbständigen wissenschaftlichen Arbeit boten auch den nötigen Raum zur geistigen Reifung. Dies war sehr hilfreich, um die Dissertation zum Abschluss zu bringen.

Bei Frau Prof. Dr. Renate Bürger-Arndt bedanke ich mich, dass sie trotz angespannten Terminplans Zeit für das Zweitgutachten fand. Herrn Prof. Dr. Norbert Weber sei hier ebenfalls für sein Gutachten gedankt. Für ihre finanzielle Unterstützung möchte ich mich zudem bei der Eva Mayr-Stihl Stiftung bedanken.

Auf meinem Weg gab es zwei Personen, ohne die ich mich vermutlich nicht „getraut“ hätte, zu promovieren. Meinen Mentoren Herrn Prof. Dr. Volker Dubbel und Prof. Dr. Uwe Meierjürgen von der Fachhochschule für angewandte Wissenschaft und Kunst in Göttingen danke ich, dass sie meinen eher theoretischen Erkenntnisdurst besonders auf dem Gebiet der Forstpolitikforschung gefördert haben.

Meinen Kollegen an der Professur für Forst- und Naturschutzpolitik danke ich für eine sehr positive Arbeitsatmosphäre und gute fachliche Diskussionen. Besonders möchte ich mich bei der „Arbeitsgruppe Böcher" bedanken: Sebastian Tränkner danke ich für die ausgiebigen inhaltlichen Beiträge und guten Diskussionen auch in schwierigen Zeiten. Dr. Michael Böcher möchte ich danken für unzählige Anregungen und die gute Einführung in den „Betrieb Wissenschaft“.

Mein besonderer Dank gilt meiner Familie. Allen Mitgliedern mütterlicherseits danke ich, dass sie mich zeitlebens bestärkt haben, meinen Weg zu finden und zu gehen. Väterlicherseits danke ich meiner Familie, dass sie mir den Wert von Bildung vermittelte sowie das Verständnis, dass Aus-bildung auch Aus-dauer braucht. Maren bin ich sehr dankbar für ihre Geduld und Flexibilität. Sie hat mir den Rücken frei gehalten und mich in schwierigen Momenten gestärkt. Für ihre Flexibilität und Geduld bin ich auch meinen Kindern Tjebbe und Jonna sehr dankbar, die sich in der Endphase meiner Promotion schon auf Tjelve freuten. Euch dreien widme ich diese Arbeit. 



\section{Inhaltsverzeichnis}

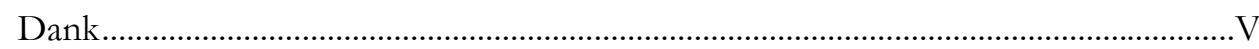

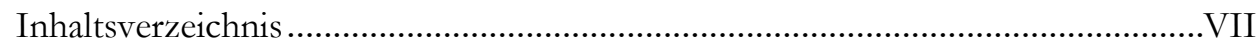

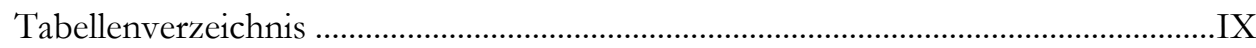

1. Einleitung: Themenrahmen, Fragestellung und konstituierende Publikationen .... 1

2. Theoretischer Bezugstahmen ................................................................................ 3

2.1 Regionalisierung und Regional Governance ........................................ 3

2.2 Der Forschungsstand zu Regional Forest Governance ........................ 5

3. Auswahl der Fallstudien und empirische Methoden.................................................... 7

3.1 Qualitatives Forschungsdesign........................................................... 7

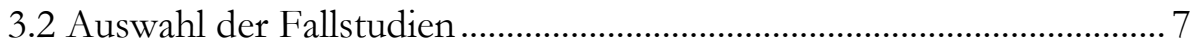

3.3 Qualitativer Methodenmix ..................................................................... 8

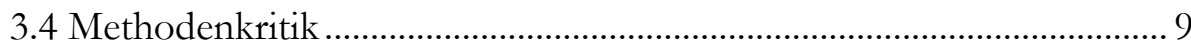

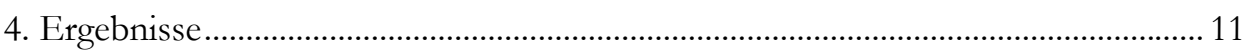

4.1 Regional Governance-Potentiale für die Forstwirtschaft.....................11

4.1.1 Konventionelle und innovative Potentiale für Forstakteure.................... 11

4.1.2 Unterschiedliche Informationen, Anreize und Kapazitäten der

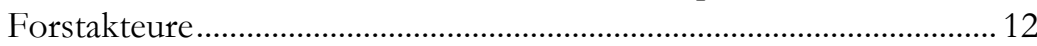

4.2 Politische Kräfte innerhalb der Regional Governance ..........................14

4.2.1 Konkurrenz zwischen Regional Governance und demokratischen Institutionen ................................................................. 14

4.2.2 Umgehung formal legitimierter politischer Ebenen ................................. 15

4.2.3 Interessengeleitete Regional Governance-Prozesse .................................15

4.2.4 Anfälligkeit von Regional Governance gegenüber starken Interessen .. 15

4.2.5 Sektoraler Bias integrierter Regional Governance-Programme............... 16

4.2.6 Sektorale Resistenz gegen Integrationsversuche durch Regional Governance........................................................................... 16

4.2.7 Integration der Sektoren nicht in der Regelförderung .............................. 17

4.2.8 Sektorübergreifende Integration nur im Vollzug auf regionaler Ebene 17

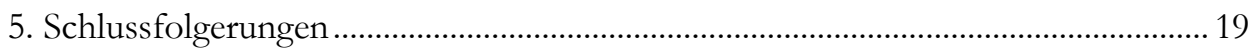

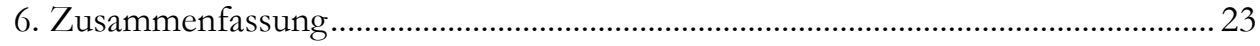

7. Summary: Regional Forest Governance - Potentials for forestry and political

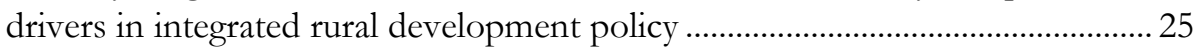

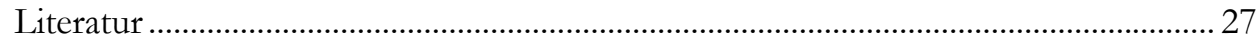

Anhang: Konstituierende Publikationen / Annex: Constitutive publications ........... 35 


\section{Konstituierende Publikationen / Constitutive publications}

1. Giessen, L. (2009): Regional governance in rural development programmes - Which Role for Forestry?. In: Folia Forestalia Polonica, series A, 51 (1), 54-60.

2. Giessen, L. (2010): Regional Governance für ländliche Räume - innovativer Ansatz, politischer Gegenwind und der Weg vorwärts. In: Raumforscbung und Raumordnung, 68 (1), 3-14.

3. Giessen, L. (2008): Die Zurückhaltung der Forstwirtschaft in der integrierten ländlichen Entwicklung - Analyse der politischen Ursachen. In: Forstarchiv, 79 (3), 116-121.

4. Giessen, L. und Böcher, M. (2009): Rural Governance, forestry, and the promotion of local knowledge: The case of the German rural development programme 'Active Regions'. In: Small Scale Forestry, 8 (2), 211-230.

5. Giessen, L. und Böcher, M. (2008): Integrated Rural Development Policy in Germany and its Potentials for new Modes of Forest Governance. Institut für Wald-, Umwelt- und Ressourcenpolitik, Wien, $114 \mathrm{~S}$.

6. Giessen, L.; Böcher, M.; Ortner, M. und Tränkner, S. (2006): Integrated Rural Development as pathway for innovations - an unexploited potential for forestry -. In: Tikkanen, I.; Zyrina, O.; Rametsteiner, E.; Barreiro, O. und Michalak, R.(Hrg.): Policies Fostering Investments and Innovations in Support of Rural Development. MCPFE, Warschau, 38-56.

7. Giessen, L. und Krott, M. (2009): Forestry Joining Integrated Programmes? A question of willingness, ability and opportunities. In: Algemeine Forst-u. Jagdzeitung, 180 (5-6), 94-100.

8. Giessen, L.; Lukesch, R.; Böcher, M. und Elbe, S. (2008): Politikintegration für ländliche Räume? Die (Nicht-) Koordination der Förderung. In: Elbe, S (Hrg.): Land-Stadt Kooperation und Politikintegration für ländliche Räume. Shaker, Aachen, 57-120. 


\section{Tabellenverzeichnis}

Tabelle 1: Fallstudien zu Potentialen der Forstwirtschaft und Beteiligungsdeterminanten in Förderprogrammen zur integrierten ländlichen Entwicklung getrennt nach temporären Pilot- und Mainstreamprogrammen sowie Ebene der Programmanbieter.

Tabelle 2: Konventionelle und innovative forstliche Potentiale der integrierten ländlichen Entwicklung... 



\section{Einleitung: Themenrahmen, Fragestellung und konstituierende Publikationen}

Im Politikfeld der integrierten ländlichen Entwicklung (ILE) liegen normative Vorstellungen über Regional Governance ${ }^{1}$ und deren tatsächliche empirische Ausprägungen in der Praxis weit auseinander (Böcher 2008, Böcher, Krott und Tränkner 2008). Daher fordern u.a. Böcher $(2008,2006)$ und Pütz (2004) mehr kritische Analysen von Regional-Governance-Phänomenen in verschiedenen Anwendungsfeldern. Regional Governance ist ein partizipativer, gebietsbezogener Politik- und Planungsansatz, der in der Regionalentwicklung z.B. ländlicher Räume Anwendung findet. Auch die Forstwirtschaft ist im Rahmen regionaler Governance-Ansätze als multifunktionaler Wirtschaftszweig betroffen und könnte hier z.B. durch neue Absatzmöglichkeiten und durch an die Regionalentwicklung angepasste politische Strategien an politischem Gewicht gewinnen. Daher erscheint eine Analyse forstlich relevanter Regional GovernanceProzesse sinnvoll, insbesondere, da bislang eine geringe Beteiligung der Forstwirtschaft an der ILE konstatiert wird, welche weit hinter ihrem eigentlichen Potential und möglichem Nutzen für die Forstakteure ${ }^{2}$ bleibt (Ortner 2004, 2009). Viele Autoren betonen, dass die Einbeziehung unterschiedlichster Akteure und Interessen in die integrierte ländliche Entwicklungspolitik Probleme bereitet (s. z.B. Elbe und Schubert 2008, Cook 2009). Fragen bezüglich Partizipation (Wer nimmt warum teil und wer nimmt warum nicht teil?) rücken daher bei der Analyse von Regional Governance ins Blickfeld.

Bislang liegen darüber wenige politikwissenschaftliche Studien und so gut wie keine forstpolitikwissenschaftlichen Analysen vor. Ortner (2009) als einer der wenigen, der die Integration der Forstwirtschaft in Regional Governance-Prozesse am Beispiel der ILE untersucht, beschränkt sich in seiner Pionier-Analyse auf die lokale Ebene des Programmvollzugs, ohne dabei intensiv auf übergeordnete politische Rahmenbedingungen und Triebkräfte einzugehen. Daher knüpft die vorliegende Dissertation an diese offenen Fragen an und untersucht das Thema einer Regional Forest Governance anhand folgender Fragestellung: Wie wirken sich das Zusammenspiel übergeordneter politischer Ebenen auf die Beteiligungsmöglichkeiten der Forstwirtschaft in der integrierten ländlichen Entwicklung (ILE) aus? Aus dieser übergeordneten Fragestellung resultieren zwei forschungsleitende Fragen:

- Welche forstlichen Potentiale bietet eine Kooperation im Rahmen der integrierten ländlichen Entwicklung und für welche Forstakteure ist dieser Nutzen realisierbar?

- Welche politischen Kräfte bestimmen die integrierte ländliche Entwicklung sowohl in der Politikformulierung auf übergeordneten politischen Ebenen als auch im regionalen Vollzug?

\footnotetext{
${ }^{1}$ Der englische Terminus Regional Governance hat sich im deutschen Fachdiskurs ebenso wie der Begriff der Governance etabliert. Da sich keine angemessene Übersetzung finden lässt, übernehme ich diese Begriffe im Folgenden.

${ }^{2}$ Unter Forstakteure verstehe ich all jene individuellen oder kollektiven Akteure, deren Interessen überwiegend von der Benutzung - im Gegensatz zum Schutz - des Waldes geprägt sind bzw. deren Interessen sich mit einer solchen Handlungsorientierung realisieren lassen.
} 
Diesen Fragen bin ich anhand des Beispiels der Einbeziehung von forstwirtschaftlichen Akteuren im Rahmen der ILE-Politik nachgegangen. Dabei spielen unterschiedliche Phasen des Politikprozesses eine wichtige Rolle. ${ }^{3}$ Zur Bearbeitung der Fragestellung wurden sowohl die Problemidentifikation, Agendasetting und Programmformulierung auf übergeordneter zentraler Ebene (hier Länder, Bund und EU) als auch Mechanismen und Verhalten der Akteure auf regionaler Ebene der Politikimplementierung berücksichtigt.

Die vorliegende Dissertation konstituiert sich aus den folgenden Publikationen, deren thematisches Gewicht jeweils unterschiedlich stark auf der Beantwortung der beiden Forschungsfragen liegt. Diese sind entsprechend der hier genannten Nummerierung im Anhang aufgeführt.

1. Giessen, L. (2009): Regional governance in rural development programmes - Which Role for Forestry?. In: Folia Forestalia Polonica, series A, 51 (1), 54-60.

2. Giessen, L. (2010): Regional Governance für ländliche Räume - innovativer Ansatz, politischer Gegenwind und der Weg vorwärts. In: Raumforschung und Raumordnung, 68 (1), 3-14.

3. Giessen, L. (2008): Die Zurückhaltung der Forstwirtschaft in der integrierten ländlichen Entwicklung - Analyse der politischen Ursachen. In: Forstarchiv, 79 (3), 116-121.

4. Giessen, L. und Böcher, M. (2009): Rural Governance, forestry, and the promotion of local knowledge: The case of the German rural development programme 'Active Regions'. In: Small Scale Forestry, 8 (2), 211-230.

5. Giessen, L. und Böcher, M. (2008): Integrated Rural Development Policy in Germany and its Potentials for new Modes of Forest Governance. Institut für Wald-, Umwelt- und Ressourcenpolitik, Wien, $114 \mathrm{~S}$.

6. Giessen, L.; Böcher, M.; Ortner, M. und Tränkner, S. (2006): Integrated Rural Development as pathway for innovations - an unexploited potential for forestry -. In: Tikkanen, I.; Zyrina, O.; Rametsteiner, E.; Barreiro, O. und Michalak, R.(Hrg.): Policies Fostering Investments and Innovations in Support of Rural Development. MCPFE, Warschau, 38-56.

7. Giessen, L. und Krott, M. (2009): Forestry Joining Integrated Programmes? A question of willingness, ability and opportunities. In: Algemeine Forst-u. Jagdzeitung, 180 (5-6), 94-100.

8. Giessen, L.; Lukesch, R.; Böcher, M. und Elbe, S. (2008): Politikintegration für ländliche Räume? Die (Nicht-) Koordination der Förderung. In: Elbe, S (Hrg.): Land-Stadt Kooperation und Politikintegration für ländliche Räume. Shaker, Aachen, 57-120.

\footnotetext{
${ }^{3}$ Die hier verwendeten Begriffe entstammen dem Policy-Cycle. In der Politikwissenschaft wird dieser als Analysemittel verwendet. Man unterscheidet verschiedene idealtypische Phasen der Politikentwicklung, welche Problemdefinition, Agenda setting (Problemthematisierung), Formulierung, Implementierung, Evaluation (Bewertung) sowie die Terminierung (Re-definition) gesellschaftlich konstruierter Probleme umfassen (Jann und Wegrich 2003, wobei die Phasenbezeichnungen je nach Autoren variieren können).
} 


\section{Theoretischer Bezugsrahmen}

\subsection{Regionalisierung und Regional Governance}

Regionalisierung wird politikwissenschaftlich als neue Form regionaler Politik verstanden, für die der Raum als Kontext zur Erfüllung öffentlicher Aufgaben relevant ist (Benz et al. 1999). Demnach definiert die Dichte von Prozessen der Interaktion und Kooperation regionalpolitischer Akteure eine Region und nicht, wie im traditionellen Verständnis, administrative Grenzen (Diller 2002, Benz et al. 1999). Im Zuge von Regionalisierung erfährt die Region eine Aufwertung als politische Handlungsebene (Bergmann 2000), im Zuge derer auch hoheitliche Aufgaben des Staates von zentraler Ebene in die Regionen verlagert werden.

Regionalisierungsprozesse zeichnen sich durch einen geringen Grad an Formalisierung und Hierarchie sowie eine Kooperation zwischen öffentlichen und privaten Akteuren vor dem Hintergrund gemeinsamer regionalpolitischer Ziele aus. Entscheidungen werden auf der Basis von Aushandlungen getroffen, wenngleich der „Schatten der Hierarchie“ (Scharpf 1993, 67), also nach wie vor relevante (ordnungs)politische Interventionen übergeordneter staatlicher Ebenen mit entsprechender Antizipation und Reaktion regionaler Akteure eine wichtige Rolle spielt. Inhaltlich konzentriert sich Regionalisierung auf Entwicklungsaufgaben und deren Steuerung, wobei Problemdefinitionen und politische Ziele raumbezogen formuliert werden.

Eine einfache Aufbauorganisation kann die komplexen Herausforderungen solcher Regionalisierungsprozesse nicht bewältigen. „Regieren in komplexen Regelsystemen“, nach Benz (2004) ein knapper Definitionsversuch des Begriffes Governance, rückt daher in den Fokus. Governance beschreibt das Zusammenwirken zwischen staatlichen und privaten Akteuren in verschiedenen Politikfeldern, wobei Letztere an Einfluss auf politische Prozesse und Entscheidungen gewinnen (Peters und Pierre 1998, Benz 2004). Politik wird nicht mehr nur durch den Zentralstaat und seine Institutionen hierarchisch gesetzt, sondern im Zuge von Aushandlungsprozessen zwischen staatlichen und nicht-staatlichen Akteuren gestaltet (Eberlein und Kerwer 2002). Wendet man dieses Konzept nun auf Regionalisierungsprozesse an so rücken die Art und Weise wie regionale Akteure zusammenwirken in den Mittelpunkt (Benz und Fürst 2003). Mit dem Begriff „Regional Governance“ (Fürst 2001) lassen sich so neue Wege der Steuerung von Regionalpolitik und deren komplexe Strukturen erfassen (Böcher 2008).

Fürst (2001: 370) definiert Regional Governance als ,schwach institutionalisierte [...] netzwerkartige Kooperationsformen regionaler Akteure für Aufgaben der Regionalentwicklung." Er versteht darunter weiter „,netzwerkartige Kooperationen zwischen Akteuren des staatlichen, privatwirtschaftlichen und zivilgesellschaftlichen Bereichs zur Bearbeitung von Problemen der regionalen Entwicklung“" (Fürst 2004). Dabei sei die Teilnahme freiwillig, der Grad der Institutionalisierung relativ schwach und informelle Regelsysteme träten an die Stelle formeller Institutionen. Der Raumbezug sei wichtig und steuere somit über sektorale Grenzen hinweg eine regionale Entwicklung. Letztlich wird jedoch anerkannt, dass Regional Gover- 
nance auch vom bestehenden institutionellen Kontext mitbestimmt wird (Fürst, Lahner und Pollermann 2005).

Böcher $(2007,2008)$ erarbeitet eine Konzeption von Regional Governance, welche auf die seiner Ansicht nach zentralen Merkmale abhebt: Regional Governance ist demnach gekennzeichnet durch (i) eine Aufwertung der Selbstverantwortung von Regionen als politische Handlungsebene, (ii) die Ablösung des Territorial- durch das Funktionalprinzip, (iii) intersektorale Kooperation durch schwach institutionalisierte regionale Netzwerke und Partnerschaften sowie (iv) eine Anreizsteuerung durch Finanzen, Wettbewerb und Evaluation (ibid.: $374-8){ }^{4}$

Da bei Regional Governance keineswegs nur Akteure mit gleichgerichteten Interessenlagen agieren (Benz und Fürst 2003), ist dabei eine wichtige Erkenntnis, dass der Schatten der Hierarchie zentral für die Initiierung und den Erfolg Regionaler Governance-Prozesse ist (Böcher 2008b, Benz et al. 1999, Benz und Fürst 2003, Diller 2004), da somit die Anreize zur Kooperation steigen.

Häufig unberücksichtigt in Regional-Governance-Studien bleibt der Aspekt der Machtverteilung zwischen den beteiligten Akteuren. Edwards et al. (2001) zeigen, dass sich die Machtverteilung unter Regional Governance-Arrangements nicht wesentlich ändert und überwiegend bei staatlichen Akteuren verbleibt. Da im Rahmen von Kooperationen unter Regional Governance starke, ressourcenreiche Akteure einer Zusammenarbeit eher ablehnend gegenüberstehen (Benz 1994) und schwache Interessen die Kooperation tendenziell hoch bewerten, um Ihre Position zu stärken (Winter und Willems 2000), sollte das Verhalten einzelner Akteursgruppen in Regional Governance-Prozessen als Ausdruck einer Machtstrategie stärker als bisher beleuchtet werden.

Ferner existieren nur wenige Analysen, die eine Beteiligung und besonders eine Nicht-Beteiligung unterschiedlicher Akteure und Akteursgruppen beleuchten. Gerade die Frage, ob an Regional GovernanceProzessen alle relevanten Gruppen oder nur bestimmte mit Macht und/oder Informationen ausgestattete Akteure und deren Koalitionen beteiligt sind, könnte hier die Theorieentwicklung weiterführen. Auch die Gründe für die (Nicht)-Teilnahme bestimmter Akteursgruppen finden bisher wenig Eingang in die Theorie. Hier könnten Nutzenerwägungen (Feiock 2007) oder fehlende Kapazitäten und Ressourcen (z.B. finanziell-personelle aber auch Informationen, z.B. Ortner 2009) der Akteure eine Rolle spielen. Die theoretisch orientierte Politikforschung weist darauf hin, dass die für Regional Governance notwendige Kooperation unterschiedlichster Akteure eine deutliche Umsetzungshürde darstellt und keineswegs als selbstverständlich anzusehen ist (Benz 1994, Axelrod 2005). Diese Umsetzungshürde und Ansätze zu deren Überwindung werden bislang jedoch noch zu wenig durch entsprechende Studien untersucht.

Die Betrachtung solcher Aspekte könnte jedoch nicht nur theoretische und analytische Hinweise erbringen, sondern auch ganz praxisnahe Empfehlungen für die effektivere Gestaltung von Regional Governance liefern (Giessen 2010). So stellt die Kooperation und Bildung von Netzwerken zwischen Akteuren unterschiedlicher Sektoren die eigentliche Innovation des Regional Governance-Ansatzes dar. Dies bedeutet, dass die Akteure Wege finden, in Koalitionen mit anderen ihre Interessen zu verfolgen, wobei neue Bündnisoptionen entstehen können. Hier kann die politikwissenschaftliche Betrachtung einen wesentlichen Beitrag leisten, indem sie die unterschiedlichen Akteursinteressen, also die „Handlungsorientierungen von Individuen und Gruppen" (Krott 2001) der an Regional Governance Beteiligten als treibende Kräfte des Politikprozesses deutlich macht (von Prittwitz 1994, Krott 2001) und somit Macht- und Durchsetzungspotentiale ins Zentrum der Analyse rücken.

Die Diskussion um Regional Governance schlägt sich auch im Rahmen der räumlichen Planung bzw. Planungstheorie nieder. Regional Governance wird dabei als neues informelles Planungsparadigma verstanden. Die empirischen Phänomene der integrierten Regionalentwicklung werden hier unter dem Begriff der informellen räumlichen Planung (Gorsler 2002) behandelt. Dabei stehen zumeist informelle Planungsinstrumente wie Regionalmanagement, regionale Entwicklungskonzepte (REK) und Regionalkonferenzen im Mittelpunkt des Interesses. Die Planungstheorie reflektiert diese Entwicklungen mit dem Konzept der kollaborativen Planung (Healey 1997, 2003). Dieser inklusive Ansatz beruht auf kommunikativem Handeln mit transformatorischer Wirkung und entwirft ein Planungsparadigma, welches sich stark auf lokales Wissen und die Beteiligung aller Stakeholder bezieht. Er bezieht sich auf die Habermas'schen Ideen eines rationalen und offenen Diskurses und Annahmen über das kommunikative Handeln der beteiligten Akteure (Healey 2003). Die Theorie der kollaborativen Planung beinhaltet sowohl analytische als auch normative Bestandteile, wie Planungsprozesse gestaltet sein sollten.

${ }^{4}$ Der Rahmen wurde durch Böcher/Krott/Tränkner (2008) dahingehend weiterentwickelt, dass auf die Kategorie (ii),,Funktionalprinzip“ verzichtet werden kann. 
Die vorliegende Dissertation befasst sich mit dem Politikfeld der integrierten ländlichen Entwicklung als praktischem Anwendungsbereich von Regional Governance. Diese dient hier als Beispiel, um zu beleuchten, welchen potentiellen Nutzen unterschiedliche Forstakteure aus ILE realisieren können und welche politischen Kräfte auch auf übergeordneten politischen Ebenen die Beteiligungsmöglichkeiten unter Regional Governance beeinflussen.

\subsection{Der Forschungsstand zu Regional Forest Governance}

Im Bereich waldrelevanter Politik werden die gemeinsame Politikgestaltung durch staatliche und private Akteure und die einhergehenden Änderungen im Steuerungsansatz unter dem Begriff der Forest Governance behandelt (s. Glück, Rayner und Cashore 2005; Agrawal, Chhatre und Hardin 2008; Hogl et al. 2008; Böcher, Giessen und Kleinschmit 2008 und 2009, Krott 2008, Giessen 2008). Das Thema forstlicher Beteiligung an Regional Governance-Prozessen wird hingegen nur von wenigen Studien aufgegriffen, auf die ich im Folgenden kurz eingehe.

Die empirischen Beispiele zur Beteiligung der Forstwirtschaft an Prozessen der kooperativen Regionalentwicklung können vor dem Hintergrund meiner Fragestellung in die folgenden drei Gruppen unterteilt werden:

1. Beispiele forstlicher Beiträge zur Regionalentwicklung ohne Kooperation zwischen Akteuren Solche Analysen konzentrieren sich auf die Einkommens- und Beschäftigungseffekte und somit auf die Primärproduktionsfunktion der Forstwirtschaft und deren Beiträge zur regionalen Entwicklung. ${ }^{5}$

2. Beispiele forstlicher Beiträge zur Regionalentwicklung aufgrund von Kooperation zwischen Akteuren in sektoralen Netzwerken und entlang einer Wertschöpfungskette (gleichgerichtete Interessenslage)

Es existieren viele Beispiele, in denen Akteure auf regionaler Ebene kooperieren müssen, um ein Kollektivgut bereitzustellen und gleichzeitig ihre spezifischen Eigeninteressen zu verfolgen. Die Kooperation von Akteuren in sektoralen Netzwerken entlang einer gemeinsamen Wertschöpfungskette ist dem sektorübergreifenden Verständnis von Regional Governance folgend hier ebenfalls von untergeordnetem Interesse. Solche Analysen zeigen, dass ein Innovationspotential in sektoralen Bündnismöglichkeiten zwischen Staat und privaten Akteuren der Forstwirtschaft besteht (Gingras und Carrier 2006, ähnlich auch Elands und Wiersum 2001, 2003 sowie Hoogstra, Schanz und Wiersum 2004), welches einen Beitrag zur Regionalentwicklung leisten kann.

3. Beispiele forstlicher Beiträge zur Regionalentwicklung aufgrund von Kooperation zwischen Akteuren in sektorübergreifenden (integrierten) Netzwerken bei teilweise entgegengesetzter Interessenslage

Mit der Frage, ob, und wenn ja, wie forstliche Akteure regionale Kooperationen in integrierten Netzwerken eingehen, haben sich bislang wenige Autoren befasst. Diese Studien dienen zunächst als Anknüpfungspunkt, um das Phänomen einer Regional Forest Governance zu umreißen.

Becker (2000) identifiziert in seiner ökonomischen Analyse forst- und holzwirtschaftlicher Regionalinitiativen solche Kooperationen, die speziell forstwirtschaftliche Ziele verfolgen. Unter 61 in Deutschland beschriebenen forstlichen Regionalinitiativen (Piesch 1998) konnten sektorübergreifende Kooperationsnetzwerke identifiziert werden, durch die ein ökonomischer Mehrwert realisiert werden konnte (Seintsch 2004).

Eine Studie von Ortner (2004) zeigt am Beispiel des LEADER+ Programms, dass die tatsächliche Beteiligung der Forstwirtschaft an ILE kleiner ist als deren Potential. Ein solches Potential sieht er auf regionaler Ebene in den Bereichen Tourismus, regenerative Energien, Holzabsatz, Umweltbildung und Naturschutz (Ortner 2004). Als mögliche Faktoren, die zu dieser Unternutzung forstlicher Potenziale führen, identifiziert Ortner (2009) die zur Verfügung stehenden Ressourcen (Zeit, Geld, Personal), das Vorhandensein von Informationen über das Programm, forstliche Promotoren, zu geringe finanzielle Anreize des Programms sowie einen hohen forstlichen Problemdruck. Ortner schlussfolgert, dass eine erfolgreiche forstliche Kooperation bei gegebenen Faktoren möglich, die Voraussetzungen dazu aber frühzeitig und genau zu prüfen seien (Ortner 2009).

Basierend auf 19 europaweiten Fallstudien zeigen Hogl et al. (2008), dass entgegen der sektorübergreifenden Rhetorik normativer Governance-Konzepte die Einbeziehung anderer Sektoren in forstpolitische Prozesse oft symbolischen Charakter trägt. Die Überwindung sektoraler Grenzen könne auf lokaler und

${ }^{5}$ Exemplarisch seien hier die Proceedings-Bände von Fjeld (1997, Hrg.) und Wiersum und Elands (2002, Hrg.) genannt. 
regionaler Ebene geleistet werden. Bezüglich der zentralen Frage der Governance-Forschung nach der Rolle des Staates und dem wachsenden Einfluss privater Akteure wird hier konstatiert, dass die betroffenen Policy-Netzwerke zwar durchgehend erweitert wurden. Jedoch verblieb die Entscheidungsmacht gemeinhin bei den bisherigen Eliten, wobei staatlichen Akteuren hier eine zentrale Rolle als ,strong metagovernor" zukommt.

Im Sinne einer Regional Forest Governance sind die in der französischen Forstpolitik neuen „,chartes forestières de territoire“ oder englisch „territorial forestry charters“ (etwa forstwirtschaftlich orientierte Regionalinitiativen) zu nennen (Buttoud und Kouplevatskaya 2008). Hier fördert der französische Staat waldbezogene Regionalentwicklung finanziell und verfolgt einen explizit sektorübergreifenden Ansatz. Jedoch beobachten Buttoud und Kouplevatskaya (2008, 36-7), dass trotz der formalen Offenheit und der sektorübergreifenden Rethorik des Programmes sektorale Netzwerke vorherrschen und sich erfolgreich gegenüber angrenzenden Politiksektoren abgrenzen.

Am Beispiel der „Model Forests“ zeigen Elbakidze, Angelstam und Axelsson (2007), dass ähnlich wie im französischen Beispiel integrierte Ansätze mit explizitem Waldbezug dazu tendieren, von traditionellen Forstakteuren dominiert zu werden, die ihre meist bis dahin ausschließliche Kompetenz zu verteidigen suchen.

Böcher, Giessen und Kleinschmit (2009, siehe auch 2008) beleuchten in ihren Sammelbänden ebenfalls aus analytischer Sicht die Rolle von Forest Governance. Der Beitrag von Ojha et al. (2009) versteht den meist regionalen Ansatz von „Community Forestry“ als Beleg dafür, dass sich ein Politikwandel im Sektor vollzieht. Jedoch wird der Bezug zur Regionalisierung lediglich über das vage Konzept der Dezentralisierung hergestellt.

Rametsteiner (2009) belegt den Begriff der Regional Forest Governance erstmals konzeptionell, indem er die drei Dimensionen „multi-actor“, „multi-level“ und „multi-sector“ auf lokaler bzw. regionaler Ebene als konstitutive Elemente benennt. Als einzigen empirischen Hinweis führt er die o.g. „Model Forests“ an.

Und letztlich zeigen eigene Arbeiten (Giessen und Böcher 2008) sowie die Analysen von Ortner (2009), dass Regional Governance-Initiativen, welche außerhalb des Forstsektors angestoßen wurden, für diesen durchaus Relevanz entwickeln können. Hierzu zählen lokale Agenda 21-Prozesse sowie die für die vorliegende Dissertation zentrale integrierte ländliche Entwicklung (ILE).

Da es bislang zu der Frage einer forstlichen Kooperation in integrierten Netzwerken auf regionaler Ebene keine weiteren politikwissenschaftlichen Forschungsarbeiten gibt, soll die vorliegende Dissertation zur Weiterentwicklung des Diskurses um Regional Forest Governance beitragen. 


\section{Auswahl der Fallstudien und empirische Methoden}

\subsection{Qualitatives Forschungsdesign}

Die vorliegende Dissertation folgt dem empirisch-analytischen Ansatz in der Politikwissenschaft (von Beyme 2000), um eine möglichst wertfreie Beschreibung der Realität forstlicher Beteiligung an ILE zu liefern. Von Beyme folgend hilft der Ansatz ferner, den normativen Gehalt integrierter politischer Problemlösungen (wie z.B. durch Regional Governance) zu senken und die realistischen Verhältnisse aufzuzeigen. Dazu zählt besonders, die politischen Determinanten zu identifizieren, welche die Beteiligung der Forstwirtschaft an Regional Governance-Programmen positiv wie negativ bedingen.

Bei dem o.g. Phänomen einer Regional Forest Governance handelt es sich um eine relativ junge Entwicklung, die durch jüngste Forderungen nach integrierter Politik (Lenschow 2002) befördert wird. Die integrierte Strategie ist jedoch im Zusammenhang mit ländlichen Entwicklungszielen und auf regionaler Ebenen für forstliche Akteure ein politisches Novum. ${ }^{6}$ Ein qualitatives Vorgehen ${ }^{7}$ erscheint zur Bearbeitung meiner Fragestellung zielführend, da anzunehmen ist, dass eine Beteiligung der Forstwirtschaft an ILE (noch) nicht routinemäßig zu beobachten, sondern auf Nischen beschränkt ist. Somit können lediglich eine geringe Zahl an Einzelfällen (z.B. Projekte) sowie beteiligten Akteuren und ausgewählten Experten Aufschluss über die forstlichen Potentiale sowie die Determinanten forstlicher Beteiligung geben. Ein quantitatives Vorgehen wäre somit nicht in der Lage, die vereinzelten Phänomene bzgl. der Potentiale und der Beteiligungsfaktoren valide aufzuspüren.

\subsection{Auswahl der Fallstudien}

Die Fragen nach den forstlichen Potentialen und den politischen Determinanten der Beteiligung im Rahmen von Regional Governance untersuche ich am Beispiel öffentlicher Förderprogramme im Politikfeld der integrierten ländlichen Entwicklung. Dabei führte ich theoriegeleitete interpretativen Fallstudien (vgl. Lijphart 1977, zit. n. Krott 1990) zu folgenden ILE-Förderprogrammen öffentlicher Verwaltungen unterschiedlicher Ebenen durch (zu 1-3 s. Giessen und Böcher 2008, zu 4-6 s. Giessen et al. 2008):

\footnotetext{
${ }^{6}$ Querschnittspolitik im Allgemeinen wird jedoch bereits seit den 1970er Jahren gefordert und gefördert wurde (Jänicke und Jörgens 2004).

7 Unter qualitativer Sozialforschung verstehe ich in Anlehnung an Jones (1996) die Erhebung nicht standardisierter Daten und deren verstehende und kategorienbildende Auswertung.
} 
- Die EU-Gemeinschaftsinitiative LEADER+ (2000-2006) in Deutschland

- Das Bundesmodellvorhaben „Regionen Aktiv“ des Bundesministeriums für Verbraucherschutz, Ernährung und Landwirtschaft (2002-2007)

- Die Gemeinschaftsaufgabe „Verbesserung der Agrarstruktur und des Küstenschutzes“ (GAK) aufgrund des neuen Fördergrundsatzes der „Integrierten ländlichen Entwicklung“ (seit 2004, s. BMVEL 2005)

- Die Gemeinschaftsaufgabe „Verbesserung der regionalen Wirtschaftsstruktur“ (GRW)

- Den Europäischen Fonds für regionale Entwicklung (EFRE) und den Europäische Sozialfonds (ESF)

- Den Europäischen Landwirtschaftsfonds für die Entwicklung des ländlichen Raums (ELER)

Die unter Punkt drei bis sechs genannten Fallstudien wurden komparativ und exemplarisch in sechs verschiedenen Regionen und jeweils unterschiedlichen Bundesländen durchgeführt, um etwaige Unterschiede in den Integrationsstrategien der Bundesländer zu berücksichtigen.

Generell eignet sich das Politikfeld der ILE, um den Steuerungsansatz der Regional Governance zu untersuchen (Böcher, Krott und Tränkner 2008, Böcher 2008). Die Förderprogramme, mittels derer die integrierte Politik umgesetzt werden soll, bemühen formal einen sektorübergreifenden Ansatz (Elbe 2007), dessen tatsächliche Wirkung jedoch noch nicht Gegenstand (forst-)politischer Analysen war. Zudem war die Erprobung von integrierter Förderpolitik in sog. Modellvorhaben wie z.B. LEADER+ und Regionen Aktiv zum Zeitpunkt der Konzipierung der Dissertation bereits fortgeschritten und erste Anpassungen der Regelförderung z.B. der GAK waren zu beobachten (Tabelle 1). Diese Umstände machen die o.g. Fallstudien zur Analyse forstwirtschaftlicher Potentiale und Beteiligung unter Regional Governance sehr fruchtbar, besonders um die Unterschiede zwischen Modellprogrammen und sektoraler Regelförderung zu untersuchen.

Tabelle 1: Fallstudien zu Potentialen der Forstwirtschaft und Beteiligungsdeterminanten in Förderprogrammen zur integrierten ländlichen Entwicklung getrennt nach temporären Pilot- und Mainstreamprogrammen sowie Ebenen der Programmanbieter.

\begin{tabular}{|l|l|l|}
\hline Ebene Programmanbieter & Pilotprogramm & Regelförderung \\
\hline EU & LEADER+ & ESF, EFRE und ELER \\
\hline Bund & Regionen Aktiv & \\
\hline Bund/Länder & & GAK und GRW \\
\hline
\end{tabular}

Die Fallstudien widmen sich den Fragen nach neuen Steuerungsansätzen (also dem Phänomen der Governance) in der integrierten ländlichen Entwicklungspolitik sowie der Beteiligung der Forstwirtschaft an ILE-Programmen. Dabei beziehe ich mich hier explizit auf eine Analyse der Beteiligung zu jedem möglichen Stadium im Politikzyklus, also nicht nur während des Vollzugs, auf den sich Ortner $(2004,2009)$ beschränkte, sowie auf jede der beteiligten politischen Ebenen. Aus genannten Studien war bereits bekannt, dass die ILE ungenutztes forstliches Potential beinhaltet. Jedoch lieferten die Analysen weder eine Typisierung der Potentiale noch Erklärungen der geringen Beteiligung, die übergeordnete politische Ebenen berücksichtigten.

\subsection{Qualitativer Methodenmix}

Zur Untersuchung der Forschungsfragen habe ich einen Mix qualitativer Methoden angewendet. Dokumentenanalysen und Experteninterviews bilden den Kern der Erhebung. Die forstlichen Potentiale sowie zentrale politische Kräfte in der Regional Governance wurden im Zeitraum von November 2005 bis August 2008 durch die folgenden qualitativen Methoden analysiert. Dabei wurden die Fallstudien nacheinander bearbeitet und die Anwendung der folgenden Methoden wiederholte sich in weiterentwickelter Form:

Dokumentenanalysen nach Jones (1996) habe ich zu öffentlichen Programmdokumenten der einzelnen Förderprogramme, zu Stellungnahmen und Publikationen zentraler Akteure der ländlichen Entwicklungspolitik sowie zu den netzbasierten Projektdatenbanken der Pilotprogramme LEADER+ und Regionen Aktiv schwerpunktmäßig zu Beginn einer jeden Fallstudie durchgeführt und bei Bedarf erweitert.

Experteninterviews: Eine Reihe teilstrukturierter Interviews (68 Stkück) wurde in Anlehnung an Meuser und Nagel (2002) mit Experten auf den Gebieten (i) der integrierten ländlichen Entwicklung, (ii) der Beteiligung von Forstwirtschaft an ILE und (iii) der Programmformulierung und -abwicklung auf Bundes-, 
Landes- und Landkreisebene geführt. Dabei wurden im Bereich (ii) Experten überwiegend über die Schneeballmethode durch andere Experten identifiziert. Ein großer Teil der Experten entstammte öffentlichen Verwaltungen (Bundes- und Landesministerien und deren nachgeordneten Stellen auf Landkreisbebene), die Einblicke in und/oder Einfluss auf die Programmgestaltung und -abwicklung hatten (s. Eigenschaften von Experten nach Meuser und Nagel 2002). Ebenso wurden freie Berater auf dem Feld der ILE, Lobbyvertreter der Forst- und Landwirtschaft, sowie ILE-kundige Wissenschaftler befragt. Die Interviews wurden zwischen Januar 2006 und August 2008 geführt. Sie waren semi-strukturiert und enthielten für den Bereich (ii) narrative Elemente, um Daten über neue, innovative und nicht weit verbreitete Aktivitäten und Strategien der Forstakteure im Bezug auf ILE zu erhalten.

Nicbtteilnehmende Beobachtungen wurden gemäß Jones (1996) während zentraler Konferenzen auf Bundesebene zur Zukunft der ländlichen Entwicklungspolitik durchgeführt, um die o.g. Daten aus dem Bereich der ILE in einem breiteren politischen Kontext zu deuten und so zu validieren. Diese Methode wurde während zweier Konferenzen des Bundeslandwirtschaftsministeriums im November 2005 und Oktober 2006 durchgeführt.

Zwei Fokusgruppen wurden in Anlehnung an Parker (2006) im November 2005 mit je fünf ausgewählten Experten zur Beteiligung der Forstwirtschaft an ILE-Programmen abgehalten, um einen ersten Überblick über die enthaltenen Potentiale und Konflikte in diesem Bereich zu erhalten (s. Böcher und Giessen 2006 für eine Dokumentation der Methode). Diese Methode diente ebenfalls der Validierung der Ergebnisse aus Dokumentenanalysen und Interviews.

Sekundärdatenanalyse: Zu den erhobenen qualitativen Primärdaten wurden punktuell auch Sekundärdaten verwendet, um Hinweisen aus meinem Datenmaterial nachzugehen und diese zu verifizieren bzw. zu falsifizieren. Diese entstammten den Arbeiten des Teams der „Begleitforschung Regionen Aktiv“, dem ich von 2007 bis Ende 2008 angehörte (für Details siehe Giessen und Böcher 2009).

Alle Daten wurden in Anlehnung an Jones (1996) einer qualitativen Inhaltsanalyse unterzogen. Dazu wurden die Daten transkribiert und mittels Kodierung durch die Software MaxQDA den Teilen der Forschungsfragen zugewiesen, zu denen sie Aufschluss boten.

\subsection{Methodenkritik}

Aufgrund der angewandten qualitativen Methodik sind meine Ergebnisse zu beiden Fragestellungen eher indikativer Natur. Ihre Reliabilität ist als gering einzuschätzen, da sich nicht quantifizieren lässt, in wie weit die identifizierten ILE-Potentiale tatsächlich und in bestimmten Regionen bestehen bzw. wie weit die vorgefundenen Strategien besonders zur Teilnahme an ILE-Prozessen unter der Vielzahl individueller und kollektiver Forstakteure verbreitet sind. Die Validität der Ergebnisse hingegen stufe ich als hoch ein. Im Bereich der forstlichen Potentiale trägt zur Gültigkeit der Ergebnisse bei, dass die ausgewählten Experten zur Rolle der Forstwirtschaft in ILE nach dem Schneeballprinzip ausgewählt wurden und somit ein höchstmögliches $\mathrm{Maß}$ an diesbezüglicher Erfahrung und Kompetenz erreicht werden konnte (Meuser und Nagel 2002). Die Befragung sowohl von Forstakteuren als auch von sektor-externen Experten nach dem Verfahren der doppelten Befragung (Krott 2001b) sowie deren nahezu identischen Angaben zum Verhalten und der Rolle der Forstwirtschaft in ILE tragen ebenfalls zu einer hohen Validität bei.

Die gewählten ILE-Fallstudien zu den Potentialen und Beteiligungsdeterminanten der Forstwirtschaft unter Regional Governance tragen ebenfalls zur Validität der Ergebnisse bei, da es sich beim ILE-Ansatz um eine nahezu idealtypische Anwendung von Regional Governance handelt. Die zuvor bekannte geringe Beteiligung der Forstwirtschaft ist ebenfalls als nützlich zu sehen, die hindernden politischen Kräfte detailliert und valide zu analysieren. Für die Analyse der forstlichen Potentiale hingegen sind aufgrund der geringen Beteiligung und noch wenig ausgereifter politischer Strategien der Akteure im Umgang mit dem Regional Governance-Ansatz lediglich indikative Ergebnisse mit geringerer Validität möglich.

Der Methodenmix bietet die Möglichkeit, die Nachteile jeder einzelnen Methode auszugleichen. So können z.B. strategische Antworten bei Interviews durch formalisierte Aussagen von Programmdokumenten identifiziert und trefflich interpretiert werden (Meuser und Nagel 2002, Hucke u. Wollmann 1980). Somit werden formale Aspekte aus Dokumenten den informalen Deutungen der Experten gegenübergestellt und ermöglichen es dem Forscher die Daten trefflich zu interpretieren. Im Folgenden stelle ich die zentralen Ergebnisse meiner Dissertation vor, zu denen ich durch die genannte Methodik komme. 



\section{Ergebnisse}

\subsection{Regional Governance-Potentiale für die Forstwirtschaft}

Die erste Forschungsfrage „Welche forstlichen Potentiale bietet eine Kooperation im Rahmen der integrierten ländlichen Entwicklung und für welche Forstakteure ist dieser Nutzen realisierbar?" , begründet sich aus der Annahme, dass die Beteiligung an Regional Governance-Prozessen einen spezifischen Nutzen für die beteiligten Akteure birgt, der es ihnen erlaubt, ihre Interessen zu verfolgen. Solche Potentiale für die Forstwirtschaft sind jedoch noch nicht bekannt und es ist unklar, für welche Akteursgruppen dieser Nutzen überhaupt realisierbar ist (Ortner 2009). Meine Dissertation kommt bezüglich dieser Forschungsfrage zu folgenden Ergebnissen.

\subsubsection{Konventionelle und innovative Potentiale für Forstakteure}

Der programmatische Anspruch der ILE besteht darin, alle relevanten Sektoren des ländlichen Raumes zu beteiligen (BMELV 2005), ILE könnte also einen spezifischen Nutzen für Forstakteure bringen.

Die Ergebnisse meiner Arbeit zeigen, dass in der ILE tatsächlich die genannten forstlichen Potentiale bestehen, jedoch nicht ausgeschöpft werden. Auf der regionalen und lokalen Ebene der Politikimplementation konnten einige Kooperationen unter forstlicher Beteiligung auf Projektebene identifiziert werden, innerhalb derer Forstakteure ihre Eigeninteressen verfolgen konnten (Giessen et al. 2006, Giessen und Böcher 2008, Giessen 2008b, Giessen und Böcher 2009).

Dabei lassen sich konventionelle von innovativen Potentialen unterscheiden. Unter konventionell ist ein direkter materieller Nutzen der Akteure zu verstehen, der sich aufgrund der Kooperation mit anderen Akteuren im Rahmen von ILE einstellt. Innovativ hingegen sind solche Potentiale, welche durch Kooperation zu einem mittelbaren und/oder strategischen Nutzen der Akteure führen. Dazu zählen z.B. Produktinnovationen, die den Akteuren einen strategischen Vorteil auf den Märkten bieten, jedoch keinen sofortigen materiellen Ertrag bringen. Der Begriff der innovativen Potentiale geht damit über das engere Innovationsverständnis von Produkt- oder Prozessneuheiten in der Produktion (vgl. Rametsteiner, Weiss und Kubeczko 2005) hinaus und beinhaltet explizit auch Neuheiten in der Interaktion mit Akteuren und Institutionen.

In der ILE konnten die zusätzliche Mobilisierung von Rohholz sowie die Akquise von öffentlichen Fördermitteln als konventionelle Potentiale für die Forstwirtschaft identifiziert werden (Tabelle 2, Giessen 2008b). Innovative Potentiale sind dagegen mögliche Produktinnovationen (z.B. Güter wie regionales Holz, sog. Mondholz oder waldbezogene Dienstleistungen). Auch politische Bündnisinnovationen wurden als Potentiale identifiziert. Diese können durch einen Diskurs der regionalen Akteure dann entstehen, wenn neue Möglichkeiten gefunden werden, durch eine Kooperation einen individuellen Nutzen zu realisieren. Ein weiteres innovatives Potential ist die Weiterentwicklung akteursspezifischer forstpolitischer Strategien zum Umgang mit integrierter Förderpolitik und Akteuren anderer Sektoren. Letztlich birgt eine 
Teilnahme an integrierten Netzwerken das Potential, die entwicklungspolitische Agenda zu seinen Gunsten mitzugestalten und forstwirtschaftliche Themen zu besetzen (Tabelle 2, Giessen 2008b).

Die Gesamtheit der hier genannten konventionellen und innovativen Potentiale bezieht sich auf den Programmvollzug auf regionaler Ebene. Forstakteure könnten durch die Beteiligung an ILE also mehr Holz mobilisieren und absetzen, mehr Fördermittel erwerben oder neue Bündnispartner finden (Giessen 2008b). Letztgenanntes innovatives Potential sowie die Weiterentwicklung forstpolitischer Strategien stellen zudem einen möglichen Nutzen für Forstakteure in der Problemdefinition, der Alternativenentwicklung sowie der Politikformulierung auf Ebene der EU, des Bundes oder der Länder dar (Giessen 2010). Somit erhöhen sich bei diesen Potentialen die politische Reichweite und der politische Nutzen enorm.

Über den Eigennutz forstlicher Akteure hinaus geht das Potential, im Rahmen von kollektiven Prozessen zu Sachlösungen regionaler Problemlagen beizutragen. Derzeit wird lokales Wissen über soziale, ökonomische und ökologische Zusammenhänge intensiv in regionalen Governance-Prozesse eingebracht, um eben solche Problemlagen politisch zu bearbeiten (Giessen und Böcher 2009). Dies geschieht aktuell nur mit einem geringen Anteil an Wissen der Waldeigentümer und Waldbewirtschafter (Giessen 2008b, Giessen et al. 2006). Da dieses Potential im Einzelfall sowohl konventionell als auch innovativ ausgeprägt sein kann und sich erst dann unter die o.g. nutzenorientierten Definitionen subsumieren lässt, wird dieses Potential hier separat angeführt.

Tabelle 2: Konventionelle und innovative forstliche Potentiale der integrierten ländlichen Entwicklung (verändert nach Giessen 2008b).

\begin{tabular}{|l|l|}
\hline Konventionelle Potentiale & Innovative Potentiale \\
\hline Finanzieller Nutzen aus Förderung & Sektorale Politikstrategien weiterentwickeln \\
\hline Zusätzliche Holzmobilisierung & \\
\hline & Produktinnovationen \\
\hline & Bündnisinnovationen \\
\hline & Forstwirtschaftliche Themen besetzen/erschließen \\
\hline
\end{tabular}

\subsubsection{Unterschiedliche Informationen, Anreize und Kapazitäten der Forstakteure}

Die bestehenden Potentiale können nicht von allen Forstakteuren gleichermaßen realisiert werden. Zum einen verfügen nur wenige Forstakteure über ausreichende Informationen über relevante Programme (Ortner 2009) und können daher ihren spezifischen Nutzen nicht selbst abschätzen. Zum anderen führen die identifizierten Potentiale zu unterschiedlichen Nutzenkalkülen der verschiedenen Forstakteure, welche differenzierte Interessen verfolgen (Krott 2001). Aufgrund der Bedeutung der Verfügungsrechte über Waldressourcen spielen die unterschiedlichen Waldbesitzformen für die Realisierung der ILE-Potentiale eine wichtige Rolle. Dabei ist anzunehmen, dass es zwischen den Besitzarten (z.B. Kleinprivatwald, Großprivatwald oder Staatswald) unterschiedliche Nutzenkalküle, Kapazitäten sowie einen unterschiedlich hohen Informationsgrad bzgl. der ILE-Programme gibt.

Die Ergebnisse meiner Dissertation zeigen, dass sich die Realisierbarkeit der forstlichen Potenziale aus diesen Unterschieden ergibt. Informationen über die Programme sind in den Staatsforstverwaltungen auf allen Ebenen gering (Giessen et al. 2006, ähnlich Ortner 2009). Dafür lassen sich zwei Gründe identifizieren:

- Verwaltungsakteure nehmen an, dass die Programme keinen forstlichen Nutzen enthalten und vermeiden daher aus Effizienzgründen eine Weitergabe der Informationen in sektoralen Netzwerken. Diese ideologische Vorgehensweise konnte punktuell beobachtet werden (Giessen et al. 2006).

- Akteure des Forstsektors sehen aus rationalen Erwägungen heraus eine Teilnahme an integrierten Programmen als kritisch an (Giessen und Krott 2009). Sie trügen mit ihrer Teilnahme zur Legitimität und Stärkung sektorübergreifender Politik bei, die im vorliegenden Fall unmittelbar mit einer Reduktion sektoraler Fördervolumina einhergeht (s.u., Giessen 2010).

Die fehlenden Informationen in den staatlichen Verwaltungen zu ILE-Programmen haben ein Informationsdefizit in großen Teilen des Kleinprivatwaldes zur Folge, da der potentielle forstliche Nutzen in der staatlichen Beratung nicht kommuniziert werden konnte. Die heterogenen Informationsquellen und Betriebsziele kleiner und mittlerer Privatwaldbesitzer führten ebenfalls dazu, dass diese Gruppen nicht über entsprechende Informationen verfügten. Folglich konnten sie die möglichen Kosten und Nutzen einer Kooperation nicht selbst auf Grundlage ihrer eigenen Handlungsorientierung bewerten (Giessen et al. 2006, Giessen und Böcher 2009). Im Kommunal- und Großprivatwald ist die Informationslage hingegen 
besser (Giessen 2008b), da sich große Privatunternehmen selbst aktiv über die Förderlandschaft informieren, mit welcher sich ihre Interessen verfolgen lassen. Die Informationsnetzwerke kommunaler Verwaltungen sind ebenfalls weniger durch ideologische Hürden bestimmt und sektorale Nutzenkalküle kommen weniger zum Tragen.

Die Nutzenkalküle und daraus resultierende Anreize, sich an ILE zu beteiligen, unterscheiden sich ebenfalls unter den Waldbesitzergruppen. Staatliche Verwaltungen dürfen gemäß dem EU-Beihilferecht nur im begrenzten Maße Fördermittel empfangen (Bultmann 2004). Da diese öffentlichen Verwaltungen über eigene Budgets verfügen und sich einmalige und ggf. geringe Einnahmen aus ILE-Förderprogrammen nicht positiv auf die Mitarbeiterbewertung auswirken, ist hier der Anreiz sowohl für die Institutionen als auch für die individuellen Sachbearbeiter gering, sich zu beteiligen. Kommunen können dagegen leichter öffentliche Förderung beziehen (Bultmann 2004) und haben im Fall der ILE davon Gebrauch gemacht (Giessen und Böcher 2008). Auch kleine Beiträge zu den angespannten kommunalen Haushalten durch kommunale Forste stellen hier einen Anreiz dar. Diese können im kommunalen Zusammenhang über Prestigegewinn und persönliche Anerkennung honoriert werden und so als Anreiz wirken, sich an ILE auch mit der Ressource Wald zu beteiligen. Private Waldbesitzer sehen zwar staatliche Förderung als Vorstufe des Ordnungsrechts und stehen dieser kritisch gegenüber (Giessen und Böcher 2008, Krott 2001). Als einmalige Steigerung des Umsatzes liegt die Mitnahme der Fördermittel jedoch in deren Interesse. Hinzu kommt, dass die Investitionen in ILE-Aktivitäten mittelfristig auch Rendite abzuwerfen vermögen. Für den großen Privatwaldbesitz kommt ein möglicher Zugewinn an regionalem Prestige als Anreiz hinzu, da hier Waldbesitz und soziales Wirken lokal oft nah beieinander liegen. Im mittleren Privatwald schränkt die oft mittelbare und standardisierte Vertretung des Waldeigentums durch den Vorstand von Forstbetriebsgemeinschaften die Anreize zur Teilnahme ein (Giessen 2008b). Da der potentielle Nutzen aus der Kooperation in ILE nur durch das Engagement dieser Vertreter erreichbar ist, der Nutzen im Folgenden aber auf alle Mitglieder der Betriebsgemeinschaft aufgeteilt würde, sind die Anreize hier gering.

Kapazitäten zur Teilnahme an ILE können Personal-, Zeit- oder Finanzressourcen umfassen. In staatlichen Forstverwaltungen könnten aufgrund interner Reformen und Umstrukturierungen freiwerdende Personalressourcen entstehen (Giessen und Böcher 2008). Jedoch ist die für kooperative Prozesse der Regionalentwicklung notwendige Kommunikations- und Verhandlungsexpertise in den Forstverwaltungen nicht immer vorhanden (Giessen 2008b, Giessen und Krott 2009). Im geringeren Umfang treffen diese beiden Befunde auch auf die kommunalen Waldbesitzer zu. Private Besitzer hingegen verfügen aufgrund ihrer Ausrichtung an rationalen Produktionsprozessen nicht über freie Ressourcen. Solche könnten lediglich von Unternehmen des Großprivatwalds bereitgestellt werden, die über Reserven verfügen, welche als Investitionen wirken.

Somit ergibt sich zusammenfassend ein differenziertes Bild bzgl. der Realisierbarkeit von ILEPotentialen für verschiedene Waldbesitzformen. Für kleine private Besitzer besteht ein großer Anreiz, sich an ILE zu beteiligen, besonders wenn sich deren Betriebsziele und Interessen ausdifferenziert gestalten (Schraml und Selter 2007). Diese Gruppe kann jedoch aufgrund fehlender Informationen und fehlender Ressourcen den Nutzen weder abschätzen noch realisieren. Ähnliches gilt für den mittleren Privatwald, wobei die Anreize in Forstbetriebsgemeinschaften nicht vorhanden sind. Der Großprivatwald und der Körperschaftswald der Kommunen verfügen am ehesten über die Informationen, haben durchaus starke Anreize und verfügen über potentielle Ressourcen zur Teilnahme. Der staatliche Waldbesitz verfügt auf operationeller Ebene nicht über die notwendigen Informationen zu den Programmen. Aufgrund des Beihilferechts sowie der Mitarbeiterbewertung in öffentlichen Verwaltungen bestehen keine Anreize zur Teilnahme, obwohl die Kapazitäten hier gegeben sind. 


\subsection{Politische Kräfte innerhalb der Regional Governance}

Bezüglich der zweiten Forschungsfrage „Welche politischen Kräfte bestimmen die integrierte ländliche Entwicklung sowohl in der Politikformulierung auf übergeordneten politischen Ebenen als auch im regionalen Vollzug?" komme ich zu folgenden Ergebnissen:

\subsubsection{Konkurrenz zwischen Regional Governance und demokratischen Institutionen}

Eine zentrale Annahme der Governance-Diskussion lautet, dass sich die Rolle nicht-staatlicher Akteure im Politikprozess verändert (Benz 2004, Peters und Pierre 1998). Wenn jedoch eine Zunahme an Einfluss und Machtpotentialen nicht-staatlicher Akteure zu verzeichnen ist, dann müsste dies auf Kosten der Macht und des Einflusses staatlicher Akteure geschehen. Daraus ergibt sich, dass Regional GovernanceInitiativen mit bestehenden, demokratisch legitimierten Akteuren und Institutionen um Einfluss und Macht konkurrieren.

Meine Ergebnisse zeigen, dass im Rahmen von ILE nichtstaatliche Akteure (erstmals teil-) autonom über die Verwendung staatlicher Fördermittel entscheiden können (Giessen und Böcher 2008, Giessen und Böcher 2009). Diese Ermächtigung (empowerment) unterer Ebenen und privater Akteure findet jedoch unter Einschränkungen statt. Eine Verschiebung informaler Machtpotentiale zu Gunsten nicht formal-demokratisch legitimierter Akteure ist zu beobachten: Der Aufbau von Governance-Strukturen und Institutionen bei der Implementierung von ILE, wie z.B. das Regionalmanagement und Regionale Partnerschaften, treten in Konkurrenz zu etablierten Strukturen des regionalen „Governments“ (Giessen 2010). Die (Vor-)Machtstellung demokratisch legitimierter regionaler Institutionen gerät von zwei Seiten unter Druck. Einerseits regieren obere politische Ebenen (hier EU und Bund) informal, im Sinne einer Multi-level Governance (Marks 1993), in die Region hinein und versuchen dort, ihre spezifischen Ziele durchzusetzen. Andererseits können in regionalen Governance-Strukturen Entscheidungen autonom und teils gegen die Interessen regionaler Institutionen sowie regionaler und lokaler Politiker mit Finanzmitteln der oberen Ebenen als Machtressourcen durchgesetzt werden (Giessen und Böcher 2008, Böcher 2006). Dies erklärt, warum das etablierte regionalpolitische System repräsentiert durch demokratisch legitimierte Akteure und Institutionen, die regionalen Prozesse oft durch öffentliche Verwaltungen zu dominieren versucht (Giessen und Böcher 2008).

Die Konkurrenz zwischen Governance und Government lässt den etablierten Institutionen folglich zwei Optionen: die Abwehr des Governance-Ansatzes und die Verteidigung der eigenen Stellung oder die Vereinnahmung und das Umdefinieren der Interventionen zum eigenen Nutzen (Giessen 2010). In erstem Falle werden durch die Gegenwehr des Government eine Ausbreitung und Etablierung der Regional Governance limitiert und der Zugang zivilgesellschaftlicher Akteure gewissermaßen im Keim verhindert. Dies ist im Falle der ILE-Reformierung im Rahmen der Gemeinschaftsaufgabe Agrarstruktur und Küstenschutz (GAK) zu beobachten, innerhalb derer Tendenzen einer Regional Governance systematisch blockiert und umdefiniert wurden (Giessen et al. 2006, Giessen und Böcher 2008). Im zweiten Falle, der Integration von Governance in das Government, wird automatisch eine Vormachtstellung von Vertretern des politischen Systems etabliert, mit der sich die „non-decisions“ des formellen Systems auf den innovativen Ansatz übertragen. Dies war der Fall bei der Formulierung der Operationellen Programme der Länder für das LEADER-Programm, wo häufig gewissermaßen „zu innovative“ Elemente, wie ein regionales Budget oder die Projektbewilligung durch die Regionen, umdefiniert und entschärft wurden (Giessen und Böcher 2008, Giessen 2010). 


\subsubsection{Umgehung formal legitimierter politischer Ebenen}

Im Bereich der EU-Strukturpolitik (hier: LEADER+) besteht ein „,beachtliches Konfliktpotential über die Kompetenzenverteilung" zwischen der EU und den Nationalstaaten (Marks 1996: 340). Der inländische institutionelle Kontext, wie z.B. die starke Tradition des „departemental policy-making“ und die Definitionsmacht nationaler Institutionen bzgl. alternativer Politikansätze der EU (Conzelmann 1998: 8-9) dürften sich bei weitreichender Einbeziehung der nationalstaatlichen Ebene restriktiv auf die Umsetzung der Ziele der EU auswirken. Ähnliches gilt für das Regional Governance-Programm des Bundes (Regionen Aktiv), welches durch umfangreiche Einbeziehung der Landesebene im Rahmen der GAK ihren integrierten Anspruch hätten reduzieren müssen (vgl. Rudolph 2005). Daher wird angenommen, dass bei der Formulierung und Implementierung von ILE-Programmen Strategien verfolgt werden, die den inhaltlichen Einfluss intermediärer politischer Ebenen reduzieren.

Für den Bereich der ILE-Programme zeigt meine Dissertation, dass diese Strategie der Umgehung formal legitimierter Strukturen sowie intermediärer politischer Ebenen Anwendung findet. Im Falle von LEADER+ verfügt die EU über keine expliziten Kompetenzen zur ländlichen Entwicklung. Da das Programm jedoch im Rahmen der Strukturpolitik als Gemeinschaftsinitiative und ebenfalls zeitlich begrenzt aufgelegt wurde, gelten in diesem Fall auch die Regeln der Strukturpolitik und deren Partnerschaftsprinzip, welches lediglich die Bundesländer als Verhandlungspartner vorsieht (Axt 2000). Somit bleiben die Nationalstaaten ohne inhaltlichen Einfluss (Giessen und Böcher 2008). Im Falle des Bundesmodellvorhabens „Regionen Aktiv“ wurden die Länder bei der Programmformulierung und zu Beginn der Implementierung faktisch und intentional umgangen (Giessen und Böcher 2008, Giessen 2010). Diese besitzen jedoch qua Grundgesetz die ausschließliche Kompetenz in der ländlichen Entwicklungspolitik (siehe dazu näher Giessen und Böcher 2008). Eine so gut wie sichere Blockade durch die Länder als „Vetospieler“ (Benz 2003) in der GAK wurde somit verhindert (Giessen und Böcher 2008). Der Politikansatz konnte als Pilotvorhaben zwar zeitlich limitiert, jedoch nicht inhaltlich abgeschwächt umgesetzt werden.

\subsubsection{Interessengeleitete Regional Governance-Prozesse}

Der formale Anspruch der ILE-Programme, innovativ zu gebietsbezogenen Problemlagen beizutragen, muss ergänzt werden um das informale Kalkül der politischen Initiatoren, mit diesem politischen Ansatz auch ihre Interessen verfolgen zu können (Prittwitz 1994). Daher nehme ich an, dass entgegen der Theorie der kollaborativen Planung (Healey 1997), Regional-Governance-Prozesse (auch) interessengeleitet sind. Dies trifft sowohl für die Formulierung der Politik auf zentraler Ebene, als auch für den Vollzug in regionalen Politikprozessen zu.

Die vorliegende Dissertation macht sowohl vor und während der Formulierung als auch im Vollzug der Programme auf regionaler Ebene eine Beteiligungsdynamik deutlich, wonach bereits vorab existierende Interessenkoalitionen im anschließenden politischen Prozess stark begünstigt werden. In den Fällen LEADER+ und Regionen Aktiv war zu beobachten, dass ein enges informales Bündnis weniger Akteure den Politikprozess initiierte und somit dessen Agenda maßgeblich (vor-) bestimmte (Giessen und Böcher 2008). Gefolgt wurde diese Phase von einer breiten Beteiligung unterschiedlichster Interessen in formalisierten Arenen (z.B. dem Regionen Aktiv Beirat oder in sog. Regionalen Partnerschaften). Der Vollzug hingegen wurde durch einige Wenige geleistet, die als Projektträger öffentlich geförderter Projekte bzw. als Berater in der Begleitung und Umsetzung des Programms profitierten. Diese Akteure gehörten meist der initiierenden Koalition an (Giessen und Böcher 2008). Somit war es den Bündnissen möglich, durch eine frühe Formulierung und Gestaltung der Rahmenbedingungen die Prozesse strukturell zu ihren Gunsten zu beeinflussen. ${ }^{8}$ Dieser Befund zeigt, dass regionale Governance-Prozesse durchaus von Anfang an interessengeleitet sein können und nicht zwangsläufig problemlösungsorientiert im Sinne kollektiver Ziele und nach dem Modell kollaborativer Planung verlaufen.

\subsubsection{Anfälligkeit von Regional Governance gegenüber starken Interessen}

Der Bedeutungszuwachs nicht-staatlicher Akteure bei Regional Governance kann sowohl zivilgesellschaftliche als auch privatwirtschaftliche Akteure betreffen. Da letztere über effektivere Organisationsstrukturen und ausreichende Ressourcen verfügen, können diese Regional Governance-Prozesse leicht zu ihrem Vorteil gestalten und schwache Interessen dominieren (Winter und Willems 2000).

\footnotetext{
${ }^{8}$ Dies muss nicht zwangsläufig immer der Fall gewesen sein, jedoch ist dieses Phänomen aus Sicht der Nutzenmaximierung einzelner Akteure durchaus zu erklären.
} 
Die Beteiligung der Akteure auf regionaler Ebene findet in der ILE meist über ehrenamtliches Engagement statt (Giessen und Böcher 2008). Vor dem Hintergrund der o.g. Beteiligungsdynamik und besonders der Beteiligung am Agenda-Setting haben die von mir durchgeführten Fallstudien Hinweise erbracht, dass diejenigen Interessen, die Personalressourcen zur Verfügung haben, sich leicht gegenüber schwach repräsentierten Interessen durchsetzen, die regionalen Prozesse dominieren und dies sogar unter der legitimatorischen Wirkung einer breiten Beteiligung tun (Giessen und Böcher 2008, 2009). Dieses Phänomen konnte in den bisherigen Analysen zwar in Ansätzen nachgewiesen werden, es verbleibt jedoch weiter ein wichtiger Gegenstand für künftige Studien.

\subsubsection{Sektoraler Bias integrierter Regional Governance-Programme}

Eine Bearbeitung und Formulierung von Politik gestaltet sich, dem Bild der rationalen Verwaltung folgend (Weber 1922), in vielen Politikfeldern sektoral (Bönker 2007). ${ }^{9}$ Die Integration externer Belange in Sektorpolitiken bleibt auch nach umfangreichen Studien und Anstrengungen um eine Politikintegration weiterhin ein meist formaler Anspruch, der sich nur schwerlich in effektive Politikpraxis transferieren lässt (Giessen 2011a, b). Selbst wenn Programme formal den Anspruch erheben, integriert zu sein, so kann eine solche Wirkung nicht automatisch angenommen werden. Akteure wirken an der Formulierung von Problemdefinitionen mit, welche die eigenen Interessen sowie die ihrer Organisationen oder deren industrieller Klientel einfließen lassen (Jänicke 2006). Somit ist davon auszugehen, dass auch integrierte Regional Governance-Programme einen sektoralen Bias aufweisen. Dies gilt auch für ILE-Förderprogramme, die auf Regional Governance-Kriterien aufbauen (Böcher, Krott und Tränkner 2008) und formal den Anspruch erheben, unterschiedliche Sektoren gleichermaßen als Adressaten zu haben (Elbe 2007).

Die Ergebnisse meiner Arbeit zeigen, dass diese Programme ebenfalls einen sektoralen Bias aufweisen (Giessen 2008b, Giessen und Krott 2009). In der ILE nehmen Forstakteure diese Programme nach wie vor als landwirtschaftlich ausgerichtet im Sinne einer erweiterten Agrarstrukturförderung wahr (Giessen 2008b). Sektoraler Bias bedeutet für mich, dass die Programme mit einigen Interessen eher kompatibel sind als mit anderen. Der sektorale Bias der ILE-Programme bewirkt, dass es zwischen den Programmen und nahestehenden Politiksektoren zu institutionelle Übereinstimmungen („level of fit“, Lenschow 2002) kommt, während der institutionelle Aufbau konkurrierender Politiksektoren häufig nicht kompatibel ist und sozusagen „level of non-fit“ auftreten (Giessen 2008b). Dies zeigt, dass manche Interessengruppen nicht die (hier: institutionellen) Kapazitäten besitzen, um zu partizipieren (Giessen und Krott 2009). Eine effektive intersektorale Koordination durch Förderprogramme ist somit nicht möglich. Zu dieser Eigenschaft der Förderprogramme kommt die Tatsache, dass es Organisationen (hier z.B. Bundesministerien und Generaldirektionen der EU als Programmanbieter) und deren Interessen entgegenläuft, untereinander koordiniert zu werden (Giessen et al. 2008). Als Folge dieser Eigenschaft der ILE-Programme fällt es der Forstwirtschaft schwer, den potentiellen Nutzen zu realisieren.

\subsubsection{Sektorale Resistenz gegen Integrationsversuche durch Regional Governance}

Politiksektoren kommt in der Bearbeitung politischer Problemlagen ein hoher Stellenwert zu (Hubo und Krott 2007). Diese sind zu verstehen als konkurrierende Politik-Subsysteme, die auf den Erhalt und Ausbau ihrer Autonomie bedacht sind (Hubo und Krott 2009, Bönker 2007). Daher liegt es nahe, dass sich Politiksektoren den Integrationsversuchen einer Regional Governance-Strategie widersetzen.

Meine Dissertation zeigt, dass sektorale Akteure die integrierte Strategie auf zentraler Ebene der Interessenvertretungen einerseits als nicht nützlich, andererseits als Bedrohung sektoraler Interessen bewerten (Giessen et al. 2006, Giessen und Böcher 2008). Sie entziehen sich folglich dem Kooperationsangebot bzw. dem Koordinationsversuch (Giessen und Krott 2009). Informationen zu den Programmen werden nicht über sektorale Netzwerke kommuniziert und stehen den Forstakteuren (z.B. privaten Waldbesitzern oder Forstamtsleitern) nicht zur Verfügung (s. Kap. 4.1.2.). Somit selektieren die Fachverwaltungen bzw. andere forstliche Interessenvertretungen die Information nicht auf ihre individuelle und tatsächliche Nützlichkeit hin, sondern aufgrund von (teils ideologischen) Annahmen und bauen dies zu einer Sektorstrategie aus (Giessen und Böcher 2009).

Dieser Befund trifft im besonderen Maße auf die Forstwirtschaft zu (siehe dazu Giessen 2008b). Bei der Programmformulierung nahmen keine forstwirtschaftlichen Interessenvertretungen teil (Böcher und Giessen 2006; Giessen und Böcher 2008). Dazu gibt es zwei mögliche Erklärungen. Eine erste erklärt das Fernbleiben forstlicher Akteure als eine politische Strategie, rein sektorale Förderpolitik zu bevorzugen

${ }^{9}$ Das Phänomen der Politikfelder an sich ist schon Beleg für diese These. 
und zu verhindern, dass eine Teilnahme zur Legitimation des intersektoralen Ansatzes beitragen würde (vgl. dazu Giessen und Böcher 2009).

Ein zweiter Erklärungsansatz ist, dass forstliche Interessenvertretungen bei der Formulierung nicht eingeladen wurden und somit keine Informationen zu den Beteiligungsmöglichkeiten vorhanden waren. Ein solches Vorgehen von Seiten der Programminitiatoren, die sich in ihrem normativen Konzept der ILE formal auf offene Prozesse und Beteiligung aller relevanter Gruppen berufen, ist als unwahrscheinlich einzustufen, da somit deren politische Interventionen anfällig gegenüber öffentlicher Kritik gewesen wären und die benötigte Output-Legitimität des Governance-Ansatzes riskiert worden wäre.

\subsubsection{Integration der Sektoren nicht in der Regelförderung}

Da es im Interesse sektoraler Verwaltungen liegt, eigene Haushalte und Förderprogramme zu erhalten und auszubauen (Krott 2001), ist eine sektorübergreifende Integration über Regional Governance im Rahmen sektoraler Förderung nicht zu erwarten. Pilotprogramme bieten hier politische Innovationsmöglichkeiten, da diese nicht unmittelbar in die Märkte, Budgets und Institutionen der Sektoren eingreifen (Jänicke und Jörgens 2004) und zeitlich begrenzt sind.

Die Interessenlagen der im Rahmen meiner Fallstudien analysierten Fachverwaltungen und deren gesellschaftlicher und industrieller Klientel lassen sich anhand eines beobachteten Pilot-MainstreamPhänomens verdeutlichen. Der Grad, zu dem der normative Anspruch von Regional Governance in der Förderpolitik umgesetzt werden konnte, variiert stark zwischen zeitlich begrenzten Pilotprogrammen und der Regelförderung (Giessen 2009, 2010, Giessen et al. 2006, Giessen und Böcher 2008). Pilotprogramme wurden i.d.R. unter der administrativen Diskretion einzelner Fachverwaltungen (also gemäß Art. 65 GG nach dem Ressortprinzip) oder Einheiten dieser initiiert und in sog. politischen „windows of opportunity“ formuliert (Giessen und Böcher 2008: 57). Regionen Aktiv wurde während einer u.a. durch BSE sowie Maul- und Klauenseuche ausgelösten agrarpolitischen Krise initiiert. Das mit der Umsetzung beauftragte Fachreferat favorisierte einen Politikansatz, der weg von reinen Agrarsubventionen führen sollte. Die Regelförderung hingegen, welche durch eine hohe Pfadabhängigkeit nur schwer reformierbar ist (Rudolph 2005), verkörpert genau jenen sektoralen Ansatz, den es durch die Pilotprogramme zu umgehen galt. Im Fall der integrierten ländlichen Entwicklung wirkten die konservatorischen bürokratischen und sektoralen Kräfte starker Agrar- und Verwaltungsinteressen. So war bei der GAK-Reform der beobachtete Effekt besonders konservatorisch (siehe Giessen 200910), da die Länder als Vetospieler auftraten. Gerade hier finden sich landwirtschaftliche Interessen besonders organisiert und institutionalisiert (Giessen und Böcher 2008) ${ }^{11}$. In der Mainstream-Förderung der EU war der Effekt bei Einführung zentraler Regional Governance-Elemente in die Regelförderung des ELER zwar auch konservatorisch, jedoch weniger stark ausgeprägt als im vorigen Falle (Giessen et al. 2008). Dies erklärt sich aus dem generellen Steuerungsdefizit, welches der EU in vielen Politikfeldern inhärent ist. Um ihre Ziele nicht gänzlich im Mehrebenenspiel durch den nationalen institutionellen Kontext verwässern zu lassen, was im Falle sektoraler Politikansätze sicherlich die Folge wäre, ${ }^{12}$ besetzt die EU mit dem Thema der ländlichen Entwicklung ein neues Politikfeld, das durch einen Querschnittscharakter geprägt ist und für welches die Zuständigkeiten noch nicht vollständig formal geregelt sind.

\subsubsection{Sektorübergreifende Integration nur im Vollzug auf regionaler Ebene}

Der beschriebene starke Einfluss sektoraler Institutionen und Akteure macht eine Integrationswirkung von Regional Governance in der Programmformulierung unwahrscheinlich. Im regionalen Vollzug bestehen dann lediglich eingeschränkte Potentiale, sektorübergreifende Kooperationen zu erreichen. Die Region als neue und relativ schwach institutionalisierte Ebene politischer Problembearbeitung (Bergmann 2000) verbleibt somit als einzige Ebene, auf der sich Integrationserfolge einstellen können.

Die Ergebnisse der vorliegende Arbeit machen deutlich, dass bei o.g. sektoraler Politikformulierung als Handlungsrahmen für den Programmvollzug lediglich geringe Möglichkeiten verbleiben, um Integrationsleistungen zu erbringen (Giessen et al. 2008). Ebenso ist es schwer, darin einen speziellen Nutzen für eine

\footnotetext{
${ }^{10}$ Eine Ausnahme könnte hier in der ELER-Förderung des Landes Schleswig-Holstein gesehen werden (siehe Tränkner und Giessen 2007). Diese Ansicht wird jedoch in Giessen et al. (2008) verworfen und gezeigt, dass das System der Regelförderung auch hier nahezu rein sektorale Interessen widerspiegelt.

${ }^{11}$ Land- und Forstwirtschaft sind nach dem Grundgesetz Länderkompetenz

${ }^{12}$ Für das Politikfeld Forstwirtschaft trifft dies sicherlich zu, da hierzu keine gemeinsame Politik nach Römer Verträgen besteht. Aber auch im Bereich Landwirtschaft dürfte der Einfluss nationaler Institutionen auf die tatsächliche Politik enorm sein (vgl. Conzelmann 1998).
} 
in der Problemdefinition, dem Agenda-setting sowie der Programmformulierung nicht beteiligte und berücksichtigte Adressatengruppe (Forst) zu realisieren (Böcher und Giessen 2006, Giessen und Böcher 2008). Generell ist eine sektorübergreifende Zusammenarbeit auf regionaler Ebene leichter, da hier tradierte und formal institutionalisiere Interessen (noch) nicht in ausgeprägter Form existieren.

Unter den Prämissen der Nichtkoordination in der Programmformulierung und der Absage forstlicher Interessenvertreter an integrierte Programme scheint es bemerkenswert, dass sich im Rahmen von Regional Governance doch einzelne erfolgreiche Kooperationsprojekte, mit denen sich forstliche Eigeninteressen verfolgen ließen, entstanden sind (siehe dazu Giessen et al. 2006, Giessen und Böcher 2008, Ortner 2009). Diese Erfolge sind auf Koordinationsbemühungen im Rahmen der Implementierung zurückzuführen. Voraussetzung hierfür waren der Austausch der Akteure im relativ offenen Diskurs im Rahmen gemeinsamer Strategiebildung und in Foren wie den Regionalen Partnerschaften sowie Kommunikationsund Koordinationsleistungen des Regionalmanagements als intermediäre Organisationen mit dem Ziel der Identifizierung von Kooperationsmöglichkeiten. Diese integrierten Arenen und Institutionen sind also nicht Selbstzweck, sondern übernehmen die Funktion einer Vermittlung für Akteure, die sich noch nicht gut (genug) kennen oder deren gegenseitiger Nutzen erst unter veränderten Problemlagen deutlich wird (Giessen 2010). Die Weiterentwicklung der integrierten Netzwerke unter Regionen Aktiv hin zu Wertschöpfungspartnerschaften (Giessen und Böcher 2008) zeigt die Dynamik, die sich dahinter verbirgt, welche auch als Effektivierung solcher Ansätze begriffen werden kann. Ihr ist allerdings eine sektoralisierende Tendenz bereits inhärent. 


\section{Schlussfolgerungen}

Ich konnte zeigen, dass die ILE sowohl konventionelle als auch innovative forstliche Potentiale bereithält. Diese sind jedoch nicht für alle Forstakteursgruppen gleichermaßen realisierbar. Daraus schließe ich, dass eine einheitliche Sektorstrategie für alle Forstakteure zur Teilnahme an Regional Governance nicht zielführend ist. Um der Forderung Ortners (2009) nach frühzeitiger und strategischer Entscheidung über eine Teilnahme einzelner Forstakteure an ILE zu entsprechen, müsste vielmehr der spezifische Nutzen einzelner Akteursgruppen deutlicher gemacht und zielgruppenorientiert verbreitet werden. Die Bereitstellung von Informationen zu ILE-Programmen wäre hier ein Ausgangspunkt, die Akteure in die Lage zu versetzen, ihren antizipierten Nutzen kalkulieren zu können. Eine solche Strategie erlaubt es dann, die konventionellen Potentiale mit geringem Aufwand zu realisieren und innovative Potentiale auf ihren Nutzen hin zu prüfen. Im Rahmen der ILE-Programmatik sind jedoch sowohl konventionelle als auch innovative Potentiale nur in Kooperation mit sektorexternen Akteuren realisierbar. Diese Erkenntnisse zur Informationspolitik und Sektorstrategie lassen sich ebenfalls auf andere sektorübergreifende Politikansätze anwenden und könnten der Forstwirtschaft helfen, neue querschnittsorientierte Politik auf ihren spezifischen Nutzen für unterschiedliche Forstakteure zu untersuchen.

Meine Befunde zeigen ferner, dass Bergmann (2000) entsprechend, die Region als Ebene politischer Koordination für die Implementierung kooperativer Governance-Ansätze geeignet ist. Dies ist u.a. darauf zurückzuführen, dass sich hier die konkurrierenden Interessen weniger organisiert und institutionalisiert vorfinden lassen, als beispielsweise auf Bundes- oder Landesebene, wo die formale Gliederung in Ministerien bzw. das Vorhandensein starker Interessenverbände die sektorale Bearbeitung politischer Probleme prägen (vgl. Bönker 2007). Jedoch wird sich bei langfristigem Bemühen der Regional GovernanceStrategie eine „Professionalisierung““ (Krott 2001) der regionalen Akteure sowie eine Institutionalisierung der Regionalpolitik einstellen, die die dortigen Macht- und Interessenlagen widerspiegelt. Folglich sind dann auch auf regionaler Ebene integrationshemmende Bedingungen zu erwarten, wie sie durch meine Ergebnisse auf EU-, Bundes- und Landesebene aufgezeigt wurden. Somit stellt sich die Frage nach den mittel- und langfristigen Erfolgsaussichten neuerlich propagierter integrierter Politikstrategien (vgl. Lenschow 2002), wobei die o.g. integrationshemmende Entwicklung auf regionaler Ebene als Hypothese für künftige Analysen verbleibt.

Die vorgefundene Resistenz einzelner Politiksektoren (hier der Forstwirtschaft) gegen integrierte Regional Governance-Programme sowie deren inhärenter sektoraler Bias legen nahe, dass ein sektorübergreifender Politikansatz nur sehr bedingt Wirkung erzielen kann. Eine solche Gesamtstrategie wird in der Politikformulierung und im Vollzug blockiert, da eine Integration dem Wesen von Politiksektoren entgegenläuft (Hubo und Krott 2009) und sich aufgrund des Bias der Programme ein Nutzen nicht für alle Akteure verschiedener Sektoren gleichermaßen realisieren lässt. Solche Phänomene sind Ausdruck von sektoralen Machtstrategien, welche auf eine Eigenständigkeit der Politiksektoren sowie deren Ausweitung abzielen. Somit muss ein sektorübergreifender Politikansatz als dauerhaft konfliktreich angesehen werden, 
dessen Wirkung sich am ehesten durch die Strategie der „punktuellen Politikintegration“ (Hubo und Krott 2007) steigern lässt.

Mein Befund, dass eine gehaltvolle sektorübergreifende Integration lediglich in Pilotprogrammen realisierbar ist, spiegelt die o.g. punktuelle Integrationsstrategie wider. Dies zeigt jedoch gleichzeitig, dass im System rivalisierender Politiksektoren eine dauerhafte Gesamtstrategie nicht durchsetzbar ist (Hubo und Krott 2009). Daraus folgt, dass die Wirkungen von ILE den normativen offen-partizipativen und intersektoralen Regional Governance-Anspruch nicht voll erfüllt. Diese Erkenntnis zur Selektivität von Regional Governance bzgl. Akteuren und Sektoren ist bislang in der Theorieentwicklung unberücksichtigt (vgl. Elbe 2007). Diese sollte daher stärker reflektieren, dass auch sektorale Interessen Determinanten der integrierten Regionalpolitik darstellen, die die Handlungsorientierungen der Akteure stark prägen und selbst die Regionalpolitik und deren Programme mitbestimmen.

Eine öffentliche Förderung des integrierten Regional Governance-Ansatzes findet im Rahmen sektoraler Regelförderung nicht statt, da es sich hier um originäre sektorale Politikinstrumente handelt. Somit verbleiben für die Umsetzung eines sektorübergreifenden Ansatzes mittels des Regional GovernanceAnsatzes lediglich temporäre Pilotprogramme. Da aber auch diese von Akteuren bestimmt und formuliert werden, die selbst sektoralen Einflüssen und Zwängen unterliegen, muss die Formulierung tatsächlich integrierter Programme als eine Herausforderung angesehen werden, die es in der politischen Praxis noch zu bewältigen gilt.

Die vorgefundenen Interessen, als primäre Handlungsorientierung der unter regionalen GovernanceArrangements agierenden Akteure verstanden (von Prittwitz 1994, Krott 2001), erklären die Beteiligung und Nichtteilnahme, aber auch programmspezifische Ausprägungen der ILE-Politik. Es wird deutlich, dass eine sektorübergreifende Integration in der realen Welt konkurrierender Interessen und Organisationen durch Regional Governance nur schwer möglich ist. Dazu ist jedoch anzumerken, dass sich das Verfolgen von Interessen auch durch Kooperation erreichen lässt (Benz 1994, Axelrod 2005). Ein relativ offener Diskurs sowie eine intermediäre Instanz, wie sie in der regionalpolitischen Praxis von Regional Governance angeboten wird, müssen in diesem Zusammenhang nicht als Forum gesehen werden, um richtige oder gute Lösungen für die Region zu finden, sondern vielmehr als Schauplatz der Interessen, assoziierten Durchsetzungspotentiale sowie Ideen, die anderweitig nicht frei im sozialen Gefüge fließen (Risse-Kappen 1994). Diese Erkenntnis aus den empirischen Beispielen dieser Arbeit stellt den Hauptbeitrag meiner Dissertation zum Regional Governance-Diskurs dar. Der Befund, dass auch solche Politikansätze interessengeleitet sind, muss sich daher künftig deutlicher und differenzierter in der Theorie widerspiegeln (ähnlich Böcher 2008).

Die beobachtete Konkurrenz zwischen regionalen Institutionen des Government und der Governance tritt wegen der fehlenden formalen Legitimation zum Handeln lediglich dann merklich in Erscheinung, wenn letztere mit Ressourcen zur Umsetzung ihrer Ziele ausgestattet sind. Eine Unterstützung kann hier entweder von öffentlicher oder privatwirtschaftlicher Seite erfolgen. Die öffentliche Förderung ist folglich eine Machtstrategie oberer politischer Ebenen (hier von EU-Kommission und Bundesregierung), die somit - teilweise unter Umgehung intermediärer Ebenen - ihre Ziele in den Regionen umsetzen können und im Kampf um Kompetenzen (Conzelmann 1998) durch die Ausübung von Staatstätigkeit Fakten zu ihren Gunsten schaffen.

Wenn Regional Governance hingegen auf materielle Unterstützung aus der Wirtschaft zurückzuführen ist, werden folglich wirtschaftliche Interessen bevorzugt. Dies kann zur Folge haben, dass schwache Interessen in solchen Prozessen der informellen Raumplanung nicht berücksichtigt werden. Somit kommt dem Staat bei Regional Governance eine wichtigere Rolle zu, als die Theorie bisher berücksichtigt. Der Schutz schwacher Interessen wird in den Fokus rücken, wenn sich professionalisierte starke Gruppierungen (wie Wirtschaftsunternehmen und -verbände, vgl. Winter und Willems 2000) routinemäßig der Regional Governance-Strategie bedienen, um ihre Interessen effektiver zu verfolgen. Aber auch im Bezug auf eine zentrale Annahme der Governance-Diskussion, nämlich dem wachsenden Einfluss privater Akteure auf Politik (Peters und Pierre 1998), bleibt festzuhalten, dass diese im vorliegenden Fall nur im Rahmen von Modellvorhaben nennenswert in Erscheinung traten. Somit ist deren Beteiligung im Rahmen der ILEPolitik insgesamt entweder symbolischer Natur oder zumindest temporär begrenzt. Damit beschreibt der untersuchte Regional Governance-Ansatz, im Gegensatz zu Agrawal et al. (2008), keinen grundlegenden Politikwechsel, was auch von Hogl et al. (2008) für weitere Bereiche einer Forest Governance bestätigt wird.

Für die Planungstheorie haben diese Ergebnisse ebenfalls Auswirkungen. Das Modell des kollaborativen Planens (Healey 1997) muss die Interessen der Beteiligten als (legitimen) Faktor berücksichtigen, der einen großen Einfluss auf Ergebnis und Wirkung informeller Raumplanungsprozesse ausübt. Ein durch- 
weg offener Diskurs, wie ihn diese Theorie unter Bezug auf Habermas zugrunde legt, konnte empirisch nicht beobachtet werden. Vielmehr bedingen die Strategien der Akteure eine strategische (z.B. sektorale) Begrenzung des Diskurses um den Planungsprozess (ähnlich Benz and Meincke 2007). Dieser strategischen Exklusion versucht die ILE mit o.g. intermediären Instanzen und der Bereitstellung eines instersektoralen Forums zu begegnen.

Bezüglich einer möglichen Bedeutungszunahme von Regional Forest Governance lässt sich abschlieBend festhalten, dass eine effektive Regelung waldbezogener Angelegenheiten im Rahmen von ILE nicht beobachtet werden konnte. Solche sektorfremde Regional Governance wird durch die organisierten und institutionalisierten Forstinteressen auf zentraler Ebene verhindert. Diese Art der standardisierten Interessenvertretung könnte hier mögliche Bündnisinnovationen auf lokaler Ebene sowie die Weiterentwicklung sektoraler Politikstrategien blockieren und sie konserviert das bestehende institutionelle und strategische Portfolio der Forstakteure. Welche Strategie aus Sicht einzelner Forstakteure nutzenbringender ist, bleibt jedoch noch zu zeigen. Notwendig für eine solche Bewertung wäre ein kalkulierter Eintritt der institutionalisierten Forstakteure (Verbände, Verwaltungen) in Regional Governance-Prozesse (vom Agendasetting und der Politikformulierung über den Vollzug bis hin zur Bewertung der Programme), um eine weitere Praxiserprobung zu ermöglichen und somit empirische Beispiele für eine nach Akteursgruppen differenzierte Analyse bereitzustellen. Um die empirische Ausprägung einer Regional Forest Governance und die politischen Rahmenbedingungen ihres Zustandekommens tiefer gehend zu analysieren, bieten sich die Beispiele der „Model Forests“ oder der französischen „chartes forestières de territoire“ für die künftige Forschung an. 



\section{Zusammenfassung}

Eine Regionalisierung von Politik wird im Rahmen der integrierten ländlichen Entwicklung (ILE) auch für die Forstwirtschaft relevant. Der Politikansatz der ILE basiert auf dem gebietsbezogenen, sektorübergreifenden und partizipativen Steuerungskonzept einer Regional Governance. Jedoch wurde hier ein möglicher Nutzen für Forstakteure bisher nicht ausführlich untersucht. Ferner deutet die geringe Beteiligung der Forstwirtschaft im Rahmen des integrierten Ansatzes darauf hin, dass hier politische Kräfte wirken, die in der Regional Governance-Diskussion nicht systematisch analysiert wurden. Daher geht die Studie der Frage nach, welche forstlichen Potentiale eine Kooperation im Rahmen der integrierten ländlichen Entwicklung bietet und für welche Forstakteure dieser Nutzen realisierbar ist. Ferner wird am Beispiel der Einbeziehung von Forstwirtschaft beleuchtet, welche politischen Kräfte die integrierte ländliche Entwicklung sowohl in der Politikformulierung auf übergeordneten politischen Ebenen als auch im regionalen Vollzug bestimmen.

Basierend auf dem theoretischen Stand der Regional Governance-Diskussion geht die Analyse den Forschungsfragen anhand qualitativer Fallstudien zu Förderprogrammen nach, welche eine integrierte Entwicklung ländlicher Räume fördern. Darunter werden als Pilotprogramme die EUGemeinschaftsinitiative „LEADER+“ sowie das Bundesmodellvorhaben „Regionen Aktiv“ betrachtet. Als Vertreter der Regelförderung werden die Gemeinschaftsaufgaben „Agrarstruktur und Küstenschutz“ (GAK) und „regionale Wirtschaftsstruktur“ (GRW), sowie die zwei wichtigsten EU-Strukturfonds (ESF, EFRE) und der „Europäische Landwirtschaftsfonds für die Entwicklung des ländlichen Raums“ (ELER) analysiert. Die angewandten Methoden umfassen Inhaltsanalysen der Programmdokumente, 68 Experteninterviews zu Governance-Fragen, der Rolle der Forstwirtschaft in ILE, sowie zur Formulierung und Implementierung o.g. Programme. Diskussionen in Fokusgruppen, Sekundärdatenanalysen und nichtteilnehmende Beobachtungen ergänzen und validieren die erhobenen Daten.

Die Ergebnisse zeigen, dass für die Forstwirtschaft sowohl konventionelle Potentiale wie die zusätzliche Mobilisierung von Rohholz und die Akquise von Fördergeldern bestehen. Zudem wurden innovative Potentiale identifiziert. Diese umfassen Produkt- und Bündnisinnovationen sowie die Möglichkeit, sektorale Strategien zum Umgang mit integrierten Programmen weiterzuentwickeln und forstliche Themen auf die (regional)politische Agenda zu setzen. Die vorgefundenen Potentiale können jedoch aufgrund eines unterschiedlichen Informationsstandes zu den ILE-Programmen, bestehender Kapazitäten und Ressourcen sowie unterschiedlicher Anreizwirkungen nicht von allen Forstakteuren gleichermaßen realisiert werden. Der Großprivatwald sowie kommunale Waldbesitzer wurden als die Akteursgruppen ausgemacht, für die der Nutzen am ehesten realisierbar ist.

Bezüglich der politischen Kräfte forstlicher Beteiligung an ILE treten die folgenden Determinanten in den Vordergrund: Regionale Governance-Prozesse und -Institutionen treten mit etablierten und demokratisch legitimierten Government-Institutionen und -Akteuren in Konkurrenz und werden entweder in ihrer Wirkung behindert, oder durch das Government umdefiniert, um dessen Ziele zu verfolgen. Durch 
den Regional Governance-Ansatz erlangen staatliche Akteure höherer politischer Ebenen Einfluss auf regionaler Ebene. Sie tun dies auch unter Umgehung formal legitimierter intermediärer politischer Ebenen (z.B. der Länder). Entgegen der zumeist problemlösungsorientierten Regional Governance-Diskussion sind sowohl die Initiierung und Formulierung von ILE-Programmen auf zentraler Ebene als auch deren regionale Umsetzung stark vom Interesse der Initiatoren und deren Interessenskoalitionen geprägt. Somit kann der Regional Governance-Ansatz leicht durch starke Akteure und deren Interessenskoalitionen instrumentalisiert werden. Der instersektorale Anspruch der Förderprogramme wird nicht durchgängig erfüllt. Tritt er in Pilotprogrammen noch zum Vorschein, so wird er in der sektoralen Regelförderung nicht erfüllt. Ein sektoraler Bias konnte aber bei allen integrierten Programmen beobachtet werden. Aber auch die adressierten Sektoren, wie z.B. die Forstwirtschaft, tragen zur Hemmung des intersektoralen Ansatzes bei. Diese erwehren sich den Integrationsversuchen durch Regional Governance-Programme auf zentraler Ebene. Eine erfolgreiche sektorübergreifende Integration konnte somit lediglich im regionalen Vollzug und unter den restriktiven Rahmenbedingungen der sektoralen Formulierung beobachtet werden.

Aus den Ergebnissen wird geschlossen, dass eine Gesamtsektorstrategie nicht geeignet ist, den Nutzen für die Forstwirtschaft aus ILE zu realisieren. Ein differenziertes Vorgehen sowie die Kooperation mit sektorexternen Akteuren sind notwendig, um die forstlichen Potentiale zu nutzen. Um diese jedoch abschätzen zu können und quantifizierbar zu machen, ist ein kontrollierter Eintritt von Forstakteuren in kooperative Regionalentwicklung sowohl in deren Formulierung, also auch in der Umsetzung nötig.

Die regionale Ebene ist (derzeit) für die Umsetzung kooperativer Regional Governance-Ansätze geeignet. Mit zunehmender Professionalisierung und Institutionalisierung werden sich voraussichtlich auch hier integrationshemmende Bedingungen einstellen. Jedoch birgt die derzeitige Machtstrategie der Regional Governance einen Nutzen für obere politische Ebenen und starke Akteure, der Gegenstand künftiger kritischer Studien sein sollte. Die Machtstrategie der adressierten Politiksektoren beinhaltet deren Resistenz gegen die Integration und den Erhalt sektoraler Politikinstrumente wie z.B. deren Förderung. Die folgenden Blockaden sowohl in der Formulierung als auch in der Umsetzung der Programme mindern daher die Effektivität des regionalen Politikansatzes. Gleichwohl wird anerkannt, dass Regional Governance Bündnisinnovationen ermöglicht, die sowohl für die individuelle Interessenverfolgung der Akteure als auch mit Bezug auf die Lösung regionaler Problemlagen einen Mehrwert bieten.

Aufgrund der o.g. Kräfte, besonders des sektoralen Bias der ILE-Programme und der Resistenz des Forstsektors kam keine effektive Regional Forest Governance zustande. Lediglich punktuell fand die Regelung waldbezogener Probleme im Rahmen konkreter ILE-Projekte auf regionaler und lokaler Ebene statt. Diese Einzelfälle konnten jedoch aus Sicht der jeweiligen Forstakteure durchaus lukrativ im Sinne eines direkten oder mittelbaren Nutzens sein, was die künftige Entwicklung forstpolitischer Strategien zur Teilnahme an integrierten Programmen zur Regionalentwicklung nahelegt. 


\section{Summary: Regional Forest Governance - Potentials for forestry and political drivers in integrated rural development policy}

This study on integrated rural development policy reveals that regionalism, as a political approach, becomes relevant for forestry. The approach is based on the normative concept of regional governance, an ideal which is place-based, participatory and inter-sectoral. Yet, regional governance has so far not been analysed regarding its utility for forestry actors. Indeed, low degrees of forestry participation have been observed within this integrated policy approach. This suggests that there are either no potential benefits for forestry, or that there are political forces in place, which have so far not been reflected by the regional governance discourse. Consequently, this study addresses the following questions: What are the potential benefits for forestry cooperation under regional governance arrangements? For which forestry actors are these potential benefits realisable? And which political forces determine integrated rural development policy at higher levels of policy formulation, as well as, during regional implementation?

Based on the theoretical discourse on regional governance, the analysis addresses these questions using a qualitative case study design. It employs case studies on public funding or support programmes in Germany, which formally claim to support integrated rural development. The EU Community Initiative LEADER + and the Federal demonstration project "Active Regions" (German title: Regionen Aktiv) serve as examples for regional governance pilot programmes. In addition the two German Joint Tasks "Improvement of Agricultural Structures and Coastal Protection" and "Improvement of Regional Economic Structures" as well as the "European Social Fund" (ESF), the "European Regional Development Fund" (ERDF) and the "European Agricultural Fund for Rural Development" (EAFRD) are analysed as case studies representing mainstream funding policy. The primary empirical methods employed are qualitative content analysis of policy documents and expert interviews (68) on rural governance issues, the role of forestry in integrated rural programmes and the formulation and implementation of the programmes. These methods are supplemented and validated using focus group discussions, secondary data analysis and non-participant observations.

The results show that regional governance confers both, conventional and innovative potentials for forestry actors. The former include the mobilisation of timber and the acquisition of public funds for forest enterprises. The latter comprise product innovations, new options for coalitions, the development of sectoral strategies within integrated networks as well as putting forestry issues onto the regional political agenda. Yet these potentials are not realised by all forestry actors. This is due to three reasons: Firstly, the availability of information on regional governance programmes differs between forestry actor groups. Secondly, different resources are available for these actor groups. Lastly, different forest owner categories are incentivised differently by these potentials. Hence, large-scale private holdings and communal forest owners may benefit the most from cooperation under regional governance. 
There are political forces in place determining the participation and potential benefits of specific actors and policy sectors, which have so far been largely neglected by the regional governance discourse. Regional governance processes and institutions are competing with the established and democratically legitimised government institutions for influence and power. As a consequence, governance institutions are either blocked and rendered ineffective, or they are re-defined by actors of rural government to their own benefit. Due to the regional governance approach, state actors from higher territorial levels are gaining influence in regional politics and over regional policy. They do so by circumventing formally legitimised intermediate levels (such as the Federal States). Contrary to the regional governance discourse, which focuses on problem-solving capacity and claims to provide more effective policy means, the case studies reveal that the initiation and formulation of regional governance programmes at central level together with their implementation at regional levels are driven by the self-interests of the initiators and their coalitions. Consequently, the regional governance approach is found to be susceptible to exploitation by powerful interest coalitions, given the implicit lack of state control. The cross-sectoral rhetoric of the programmes has not been fully accomplished. While pilot programmes do indeed meet this claim to a certain extent, mainstream programmes render it ineffective at many stages of the policy cycle. This is partly due to its sectoral bias, which the formally integrated and cross-sectoral regional governance programmes hold. But also the addressee sectors, such as forestry, are impeding cross-sector approaches at all levels and stages. Most resistance can be observed at central levels, such as the Federal States, the federal Government and EU-level, where strong sectoral institutions exist. Successful cross-sector integration can only be observed at regional levels of policy implementation. This, however, has to operate under all the restricting general conditions mentioned above.

No effective regional forest governance can be observed, due to the abovementioned political forces, and especially the sectoral bias of funding programmes and the resistance of the forest sector. Forest issues have been addressed only selectively under regional governance arrangements. These particular cases, however, are beneficial for the respective forestry actors, suggesting the further development of a sector strategy on how to deal with regional governance approaches and integrated programmes. Based on the study's findings, it is concluded that a uniform sector strategy is not appropriate for eliciting the potential benefits from regional governance for diverse forestry actors. Rather, a target group-specific approach, based on forest owner types and/or sizes of enterprises, alongside with cooperation with actors from outside forestry are necessary for successful participation. Yet to assess the potential benefits from cooperation under regional governance, forestry actors need to enter into pilot cooperation during policy formulation and implementation. Based on such experience, the specific benefits of the programmes must be communicated to the specific target groups amongst forestry actors.

The results also indicate that regions are (currently) a convenient level for cooperative and integrated governance approaches due to low degrees of formalisation and institutionalisation, especially of sectoral interests. However, regional politics will necessarily become more professionalised and institutionalised, resulting in conditions which are also impeding integrated approaches. Regional governance, as a power strategy, privileges upper political levels and powerful stakeholders. This should be subject to future scrutiny. The power strategy of the policy sectors involved includes maintaining autonomous sectoral instruments, such as funding budgets and resisting any integration attempts. Resulting blockages to the programmes during their formulation and implementation hence further diminish the effectiveness of the regional governance approach. Despite this, it has to be acknowledged that regional governance is able to produce coalition innovations. These may hold an added value for individual actors in pursuing their interests and may foster regional problem-solving. 


\section{Literatur}

Agrawal, A.; Chhatre, A. und Hardin, R. (2008): Changing Governance of the World's Forests. In: Science, 320, 2008, S. 1460-1462.

Axelrod, R (2005): Die Evolution der Kooperation, 6. Aufl. München u. Oldenbourg.

Axt, H.-J. (2000): EU-Strukturpolitik. Einführung in die Politik des wirtschaftlichen und sozialen Zusammenhalts. Leske + Budrich. Opladen.

Becker, M. (2000): Neuartige Initiativen zur Förderung regionaler Forst- und Holzwirtschaft. In: Dachverband Agrarforschung (Hrsg.), Schriftreihe Agrarspectrum Bd. 30: Regionale Vermarktungssysteme in der Land-, Ernährungs- und Forstwirtschaft. Frankfurt, S. 147 - 155.

Benz, A. (1994): Kooperative Verwaltung: Funktionen, Voraussetzungen und Folgen. 1. Aufl. BadenBaden. Nomos.

Benz, A. (2003): Konstruktive Vetospieler in Mehrebenensystemen. In: Renate Mayntz, Wolfgang Streeck (Hrsg.), Die Reformierbarkeit der Demokratie. Innovationen und Blockaden, Schriften des MPIfG Bd. 45, Frankfurt a.M./New York: Campus, S. 205-236

Benz, A. (2004): Governance - Modebegriff oder nützliches sozialwissenschaftliches Konzept?. In: Benz, A. (Hrsg.): Governance - Regieren in komplexen Regelsystemen. Wiesbaden. S 12-28.

Benz, A.; Meincke, A. (2007): Analyse der Governance Strukturen. Abschlussbericht der Module 3 und 4 zur Begleitforschung Regionen Aktiv 2004-2006.

Benz, A. und Fürst, D. (2003): Region - Regional Governance - Regionalentwicklung. In: Adamaschek, B. und Pröhl, M. (Hrsg.): Regionen erfolgreich steuern. Gütersloh: Bertelsmann-Stiftung. S. 1166.

Benz, A.; Fürst, D.; Kilper, H. und Rehfeld, D. (1999): Regionalisierung. Theorie, Praxis, Pespektiven. Opladen.

Bergmann, E. (2000) Nachhaltige Entwicklung im föderalen Kontext: Die Region als politische Handlungsebene. In: K. Bizer, B. Linscheidt, und A. Truger (Hrsg.) Staatshandeln im Umweltschutz. Berlin. S. 215-239. 
Beyme, von K. (2000): Die politischen Theorien der Gegenwart. 8. Auflage, Wiesbaden.

BMVEL (2005): Ländliche Entwicklung aktiv gestalten. Bonn. Bundesministerium für Verbraucherschutz, Ernährung und Landwirtschaft.

Bodegom, van, A. J.; Klaver, D.; van Schoubroeck, F. und van der Valk, O. (2008): FLEGT beyond T: Exploring the meaning of 'Governance' concepts for the FLEGT process. Wageningen.

Böcher, M. (2006): Regional Governance - Ein Konzept im Spannungsverhältnis zwischen Anspruch und Wirklichkeit. In: v. Blumenthal, J. und Bröchler, S. (Hrsg.): Von Government zu Governance - Analysen zum Regieren im modernen Staat. Münster, Lit-Verlag: 119-141.

Böcher, M. (2007): The concept of regional governance and the promotion of sustainable rural development processes in Germany - Insights from the implementation of 'Active Regions' and 'LEADER+'. In: Rametsteiner, E. (Hrsg.): Proceedings of the 1 ${ }^{\text {st }}$ COST Action E51 Joint $\mathrm{MC}$ and WG meeting. Wien.

Böcher, M. (2008): Regional Governance and Rural Development in Germany: the Implementation of LEADER+. In: Sociologia Ruralis, 48, 4, S. 372 - 388.

Böcher, M. (2008b): Instrumentenwandel in der Umwelt- und Naturschutzpolitik und der Politik zur integrierten ländlichen Entwicklung. Theoretische Grundlagen und Strategien der Praxisumsetzung. Dissertation. Göttingen.

Böcher, M. und Giessen, L. (2006): Forst als Partner in der integrierten ländlichen Entwicklung. In: AFZ Der Wald, 5/2006, S. 263-264.

Böcher, M.; Krott, M. und Tränkner, S. (2008): Regional Governance und integrierte ländliche Entwicklung. In: Böcher, M.; Krott, M. und Tränkner, S (Hrsg.): Regional Governance und integrierte ländliche Entwicklung. Ergebnisse zum Modell- und Demonstrationsvorhaben „Regionen Aktiv“. VS. Wiesbaden. S. 11-22.

Böcher, M; Giessen, L. und Kleinschmit, D. (2008, Hrsg.): Environmental and Forest Governance - The Role of Discourse and Expertise: Proceedings of the International Conference, Göttingen 2007. Göttingen.

Böcher, M; Giessen, L. und Kleinschmit, D. (2009): The role of discourses and expertise in environmental and forest governance. In: Forest Policy and Economics (Sonderheft, im Erscheinen).

Bönker, F. (2007): Interdependenzen zwischen Politikfeldern - die vernachlässigte sektorale Dimension der Politikverflechtung. In: Janning, F. und Toens, K. (Hrsg.): Die Zukunft der PolicyForschung - Theorien, Methoden, Anwendungen. Wiesbaden. VS.

Bultmann, P. (2004): Beihilfenrecht und Vergaberecht : Beihilfen und öffentliche Aufträge als funktional äquivalente Instrumente der Wirtschaftslenkung - ein Leistungsvergleich. Tübingen. 397 S.

Buttoud, G. und Kouplevatskaya, I. (2008): Two new approaches in French forest policy. In: Hogl, K., Nordbeck, R.; Nußbaumer, E. und Pregernig, M. (Hrsg.) New Modes of Governance for Sustainable Forestry in Europe. online unter http://www.boku.ac.at/GoFOR/.

Conzelmann, T. (1998): 'Europeanisation' of Regional Development Policies? Linking the Multi-Level Governance Approach with Theories of Policy Learning and Policy Change. In: European Integration online Papers (EIoP), 2, 4.

Cook, I. R. (2009): Private sector involvement in urban governance: The case of Business Improvement Districts and Town Centre Management partnerships in England. In: Geoforum (2009), doi:10.1016/j.geoforum.2009.07.003. 
Diller, C. (2002): Zwischen Netzwerk und Institution. Eine Bilanz regionaler Kooperationen in Deutschland. Opladen.

Diller, C. (2004): Regional Governance im "Schatten der Hierarchie". In: Raumforschung und Raumordnung, 4-5, 2004, S. 270-279.

Eberlein, B. und D. Kerwer (2002): Theorising the new modes of European Union governance. European Integration online Papers (EIoP). 6 (5). Online unter http://eiop.or.at/eiop/texte/2002005a.htm.

Edwards, B.; Goodwin, M.; Pemberton, S. und Woods, M. (2001) Partnerships, power, and scale in rural governance. Environment and Planning C: Government and Policy, 19, 2, S. 289-310.

Elands, B. H. M. und Wiersum, F. K. (2001): Forestry and rural development in Europe: an exploration of socio-political discourses. In: Forest Policy and Economics, 3, 2001, S. 5-16.

Elands, B. H. M. und Wiersum, F. K. (2003): Forestry and rural development in Europe - Research results and policy implications of a comparative European study. Wageningen.

Elbakidze, M., Angelstam, P. und Axelsson, R. (2007): Sustainable forest management as an approach to regional development in the Russian Federation: State and trends in Kovdozersky Model Forest in the Barents region. In: Scandinavian Journal of Forest Research, 22, (6), S.568-581.

Elbe, S. (2007): Die Voraussetzungen der erfolgreichen Steuerung integrierter Ansätze durch Förderprogramme. Untersucht am Beispiel des Modellvorhabens Regionen Aktiv Dissertation. Aachen.

Elbe, S. und Schubert, D. (2008): Mehr Ökonomie in integrierten Ansätzen, mehr integrierte Ansätze in der Ökonomie. In: Ländlicher Raum, 2008, 1, S. 39-42.

Feiock, R.C. (2007): Rational choice and regional governance. In: Journal of Urban Affairs, 29, Nr. 1, S.47-63.

Fjeld, D. (1997, Hrsg.): Forestry in the Context of Rural Development. Proceedings from the Seventh Meeting-COST Action E3, Bergen Norway, June 8 - 10.1997.

Fürst, D. (2001): Regional Governance - ein neues Paradigma der Regionalwissenschaften? In: Raumforschung und Raumordnung (59) 2001, S. 370 - 380.

Fürst, D. (2004): Regional Governance. In: Benz, A. (Hrsg.): Governance - Regieren in komplexen Regelsystemen. Wiesbaden. S. 45-64.

Fürst, D.; Lahner, M. und Pollermann, K. (2005): Regional Governance bei Gemeinschaftsgütern des Ressourcenschutzes: das Beispiel Biosphärenreservate. In: Raumforschung und Raumordnung 5/2005, S. 330-339.

Giessen, L. (2011a): Horizontal Policy Integration. In: Robbins, P.; Schiffman, H. and Golson, G. (Eds.): Green Issues and Debates. Sage. In press.

Giessen, L. (2011b): Vertical Policy Integration. In: Robbins, P.; Schiffman, H. and Golson, G. (Eds.): Green Issues and Debates. Sage. In press.

Giessen, L. (2010): Regional Governance für ländliche Räume - innovativer Ansatz, politischer Gegenwind und der Weg vorwärts. In: Raumforschung und Raumordnung, 68 (1), .i.E.

Giessen, L. (2009): Regional governance in rural development programmes - Which Role for Forestry? In: Folia Forestalia Polonica, series A, 51 (1), 54-60. 
Giessen, L. (2008): Ministerial conference on the protection of forests in Europe : expert level meetings as a means to integrate the concept of 'public participation' into pan-European decision-making. Göttingen.

Giessen, L. (2008b): Die Zurückhaltung der Forstwirtschaft in der integrierten ländlichen Entwicklung Analyse der politischen Ursachen. In: Forstarchiv, 79/3, S. 116-121.

Giessen, L. und Böcher, M. (2008): Integrated Rural Development Policy in Germany and its Potentials for new Modes of Forest Governance. Institut für Wald-, Umwelt- und Ressourcenpolitik. Wien. $114 \mathrm{~S}$.

Giessen, L. und Böcher, M. (2009): Rural Governance, forestry, and the promotion of local knowledge: The case of the German rural development programme 'Active Regions'. In: Small Scale Forestry, 8 (2), 211-230.

Giessen, L. und Krott, M. (2009): Forestry Joining Integrated Programmes? A question of willingness, ability and opportunities. In: Algemeine Forst- u. Jagdzeitung, 180 (5-6), S. 94-100.

Giessen, L.; Böcher, M.; Ortner, M. und Tränkner, S. (2006): Integrated Rural Development as pathway for innovations - an unexploited potential for forestry -. In: Tikkanen, I.; Zyrina, O.; Rametsteiner, E.; Barreiro, O. and Michalak, R. (Hrsg.) Policies Fostering Investments and Innovations in Support of Rural Development. Warschau. S.38-56.

Giessen, L.; Lukesch, R.; Böcher, M. und Elbe, S. (2008): Politikintegration für ländliche Räume? Die (Nicht-) Koordination der Förderung. In: Elbe, s: (Ed.): Land-Stadt Kooperation und Politikintegration für ländliche Räume - Zentrale Ergebnisse und Handlungsempfehlungen der Begleitforschung Regionen Aktiv 2007 bis 2008. Shaker. Aachen. S. 57-120.

Gingras, P. und Carrier, M. (2006): Economic integration and social cohesion in Quebec: forest cooperatives and regional development. In: Canadian Geographer, 50, (3), S. 358-375.

Glück, P., J. Rayner, und B. Cashore, (2005): Changes in the Governance of Forest Resources. In: Mery, G.; Alfaro, R, Kanninen, M. and Lobovikov, M. (Hrsg.): Forests in the Global Balance Changing Paradigms. IUFRO World Series, Wien. S. 51-74.

Gorsler, D. (2002): Informelle räumliche Planung - Stand der aktuellen Forschung und Forschungsbedarf. ARL: Hannover.

Healey, P. (1997). Collaborative planning. Shaping places in fragmented societies. London, MacMillan.

Healey P. (2003), Collaborative planning in perspective. In: Planning theory, 2 (2), S. 101-123.

Hogl, K., Nordbeck, R.; Nußbaumer, E. und Pregernig, M. (2008): New Modes of Governance for Sustainable Forestry in Europe (Forschungsbericht). online unter http://www.boku.ac.at/GoFOR/.

Hoogstra, M. A.; Schanz, H. und Wiersum, F.K. (2004): Editorial - The future of European forestry between urbanization and reual development. In: Forest Policy and Economics, 6, 2004, S. $441-445$.

Hubo, C. und Krott, M. (2007): Umsetzungsstrategien für integrative Politikansätze am Beispiel invasiver gebietsfremder Arten. In: Zeitschrift für angewandte Umweltforschung, 18, 2, S. 216-226.

Hubo, C und Krott, M. (2009): Politiksektoren als Determinanten von Umweltkonflikten am Beispiel invasiver gebietsfremder Arten. In: Feindt, P. H.; Saretzki, Th. (Eds.): Umwelt- und Technikkonflikte, VS Verlag für Sozialwissenschaften. Wiesbaden.i.E. 
Hucke J., Wollmann H. (1980): Methodenprobleme der Implementationsforschung. In: Mayntz R. (Hrsg) Implementation politischer Programme. Königstein/Ts, 225-226.

Hyttinen, P.; Niskanen, A. und Otitsch, A. (2000): New challenges for the forest sector to contribute to rural development in Europe. In: Land Use Policy, 17, S. 221-232.

Hyttinen, P.; Niskanen, A. und Ottitsch, A., Tykkyläinen, M. und Väyrynen, J. (2002): Forest related perspectives for regional development in Europe. Leiden. Boston. 129 S.

Jänicke, M. (2006): Politikintegration im Mehrebenensystem: das Beispiel der deutschen Umweltpolitik. In: Koch-Baumgarten, S; Rüttgers, P. (Hrsg.): Pluralismus und Demokratie: Interessenverbände - Länderparlarmentarismus - Föderalismus - Widerstand: Siegfried Mielke zum 65. Geburtstag. Bund Verlag, Frankfurt. S. 63-73.

Jänicke, M. und Jörgens, H. (2004): Neue Steuerungskonzepte in der Umweltpolitik. In: Zeitschrift für Umweltpolitik und Umweltrecht, 3, 2004, S. 297-348.

Jann, W. und Wegrich, K. (2003): Phasenmodelle und Politikprozesse: Der Policy Cycle. In: Schubert, K. und Bandelow, N. (Hrsg.): Lehrbuch der Politikfeldanalyse. München, Wien. S. 71-105.

Jones, R.A. (1996): Research methods in the social and behavioral sciences, vol 2. Sinauer, Sunderland.

Kerwer, D. und Eberlein, B. (2002): Theorising the new modes of European Union governance. In: European integration online Papers (EIoP), $6 \mathrm{Nr} .5$, online unter http://eiop.or.at/eiop/texte/2002-005a.htm.

Krott M. (1990): Öffentliche Verwaltung im Umweltschutz, Ergebnisse einer behördenorientierten PolicyAnalyse am Beispiel Waldschutz. Braunmüller, Wien.

Krott, M. (2001): Politikfeldanalyse Forstwirtschaft. Eine Einführung für Studium und Praxis. Berlin. Parey.

Krott, M (2001b): Institutionelle Strategien für den Einsatz von forstpolitikwissenschaftlichen Befragungen. In: Krott, M und Suda, M. (Hrsg.): Befragung als Methode der Sozialforschung in der Forstwissenschaft. Sauerländer`s Verlag, Frankfurt.

Krott, M. (2008): Forest government and forest governance within a Europe in Change. In: Cesaro, L.; Gatto, P. and Pettenella, D (Hrsg.): The multifunctional role of forests - policies methods and case studies. EFI Proceedings No. 55. Gummerus Printing, Saarijärvi, S. 13-25.

Lenschow, A. (2002): Environmental Policy Integration - Greening Sectoral Policies in Europe. Earthscan, London.

Lijphart A. (1977): Comparative Politics and the Comparative Method. In: Macridis R. C., Brown B. E. (Hrsg) Comparative Politics, Illinois, 50-66.

Marks, G. (1993): Structural Policy and Multilevel Governance in the EC. In: Carfuny, A; Rosenthal, G. (Hrsg.): The State of European Community, 2. Aufl. Lynne Rienner Publishers. S. 391-410.

Marks, G. (1996): Politikmuster und Einflusslogik in der Strukturpolitik. In: Jachtenfuchs, M.; KohlerKoch, B. (Hrsg.): Europäische Integration. Leske + Budrich. Opladen. S. 313-344.

Meuser M., Nagel U. (2002): ExpertInneninterviews - vielfach erprobt, wenig bedacht. Ein Betrag zur qualitativen Methodendiskussion. In: Bogner A., Littig B., Menz W.(Hrsg.) Das Experteninterview. Theorie, Methode, Anwendung. Leske u. Budrich, Opladen, 71-94. 
Ojha, H. R.; Cameron, J.; Kumar, C. (2009): Deliberation or symbolic violence? The governance of community forestry in Nepal. In: Forest Policy and Economics, i.E.

Ortner, M. (2009): Erfolgsfaktoren für die Beteiligung forstlicher Akteure an der integrierten ländlichen Entwicklung - Beispiel: LEADER+ Programm der EU-Strukturpolitik. Göttingen.

Ortner, M. (2004): Zusammenarbeit zwischen Forstwirtschaft und LEADER+ weiter ausbaubar. In: LEADERforum (2004), Nr. 2, S. 41.

Parker, A. (2006): Focus group method and methodology: current practice and recent debate. In: International Journal of research and method in education, No. 29, pp. 23-38.

Peters, B. G.und Pierre, J. (1998): Governance without government? Rethinking public administration. In: Journal of Public Administration Research and Theory, 8, Nr. 2, S. 223-243.

Piesch, S. (1998): Neue regionale Initiativen zur Förderung von Forst- und Holzwirtschaft. Diplomarbeit, Freiburg.

Prittwitz, von, V. (1994): Politikanalyse. Leske+Budrich. Opladen.

Pütz, M. (2004): Regional Governance - Theoretisch-konzeptionelle Grundlagen und eine Analyse nachhaltiger Siedlungsentwicklung in der Metropolregion München. Oekom.

Rametsteiner, E. (2009): Governance Concepts and their Application in Forest Policy Initiatives from Global to Local Leve. In: Small-scale Forestry, 8 (2), 143-158.

Rametsteiner, E. ; Weiss, G. und Kubeczko, K. (2005): Innovation and entrepreneurship in forestry in Central Europe. European Forest Institute research report 19. 250 S.

Risse-Kappen, T. (1994): Ideas do not float freely: transnational coalitions, domestic structures, and the end of the cold war. In: International Organization, 48, (2), S. 185-214.

Rudolph, M. (2005): Agrarstrukturpolitik im vereinten Deutschland. Eine Analyse der Gemeinschaftsaufgabe "Verbesserung der Agrarstruktur und des Küstenschutzes" im Lichte der Neuen Politischen Ökonomie. Shaker.

Scharpf, F. W. (1993): Positive und negative Koordination in Verhandlungssystemen. In: Héritier, A. (Hrsg.). Policy-Analyse. Kritik und Neuorientierung. (PVS-Sonderheft 24) Opladen. S. 57 83.

Schraml, U. und Selter, A. (2007): Beyond traditional cooperation: Establishing new commons in private forestry. In: Proceedings of the IUFRO 3.08 Conference 'Improving the triple bottom line returns from small-scale forestry, held in Ormoc, The Philippines, 17.-21.6.2007. (im Erscheinen).

Seintsch, B. (2004): Regionalinitiativen der Forst- und Holzwirtschaft - Wirkungen des Regionalmarketings forst- und holzwirtschaftlicher Akteure zur Aktivierung von regionalen Potentialen. Dissertation. Freiburg.

Tränkner, S. und Giessen, L. (2007): Four paths to mainstreaming the LEADER approach in Germany the case of Schleswig-Holstein. Als beitragende Autoren in: Soto, P. (Hrsg.): Which direction for Rural Development?. critica.

Weber, M. (1922): Wirtschaft und Gesellschaft. Herrschaft. Hanke, E. und Kroll, T. (Hrsg.). Tübingen. Verlag J. C. B. Mohr.

Wiersum, K.F. und Elands, B.H.M. (Hrsg. 2002): The changing role of forestry in Europe: perspectives for rural development. Nature Forest in Society. Universität Vageningen. 
Winter T. v., Willems U. (2000): Die politische Repräsentation schwacher Interessen: Anmerkungen zum Stand und zu den Perspektiven der Forschung. In: Willems U.,

Winter T. v. (Hrsg.): Politische Repräsentation schwacher Interessen, Leske u. Budrich, Opladen, 9-36. 



\section{Anhang: Konstituierende Publikationen / Annex: Constitutive publications}

1. Giessen, L. (2009): Regional governance in rural development programmes - Which Role for Forestry?. In: Folia Forestalia Polonica, series A, 51 (1), 54-60.

2. Giessen, L. (2010): Regional Governance für ländliche Räume - innovativer Ansatz, politischer Gegenwind und der Weg vorwärts. In: Raumforschung und Raumordnung, 68 (1), 3-14.

3. Giessen, L. (2008): Die Zurückhaltung der Forstwirtschaft in der integrierten ländlichen Entwicklung - Analyse der politischen Ursachen. In: Forstarchiv, 79 (3), 116-121.

4. Giessen, L. und Böcher, M. (2009): Rural Governance, forestry, and the promotion of local knowledge: The case of the German rural development programme 'Active Regions'. In: Small Scale Forestry, 8 (2), 211-230.

5. Giessen, L. und Böcher, M. (2008): Integrated Rural Development Policy in Germany and its Potentials for new Modes of Forest Governance. Institut für Wald-, Umwelt- und Ressourcenpolitik, Wien, $114 \mathrm{~S}$.

6. Giessen, L.; Böcher, M.; Ortner, M. und Tränkner, S. (2006): Integrated Rural Development as pathway for innovations - an unexploited potential for forestry -. In: Tikkanen, I.; Zyrina, O.; Rametsteiner, E.; Barreiro, O. und Michalak, R.(Hrg.): Policies Fostering Investments and Innovations in Support of Rural Development. MCPFE, Warschau, 38-56.

7. Giessen, L. und Krott, M. (2009): Forestry Joining Integrated Programmes? A question of willingness, ability and opportunities. In: Algemeine Forst-u. Jagdzeitung, 180 (5-6), 94-100.

8. Giessen, L.; Lukesch, R.; Böcher, M. und Elbe, S. (2008): Politikintegration für ländliche Räume? Die (Nicht-) Koordination der Förderung. In: Elbe, S (Hrg.): Land-Stadt Kooperation und Politikintegration für ländliche Räume. Shaker, Aachen, 57-120. 



\title{
Regional governance in rural development programmes - which role for forestry?
}

\author{
Lukas Giessen \\ Forest and Nature Conservation Policy, University of Goettingen, Wilhelmsplatz 1, 37073 Goettingen, Germany, \\ tel. +49 055139 0, e-mail: lgiesse@uni-goettingen.de
}

\begin{abstract}
Rural development policies lately take an inter-sectoral area-based approach. This turn raises questions relating to governance on the one hand and issues relating to the participation of different sectors therein on the other. In this paper I present a case study from Germany, focussing on three area-based rural development funding programmes, two temporary pilot programmes and a mainstream scheme. The concept of regional governance is shown to play a crucial role in the implementation of pilot programmes, while mainstream policy only partly is affected. Forestry as a sector was found to only play a minor role in such processes of regional governance. This paper reveals sector - internal as well as - external causes of this phenomenon and closed with conclusions on how to (sector-internally and - externally) enhance forestry participation to area-based rural development programmes.
\end{abstract}

\section{KeY WORDS}

area-based rural development, forestry sector, regional governance, mainstream and pilot programmes, LEADER+, Active Regions, GAK, integrated rural development

\section{INTRODUCTION}

Rural development policy currently is gaining momentum, having far-reaching implications for agriculture and forest policy. This, for instance, is reflected in a series of OECD studies dealing with the issue of rural development (OECD 2006), describing the advent of 'The new rural paradigm'. The newly established European Agricultural Fund for Rural Development (EAFRD) shows, that not only paradigms may be subject to change but also the way in which financial resources are devoted to rural development. Rural development programmes themselves show a trend from sector-oriented towards more integrated, area-based approaches $^{1}$ (Lenschow 2002, OECD 2006). This means that public funding is provided for harnessing areas' endogenous potentials rather than addressing isolated sectors. However, we may distinguish two types of funding programmes supporting such endogenous action: Firstly, such approaches are tested in temporary pilot schemes. More permanent long-term oriented mainstream programmes may then take up the approaches (or parts of them) after they proved

1 The terms area-based, place-based or territorial approach often are used synonymously. In the course of this paper I will use 'area-based' only. The term refers to the fundamental approach taken by public funding programmes, and mainly contrasts a sector-oriented strategy for supporting development in rural areas. 
practicability and usefulness. In a German context two prominent pilot examples are the EU Community Initiative LEADER+ as well as the German Federal Government's Active Regions programme. Contrary, the EU's EAFRD as well as the German 'Joint Task Improvement of Agricultural Structures and Coastal Protection' (GAK, German acronym) present the mainstream end of public funding programmes which partly also apply an area-based approach.

Given the trend towards integrated, area-based rural development programmes, several critical questions arise concerning the role of this approach within rural development policy, its theoretical base as well as the consequences for specific sectors, which traditionally were supported by sectoral funding. In this paper I will address the following two: First, how can we theoretically capture the area-based approach taken by funding programmes? I.e. which theoretical framework proves useful for empirically analysing area-based rural development? I will argue that the 'regional governance' concept may serve this function. Furthermore, the participation of individual sectors to area-based attempts is crucial for its success. I will consequently ask, which role forestry, as one exemplary sector in rural regions, actually plays in the implementation of the area-based approach? In doing so I will present causes hindering forestry participation in related programmes. These questions will be addressed drawing on empirical material derived from a case study. I will close with some conclusions on the importance of area-based rural development for the forest sector.

\section{THEORETICAL FRAMEWORK FOR AREA-BASED RURAL DEVELOPMENT}

Within the political discourse on area-based rural development the German Federal Ministry of Food, Agriculture and Consumer Protection (BMELV, German acronym) uses the term 'integrated rural development'. According to BMELV (2005) the concept employs the economic instrument of public funding for triggering endogenous processes of collective action within self-defined regions. ${ }^{2}$ In such settings public-private-

2 The term region here refers to an area comprising more than a municipality and less than a Federal State. A region may coincide with partnerships are financially supported and function as the steering body of the development process. They are granted decision-making authority over a regional budget, which is provided by the respective funding programme. During an initial phase of wide public participation at the regional level a joint development strategy is being developed, including projects benefiting a diverse set of regional actors. Further projects can then be proposed to the steering body, which in turn may approve them for funding. This whole process is being accompanied by a regional management facility, which supports networking among the different actors. Figure 1 illustrates this model at the regional level.

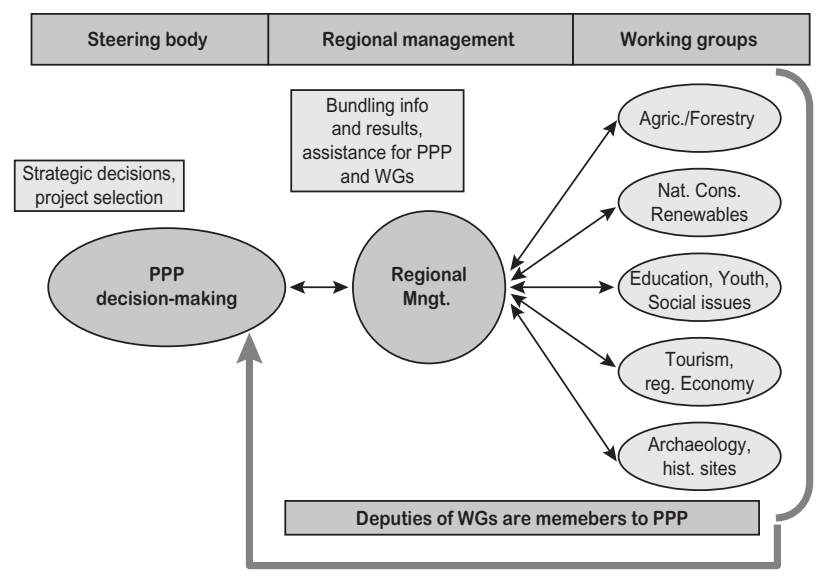

Fig. 1. Exemplary design of a regional process within the area-based rural development frame

While the aforementioned illustrates the practice of area-based approaches in empirical reality, Hahne (1987) provides us with first theoretical insights. He uses the term 'endogenous regional development' as a concept for spatial planning in which socio-economic development of a specific region is not primarily caused by external interventions but by activating internal social as well as economic potentials. Ray (2000) adds to that by emphasising that endogenous development is animated along a 'bottom-up trajectory' by searching for development resources and mechanisms focussing

administrative boundaries of e.g. districts. However, the self-defining nature here also allows the constitution of regions along historic or cultural demarcation lines. In the English literature the term 'local' is preferred over 'regional' in this context. 
on the local territorial level. However, in his 'neo-endogenous rural development approach' the role of extra-local actors is emphasised. By this he refers to the politic-administrative system as well as to actors from other localities, which may be recruited by regions in support of their endogenous process (ibid). He bases his approach on social economy and economic coordination theory, lending the concept a rather developmentoriented character.

Recent studies put emphasis on political issues relating to the governance of such endogenous development processes (Goodwin 1998, Douglas 2005, Mardsen and Murdoch 1998). One such outflow can be seen in the more general (not only development-oriented) discourse on 'regional governance'. It has been prominently dealt with in the UK, Germany as well as Italy (BBR 2003, Pütz 2005, Fürst and Knieling 2001). In general the term refers to 'political modes of interaction which have recently appeared at the regional level' and can be described as new modes of regional steering that are characterised by a set of institutions and negotiated rules, network interactions among public and private actors and horizontal interactions (Fürst 2007). Fürst (2001) elaborates this in more detail. For him regional governance is characterised by regional self-coordination at low degrees of institutionalisation for enabling flexible collective action among public and private actors.

As no universal definition exists, Pütz (2005) identifies two major base lines in how regional governance is conceptualised. In the first one a steering character is prevailing, putting emphasis on the management of regional interdependencies, networks and modes of interaction. A second conception (Benz and Fürst 2003) pays attention to the modes of interaction, inter-organisational cooperation and degree of institutionalisation. For Böcher (2007), and in line with the first conception, regional governance can be characterised by four summarising trends in empirical reality (Tab. 1):

- increase of regions as level for political coordination,

- territorial functions dominate over administrative boundaries,

- inter-sectoral cooperation through weakly institutionalised networks,

- incentive steering by various means and instruments.
Tab. 1. Characteristics of regional governance (Böcher 2007)

\begin{tabular}{|l|l|}
\hline \multicolumn{2}{|c|}{ Characteristics of Regional Governance } \\
\hline $\begin{array}{l}\text { Increase in } \\
\text { significance of } \\
\text { the region as } \\
\text { a level of political } \\
\text { coordination }\end{array}$ & $\begin{array}{l}\text { De-central self coordination } \\
\text { Free will principle } \\
\text { Use of endogenous potentials }\end{array}$ \\
\hline $\begin{array}{l}\text { Replacement of the } \\
\text { territorial principle } \\
\text { by the functional } \\
\text { principle }\end{array}$ & $\begin{array}{l}\text { 'Region' determined by density of } \\
\text { Fucial relations } \\
\text { (just) geographical or administrative } \\
\text { delimitation }\end{array}$ \\
\hline $\begin{array}{l}\text { Inter-sectoral } \\
\text { cooperation } \\
\text { through weakly } \\
\text { institutionalised } \\
\text { regional networks } \\
\text { and partnerships. }\end{array}$ & $\begin{array}{l}\text { Networks and cooperation through } \\
\text { private and public actors } \\
\text { Elaboration of regional development } \\
\text { concepts } \\
\text { Inter-sectoral collaboration }\end{array}$ \\
\hline $\begin{array}{l}\text { Steering of } \\
\text { incentives through } \\
\text { various instruments } \\
\text { and forms }\end{array}$ & $\begin{array}{l}\text { Competition as an instrument to } \\
\text { identify and support 'best practices' } \\
\text { Financial incentives through funds } \\
\text { with preconditions } \\
\text { Steering through regional management } \\
\text { as organizational core } \\
\text { Increase of the importance of } \\
\text { evaluations }\end{array}$ \\
\hline
\end{tabular}

\section{EMPIRICAL RESULTS}

\section{Methods}

The empirical results presented here have been derived from a qualitative case study on area-based rural development as new modes of governance ${ }^{3}$. Some 28 semistructured expert interviews, two focus group discussions $(n=2 *(5))$, two participant observations to rural development conferences as well as qualitative document analysis build the empirical base for the analysis. In the focus have been three funding programmes - namely the EU's LEADER+, the Federal Government's Active Regions as well as the area-based funding measures of the national 'Joint Task' (GAK) ${ }^{4}$, for which elements of new modes of governance have been analysed. As all

\footnotetext{
${ }^{3}$ Giessen and Böcher (2007) for a case study on 'integrated rural development' within the EU-funded research project 'New modes of governance for sustainable forestry in Europe - GoFOR'. http://www.boku. ac.at/GoFOR/

${ }^{4}$ In 2004 the GAK has taken up a new funding principle called, Integrated Rural Development', largely building on the area-based approach.
} 
three funding schemes take a regional approach, it will be worthwhile assessing whether the framework of regional governance is useful in this particular empirical field.

\section{Regional governance in rural development programmes}

Böcher (2007) finds that LEADER+ as well as Active Regions both reflect all key aspects of regional governance. Therefore, I now will only highlight important differences between pilot and mainstream policies as well as shortcomings of the GAK as concerns regional governance aspects (Tab. 2).

Within the GAK some aspects of Regional Governance are either not addressed explicitly (Tab. 2 'n.s.') or are even constrained by the regime (Tab. 2 '-'). In the former case, such aspects are likely to be addressed in subsequent Laender policies. However, within the GAK four lacking aspects of Regional Gov- ernance have been identified, which inhibit it from effective functioning. Continuous de-centralised selfcoordination is being obstructed by the GAK regime, since common decision-making and collective action is only funded in the initial phase of a development process. Likewise, the lack of institutionalised fora for continuous discussion and decision-making leads to an under-utilisation of endogenous potentials over time. Thirdly, GAK support for IRD does not take a competition approach. Again, this may cause respective regional actors not to unfold their full potentials of performance. Finally, the issue of evaluations does not yet play a meaningful role under the regime, which again narrows opportunities for learning and reflexivity. Hence, a significant difference between pilot schemes and mainstream programmes could be observed as regards the application of regional governance elements, where pilots seem to represent such elements much more rigorously Giessen et al. (2006).

Tab. 2. Regional governance in selected rural development programmes (own depiction based on Böcher 2007); (+) policy aligns with aspects of Regional Governance; (-) does not align, even constraints Regional Governance; (n.s.) not specified in GAK framework

\begin{tabular}{|c|c|c|c|}
\hline \multirow[b]{2}{*}{ Aspects of Regional Governance } & \multicolumn{2}{|c|}{ Pilot programmes } & \multirow{2}{*}{\begin{tabular}{|c|} 
Mainstream policy \\
GAK \\
(IRD section)
\end{tabular}} \\
\hline & $\begin{array}{l}\text { REGIONEN } \\
\text { AKTIV }\end{array}$ & LEADER + & \\
\hline \multicolumn{4}{|c|}{ Significance of regions as level of political coordination } \\
\hline De-central self-coordination & + & + & - \\
\hline Free-will principle & + & + & + \\
\hline Use of endogenous potentials & + & + & - \\
\hline \multicolumn{4}{|c|}{ Replacement of the territorial principle by the functional principle } \\
\hline 'Region' determined by density of social relations & + & + & n.s. \\
\hline $\begin{array}{l}\text { Function of a region is central, not (just) geographical or } \\
\text { administrative delimitation }\end{array}$ & + & + & + \\
\hline \multicolumn{4}{|c|}{ Inter-sectoral cooperation through weakly institutionalised regional networks and partnerships } \\
\hline Networks and cooperation through private and public actors & + & + & n.s. \\
\hline Joint visions & + & + & n.s. \\
\hline Elaboration of regional development concepts & + & + & + \\
\hline Inter-sectoral collaboration & + & + & n.s. \\
\hline \multicolumn{4}{|c|}{ Steering of incentives through various instruments and forms } \\
\hline Competition as instrument to identify and support 'best practices' & + & + & - \\
\hline Financial incentives through funds with preconditions & + & + & n.s. \\
\hline Steering through regional management as organizational core & + & + & + \\
\hline Increase of the importance of evaluations & + & + & - \\
\hline
\end{tabular}




\section{Forestry in regional governance processes}

Besides the fact that forestry at least in some regions could have the potential of economically contributing to rural development efforts, political impediments are likely to exist, hindering forestry participation in areabased rural development. Earlier studies indicated that forestry only plays a minor role in such regional cooperative processes. In the field of rural development this was shown by Ortner (2004) for the LEADER+ pro- gramme. Similarly, Böcher and Giessen (2006) as well as Giessen et al. (2006) state that forestry does not tap the full potential from area-based rural development programmes. Such potential for forestry has been analysed by e.g. Ortner (2004) and in more detail by Giessen (2007).

The empirical material indicates two explanations for this - a sector-external and an internal one: Firstly, sector-external reasons may hinder forestry participa-

Tab. 3. Sector-external and -internal reasons for low degrees of forestry participation in area-based rural development programmes and exemplary

\begin{tabular}{|c|c|}
\hline Sector-external reasons & Exemplary specification \\
\hline \multirow[t]{2}{*}{ Agricultural bias of funding programmes } & Inappropriate funding conditions for forestry \\
\hline & Lack of specific benefits to forestry \\
\hline \multicolumn{2}{|l|}{ Perception of forestry as environmental issue } \\
\hline \multirow[t]{2}{*}{$\begin{array}{l}\text { Institutional reasons within politico- } \\
\text { administrative system }\end{array}$} & $\begin{array}{l}\text { Agricultural institutions (strong at Federal State, national and EU-level) which } \\
\text { deliver programmes do not correspond with forestry institutions (mostly } \\
\text { Federal State-level) }\end{array}$ \\
\hline & $\begin{array}{l}\text { Forestrey's auto-representation of being an absolute responsibility of Federal } \\
\text { States }\end{array}$ \\
\hline \multicolumn{2}{|l|}{$\begin{array}{l}\text { Rural development funds traditionally devoted } \\
\text { to sectoral measures in favour of primary sector }\end{array}$} \\
\hline \multirow[t]{2}{*}{ Process design at regional level } & $\begin{array}{l}\text { Often wide public participation processes, hence high degree of uncertainty } \\
\text { about expectations towards forests }\end{array}$ \\
\hline & $\begin{array}{l}\text { Collective processes often not goal-oriented and specific benefits not clear } \\
\text { from the outset }\end{array}$ \\
\hline Sector-internal reasons & Exemplary specification \\
\hline \multirow[t]{2}{*}{ Managerial approach in forestry } & Dependency on public funds viewed critically \\
\hline & Sector-external funds viewed critically \\
\hline \multirow[t]{2}{*}{ Policy approach in forestry } & Traditional approach to lobby for sectoral measures prevails \\
\hline & Lack of strong political representation at e.g. EU- and national level \\
\hline Regional relevance of forestry & e.g. forest cover or related industries may be determining \\
\hline Isolationism by forestry & $\begin{array}{l}\text { 'no one is supposed taking a hand in our business [i.e. forest-related issues] } \\
\text { and in turn we [i.e. forestry actors] will also leave others alone' }\end{array}$ \\
\hline Lack of skills and capacity & $\begin{array}{l}\text { communication of interests to public not a routine in forestry as e.g. in } \\
\text { agriculture }\end{array}$ \\
\hline Climate hostile to innovations & $\begin{array}{l}\text { Innovators (individual niche ideas etc.) within the forest sector often regarded } \\
\text { as exotic }\end{array}$ \\
\hline Lack of information on programmes & Among public forestry actors and associations \\
\hline \multirow[t]{2}{*}{ Ownership-related reasons } & $\begin{array}{l}\text { State forest administration inflexible, non-innovative and institutional } \\
\text { impediments }\end{array}$ \\
\hline & Private owners lack resources for participation \\
\hline \multirow[t]{2}{*}{ Lack of trust in cooperative processes } & Collective action including forest(resources) reduces freedom to act \\
\hline & Bad experiences with collectivisation esp. in Eastern Germany \\
\hline
\end{tabular}


tion. Even though the area-based approach tries to be inter-sectoral, an agricultural bias of the programmes was perceived by respondents. Also, forestry often was not associated with economic activity or viability and was perceived as not being able to contribute to development. The design of regional governance processes also may keep forestry actors from participation, as they tend to be quite open in scope and entail a diversity of actors, so the ultimate goal does not get clear. Most importantly, the institutional non-fit between forestry and public institutions delivering the area-based programmes (mostly agricultural institutions) was mentioned as an impeding external factor.

Among sector-internal reasons the rather conservative, isolational political as well as managerial approach of forestry was mentioned prominently, also having negative implications on the general climate for innovations. Likewise, the lack of specific skills (mostly communicative capacity of the whole sector) as well as lacking information on rural development programmes was mentioned as sector-internal reason. Ownership-related factors, hindering participation in such programmes also played a prominent role herein. Lastly, a critical attitude towards cooperative action was identified as a reason (Tab. 3).

\section{Conclusions}

Area-based rural development programmes largely built on the concept of regional governance for steering and coordinating collaborative endogenous development processes. However, the study shows that a significant difference exists between temporary pilot and more enduring mainstream programmes, leading to the assumption that area-based rural development (through regional governance), once successfully tested, may encounter severe difficulties in the reality of different existing funding schemes.

The findings further reveal that forestry actors participate merely at a low degree in area-based rural development programmes. I further exposed some reasons for this phenomenon. Such reasons may lie within or outside the direct influence of forestry actors and consequently are distinguished into sector-internal and -external causes. Based on this division I want to propose several measures to be possibly taken for enhancing for- estry's participation in as well as its direct benefits from area-based rural development programmes.

Internally forestry should position itself actively with regard to area-based rural development funding. This requires identifying and analysing systematically the specific benefits and hidden potentials rural development programmes hold for forestry. Such analysis as well as respective programme information could then be provided to public as well as private forest owners and their associations. Lastly, a system of mobile consultants and funding advisers at field level could function as interface between inter-sectoral (rural development) programmes and forestry. Due to ongoing reforms of the state forest services personnel resources may be set free for such task. Ortner (2008) provides insights on how to professionally estimate political benefits for forestry in area-based rural development programmes.

Outside the forest sector, however, respective programmes could require the participative processes to be more goal-oriented and time-efficient. Furthermore, some appealing specific benefits (lighthouse measures) may attract sectoral actors such as forest owners. Lastly, area-based rural development programmes may reduce their agricultural bias, if reaching out to various sectors of the rural economy remains their primary logic of intervention.

\section{References}

BBR Bundesamt für Bauwesen und Raumordnung. 2003. Aktionsraum Region - Regional Governance. Informationen zur Raumentwicklung, 8/9.

Benz A., Fürst D. 2003. Region - Regional Governance - Regionalentwicklung. [In:] Regionen erfolgreich steuern (eds: B. Adamaschek, M. Pröhl), Gütersloh: Bertelsmann-Stiftung, 11-66.

BMVEL. 2005. Actively shaping rural development - Guidelines for integrated rural development. Bonn.

Böcher M. 2007. The concept of regional governance and the promotion of sustainable rural development processes in Germany - Insights from the implementation of 'Active Regions' and 'LEADER+'. Proceed. "The $1^{\text {st }}$ COST Action E51 Joint MC and WG meeting (ed: E. Rametsteiner)", Vienna. 
Böcher M., Giessen L. 2006. Forst als Partner in der integrierten ländlichen Entwicklung. AFZ-Der Wald, $5,263 \mathrm{p}$.

Douglas D. 2005. The restructuring of local government in rural regions: A rural development perspective. Journal of Rural Studies, 21: 231-246.

Fürst D. 2001. Regional governance zwischen Wohlfahrtsstaat und neo-liberaler Marktwirtschaft. [In:] Demokratien in Europa: Der Einfluss der Europäischen Integration auf Institutionenwandel und neue Kontouren des demokratischen Verfassungsstaates (eds: I. Katenhusen, W. Lamping), VS Verlag.

Fürst D. 2007. Regional Governance - Concepts, process, instrument? [In:] Regional Governance - Stimulus for Regional Sustainable Development (ed: G. Nischwitz), Oekom. Munich.

Fürst D., Knieling J. 2001. Regional Governance - New modes of self-government in the European Community. ARL. Hannover.

Giessen L. 2007. Forst gering vertreten in integrierten Programmen - Gründe dafür am Beispiel der integrierten ländlichen Entwicklung. Forstpolitikertreffen - Sammelband, Prag, 39.

Giessen L., Böcher M. 2007. New modes of governance in integrated rural development policies. Report "New modes of governance for sustainable forestry in Europe", Chair of Forest and Nature Conservation Policy, Göttingen.

Giessen L., Böcher M., Ortner M., Tränkner S. 2006. Integrated Rural Development as pathway for inno- vations - an unexploited potential for forestry. [In:] Policies Fostering Investments and Innovations in Support of Rural Development (ed: MCPFE), 27-29 March 2006, Zvolen, Slovakia.

Goodwin M. 1998. The Governance of Rural Areas: Some Emerging Research Issues and Agendas. Journal of Rural Studies, 14 (1), 5-12.

Hahne U. 1984. Ökologische Regionalentwicklung. Informationen zur Raumentwicklung, 1/2, 53-62.

Lenschow A. 2002. Environmental Policy Integration - Greening Sectoral Policies in Europe. Earthscan, London.

Marsden T., Murdoch J. 1998. The shifting nature of rural governance and community participation. Journal of Rural Studies, 14 (1), 1-4.

OECD. 2006. The new rural paradigm: Policies and governance. Paris.

Ortner M. 2008. Erfolgsfaktoren für die Beteiligung forstlicher Akteure an der integrierten ländlichen Entwicklung - Beispiel: LEADER+ Programm der EU-Strukturpolitik. Dissertation. Universitätsverlag Göttingen, in press.

Ortner M. 2004. Zusammenarbeit zwischen Forstwirtschaft und Leader+. In: LEADER forum, 2, p 41.

Pütz M. 2005. Regional Governance - Theoretisch-konzeptionelle Grundlagen und eine Analyse nachhaltiger Siedlungsentwicklung in der Metropolregion München. Oekom.

Ray Ch. 2000. The EU LEADER Programme: Rural Development Laboratory. Sociologia Ruralis, 40 (2), 163-171. 



\title{
Regional Governance für ländliche Räume - innovativer Ansatz, politischer Gegenwind und der Weg vorwärts
}

\author{
Lukas Giessen
}

Eingegangen: 23. Juni 2009 / Angenommen: 11. September 2009 / Online publiziert: 12. Januar 2010

(C) Springer-Verlag 2010

Zusammenfassung Dieser Beitrag identifiziert die inhaltlichen und politischen Innovationen von Regional Governance am Beispiel der integrierten ländlichen Entwicklung. Die politischen Probleme des Ansatzes werden anhand einer Reihe von Fallstudien analysiert. Hier treten die Konkurrenz von Regional Governance zum regionalen „Government“, starke sektorale Interessen und Institutionen sowie der Mehrebenencharakter von Politik für ländliche Räume als Hindernisse in den Vordergrund. Der Beitrag schließt mit einer ausführlichen und realistischen Diskussion der Handlungsoptionen zur Stärkung der integrierten ländlichen Entwicklung.

Schlüsselwörter Integrierte ländliche Entwicklung ·

Ländliche Politikintegration · Sektoren ·

Politikverflechtung · Multilevel-Governance

\section{Regional Governance for Rural Areas - An Innovative Approach, its Political Obstacles and the Way Ahead}

Abstract This article identifies the programmatic as well as political innovations of Regional Governance in the context of integrated rural development. Based on a number of case studies it is argued that these innovations do not automatically materialise in political reality. Regional Governance was shown to compete with regional government. In addition, strong sectoral interests and institutions and the multi-level character of rural policy are identified as main obstacles to the approach. The paper closes with a realistic discussion of options for strengthening the inte-

\footnotetext{
L. Giessen $(\bowtie)$

Professur für Forst- und Naturschutzpolitik

Georg-August-Universität Göttingen, Büsgenweg 3

37077 Göttingen, Deutschland

E-Mail: lgiesse@gwdg.de
}

grated approach politically through ambitious rural policy integration.

Keywords Integrated rural development - Rural policy integration - Sectors - Interlocking politics - Multilevel governance

\section{Regional Governance für ländliche Räume}

\subsection{Untersuchungsansatz}

Dieser Beitrag beschäftigt sich mit einem sowohl inhaltlich als auch politisch innovativen Ansatz einer nachhaltigen Regionalentwicklung für ländliche Räume, dem Konzept der integrierten ländlichen Entwicklung (ILE).

Der der integrierten ländlichen Entwicklung innewohnende Steuerungsansatz von Regional Governance und die damit verbundenen inhaltlichen wie politischen Innovationen sollen im Folgenden Ausgangspunkte einer kritischen Diskussion sein. Zunächst werde ich die integrierte ländliche Entwicklung konzeptionell als innovativen Ansatz zur nachhaltigen Regionalentwicklung vorstellen und deutlich machen, dass es sich dabei um normative Ideale handelt, deren Umsetzung nicht von vornherein angenommen werden kann. Auf der Basis eigener Forschungsergebnisse und zentraler politikwissenschaftlicher Erkenntnisse werden dann politische Probleme des Ansatzes als Innovationsbremsen der Praxis beschrieben.

Grundlage dieser kritischen Bewertung sind Studien, die ich im Rahmen der Arbeitsgruppe ,Integrierte ländliche Entwicklung"1 der Abteilung für Forst- und Naturschutzpolitik

\footnotetext{
${ }^{1}$ Meinen Kollegen Michael Böcher, Sebastian Tränkner und Max Ortner sei hier für die fruchtbare Zusammenarbeit der vergangenen Jahre gedankt, ohne die dieser Beitrag nicht entstanden wäre.
} 
an der Georg-August-Universität Göttingen in einem größeren Forschungszusammenhang durchführen konnte. Diese Arbeiten wurden in Form von qualitativen Fallstudien zum Bundesmodellvorhaben „Regionen Aktiv“, zur Gemeinschaftsinitiative Leader+ und der Förderung der integrierten ländlichen Entwicklung im Rahmen der Gemeinschaftsaufgabe „Agrarstruktur und Küstenschutz“ (GAK) erstellt. Komplettiert wurden diese Untersuchungen durch Fallstudien zur Gemeinschaftsaufgabe ,regionale Wirtschaftsstruktur", den EU-Strukturfonds und den Europäischen Fonds zur Entwicklung ländlicher Räume (ELER). ${ }^{2}$ Die Arbeiten widmeten sich aus politikwissenschaftlicher Perspektive Fragen der politischen Umsetzung von Regional Governance sowie der Beteiligung bestimmter Sektoren, insbesondere der Forstwirtschaft, an Prozessen der integrierten ländlichen Entwicklung. Diesen Fragen wurde mittels Inhaltsanalysen von Programmdokumenten und 68 Experteninterviews zur ILE-Programmatik, der Beteiligung von Forstwirtschaft und der Programmformulierung und -umsetzung im Zeitraum von November 2005 bis August 2008 nachgegangen. Die Daten wurden mittels Beobachtungen, Diskussionen in zwei Fokusgruppen sowie durch Sekundärdatenanalysen der „Begleitforschung Regionen Aktiv“ validiert. Es handelt sich bei diesem Beitrag also nicht um eine eigenständige empirische Studie. Vielmehr beschreibe ich den Ansatz der integrierten ländlichen Entwicklung konzeptionell und arbeite dessen politische Innovationen heraus. Anhand von empirischen Beispielen illustriere ich Probleme des Ansatzes in dessen politischer Umsetzung.

\subsection{Die Problemlagen ländlicher Räume}

Die Problemlagen ländlicher Räume ändern sich. Waren es einst vornehmlich Produktionsfragen der Land- und Forstwirtschaft, so geraten nun auch Fragen nach Beschäftigung, gesundheitlicher Infrastruktur, Bildungsinstitutionen, Verkehrsinfrastruktur, regionalen Wirtschaftskreisläufen und demographischem Wandel in den Mittelpunkt (vgl. z. B. Franzen et al. 2008; ARL 2008; OECD 2006; OECD 2007; Böcher 2009). Politikwissenschaftlich handelt es sich dabei um eine geänderte Problemstruktur in der Raumentwicklungspolitik. Diesem Verständnis nach ergeben sich die aus realen Problemlagen resultierenden politischen Konflikte aus der Verteilung von Kosten und Nutzen entlang bestimmter Problemlagen (Wilson 1980). Diese Verteilung spiegelt die Macht- und Einflussverhältnisse zwischen den Akteuren und Politiksektoren auf die ausgestaltete Politik wider. Somit ergibt sich heute - bei schrumpfender Bedeutung der Landwirtschaft - ein polyzentrisches Einflusspotenzial verschiedener Akteure, welche die politischen Probleme ländlicher

\footnotetext{
${ }^{2}$ Zur Methodik im Einzelnen siehe Giessen (2009b) und Giessen/ Böcher (2008).
}

Räume mitdefinieren, Handlungsalternativen mitbestimmen und deren Umsetzung mittragen. Aber auch die Probleme selbst haben sich geändert. Neben persistenten Problemen wie hohen Arbeitslosenraten kommen nun auch Langzeitprobleme wie der demographische Wandel auf ländliche Räume zu. Diese neue Problemstruktur führt dazu, dass weniger die einzelnen Sektoren betrachtet werden als vielmehr eine Querschnittspolitik gefordert wird, um die Probleme des ländlichen Raums adäquat behandeln zu können. Diese Änderungen nehme ich zum Ausgangspunkt, um ein normatives Konzept zur politischen Behandlung der vielfältigen Problemlagen vorzustellen.

\subsection{Integrierte ländliche Entwicklung: politische} Innovationen für nachhaltige Regionalentwicklung

\subsubsection{Das Konzept}

Als integrierte ländliche Entwicklung verstehe ich - in Anlehnung an BMVEL (2005) - einen gebietsbezogenen und sektorübergreifenden Politikansatz, der die endogenen Potenziale ländlicher Räume als zentralen Ausgangspunkt für deren wirtschaftliche Entwicklung zugrunde legt und dazu die partnerschaftliche Aushandlung von Zielen und Maßnahmen betont. Die kontinuierliche Fortentwicklung der Ziele und Maßnahmen sowie externe und interne Evaluationen sind ebenfalls wichtige Elemente des Ansatzes, der meist auf regionaler Ebene umgesetzt wird. Zentrales Anliegen des integrierten Ansatzes ist es, Kooperationen zwischen regionalen Akteuren zu fördern, um bisher ungenutzte endogene Entwicklungspotenziale zu nutzen (Böcher 2002), da hier die „Ursache-/Wirkungszusammenhänge menschlichen Handelns eng aneinandergekoppelt" sind (Böcher 2009: 127). Das Einbeziehen der lokalen Akteure mit deren Ressourcen - spezielle Informationen, finanzielle Mittel, Personalressourcen, Reputation und Akzeptanz - und ihrem spezifischen Wissen dient dabei dem Auffinden effektiver Lösungen für regionale Problemlagen (Fischer 2000) sowie der Akzeptanzsteigerung des Politikansatzes (Giessen/Böcher 2009).

Das normative Konzept einer integrierten ländlichen Entwicklung verfolgt im Gegensatz zu sektoralen Landnutzungspolitiken einen gebietsbezogenen Ansatz. Im Fokus steht die Gesamtfunktion ländlicher Räume, nicht die Interessen einzelner Sektoren (OECD 2006). Auf regionaler Ebene sollen sich idealtypisch Netzwerke und Koalitionen regionaler Akteure entlang ökonomischer Verflechtungen, sozialer Beziehungen oder naturräumlicher Gegebenheiten bilden, die dann einen endogenen Entwicklungsprozess tragen (BMVEL 2005). Dies bedeutet, dass sich eine Region nicht nur anhand von administrativen Grenzen konstituiert, sondern dass funktionale Charakteristika in den Vordergrund treten, die ein Entwicklungspotenzial für die Region beinhal- 
ten - es sei hier z. B. an Tourismusgebiete, also Destinationen oder naturräumliche Abgrenzungen wie Naturparke gedacht. Die beteiligten Akteure sollen eine gemeinsame Entwicklungsstrategie erarbeiten, z. B. im Rahmen eines Regionalen Entwicklungskonzepts (REK), eines Integrierten Ländlichen Entwicklungskonzepts (ILEK) oder einer Integrierten Entwicklungsstrategie (IES), in der die anvisierten Entwicklungspfade (so genannte Handlungsfelder wie Bioenergie oder Tourismus) ausgehandelt und konkretisiert werden (EU Kommission 2000). Diese Strategie dient fortan als Kooperations- und Entscheidungsgrundlage, um regionale Projekte umzusetzen. Explizit soll die Strategie mehrere zentrale Akteure der Region einbeziehen und einen sektorübergreifenden Charakter aufweisen (BMVEL 2005). Somit werden Synergien zwischen den Akteuren unterschiedlicher Bereiche (wie Politik, Verwaltung, Wirtschaft, Zivilgesellschaft) und Interessen (z. B. Landwirtschaft, Handwerk, Naturschutz, Forstwirtschaft) leichter identifiziert und für den Entwicklungsprozess nutzbar gemacht. Die Umsetzung des Ansatzes in den Regionen folgt dem Partnerschaftsprinzip, wonach sich die Akteure in einer „Public Private Partnership“ zusammenfinden und den Entwicklungsprozess von der Formulierung der Strategie über die Umsetzung von Projekten bis hin zur Bewertung des eigenen Erfolgs organisieren und steuern (EU Kommission 2000; BMVEL 2005). Dabei ist von zentraler Bedeutung, dass diesen regionalen Partnerschaften ein großes $\mathrm{Ma}$ an Verantwortungen übertragen wird. So sollen idealerweise inhaltliche, administrative und finanzielle Kompetenzen an die Regionen übertragen werden (Elbe 2007). Doch neben der Partnerschaft als zentralem Entscheidungs- und Steuerungsgremium kommt der Bewertung des kollektiven Handelns eine wichtige Rolle zu (BMVEL 2005; EU Kommission 2000; Ray 2006). Die Reflexion mittels externer und Selbst-Evaluationen dient hier der Steigerung von Effektivität und Effizienz des Prozesses. Das hier skizzierte normative Konzept, wie nachhaltige Regionalentwicklung zu gestalten sei, entspricht somit dem Paradigma der neo-endogenen Regionalentwicklung ländlicher Räume (Ray 2006) und wird über das politische Instrument der Anreizsteuerung mittels Förderprogrammen initiiert und unterstützt. Auf zentraler politischer Ebene erfolgt die so genannte Rahmensteuerung durch Programme und Förderrichtlinien, während den Regionen und deren Partnerschaften eine weitgehende Detailsteuerung obliegt, welche somit ein „Empowerment“ erfahren (Peter/Knickel 2006).

\subsubsection{Anwendungsbereiche}

Der Ansatz der integrierten ländlichen Entwicklung schlägt sich in der politischen Praxis in Form von Förderprogrammen nieder. Dabei ist zu unterscheiden, ob ein solches temporär besteht, also nach einem gewissen Zeitraum grundsätzlich wieder zur (politischen) Disposition steht, oder ob die Programme als Teil der so genannten Regelförderung fest in das institutionelle Gefüge der Förderpolitik integriert sind. In ersterem Fall spricht man von Pilotprogrammen, Modell- oder Demonstrationsvorhaben, während sich für die Regelförderung der Begriff „Mainstream“ durchgesetzt hat. ${ }^{3}$ Mit Pilotcharakter wurde der Ansatz der integrierten ländlichen Entwicklung zwischen 1991 und 2006 innerhalb der EU-Gemeinschaftsinitiative „Leader“ sukzessive entwickelt. ${ }^{4}$ Die Bundesregierung hat auf Initiative der Landwirtschaftsministerin Künast ${ }^{5}$ in Anlehnung an den Leader-Ansatz das Pilotprogramm „Regionen Aktiv“ aufgelegt, welches von 2002 bis 2007 in 18 Modellregionen im Rahmen der nationalen Nachhaltigkeitsstrategie umgesetzt wurde. Als (Zwischen-)Resultat der Pilotprogramme wurden 2004 Teile des Ansatzes in die deutsche Regelförderung der Gemeinschaftsaufgabe „Agrarstruktur und Küstenschutz" unter dem Förderprinzip der integrierten ländlichen Entwicklung aufgenommen. Auf europäischer Ebene ist der Leader-Ansatz seit Beginn der aktuellen Förderperiode 2007-2013 fester im Mainstream institutionalisiert, indem ein Mindestanteil des ELER-Volumens mittels der LeaderMethode umgesetzt werden muss.

\subsubsection{Regional Governance als Steuerungsansatz}

Regionalisierung als „neue Form von Politik“ vollzieht sich seit einigen Jahren (Benz/Fürst/Kilper et al. 1999) und bedeutet nicht mehr bloß staatliche „Politik für die Regionen“, sondern umfasst ebenso die „Politik in den Regionen“" selbst (Benz/Crow/Holtmann 1998). Somit erfährt die Region eine Aufwertung als politische Handlungsebene (Bergmann 2000), wie durch den Ansatz der integrierten ländlichen Entwicklung anschaulich unterstrichen wird.

Im Modus der Top-down-Regulation können die komplexen und vielschichtigen Herausforderungen solcher Regionalisierungsprozesse nicht bewältigt werden. Somit rückt der Governance-Begriff in den Fokus. Er umschreibt dabei das Zusammenwirken von staatlichen und privaten - wirtschaftlichen und zivilgesellschaftlichen - Akteuren, wobei Letztere an Einfluss auf die Politik gewinnen (Benz 2004; Peters/Pierre 1998). In „new modes of governance“ wird Politik zwischen den beteiligten Akteuren nicht mehr (nur) hierarchisch, sondern auch im Zuge von Aushandlungspro-

\footnotetext{
${ }^{3}$ Die Unterscheidung zwischen Pilot- und Mainstream-Programmen wird im Folgenden öfter bemüht, um anhand empirischer Beispiele deutlich zu machen, wie politische Kräfte unterschiedlich wirken. Eine stringentere und systematische Analyse der Unterschiede findet sich in Giessen/Böcher/Ortner et al. (2006).

${ }^{4}$ Leader 1991-1994; Leader II 1994-2000; Leader+ 2000-2006. Vgl. zur Weiterentwicklung Hahne (2004).

${ }^{5}$ Renate Künast, Bundesministerin für Verbraucherschutz, Ernährung und Landwirtschaft, 2001 bis 2005.
} 
zessen gestaltet (Eberlein/Kerwer 2002). Mit dem Begriff der „Regional Governance“ (vgl. Benz/Fürst 2003; Fürst 2001) lassen sich neue Wege der Steuerung regionalisierter Politik und deren komplexe Strukturen erfassen (Böcher 2008a; Böcher 2008b).

Regional Governance umreißt ,schwach institutionalisierte [...] netzwerkartige Kooperationsformen regionaler Akteure für Aufgaben der Regionalentwicklung" (Fürst 2001: 370) bzw. „netzwerkartige Kooperationen zwischen Akteuren des staatlichen, privatwirtschaftlichen und zivilgesellschaftlichen Bereichs zur Bearbeitung von Problemen der regionalen Entwicklung“ (Fürst 2004: 45). Dabei sei die Teilnahme freiwillig, der Grad der Institutionalisierung relativ schwach und informelle Regelsysteme träten an die Stelle formeller Institutionen. Deren Raumbezug sei wichtig und steuere somit über sektorale Grenzen hinweg eine regionale Entwicklung. Letztlich wird jedoch anerkannt, dass Regional Governance auch vom bestehenden institutionellen Kontext mitbestimmt wird (Fürst/Lahner/Pollermann 2005) und nur „im Schatten der Hierarchie“ erfolgreich sein kann (Böcher 2008b; Benz/Fürst/Kilper et al. 1999; Benz/ Fürst 2003; Diller 2004).

Anstelle einer umfassenden Definition schlägt Böcher (2008a: 374-378), basierend auf einer umfangreichen Literaturstudie, eine Konzeption von Regional Governance vor, welche die zentralen Merkmale des Ansatzes herausstellt. Das empirische Phänomen der Regional Governance sei demnach gekennzeichnet durch (i) eine Aufwertung der Verantwortung von Regionen zu einer selbstständigen politischen Handlungsebene, (ii) die Ablösung des Territorial- durch das Funktionalprinzip ${ }^{6}$, (iii) intersektorale Kooperation durch schwach institutionalisierte regionale Netzwerke und Partnerschaften sowie (iv) eine Anreizsteuerung durch Finanzen, Wettbewerb und Evaluation. Die Relevanz des Steuerungsansatzes im Rahmen der politischen ILE-Initiativen wurde dabei bereits eindrücklich bei Böcher/Krott/Tränkner (2008) demonstriert.

Freiwillige Kooperation als zentraler Baustein einer Regional Governance ist aus Sicht der Politikwissenschaft jedoch keineswegs selbstverständlich und bedarf bestimmter Rahmenbedingungen (vgl. grundsätzlich Axelrod 2005; spezifisch Böcher 2009; Tränkner 2010). Bei Regional Governance agieren nämlich keineswegs nur Akteure mit gleichgerichteter Interessenlage (Benz/Fürst 2003). Jedoch wird angenommen, dass gewisse individuelle Gewinne nur durch Kooperationen zu realisieren sind, also den Charakter eines Positivsummenspiels aufweisen.

\footnotetext{
${ }^{6}$ Gemeint ist hier, dass regionale Entwicklungspotenziale (Funktionen) und nicht territoriale administrative Grenzen ausschlaggebend für die Regionsabgrenzung sind.
}

\subsubsection{Die politischen Innovationen}

Empowerment durch Regionalisierung

Durch die Verantwortungsübertragung weitreichender Kompetenzen auf die regionale Ebene können Akteure vor Ort über administrative, inhaltliche und finanzielle Belange der Förderung und Gestaltung des Entwicklungsprozesses entscheiden. Der regionsorientierte Ansatz der integrierten ländlichen Entwicklung trägt der Tatsache Rechnung, dass manche Entwicklungspotenziale erst dann nutzbar gemacht werden können, wenn Räume nicht (nur) in ihrer administrativen Form betrachtet werden, sondern sich Regionen entlang innovativer Kriterien entwickeln. Dies beinhaltet die Betonung funktionaler Zusammenhänge (Böcher 2008a). Durch eine freie Regionsabgrenzung entlang produktiver Kriterien fördert die integrierte ländliche Entwicklung die Mobilisierung genau jenes Potenzials, welches häufig durch stark institutionalisierte administrative Gebietskörperschaften blockiert wird.

Im Zuge der Regionalisierung bekommen lokale Akteure sowie deren Wissen um die Entwicklungspotenziale der Region eine neue Rolle bei der inhaltlichen Gestaltung ländlicher Politik (Fischer 2000; Giessen/Böcher 2009). Gemäß dem Leitbild einer informellen räumlichen Planung (vgl. Gorsler 2002) gestalten die Adressaten von Politik und Planung diese aktiv mit. Ferner bringt integrierte ländliche Entwicklung durch Evaluierungen ein großes Maß an Reflexivität in die Prozesse. Mit der Einbeziehung regionsexterner Expertisen erweitert die integrierte ländliche Entwicklung somit frühere Politikansätze der endogenen Regionalentwicklung (Hahne 1985; van der Ploeg/Long 1994), weil neben endogenen Ressourcen auch externe Faktoren wie z. B. Beratungsexpertisen als zentral für den Erfolg angesehen werden (Giessen/Böcher 2009).

Den deutlichsten Beitrag in Richtung „Empowerment“ durch integrierte ländliche Entwicklung leistet jedoch die Verknüpfung der inhaltlichen mit der finanziellen Dimension regionaler Entwicklung. Die regionalen Partnerschaften können relativ autonom über die Verwendung öffentlicher Mittel in ihrer Region entscheiden und somit ihrer Entwicklungsstrategie konkrete Projekte folgen lassen - eine Innovation, die dem System der formellen Raumplanung bisher nicht gelungen ist.

\section{Sektorübergreifende Förderpolitik}

Der Ansatz der integrierten ländlichen Entwicklung ist auch auf die sich ändernden Problemlagen ländlicher Räume zurückzuführen, wo nicht mehr nur die Probleme einer landwirtschaftlichen Produktion im Vordergrund stehen, sondern auch Fragen der Bildungs- und Gesundheitsinfrastruktur oder des demographischen Wandels immer 
lauter gestellt werden. Deren Lösung durch rein sektorale Ansätze scheint fraglich zu sein. So versucht die integrierte ländliche Entwicklung, das weit entwickelte System der sektoralen Regelförderung sensibler zu machen für mögliche Synergien zwischen Politiksektoren und Wirtschaftsbranchen. Besonders sei hier auf die oft kritisierte Agrarförderung verwiesen, die (auch) durch den Ansatz einer integrierten ländlichen Entwicklung in Richtung auf eine umfassendere ländliche Politik weiterentwickelt werden sollte (BMVEL 2005). Die Umsetzung der ILEProgramme unterstreicht die Querschnittsorientierung dieser informellen Planungen sowie den intersektoralen Charakter der regionalen Entwicklungsstrategie, indem sie diese mit Finanzmitteln zur Implementierung ausstattet. Im Rahmen von sektoraler Förderung und vor dem Hintergrund verschieden starker Politiksektoren und ihrer Verwaltungen als den „Hütern“ sektoraler Interessen hätten diese Mittel niemals in einer solch innovativen Weise genutzt werden können.

\section{Innovationsförderung}

Die integrierte ländliche Entwicklung versucht auch, gezielt Innovationen hervorzubringen. Der dezentrale Steuerungsansatz hilft dabei, indem durch zentrale Instanzen lediglich eine grobe Rahmensteuerung $z$. B. durch nur wenig konkrete Förderrichtlinien angestrebt wird und die Detailsteuerung in den Regionen erfolgt (Elbe 2007). Durch diesen Ansatz werden unterschiedliche Innovationen ermöglicht: So werden neue Bündnisse zwischen Akteuren verschiedener Sektoren leichter eingegangen. Daneben kann es zu Produkt- und Dienstleistungsinnovationen kommen. Da integrierte ländliche Entwicklung aufgrund eines fehlenden komparativen Vorteils im Vergleich zu industrieller Produktion fortwährend nach Nischenmärkten suchen muss, kann es einfacher zu neuen Produkten wie z. B. dem „Mondholz ${ }^{\text {“7 }}$ kommen. Die gezielte Förderung von Innovationen entstammt explizit dem Programm einer integrierten ländlichen Entwicklung (vgl. DVS 1999).

\section{Wettbewerb als Politikprinzip}

Letztlich kann auch der Leistungswettbewerb zwischen Regionen als politische Innovation von integrierter ländlicher Entwicklung gesehen werden. Dieses in Deutschland bisher eher schwach verbreitete Politikprinzip dient dazu, Anreize für Regionen zu setzen, politisch gewollte regionalpolitische Ziele zu verfolgen. Sie können daher als neues

\footnotetext{
${ }^{7}$ Mondholz wird von Bäumen gewonnen, die entsprechend des forstwirtschaflichen Mondkalenders gefällt werden. Ihm werden besondere Eigenschaften bezüglich Haltbarkeit etc. nachgesagt.
}

Steuerungsinstrument in der Regionalpolitik bezeichnet werden (Benz 2007a), durch das die innovativsten regionalen Konzepte den weniger erfolgversprechenden vorgezogen werden.

\section{Regional Governance als innovative Steuerung}

Der Steuerungsansatz von Regional Governance versucht, lange beobachtete Steuerungsdefizite des "Government“ zu umgehen. Diese kommen überwiegend durch die Aufsplitterung öffentlicher Politik und öffentlicher Verwaltungen in die "departmental politics“ zustande, welche recht autonome, stabile und reformresistente Politiksektoren etablieren (Giessen 2009a; Giessen/Krott 2009; Jänicke 2006). Hinzu kommt, dass das System der formellen Raumplanung als Teil des „Government“ aus politikwissenschaftlicher Sicht ebenfalls eher konservatorische Wirkungen entfaltet (Scharpf/Schnabel 1979), da es zahlreiche „non decisions“ festschreibt, welche die Thematisierung bestimmter Probleme oder gewisser Lösungsansätze nicht zulässt (vgl. bereits Naschold 1978; ähnlich Fürst/ Löb/Rudolph/Zimmermann 2003). Da ländliche Politik aufgrund der geänderten Problemstruktur der Raumentwicklung einen Querschnittscharakter hat, verbessern die netzwerkartige Erscheinung sowie die hohe Flexibilität von Regional Governance die Chancen, Regionalpolitik effektiver zu gestalten. Die Beteiligung unterschiedlicher Akteure ermöglicht einen breiten Diskussionsprozess zwischen diesen bezüglich neuer Lösungsbeiträge. Das innovative an diesem „Schauplatz der Interessen“ (Giessen 2009b) ist, dass die Interessenlage der Beteiligten relativ offen dargelegt wird und somit themenorientierte Überlappungen der Interessen identifiziert werden können. Somit versucht Regional Governance, eine standardisierte Antizipation der Interessenlage anderer Akteure zu vermeiden und die Frage, mit welchen Bündnispartnern sich ein Eigeninteresse realisieren ließe, immer wieder aufs Neue zu stellen. Dieser Prozess ist der Grundstein für Kooperationen, die in diesem Zusammenhang unter den Begriffen der „Synergien“ bzw. der ,win-win-Situationen“ verstanden werden.

Regional Governance ermöglicht zudem innovative Bündnismöglichkeiten über die regionalpolitische Ebene hinaus. Im Sinne einer Multi-Level-Governance (Marks 1993) kommt es hier zu neuen Allianzen: Die EU-Kommission wird Partner der Bundesländer, der Bund Anwalt von regionalen Entwicklungsprozessen.

Diese theoretischen Ausführungen führen zu einem idealtypischen Modell einer ländlichen Politik. Welche Formen dieses Modell in der politischen Wirklichkeit annimmt, soll im folgenden Teil exemplarisch behandelt werden. 


\section{Nadelöhre, Stolpersteine und politischer Gegenwind in der politischen Praxis}

Die bisherige Würdigung des konzeptionellen Ansatzes einer integrierten ländlichen Regionalentwicklung durch Regional Governance muss jedoch auch die realen politischen Rahmenbedingungen und Determinanten der politischen Umsetzung zur Kenntnis nehmen. Einer zu idealistischen Vorstellung von reibungsloser Implementation soll mit dem folgenden Blick auf die Umsetzung ländlicher Entwicklungspolitik vorgebeugt werden. Die hier analysierten „Probleme“" wurden überwiegend in zwei Stadien des Politikprozesses beobachtet. ${ }^{8}$ Zunächst treten diese in der Formulierung der ILE-Programme auf. Diese findet auf zentraler Ebene (z. B. EU oder Bundesland) statt. In der folgenden Umsetzung auf regionaler Ebene herrschen andere politische Rahmenbedingungen und Determinanten vor.

\subsection{Zugang nicht-staatlicher Akteure vs. verwaltete Politik - wo verbirgt sich mehr Innovation?}

Der Regional Governance-Ansatz betont die Rolle nichtstaatlicher Akteure in der Regionalpolitik. Er tritt im Falle von integrierter ländlicher Entwicklung jedoch in Konkurrenz zum traditionellen Government. Dies konnte sowohl in der Vorbereitung und Formulierung der Programme als auch in der Umsetzung beobachtet werden.

Die Definition von zu lösenden Problemen, das Setzen der Agenda sowie ein Großteil der Formulierung des Förderprogramms erfolgte im Falle von „Regionen Aktiv“ im Rahmen einer kleinen Koalition aus Befürwortern des Ansatzes. Die Beteiligung anderer Interessensgruppen, wie z. B. dem Bauernverband, war nicht kontinuierlich, oder z. B. den Waldbesitzerverbänden, überhaupt nicht vorhanden (Giessen/ Böcher 2008). Ein weiteres Beispiel der Nichteinbeziehung der Zivilgesellschaft stellt die so genannte Weiterentwicklung der Gemeinschaftsaufgabe „Agrarstruktur und Küstenschutz“ um eine ILE-Förderung dar. Hier wurde die Formulierung der Förderpolitik als reine Staatsaufgabe verstanden und keine Notwendigkeit gesehen, sich gegenüber nicht-staatlichen Interessen zu öffnen (Giessen/Böcher 2008).

In der Implementierung der Programme drückt sich die Konkurrenzsituation durch eine Verschiebung und Akkumulation informeller Machtpotenziale zu Gunsten nicht demokratisch legitimierter Akteure aus. Der Aufbau von

\footnotetext{
${ }^{8}$ Die hier verwendeten Begriffe beschreiben einen so genannten PolicyZyklus, wie er in der Politikwissenschaft analytisch gefasst wird. Man unterscheidet verschiedene idealtypische Phasen des Politikprozesses, welche Problemdefinition, Agenda Setting (Problemthematisierung), Formulierung, Implementierung (Umsetzung oder Vollzug), Evaluation (Bewertung) sowie die Terminierung (Re-Definition) gesellschaftlich konstruierter Probleme umfassen (Jann/Wegrich 2003), wobei die Phasenbezeichnungen je nach Autoren variieren können.
}

Governance-Strukturen und -Institutionen bei der Implementation von integrierter ländlicher Entwicklung tritt in Konkurrenz zum regionalen Government. Somit gerät die (Vor-)Machtstellung demokratisch legitimierter regionaler Institutionen von zwei Seiten unter Druck. Einerseits regiert die obere politische Ebene (hier EU oder Bund) informal in die Region hinein und versucht, dort ihre spezifischen Ziele durchzusetzen (vgl. z. B. Böcher 2008a). Andererseits können in regionalen Governance-Strukturen Entscheidungen autonom und teils vorbei an regionalen Institutionen (einschließlich regionaler und lokaler Politiker) mit Finanzmitteln der oberen Ebenen durchgesetzt werden (Giessen/Böcher 2008). Dies ergibt sich aus der Zusammensetzung der regionalen Partnerschaften auf Entscheidungsebene, die maximal $50 \%$ öffentliche Akteure (also Vertreter demokratisch legitimierter Institutionen) aufweisen dürfen, und der Tatsache, dass die Fördermittel oft durch Gemeinden und Landkreise kofinanziert werden müssen. Somit reduziert sich der Einfluss formaler Institutionen des Government auf die eigenen Haushaltsmittel. Ferner benachteiligten die analysierten ILE-Programme privatwirtschaftliche Akteure durch langwierige Prozesse und unpassende Förderbedingungen (Giessen 2008). Letztlich konnte beobachtet werden, dass die regionalen Prozesse oft durch öffentliche Verwaltungen dominiert wurden (Giessen/Böcher 2008). Das innovative Potenzial der zivilgesellschaftlichen Akteure, deren Ressourcen, Ideen und Durchsetzungspotenziale werden so blockiert. Dieser Befund trifft besonders für die Regelförderung der Gemeinschaftsaufgabe „Agrarstruktur und Küstenschutz" zu, in der das Ausmaß staatlicher Beteiligung in den Förderrichtlinien nicht beschränkt wurde (Giessen/Böcher/ Ortner et al. 2006).

Die Konkurrenz zwischen Governance-Strukturen und Vertretern des Government auf beiden Ebenen lässt Letzteren folglich zwei Optionen: die Abwehr des Ansatzes und Verteidigung der eigenen Stellung oder die Vereinnahmung und Abmilderung der Initiative bzw. das Umdefinieren der Interventionen zum eigenen Nutzen. Im ersten Falle wird durch die Gegenwehr des Government eine Ausbreitung und Etablierung der Regional Governance limitiert und der Zugang zivilgesellschaftlicher Akteure gewissermaßen im Keim verhindert. Dies war bei der Gemeinschaftsaufgabe „Agrarstruktur und Küstenschutz“ zu beobachten. Dort wurden Tendenzen einer Regional Governance systematisch blockiert und stark relativiert, also umdefiniert (Giessen/Böcher 2008; allgemein vgl. Benz 2003). Im Falle der Integration von Governance in das Government wird automatisch eine Vormachtstellung von Vertretern des politischen Systems etabliert, mit der sich die „non-decisions“ des formellen Systems auf den innovativen Ansatz übertragen. Dies war der Fall bei der Formulierung der Operationellen Programme der Länder für das Leader+Programm, als häufig „zu innovative“ Elemente, wie ein regionales 
Budget oder die Projektbewilligung durch die Regionen, kraft Operationeller Programme entschärft wurden (Giessen/Böcher 2008).

\subsection{Ländliche Politik vs. sektorale Interessen - die horizontale Herausforderung}

Die sektorübergreifende Förderung regionaler Projekte durch Programme der integrierten ländlichen Entwicklung kann durchaus als erfolgreich bewertet werden. So konnten durch gemeinsame Projekte und durch den Austausch der jeweiligen Interessen ein gegenseitiger Nutzen durch innovative Bündnisse, z. B. zwischen Landwirten und Vertretern des Naturschutzes, erzielt werden (Elbe et al. 2007). Die einzelnen Beispiele intersektoraler Kooperation sollten jedoch nicht darüber hinwegtäuschen, dass eine Beteiligung bestimmter Akteure, die für die Entwicklung ländlicher Räume eine sachlich bedeutsame Rolle spielen könnten, in der politischen Praxis der integrierten ländlichen Entwicklung zum Teil gering ausfallen. Am Beispiel der Forstwirtschaft als Sektor bzw. Waldbesitzern, Forstverwaltungen und forstlichen Dienstleistern als potenziellen Partnern in integrierter ländlicher Entwicklung sei dies hier illustriert. Die Forstwirtschaft ist ein expliziter Adressat der ILE-Programme (Giessen 2008), da sie bei einem Waldanteil von gut $30 \%$ an der Gesamtfläche Deutschlands ein gewisses Potenzial zur nachhaltigen Regionalentwicklung besitzt. Die tatsächliche Beteiligung bleibt jedoch stark hinter diesem Potenzial zurück (Ortner 2004; 2009). Die geringe Beteiligung kann nun verschieden erklärt werden: Einerseits fehlt es dem Sektor an Informationen zu den Programmen, einem generellen Willen, sich integrierten Ansätzen gegenüber zu öffnen und folglich an geeigneten Strategien, sich dort erfolgreich einzubringen (Giessen 2008, Giessen/Krott 2009). Andererseits werden ILE-Programme von den o. g. Forstakteuren als erweiterte landwirtschaftliche Strukturprogramme empfunden, die im Falle von „Regionen Aktiv“ einen starken Bias in Richtung ökologischer Landwirtschaft und Verbraucherschutz aufwiesen (Giessen 2008; Giessen/ Krott $2009^{9}$ ). Hieraus erwächst ein kompetitiver Vorteil von Öko-Landwirten gegenüber anderen Beteiligten.

Die strukturelle Schwäche des ILE-Ansatzes, die Umsetzung tatsächlich intersektoral zu gestalten, lässt sich letztlich aber weitaus plausibler mit der Art und Weise der Politikformulierung auf zentraler Ebene erklären. Betrachtet man hier das Zustandekommen der Politik, wird noch deutlicher, dass die Sektoralisierung von Politik und Verwaltung, also die „departmental politics“, einen enormen Einfluss auf die Förderpolitik für ländliche Räume haben

\footnotetext{
${ }^{9}$ Nach den Autoren weist ein jedes politisches Programm naturgemäß einen ,sektoralen“ Bias auf, der die Werte und Interessen der Initiatoren und deren gesellschaftlichen Umfeldes widerspiegelt.
}

(Giessen/Lukesch/Böcher et al. 2008). Zwar wurde mittlerweile zum Thema ,ländliche Räume“ eine interministerielle Arbeitsgruppe etabliert, die sich dem Thema sektorübergreifend widmen soll (BMELV 2009), jedoch dürfte unstrittig sein, dass diese nicht per se ,zu einer besseren Koordinierung und Bündelung von Instrumenten in der ländlichen Entwicklung" (BMELV 2009: 13) führt. Vielmehr werden gerade bei einer intersektoralen Bearbeitung von Problemen die Interessenskonflikte zwischen beteiligten Ressorts und anderen Akteuren deutlich. Es ergeben sich zwei Optionen, mit dieser Situation umzugehen: Einerseits können Konflikte unterschiedlicher sektoraler Interessenslagen vermieden werden, d. h. die Beteiligung konfligierender Interessen wird umgangen, wie im Falle der Formulierung von „Regionen Aktiv" beobachtet werden konnte. Hier wurden Vertreter der Bundesländer sowie der Bauernverband erst spät im Prozess (wieder) ${ }^{10}$ in den Beirat berufen, welchem die kontinuierliche Weiterentwicklung und Anpassung des Programms oblag (Giessen/Böcher 2008). Zweitens kann zur Lösung von sektoralen Interessenskonflikten eine verbindliche Regelung per Entscheidung herbeigeführt werden, ohne die intersektorale Besetzung politischer Gremien zu verändern. Diese Variante konnte nicht beobachtet werden und ist für den wenig konfliktfähigen Ansatz der Regional Governance untypisch. Somit ist der Ausschluss bestimmter Interessen und Sektoren paradoxerweise die einzige Möglichkeit, die politische Innovation der Intersektoralität voranzutreiben, ohne den Ansatz durch die Konkurrenz starker Sektoren zu verwischen.

Der deutsche Föderalismus sieht eine weitgehende Länderzuständigkeit bei den Themen Landwirtschaft, Naturschutz, Forstwirtschaft und ländliche Entwicklung vor. Im Falle von Leader+ waren die Bundesländer aufgefordert, den integrierten Ansatz mittels so genannter Operationeller Programme auszugestalten (Axt 2000). Die Zuständigkeit für deren Formulierung oblag in den meisten Fällen dem Landwirtschaftsressort, wo sich Agrarinteressen stark institutionalisiert wiederfanden, somit die Programme prägten und ein großes Innovationspotenzial des Ansatzes herausfilterten (Giessen/Böcher 2008).

In der Förderung integrierter ländlicher Entwicklung nach der Gemeinschaftsaufgabe „Agrarstruktur und Küstenschutz" wurde eine Bewertung der ILE-Programme, die integraler Bestandteil der integrierten ländlichen Entwicklung ist, generell abgelehnt, oder sie wurde lediglich punktuell durch die Ressortforschung des Bundeslandwirtschaftministeriums zugelassen (Giessen/Böcher 2008). Diese Tatsache zeigt, dass im Umfeld intersektoraler Forderungen an sektorale Politik hohe Spannungen herrschen und Infor-

\footnotetext{
${ }^{10}$ Der Bauernverband war bereits in der Initialphase in der so genannten Jury vertreten, wurde jedoch nicht direkt in das Folgegremium - den Beirat - bestellt.
} 
mationen über die Leistungsfähigkeit sektoraler Politik, die durch Evaluationen einer breiteren Masse zugänglich werden würden, keine Selbstverständlichkeit darstellen.

Letztlich wurde deutlich, dass eine Integration ländlicher Politikbelange entsprechend der ILE-Programmatik in die sektorale Regelförderung den Ansatz stark schwächt. Hier wird weder die Entscheidungsmacht in die Regionen verlegt noch werden Evaluationen durch die Förderprogramme unterstützt (Giessen/Böcher/Ortner et al. 2006). Dies führt zu einer stark eingeschränkten und fragmentierten Umsetzung von integrierter ländlicher Entwicklung im Rahmen der sektoralen Regelförderung (Giessen/Lukesch/Böcher et al. 2008).

\subsection{Multilevel Governance vs. Hierarchie und Zuständigkeiten - die vertikale Herausforderung}

Da die integrierte ländliche Entwicklung oft im Zusammenspiel mit EU-Strukturpolitik erfolgt, kann hier auch der Ansatz der Multilevel Governance beobachtet werden (Marks 1993; Benz 2007b; Heinelt 1996). Dieser basiert auf informalen Beziehungen zwischen politisch miteinander verflochtenen Ebenen, ohne dass diese in eine direkte Hierarchie eingebunden sind; fehlende formale Kompetenzen werden kompensiert durch aktives Ausüben von Staatsfunktionen wie die Formulierung von Programmen (Tömmel 1994).

Durch die Richtlinien der EU-Kommission zu der Gemeinschaftsinitiative Leader+ wurde der innovative Ansatz geschaffen und seine Umsetzung mit eigenen Finanzmitteln unabhängig von der Regelförderung garantiert. Jedoch konterkariert das Programmplanungsverfahren der EU (vgl. Axt 2000) die effektive Umsetzung der politischen Innovationen erneut durch die weitreichende Gestaltungsmacht der Länder innerhalb der Operationellen Programme. So wurde beispielsweise die effektive Verlagerung von inhaltlicher Verantwortung in die Regionen stark durch administrative Vorgaben und letztlich den Verbleib der Projektbewilligungskompetenz bei den Länderministerien oder deren nachgeordneten Stellen verhindert (Giessen/ Böcher 2008).

Auch im Falle von „Regionen Aktiv“ wurde der informal geprägte Multilevel Governance-Ansatz bemüht. So wurde es als ein Modellprogramm zur ländlichen Regionalentwicklung etabliert, ohne die nach dem Grundgesetz zuständigen Bundesländer einzubeziehen (Giessen/Böcher 2008). Da die Länder im Rahmen der Politikverflechtung bei der Wahrnehmung der Gemeinschaftsaufgabe „Agrarstruktur und Küstenschutz" jedoch eine Blockademacht gegenüber dem Bund haben (Scharpf/Reissert/Schnabel 1976) und ihren Agrarinteressen folgend als Vetospieler gegen den intersektoralen Ansatz der integrierten ländlichen Entwicklung aufgetreten wären, hat man im Rahmen von Multile- vel Governance eine fachlich zuständige politische Ebene umgangen. ${ }^{11}$ Dieses Vorgehen stieß bei den Ländern auf heftige Gegenwehr unter Verweis auf deren Zuständigkeit im Politikfeld (Giessen/Böcher 2008). Die politische Neuheit eines innovativen Programmes zur integrierten ländlichen Entwicklung wurde also auf dem Wege des Umgehens einer zuständigen Ebene mit dem Verprellen der Länder erkauft, ohne deren Unterstützung jedoch eine langfristige Politik integrierter ländlicher Entwicklung nicht möglich ist.

\subsection{Die Summe der Probleme: Fazit der Analyse}

Das Beispiel der ILE-Politik zeigt, dass sich die Umsetzung eines innovativen Ansatzes zur Regionalentwicklung durch Regional Governance erheblichen politischen Widerständen gegenübersieht. Erfolgreich konnte sie lediglich im Rahmen von so genannten Pilotprogrammen gestaltet werden. Eine substanzielle Integration und Institutionalisierung im Rahmen des traditionellen Government bzw. der Regelförderung hingegen ist nicht gelungen. Die Gründe dafür sind vielfältig. Die sektoralen Interessen z. B. der Landwirtschaft sowie die schwere Reformierbarkeit sektoraler Institutionen, z. B. der Gemeinschaftsaufgaben (Rudolph 2005), und die Interessen der beteiligten politischen Ebenen sind hier die treibenden (oder besser konservierenden) politischen Kräfte. Das System der Regelförderung, für das die Länder eine weitgehende Programmformulierungskompetenz besitzen, hat dem Druck von Seiten höherer politischer Ebenen (überwiegend der EU, aber auch des Bundes) und einer Koalition von Gegnern der rein sektoralen Mittelverwendung (z. B. Gegenkoalition zu Agrarsubventionen inklusive des Naturschutzsektors) nach mehr Regional Governance hier nur minimal nachgegeben und erstickte den Ansatz teilweise bereits früh im politischen Prozess. Dies ist bei der Formulierung im Rahmen der Gemeinschaftsaufgabe ,Agrarstruktur und Küstenschutz" zu beobachten, woran auch die Föderalismusreform nichts ändern konnte. Ebenso ersichtlich wird dies bei der Ausgestaltung des ELER, wonach Komponenten der integrierten ländlichen Entwicklung mittels der Leader-Methode nur dann zum Einsatz kommen, wenn sie den vorab etablierten Förderbereichen (ELERAchse 1-3) entsprechen. Die Frage nach dem Erfolg des Regional Governance-Ansatzes in Pilotprogrammen lässt sich ähnlich erklären. Die ILE-Pilotprogramme entstanden im Rahmen breiterer (agrar)politischer Krisen wie BSE ${ }^{12}$ und Druck aus internationalen Freihandelsverhandlungen. Eine Verweigerung der etablierten, sektoral ausgerichteten Akteure gegenüber innovativen politischen Interventionen zu einem solchen Zeitpunkt hätte die entsprechenden sektoralen Politikinstrumente zusätzlich unter legitimatori-

\footnotetext{
${ }^{11}$ Keating/Hooghe (1996) sprechen dabei vom „by-passing“.

${ }^{12}$ Bovine Spongiforme Enzephalopathie (Rinderkrankheit)
} 
schen Druck gebracht. Die zeitlich begrenzte Unterstützung des Regional Governance-Ansatzes durch die etablierten Akteure wurde ebenfalls durch die Tatsache befördert, dass die Finanzierung der Pilotprogramme nicht direkt in sektorale Budgets eingriff, sondern diese daran sogar partizipieren konnten.

Die Thematisierung und Problemdefinition sowie große Teile der Formulierung von Programmen der integrierten ländlichen Entwicklung wurden durch eine kleine Koalition vorgenommen, die in der Umsetzung der Programme profitierten. In diesem Zuge war ein wachsender Einfluss von nicht-staatlichen Akteuren auf die Politikgestaltung zu beobachten. Dieser wiederum führte zu einer Konkurrenzsituation zwischen den Systemen des Government und der Governance, welche entweder durch Blockaden oder durch Integration der integrierten ländlichen Entwicklung in das Government bewältigt wurden. Als klarer Gegensatz zu diesen Phänomenen kann die ILE-Regelförderung der Gemeinschaftsaufgabe „Agrarstruktur und Küstenschutz“ gesehen werden, bei der private Akteure keine Rolle spielen. Im Rahmen des ELER wie auch der restlichen Strukturpolitik kommt privaten Akteuren wiederum eine aktivere Rolle mit mäßigen Einflusspotenzialen in den Begleitausschüssen zu.

Die horizontale Integration ländlicher Entwicklungsziele (oder horizontale Politikintegration, vgl. Giessen 2009a) scheiterte an einer sektoralen Bearbeitung von Politik durch relativ autonomes Handeln einzelner Verwaltungszweige und deren Organisations- und Sektorinteressen. Der Anspruch, sektorübergreifend zu fördern, wurde während der Umsetzung der Pilotprogramme durchaus erfüllt. Aber auch hier war die Formulierung stark von den beteiligten Sektoren geprägt, was zu einer Re-Sektoralisierung führte. Die Herkulesaufgabe der intersektoralen Koordination wurde somit in den Pilotprogrammen überwiegend in den Vollzug und somit in die Regionen verschoben (Giessen/ Böcher 2008; Böcher 2009a). Anstrengungen, diesen Ansatz auch auf die Regelförderung zu übertragen, sind hingegen gänzlich gescheitert. Es fehlte einerseits an einer hochrangigen Beauftragung zur Integration durch zentrale politische Gremien (Jänicke 2006). Der intersektorale Ansatz wurde andererseits in der Formulierung des Rahmenplans zur Gemeinschaftsaufgabe „Agrarstruktur und Küstenschutz“ stark zugunsten von Agrarinteressen sowie den Interessen kommunaler Gebietskörperschaften ausgestaltet. Hier spiegeln sich hohe Pfadabhängigkeit und schwere Reformierbarkeit der Gemeinschaftsaufgabe (Rudolph 2005) wider. Auch im Falle anderer Förderinstrumente (wie z. B. der Strukturfonds) muss von einer sektoralen Bearbeitung ausgegangen werden, die lediglich durch hochrangig beauftragte landesweite Strategien aufgeweicht werden konnten (Giessen/Lukesch/Böcher et al. 2008). Die Leader-Förderung im Rahmen des ELER könnte hier als Gegenbeispiel angeführt werden. Jedoch ist, wie oben angeführt, die
Umsetzung der Prinzipien integrierter ländlicher Entwicklung an die vorab etablierten Programmziele (Achse 1-3) gekoppelt. Zudem wird die Kofinanzierung des ELER zu großen Teilen über die Gemeinschaftsaufgabe „Agrarstruktur und Küstenschutz" als nationale Rahmenregelung bereit gestellt, was den innovativen Ansatz erneut stutzt. Dieser lässt sich auf regionaler Ebene umsetzen, er bietet jedoch keine chancengleichen Beteiligungsmöglichkeiten für alle relevanten Sektoren.

Eine vertikale Politikintegration (Giessen 2009c) gestaltete sich schwierig, da der Föderalismus vielfältige Blockademöglichkeiten etabliert (Benz 2003), die von Akteuren genutzt werden. Die Politikverflechtung bei den Gemeinschaftsaufgaben und die daraus resultierende Vetomacht der Bundesländer machten 2004 eine gehaltvolle Reform der Gemeinschaftsaufgabe „Agrarstruktur und Küstenschutz“ in Richtung integrierte ländliche Entwicklung unmöglich. Diese Verflechtung zu umgehen gelang durch eine Konstellation der Multilevel Governance beim Leader-Programm. Als Folge war jedoch eine geringere horizontale Integration zu beobachten, was die Re-Sektoralisierung des ILEAnsatzes durch einige Operationelle Programme der Länder belegen.

\section{Der Weg vorwärts: Regional Governance politisch erfolgreich betreiben}

Jeder Versuch, ländliche Politikbelange als Querschnittsaufgabe in bestehende Politiken zu etablieren, muss akzeptieren, dass es sich bei Politikintegration um eine dauerhaft konfliktreiche Angelegenheit handelt (Hubo/Krott 2007; Giessen 2009a; Giessen 2009c). Die größten Aussichten auf Wirkung (nicht nur politischen Erfolg) haben demnach Ansätze einer punktuellen Integration, bei denen die spezifischen Rahmenbedingungen und mögliche Bündnispartner immer aufs Neue geprüft werden, ob sie einen Integrationserfolg versprechen (Giessen/Lukesch/Böcher et al. 2008). Ziel dieses Ausblicks soll es sein zu eruieren, welche politischen Strategien geeignet scheinen, die beschriebenen Defizite hinsichtlich der horizontalen und der vertikalen Politikintegration ländlicher Belange zu reduzieren und somit eine effektivere Umsetzung einer integrierten ländlichen Entwicklung durch Regional Governance zu erreichen.

\subsection{Politikverflechtung oder Multilevel Governance}

Fragt man sich, innerhalb welches institutionellen Rahmens eine ausgeweitete und effektive Förderung integrierter ländlicher Entwicklung stattfinden soll, bieten sich drei Möglichkeiten. Erstens kann jedes Bundesland frei gemäß den herrschenden politischen und strukturellen Bedingungen 
eigene Programme zur integrierten ländlichen Entwicklung auflegen und deren Umsetzung mit Mitteln ausstatten. Da ILE-Förderungen meist auch eine Gefährdung der Finanzmittel für die Agrarpolitik bedeuten, ist die Umsetzung von ILE-Programmen nur in Ländern mit gering ausgeprägten Agrarinteressen realistisch.

Zweitens könnten die Gemeinschaftsaufgabe „Agrarstruktur und Küstenschutz" oder die Gemeinschaftsaufgabe „regionale Wirtschaftsstruktur“ für die weitere Verbreitung einer integrierten Regionalentwicklung herangezogen werden. Die Gemeinschaftsaufgabe „Agrarstruktur und Küstenschutz" hat sich jedoch als reformresistent gezeigt (vgl. Rudolph 2005). Dies ist auf die Politikverflechtung zurückzuführen, die hier besonders ausgeprägt ist (Scharpf 1999). Ein Versuch, integrierte ländliche Entwicklung hier einzubinden und damit die Gemeinschaftsaufgabe „Agrarstruktur und Küstenschutz" gleichsam zu entsektoralisieren, ist bereits 2004 inhaltlich weitgehend gescheitert (Giessen/ Böcher 2008). Starke Länder- und Agrarinteressen machen es folglich ebenfalls wenig aussichtsreich, die integrierte ländliche Entwicklung in den Bereich starker Politikverflechtung einzubinden.

Drittens und etwas positiver ist hier der Multilevel Governance-Ansatz der EU-Strukturpolitik zu bewerten, in welchem keine Vetomacht unterer Ebenen existiert (Marks 1993). Diese erhalten im Rahmen Operationeller Programme jedoch eigene Gestaltungsspielräume (Axt 2000), die nur in seltenen Fällen zu Gunsten eines Querschnittsansatzes genutzt werden dürften. Begünstigend kommt hinzu, dass im System der ELER-Förderung bereits Komponenten einer integrierten ländlichen Entwicklung im Rahmen der Leader-Achse existieren und mit 5\% des Fondsvolumens eine prominentere Rolle einnehmen, als dies die ILE-Förderung im Regime der Gemeinschaftsaufgabe „Agrarstruktur und Küstenschutz“ tut. Allerdings bleibt relativierend festzustellen, dass die Mittel hier lediglich zur Umsetzung von Maßnahmen der konventionellen Förderbereiche genutzt werden können.

\subsection{Ländliche Politik intersektoral gestalten}

Die Eigeninteressen von Fachverwaltungen und sektorale Kräfte akzeptierend muss zur Integration neuer Belange (hier der ländlichen Entwicklung als Querschnittsaufgabe) in bestehende Politik eine hochrangige Beauftragung, z. B. durch Parlament, Kabinett oder Regierungschefs, erfolgen (Jänicke 2006). Denn das Argument der effektiveren Lösung ländlicher Problemlagen allein dürfte hier wenig bewirken. Ein solches Vorgehen kann in einigen Bundesländern bei der Verwendung der Strukturfondsmittel beobachtet werden (vgl. Giessen/Lukesch/Böcher et al. 2008). Grundlage hierfür ist jedoch die Thematisierung ländlicher Problemlagen als Querschnittsproblem, welches einer den Fachverwaltungen übergeordneten Koordination bedarf.
Die konkrete Formulierung von Programmen muss dann von einer Regierungseinheit (z. B. der Staatskanzlei) betrieben werden, die nicht nur sektorale Interessen verfolgt. Deren Berufung zur Gestaltung integrierter ländlicher Politik wäre selbstverständlich mit einem Autonomieverlust der Fachressorts, also einer politischen Abschwächung des Ressortprinzips verbunden und verursachte deren Widerstand.

Um der resultierenden Politik jedoch einen Querschnittscharakter und eine hohe Akzeptanz zu verschaffen, müssten diverse Akteure und Sektoren frühzeitig am Prozess beteiligt werden. Diese Beteiligung wiederum kann nicht beliebig breit und einflussreich gestaltet werden. Denn mit steigender Zahl an Interessen mit weitreichendem Einfluss steigt ebenfalls die Zahl der Vetospieler. Die Beteiligung muss aber so umfangreich und substanziell sein, dass die Ressourcen der Beteiligten, insbesondere die Expertise um ländliche Problemlagen und Lösungsalternativen nichtstaatlicher Akteure, genutzt werden können. Somit reduziert sich mit wachsendem Anspruch an Intersektoralität der Einfluss nichtstaatlicher Akteure, und die Rolle des Staates rückt wieder in den Mittelpunkt.

\subsection{Gibt es Aussicht auf Erfolg?}

Um eine integrierte ländliche Politik zu forcieren, bedarf es einer starken Koalition aus Anhängern des Ansatzes. Der Versuch einer Gegenmachtbildung (Naschold 1978) zu starken Agrarinteressen muss einflussreiche Verbündete umfassen. Dabei trifft man auf die EU, die im Rahmen der GATT-Verhandlungen $^{13}$ zur Handelsliberalisierung ihre Agrarförderung unter wachsendem Druck sieht und in der ländlichen Entwicklung Alternativen zur ersten Säule der Gemeinsamen Agrarpolitik sieht. Bundesländer, bei denen reine Agrarinteressen weniger ausgeprägt sind, zählen ebenso zur Gruppe möglicher Unterstützer wie die Teile der Bundesregierung, die eigene Programme zur integrierten ländlichen Entwicklung betrieben haben. Letztlich könnten auch Kommunalverbände hier geeignete Partner darstellen, weil durch den sektorübergreifenden Ansatz relativ freie Fördermittel in die Regionen fließen, die dort durch die lokale Politik mitbestimmt verwendet werden können.

Eine gemeinsame Strategie einer solchen Koalition könnte folgende Komponenten beinhalten: das formale Hinwirken auf eine integrierte ländliche Politik im Agrarministerrat, was relativ unwahrscheinlich ist; Initiativen der Ministerpräsidenten zur integrierten Verwendung der Mittel von Strukturfonds und Gemeinschaftsaufgaben (vgl. Giessen/Lukesch/Böcher et al. 2008) und informaler Druck auf die EU-Kommission durch entsprechende Länder, das Monofondsprinzip der Strukturpolitik (wieder) abzulegen (vgl. Giessen/Lukesch/

\footnotetext{
${ }^{13}$ General Agreement on Tariffs and Trade (Allgemeines Zoll- und Handelsabkommen), 1947 abgeschlossen und seit 1948 in Kraft.
} 
Böcher et al. 2008). Es wird jedoch klar, dass die Verwirklichung dieses innovativen Ansatzes im Rahmen realer Politik und deren Determinanten ein äußerst ambitioniertes wie voraussetzungsvolles Anliegen darstellt, welches ohne Krisenereignisse nur wenig Aussicht auf Erfolg hat.

\section{Literatur}

Akademie für Raumforschung und Landesplanung (ARL) (2008): Politik für periphere, ländliche Räume: Für eine eigenständige und selbstverantwortliche Regionalentwicklung. Hannover. = Positionspapier aus der ARL, Nr. 77.

Axelrod, R. M. (2005): Die Evolution der Kooperation. München.

Axt, H.-J. (2000): EU-Strukturpolitik. Einführung in die Politik des wirtschaftlichen und sozialen Zusammenhalts. Opladen.

Benz, A. (2003): Konstruktive Vetospieler in Mehrebenensystemen. In: Mayntz, R.; Streeck, W. (Hrsg.): Die Reformierbarkeit der Demokratie. Innovationen und Blockaden. Festschrift für Fritz Scharpf. Frankfurt/New York, 205-236.

Benz, A. (2004): Governance - Modebegriff oder nützliches sozialwissenschaftliches Konzept?. In: Benz, A.. (Hrsg.): Governance - Regieren in komplexen Regelsystemen. Wiesbaden, 12-28.

Benz, A. (2007a): Politischer Wettbewerb. In: Benz, A.; Lütz, S.; Schimank, U.; Simonis, G. (Hrsg.): Handbuch Governance. Wiesbaden, 54-67.

Benz, A. (2007b): Multilevel Governance. In: Benz, A.; Lütz, S.; Schimank, U.; Simonis, G. (Hrsg.): Handbuch Governance. Wiesbaden, 297-310.

Benz, A.; Crow, K.; Holtmann, E. (1998): Regionen und regionale Politik - eine Einführung. In: Benz, A.; Holtmann, E. (Hrsg.): Gestaltung regionaler Politik. Empirische Befunde, Erklärungsansätze und Praxistransfer. Opladen, 15-29.

Benz, A.; Fürst, D. (2003): Region - Regional Governance - Regionalentwicklung. In: Adamaschek, B.; Pröhl, M. (Hrsg.): Regionen erfolgreich steuern. Gütersloh, 11-66.

Benz, A.; Fürst, D.; Kilper, H.; Rehfeld, D. (1999): Regionalisierung. Theorie, Praxis, Pespektiven. Opladen.

Bergmann, E. (2000): Nachhaltige Entwicklung im föderalen Kontext: Die Region als politische Handlungsebene. In: Bizer, K.; Linscheidt, B.; Truger, A. (Hrsg.): Staatshandeln im Umweltschutz. Berlin, 215-239.

Böcher, M. (2002): Nachhaltige Regionalentwicklung durch Kooperation? Erfolgskriterien für regionale Partnerschaften aus politikwissenschaftlicher Sicht. In: Müller, K.; Dosch, A.; Mohrbach, E. et al. (Hrsg.): Wissenschaft und Praxis der Landschaftsnutzung - Formen interner und externer Forschungskooperation. Weikersheim, $65-75$.

Böcher, M. (2008a): Regional Governance and Rural Development in Germany. The Implementation of LEADER+. In: Sociologia Ruralis 48, 4, 372-388.

Böcher, M. (2008b): Instrumentenwandel in der Umwelt- und Naturschutzpolitik und der Politik zur integrierten ländlichen Entwicklung. Theoretische Grundlagen und Strategien der Praxisumsetzung. Dissertation an der Georg-August-Universität Göttingen.

Böcher, M. (2009): Faktoren für den Erfolg einer nachhaltigen und integrierten ländlichen Regionalentwicklung. In: Friedel, R.; Spindler, E. (Hrsg.): Nachhaltige Entwicklung ländlicher Räume: Chancenverbesserung durch Innovation und Traditionspflege. Wiesbaden, $127-138$.

Böcher, M.; Krott, M.; Tränkner, S. (Hrsg.) (2008): Regional Governance und integrierte ländliche Entwicklung. Wiesbaden.
Bundesministerium für Ernährung, Landwirtschaft und Verbraucherschutz (BMELV) (2009): Handlungskonzept der Bundesregierung zur Weiterentwicklung der ländlichen Räume. Bonn.

Bundesministerium für Verbraucherschutz, Ernährung und Landwirtschaft (BMVEL) (2005): Ländliche Entwicklung aktiv gestalten. Bonn.

Deutsche Vernetzungsstelle LEADER+ (DVS) (1999): LEADER+ - Die Europäische Initiative für den ländlichen Raum. Bonn.

Diller, C. (2004): Regional Governance im „Schatten der Hierarchie“. In: Raumforschung und Raumordnung, 62, 4/5, 270-279.

Eberlein, B.; Kerwer, D. (2002): Theorising the New Modes of European Union Governance. $=$ European Integration online Papers 6, 5. Online unter: http://eiop.or.at/eiop/texte/2002-005a.htm. Zugriff am 08.09.2009.

Elbe, S. (2007): Die Voraussetzungen der erfolgreichen Steuerung integrierter Ansätze durch Förderprogramme. Untersucht am Beispiel des Modellvorhabens Regionen Aktiv. Aachen (Dissertation).

Elbe, S. et al. (2007): Begleitforschung „Regionen Aktiv“ - Synthesebericht und Handlungsempfehlungen. Göttingen.

EU Kommission (2000): Commission Notice to the Member States of 14 April 2000laying down guidelines for the Community initiative for rural development (LEADER+), 2000/C 139/05.

Fischer, F. (2000): Citizens, Experts and the Environment: The Politics of Local Knowledge. Durham.

Franzen, N. et al. (2008): Herausforderung Vielfalt - Ländliche Räume im Struktur- und Politikwandel. Hannover. = E-Paper der ARL, Nr. 4.

Fürst, D. (2001): Regional Governance - ein neues Paradigma der Regionalwissenschaften? In: Raumforschung und Raumordnung $59,5 / 6,370-380$.

Fürst, D. (2004): Regional Governance. In: Benz, A.. (Hrsg.): Governance - Regieren in komplexen Regelsystemen. Wiesbaden, $45-64$.

Fürst, D.; Lahner, M.; Pollermann, K. (2005): Regional Governance bei Gemeinschaftsgütern des Ressourcenschutzes: das Beispiel Biosphärenreservate. In: Raumforschung und Raumordnung 63, $5,330-339$.

Fürst, D.; Löb, S.; Rudolph, A.; Zimmermann, K. (2003): Steuerung durch Regionalplanung. Baden-Baden. = Schriften zur Rechtspolitologie, Bd. 15.

Giessen, L. (2008): Forstwirtschaft zurückhaltend bei Programmen zur integrierten ländlichen Entwicklung - Analyse der politischen Ursachen. In: Forstarchiv 79, 3, 116-121.

Giessen, L. (2009a): Horizontal Policy Integration. In: Robbins, P.; Mulvaney, D.; Golson, G. (Hrsg.): Green Food (im Erscheinen).

Giessen, L. (2009b): Regional Forest Governance: Potentiale und politische Triebkräfte im Politikfeld um eine integrierte ländliche Entwicklung. Dissertation an der Georg-August-Universität Göttingen (im Erscheinen).

Giessen, L. (2009c): Vertical Policy Integration. In: Robbins, P.; Mulvaney, D.; Golson, G. (Hrsg.): Green Food (im Erscheinen).

Giessen, L.; Böcher, M. (2008): Integrated Rural Development Policy in Germany and its Potentials for new Modes of Forest Governance. Wien.

Giessen, L.; Böcher, M. (2009): Rural Governance, forestry, and the promotion of local knowledge: The case of the German rural development programme „Active Regions”. In: Small Scale Forestry 8, 2, 211-230.

Giessen, L.; Böcher, M.; Ortner, M.; Tränkner, S. (2006): Integrated Rural Development as pathway for innovations - an unexploited potential for forestry. In: Ministerial Conference on the Protection of Forests in Europe (MCPFE). (Hrsg.): Policies Fostering Investments and Innovations in Support of Rural Development. Warschau, 38-56. 
Giessen, L.; Krott, M. (2009): Forestry Joining Integrated Programmes? A question of willingness, ability and opportunities. In: Allgemeine Forst- und Jagdzeitung (im Erscheinen).

Giessen, L.; Lukesch, R.; Böcher, M.; Elbe, S. (2008): Politikintegration für ländliche Räume? Die (Nicht-)Koordination der Förderung. In: Elbe, S.. (Hrsg.): Land-Stadt Kooperation und Politikintegration für ländliche Räume - Zentrale Ergebnisse und Handlungsempfehlungen der Begleitforschung Regionen Aktiv 2007 bis 2008. Aachen, $57-120$.

Gorsler, D. (2002): Informelle räumliche Planung - Stand der aktuellen Forschung und Forschungsbedarf. Hannover. = Arbeitsmaterial der ARL, Nr. 286.

Hahne, U. (1985): Regionalentwicklung durch Aktivierung intraregionaler Potentiale: zu den Chancen ,endogener“ Entwicklungsstrategien. München. $=$ Schriften des Instituts für Regionalforschung der Universität Kiel. Bd. 8.

Hahne, U. (2004): Ländliche Regionalentwicklung mit LEADER+. In: Raumplanung 116, 199-204.

Heinelt, H. (1996): Politiknetzwerke und europäische Strukturfondsförderung - Ein Vergleich zwischen EU-Mitgliedstaaten. Opladen.

Hubo, C.; Krott, M. (2007): Umsetzungsstrategien für integrative Politikansätze am Beispiel invasiver gebietsfremder Arten. In: Zeitschrift für Angewandte Umweltforschung 18, 2, 216-226.

Jänicke, M. (2006): Politikintegration im Mehrebenensystem: das Beispiel der deutschen Umweltpolitik. In: Koch-Baumgarten, S; Rüttgers, P.. (Hrsg.): Pluralismus und Demokratie: Interessenverbände - Länderparlamentarismus - Föderalismus - Widerstand: Siegfried Mielke zum 65. Geburtstag. Frankfurt, 63-73.

Jann, W.; Wegrich, K. (2003): Phasenmodelle und Politikprozesse: Der Policy Cycle. In: Schubert, K.; Bandelow, N. (Hrsg.): Lehrbuch der Politikfeldanalyse. München, Wien, 71-105.

Keating, M.; Hooghe, L. (1996): By-Passing the Nation-State? Regions and the EU Policy Process. In: Richardson, J.. (Hrsg.): European Union: Power and Policy Making. London, 216-229.

Marks, G. (1993): Structural Policy and Multilevel Governance in the EC. In: Carfuny, A; Rosenthal, G.. (Hrsg.): The State of European Community. Boulder, 391-410.

Naschold, F. (1978): Alternative Raumpolitik: ein Beitrag zur Verbesserung der Arbeits- und Lebensverhältnisse. Kronberg.

OECD (2006): Das neue Paradigma für den ländlichen Raum: Politik und Governance. Paris.
OECD (2007): OECD Prüfbericht zur Politik für ländliche Räume - Deutschland. Paris.

Ortner, M. (2004): Zusammenarbeit zwischen Forstwirtschaft und Leader+ weiter ausbaubar. In: LEADERforum 2, 41.

Ortner, M. (2009): Erfolgsfaktoren für die Beteiligung forstlicher Akteure an der integrierten ländlichen Entwicklung - Beispiel: LEADER+ Programm der EU-Strukturpolitik. Dissertation an der Georg-August-Universität Göttingen.

Peter, S.; Knickel, K. (2006): Empowerment of regional partnerships - The example of the Regional Action Pilot Program in Germany. In: $\operatorname{disP} 42,3,16-25$.

Peters, B. G.; Pierre, J. (1998): Governance without government? Rethinking public administration. In: Journal of Public Administration Research and Theory 8, 2, 223-243.

Ray, C. (2006): Neo-endogenous rural development in the EU. In: Cloke, P.; Marsden, T.; Mooney, P. (Hrsg.): Handbook of Rural Studies. London, 279-291.

Rudolph, M. (2005): Agrarstrukturpolitik im vereinten Deutschland. Eine Analyse der Gemeinschaftsaufgabe ,Verbesserung der Agrarstruktur und des Küstenschutzes“ im Lichte der Neuen Politischen Ökonomie. Aachen.

Scharpf, F. W. (1999): Föderale Politikverflechtung: Was muß man ertragen - was kann man ändern? Köln. = MPIfG Working Paper 99/3.

Scharpf, F. W.; Reissert, B.; Schnabel, F. (1976): Politikverflechtung: Theorie und Empirie des kooperativen Föderalismus in der Bundesrepublik. Kronberg.

Scharpf, F. W.; Schnabel, F. (1979): Steuerungsprobleme der Raumplanung. Hannover. $=$ Beiträge der ARL, Bd. 27.

Tömmel, I. (1994): Staatliche Regulierung und europäische Integration. Die Regionalpolitik der EG und ihre Implementation in Italien. Baden-Baden.

Tränkner, S. (2010): Politische Erfolgsfaktoren für regionale Partnerschaften in der integrierten ländlichen Entwicklung. Dissertation an der Georg-August-Universität Göttingen.

Van Der Ploeg, J. D.; Long, A. (1994): Born from within: practice and perspectives of endogenous rural development. Assen.

Wilson, J. Q. (1980): The politics of regulation. In: Wilson, J. Q. (Hrsg.): The politics of regulation. New York, 357-394. 


\title{
Die Zurückhaltung der Forstwirtschaft in der integrierten ländlichen Entwicklung - Analyse der politischen Ursachen
}

\author{
Lukas Giessen \\ Abteilung für Forst- und Naturschutzpolitik, Georg-August-Universität Göttingen, Büsgenweg 3, D-37077 Göttingen (lgiesse@uni-goettingen.de)
}

Eingegangen: 08.01.2008 Angenommen:04.03.2008

\begin{abstract}
Kurzfassung: Die bisherige Beteiligung der Forstwirtschaft an Programmen zur integrierten ländlichen Entwicklung (ILE) ist gering. Basierend auf empirischen Daten aus einer qualitativen Fallstudie bestätigt der Beitrag zunächst diese Erkenntnis und versucht forstwirtschaftliche Potenziale der Programme zu identifizieren. Danach wird der Frage nachgegangen, warum die Forstwirtschaft nur eine geringe Rolle in der ILE spielt. Neben sektor-internen Ursachen wie mangelnden kommunikativen Fähigkeiten, fehlenden Informationen zu Programmen und einem konservativen Forstpolitikverständnis wurden auch sektor-externe Gründe identifiziert. Ein landwirtschaftlicher Zuschnitt der Programme, fehlende Schnittstellen im institutionellen Aufbau zwischen ILE- und Forstinstitutionen sowie eine einseitige Wahrnehmung der Forstwirtschaft als Umweltsektor erschwerten die Beteiligung ebenfalls. Der Artikel enthält Schlussfolgerungen und Handlungsempfehlungen für forstliche Akteure wie Waldbesitzer(Verbände) und öffentliche Verwaltungen, wie die Teilhabe an solchen integrierten Programmen verbessert und deren spezifischer Nutzen optimiert werden kann.
\end{abstract}

\section{Forestry's hesitance in area-based rural development programmes - Analysis of political causes}

\begin{abstract}
Participation of forestry actors, such as forest owners, their associations, public forest administrations and downstream industries in areabased rural development activities so far has been low. Based on empirical data from a qualitative case study this article firstly validates this finding also for the political involvement of institutional (collective) actors. It then reveals potential benefits of area-based rural development funding programmes for forestry actors. The subsequent analysis of political causes for the low degree of involvement identifies sector-internal reasons such as a lack of communicative skills, information deficits and a conservative attitude towards forest policy. The main sector-external causes were observed to be an agricultural bias of funding programmes, the incongruence between the programmes and forestry institutions as well as the prevailing public perception of forestry as an ecological sector. The article closes with some brief conclusions as well as recommendations for e.g. forest owners, their associations and public forest administrations on how to enhance their benefits from integrated funding programmes.
\end{abstract}

Key words: forest policy, area-based rural development, integrated rural development

\section{Einleitung}

\section{1 „Integrierte ländliche Entwicklung“ als sektorübergreifen- der Ansatz}

In der Politik um die Entwicklung ländlicher Räume haben in der letzten Zeit gebietsbezogene Ansätze stark an Bedeutung gewonnen (OECD 2006, BMVEL 2005). Beispielhaft sei hier auf die Gemeinschaftsinitiative LEADER+ der Europäischen Union verwiesen. Nachdem der gebietsbezogene Leader-Ansatz bereits seit 1991 angewendet und seither weiterentwickelt wurde, hatte die Gemeinschaftsinitiative LEADER+ eine Laufzeit von 2000-2006. In der folgenden EU Förderperiode 2007-2013 wurde der Ansatz durch die „ELER-Verordnung“ in seinen Grundzügen in die Regelförderung übernommen (Tränkner u. Giessen 2007). Dem gebietsbezogenen Ansatz von Förderprogrammen liegt als wesentliche „Neuerung“ zugrunde, dass nicht sektorale Programme allein eine positive Entwicklung begünstigen. Vielmehr zielt der Ansatz darauf ab, Potenziale, Akteure und somit auch Sektoren eines Gebietes durch Förderimpulse zu mobilisieren, um ein auf das jeweilige Gebiet abgestimmtes Vorgehen zu ermöglichen. Dieses normative Konzept greift auf Annahmen zurück, die aus der Diskussion um „autonome“ oder „neo-endogene“ ländliche Entwicklung bekannt sind (Hahne 1984, Ray 2000) und wird in der politischen Praxis meist auf regionaler Ebene angewendet. Als wesentlich kann hierbei gesehen werden, dass Akteure aus verschiedenen Bereichen mit unterschiedlichen Handlungslogiken (Verwaltung, Politik, Wirtschaft, Handwerk,
Verbände, Freiwillige etc.) in partizipativen Prozessen mobilisiert werden, um gemeinsam regionale Entwicklung zu gestalten (BMVEL 2005). Eine solche Mobilisierung wird durch öffentliche Fördermittel angestrebt, wie sie in verschiedenen Programmen angeboten werden. Als Fallbeispiele dienen in diesem Artikel die EU-Gemeinschaftsinitiative LEADER+, das Bundesmodellvorhaben „Regionen Aktiv“ sowie die ILE-Förderung nach der Gemeinschaftsaufgabe "Verbesserung der Agrarstruktur und des Küstenschutzes" (GAK), die in verschiedenen Bundesländern zur Verfügung stehen. In der derzeitigen Diskussion um eine Politik für ländliche Räume wird der gebietsbezogene Ansatz meist als ,,integrierte ländliche Entwicklung “(ILE) bezeichnet ${ }^{1}$, die sich jedoch nicht nur über die räumliche Komponente, sondern durch andere Charakteristika beschreiben lässt (Tab. 1). Somit ist ILE als regionalisierter, gebietsbezogener, partizipativer und sektorübergreifender Ansatz zu verstehen.

\subsection{Forstwirtschaft in der integrierten ländlichen Entwicklung}

Die Forstwirtschaft kann als wichtiger Adressat und Partner für eine Politik um ländliche Räume gesehen werden (Elands u. Wiersum 2003). Als solche wird sie definiert über Akteure mit ähnlich gerichtetem Interesse bzgl. der Nutzung des Waldes, die in Advokacy-Koa-

Der normative Praxisdiskurs der ILE mündete 2004 in einem neuen Fördergrundsatz der deutschen GAK, wo fortan unter ILE meist lediglich die entsprechenden GAK Maßnahmen verstanden wurden. Hier meint ILE jedoch das breitere Konzept und die Grundideen hinter diesem. 
Tab. 1. Der Ansatz der integrierten ländlichen Entwicklung (nach BMVEL 2005).

The area-based approach to rural development (after BMVEL 2005).

\begin{tabular}{ll}
\hline Charakteristikum & Erläuterung \\
\hline Gebietsbezogener Ansatz & $\begin{array}{l}\text { Betrachtet werden Räume, nicht } \\
\text { Sektoren }\end{array}$ \\
Sektorübergreifender Ansatz & $\begin{array}{l}\text { Synergien zwischen unterschied- } \\
\text { lichen Politik- und Wirtschaftsbe- } \\
\text { reichen stehen im Mittelpunkt } \\
\text { Akteure schließen sich in Partner- } \\
\text { schaften zusammen, stellen gemein- } \\
\text { same Programme/Strategien auf und }\end{array}$ \\
& $\begin{array}{l}\text { setzen diese um } \\
\text { Der Prozess wird im Austausch des }\end{array}$ \\
& $\begin{array}{l}\text { Akteursnetzwerkes kontinuierlich } \\
\text { bewertet und weiterentwickelt }\end{array}$ \\
Dynamischer Ansatz & Mittel- und langfristige Perspektiven \\
& stehen im Mittelpunkt \\
\hline
\end{tabular}

litionen (Sabatier 1988, 139) wie dem Deutschen Forstwirtschaftsrat zusammengefasst werden können. ILE spricht nun die Akteure im ländlichen Raum generell, aber auch speziell die Forstwirtschaft als teilweise wichtigen Wirtschaftszweig in ländlichen Regionen an (exemplarisch u. a. BMVEL 2005, 11). Diesem rhetorischen Anspruch von ILE-Programmen steht eine geringe tatsächliche Beteiligung forstwirtschaftlicher Akteure bei ILE-Projekten sowie auf der politischen Ebene kollektiver Akteure gegenüber (Ortner 2004, 2008, Böcher u. Giessen 2006, 113). Ortner (2004) zeigt in einer schriftlichen Vollerhebung aller LEADER+-Regionen in Deutschland, dass die Forstwirtschaft weit hinter ihren Potenzialen zurückbleibt (Abb. 1). Ähnlich konstatieren Giessen et al. (2006), dass der gebietsbezogene Ansatz der ILE nicht auch automatisch eine forstliche Beteiligung an den Programmen mit sich bringt und sich forstliche Akteure hier besonders zurückhielten. Diese Befunde werden dadurch gestützt, dass z. B. Setzer (2007) in einer Abhandlung über die forstliche Relevanz einzelner Maßnahmen der ELER-Verordnung die Möglichkeiten des 4. Förderschwerpunktes, auch als LEADER-Maßnahmen bekannt, als nicht erwähnenswert ansieht.

\subsection{Forschungsfragen}

Die skizzierte Darstellung von ILE als sektorübergreifender und regionalisierter Ansatz zeigt deutlich auf, dass die Programmatik verschiedene regional bedeutsame Sektoren adressiert. In ländlichen Regionen muss davon ausgegangen werden, dass einzelne Teile der Forstwirtschaft, verstanden als ein breiter Akteurskreis rund um die Nutzung des Waldes, häufig einen signifikanten wirtschaftlichen sowie organisatorischen Beitrag zu endogenen Entwicklungsprozessen leisten könnte. Jedoch beobachten wir eine relativ geringe forstliche Beteiligung an den integrierten Programmen. Dieser Sachverhalt wirft nun die folgenden Forschungsfragen auf:

- Ist die forstliche ${ }^{2}$ Beteiligung an ILE-Programmen (tatsächlich) gering?

- Wenn ja, sind in ILE Potentiale (politische, wirtschaftliche, Fördermittel, etc.) für die Forstwirtschaft vorhanden?

- Sollte die Beteiligung trotz vorhandener Potentiale gering sein, was sind die Ursachen dafür?

\section{Methodik}

Den oben genannten Fragen wurde im Zeitraum von Juni 2005 bis August 2007 in einer qualitativ-empirischen Untersuchung nachgegangen. Diese war Teil einer deutschen Fallstudie zur ,integrierten ländlichen Entwicklung“ im EU-geförderten Forschungsprojekt „GoFOR - New modes of governance for sustainable forestry in Europe" (http://www.boku.ac.at/GoFOR/). Dabei wurden die drei Programme als Vertreter des ILE-Ansatzes untersucht, um Verbindungen zur Forstwirtschaft zu identifizieren. In der Fallstudie wurde eine Dokumentenanalyse bei Programmplanungsdokumenten durchgeführt, welche zu Erkenntnissen über den rhetorischen Anspruch der Programme, die Forstwirtschaft als Sektor in ILE einzubinden, führen sollte. Des Weiteren wurden bundesweit 11 teilstrukturierte qualitative Interviews (Atteslander 1995) mit forstwirtschaftlichen und sektor-externen Experten durchgeführt, um sowohl die sektorale Innensicht als auch die Fremdwahrnehmung der Rolle forstwirtschaftlicher Akteure in ILE-Programmen abzubilden. Dieses Vorgehen erlaubte das Anwenden der „,doppelten Erhebung“ (Krott 1999), welche die Validität von Interviewaussagen durch Befragung der jeweils anderen Gruppe von

${ }^{2}$ Die Begriffe Forstwirtschaft bzw. forstwirtschaftlich und Forst bzw. forstlich werden im Folgenden synonym verwendet Sie beziehen sich jeweils auf Akteure der Forstwirtschaft (s. DFWR 2001) und deren Interessen, die die Nutzung des Waldes in den Vordergrund stellen.

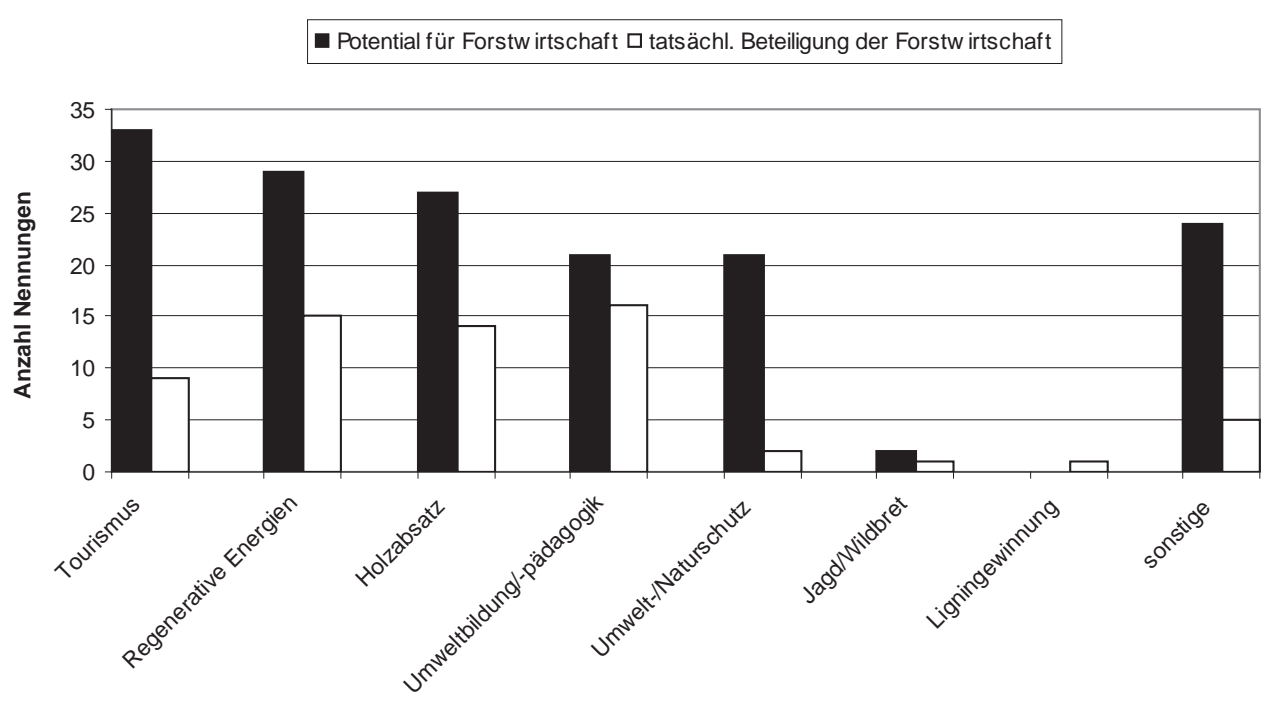

Abb. 1. Potenziale für Forstwirtschaft und aktuelle Beteiligung in verschiedenen Themenfeldern in LEADER+ (nach Giessen et al. 2006, Ortner 2004).

Forestry potentials and actual participation in different fields of action of LEADER+ (after Giessen et al. 2006, Ortner 2004). 
Tab. 2. Population der qualitativen Erhebung zur Rolle der Forstwirtschaft in der integrierten ländlichen Entwicklung.

Population of the qualitative survey on the role of forestry within area-based rural development.

\begin{tabular}{|c|c|c|}
\hline Akteursgruppe & Organisation & Codierung \\
\hline \multirow[t]{6}{*}{ Verbände } & Deutscher Bauernverband (DBV) & Verb-6 \\
\hline & Arbeitsgemeinschaft Deutscher Waldbesitzerverbände (AGDW) & Verb-1 \\
\hline & Deutscher Forstverein (DFV) & Verb-2 \\
\hline & Naturschutzbund (NABU) & Verb-3 \\
\hline & Arbeitsgemeinschaft bäuerliche Landwirtschaft (AbL) & Verb-4 \\
\hline & Deutscher Verband für Landschaftspflege (DVL) & Verb-5 \\
\hline \multirow[t]{6}{*}{ Öffentl. Verwaltungen } & Ministerium für Wirtschaft, Verkehr, Landwirtschaft und Weinbau Rheinland-Pfalz & Land-1 \\
\hline & Landesforstverwaltung des Freistaates Thüringen & Land-2 \\
\hline & Bundesministerium für Ernährung, Landwirtschaft und Verbraucherschutz, Unterabteilung 53 (a) & Bund-1 \\
\hline & Bundesministerium für Umwelt, Naturschutz und Reaktorsicherheit & Bund-2 \\
\hline & Bundesministerium für Ernährung, Landwirtschaft und Verbraucherschutz, Unterabteilung 53 (b) & Bund-3 \\
\hline & Bundesministerium für Ernährung, Landwirtschaft und Verbraucherschutz, Unterabteilung 52 & Bund-4 \\
\hline \multirow[t]{2}{*}{ Wissenschaft } & Universität Kassel & Wiss-1 \\
\hline & Universität Göttingen & Wiss-2 \\
\hline Berater & Nova Institut & Büro-1 \\
\hline
\end{tabular}

Experten erhöht. Die Interviews enthielten zu den teilstrukturierten Aspekten auch narrative Elemente, um den explorativen Charakter der Erhebung zu betonen und auch Daten zu „Nischenerfahrungen“ erfassen zu können (Rosenthal 2005). Zusätzlich zu den Interviews wurden im November 2005 zwei Fokusgruppen-Diskussionen mit je 5 Mitgliedern abgehalten, die ebenfalls beide Gruppen an Experten repräsentierten. Die Erhebung wurde auf institutionalisierter Ebene durchgeführt und umfasste Verbände, öffentliche Verwaltungen auf Bundes- und Länderebenen sowie Wissenschaftler und Beratungsdienstleister aus dem Bereich integrierter ländlicher Entwicklung. Die Quellen werden im Folgenden in Form von Codes angegeben, um die Anonymität der Betroffenen zu wahren (Tab. 2). Durch diese Art der Populationsgestaltung sollten die Erkenntnisse auf lokaler Ebene (Ortner 2004) ergänzt und das Verständnis auch institutioneller sowie politischer Hindernisse verbessert werden.

\section{Ergebnisse}

\subsection{Forstwirtschaft hat wenig Teilhabe an den Programmen}

Die Beteiligung forstwirtschaftlicher Akteure bei ILE-Programmen wurde sowohl von sektor-externen als auch von internen Experten als gering eingeschätzt. Erstere bemerkten, dass „Forst bei solchen Ansätzen kaum beteiligt ${ }^{\text {“3 }}$ sei und ein ,zögerliches Verhalten“" diesbezüglich an den Tag lege. Referenzpunkt dieser Beurteilung forstlicher Beteiligung waren jedoch ganz überwiegend die Implementation von ILE-Programmen auf regionaler Ebene. Forstliche Akteure hingegen beschrieben die Art der Nicht-Beteiligung differenzierter. Die Zusammenarbeit im Programmvollzug sei verbesserungsfähig, da „Forst- und Fischereiwirtschaft bei der Neugestaltung von Politiken für ländliche Räume, wie z. B. ELER, ganz außen vor" seien". Man sei in der Formulierung der Programme ,nicht ausreichend präsent gewesen. Wenn man jetzt in den Programmen mit Forstwirtschaft argumentiere, merke man, dass daran eigentlich nicht gedacht wurde. Daher hapere es dann in der Umsetzung "6.

Diese Befunde zeigen, dass die Beteiligung forstlicher Akteure auf institutionalisierter Ebene generell als gering empfunden wird Diese Wahrnehmung wird von sektoralen und externen Experten ge-

${ }^{6}$ Interview Verb-I teilt und ganz überwiegend auf die Implementierung der Programme bezogen. Im Sektor selbst hingegen wird die geringe Beteiligung beim Vollzug als Folge der Abwesenheit während der Programmformulierung betrachtet.

\subsection{Forstwirtschaftliche Potenziale vorhanden}

Bei der Einschätzung des forstwirtschaftlichen Potenzials in ILE-Programmen ließen sich zwei Arten unterscheiden. Eher konventionelle Möglichkeiten, wie z. B. die (vermehrte) Nutzung und Mobilisierung von Holzressourcen werden ergänzt durch innovative Potenziale, die der Sektor in den Programmen erschließen könnte. Bei den wahrgenommenen Potenzialen finden sich größere Unterschiede zwischen den Expertengruppen. Während beide Gruppen generell forstwirtschaftliches Potenzial sehen, werden von sektor-externen neben dem konventionellen Potential mehr innovative Möglichkeiten gesehen. Diese finden sich überwiegend im Bereich der politischen Strategieund Bündnisbildung, wo ILE einen Beitrag leisten könne, strategisches Lernen zu integrierten Programmen zu forcieren sowie mögliche innovative Bündnisoptionen zu identifizieren. So wird generell in dieser Gruppe der Befragten ein breiteres Spektrum an potenziellem Nutzen aus den Programmen wahrgenommen. (Tab. 3)

\subsection{Ursachen einer geringen Beteiligung}

Bei der Analyse möglicher Gründe für die geringe Beteiligung des Forstsektors bei ILE-Programmen lassen sich wiederum zwei Arten erkennen. Gründe, die außerhalb des Sektors oder seines direkten Einflusses liegen, werden als sektor-externe Gründe behandelt. Interne Ursachen sind solche, die von sektoralen Akteuren selbst beeinflusst werden können.

\subsubsection{Sektor-externe Ursachen}

Beide Gruppen von befragten Experten nannten den institutionellen Aufbau konkurrierender Sektoren, besonders den der entsprechenden öffentlichen Verwaltungen, als Grund für eine geringe Beteiligung. Während die landwirtschaftliche Verwaltung, bei der die ILE-Programme angesiedelt sind, sowohl auf Landes-, Bundes- als auch auf EU-Ebene stark institutionalisiert ist, seien forstliche Belange lediglich auf Landesebene prominent vertreten. Forstwirtschaft und 
Tab. 3. Potenziale für die Forstwirtschaft in ILE-Programmen.

Forestry potentials in area-based rural development.

\begin{tabular}{lll}
\hline Wahrgenommen durch ... & Konventionelle Potenziale & Innovative Potenziale \\
\hline Forstliche Akteure & Zusätzliche Holzmobilisierung & Sektorale Politikstrategien weiterentwickeln \\
& Finanzieller Nutzen aus Förderung & \\
Sektorfremde Akteure & Zusätzliche Holzmobilisierung & Sektorale Politikstrategien weiterentwickeln \\
& Finanzieller Nutzen aus Förderung & Produktinnovationen \\
& Politische Relevanz einbringen, um Nutzen zu erlangen & Bündnisinnovationen \\
& & Forstliche Themen besetzen/erschließen \\
\hline
\end{tabular}

Tab. 4. Sektor-externe Ursachen für eine geringe Beteiligung des Forstes an ILE-Programmen und exemplarische Ausprägungen. Sector-external causes for low forestry involvement in area-based rural development programmes and exemplary occurrences.

\begin{tabular}{lll}
\hline Wahrgenommen durch ... & Art sektor-externer Grund & Ausprägung des Grundes (beispielhaft) \\
\hline Beide Akteurs-Gruppen & - ILE als LW-Domaine & - Unpassende Förderbedingungen für Forstwirtschaft, \\
& - Institutionelle Gründe im administrativen Aufbau & mangelnder Nutzen \\
& - Einseitige Wahrnehmung der Forstwirtschaft als & - LW auf Bundes- u. EU-Ebene institutionalisiert; \\
& Umweltsektor & Forstwirtschaft als ,Ländersache und ist somit isoliert“ \\
Sektorfremde Akteure & - ILE = Mittelabfluss aus Förderung der Primärproduktion & - Sehr breite Beteiligung, , so dass die Kernidee und der \\
& - Wenig umsetzungsorientiertes Design regionaler ILE- & Nutzen nicht herauskamen“ \\
& Prozesse &
\end{tabular}

Forstliche Akteure

-politik wird als „Ländersache gesehen und ist somit isoliert ${ }^{67}$. Ferner sei ein eher landwirtschaftliche Charakter und Zuschnitt der ILEProgramme zu erkennen, die selbst eigentlich ,landwirtschaftliche Strukturprogramme" seien ${ }^{8}$. Unpassende Förderbedingungen zeigten, dass ein ,fehlender kurzfristiger Nutzen" die Beteiligung forstlicher Akteure behindere 9 . Die einseitige Wahrnehmung der Forstwirtschaft in Politik und Öffentlichkeit als Umweltsektor sei ebenfalls abträgig für eine wirtschaftsstarke Position der Forstwirtschaft in regionalen Prozessen. Zudem sehe sich der Sektor auch nicht als integraler Teil der ländlichen Entwicklung ${ }^{10}$.

Die Gruppe der externen Experten erkannte zudem, dass die Finanzierung von ILE-Programmen vornehmlich aus Budgets stamme, die traditionell in die Primärsektoren geflossen seien. Daher falle es nun Land- und Forstwirtschaft schwer, diesem aus ihrer Sicht Mittelabfluss etwas Positives abzugewinnen und sich aktiv auch auf institutionalisierter Ebene einzubringen ${ }^{11}$. Auf der regionalen Ebene der Programmimplementation beobachteten die Experten, dass das Design regionaler ILE-Prozesse einer forstlichen Beteiligung ebenfalls abträglich sein könne. Man beobachte dort in den Initialphasen häufig eine sehr breite Beteiligung, ,sodass die Kernidee und der Nutzen nicht herauskamen [...] Wenn kapitalintensive Maschinen im Einsatz sind, kann man nicht erwarten, dass die Akteure am Nachmittag an Diskussionen teilnehmen "12. Tabelle 4 fasst die hier genannten Gründe nochmals zusammen.

\subsubsection{Sektor-interne Ursachen}

Externe als auch interne Akteure sahen in der jeweiligen regionalen Bedeutung sowie der mangelnden Wahrnehmung der Forstwirtschaft als ökonomischen Zweig einen möglichen sektor-internen Grund ${ }^{13}$ Dazu komme ein gewisses forstbetriebliches Verständnis, welches die Teilnahme erschwere. Darunter fällt eine kritische Sicht auf öffentliche Förderung, die jeweils abhängig von der Kassenlage der

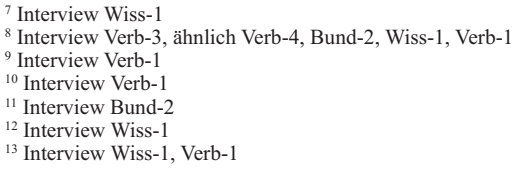

öffentlichen Haushalte und somit schlecht planbar sei. Zudem werde diese als Vorstufe zum Ordnungsrecht sehr kritisch gesehen ${ }^{14}$. Aus betriebswirtschaftlicher Sicht vermeide man die Unsicherheiten, die mit kooperativen Prozessen verbunden seien ${ }^{15}$, und man versuche, die mit ILE verbundenen relativ hohen Transaktionskosten, um ans Ziel zu kommen, zu umgehen ${ }^{16}$. Gründe, die im forstpolitischen Verständnis und Handeln begründet liegen, konnten als ein weiterer gemeinsamer Punkt beider Befragtengruppen identifiziert werden. Die Wahrnehmung eines sehr sektoralen und konservativen Vorgehens ${ }^{17}$ sowie einer eher zurückhaltenden Lobbyarbeit bei der Gestaltung von Förderprogrammen ${ }^{18}$ seien ebenfalls Gründe für eine geringe Teilhabe.

Sektorfremde Akteure sahen zudem im forstlichen Selbstverständnis ein Hemmnis. Die Wahrnehmung Externer wie „Der Forst hat eine Welt für sich “ und „Keiner hat uns reinzureden und wir mischen uns nicht bei anderen ein "19 verdeutlichen dies. Aber auch ein geringes Selbstbewusstsein wird der Forstwirtschaft attestiert und als Grund angeführt. Erst durch die Clusterstudie hätten forstliche Akteure gemerkt „Huch, in meiner eigenen Branche sind wir ja gar nicht blo $\beta$ ein paar Hansels! ${ }^{“ 20}$ Des Weiteren verfüge der Forstsektor meist nicht über Schlüsselfähigkeiten, die in der ILE von zentraler Bedeutung seien. Fehlende Kommunikationsfähigkeiten und die Einsicht, seine Interessen auch in der Öffentlichkeit artikulieren zu müssen, was in der Landwirtschaft üblich sei, erschwerten die Beteiligung. Letztlich wurde von der Gruppe angemerkt, dass in der Forstwirtschaft ein eher innovationsunfreundliches Klima herrsche. "Innovatoren werden in forstlichen Reihen häufig als Exoten angesehen. In ILE geht es genau um solche Ideen, mit denen man Nischen besetzen kann wie z. B. Mondholz oder regionale Holzvermarktung. " Eine standardisierte Interessenvertretung wie beispielsweise durch den Geschäftsführer einer Betriebsgemeinschaft und die Beratung durch staatliche Institutionen verstärke den Mangel an politischen Innovationen ${ }^{21}$. Letztlich, erklärten sektor-externe Akteure, sei es schwierig, im

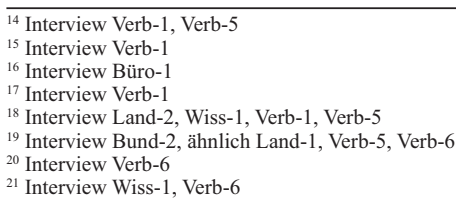




\section{Giessen}

Tab. 5. Sektor-interne Gründe für eine geringe Beteiligung des Forstes and ILE-Programmen und exemplarische Ausprägungen.

Sector-internal causes for low forestry involvement in area-based rural development programmes and exemplary occurrences

\begin{tabular}{lll}
\hline Wahrgenommen durch... & Art sektor-interner Grund & Ausprägung des Grundes (beispielhaft) \\
\hline Beide Akteurs-Gruppen & - Regionale Relevanz des Sektors & - „Forst ist bei früheren rein nationalen Programmen immer dabei \\
& - Forstbetriebliches Verständnis u. Handeln & gewesen. Nun denken die Forstakteure, dass sie auch bei EU-Program \\
& - Forstpolitisches Verständnis u. Handeln & $\begin{array}{l}\text { men automatisch dabei sind. } \text { Man hat sich in der Vergangenheit sehr auf } \\
\text { traditionelle forstliche Aspekte konzentriert und so möglicherweise den }\end{array}$ \\
& & Anschluss auf EU-Ebene verpasst.“ \\
Sektorfremde Akteure & - Forstliches Selbstverständnis & - „Keiner hat uns reinzureden und wir mischen uns nicht bei anderen ein” \\
& - Mangel an ILE-relevanten Fähigkeiten & - Mangelnde Kommunikationsfähigkeiten \\
& - Innovations-unfreundliches Klima & - Innovatoren als „Exoten“ gesehen \\
Forstliche Akteure & - Fehlende Information & - Staat: unflexibel, institutionelle Hindernisse \\
& - Besitzartenabhängige Gründe & - Privat: fehlende Ressourcen
\end{tabular}

Forstsektor den richtigen Ansprechpartner für bestimmte Fragen zu finden. Die Trias aus Staats-, Kommunal- und Privatwald erschwere dies zusätzlich ${ }^{22}$.

Sektorale Interviewpartner erklärten die geringe Beteiligung mit fehlenden Informationen zu solchen Programmen, besonders im kleinen und mittleren Privatwald ${ }^{23}$. Bezüglich der Besitzart merkten sie an, dass der Staatswald eine überwiegend unflexible Verwaltung sei, die mit der Grundidee von ILE nur schwer vereinbar scheint. Zudem setzten Verwaltungsreformen besonders Staatsbetriebe unter Druck, sodass sich diese auf ihr Kerngeschäft fokussierten. „Wie soll man Partizipation machen, wenn man damit beschäftigt ist, die Basisfunktionen aufrecht zu erhalten? "Die Ressourcen personeller Art jedoch seien in den öffentlichen Verwaltungen durchaus vorhanden, nicht zuletzt durch frei werdende Mitarbeiter, die von den Reformen direkt betroffen sind ${ }^{24}$. Kommunale Besitzer wurden von den Experten als vielversprechende Zielgruppe für ILE-Aktivitäten gesehen. Hier seien sowohl personelle Ressourcen für solche Vorhaben vorhanden als auch die nötigen Informationen zu den Programmen ${ }^{25}$. Dem Privatwald, als der heterogensten Besitzart, wurde ein vordergründiges ökonomisches Interesse bestätigt, woraus personelle Schwierigkeiten für kollektive ILE-Prozesse erwachsen. Das Abstellen von Mitarbeitern oder das Investieren von eigenen Zeitressourcen müsse mit einem entsprechenden kurzfristigen Nutzen verbunden sein, was meist nicht der Fall wäre. Die Befürchtung, die Handlungsautonomie über sein Eigentum zu verlieren, dürfe bei dieser Zielgruppe auf keinen Fall vernachlässigt werden. Kollektive Prozesse bergen das Risiko, sich durch Zusagen und Absprachen in Abhängigkeit zu begeben, die die hochrangige Handlungsautonomie einschränke. Diese Angst sei im Osten Deutschlands aufgrund der Erfahrungen mit Enteignungen und Kollektivierung besonders hoch. Bei differenzierter Betrachtung des Privatwaldes gingen ILE-Programme vermutlich komplett am kleinen und mittleren Besitz vorbei. Es fehle an Informationen, und zudem seien dies ,oft alte Männer, die machen da nicht mit!“ Hinzu kämen das Problem der extremen Heterogenität eben dieser Gruppe und die Tatsache, dass die Eigentümer oft andernorts wohnten. Zusammenschlüsse hingegen könnten an ILE interessiert sein. Jedoch sei hier eine standardisierte Interessenvertretung gegeben, die das innovative Einbringen in die Prozesse ebenfalls hemme. Große Waldbesitzer hingegen könnten ein persönliches Interesse an ILE-Prozessen haben, da diese oft sehr regional verbunden seien und ihr Prestige somit pflegen könnten. Dies treffe insbesondere auf den Adel zu. Allenfalls die genannten Gründe wie unternehmerische Ausrichtung könnten dem entgegenstehen ${ }^{26}$ (Tab. 5).

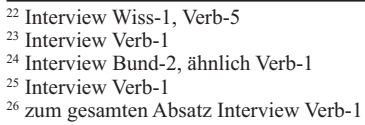

\section{Schlussfolgerungen und forstliche Handlungsoptionen}

Anhand der präsentierten Ergebnisse wird deutlich, dass selbst in integrierten Förderprogrammen das sektorale Verständnis, Netzwerke sowie sektorale Mechanismen eine wichtige Rolle spielen (s. a. Hubo u. Krott 2007). Dies wird umso deutlicher, wenn wir uns den Befund, ILE-Programme wiesen eine starke landwirtschaftliche Tendenz auf, genauer betrachten. Als Programme von ausschließlich landwirtschaftlichen Institutionen (Generaldirektion Landwirtschaft bei LEADER+, BMVEL bei Regionen Aktiv sowie diverse Ministerien, die mit einer Ausnahme alle auch bzw. hauptsächlich Kompetenzen für Landwirtschaft haben) stellen sich der Forstwirtschaft hier zwei Probleme. Zum einen ist der Zuschnitt der Programme stark auf landwirtschaftliche Bedürfnisse abgestellt (z. B. hohe Flächengenauigkeit, die im Wald nicht zu erreichen ist, sowie die Jährlichkeit der landwirtschaftlichen Produktion). Zum anderen tritt eine erhebliche Ungleichheit im institutionellen Design der beiden Sektoren (Land- und Forstwirtschaft) als hinderlich hervor. Während die Landwirtschaft auf nahezu allen Verwaltungsebenen relativ stark institutionalisiert ist (EU, national durch BMELV und GAK, Länder), sind starke öffentliche Forstinstitutionen lediglich auf Länder- und regionaler Ebene zu finden. Daraus ergibt sich ein institutionelles ,level of non-fit ${ }^{\text {“27 }}$ auf den Ebenen, in denen keine äquivalente Vertretung der forstwirtschaftlichen Interessen gegeben ist. Dieses führt bei der ILE-Programmformulierung im Mehrebenensystem (zwischen EU-Kommission - Ländern - Regionen bei LEADER + , Bund - Regionen bei Regionen Aktiv sowie Bund - Ländern - Regionen) zu Vorentscheidungen, die je nach ihrer Ausprägung einer oder mehreren Interessenlagen eher dienlich sind, als anderen. Wir sehen somit, dass sektorale Interessen und Mechanismen in unserem Fall zweifach zur Geltung kommen: durch forstliche Nichtteilnahme und landwirtschaftliche Programmgestaltung. Als Erklärung soll hier ebenfalls auf die historischen Entwicklungen verwiesen werden. Da mit den Römischen Verträgen die Landwirtschaft mit einer gemeinsamen Agrarpolitik der EU konfrontiert war, ergaben sich hier frühzeitig politische Lernprozesse, die sich besonders im Bereich der integrierten bottom-up-Ansätze bemerkbar machen. Die Forstwirtschaft als rein nationale bzw. Länderverantwortlichkeit war diesen Anpassungsanforderungen nicht in gleichem Maße ausgesetzt. Folglich ergab sich bisher keine Notwendigkeit, forstpolitische Strategien entsprechend zu adaptieren. Da die Förderpolitik jedoch Tendenzen zu mehr integrierten Ansätzen an den Tag legt (Krul u. Ozinga 2005), bieten sich nun adaptierte Strategien an, um auch künftig alle politischen Optionen der Nutzenmaximierung durch Fördermittel zu gewährleisten.

Um die Forstwirtschaft aktiv als Partner zu gewinnen, sollen nun

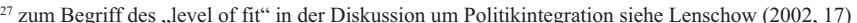


folgende (normativ geprägten) Empfehlungen ausgesprochen werden. Integrierte Programme sollten ihrem Anspruch gerecht werden und tatsächlich Nutzen für alle Adressaten beinhalten und deren spezifische Rahmenbedingungen (Interessen, Institutionen) berücksichtigen. Dieser Appell richtet sich an die sog. „Policy maker“ integrierter Programme.

Einer geringen Beteiligung kann allerdings auch und im hohen Maße von forstwirtschaftlichen Akteuren selbst entgegengewirkt werden. Grundlegende Frage hierbei muss sein, ob eine Teilhabe (beispielsweise eines einzelnen mittleren Privatwaldbesitzers oder eines Besitzerverbandes) einen spezifischen Nutzen hat. Dieser Frage sollten sich öffentliche wie private Waldbesitzer und deren Verbände und Verwaltungen stellen, da davon auszugehen ist, dass in Zeiten knapp werdender öffentlicher Mittel und des gesellschaftlichen Ziels der nachhaltigen Entwicklung integrierte Programme eher zunehmen werden (Lenschow 2002, Stead et al. 2004, Brissoulis 2005, Krul u. Ozinga 2005). Somit drängt sich die Frage auf, ob es sich forstliche Akteure auf absehbare Zeit leisten können, sich nicht mit integrierten Programmen zu beschäftigen und nicht aktiv in den Abwägungsprozess einzusteigen. Ortner (2008) bietet hier Möglichkeiten zur Abschätzung des politischen Nutzens für Forstakteure in ILE-Prozessen.

Nun lassen sich einige wenige konkrete Handlungsoptionen für Akteure der Forstwirtschaft vorschlagen, um deren Teilhabe an ILEProgrammen zu verbessern. Drei Handlungsfelder können hierfür dienlich sein. Zunächst könnten die öffentlichen Forstverwaltungen im Sinne eines aktivierenden Staats als Vermittler wirken, indem sie erfolgreiche Beispiele forstlicher Beteiligung an ILE - und besonders des erzielten spezifischen Nutzens - sammeln und für ihre sektorale Klientel aufbereiten. Beispiele hierzu liefern u. a. Giessen et al. (2006), Ortner $(2004,2008)$ sowie Giessen u. Böcher (2007). Diese Aufgabe mag zwar ebenso von privaten Organisationen durchgeführt werden können, die somit als Wirtschaftssubjekte ihren eigenen Nutzen zu maximieren suchen. Jedoch hat die Studie gezeigt, dass die Ressourcenausstattung (besonders mit Personal) eben dieser Akteursgruppe sehr beschränkt ist und deren Bereitschaft, Ressourcen in ILE-Prozessen aufzubringen, solange gering bleibt, bis ein spezifischer Nutzen in Aussicht ist. Da dieses in kollaborativen Aushandlungsprozessen jedoch nicht immer direkt gegeben ist, könnten somit öffentliche Ressourcen als Startinvestition gesehen werden. Ferner sollten Informationen zu Programmen, die einen forstwirtschaftlichen Nutzen bergen, aktiv durch entsprechende Netzwerke mit Verweis auf die o. g. aufbereiteten Materialien verbreitet werden. Zweitens kann dem institutionelle n,,non-fit" auf verschiedenen territorialen Ebenen begegnet werden. So könnten beispielsweise „mobile Berater für integrierte Förderung“ auf regionaler (z. B. LW-Kammer), Landes-, Bundes-, aber auch auf EU-Ebene als Schnittstelle zwischen dem Sektor und integrierten Programmangeboten fungieren und Forstakteuren den spezifischen Nutzen vermitteln sowie Informationen zu den Programmen liefern. Solche Vermittler müssten jedoch mit den nötigen Fähigkeiten (z. B. Kommunikations- und Networking-Talent) ausgestattet sein. Ein solcher Ansatz würde drittens auch der personellen Ressourcenknappheit besonders bei privaten Waldbesitzern - entgegenwirken, die ebenfalls als hinderliche Ursache identifiziert wurde.
Die Ressourcen für eine solche Initiative mögen im Forstsektor knapp sein. Allerdings setzen andauernde Verwaltungsreformen auch Kapazitäten (Kollegen) frei, die in der o. g. Idee vielleicht eine lohnenswerte und spannende Aufgabe finden. Somit würde die Forstwirtschaft den Herausforderungen einer sich wandelnden Förderlandschaft aktiv begegnen, sich für zukünftige politische Entwicklungen alle Optionen erhalten und ihren spezifischen Nutzen aus integrierten Programmen ziehen können.

\section{Literatur}

Atteslander P. 1995. Methoden der empirischen Sozialforschung. 8. Aufl. Walter de Gruyter, Berlin

BMVEL (Bundesministerium für Verbraucherschutz, Ernährung und Landwirtschaft) 2005. Ländliche Entwicklung aktiv gestalten - Leitfaden zur integrierten ländlichen Entwicklung. Bonn

Böcher M., Gießen L. 2006. Forst als Partner in der integrierten ländlichen Entwicklung. AFZ/DerWald 61, 263-264

Briassoulis H. 2005. Policy integration for complex environmental problems - The example of Mediterranean desertification. Ashgate, Burlington

DFWR (Deutscher Forstwirtschaftsrat) 2001. Satzung des Deutschen Forstwirtschaftsrates e. V.

Elands B.H.M., Wiersum, K.F 2003. Forestry and rural development in Europe - Research results and policy implications of a comparative European study. Wageningen

Giessen L., Böcher M. 2007. New Modes of Governance in Integrated Rural Development Policies. Göttingen

Giessen L., Böcher M., Ortner M., Tränkner S. 2006. Integrated rural development as pathway for innovations - an unexploited potential for forestry. In: MCPFE (ed.) Policies fostering investments and innovations in support of rural development. Warschau, 38-56

Hahne U. 1984. Ökologische Regionalentwicklung. Informationen zur Raumentwicklung 1/2, 53-62

Hubo Ch., Krott M. 2007. Politiksektoren als Determinanten von Umweltkonflikten am Beispiel invasiver gebietsfremder Arten. In: Feindt P.H., Saretzki T. (Hrsg.) Umwelt- und Technikkonflikte. Wiesbaden

Krul L., Ozinga S. 2005. Funding Europe's forests - How to use EU funds for sustainable forest management and nature protection. Brussels

Lenschow A. 2002. Environmental policy integration - Greening sectoral policies in Europe. Earthscan, London

OECD 2006. The new rural paradigm: Policies and governance. Paris

Ortner M. 2004. Zusammenarbeit zwischen Forstwirtschaft und Leader+. In: LEADERforum 2/2004, 41

Ortner M. 2008. Erfolgsfaktoren für die Beteiligung forstlicher Akteure an der integrierten ländlichen Entwicklung - Beispiel: LEADER+ Programm der EU-Strukturpolitik. Göttingen (im Druck)

Ray Ch. 2000. The EU LEADER programme: Rural development laboratory. Sociologia Ruralis 40/2, 163-171

Sabatier P.A. 1988. An advocacy coalition framework of policy change and the role of policy-oriented learning therein. Policy Sciences 21, 129-168

Setzer F. 2007. Welche Akzente wurden in der Forstförderung bei der Umsetzung der ELER-VO in den Bundesländern gesetzt? Forst u. Holz 62, 8

Stead D., Geerlings H., Meijers E. 2004. Policy integration in practice. The integration of land use planning, transport and environmental policymaking in Denmark, England and Germany. Delft

Tränkner S., Giessen L. 2007. Four paths to mainstreaming the LEADER approach in Germany - the case of Schleswig-Holstein. In: Critica France (ed.) Which direction for rural development? CNASEA/INEA 


\title{
Rural Governance, Forestry, and the Promotion of Local Knowledge: The Case of the German Rural Development Program 'Active Regions'
}

\author{
Lukas Giessen • Michael Böcher
}

Accepted: 5 March 2009/Published online: 24 March 2009

(C) Steve Harrison, John Herbohn 2009

\begin{abstract}
This article investigates the role of local knowledge in the policy approach of neo-endogenous rural development, which may be held by local and regional actors such as municipal and county level politicians, local and regional level administration, entrepreneurs as well as local third sector representatives. The main question addressed is whether local knowledge under this approach is merely mobilised or if rural development processes are even based on such knowledge, placing it at the centre of such policy. The relevance of this approach to forestry is also explored. The types of forest owners for which the neo-endogenous rural development approach is appropriate and the types that may have difficulties in coping with this cross-sectoral and area-based approach are especially examined. Using a case study design on the German Active Regions funding program it is shown that the neo-endogenous approach is most relevant to large private forest owners and small-scale corporate enterprises, but also has potential for small- and medium-sized private owners. Concerning the role of knowledge held by local and regional actors, the approach is shown to largely build on the use of local expertise, and hence policy acceptance increases. However, scientific knowledge as well as politics are found to play a major role in the use, production and interpretation of local knowledge.
\end{abstract}

Keywords Integrated rural development - Small-scale forestry - Forest owners . Knowledge transfer $\cdot$ Knowledge production $\cdot$ Scientific knowledge

L. Giessen $(\bowtie) \cdot$ M. Böcher

Chair of Forest and Nature Conservation Policy, University of Göttingen/Germany,

Buesgenweg 3, 37077 Goettingen, Germany

e-mail: lgiesse@uni-goettingen.de

M. Böcher

e-mail: mboeche@uni-goettingen.de 


\section{Introduction}

Traditional policy approaches to rural development have been based predominantly on rural government, mainly coordinating agricultural concerns and interests. In contrast, the term rural governance implies a multi-dimensional steering and managing of various demands currently being made upon rural space (Marsden and Murdoch 1998; Goodwin 1998). In Germany this discourse is reflected by the term regional governance (Böcher 2008a; Giessen 2008). This new paradigm of rural governance has been conceptualised as neo-endogenous rural development (Ray 2006, who introduces NERD as acronym for the approach).

\section{Rural Governance and Local Knowledge}

This new approach to rural development is characterised by a shift in focus from a centralised and sectoral approach of interventions towards more participatory, negotiated and cross-sectoral approaches, activating local endogenous potentials of key rural stakeholders. Potential local and regional stakeholders include forest owners, farmers, nature conservationists and entrepreneurs. The approach is supposed to mobilise endogenous potentials of 'autonomous self-governing networks' (Goodwin 1998, p. 8) and in doing so actively involves the knowledge of rural actors about immediate living circumstances (Böcher 2008a). Ray (2006, p. 278) in this context developed the neo-endogenous rural development approach which assumes that 'socio-economic well-being can best be brought about by restructuring public interventions away from individual sectors in favour of a mosaic of local/regional territories'. Central to the approach is that along a bottomup trajectory a 'local area must acquire the capacity to assume some responsibility for bringing about its own socio-economic development'. ${ }^{1}$ A key feature is the partnerships among a range of local public and private actors, potentially including communal and county politicians and administrational representatives, locallybased businessmen as well as local-level NGOs. Such local partnerships are supposed to pool the knowledge held by these local actors as one of the most crucial factors determining the success of a partnership approach (OECD 2001, 2006; Moseley 2003). However, besides the high relevance of local knowledge within neo-endogenous rural development (NERD), Ray (2006) also emphasises the role of 'the extralocal'. In the context of rural development efforts, this may be for example external technical or political advisers, actors from other localities with relevant knowledge which has been accumulated at local level, and institutions such as supranational, national or sub-national (government) agencies. Here lies the major

\footnotetext{
${ }^{1}$ Ray uses the terms 'local' as well as 'regional' almost synonymously. He refers to formal as well as informal levels of political coordination at which the policy approach applies and which are neither purely local (in terms of communal) nor sub-national (in terms of federal states). In this paper the two terms are used in the same quasi-synonymous way, even though the literature on local knowledge obviously refers to local while rural governance and neo-endogenous development scholars often cite the term 'regional', especially in a German context. The latter term in its empirical occurrence usually consists of one up to several counties, yet smaller than a Federal State.
} 
difference and advancement of NERD as compared to the earlier concept of 'endogenous rural development'. The latter emphasises autonomous potentials and approaches to development for individual localities (for example, see Bruckmaier 2000; van der Ploeg and Long 1994; Hahne 1985, 1986) where extra-local agents, conditions and incentives have not played a major role in explaining rural development.

An example of the increasing role of external incentives and actors can be seen in recent developments within rural studies as well as rural development policy, especially when considering the European rural development paradigm. In science this new paradigm is being discussed under the NERD approach (see Ray 2006), in concepts of rural governance (see e.g. Marsden and Murdoch 1998; Goodwin 1998; Edwards et al. 2001; Woods and Goodwin 2003) or regional governance respectively (Böcher 2008a; Böcher et al. 2008). Recent policy in many OECD countries is designed following the NERD-approach. Wider rural policy thinking reflects this discussion by applying 'The New Rural Paradigm' (OECD 2006). The OECD—especially with its related publications OECD (2001) and OECD (2006) thereby sets the stage for a "less defensive approach to rural policy and stronger coordination across sectors, across levels of government, between public and private actors [... and] a new focus on place rather than sectors' (OECD 2006, p. 3). Since 1991, within the EU, the new European rural paradigm has been tested and continuously developed as the 'LEADER-approach' in successive programs (the community initiatives Leader, Leader II and Leader+, see EU Commission 2006 for details). As noted by EU Commission (2005) LEADER is now an integral part of the recent European Agricultural Fund for Rural Development (EAFRD 20072013).

In Germany, the Ministry of Consumer Protection, Food and Agriculture (hereafter BMVEL, German acronym) also contributed to this political discourse by initiating 'Active Regions' as an individual model and demonstration funding program for rural development (BMVEL 2005). Active Regions has been implemented between 2002 and 2007, in parallel with Leader+ as a central component of the German sustainability strategy. It is the second important NERDprogram in Germany and can be interpreted as a national proxy to the EU's Leader+ initiative, which was launched in the context of the change-oriented 'Agrarwende'-policy of the green Minister of Agriculture in 2001 (for details see Giessen and Böcher 2008).

Relevance of Neo-endogenous Rural Development to Forestry

The role of forestry in NERD is ambiguous. At local levels forestry is perceived as a relevant partner with considerable potential for contributing to and participating in NERD efforts. A quantitative survey among local rural development experts of all 148 Leader+ regions in Germany revealed forestry's potential in different fields of action and its actual participation under the program in Germany (Fig. 1). Giessen et al. (2006), Giessen and Böcher (2008) and Ortner (2008) have reported examples of successful forestry participation at the local level under NERD funding programs. Yet forestry actors do not tap the full potential of respective funding programs, as 


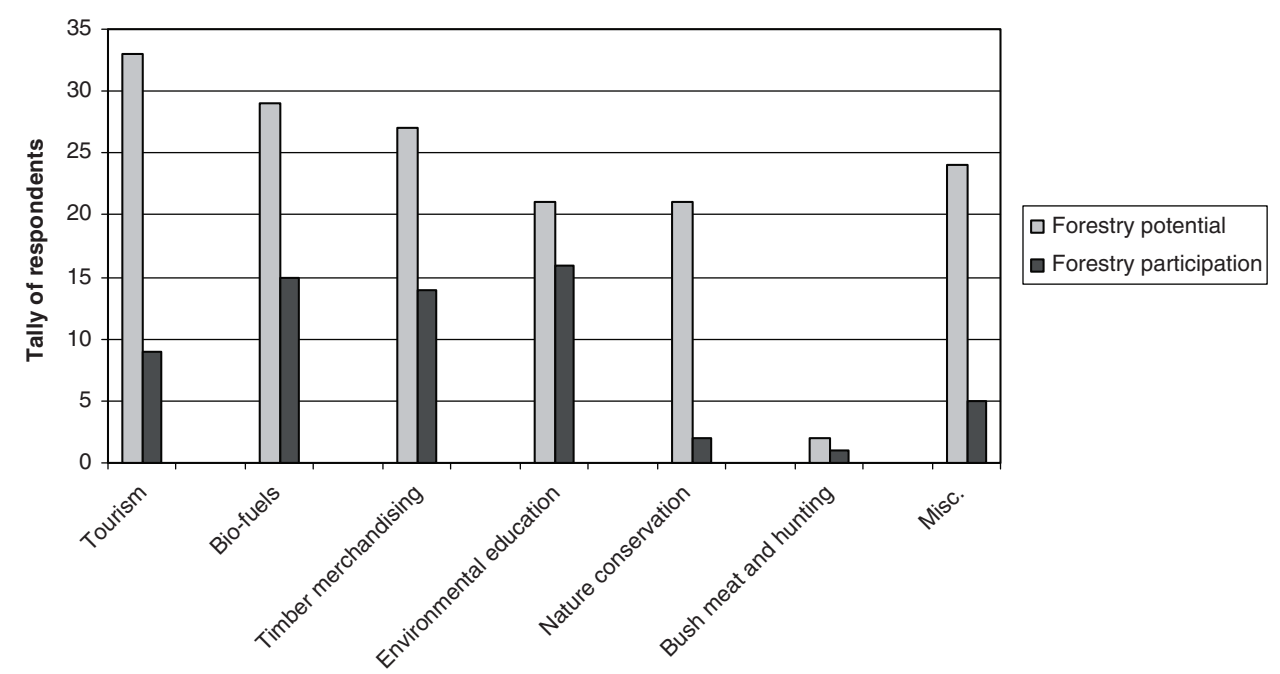

Fig. 1 Forestry potential and participation in German Leader+ projects by fields of action. Note: Leader+ here serves as an example of the NERD approach. Source: Giessen et al. (2006)

the participation of for example forest owners lags behind their potential. Significant institutional as well as programmatic reasons structurally hindering the involvement of forestry into NERD efforts were observed (Giessen 2008; Giessen and Krott 2009). The authors explain this hesitation of forest owners, their associations and public forest administrations as due to the cross-sectoral nature of NERD programs, concluding that there was no necessity for forest owners to cooperate under these funding schemes.

\section{Research Questions}

This article firstly analyses the role that local knowledge plays in political practice on NERD. The question here is whether local knowledge is merely mobilised in one way or another, or whether rural development programs are based on such knowledge and are capable of transferring local knowledge to other levels or places. Recent work in political science (e.g. Fischer 2000), social anthropology (Neubert and Macamo 2005) and rural studies (Ray 2006) indicates however, that a combination of local knowledge resources and extra-local scientific knowledge can provide a more fruitful approach. Secondly, whether the NERD approach is of relevance to and has positive potential for forestry in general and forest owners in particular is investigated. In more detail it is asked for which types of forest owners such programs are most relevant and which types of owners may have difficulty in coping with the cross-sectoral approach, because NERD seems to become a more and more important policy field for forestry issues (Böcher and Giessen 2006). This question is especially interesting to examine because small and medium forest owners may contribute a wealth of locally grounded social as well as physical forest-related knowledge to local development processes. 


\section{The Role of Local Knowledge in Political Problem-Solving}

Scientific knowledge is viewed as being crucial to find policy solutions to current political challenges including questions relating to the environment, and the use of natural resources in particular (Böcher 2008b). Referring to the sociology of knowledge, the general role of knowledge in the policy process can be described as follows (Stehr 2007):

Knowledge serves as a model for reality.

Knowledge illuminates and comprises discovery.

Knowledge can be a first step of action for changing reality.

Hence, facing political challenges, knowledge can serve as a resource for changing the political reality by discovering and evaluating alternative solutions as reactions to these challenges and finally finding an adequate problem solution.

In traditional technocratic views, scientific expertise produces the necessary political knowledge to be applied in the political process. This view is lately being challenged by demands to integrate the knowledge of citizens and that held by collective locally-based actors adequately into political-decision making (Fischer 2000). The social studies of science even consider a new mode of knowledge production in which traditional scientific knowledge (referred to as Mode 1 knowledge) is more or less supplemented by so-called Mode 2 knowledge, which integrates the knowledge production that is carried out in the context of application as well as tacit knowledge (Gibbons et al. 1994).

Two main reasons for this debate can be identified. Firstly, current policy problem solutions (e.g. to environmental problems or sustainability issues) are increasingly complex and thus are dependent on science-laden problem solutions. Consequently, it is argued that political decisions might lack democratic legitimacy due to the rising influence of scientific 'facts', which in turn are only weakly democratically legitimised (Fischer 2000; Pregernig and Böcher 2008). The incorporation of other knowledge sources such as local knowledge could then be a strategy to secure the democratic legitimacy of political decisions, even if these decisions are more and more dependent on scientific knowledge (Fischer 2000). Secondly, many political problems can be more readily solved if local knowledge is incorporated in the process of finding adequate problem solutions. This is for at least two reasons: (1) If local citizens' knowledge is integrated in the policy process at an early stage, political decisions might be more readily accepted by local actors because they see their interests and wishes better reflected (Cash et al. 2002). Under this argument, the integration of local knowledge serves as an instrument to strengthen political legitimacy, political acceptance and the implementation of political decisions. (2) It has been asserted that policy problems which are related to specific local aspects can be solved more appropriately by incorporating the expertise of local politicians and the local administration, organised stakeholder groups and citizens concerning their immediate living conditions (Fischer 2000, 2003; Böcher 2008a). These arguments are well in line with the governance debate, according to which the central state no longer has all knowledge resources at hand 
for coping with complex problems, and thus needs input from various actors (Rosenau 1998).

In the case of NERD it is argued that rural development policy, which is actually designed to suit local conditions of individual rural areas, simply depends on knowledge held by local and regional actors in the public, business as well as the non-profit sector, because rural stakeholders, citizens and polititians know best about weaknesses and strengths of 'their' locality (Böcher 2008a). As a consequence, political approaches for area-based development emphasize the role of rural citizens' knowledge as an important source for more appropriate and effective implementation of rural development policy (BMVEL 2005; OECD 2006; Ray 2006; Böcher 2008b).

\section{Conceptualising Local Knowledge}

For Antweiler (1998, p. 490) 'local knowledge consists of factual knowledge as well as skills and capabilities, most of which have some empirical grounding. Since it is locally and culturally situated and thus a 'social product', local knowledge is often barely conscious and only partly verbalized, even though it may be complex and comprehensive'. Because this definition focuses excessively on the implicit nature of local knowledge it will be supplemented with notions based on Schultze (1998) and Schröder (1995). As a kind of lowest common denominator, local knowledge then can be considered as comprising factual knowledge and practical skills, which have emerged under (local) conditions, i.e. are situated in specific ecological and socio-cultural contexts, which adapt over time. Similar conceptions have been used in connection with 'farming styles' (e.g. by van der Ploeg 1994). Farming styles refer to specific farming strategies, which are conscious responses of farmers to the prevailing ecological and socio-economic conditions (van Averbeke and Mohamed 2006). This conception of locally grounded practices of natural resource management has also been applied in the field of forestry (e.g. van der Ploeg and Wiersum 1997).

Expectations about the Role of Local and Forest-Related Knowledge

Following the theoretical reflections it is firstly assumed that NERD practice emphasises the role and significance of local knowledge and makes it an integral part of the policy approach. Secondly, and reflecting the theoretical background, it is assumed that the political practice of neo-endogenous development does not stress local knowledge as the sole source of knowledge mobilised for bringing about development. Rather, local knowledge is supplemented by other extra-local sources. NERD consequently involves various local actors, including forest owners, who are addressees of the rural development programs. Consequently, it thirdly is hypothesised that emphasising the role of local knowledge increases policy acceptance among policy addressees. Lastly, the low degree of actual participation of forest owners into related funding programs, despite a high perceived potential for the sector, suggests that NERD programs entail potential only for particular 
types of forest owners. It is hypothesised that such cross-sectoral and locallygrounded activities are more attractive to small-scale forest enterprises than for large-scale operations, because small enterprises are more likely to engage in niche markets and their interests may be more diverse than mobilising timber as their first priority. (See Schraml and Selter 2008). In accordance with Harrison and Herbohn (2000) 'small-scale' here is understood as a contrast with large-scale or industrial forestry, which is usually owned or managed by governments or large enterprises.

\section{Research Method}

Following the empirical-analytical approach, a qualitative research method has been adopted. Using a case study approach on the German Active Regions funding program, the analysis is primarily based on two qualitative methods: (i) document analysis (as described by Jones 1996) has been employed on Active Regions policy documents, on the detailed web-based documentation of Active Regions local processes and projects, as well as on related publications by key actors of rural development policy. (ii) 28 interviews among experts in the field of area-based rural development and forestry were carried out. Most of the interviewees can be described as collective actors at an institutionalised level. Table 1 provides an overview of the population of interviewees. The interviews were of a semistructured nature (after Jones 1996), also comprising narrative elements on individual experiences with forestry in cooperative programs.

For complementing the primary data, other empirical data and findings from the accompanying research to the Active Regions program have been consulted. Being part of the accompanying research team from 2004 allowed the authors to overview of all data produced and to select from it as appropriate. The respective results and data are documented in Böcher et al. (2008), Elbe et al. (2007) and in more detail in Elbe (2007), Lukesch et al. (2008), Benz and Meincke (2007) and Böcher and Tränkner (2007). In short, Böcher and Tränkner (2007) as well as Elbe (2007) built their inquiries on document analysis of mandatory reporting by the Active Regions model regions. Lukesch et al. (2008) relied on data derived from participant observations during focus group sessions whereas Benz and Meincke (2007) employed a combination of quantitative and qualitative network analyses.

\section{Relevance of Active Regions to Forestry and Forest Owners}

Within Active Regions several local projects have been implemented with direct or indirect relevance to and participation of forest owners, forest management associations and the forest service. Table 2 provides an overview of projects with forestry involvement under the funding scheme. Thirty-six projects, which were approved in 18 model regions up to the end of 2005, were of direct relevance to forestry (Own inquiry from Nova-Institut 2008). 
Table 1 Population of the qualitative survey on the role of forestry within neo-endogenous rural development

\begin{tabular}{|c|c|c|}
\hline Actor group & Organisation & Code \\
\hline \multirow[t]{6}{*}{ Associations } & Working Group of German Forest Owners' Associations (AGDW) & Assoc 1 \\
\hline & German Forestry Society (DFV) & Assoc 2 \\
\hline & Federation for Nature Conservation (NABU) & Assoc3 \\
\hline & Working Group for Peasant Agriculture (AbL) & Assoc4 \\
\hline & German Association for Land Care (DVL) & Assoc5 \\
\hline & German Farmers' Association (DBV) & Assoc6 \\
\hline \multirow[t]{6}{*}{$\begin{array}{l}\text { Public } \\
\text { administration }\end{array}$} & $\begin{array}{l}\text { Ministry of Economy, Traffic, Agriculture and Viniculture, } \\
\text { Rhineland-Palatine }\end{array}$ & FedSt1 \\
\hline & State Forest Service, Thuringia & FedSt2 \\
\hline & $\begin{array}{l}\text { Federal Ministry for Food, Agriculture and Consumer Protection, } \\
\text { Department } 53 \text { (a) }\end{array}$ & FedGov1 \\
\hline & $\begin{array}{l}\text { Federal Ministry for the Environment, Nature Conservation } \\
\text { and Nuclear Safety }\end{array}$ & FedGov2 \\
\hline & $\begin{array}{l}\text { Federal Ministry for Food, Agriculture and Consumer Protection, } \\
\text { Department } 53 \text { (b) }\end{array}$ & FedGov3 \\
\hline & $\begin{array}{l}\text { Federal Ministry for Food, Agriculture and Consumer Protection, } \\
\text { Department } 52\end{array}$ & FedGov4 \\
\hline \multirow[t]{2}{*}{ Science } & University of Kassel & Sci1 \\
\hline & University of Göttingen & Sci2 \\
\hline \multirow[t]{3}{*}{ Consultants } & Nova-Institut & Cons1 \\
\hline & SPRINT consult & Cons2 \\
\hline & ÖAR consultancy & Cons 3 \\
\hline
\end{tabular}

Note: The codes given in the last column stand for the respective interviewee, indicating whether he or she represent associations (Assoc), Federal States' (FedSt) or Federal Government (FedGov), scientists (Sci) or consultants (Cons)

Despite the actual participation of forest owners in projects, a much higher potential for forestry has been perceived by interviewees. While Fig. 1 referred mainly to sector-external respondents, Table 3 provides a more distinct picture of the potential of NERD programs for forest owners as perceived by respondents within and external to the forestry sector. Hence, the type of ownership may provide further explanations for the discrepancy between low participation and high perceived potentials for forestry.

The regionalised and inter-sectoral approach employed by Active Regions has implications for the type of forest owners with their respective knowledge, who potentially could benefit from funding, and thus could contribute to the program's aim of cross-sectoral action. It is assumed that small-scale forestry enterprises are an appropriate benficiary of the approach. In a German context the term 'small-scale forestry' comprises most of the corporate forests owned by municipalities as well as small (less than $200 \mathrm{ha}$ ) and medium-sized private forest holdings (between 200 and $1000 \mathrm{ha}$ ), while excluding state-owned public forests and private large-scale operations.

\section{Springer}


Table 2 Examples of Active Regions projects with immediate relevance to forestry

\begin{tabular}{ll}
\hline Project domain & Exemplary projects \\
\hline $\begin{array}{l}\text { Recreation and tourism } \\
\text { Social integration }\end{array}$ & Promotion of health-tourism in the Tharandt forest \\
& Creation of a Forest School with forest experience facilities \\
Centre of learning for nature, environment, forests and forestry \\
$\begin{array}{l}\text { Nature conservation } \\
\text { Renewable energy } \\
\text { and fuelwood }\end{array}$ \\
Establishing a coppice forest for biodiversity \\
pocal wood resources for generating power and heat for a public indoor \\
Farmers and forest owners as biofuel producers and service providers \\
Establishment of a production and marketing cooperative for fuelwood \\
Feasibility study for a local fuelwood centre \\
Local land register for fuelwood \\
Initiation of a cooperative on local timber production \\
Online market-place for local high quality timber \\
Sensitising forest owners for the regional brand 'Eifel'
\end{tabular}

Source: Own inquiry from Nova-Institut (2008)

Table 3 Potential for forest owners in NERD programs in Germany

\begin{tabular}{|c|c|c|}
\hline Respondent group & $\begin{array}{l}\text { Conventional potential } \\
\text { for forestry }\end{array}$ & $\begin{array}{l}\text { Innovative potentials } \\
\text { for forestry }\end{array}$ \\
\hline $\begin{array}{l}\text { Forestry actors (such as } \\
\text { representatives of forest } \\
\text { owners associations and } \\
\text { public forest services) }\end{array}$ & $\begin{array}{l}\text { Additional mobilisation } \\
\text { of timber } \\
\text { Financial returns from } \\
\text { public funding }\end{array}$ & $\begin{array}{l}\text { Further develop sectoral } \\
\text { strategies for coping with } \\
\text { cross-sectoral programs }\end{array}$ \\
\hline \multirow[t]{3}{*}{$\begin{array}{l}\text { Sector-external actors (other } \\
\text { experts on the role of forestry } \\
\text { in NERD) }\end{array}$} & $\begin{array}{l}\text { Additional mobilisation } \\
\text { of timber }\end{array}$ & $\begin{array}{l}\text { Further develop sectoral strategies } \\
\text { for coping with cross-sectoral } \\
\text { programs }\end{array}$ \\
\hline & $\begin{array}{l}\text { Financial returns from } \\
\text { public funding }\end{array}$ & $\begin{array}{l}\text { Product innovations (e.g. } \\
\text { for recreation or tourism markets) }\end{array}$ \\
\hline & $\begin{array}{l}\text { Increasing the political } \\
\text { visibility and relevance } \\
\text { of the sector }\end{array}$ & $\begin{array}{l}\text { Innovations in political alliances } \\
\text { Setting forestry issues onto } \\
\text { development agenda }\end{array}$ \\
\hline
\end{tabular}

Since public as well as private forest owners in Germany are organised at the local level, all types could potentially participate in the program. However, closer examination reveals that state forest services, which operate on a large-scale, are inflexible administrations which are not compatible with the fundamental idea of a cross-sectoral, area-based and participative approach (Interview Assoc 1). However, the state forest service was reported having personnel resources at their disposal for participating in NERD. German corporate forests are mainly owned by municipalities. Given a relative high importance of social and protective goals of this owner type (Krott 2005), corporate forest owners are considered as non-industrial and hence qualify under the above small-scale forestry definition. Besides their personnel resources, municipalities were perceived to have information about cross-sectoral 
funding programs including Active Regions, making them a promising target group for the NERD policy approach. For private forest owners in general, the time and labour-intense participation in collective processes and negotiations were identified as hindering their access to the program. Additionally, property rights and the freedom of action are important values among private forest owners (Krott 2005). Forest owners perceived cross-sectoral strategies, including Active Regions, as bearing the risk of underestimating this point at the cost of the owners' control over forest resources. In addition, voluntary public funding programs are perceived as a form of prelude to tightening of regulations. Collective NERD action thus presents a limitation of the freedom of action, causing rejection among a number of private owners. Closer examination of the group of private owners reveals that small and medium private owners often do not live on or near of their forest estate, making them difficult to engage in local development processes in the vicinity of the resource base. Information on integrated rural development programs such as Active Regions was perceived as being scarce among these owner types. Further, dealing with small and medium owners was reported to mean dealing with old men, who were perceived as being reluctant to join in such progressive and communicative approaches. In contrast, forest management associations of small and medium-scale owners could be a valuable target group. However, a rather standardised representation of these owners by a single consultant, who usually manages all their commercial operations, was perceived as not being innovative in a NERD context. In contrast to small private owner types, large-scale private owners, who are living close to their property, could be a promising target group, unless they assert the primacy of unfettered private ownership. Participation in local collective processes was perceived as enhancing their prestige within their communities, which as a motivation to engage, especially among aristocratic owners, was observed to be of importance, too.

Synthesising these findings leads to an overview of forest owner-type related factors, which are facilitating and inhibiting owner's active involvement into NERD programs. Table 4 summarises these findings based on the expert interviews with actors within the forest sector. Corporate small-scale forestry operations as well as large private owners seem to be the most promising target groups. However, combining the personnel resources of state forest services with the forest area held by small and medium owners could be seen as another promising approach to attracting the remaining small-scale forest owners to NERD programs. Hence, the above hypothesis, according to which NERD programs were more attractive to small-scale owners, may only partly be adopted.

A critical review of forestry participation under NERD funding programs reveals that major political factors hinder a wider engagement. Because NERD programs tend to take an agricultural focus and largely are administered by agricultural institutions, a 'level of institutional non-fit' (Giessen 2008) can be observed as compared to forestry institutions. Furthermore, NERD schemes take a cross-sectoral approach, which must be seen as competing with sectoral funding arrangements. Hence, interests of a rather sectoral clientele (such as farmers' or forest owners' associations) may be better pursued using sectoral rather than cross-sectoral programs. Consequently, integrating forestry into NERD is obstructed by an agricultural bias of the programs as well as by the reluctance of the forest sector to 


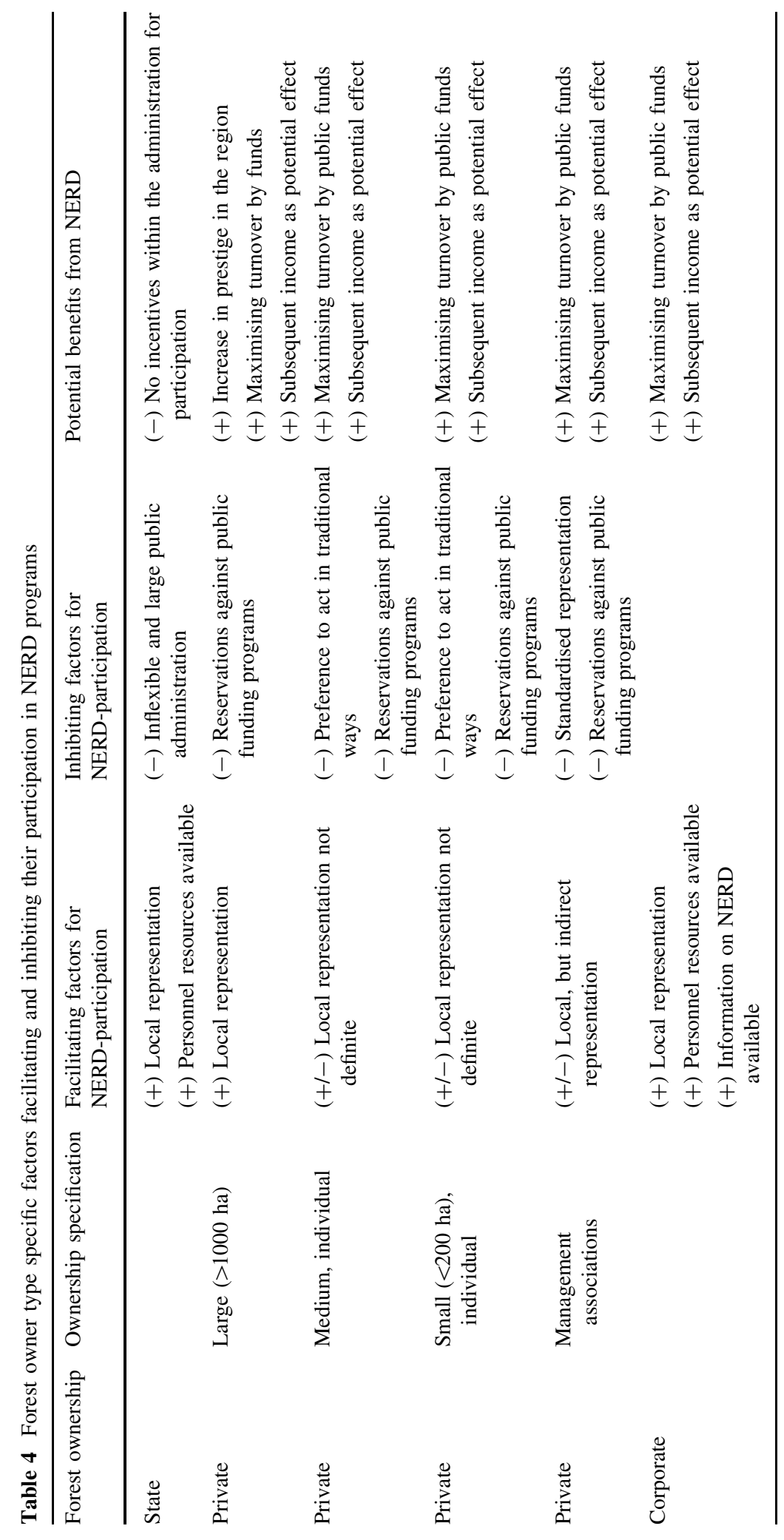


engage in cross-sectoral action (Giessen and Krott 2009). In addition to these major hindrances a lack of information on NERD among forest owners and administrations can be observed (Ortner 2008; Giessen 2008). Forest administrations at regional level currently are under enormous pressure as a consequence of administrative reforms and do not have the capacity to engage in participatory processes (Giessen 2008). Furthermore, rural development is mainly discussed in the agricultural policy domain at national and EU-level, at which the Common Agricultural Policy provides for a framework assuring representation of strong agricultural interests. This strong representation of agriculture is also the case at the national level in Germany, where the 'Joint Task Agricultural Structures and Coastal Protection' (GAK, German acronym) represents such a framework. Finally, the Active Regions program has been initiated and administered by the Federal Ministry of Agriculture's rural development department, without cooperation with its forestry department. Forestry, in contrast, is only weakly represented at the EU or the national level in Germany due to the lack of political responsibilities for forestry issues which lies within the Federal States.

\section{Local Knowledge Under the Active Regions Program}

Active Regions was observed to mobilise local knowledge through local institutions, which have been newly created as a consequence of the funding program and process features, which have characterised program implementation.

Regionalisation of Public Funding as Avenue for Local Expertise

Active Regions applies a new approach to rural development, which is distinct from mainstream funding programs within agricultural and regional policy (BMVEL 2004). The program builds on the principles of (i) regionalisation, (ii) partnership, (iii) integration, (iv) competition, (v) know-how and (vi) new modes of governance in rural development policy (BMVEL 2004; Elbe et al. 2007). The principle of regionalisation has far-reaching implications for the use of local knowledge, placing it at the centre of the approach. 'Every region has its individual strengths, which can serve as the basis for its future development ... people in the region themselves can best recognize the strengths of a region and potentials for future development' (BMVEL 2005, p. 4). The approach consequently shifts all responsibilities known in administrative science (i.e. content-wise, financially as well as administratively) to the level of the regional public private partnerships (similar Elbe et al. 2007).

\section{Regional Management: Mediating Local Knowledge}

Under Active Regions so-called Regional Management (RM) staff are supposed to organise and guide the development process in the local contexts and provide for networking among local actors (Giessen and Böcher 2008). RM staff played a key role as service provider in the local rural development process of the model regions (BMVEL 2004) and accounts for a considerable share of total Active Regions' 
funds. In this capacity they perform a variety of tasks, most of which are related to the management of local internal affairs (BMVEL 2002, 2004). This focus emphasises that RM staff activities necessarily have to be deeply rooted in the local context. Consequently, they need extensive knowledge of local settings, actors and issues and serve as crucial mediators and disseminators of local knowhow.

Financial Responsibility by Local Public Administrative Partners

In contrast to traditional funding programs Active Regions decentralises financial responsibilities to the local level (Interviews Cons1; FedGov3; FedGov4; FedSt2). A local public authority assumes responsibility for financial management, budget administration and formal project approval (BMVEL 2002). This regionalised design for controlling public funds entails considerable simplifications as personal contacts and short distances are perceived as facilitating the development process (Interview FedGov1). Thus, local administrative knowledge also is included in the local institutional structure used by Active Regions, which can be seen as a novel devolution of responsibility to the local level. ${ }^{2}$

\section{Regional Partnerships as Central Decision-Making Bodies}

Regional Partnerships (RPs)—which are subject to rights and duties-form the central steering and decision-making bodies at local levels of implementation (BMVEL 2004). They consist of local actors only, and public authorities may not exceed 50\% of the board membership (BMVEL 2001; BMVEL, undated). RPs are supposed to include key regional interest groups, including 'consumers, farmers and forest owners, conservationists, retail, crafts and trades, commerce, health, municipalities, education and science' (BMVEL 2002, p. 7). Throughout the whole process the RP 'must ensure that the respective social groups are included in planning, implementation and assessment of the regional development process and in the use of available funding' (BMVEL 2002, p. 8). Forestry as a sector has been represented in all of the RPs established under the funding scheme. Within RPs, socalled regional development strategies are negotiated and formulated, which build the basis for subsequent local projects. The public funds may then be used 'to implement strategies developed by regional partnerships ... while the regions can select and implement the measures they see as appropriate' (BMVEL 2002, p. 7). 'Measures' in this context are usually projects initiated and conducted by local actors or services and advice provided by external experts. Under Active Regions, individual projects are eligible only if they are in line with the wider development strategy (BMVEL 2004). Other than traditional funding schemes, where external entities including ministries select and approve project grants, Active Regions empowers RPs with the authority to select and to decline such proposals. A further responsibility of RPs lies in the evaluation of the local development process. RPs

\footnotetext{
${ }^{2}$ A similar approach to local empowerment has been applied under the LEADER+ program. However, formal project approval in that program remains the responsibility of Federal States' ministries or subordinate organisations.
} 
are required to assess goal attainment and progress made with respect to their development strategy as a continuous mandatory self-evaluation exercise (Elbe et al. 2007). Local knowledge in this regard is being activated by the RPs' responsibilities concerning the formulation of a local development program, its implementation by selecting projects which then are eligible for public funding, and the evaluation of the local process through local expertise.

\section{Self-Evaluations for Internal and External Review}

Other notable points of entry for local knowledge have been mandatory selfevaluations. The self-evaluations were based upon own local experiences and followed scientific methods (Böcher 2006) and were carried out and externally interpreted by an accompanying research team (see Böcher and Tränkner 2007). These self-evaluations have then been combined with results of the external scientific knowledge production by the accompanying research (BMVEL 2004). In addition, self-evaluations delivered data for the accompanying research and served as a basis for a mid-term review of the funding program (BMVEL 2004). Thus, the role of local insider knowledge received notable attention. Consequently, activating insider knowledge of local actors through self-assessments facilitated learning processes at the local level, resulting in an increase of endogenous knowledge about the development process, and its strengths and weaknesses (Interview FedGov1). Self-evaluations hence produced new local knowledge. Finally, the extensive use of the elicited materials for external process evaluation by the accompanying research and its communication to policy-makers reflects the transfer of this knowledge to other levels.

\section{Horizontal and Vertical Transfer of Local Knowledge}

The role of local knowledge under Active Regions peaks in the mobilisation of local actors' experiences for an actively steered vertical as well as horizontal transfer of their practical knowledge. In summary, at least 19 network meetings, workshops and training courses were organised between 2002 and 2006 (Elbe 2007). Such meetings brought together local actors (i.e. RP-representatives, RM, project officials, Public Administrative Partners) from all 18 participant regions, and by this facilitated the horizontal transfer of locally accumulated knowledge. By making local expertise available to other localities the program goes beyond the mere utilisation of local knowledge in an individual local context. The policy approach builds on local knowledge sources, which then are de-localised for extracting the essence in de-localised (i.e. abstracted) contexts.

The vertical transfer was carried out by regional and national focus groups, which were established to obtain 'knowledge from inside' for the accompanying research and the ministry. During the implementation of Active Regions, 27 meetings of regional focus groups and two meetings of the national focus group were held (Lukesch et al. 2008). Participants of the regional focus groups were members of the regional partnerships, regional management, project initiators and 
staff from the local Administrative Partners. At national level, representatives from the federal government, federal states, the Active Regions program, as well as the Leader+ networking units, selected local actors, independent experts on area-based rural development and the accompanying research team have been part of the focus group. A major result of the focus groups' work has been the formulation of an 'imaginary ideal funding program' for future policies of integrated rural development, as described by Lukesch et al. (2008). The imaginary program has been supplemented with the knowledge of the scientists of the accompanying research team in order to formulate central policy recommendations (documented in Elbe et al. 2007). The recommendations genuinely integrate the ideas, experiences and suggestions of the actors involved in local NERD activities (Interview Cons2). In some cases even the wording of local actors' suggestions has been included in the policy recommendations (Interview Cons3).

In summary, institutional as well as process-oriented interventions made under the Active Regions program opened up multiple avenues for meaningful inclusion of local knowledge into development efforts, making the use of such knowledge resources a central component of the overall policy approach. An overview of these features is presented in Fig. 2.

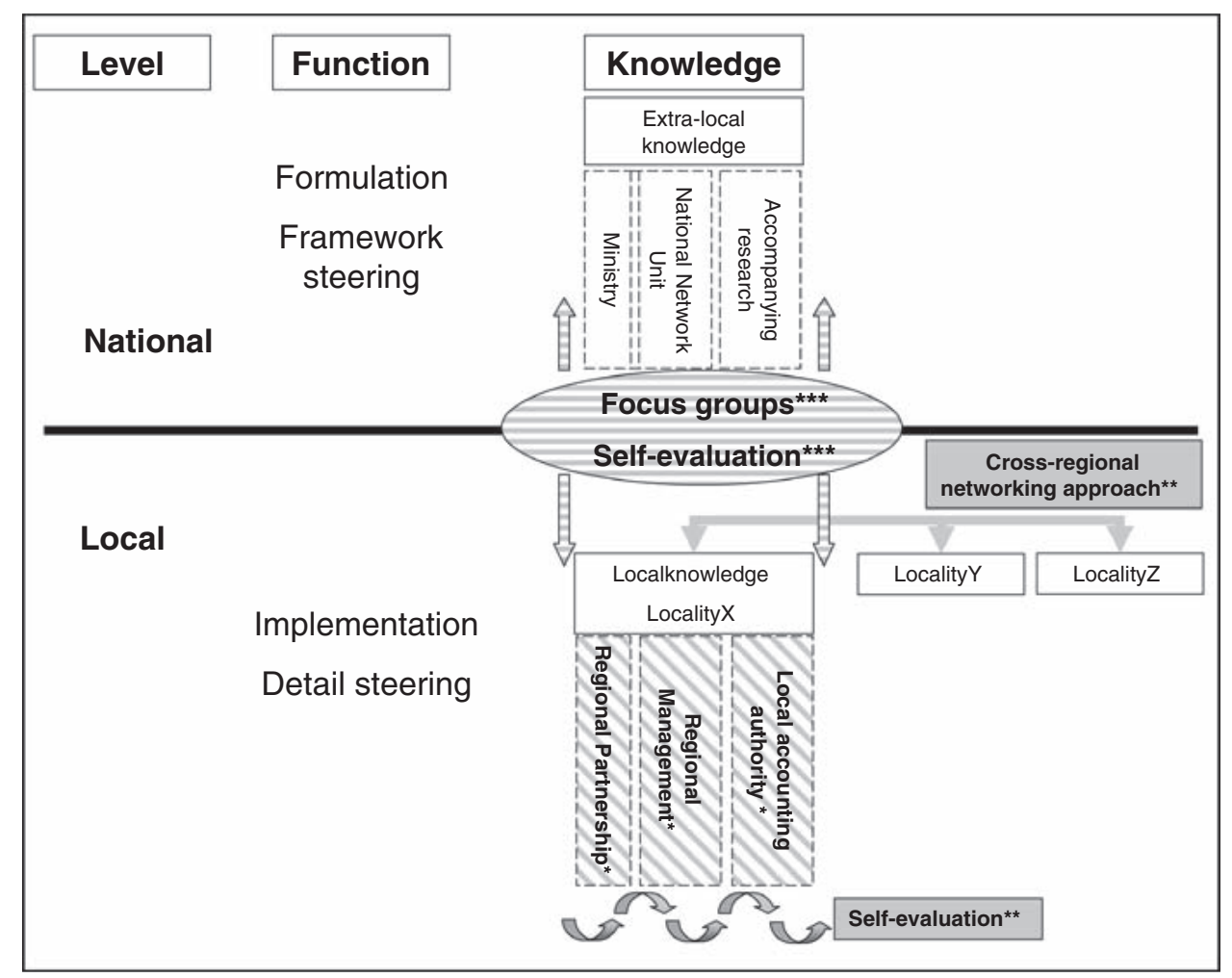

Fig. 2 Avenues for local knowledge within the multi-level policy setting of the Active Regions funding program. Note: * Primarily mobilisation, ** primarily production, *** primarily transfer of local knowledge 
Policy Acceptance as One Result of Local Knowledge Inclusion

An indication that the involvement of local knowledge increases policy acceptance is provided by secondary empirical material gathered by the accompanying research on the Active Regions program. Representatives of the model 'regions' ${ }^{3}$ were asked to weight the five above-mentioned Active Regions principles concerning their importance for the success of the policy approach. Participants rated the principles of 'regionalisation' and 'partnership' the highest (Fig. 3).

These two principles also showed some remarkable interplay, ${ }^{4}$ indicating that program characteristics adding to one of both were seen as the main success factors during program implementation. Elbe (2007) conceptualised both principles by analysing the program's instruments contributing to each of them (Table 5). It becomes obvious that Regional Management and Administrative Partners as well as Regional Partnerships including their extensive decision-making competencies, have been addressed under the two principles of the program, which were perceived as being of paramount importance among addressees. Hence, program instruments building on the extensive use of local knowledge are rated so prominent for the success of the approach by policy addressees that the hypothesis of a positive impact of local knowledge use on policy acceptance may be accepted.

\section{Conclusions}

Scientific and political discussions about rural governance emphasize the increased role of local knowledge for the establishment and successful steering of rural development processes. Political practice, in the form of funding schemes, ties in with these ideas and even implements them within political funding programs such as Active Regions, as has been empirically shown here. The active incorporation of local knowledge into the funding program also raises policy acceptance among its addressees. In the NERD framework, local knowledge, however, is not used in an eco-romantic way as being the ultimate source of knowledge (as suggested by Neubert and Macamo 2005). Rather, it is used in combination with other knowledge sources including science and expertise provided by national policy-makers and advisers. Hence, local knowledge could not be shown to replace other sources of knowledge. Rather, the combination of sources in the case study was used for optimising local development processes by a mixture of the 'best of both worlds', for providing policy-makers with knowledge which they themselves may not obtain from other sources and for increasing policy acceptance and legitimacy of the intervention.

Regarding types of forest owners, large-scale public forest administrations do not seem to be appropriate addressees of NERD policies. Large private owners as well as municipalities owning forest land and operating at a small scale were found to be

\footnotetext{
${ }_{3}$ Respondents were drawn from regional partnerships, regional management, administrative partners and project officials.

${ }^{4}$ The highest correlation between individual principles occurred among 'regionalisation' and 'partnership' (coefficient of correlation $=0.68$ ).
} 


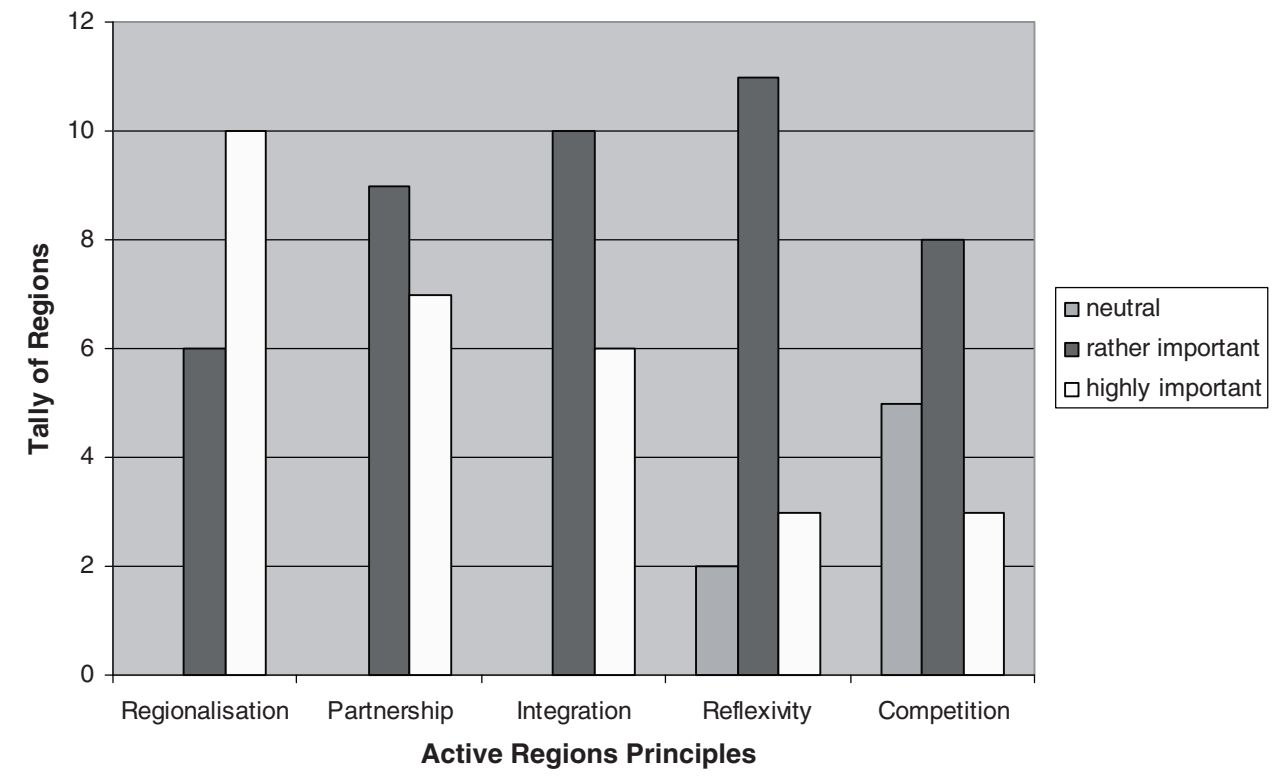

Fig. 3 Relative importance of Active Regions' policy principles as perceived by key actors from 18 model regions. Source: Elbe (2007), translated

Table 5 Excerpt from conceptualising the five Active Regions' principles

\begin{tabular}{|c|c|}
\hline Principle & $\begin{array}{l}\text { Instruments for the implementation } \\
\text { of the principle }\end{array}$ \\
\hline Regionalisation & $\begin{array}{l}\text { Regional identity and demarcation of regions } \\
\text { Regional development strategy } \\
\text { Regional project selection } \\
\text { Regional budget } \\
\text { Regional administrative partner }\end{array}$ \\
\hline Partnership & $\begin{array}{l}\text { Partnership approach for policy formulation } \\
\text { (Ministry with external experts, } \\
\text { Ministry with regions) } \\
\text { Regional partnerships for implementation } \\
\text { at local level } \\
\text { Regional management }\end{array}$ \\
\hline
\end{tabular}

Source: Elbe (2007), translated

promising target groups for NERD programs, because they had either information and resources or an interest in local cooperation for increasing their prestige. These findings, however, should not lead to other small-scale forestry enterprises, namely small and medium private owners and their management associations, being ignored as potential partners. With their extensive resource base and knowledge about local ecological, forest management and social conditions, these types of owners could contribute a great wealth to cross-sectoral area-based policy approaches. Overcoming the information gap within this group of owners has the potential of identifying those owners who, based on their individual interests and values, could contribute to NERD efforts, find new allies and discover innovative solutions to 
existing problems of rural areas and small-scale forestry. Still, the sectoral nature of policy formulation and implementation, as was observed in this study, is the main obstacle for forestry participation in NERD programs. Overcoming this sectoral divide would require additional capabilities within forestry to cooperate at an intersectoral level, or a crisis in the sectoral system of public funding, which then touches upon the material interests of the sector, or a rather high innovation potential of the NERD approach for forestry, which cannot be ignored by forest owners and administrations.

\section{References}

Anonymous (2006) Member of the Active Regions council. Interview 8 (December) 2006. Bonn, Germany

Antweiler C (1998) Local knowledge and local knowing: an anthropological analysis of contested 'Cultural Products' in the context of development. Anthropos 93(4-6):469-494

Benz A, Meincke A (2007) Analyse der Governance Strukturen. Abschlussbericht der Module 3 und 4 zur Begleitforschung Regionen Aktiv 2004-2006. www.regionenaktiv.de. Accessed 05 Sep 2008

BMVEL (2001) Regionen Aktiv - Land gestaltet Zukunft - Informationen zum Wettbewerb. BMVEL, Bonn

BMVEL (2002) Active regions—shaping rural futures—competition winners. BMVEL, Bonn

BMVEL (2004) Regionen Aktiv - Land gestaltet Zukunft. Zwischenbericht zum Wettbewerb. BMVEL, Bonn

BMVEL (2005) Actively shaping rural development-guidelines for integrated rural development. BMVEL, Bonn

BMVEL, German Federal Ministry of Food, Agriculture and Consumer Protection (undated) Notifizierung Regionen Aktiv - Land gestaltet Zukunft. www.nova-institut.de/modellregionen/nachricht. php?id=798\&typ=3. Accessed 052008

Böcher M (2006) Participatory policy evaluation as an innovative method to improve processes of sustainable rural development. Agric Econ Rev 7(1):49-62

Böcher M (2008a) Regional governance and rural development in germany the implementation of LEADER+. Sociol Ruralis 48(4):372-388. doi:10.1111/j.1467-9523.2008.00468.x

Böcher M (2008b) The role of scientific knowledge in theory and political practice-the case of integrated rural development. In: Stehr N (ed) Knowledge and democracy-a 21st century perspective. Transaction Publishers, New Brunswick, pp 183-198

Böcher M, Giessen L (2006) Forst als Partner in der integrierten ländlichen Entwicklung. In: AFZ-Der Wald 05/2006, pp 263-264

Böcher M, Tränkner S (2007) Regionen Aktiv - Land gestaltet Zukunft Begleitforschung 2004 bis 2006. Endbericht des Moduls 5 - Erfolgsfaktoren und Rahmenbedingungen. www.regionenaktiv.de. Accessed 05 Sep 2008

Böcher M, Krott M, Tränkner S (2008) Regional Governance und integrierte ländliche Entwicklung. VS Verlag für Sozialwissenschaften, Wiesbaden

Bruckmaier K (2000) LEADER in Germany and the discourse of autonomous regional development. Sociol Ruralis 40(2):219-227. doi:10.1111/1467-9523.00144

Cash DW, Clark WC, Alcock F, Dickson N, Eckley N, Jäger J (2002) Salience, credibility, legitimacy and boundaries: linking research, assessment and decision making. KSG faculty research working paper 02-046. Kennedy School of Government, Harvard University, Cambridge, MA

Edwards B, Goodwin M, Pemberton S, Woods M (2001) Partnerships, power, and scale in rural governance. Environ Plann C Gov Policy 19(2):289-310. doi:10.1068/c12m

Elbe S (2007) Die Voraussetzungen der erfolgreichen Steuerung integrierter Ansätze durch Förderprogram. Untersucht am Beispiel des Modellvorhabens Regionen Aktiv (Ph.D. Dissertation). Aachen

Elbe S, Kroës G, Benz A, Lukesch R, Weiß K, Böcher M, Krott M, Meincke A, Middelmann U, Payer H, Rabenau J, Tränkner S (2007) Begleitforschung 'Regionen Aktiv' - Synthesebericht und Handlungsempfehlungen. Göttingen

\section{Springer}


EU Commission (2005) Regulation (EC) No 1698/2005 of 20 September 2005 on support for rural development by the European Agricultural Fund for Rural Development (EAFRD). EU Commission, Brussels

EU Commission (2006) Fact sheet: the leader approach. EU Commission, Luxembourg

Fischer F (2000) Citizens experts and the environment: the politics of local knowledge. Duke Univiversity Press, Durham

Fischer F (2003) Reframing public policy. Discursive politics and deliberative practices. Oxford University Press, Oxford

Gibbons M, Limoges C, Nowotny H, Schwartzmann S, Scott P, Trow M (1994) The new production of knowledge: the dynamics of science and research in contemporary societies. Sage, Thousand Oaks

Giessen L (2008) Forstwirtschaft zurückhaltend bei Programmen zur integrierten ländlichen Entwicklung: Analyse der politischen Ursachen. Forstarchiv 79(3):116-121

Giessen L (2009) Regional governance in rural development programs-which role for forestry? In: Forests and forestry in the context of rural development. Proceedings of the IUFRO European Congress 2007. Warsaw (in press)

Giessen L, Böcher M (2008) Integrated rural development policy in Germany and its potentials for new modes of forest governance. Institute of Forest, Environmental, and Natural Resource Policy, Vienna

Giessen L, Krott M (2009) Forestry joining integrated programs? A question of willingness, ability and opportunities. Allgemeine Forst- und Jagdzeitschrift (accepted, in press)

Giessen L, Böcher M, Ortner M, Tränkner S (2006) Integrated rural development as pathway for innovations-an unexploited potential for forestry. In: Tikkanen I, Zyrina O, Rametsteiner E, Barreiro O, Michalak R (eds) Policies fostering investments and innovations in support of rural development, 27-29 March 2006, Zvolen, Slovakia. MCPFE, Warsaw

Goodwin M (1998) The Governance of rural areas: some emerging research issues and agendas. J Rural Stud 14(1):5-12. doi:10.1016/S0743-0167(97)00043-0

Hahne U (1985) Regionalentwicklung durch Aktivierung intraregionaler Potentiale: zu den Chancen „endogener” Entwicklungsstrategien. Schriften des Instituts für Regionalforschung der Universität Kiel. 8, München

Hahne U (1986) Changes in the international division of labour and prospects for endogenous development. In: Bassand $\mathrm{M}$ et al (eds) Self-reliant development in Europe. Theory, problems, actions. Gower, Aldershot, pp 90-102

Harrison S, Herbohn J (2000) The role of small-scale forestry throughout the world. In: Harrison S, Herbohn J (eds) Sustainable small-scale forestry: social and economic analysis and policy. Edward Elgar, Cheltenham, pp 3-13

Jones RA (1996) Research methods in the social and behavioral sciences, vol 2. Sinauer, Sunderland

Krott M (2005) Forest policy analysis. Springer, Dordrecht

Lukesch R, Payer H, Rabenau J (2008) Wissen von innen - Regionale Fokusgruppen in der Begleitforschung zu Regionen Aktiv. In: Böcher M, Krott M, Tränkner S (eds) Regional Governance und integrierte ländliche Entwicklung. Wiesbaden (in press)

Marsden T, Murdoch J (1998) Editorial: the shifting nature of rural governance and community participation. J Rural Stud 14(1):1-4. doi:10.1016/S0743-0167(97)00042-9

Moseley MJ (ed) (2003) Local partnerships for rural development: the european experience. CABI, Wallingford

Neubert D, Macamo E (2005) Wer weiß hier was? Lokales Wissen und der Globalitätsanspruch der Wissenschaft. In: Loimeier R, Neubert D, Weißköppel C (eds) Globalisierung im lokalen KontextPerspektiven und Konzepte von Handeln in Afrika. LIT, Münster

Nova-Institut (2008) Active regions project database. Online under www.modellregionen.de. Accessed 04 2008

OECD (2001) Local partnerships for better governance. OECD, Paris

OECD (2006) The new rural paradigm: policies and governance. OECD, Paris

OECD (2007) OECD rural policy reviews: Germany. OECD, Paris

Ortner (2008) Erfolgsfaktoren für die Beteiligung forstlicher Akteure an der integrierten ländlichen Entwicklung - Beispiel: LEADER+ Programm der EU-Strukturpolitik. Dissertation. Göttingen University Press

Perlis A (2007) Editorial: small-scale forestry. Unasylva 58(3):2

Pregernig M, Böcher M (2008) The role of expertise in environmental governance: tensions between effectiveness and democratic accountability? In: Paper to be presented at the 2008 Berlin conference on the human dimensions of global environmental change, Berlin 
Ray C (2000) The EU LEADER programme: rural development laboratory. Sociol Ruralis 40(2):163171. doi:10.1111/1467-9523.00138

Ray C (2006) Neo-endogenous rural development in the EU. In: Cloke P, Marsden T, Mooney P (eds) Handbook of rural studies. Sage, London, pp 279-291

Rosenau JN (1998) Governance and democracy in a globalizing world. In: Archibugi D, Held D, Köhler M (eds) Re-imagining political community. Studies in cosmopolitan democracy. Cambridge, Oxford

Schraml U, Selter A (2008) Beyond traditional cooperation: establishing new commons in private forestry. In: Proceedings of the IUFRO 3.08 conference improving the triple bottom line returns from small-scale forestry, held in Ormoc, The Philippines, 17-21 June 2007

Schröder P (1995) Einführung: Lokales Wissen als konstruktives und kritisches Potential für die Entwicklungszusammenarbeit. In: Honerla S, Schröder P (eds) Lokales Wissen und Entwicklung Zur Relevanz kulturspezifischen Wissens für Entwicklungsprozesse, Saarbrücken, pp 1-18

Schultze U (1998) Lokales Wissen und Entwicklungszusammenarbeit. Eine Einführung. In: Pasquale S, Schröder P, Schulze U (eds) Lokales Wissen für nachhaltige Entwicklung. Ein Praxisführer, Saarbrücken

Stehr N (2007) Die Moralisierung der Märkte. Suhrkamp, Frankfurt

van Averbeke W, Mohamed SS (2006) Smallholder farming styles and development policy in South Africa: the case of Dzindi Irrigation Scheme. Agrekon 45(2):136-157

van der Ploeg JD (1994) Styles of farming: an introductory note on concepts and methodology. In: Haan HJ, van der Ploeg JD (eds) Endogenous regional development in Europe. Luxembourg, pp 7-31

van der Ploeg JD, Long A (1994) Born from within: practice and perspectives of endogenous rural development. Van Gorcum, Assen

van der Ploeg JD, Wiersum KF (1997) Styles of forest management by small forest owners, characteristics and scope for rural development. In: Glück P, Weiss G (eds) Forestry in the context of rural development: future research needs. EFI proceedings 15, pp 45-57

Woods M, Goodwin M (2003) Applying the rural: governance and policy in rural areas. In: Cloke P (ed) Country visions. Pearson, London, pp 245-262 

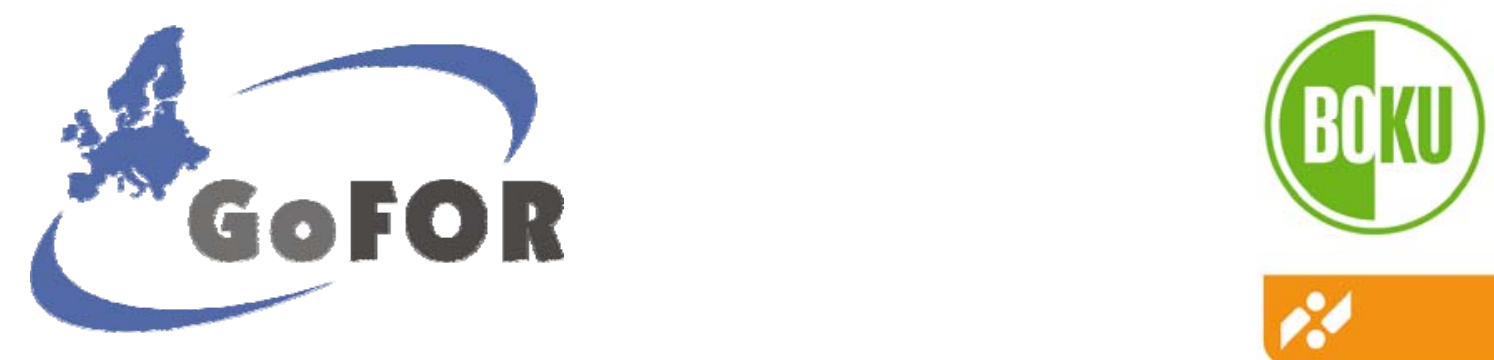

\section{8}

Universität für Bodenkultur Wien

Department für Wirtschafts- und

Sozialwissenschaften

\section{Integrated Rural Development Policy in Germany and its Potentials for new Modes of Forest Governance}

\section{Lukas Giessen and Michael Böcher}

Forschungsbericht / Research Report 5-2008

Institut für Wald-, Umwelt- und Ressourcenpolitik Institute of Forest, Environmental, and Natural Resource Policy

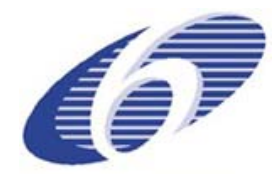

SIXTH FRAMEWORK PROGRAMME 
Diese Reihe ist ein Publikationsorgan des Instituts für Wald-, Umwelt- und Ressourcenpolitik der Universität für Bodenkultur Wien. Der Inhalt der Forschungsberichte unterliegt keinem Begutachtungsverfahren, allein die Autorinnen und Autoren zeichnen verantwortlich. Anregungen und Kritik seitens der Leserinnen und Leser sind ausdrücklich erwünscht.

This series is edited by the Institute of Forest, Environmental, and Natural Resource Policy at the University of Natural Resources and Applied Life Sciences, Vienna (BOKU). The research reports are not subject to review procedures. Therefore, responsibility for the content lies solely with the author(s). Comments and critiques by any and all readers are highly appreciated.

ISSN 2071-4068

\section{Bestelladresse / orders to:}

Institut für Wald-, Umwelt- und Ressourcenpolitik

Universität für Bodenkultur Wien

Feistmantelstr. 4

A - 1180 Wien

Tel: $+43-1-47654-4410$

Fax: $+43-1-47654-4417$

e-mail: edith.hoermann@boku.ac.at

In dieser Reihe erschienene Forschungsberichte können von folgender Hompage als PDF-Files geladen werden: http://www.wiso.boku.ac.at/reports.html

The papers published in this series can be downloaded in PDF-format from: http://www.wiso.boku.ac.at/reports.html

Eigenverlag des Instituts für Wald-, Umwelt- und Ressourcenpolitik, Universität für Bodenkultur Wien

Published by the Institute of Forest, Environmental, and Natural Resource Policy, University of Natural Resources and Applied Life Sciences, Vienna (BOKU) 


\section{Foreword}

The research that is reported in this Research Report was conducted in the context of the collaborative project 'New Modes of Governance for Sustainable Forestry in Europe (GoFOR)'. GoFOR was funded by the European Commission under the Sixth EU Framework Programme for Research and Technological Development (Contract No. 6447GoFOR).

The GoFOR team comprised more than 30 researchers from ten European countries:

- Austria: University of Natural Resources and Applied Life Sciences, Vienna - Karl Hogl and Michael Pregernig (project co-ordinators), Ralf Nordbeck, Eva Kvarda, Eva Nußbaumer, and Johannes Voitleithner

- Denmark: University of Copenhagen - Tove Enggrob Boon, Iben Nathan, and Dorthe Hedensted Lund

- France: French Institute of Forestry, Agricultural and Environmental Engineering (ENGREF), Laboratory of Forest Policy, Nancy - Gérard Buttoud, Irina Kouplevatskaya, and Jean Croisel

- Germany: Georg-August-University Göttingen - Max Krott, Michael Böcher, and Lukas Giessen

- Greece: National Agricultural Research Foundation, Ioannina - Kostas Kassioumis, Kostas Papageorgiou, and Michael Vakkas

- Hungary: University of West Hungary, Sopron - Károly Mészáros, Atilla Lengyel, Endre Schiberna, Attila Hegedüs, and Gyöngyvér Boltos

- The Netherlands: Wageningen University - Mariëlle van der Zouwen, Esther Turnhout, and Rikke Arnouts

- Norway: Møre Research, Volda - Johan Barstad, Paul Mitchell-Banks, Susanne Moen Ouff, Else Ragni Yttredal, and Lars Julius Halvorsen

- Romania: University Stefan cel Mare, Suceava - Laura Bouriaud and Delia Bancu

- Spain: Forest Technology Centre of Catalonia, Solsona - Gloria Dominguez, Mireia Pecurul, Eduard Plana, and Jordi Tena.

Many people generously contributed their time and expertise to the successful implementation of this research project. The GoFOR team gratefully acknowledges the valuable support provided by the members of the Scientific Advisory Panel, Prof. Margaret Shannon (University of Buffalo, USA), Prof. Arthur Benz (FernUniversität Hagen, Germany), and Prof. Heiner Schanz (Freiburg University, Germany) who participated in the project workshops and provided exceptional external scientific monitoring and advice. In particular, we would like to thank the members of the National Advisory Panels, various external experts, and the many interviewees who shared their experiences with us and thereby provided us with extensive empirical data.

Karl Hogl and Michael Pregernig

Vienna, October 2008 


\section{Executive summary}

Rural development policies show a gradual but distinct shift in paradigm concerning the governance or rural areas (OECD 2006). Traditional rather sector-oriented policies are recently being complemented by more integrated and area-based strategies. Similar policy approaches such as 'neo-endogenous rural development' (Ray 2006) and 'integrated rural development' (IRD; Böcher 2005) are largely build around the theory-driven concept of 'regional governance' as a frame for facilitating negotiated spatial planning among a variety of public, private and civil society actors.

\section{New modes of governance in Integrated Rural Development (IRD)}

Three integrated rural development funding programmes, i.e. the EU's community initiative LEADER+, Germany's pilot programme REGIONEN AKTIV as well as the German 'Joint Task for Agricultural Structures (GAK)', serve as case studies to empirically analyse new modes of governance in Germany's IRD policy. These programmes trigger, support or even require regional governance processes. Based on empirical data from the three case studies our inquiry examines new modes of governance in the different funding programmes by analysing (a) public participation, $(b, c)$ the coordination of various sectors and territorial levels, (d) issues of reflexivity and adaptiveness within policies as well as (e) the role of scientific and other sources of expertise.

Such modes are shown to play a prominent role in integrated rural policies, especially in programmes of explicit pilot nature. Still, representative participation remains an illusion as funding programmes bring along e.g. difficulties for private sector actors. The challenge of coordinating different sectors is not being met at national and sub-national levels, but is dispersed to the regional level where actors are required to act cooperatively. In turn, national and supra-national levels play an ever important (also informal) role in the formulation and delivery of IRD programmes. As a very important finding we also observe that scientific expertise is being complemented by advice delivered through private consultants and through involved regional actors themselves: a phenomenon which may be best described as endogenous expertise. Lastly, IRD programmes seem to cultivate an evaluation culture in a domain, where reflexive elements in policies so far have been unusual. However, governance features in our cases have been observed to only emerge and function properly when backed by more 'governmentlike' modes. This leads us to the figurative conclusion that regional rural governance delivered through funding programmes is likely to occur only 'in the shadow of hierarchy' of higher state-levels.

\section{Integrated Rural Development as new mode of forest governance?}

The above trends in rural development policy, as an adjacent field to forest policy, also affect forestrelated actors as potential addressees and beneficiaries of respective funding programmes. We briefly investigate on the role of forestry within the three funding schemes, illustrate their potential for the sector and present reasons why forestry actors rarely enter into IRD-cooperation. Our material indicates that, for sector-internal as well as external reasons, IRD policies mark a considerable challenge for forestrelated actors: a) forestry actors are incapable or reluctant to enter into cooperative rural development activities and b) IRD policies show programmatic deficits as regards benefits for non-agricultural actors in general and forest-related actors in particular. Lastly, (c) institutional reasons are presented explaining the low degree of forestry representation in IRD programmes. We conclude that effective forest governance through IRD funding programmes is hindered by forestry's incompatibility with such new modes of governance, while at the same time funding programmes show deficits as regards the integration of different sectors into policy implementation. 


\section{Table of content}

1

1.1

1.2

1.3

2

2.2

2.3

2.4

3

4

4.1

"GoFOR project": the case study research context. 1

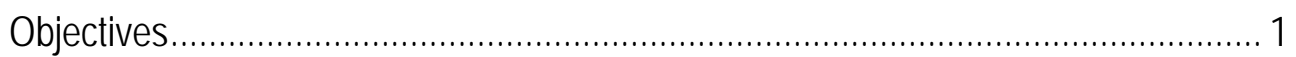

Conceptual framework and overall methodology ............................................. 1

The GoFOR case studies. 3

Introduction: German rural development policy and New Modes of Governance. 6

Governance of rural development policies in a federal system............................... 6 A 'new rural paradigm' - Integrated Rural Development Policy................................ 7 Selected IRD case studies ........................................................................... 10

Structure and logics of the report................................................................... 12

Particular Methodology in IRD-Case Studies................................................ 12

Case Study on the Governance Rhetoric of Integrated Rural

Development (IRD) ............................................................................. 15

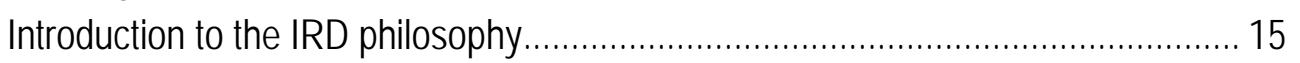

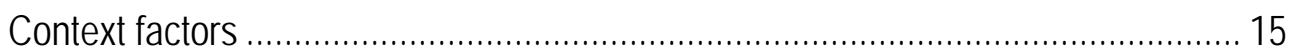

The governance rhetoric of IRD and some general practices............................... 16

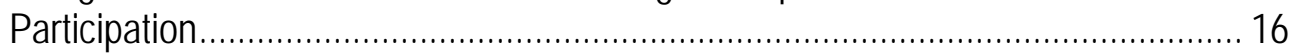

Inter-sectoral coordination (ISC) .............................................................. 19

Multi-level coordination (MLC) .................................................................... 21

Accountable Expertise (AE) ...................................................................... 23

Adaptive and Iterative Planning (AIP)............................................................ 24

The LEADER+ Case Study - EU Community Initiative for rural

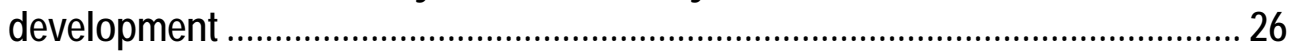

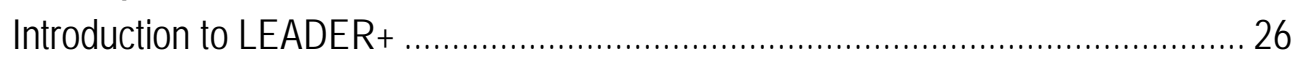

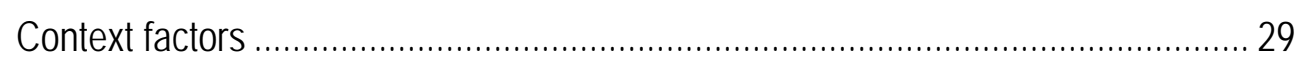

Governance practices under LEADER+ ............................................................. 30

Participation ..................................................................................... 30

Inter-sectoral coordination ......................................................................... 35

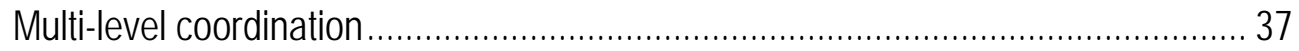

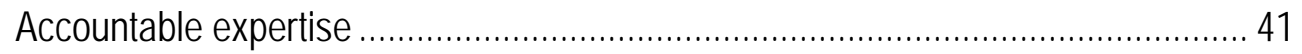

Adaptive and Iterative planning ................................................................... 46

Effects of LEADER+ as a governance process ................................................50

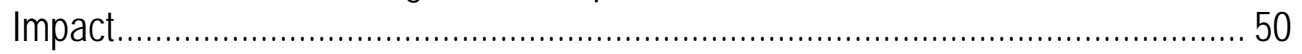

Output .

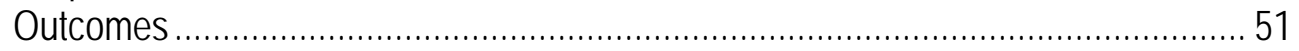

Conclusions on LEADER+ as governance process.............................................. 52 
6.2.2 The context of major adaptations - Phase II and re-elections in 2005 ..................... 55

6.3 Governance practices under REGIONEN AKTIV ............................................ 56

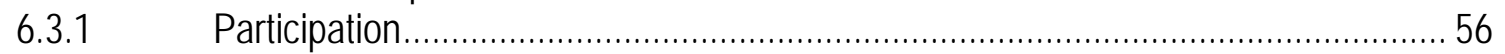

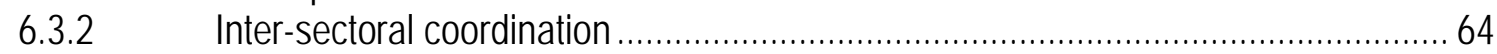

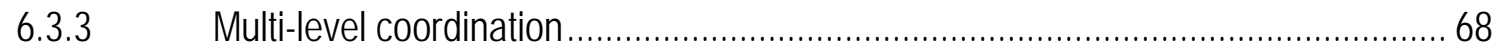

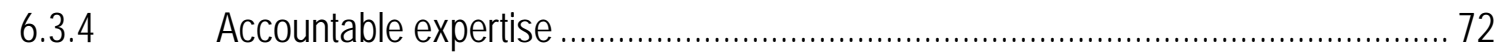

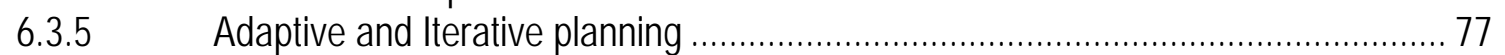

6.4 Effects of REGIONEN AKTIV as a governance process ..................................... 83

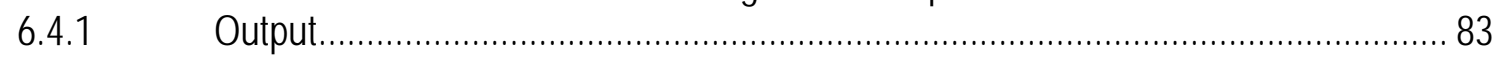

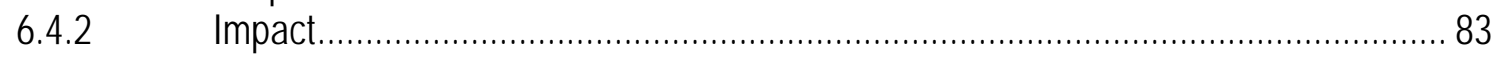

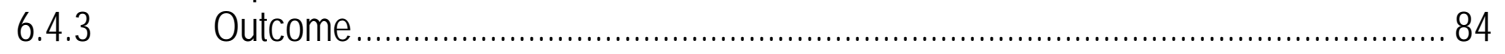

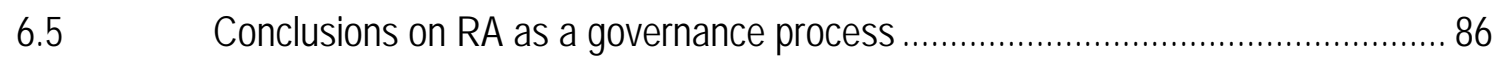

7 The 'GAK' Case Study - IRD-uptake by an Instrument of Mainstream Funding ...................................................................................................8 87

7.1 Introduction to the Joint Task ,Improvement of Agricultural Structures and

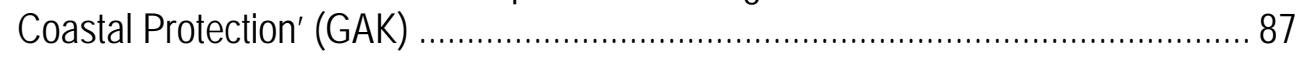

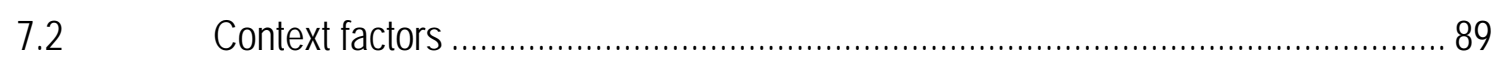

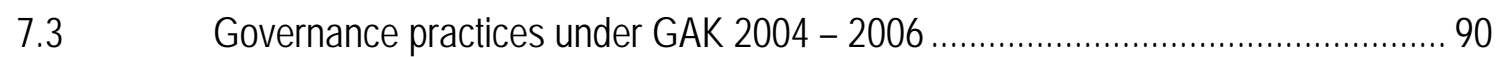

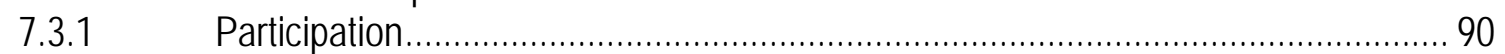

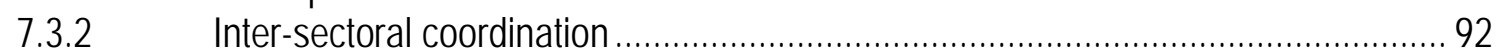

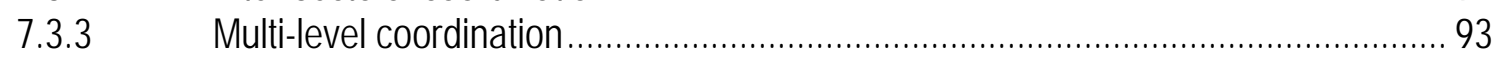

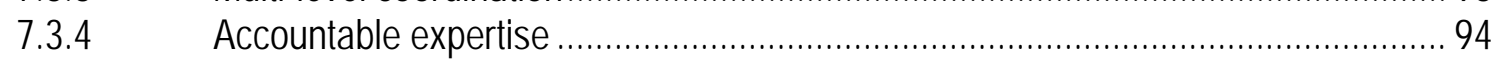

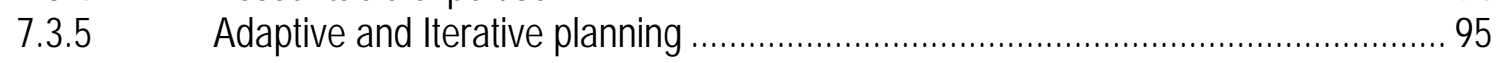

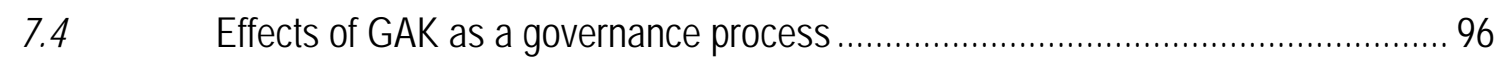

7.5 Conclusions on GAK as a governance process................................................... 97

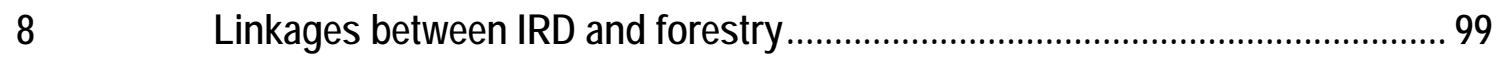

$9 \quad$ Closing the frame: IRD as New Mode of Governance? .................................. 102

9.1 Overall effects of the IRD philosophy as a governance process.......................... 102

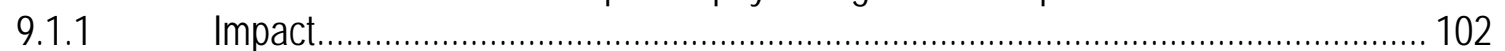

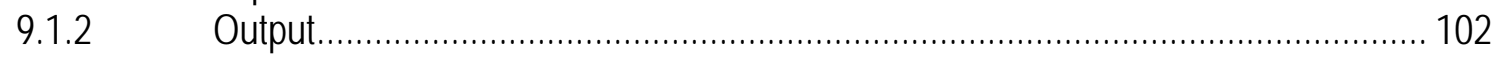

9.2 Conclusions on IRD as a governance philosophy …......................................... 103

9.2.1 Comparison of programmes' practices with programmatic rhetoric ...................... 103

9.2.2 Comparison of programmes' practices with the overall IRD rhetoric ..................... 104

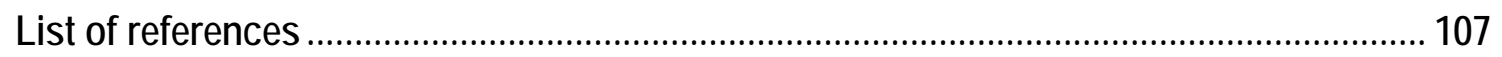

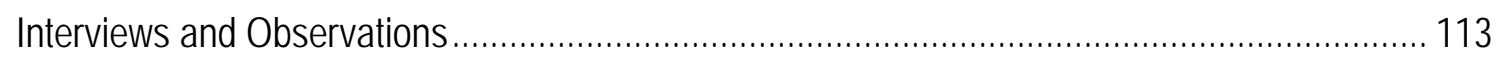




\section{List of figures}

Figure 1:

Figure 2:

Figure 3:

Figure 4:

Figure 5:

Figure 6:

Figure 7:

Figure 8:

Figure 9:

Figure 10:

Figure 11:

Figure 12:

Figure 13:

Figure 14:
General conceptual framework of GoFOR . 2

GoFOR overall work plan and timeframe

The IRD policy continuum. Case studies from a normative concept to the integration into mainstream policy 11

Exemplary representation of the Leader features in different IRD funding programmes 27

Exemplary design of regional LEADER+ processes ..................................... 28

Exemplary composition of LAGs ............................................................ 29

Multi-level coordination under the EU Community Initiative LEADER+ ......... 38

Relations between objectives and impacts in the programming cycle........... 49

Chronology of REGIONEN AKTIV phases and its governmental context

The regional value-chain approach taken in phase II of REGIONEN

AKTIV illustrated by the wood value-chain (left part) and its potential benefits in terms of regional value-added.

Governance system established under REGIONEN AKTIV

distinguished between framework steering at the national (upper) and

detailed steering at regional level (lower part).

The GAK framework plan's role for the design of federal states' funding programmes

Dynamics of the GAK framework plan as regards 'IRD'-relevant changes.

Forestry potential and actual participation at the regional level of

LEADER+ implementation 99

\section{List of tables}

Table 1:

Table 2:

Table 3:

Table 4:

Table 5:

Table 6:

Table 7:

Table 8:

Table 9:

Table 10:
Cases analysed in GoFOR (main assessment) ........................................... 4

The concept of Integrated Rural Development as interpreted by BMVEL ....... 9

The new rural paradigm as interpreted by OECD ....................................... 10

Population of the qualitative survey on the role of forestry within integrated rural development.

Exemplary constitution of a Local Action Group under LEADER+, the example of the LAG "Rügen" (Federal State of Mecklenburg-Western

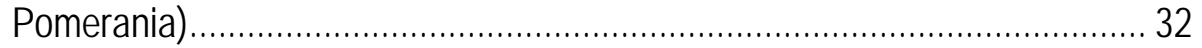

Kinds and types of expertise employed under LEADER+ in Germany.......... 44

Programme adaptations from LEADER II to LEADER+ ................................. 47

Participants in the formulation of REGIONEN AKTIV ................................... 62

Significance of different sources for expertise at different stages of the

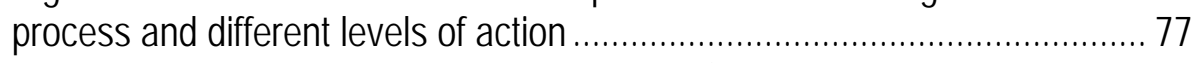

Obligatory and necessary reporting under REGIONEN AKTIV

requested from model regions. 79 
Table 11:

Table 12:

Table 13:

Table 14:
Reasons for low degree of forestry participation to IRD programmes 100 Best practice examples of forest-related projects under LEADER+, sorted after categories and dimensions of sustainability 101 Comparison of governance rhetoric (as stated in the respective policy documents) and practices (as analysed in the case studies) 104 Comparison of governance rhetoric (as lined out in IRD philosophy) and practices (as analysed in the case studies). 105 


\section{1 "GoFOR project": the case study research context}

The case study on 'Integrated Rural Development Policy in Germany and its Potentials for new Modes of Forest Governance' that is presented in this report was conducted in the course of the project 'New Modes of Governance for Sustainable Forestry in Europe (GoFOR)', which was funded by the European Commission under the Sixth EU Framework Programme for Research and Technological Development. This chapter briefly outlines the overall approach of the GoFOR project in order to describe the context in which the research work for this report was conducted. It outlines the major project objectives and briefly describes the research approaches that were employed.

\subsection{Objectives}

The main objective of the GoFOR project was to study and evaluate the evolving practices of new modes of governance in the field of forest policy as well as within adjacent policy domains (such as nature conservation policy, rural development policy, etc.). More concretely, GoFOR aimed to evaluate new practices of governance by:

- analysing programmatic policy statements in order to learn about the role that governance and its elements play in the repertoire of different policy actors,

- investigating current and evolving practices of governance in order to find out whether they are applied in a substantive way or whether they are merely symbolic rhetoric,

- exploring the broader political context in order to see how far effective governance is contingent on environmental, social, political, and economic factors, and

- carrying out cross-sectoral comparisons of governance processes in ten countries in order to search for common patterns in governance arrangements and to learn about the factors that either facilitate or hamper effective governance.

\subsection{Conceptual framework and overall methodology}

'Governance' is a multi-faceted concept. At times, governance has been used as a normatively-laden catchword in political language. In other cases, it is used as an analytical term in the fields of political science and economics where it particularly describes those types of political processes in which nonhierarchical modes of guidance, such as persuasion and negotiation, are employed, and where public as well as private actors are engaged in policy formulation and implementation.

When setting up the general conceptual framework in the GoFOR project, the first and foremost challenge was to operationalise the concept of 'governance'. Even though governance and new modes of governance have been in frequent use in both politics and science, a coherent governance theory along with clear definitions that are close to being empirically applicable, are still lacking. Since the prevailing concepts of governance are excessively vague to productively guide empirical analysis, GoFOR operationalised governance by five, more concretised procedural elements: Participation, intersectoral co-ordination, multi-level co-ordination, adaptive and iterative approaches, and the use of democratic and accountable expertise. These elements can be found in political documents, such as the White Paper on European Governance, and in theoretical-conceptual discussions on new forms of policy making. 
In focusing on these five elements, the conceptual framework of GoFOR followed three distinct but interrelated lines of inquiry: First, the analysis of programmatic policy statements sought to assess the salience of the new modes of governance and its constituting elements based on the strategic and programmatic role that they play in the repertoire of political institutions and policy actors. Empirically, those roles were determined by investigating programmatic policy statements such as White Papers and other strategy documents, position papers, and general procedural guidelines for governance processes, but also the more programmatic parts of legislative texts, subsidy schemes, and the like. Analysis of the 'rhetoric' of governance was expected to provide a straightforward image of the current political compromises on the meaning and materialisation of the new modes of governance in a given policy arena. Second, GoFOR also (and primarily) assessed the current and evolving practices of governance. The term 'practice' refers, on the one hand, to policy processes (e.g., the formulation and implementation of national forest programmes or biodiversity strategies, and the planning of a national park), but also refers to the outputs of those processes (such as new policy programmes or procedural and institutional reforms). Third, the operationalisation of the new modes of governance was not only based on empirical evidence, in which the potential of new governance was also assessed in the light of theoretical approaches and concepts.

Figure 1 shows the overall conceptual framework of the GoFOR project, presenting the main analytical concepts that were addressed in the case studies and the three research steps that were described above (arrows).

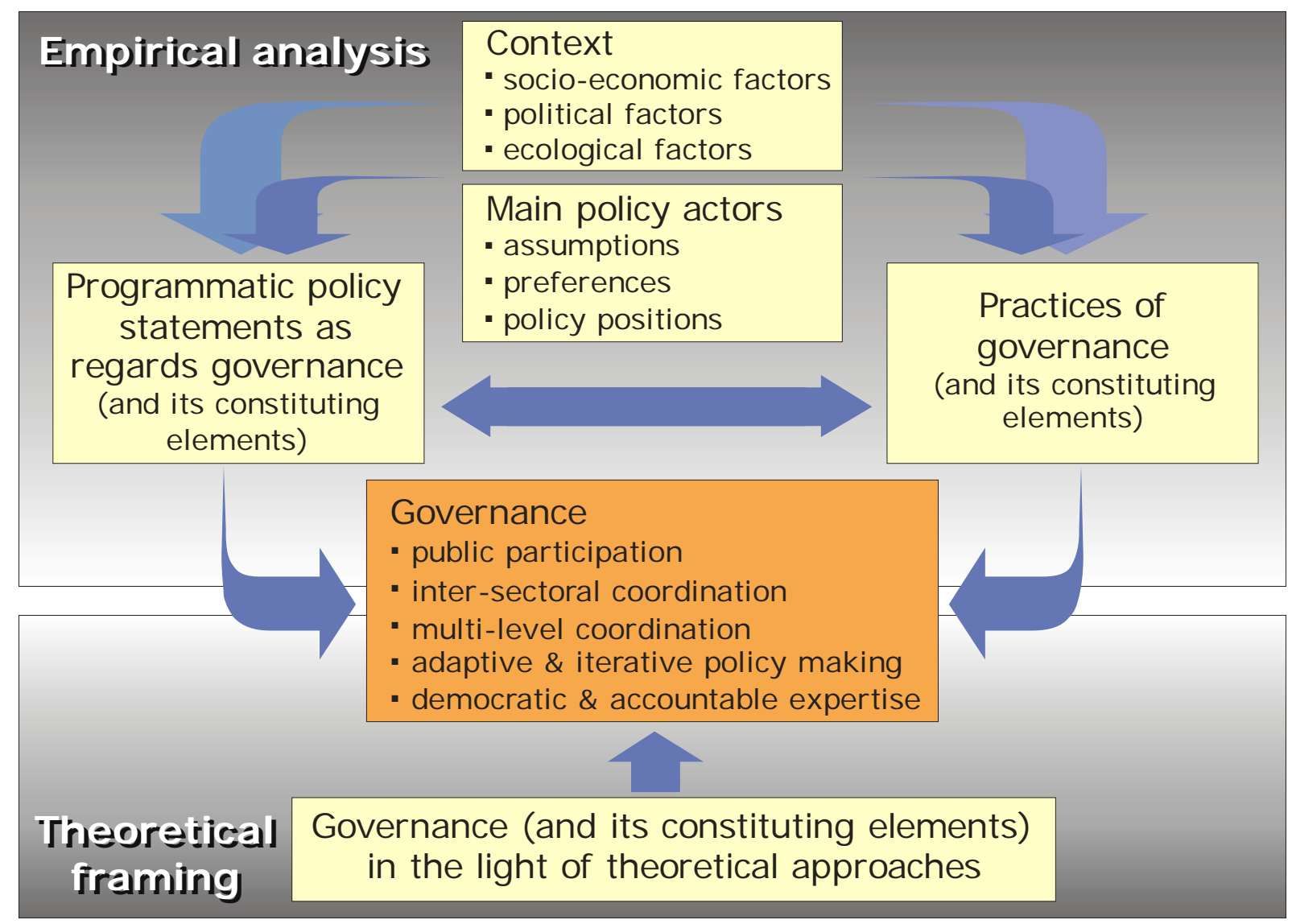

Figure 1: $\quad$ General conceptual framework of GoFOR 
In its empirical research work, GoFOR was structured into three distinct phases (Figure 2):

(i) A pre-assessment phase in which a set of criteria that operationalise the concept of governance was developed and translated into a common research protocol (ToR); this common research protocol was, then, tested with an enlarged set of pilot studies,

(ii) a main assessment phase in which a reduced set of governance case studies was analysed in detail, and finally

(iii) a synthesis phase of cross-case comparison, in turn searching for the general patterns of governance arrangements.

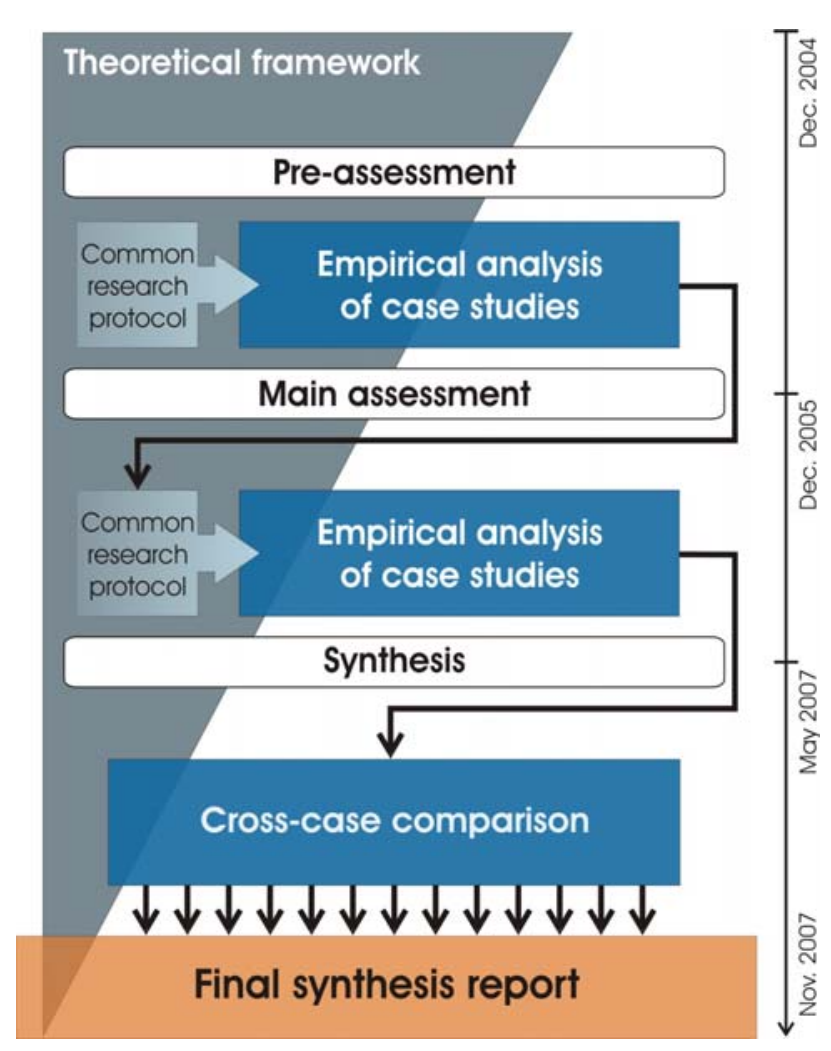

Figure 2: GoFOR overall work plan and timeframe

This research report is the result of phase II, which was the main assessment stage. Together with 18 other case studies, it was input to phase III, which was the comparative synthesis report for GoFOR (Hogl et al., 2008).

\subsection{The GoFOR case studies}

The GoFOR project applied a multiple case study research design. GoFOR case studies are not 'country reports' or 'sector reports', but rather analyses of concrete policy processes in which new modes of governance or certain elements thereof were applied. Hence, the GoFOR project can also be seen as an attempt to further clarify the manifestation of governance practices in forest policy and in adjacent policy domains.

Cases were selected in a three-step approach: First, potential cases were classified along a list of criteria (such as the respective policy field, scope, and time span of the processes and their respective stage of implementation, along with the territorial levels involved, and the role of those governance elements that were central to the GoFOR project design). In an exploratory phase, this broader range of possible cases was empirically probed and a case selection was co-ordinated among the partner countries in order to obtain a well-balanced, analytically fruitful set of case studies. Second, and based on the exploratory phase, 24 cases were selected for pre-assessment. The pre-assessment was intended to provide deeper insights into the cases as a basis for the final selection. The Terms of Reference (ToR) were developed in order to provide a common list of research questions and guidance as regards the methods of data collection and documentation. Third and finally, based on the preassessments results, 19 governance processes (cases) were selected for the main assessment. Table 1 provides a brief characterisation of these cases. 


\begin{tabular}{|c|c|c|}
\hline Country & Case title & Brief characterisation \\
\hline \multirow[t]{2}{*}{ Austria } & $\begin{array}{l}\text { Implementation Strategy for the } \\
\text { Convention on Biological Diversity }\end{array}$ & $\begin{array}{l}\text { national strategy process mainly } \\
\text { driven by international obligations }\end{array}$ \\
\hline & Austrian Forest Dialogue & $\begin{array}{l}\text { participatory and sector-integrated } \\
\text { national strategy process }\end{array}$ \\
\hline \multirow[t]{2}{*}{ Denmark } & $\begin{array}{l}\text { Implementation of the Habitats } \\
\text { Directive }\end{array}$ & national implementation of EU policy \\
\hline & National Park Pilot Projects & $\begin{array}{l}\text { participatory planning processes at } \\
\text { the regional level as non-binding input } \\
\text { to policy formulation at the national level }\end{array}$ \\
\hline \multirow[t]{2}{*}{ France } & Territorial Forest Charters & $\begin{array}{l}\text { participatory and sector-integrated strategic } \\
\text { planning approach at the regional level }\end{array}$ \\
\hline & Relief Plan for Forests in France & $\begin{array}{l}\text { ad hoc governmental assistance programme } \\
\text { in the aftermath of devastating storms }\end{array}$ \\
\hline \multirow[t]{4}{*}{ Germany } & $\begin{array}{l}\text { Integrated Rural Development policies } \\
\text { (with three embedded sub-cases): }\end{array}$ & $\begin{array}{l}\text { integration of new policy approach } \\
\text { (regional governance) in three programmes: }\end{array}$ \\
\hline & - LEADER+ & $\begin{array}{l}\text { - EU pilot programme for sustainable } \\
\text { rural development }\end{array}$ \\
\hline & - REGIONEN AKTIV & $\begin{array}{l}\text { - national pilot programme for } \\
\text { sustainable rural development }\end{array}$ \\
\hline & $\begin{array}{l}\text { - Joint Task "Improvement of } \\
\text { Agricultural Structures and Coastal } \\
\text { Protection" }\end{array}$ & $\begin{array}{l}\text { - mainstream funding instrument } \\
\text { of agricultural policy }\end{array}$ \\
\hline Greece & $\begin{array}{l}\text { Restructuring of management agencies } \\
\text { for protected areas }\end{array}$ & $\begin{array}{l}\text { reorganisation of the administration and } \\
\text { management of protected areas } \\
\text { mainly driven by EU policies }\end{array}$ \\
\hline Hungary & $\begin{array}{l}\text { National Forest Programme } \\
\text { Hungary }\end{array}$ & $\begin{array}{l}\text { participatory and sector-integrated } \\
\text { national strategy process }\end{array}$ \\
\hline Norway & Norwegian Living Forests Project & $\begin{array}{l}\text { participatory and sector-integrated } \\
\text { strategy process initiated and } \\
\text { promoted by private actors }\end{array}$ \\
\hline \multirow[t]{3}{*}{$\begin{array}{l}\text { The } \\
\text { Netherlands }\end{array}$} & $\begin{array}{l}\text { "Nature for People, People for Nature" } \\
\text { programme (NL-NPPN) }\end{array}$ & $\begin{array}{l}\text { formulation and implementation } \\
\text { of strategic policy document }\end{array}$ \\
\hline & $\begin{array}{l}\text { Nature policy in the Groene } \\
\text { Woud area }\end{array}$ & $\begin{array}{l}\text { long-term policy development } \\
\text { around nature conservation }\end{array}$ \\
\hline & $\begin{array}{l}\text { Nature policy in the Utrechtse } \\
\text { Heuvelrug area }\end{array}$ & same as above \\
\hline \multirow[t]{2}{*}{ Romania } & Anti-corruption policies & $\begin{array}{l}\text { policy formulation and implementation driven } \\
\text { by international obligations and pressures }\end{array}$ \\
\hline & $\begin{array}{l}\text { Implementation of Acquis } \\
\text { Communautaire in Nature } \\
\text { Protection Policies }\end{array}$ & national implementation of EU policy \\
\hline Spain & $\begin{array}{l}\text { Forest Policy General Plan of } \\
\text { Catalonia }\end{array}$ & $\begin{array}{l}\text { participatory and sector-integrated } \\
\text { regional strategy process }\end{array}$ \\
\hline
\end{tabular}

Table 1: Cases analysed in GoFOR (main assessment) 
Overall these case studies relate to three broad thematic fields: first, biodiversity and nature conservation, including those processes engaged in the implementation of the EU Habitat Directive (92/43/EEC); second, forest policy; and third, rural development policy processes. One out of these 19 case studies is presented in this report: "Integrated Rural Development Policy in Germany and its potentials for new modes of Forest Governance". 


\section{Introduction: German rural development policy and New Modes of Governance}

\subsection{Governance of rural development policies in a federal system}

Germany is a de-centralised and federal country consisting of 16 federal states. According to the constitutional law the federal states have the ability of legislation (Grundgesetz Article 70). Article 73, however, identifies several policy fields for which only the federal government may claim responsibilities, while Article 72 lists policy fields where the federal states have the ability of legislation as long as the federal government does not intervene with higher priority. Art. 91 and 104 create opportunities for overcoming this rather strict distinction of legislative abilities among the two institutional levels - the socalled 'Joint Tasks', where the federal government together with the federal states are obliged to jointly plan, decide on and finance the specific 'task' addressed by the arrangement. Two of these institutional agreements exist, namely the GRW (Joint Task Improvement of Regional Economic Structures) and GAK (Joint Task for the Improvement of Agricultural Structures and Coastal Protection). Thus, the federal states are i.e. responsible for policy fields, such as nature conservation, agriculture and forestry. ${ }^{1}$

However, the federal states alone have not been able to adequately address certain issues within these responsibilities (OECD 2007: 96), especially as regards the rather emerging policy field of rural development or at least the recent focus on the wider rural context. At the EU level this issue also gains momentum and through the EU's Common Agricultural Policy (CAP) the EU has a strong influence on the rural development discourse and policy practice (Jäger 2006, Interview; similar Augustin 2006c, Interview).

Rural policy in a German context embraces different programmes and institutions. The GAK formally is the central institution where the federal government defines its approach to rural policy (OECD 2007: 99). GRW plays a similar, yet less important role as regards the model function for other programmes and the impacts on sustainable rural development. Besides these two also other programmes may be considered under the rural policy. The EU's rural development policy as well as some area-based pilot programmes also contributes to the canon of rural policy. OECD, however, finds that the German approach to rural policy is 'largely sector-oriented and mainly focussed on agriculture. This approach mirrors past conditions and does not do justice to present characteristics of rural areas in Germany. [...] Consequently, the German approach aims at supplementing EU structural policy for agriculture instead of moving towards a national and strategic framework for rural policy (OECD 2007: 92)'.

Rural policy governance was also found to show deficits. Effective horizontal coordination among public and private actors as well as vertical coordination among different levels of government is being impeded by the institutional setting, where no clear lead role exists for the federal government (OECD 2007: 93).

1 The federal government has some formal responsibilities also in those fields. They are, however, limited to special issues such as the import and export of primary products and do not contest the primary responsibility of the federal states in those fields. 
Besides the institutional impediments to effective rural policy a lack of 'area-based'2 elements is also criticised. Such programmes are known to foster innovations and effectiveness, but have been found to have a niche character only. They were under-equipped financially speaking and hence could not produce significant effects (OECD 2007: 93).

The above outline of rather traditional approached to rural development policy combined with recent critiques resulted in the consideration of alternative approaches and finally the uptake of territorial elements into current policy. The subsequent chapters (and the whole report) are dealing with one alternative to traditional sectoral approaches to rural development, namely the concept of 'Integrated Rural Development' (IRD).

\subsection{A 'new rural paradigm' - Integrated Rural Development Policy}

Within the IRD philosophy at least four basic assumptions are made:

- Rural areas are diverse in their regional characteristics and problems.

- Dealing with the strengths and weaknesses of the region is decisive for a positive outlook.

- Every region has its individual strengths, which can serve as the basis for its future development.

- The people in the region themselves can best recognize the strengths of a region and potentials for future development.

This IRD debate is a political discussion as well as a scientific discourse. In science ${ }^{3}$ rural development has been discussed for some time now under the aspect that the forms and means whereby rural areas are governed "have changed remarkably in recent years" (Marsden/Murdoch 1998: 1). Whereas rural government traditionally meant mainly to steer agricultural concerns and interests rural governance now means steering and managing the different demands currently being made upon rural space, especially against the background of demands for sustainability (Marsden/Murdoch 1998: 1). The governance of rural areas is now seen as being multi-dimensional (Marsden/Murdoch 1998: 1), whereas the role of agriculture has been described as becoming more and more multi-functional (Knickel 2002). Concepts of endogenous (Ray 2006) or autonomous (Hahne 1984) rural development are discussed in different scientific disciplines focusing on the region as "socio-cultural actor" (Bruckmaier 2000: 219) in order to react to ecological, economic and social challenges of rural areas. "Regions are constituted by a plurality of actors, with the participation of the local population in decisions concerning development and self-management (rather than solely by governmental institutions and powerful actors) being at the core of the new governance (Bruckmaier 2000: 219). This scientific debate is reflected by the terms "rural governance" (see e.g. Marsden/Murdoch 1998, Goodwin 1998) and - especially in Germany - by the term "Regional Governance"4 (Tränkner 2006). The scientific rural (respectively regional) governance debate reflects different main aspects/topics which are also discussed in a wider general governance discussion (Goodwin 1998: 8, Böcher 2008):

2 Throughout the report the terms area-based, place-based and territorial approach to rural development are used synonymously. They all refer to a shift in focus from sectors to functional units, such as territories and areas which for different social reasons may be characterised as a functional unit.

3 Rural development is an multi-disciplinary issue, discussed in political science, rural sociology, geography, and economics amongst others.

4 The regional governance debate in Germany reflects the development of all kinds of regions without the existence of a special "rural governance" term whereas the international scientific debate especially reflects rural development issues within the term "rural governance" 
- The observation of the boundaries/limits of state-hierarchical intervention abilities within rural policy (Böcher 2008)

- The potentials of self responsibility of a region as a level of political coordination and decisions and the improvement of the coordination of land use and a better impact of funding programmes through more autonomy of rural areas (Böcher 2008)

- The potentials and limits of a collaboration of different institutions and actors in rural areas that are drawn from but also beyond "traditional" government (Goodwin 1998)

- The role of autonomous rural self-governing networks of actors Goodwin 1998)

- The relation between new forms of rural governance and traditional forms of higher levels' government (Multi-level governance) (Goodwin 1998, Böcher 2008)

- The improvement of citizens' participation and strengthening of democracy (Marsden/Murdoch 1998) in rural areas

- The reach of sustainability through new forms of governance (Bergmann 2000)

This scientific discussion serves as the underlying framework for the establishment of an "integrated rural development (IRD) philosophy"5. According to the IRD philosophy cooperation between policymakers, administrations, the various economic sectors and the citizens for the benefit of their rural region is the foundation of successful development. Working together to recognize and make use of regional potentials is the prerequisite for successful change. All actors important to a region should, if possible, get involved and think about how they together can move the region they live in a step ahead. No solutions for individual sectors, but cross-sector regional approaches are sought for. It is no longer: "how can I get my agricultural products sold or what can I do for nature conservation", for example to protect an area, but: "what benefits could cooperation between nature conservation and agriculture have for the people of our region and what profits can be gained through this cooperation for agriculture and nature conservation?" Integrated rural development is a regionally focused, cross-sector, partnered, learning and long-term approach. The goal is to integrate the different sectors in one joint development strategy. Thus, IRD requires a less defensive approach to rural policy and stronger coordination across sectors, across levels of government, between public and private actors (... and) a new focus on place rather than sectors and an emphasis on investments rather than subsidies' (OECD 2006: 3ff; see also BMVEL 2005). The concept has been taken up by different key political actors as illustrated in Table 2.

In Germany the issue of IRD has been on the political agenda of state- and non-state actors for quite some time. Several milestones can be identified in the field of IRD which mirror the evolution-process of the concept. Besides the application of the approach in development cooperation of the 1980s and an emerging discussion about the new roles of agriculture besides food production in the 1990s (Bruckmaier 2000, SRU 1996), two conferences initiated by BMVEL, held in Berlin in 2004 (The future of rural development in Germany) and in Potsdam in 2001 (Rural21), are significant points in the progress of the more recent IRD philosophy. More current steps in the advancement of IRD is the publication of guidelines for integrated rural development by BMVEL as well as the process of developing a German "White Book" on rural development, in which a dialogue with German stakeholders has been established by the BMVEL. Table 2 summarises the interpretation of the concept by BMVEL.

5 This IRD philosophy is outlined by BMVEL 2005 
Table 2: The concept of Integrated Rural Development as interpreted by BMVEL

\begin{tabular}{|c|c|}
\hline \multicolumn{2}{|c|}{ What is integrated rural development? } \\
\hline Region-specific approach & Looks at regions rather than individual sectors \\
\hline Cross-sector approach & $\begin{array}{l}\text { Focused on synergies between different areas of } \\
\text { government and industry }\end{array}$ \\
\hline Partnership approach & $\begin{array}{l}\text { People form partnerships, set up and implement joint } \\
\text { programmes }\end{array}$ \\
\hline Dynamic approach & $\begin{array}{l}\text { The process is continually evaluated and further de- } \\
\text { veloped by the network of actors }\end{array}$ \\
\hline Long-term approach & Focused on medium and long-term potentials \\
\hline
\end{tabular}

Source: $\quad$ BMVEL (2005).

After re-elections in late 2005 this process, however has been replaced by a high-level campaign on rural policy issues in form of subsequent conferences on rural areas at regular intervals initiated by the new Minister for Food, Agriculture and Consumer Protection Seehofer (hereafter referred to as Minister). The first of these conferences was a Berlin conference on "the future of rural areas", held in October 2006 (Observation 2006a) which has been followed by conferences on "Economy in rural areas" (Feb 2007), "Infrastructure in rural areas" (May 2007), and "New approaches of rural development: good examples" (June 2007). The altered understanding of addressing rural problems by cross-sectoral and participatory policies under present political conditions is accompanied by ambitions of the present Minister to actively put the IRD approach onto the political agenda (Augustin 2006c, Interview; Stöppler 2006, Interview). The OECD also contributed to the philosophy by recent activities ${ }^{6}$ and by publishing 'The new rural paradigm: Policies and governance' (OECD 2006), an important publication for the current international policy discussion about rural development approaches which contains partly case studies from Germany as best practice examples. OECD's understanding of the new paradigm is illustrated in Table 3. The OECD (2007) also reviewed German rural policy in light of this new paradigm and criticises traditional policies as 'reflecting past conditions and not doing justice to today's challenges in rural regions' (OECD 2007: 92). Contrary, area-based policies such as the two pilots LEADER+ and REGIONEN AKTIV, are mentioned as 'exceptions from traditional mainstream policy', innovative and place-based and hence, are presented as typifying the new rural paradigm (OECD 2006).

6 See OECD conferences held in Warrenton, Virginia (US) and Oaxaca (Mexico); OECD study on 'German rural policy review' launched in early 2006 (OECD 2007) 
Table 3: The new rural paradigm as interpreted by OECD

\begin{tabular}{lll}
\hline & \multicolumn{1}{c}{ Old approach } & \multicolumn{1}{c}{ New approach } \\
\hline Objectives & $\begin{array}{l}\text { Equalisation, farm income, farm } \\
\text { competitiveness }\end{array}$ & $\begin{array}{l}\text { Competitiveness of rural areas, } \\
\text { valorisation of local assets, } \\
\text { exploitation of unused resources } \\
\text { Key target sector }\end{array}$ \\
Agriculture & $\begin{array}{l}\text { Various sectors of rural economies } \\
\text { (ex. rural tourism, manufacturing, ICT } \\
\text { industry, etc.) }\end{array}$ \\
Main tools & Subsidies & $\begin{array}{l}\text { Investments } \\
\text { Key actors }\end{array}$ \\
National governments, farmers & $\begin{array}{l}\text { All levels of government (supra- } \\
\text { national, national, regional and local), } \\
\text { various local stakeholders (public, } \\
\text { private, NGOs) }\end{array}$ \\
\hline
\end{tabular}

Source:

OECD 2006

The IRD philosophy seems to be more some kind of a philosophy which delivers a conceptual (rhetorical) framework for the design of special policy programmes like "REGIONEN AKTIV" or "LEADER+". Nevertheless IRD seems to be a good starting point for our assessment, because it reflects the current rural development approach of one of the most important rural policy actors in Germany, namely the BMELV. In the course of the following analysis we will highlight the central rhetoric and recent practices in the IRD philosophy. The IRD rhetoric set out here may be interpreted as a general reference framework for policies applying the approach. In a final chapter we will then synthesise the policy evaluations based on the comparison of rhetoric and practices inter alia based on the general IRD rhetoric. However, no concrete examples will be presented and we will not focus on the answering of individual research questions. The concept of IRD in general serves for us as starting point of the analysis as well as some kind of a normative-oriented background (framework) for the assessment of concrete policy programmes and measures. Hence, rhetoric from the IRD philosophy may also be interpreted as overarching rhetoric for all subsequent cases and will serve as point of reference for the comparison of respective rhetoric and practices.

\subsection{Selected IRD case studies}

For the GoFOR project the Goettingen-Team focussed on "integrated rural development policies" in a German context. Under this topic we included case studies on the four following governance processes.

\section{- IRD philosophy}

Even though integrated rural development (IRD) rather reflects a school of thought or a general approach to rural development, it also serves as a first case study for the GoFOR main assessment. In recent years integrated rural development has been institutionalized as a concept frequently encountered in rural development practice and theory. The concept here is presented as a governance process (case) since it builds - as aforementioned - on many also scientifically discussed governance aspects, especially on regional governance, and because it has been subject to changes over time. IRD as a normative concept also has had far-reaching implications for different rural development policies, at EU, national and sub-national level. In our understanding, the IRD philosophy can be seen as an umbrella for the three following special policies of integrated 
rural development. It may be seen as a rhetorical framework for the more detailed case studies, which in turn rather reflect IRD practices. For an analysis of governance practices including our detailed research questions, however, the IRD philosophy case does not suffice. We neither addressed all the research questions in this case, nor did we make reference to the ToR. Thus, for an in-depth analysis and a cross-case comparison please refer to the other three cases (REGIONEN AKTIV, LEADER+, GAK).

\section{- LEADER+ and REGIONEN AKTIV}

The EU Community Initiative LEADER+ as well as the German pilot project REGIONEN AKTIV (English: "Active Regions") both are governance processes which nicely illustrate the advent of the IRD philosophy in publicly-funded model programmes. Both programmes have been designed inter alia for the development of new approaches to rural development and for the improvement of mainstream policies, where the source of LEADER+ is the European Commission whereas the origin for REGIONEN AKTIV is the German federal government.

\section{- GAK}

The case study on the GAK ("Gemeinschaftsaufgabe zur Verbesserung der Agrarstruktur und des Küstenschutzes"; English: "Joint Task Improvement of Agricultural Structures and Coastal Protection") analyses the central institution in rural policy (OECD 2007: 92), which recently has been 'reformed' through the uptake of IRD elements as a new funding principle.

The selection of case studies coincides with a process continuum including a policy philosophy or concept (IRD), pilot programmes (LEADER+, REGIONEN AKTIV) to test the application of this concept in a given issue area such as rural development, and finally a case showing effects of the aforementioned processes in mainstream policy (Figure 3). So the different cases cannot be seen isolated but have to be understood as one overarching policy concept which has emerged during the last 20 years and concrete policy programmes trying to implement this normative concept of IRD into political practice in Germany.

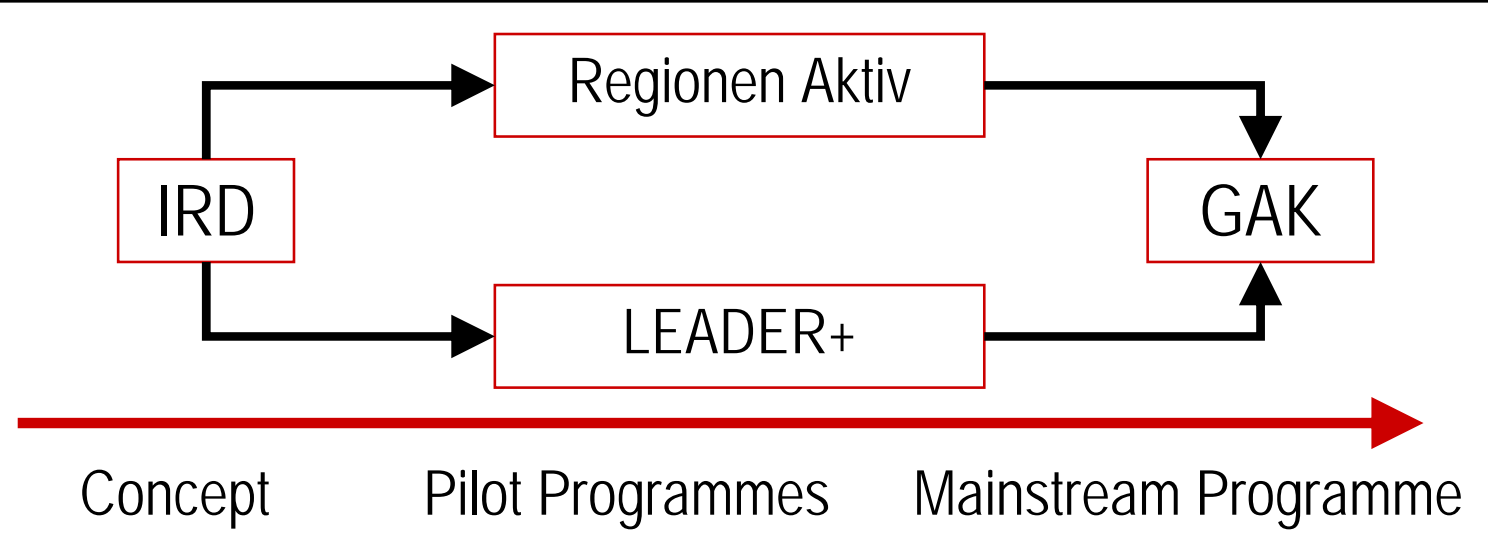

Figure 3: The IRD policy continuum. Case studies from a normative concept to the integration into mainstream policy 


\subsection{Structure and logics of the report}

In separate chapters $(3,4,5$ and 6$)$ each case study will be briefly introduced, providing the reader with necessary background information. Subsequently, each of the chapters will provide an analysis as regards the constituting elements of our theoretical governance concept. After this presentation of the case studies some empirical findings of how the IRD case study links to aspects of forest policy and the forest governance are presented (chapter 7 ) will be provided. We will conclude the report with chapter 8 on overall conclusions regarding new modes of governance from the IRD philosophy in more general.

It seems to be useful to provide the reader with some background information on the German context. We quite frequently cited the Federal Ministry of Consumer Protection, Food and Agriculture. The German acronym is BMVEL (Bundesministerium für Verbraucherschutz, Ernährung und Landwirtschaft). Due to the results of the federal elections in 2005 and a change in the German government some minor changes in nomenclature occurred. The Ministry now is referred to as BMELV. Hence, the reader will find both abbreviations throughout the report. We would like to also note that Germany is a federal state. The term "federal level" is used synonymously with national level. The subnational level is referred to as "Laender", which translates into "federal states", while local level stands for communes. The term 'regional' in our context refers to an area which consists of more than one commune but is smaller than a federal state.

\section{$3 \quad$ Particular Methodology in IRD-Case Studies}

Following the empirical-analytical approach, a qualitative research method was adopted for eliciting data about new modes of governance in the field of integrated rural policy in Germany and its links to forestry. This seemed especially appropriate because a previous study by Ortner (2004, see also Ortner 2008) took a quantitative approach in estimating forestry participation under an IRD-programme. We consequently have been interested in complementing Ortner's findings by investigating on potential reasons explaining the phenomenon of low forestry participation, rather than in its relative frequency.

Using a case study approach on three IRD-funding programmes the analysis primarily is based on the following qualitative research methods (after Jones 1996):

Firstly, content analysis has been employed on the programmes' policy documents, on the detailed web-based documentation of the Leader+ and REGIONEN AKTIV programmes as well as on related publications by key actors of rural development policy for eliciting programmatic aspects of IRD funding schemes and for validating subsequent interview data.

Secondly, 29 expert interviews among specialists in the field of integrated rural development as well as IRD relating to forestry were carried out. The survey included experts from the field of integrated rural development (policy makers at national and Federal States' level, public administration staff members at regional, Federal States' and national level, consultants, representatives of interest groups and scientists; for a full list of interviewees see the references chapter). Respondents for questions relating to the role of forestry mostly can be described as collective actors at an aggregate level (no individual forest owners or managers were interviewed; an overview of these interviewees is provided in Table 4). All interviews were of a semi-structured nature, also comprising narrative elements on individual experiences with forestry in rural development programs. These narrative components were useful for eliciting information about new, innovative and widely unknown or implicit fields of action and actors' strategies for dealing with integrated programmes. 
Thirdly, observation of political conferences on IRD-issues also has been employed as form of primary data collection. Especially events organised by the BMELV, as the main actor in IRD policy, have been of interest for validating interview data and contributing to a dynamic understanding of IRD policy changes.

Lastly, the method of focus group discussions has been carried out among selected experts on forestry issues within the IRD framework (documented in Böcher/Giessen 2006). The so called "national advisory panel" included the following representatives, while the focus group was held among the first five members:

- Dr. Ute Seeling (Working Group of German Forest Owners' Associations, AGDW)

- Dr. Volker Düssel (Head of the State Forest Service, Thuringia, Ministry of Agriculture, Nature Conservation and the Environment Thuringia)

- Graf von Kanitz (German Forestry Society, DFV)

- Dirk Schubert (nova-Institute)

- Florian Schöne (Federation for Nature Conservation, NABU)

- Theo Augustin (Federal Ministry of Food, Agriculture and Consumer Protection)

- Hildegard Zeck (Ministry of Agriculture, Lower Saxony)

- Prof. Dr. Wolfgang Krumbein (University of Göttingen).

All qualitative data derived from the interviews and focus groups has been processed using the coding functions of MaxQDA software.

Additionally, this set of primary data on new modes of governance in IRD-policy has been supplemented with secondary data and results from the REGIONEN AKTIV accompanying research. Being part of the accompanying research team from 2004-date allowed the authors to overview all data produced and to select it appropriately. The respective results and data are documented in Elbe et al. (2007 and in more detail in Elbe 2007, Lukesch et al. 2007, Benz and Meincke 2007 and Böcher and Tränkner 2007 respectively). For a rough description Böcher and Tränkner (2007) as well as Elbe (2007) built their inquiry on document analysis of mandatory reporting by the model regions. Lukesch et al. (2007) rely on data derived from participant observations during focus group sessions whereas Benz and Meincke (2007) employed a combination of quantitative and qualitative network analysis. 


\section{Table 4: Population of the qualitative survey on the role of forestry within integrated rural} development

\begin{tabular}{ll}
\hline Actor group & Organisation \\
Associations & Working Group of German Forest Owners' Associations (AGDW) \\
& German Forestry Society (DFV) \\
& Federation for Nature Conservation (NABU) \\
& Working Group for Peasant Agriculture (AbL) \\
& German Association for Land Care (DVL) \\
& German Farmers' Association (DBV) \\
& Ministry of Economy, Traffic, Agriculture and Viniculture, Rhineland- \\
Public & Palatinehttp:///WWW.MWvlW.rlp.de/internet/nav/fe7/fe770101-a350-6401-a3b2- \\
& 1714462b74cf.htm \\
& State Forest Service, Thuringia \\
& Federal Ministry for Food, Agriculture and Consumer Protection, Department 53 (a) \\
& Federal Ministry for the Environment, Nature Conservation and Nuclear Safety \\
& Federal Ministry for Food, Agriculture and Consumer Protection, Department 53 (b) \\
& Federal Ministry for Food, Agriculture and Consumer Protection, Department 52 \\
Science & University Kassel \\
& University Göttingen \\
& Nova Institute \\
\hline
\end{tabular}




\section{$4 \quad$ Case Study on the Governance Rhetoric of Integrated Rural Development (IRD)}

\subsection{Introduction to the IRD philosophy}

The general ideas and the philosophy of IRD have already been introduced in the preceding chapter. It becomes obvious that under IRD all governance elements used in our analysis will be actively touched upon. The IRD philosophy e.g. enters into policy in the EU Community Initiative LEADER+, where as a core element of the Leader approach, public-private-partnerships (PPPs) called Local Action Groups are the drivers and decision-makers of a regionally based development process. The PPP has the task of negotiating, formulating and implementing a local development strategy, making decisions about the allocation of its financial resources and managing them. Evaluation of the process also lies within the PPPs responsibilities (EU Commission 2006: 10). This de-centralised and regionalised approach enables local and regional actors to deliberately and actively create a process of endogenous regional development. The approach taken under IRD shows, that implementation of IRD policies necessarily is located at regional level. Hence, the PPPs analytically can be seen as the central institutionalised governance mechanism at for implementing IRD at regional level. The distinction between policy implementation at regional and its formulation mainly at superior levels will be central in the following analysis.

In the following section the concept of IRD will be analysed against the constituting elements, which then serve as an overall framework for deducing some overall governance rhetoric of the IRD philosophy.

\subsection{Context factors}

The general decline of agriculture as main source of income for rural citizens in developed countries since some time lead to a discussion of the role agriculture plays for rural areas. After WW II, in Western Germany $30 \%$ of the whole workers were employed in agriculture, whereas in the 1990s, after the German reunification, this percentage decreased to 3\% (SRU 1996: $67 \mathrm{f}$.). As a consequence caused by this development, agriculture has been described as becoming more and more multi-functional, "replacing the traditionally dominant place of food production in rural development with posited new and complementary roles: producer of renewable energy, nature protection and landscape preservation, and agent for sustainability" (Bruckmaier 2000: 220; SRU 1996: $71 \mathrm{ff})$. Agricultural policy in general has been discussed in order to reformulate the role agriculture can play against the background of the described overall conditions, for example in a report of the German Advisory Council on the Environment (SRU 1996).

Structural changes in agriculture due to international agreements and competition and market liberalisations must be seen as additional context factors facilitating/necessitating new approaches to more integrated approaches to agricultural policy (BMVEL 2002a: 4; BMVEL 2002b: 4). In the Uruguay GATT-negotiations new forms of supporting rural areas beyond mere agricultural subsidies have been discussed. Decreasing public funds and the experiences gained in the Eastern part of Germany, where public funds were spent using the "shotgun approach" or "something for everybody principle" also 
boosted the evolution of more integrated approaches to rural development and finally the idea of even applying competitive approaches.

EU agricultural policy also plays a key role in the evolution of IRD. With a shift from sector-oriented subsidies (1st pillar) towards more integrated approaches (2nd pillar) the Common Agricultural Policy (CAP) facilitates integrated approaches to agricultural policy in general and rural development in particular. This second pillar has a special meaning for the sustainable development of rural areas. By Council Regulation (EC) 1257/99 farmers can apply for subsidies if they make a contribution to environmental protection in rural areas (AGRI-ENVIRONMENT). With 1257/99, the EU wanted to "introduce a sustainable and integrated rural development policy governed by a single legal instrument to ensure better coherence between rural development and the prices and market policy of the common agricultural policy (CAP) and to promote all aspects of rural development by encouraging the participation of local actors" (EU-Commission 1999).

Agricultural crises such as "mad cow disease" also led to distrust in current practices of agricultural policy, especially at the EU and national level. In a German context the process called "Agrarwende" (which translates into "agrarian turnaround"), driven by a change in the federal government in 1998 and subsequently the coming into power of the first "Green" Minister for agriculture in 2001, also promoted new approaches to agricultural policy including consumer demands, environmental claims and more people-oriented approaches.

Decreasing public funds, especially on the EU level against the background of the enlargement of the union, must be assumed to have an impact on policy design. Integrated approached promise to fulfil multiple objectives and promote multifunctionality. Hence, a shift in policy design and implementation could also be explained by the scarcity of financial means throughout all administrative levels.

One can say that actor-centred approaches are suitable within a German context. Civil society organisations are well established and the political culture seems to be in favour of such developments. However, the sectors of agriculture and forestry as a potential starting point for rural development activities must be considered as rather conservative and partly reluctant of taking integrated approaches (Giessen et al. 2006; Giessen 2007, 2008). Empirical results suggest that the primary sector under LEADER+ does not play the role commonly and theoretically attributed to it (Ortner 2004; Hemmerling 2006, Interview; Seeling 2006, Interview).

\subsection{The governance rhetoric of IRD and some general practices}

\subsubsection{Participation}

OECD states that IRD requires a 'less defensive approach to rural policy and stronger coordination (...) between public and private actors'. It should be aimed at enforcing and exploring local Public-PrivatePartnerships (PPP) (OECD 2006: 3, 147). IRD thus builds on local and regional potentials which are to be mobilised for the planning, implementation and evaluation of rural development strategies and activities. This bottom-up approach is being complemented with facilitating framework conditions determined by a top-down steering framework (BMVEL 2005: 4). The process is characterised by quality partnerships (in a vertical and horizontal way) among all actors involved at different levels. At the regional level public administrations, citizens, associations, scientific actors as well as economic actors are engaged in order to integrate various needs and perspectives. However, the development initiative is expected to maintain its creative independence, while policymakers and administration contribute their administrative professionalism and support to the process (BMVEL 2005: 11; 13). 
The regional actors work together in a so called "regional partnership" for a common vision and collaboratively elaborate rural development strategies. Such plans are supposed to cover all stages of the development cycle and hence ample participation is supported throughout the whole process. These two features of (1) a regional partnership as decision institution and (2) the formulation of rural development strategies are the central items reflecting and institutionalising participation processes in IRD. Altogether, it is recommended that the initiative has transparent structures and clear rules for all actors involved (BMVEL 2005: 11; 13).

In a joint position paper the BMVEL together with leading environmental NGOs states that participation of regional actors and citizens is a key element for rural development policies and that the input of such social capital is inevitably linked to the success of development efforts (BMVEL unknown :14). In a position paper the Agrarbündnis calls for an inclusion of local actors and citizens from various aspects. People in the regions are recognised as the ones concerned with rural issues, as taking part in the development of their regions and finally as decision-makers for their own good. Hence, the authors emphasise the importance of participation in the development process (Agrarbündnis 2002: 8).

Setting favourable framework conditions for active participation in the regions is stated to be one of the central future challenges. Traditional planning- and decision making-processes need to be adapted to the present needs of genuine participation. Likewise, the self-image of governance procedures and logics should be subject to further democratisation (Agrarbündnis 2002: 10).

A deepening of the partnership approach among various public and private actors is called for by WWF. It is emphasised that especially improving the horizontal partnerships (at one level) could positively contribute to the perfection of rural development policies (WWF 2003: 10; WWF 2002a: 36).

The involvement of citizens in general and landowners in particular into the planning of development activities is demanded by a rural development association of landowners (BTG 2003: 3).

The final statement of the conference Future of rural development in Germany, held by the BMVEL in Berlin in 2004 concludes that the participation of the private sector and of the citizens at all stages of the process has proven to be a key factor for the success of regional development (BMVEL 2004b: 9).

\section{Some general practices}

Under IRD initiatives a mutual and reciprocal approach to stakeholder identification and mobilisation is necessary for making sure to address all interests and at the same time involve those actors who are deeply committed to the process. Hence, IRD funding programmes by addressing 'a wider circle of beneficiaries' offer opportunities for new actors to get involved in political processes. This, however, holds true for pro-active actors having information on these opportunities. In a reciprocal sense more reluctant or 'remote' actors should be actively addressed and 'invited at an early stage of the process through their respective networks' (Seeling 2006, Interview). Here, public agencies may fulfil their 'new role as activating and moderating administration' in delivering information to such actors and in communicating the specific benefit for their clients (Schubert 2006, Interview; Augustin 2006c, Interview).

OECD recognises that IRD policies, by applying a territorial approach, have 'helped foster public-private partnerships and integrate new stakeholders into the development process' (OECD 2006: 18).

The impetus for a more pro-active approach to participation in IRD stems from several origins. Scientific discussions $^{7}$ formulate some sometimes normative-laden claims for new forms of "community

7 See for example Woods 1998, Goodwin 1998, Moseley et al 2003, and more recently Douglas 2005. 
participation" (Marsden/Murdoch 1998) within rural governance. The question of participation can also be found in more theory-oriented discussions on the legitimacy of new forms of rural governance (Goodwin 1998: 8) especially regarding the question how rural governance processes can be democratically legitimised if weakly institutionalised rural actor networks become more powerful in decision-making processes - the principle of participation seems perfectly to accompany processes of rural development. In this sense, - according to our interviewees - present policy experiences e.g. with LEADER+, REGIONEN AKTIV and InnoRegio caused a change in paradigm towards an 'activating and enabling state' (Augustin 2006c, Interview). Yet, offers from the state would not suffice. Citizens must (re)discover forms of civic engagement e.g. within their communities (Jäger 2006, Interview). This was facilitated and actually achieved through IRD processes in the regions (Augustin 2006c, Interview). Results show, however, that regional actors only deliberately enter into IRD processes, if specific benefits for respective actors are associated with the cooperation and if actors are given the opportunity 'to make a difference' (Schubert 2006, Interview; Delbrück 2006, Interview). Such benefits not necessarily have to be profits in material terms, but also community appreciation etc. may reward participants (DVS unknown b). Such benefits should be made visible to actors by their respective networks and especially public agencies (Schubert 2006, Interview; Schubert, statement during Observation 2006b). Having said this, it becomes obvious that participation in IRD processes is quite a challenge for private sector (corporate) actors as they necessarily depend on material benefits. IRD processes tend to 'take a long time and a lot of effort including secondary tasks for obtaining the goal' and do not provide for certainty as regards the benefits (e.g. the granting of public funding) (Schubert 2006, Interview; Hemmerling 2006, Interview). This general weakness of private enterprise representation will be referred to as ,structural exclusion'. The term does not imply a purposeful exclusion, but draws on programmatic characteristics of the funding scheme, which are not suitable for firms and companies and does not imply the exclusion of e.g. citizens. As compared to more traditional approaches to rural development IRD practices, even though such structural exclusion may occur, can be interpreted as a meaningful and democratic attempt to include and even empower societal groups base don state interventions. Intervention here means to deliver a funding programme, which per se has certain addressees and other non-addressees, who automatically are 'excluded'. The interesting point here is that under IRD practice groups which are formal addressees of the programmes are represented to a small degree only. We consider this under-representation as disfigurement, which certainly does not dispute the democratic qualities of the process.

A possible solution to the problem of structural exclusion may be taking a value-chain approach, which has been developed by and applied in cooperation between enterprises before. Such an approach is described under REGIONEN AKTIV, as this funding programme in its current second phase has been focused towards regional value-chains (nova 2007). However, the degree of integration and the open character of IRD may become constrained by focussing on value-chains, as described later on.

Participation in IRD was reported to initially take rather narrow and focussed forms to maintain momentum, consensus and ownership of the core ideas among the core actors. This phase is then followed by broad participation for developing visions, and identifying different alternatives (Hahne 2006, Interview; Swoboda 2006, Interview). This phase would also be used by actors to appraise the process' potentials regarding the actors' interests and for ,sticking out claims' (Hahne 2006, Interview).

The creation of somewhat non-legitimate structures at regional level parallel to existing ones is seen as an evident problem with participation in the empirical reality (Hemmerling 2006, Interview; Hahne 2006, Interview; Spöring 2006, Interview). The relation between emergent process structures of participatory processes to e.g. county and communal governance institutions is often perceived as being 'undefined and not well thought-out'. In addition to such competing structures, also different IRD or other bottom-up initiatives may overlap in some regions contending each other. Such duplicate processes may involve 
ever the same people and are likely to lead to over-extension especially of honorary actors (Spöring 2006, Interview; Hemmerling 2006, Interview).

Trends towards more active participation in IRD also became evident at the higher federal political level. At a mile stone conference organised by BMELV in late 2006, this shift in paradigm manifested in the ministerial commitment to enter into 'a broad and long-term societal dialogue with stakeholders on the future of rural policy' (Eberlein 2006, Interview; Observation 2006a). Also it became evident in the provision of an online forum for stakeholder comments and discussions. The latter feature is a novel to the work of BMELV and can be seen as 'a non-customary offer for stakeholders to contribute their input and ideas' (Eberlein 2006, Interview; Observation 2006a). The ideas generated through the forum and three subsequent BMELV conferences are supposed to feed into an overall strategy for addressing rural development issues (Stöppler 2006, Interview; Observation 2006a). For actors to be identified and perceived as stakeholders by BMELV a minimum of 'assumed expertise' must be given. Although a participatory approach was 'desirable' potentials of participation largely depend on individuals' ability to cooperate and their willingness to do so (Augustin 2006c, Interview).

\subsubsection{Inter-sectoral coordination (ISC)}

According to OECD IRD requires a 'less defensive approach to rural policy and stronger coordination across sectors, (... and) a new focus on place rather than sectors and an emphasis on investments rather than subsidies'. Thus, OECD calls for 'strong horizontal coordination effort at (...) at central, regional and local level between public and private actors' (OECD 2006: 3, 147).

IRD employs a territorial or region-specific approach, which implies that sectors are no more the addressees of development efforts but regions as a whole. This leads IRD to a cross-sectoral approach. Social, cultural, economic as well as ecologic demands are supposed to be considered jointly and across sectors (BMVEL 2005: 4).

One central goal of IRD is to harmonise and integrate the different sectors in one joint development strategy and to overcome conventional sector specific funding and development. This is assumed to be achieved through motivation and an activating process which points out potential individual gains and develops inter-sectoral innovations and alternatives. Such potential win-win situations are perceived to facilitate cross-sector alliances and hence, the detection of synergies can be interpreted as a core element of IRD (Augustin 2006c, Interview; BMVEL 2005: 19).

The federal ministry BMVEL together with leading environmental NGOs state that the key to sustainable rural development lies in developing a strategy for integrating various interests and to achieve synergies among sectors (BMVEL et al. 2002: 14).

The Confederation of European Forest Owners points out, that forestry offers a broad potential of contributing to cross-sectoral rural development (CEPF 2005: 5).

WWF emphasises the central role of integrated approaches to rural development. Sustainable development in rural areas requires a broadening of the support spectrum to areas outside agriculture. The authors call for a shift in mainstream policies from project and sector-oriented towards means for sustainable rural development (WWF 2002:37). Integration can be reached by inter-sectoral analyses and solutions (WWF 2003: 5; 10). WWF also criticises the emphasis put on agricultural funding under rural development policies and urges for policy amendments which facilitate the integration of different sectors (WWF 2002b: 1; 3).

Agrarbündnis claims that public support ought to take a territorial and hence integrated approach to rural development. They call for the cooperation of sectors such as agriculture, trade, commerce, education and service (tourism, recreation). 
Finally, the conference on the Future of rural development in Germany criticises the sectoral nature of most of the support within the agricultural policy and a lack of correspondence with other support policies (BMVEL 2004b: 8).

\section{Some general practices}

According to OECD the new paradigm has developed a culture of cross-sectoral cooperation within central and local governments'. Still, many central governments 'often struggle with overcoming their own sectoral approach'. Also at local level horizontal coordination was needed, especially 'because regional and local level administrative boundaries do not always correspond to development needs' (OECD 2006: 18, 17).

Empirical material shows that the IRD philosophy (as interpreted in this study) and resulting policy implications, which both originate and manifest predominantly in the agricultural realm, also impede ISC. The increasing IRD programme and process expenditures are currently funded by former agricultural funds. This drain of sectoral resources certainly is not appreciated by the respective sectors (agriculture, forestry and fisheries). A certain reluctance of these sectors to even support this trend by IS-cooperation was the result of this practice (Delbrück 2006, Interview).

In empirical practices of IRD some parallels with participation could be identified. Certain benefits for individuals or sectoral representatives were perceived as necessary for cooperation. 'ISC also must not be an end in itself. (...Sectors should) cooperate when it suits well' (Hemmerling 2006, Interview).

Recent developments in the IRD philosophy, namely the economisation of the approach as well as focussing on regional value chains may hamper ISC at regional level. Such economic perspective is believed to narrow down the view for the comprehensive picture of a region's potentials. The value chain perspective in turn further narrows the economical view, which may result in a loss of synergies among different value chains and sectors (Hahne 2006, Interview).

At the political level of the federal government ISC issues currently gain momentum. At the aforementioned conference "the future of rural areas" in late 2006 a much wider approach to rural development policy in terms of sectors addressed has been applied than during past conferences (Observation 2006a; Stöppler 2006, Interview; Eberlein 2006, Interview). BMELV has called for increased ISC and tried to position as the central coordinator among sectoral interests and ministerial portfolios (Observation 2006a).

In contrast, at the present it is still unclear how the different sectors under the BMELV initiative will be coordinated and if all aspects discussed under IRD may be covered by BMELV in an appropriate manner (Thomas 2006, Interview). The issue has been addressed in a dialogue with the chancellery at federal level (Eberlein 2006, Interview). Yet, there is no operational ISC among ministries in place and 'no real changes' can be observed' (Stöppler 2006, Interview; Augustin 2006, Interview). BMELV was perceived to be in a 'process of transformation and persuasion'. A lack of ISC among governments at both, national and provincial level and prevailing sectoral approaches are seen as a major obstacle to further promote ISC. Instead of having a harmonised government strategy, portfolios' interests in Germany were prevailing and contradictory strategies addressing the same rural problems existed (Augustin 2006c, Interview). At ministerial levels such efforts, however, would be 'necessary in order to maintain credibility' of the IRD approach especially among regional actors, who themselves have 'shown the applicability of ISC in their regions during the past 15-20 years'. Integrating ISC into the government self-conception is perceived as 'the central future challenge' for IRD to work in practice (Schubert 2006, Interview; Hemmerling 2006, Interview). 


\subsubsection{Multi-level coordination (MLC)}

The issue of MLC is not addressed as extensive as e.g. participation. This may be due to the fact that IRD may take place in any given context including various levels. However, a bottom-up approach alone, where decisions are taken entirely autonomously is perceived to inhibit development processes. It is recognised that EU, national or sub-national policies may promote or hinder rural development. In the scientific discussion as well the bottom up approach alone is not seen as "the healer" for the successful initiation of rural development processes. Most scholars describe a combination of top down incentives and bottom up initiatives as most promising strategy for rural development policies in future (Böcher 2008). Hence, a fruitful combination of the potentials of bottom-up steering as well as the existing top-down policy guidelines is proposed. European and national framework conditions ought to promote rural development by creating incentives for the application of IRD principles (BMVEL 2005: 13).

The new approach requires a 'less defensive approach to rural policy and stronger coordination (...) across levels of government (...) and should be attained by e.g. contracts (OECD 2006: 3, 147). Besides this no further statements concerning MLC could be identified. However, the connotation of BMVEL's understanding of IRD build upon an already existing scheme for MLC. The guidelines on integrated rural development have been published simultaneously with the reform of the so called GAK (Gemeinschaftsaufgabe Verbesserung der Agrarstruktur und des Küstenschutzes) which was supplemented with the new funding principle "IRD". Hence, when talking about IRD the BMVEL in those days probably made reference to the GAK. This national policy is based on a thorough system for MLC as described in subsequent chapters.

In a joint brochure the BMVEL together with leading environmental NGOs sketch their visions of IRD. It explicitly calls for area-based approaches, to adequately address rural problems in their complexity and specifity (BMVEL et al. 2002: 14).

WWF states that sustainable development of rural regions can only be achieved, if all different levels concerned collaboratively work together. This includes the sharing of costs among such levels through co-financing arrangements. They call for a vertical partnership of all relevant actors in planning, implementation and evaluation of rural development policies and respective measures (WWF 2002a: 37).

The integration of local, regional, national and international interests should be achieved by an areabased approach and the promotion of regionalisation (i.e. transfer of decision-making competencies to subordinate levels) following the principle of subsidiarity (WWF 2003: 5, 11; WWF 2002a: 36).

In a German context WWF sees the principle of subsidiarity only applied at international, national and sub-national levels. For achieving positive impacts in rural development, however, this principle should be applied at the regional and even local level. EU is supposed to set the frame for rural development and the Germen federal ministry is expected to coordinate the different interests of sub-national bodies. At the sub-national level programmes addressing regional-specific problems should be designed, whilst transferring planning and decision-making competencies to the regional/local level (WWF 2002b: 3f).

The same argument is put forward by the Agrarbündnis. They find the principle of subsidiarity useful in the context of rural development. However, a lack of consistency with the principle is identified below the sub-national level as well. The authors call for a shift of as many competencies to the local and regional level as possible (Agrarbündnis 2002: 7) .

In addition, discrepancies between competencies of the different levels are criticised. For instance, at the EU level rural development competencies are scattered among DG Agriculture, DG Environment and DG Competition. In Germany the BMVEL is hindered to address rural development as a whole, 
since e.g. environmental issues are within the constitutional responsibilities of the Federal states (Agrarbündnis 2002: 2).

Participants of the conference on the Future of rural development in Germany stated that the diversity of local contexts and problems could only be adequately addressed by development strategies, which are designed in the regions and which are implementation-oriented. In order to implement such strategies, regional actors, however, need room for manoeuvre and genuine decision-making competencies. This would necessitate the application of subsidiarity especially among public administrations and local/regional actors (BMVEL 2004b: 8f).

\section{Some general practices}

Most of the relevant funding programmes for integrated rural development like REGIONEN AKTIV or LEADER (as well as the whole CAP) are based on multi-level coordination in form of more or less complicated and intensive systems of incentives given by higher state levels and self-coordination on the regional state levels. The emergence of more bottom-up initiatives has been observed as a consequence of place-based policies (OECD 2006: 18).

In the empirical practice the significance of different levels involved in IRD policies is being discussed. While EU, national and sub-national authorities are perceived as programme and fund provider, regional levels are attributed a 'highly significant informal role' for the successful implementation of policies. This notion is being counteracted by the fact that IRD regions in most cases are no administrative units. Yet, without proper and innovative regions, programme provider could not achieve satisfactory results through their programmes. Hence, regions play a crucial role in implementing policies, while programme providers should facilitate the process through innovative programmes (Augustin 2006c, Interview). In recent times the EU has taken up many IRD features in its rural development policy (see subsequent chapters). Such concentration of competences should also be reflected in the financial equipment of the respective level and its programmes. This, however, does not hold true for empirical reality (Thomas 2006, Interview).

Another aspect currently discussed with regard to MLC deals with responsibilities of different administrational levels in the field of rural development policy. According to the subsidiarity principle responsibility for all policy fields not mentioned by the German constitutional law lies within the provinces. Constitutionally, the federal government has competencies regarding agricultural structures and in promoting agricultural and forestry production. ${ }^{8}$ However, concerning rural development not such competency can be deduced except for rural development measures closely related to agricultural structures in a wide sense (Delbrück 2006, Interview; Vogelgesang 2006, Interview). Yet, the federal state plays a certain role in rural development policy as will be shown in the subsequent case studies. The engagement of the national level throughout the case studies has been observed to cause tensions relating to the aforementioned issue.

Parallel structures have been reported as a shortcoming of recent IRD activities. Firstly, various bottomup initiatives, many of which are based on the IRD philosophy, manifest in rural regions paralleling and even duplicating each other. This was observed to overextend regional actors and lead to deficits in programme efficiency. 'Too many levels are doing exactly the same things' was perceived as being one reason for these deficits, assigning most of the responsibility to the coordination of multiple levels (Delbrück 2006, Interview; Spöring 2006, Interview; Hemmerling 2006, Interview). In addition to parallel

8 Article 91GG through the GAK, see chapter IV; Article 74, 17GG 
structures among different bottom-up initiatives, such arrangements compete with existing governance institutions at county and municipal level and their relation remains 'undefined and not well thought-out' (Spöring 2006, Interview; Hemmerling 2006, Interview).

\subsubsection{Accountable Expertise (AE)}

From the BMVEL's point of view external moderators and consultants are valuable in contributing external expertise to rural development processes. Other kinds of external expertise come into play with the evaluation of the development process. External evaluations by independent public or private bodies as well as accompanying scientific research form the kind of expertise, which is called for in this context. One of the rationales provided by the ministry is the perception, that an outsiders' view can provide new solutions that are not visible to those too intensely involved in the process (BMVEL 2005: 8, 38f).

However, also internal expertise, i.e. expert knowledge which is evolving in the course of the development process in the regions is being acknowledged in the IRD philosophy. As an example internal evaluations are recognised as expertise supporting cyclic planning processes and self-reflexivity of various actors and procedures. Likewise, Regional management is associated with a high degree of genuine expertise regarding communication and coordination skills in the region-specific context (BMVEL 2005: 22f). Thus, a high priority which is being given to internal, local or evolving expertise is reflected in the following citation: "With all due respect to the elected local structures, the development initiative must maintain its creative independence, while policy-makers and administration contribute their administrative professionalism and support to the process." Such statements make clear that in IRD a diversity of expertise is called for (BMVEL 2005:11).

NGO claims concerning AE do not go beyond a call for the establishment and funding of regional management personnel (Agrarbündnis 2002: 7f).

\section{Some general practices}

For studying the practice of $A E$ in the IRD philosophy empirical evidence is scarce. The aforementioned BMELV conferences on a "white book" in 2004 and on "the future of rural areas" in 2006, where experts have been invited to jointly discuss new approaches to rural development, build the basis for the analysis. At the former conference the circle of experts represented science, churches, county administration, Ministry for Infrastructure and Traffic and agriculture. As compared to former federal conferences this circle has been widened (Stöppler 2006, Interview; Observation 2006a). However, a renaissance of the role of agriculture for rural development coincides with the absence of environmental NGOs from the panel (Observation 2006a). Two different types of expertise have been invited to the conference: a) more theoretically grounded, political experts as well as b) experts from practice (Eberlein 2006, Interview). The selection of experts has been politically driven in order to signal a wide approach to the issue of rural development policy (Stöppler 2006, Interview; Eberlein 2006, Interview).

The aforementioned selection of experts certainly mixes up a bit the distinction between experts and political representatives. Genuine expertise in the IRD philosophy seems to stem from two origins: a) from science and b) from private consultancies. The latter are perceived as scientifically grounded and provide for a 'link between science and practice' (Augustin 2006c, Interview; Seibert 2006, Interview). Such expertise would be mobilised in situations where 'own expertise or capacities do not suffice' for achieving a given goal. Experts were rarely consulted for technical problems, but rather for process oriented advice (Augustin 2006c, Interview). 
The selection of expertise seems to undergo a five-phase process: (Augustin 2006c, Interview)

- Clarity about ones own goals and aims which are to be achieved with the assistance of experts

- $\quad$ Checking technical skills of different experts (e.g. University degrees, prior experiences with expert, experiences of others with the expert. Here trust comes into play as one's own judgement is based on ones other's experience.

- $\quad$ By intuition checking for trust (do I trust this expert?), which may be a result of prior experiences and of knowing the expert for a longer period of time, etc.

- Checking for compatibility of different experts with own ideas, aims, values, etc. The motives of an expert for doing the job may shed light on his engagement for and compatibility with one's own ideas. Usually, experts would be selected from a 'web of people who are perceived to having skills in rural development or segments of it. This web has been built up over time.'

- Checking for alignment of expert selection with regulations in place (e.g. rules for tendering)

This process may be run through successfully or may be terminated after each phase. Since phases IIV seem to lie within one's own discretion and alternatives may be at hand easily through the 'web of people', phase $\mathrm{V}$ is perceived to in a way hinder appropriate expert selection (Augustin 2006c, Interview; Swoboda 2006, Interview).

Another motive of the BMELV for the use of scientific expertise can be to get external legitimacy for its own political position. Expertise serves here as a source for the justification of own policy goals or strategies. ${ }^{9}$ In the foreword for a new book on regional governance and integrated rural development (Böcher/Krott/Tränkner 2007) the BMELV asks for a strengthening of the integrated rural development philosophy within the German agricultural policy by explicitly referring to the OECD as external expert body as well as to similar suggestions from the German scientific advisory council of the BMELV (Augustin 2007, Wissenschaftliche Beirat für Agrarpolitk beim BMELV 2006).

\subsubsection{Adaptive and Iterative Planning (AIP)}

Integrated rural development is supposed to manifest in so-called integrated regional development concepts or strategies. The process of actors' formation, continuous negotiation and mutual learning also beyond the design of a strategy is a central feature in IRD promoting adaptive planning. This approach replaces central mid- and long-term planning by public authorities.

'Evaluation is a fundamental part of the whole picture!' Evaluation as an integral part of IRD also largely contributes to the iterative nature of integrated rural development processes. The recognition of internal as well as external evaluation and monitoring even reflects a more thorough approach to adaptive and reflexive processes. With internal self-evaluation exercises for example, continuous monitoring of ones' own performance can be provided, whilst enhancing the analytical skills of actors involved. This approach in IRD opens up interesting questions and provides linkages concerning the evolution of something like regionally accountable expertise or process-specific accountability.

$9 \quad$ Such a function of expertise for policy actors in controverse policy discourses has been well described by Boehmer-

Christiansen (1995) or Pregernig (2007). See also the input paper on AE (Böcher/Kvarda/Pregernig 2005) 
Evaluations are called for being 'a process that accompanies step by step the policy decision-making process and the programme's implementation life.' Ex-ante evaluations are perceived to inform policy makers on region specific needs, potentials and most promising fields for investment. Also, ex-ante evaluations may facilitate the emergence of local knowledge. Ex-post as well as self-evaluations are seen as ways to 'test adopted development strategies and to be ready to re-address them(...)'. They should allow policy makers to also set some 'fuzzy objective' to be adapted later to modifiable contexts (OECD 2006: 148).

One of WWF's principles for a sustainable rural development calls for adaptability of rural development approaches by ensuring continuous monitoring and systematic and accompanying evaluation (WWF 2003: 5). Before this background, WWF calls for the inclusion of inter alia the principle of evaluation into rural development policies (WWF 2002a: 37; 2002b: 3). Other authors emphasise the importance of continuous exchange among the actors involved in development processes and between different regions. Such exchange would contribute to the self-reflexivity of actors and, thus, facilitate cyclic planning (Agrarbündnis 2002: 9). Finally, the concluding declaration of the rural development conference held in Berlin in 2004 states that progress made in rural development policies would need continuous feedback for constant improvement of the programmes. Consequently, a meaningful monitoring and both, self- as well as external evaluations are called for (BMVEL 2004b: 9).

\section{Some general practices}

A key challenge for policy makers in addressing AIP or evaluations is to 'identify indicators which fairly picture the impacts of policies when cause and effect are not always identifiable and where results may appear only in the medium to long term' (OECD 2006: 18). The use of evaluation results in feeding them back into the process was easier when decision-makers were independent from other actors in programme design (Augustin 2006, Interview). In addition, reporting, if required by respective IRD programmes, plays a key role for AIP. As far as these are available, they are used to further develop the programme. Mid-term reports were perceives as having the highest value in this regard, as they were at hand just in time, when programme adaptations are on the agenda. Thus, as regards programme development final reports were of little value (Augustin 2006, Interview; Swoboda 2006, Interview). The relative influence of reports must, however, be also been seen critically. Personal conversations and the appraisal of e.g. colleagues, combatants, etc. may even exceed the influence of reporting (Augustin 2006, Interview). Supporting for AIP would also be the work of the regional management. If it focused merely on the implementation of plans and agreed projects, rather than actively accompanying the process, little contributions to AIP may be expected. However, if regional management drives the process in light of continuous improvement, this may result in high AIP (Thomas 2006, Interview). The institutional frame for actors, such as working climate, the boss' attitude towards innovations, etc. are also perceived as having an effect on the adaptiveness of processes (Augustin 2006, Interview). Lastly, a notorious focus on projects instead of considering the overall strategy was perceived as hindering AIP (Augustin 2006, Interview). 


\section{The LEADER+ Case Study - EU Community Initiative for rural development}

\subsection{Introduction to LEADER+}

Since 1991 the European Union (EU) has been implementing new territorial approaches to rural development in a pilot program called LEADER. The name stands for 'Liaison entre actions pour le développement économique rural'. After the completion of LEADER and LEADER II the Council of the European Union in 1999 agreed on a reform of the Common Agricultural Policy (CAP), as part of which four Community Initiatives were launched in policy fields of special interest with respect to Agenda21 commitments. Hence, the LEADER initiative was continued under the name LEADER+ to support and advance rural development policies in the European Union for the EU programming period of 2000 to 2006 (Deutsche Vernetzungsstelle LEADER+ 1999a).

In the programming period from 2000-2006 LEADER+ was financed with Euro 2000 million, of which approx. Euro 250 million have been transferred to Germany (Deutsche Vernetzungsstelle LEADER+ 1999a). The EU initiative has been supporting local project groups in 148 rural regions in Germany, aiming to realise innovative pilot strategies for sustainable regional development since 2000 . However, LEADER+ has neither been designed as an instrument for replacing investments in agriculture, nor to achieve policy goals by the allocation of enormous financial resources (actually, the financial means of LEADER+ have just been app. $1 \%$ of the whole European Union's structural funds in this funding period). It must rather be seen as a pilot program aiming at the development and demonstration of innovative approaches to rural development which then might become part of the mainstream policies for rural development (Deutsche Vernetzungsstelle LEADER+ 1999a).

Being well established as a European Community Initiative the LEADER+ approach develops locally managed, so-called 'bottom-up' rural development projects across the EU. LEADER+ projects have developed across the EU in a variety of well-defined local areas. Currently there exist 893 LEADER+Regions in 15 European countries. The approach is characterised by high levels of local stakeholder and community involvement, by partnership and cooperation, and by the encouragement of innovative approaches to rural development (Land Use Policy Group 2005).

The LEADER approach stands for a mode of governance. The term epitomises the combined and synergetic implementation of the so-called seven LEADER features: ${ }^{10}$

- Area-based local development strategies related to well-identified sub-regional rural territories ${ }^{11}$

- Local public-private partnerships called Local Action Groups (LAGs) by which decentralised management and financing are realised

- A bottom-up approach with decision making powers for LAGs in the development and implementation of local development strategies

10 Council of the European Union (2005) c.f. Land Use Policy Group (2005); Hahne (2004); ÖIR (2004)

11 Sub-regional means for Germany rural regions below the federal states' level 
- Multi-sectoral design and implementation of the strategy involving actors and projects from different sectors of the local economy

- Implementation of innovative approaches

- Implementation of (trans-national) cooperation projects

- Networking of local partnerships

These features have evolved and developed over time from Leader I to LEADER+. Figure 4 exemplarily illustrates how the features are represented in the different Leader programmes and other policies considered under this report.

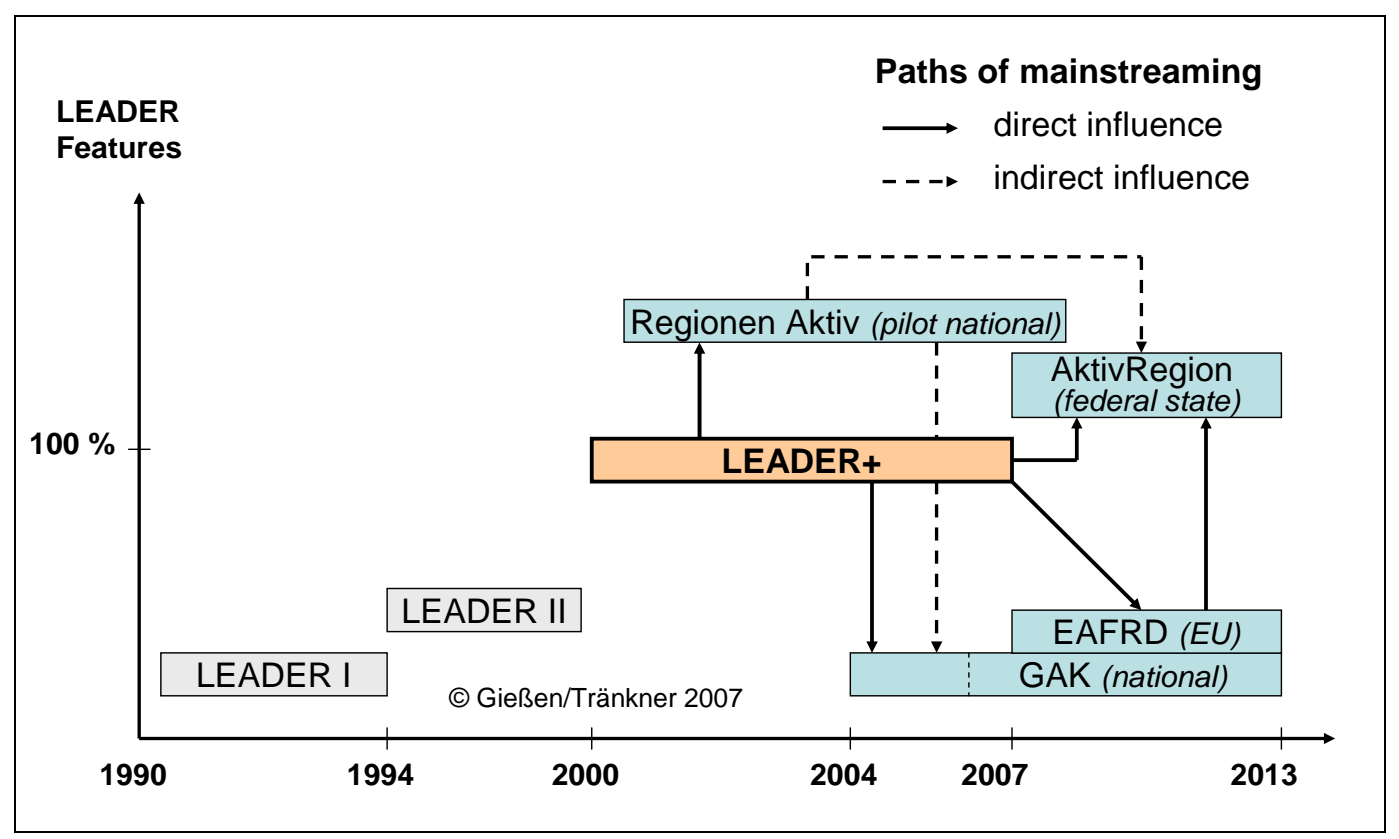

Figure 4: $\quad$ Exemplary representation of the Leader features in different IRD funding programmes

Source: $\quad$ Tränkner and Giessen (2007).

The funding programme through its guidelines establishes a thorough governance system throughout all territorial levels. At EU level the Commission provides for funding and framework regulation. A European Observatory facilitates cross-national cooperation and networking activities between all involved 15 countries. At national levels so-called National Network Units (NNU) are the counterparts of the Observatory. In the German federal context the federal states (the LAENDER) are supposed to elaborate Operational Programmes based on the Commission guidelines, further elaborating the Leader approach under the specific federal states' conditions. LEADER+ coordinators may also be funded at provincial level for facilitating cooperation and exchange with the regions. At regional level LEADER+ builds upon Local Action Groups (LAGs). Within the overall framework LAGs are the central feature of LEADER+. In the regions these public private partnerships can be seen as the central decision-making body concerning all LEADER+-related decisions. According to the EU Commission's LEADER+ guidelines LAGs are supposed to be established representing all relevant regional actors and their 
interests. These groups should be open to all citizens and representatives of different organised interest groups (farmers, Nature conservationists, Tourism, Handicraft, enterprises, social groups, etc.). Actors representing the regional or local government and administration may make up to 50\% of the LAG members. A wide range of competencies has been attributed to the LAGs. For example, this partnership is supposed to formulate a homogenous regional development strategy (so-called Regional Development Concept). According to the guidelines of such a genuine regional development strategy, LAGs develop and select regional development projects for EU funding (EU Commission 2000; Böcher 2005:11). In addition to the LAGs LEADER+ also provides for "regional management". So-called regional management facilities (Leader-Managers) are the organisational core assisting LAGs and facilitating their work (Figure 5). The Leader+ programme is therefore highly oriented to modern concepts of endogenous rural development which are based on a combination of network steering, the guideline functions of regional development concepts and the work of a regional management as steering actor (on the role of regional management see e.g. Benz/Fürst/Kilper/Rehfeld 2000).

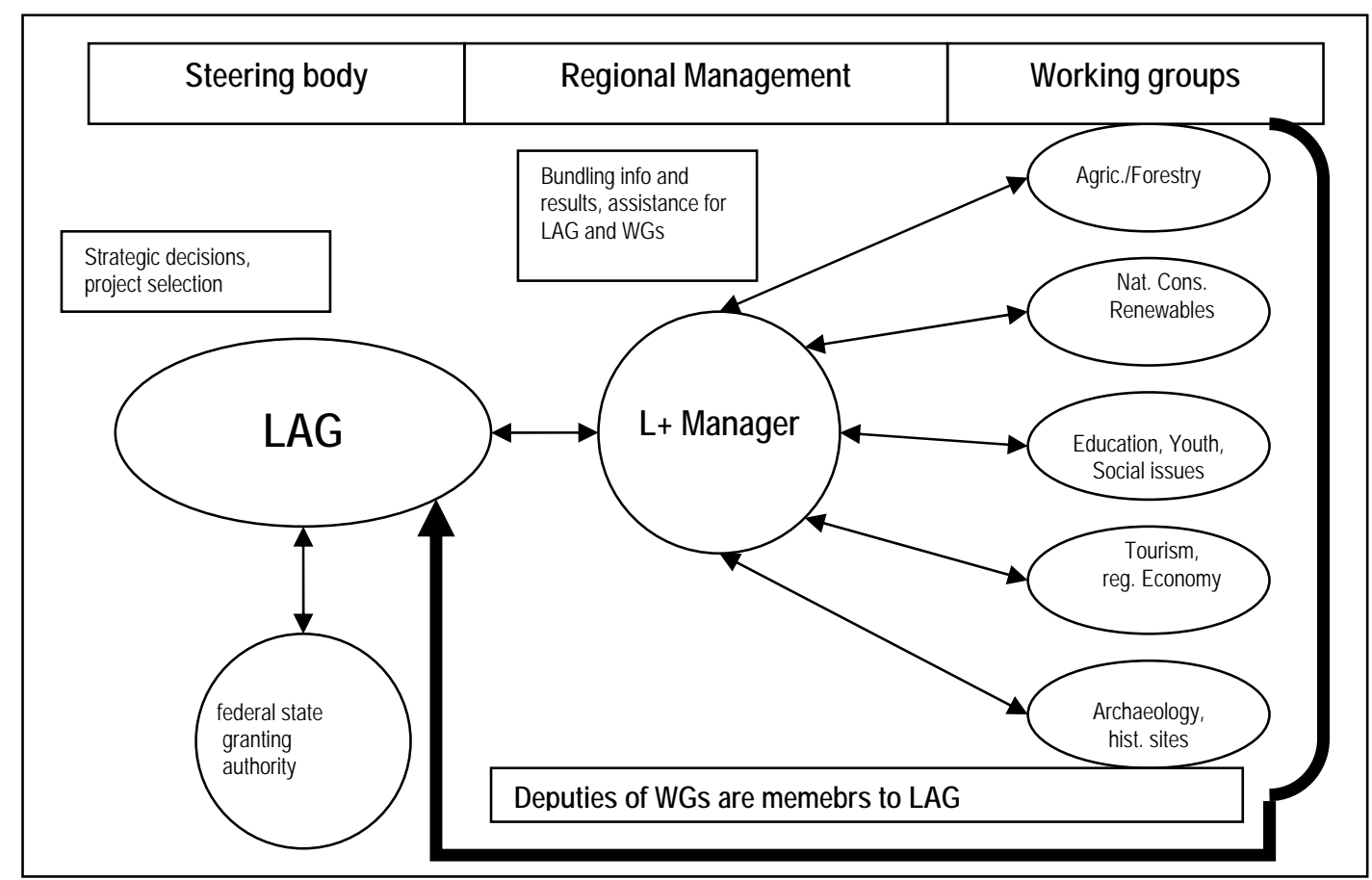

Figure 5: Exemplary design of regional LEADER+ processes 


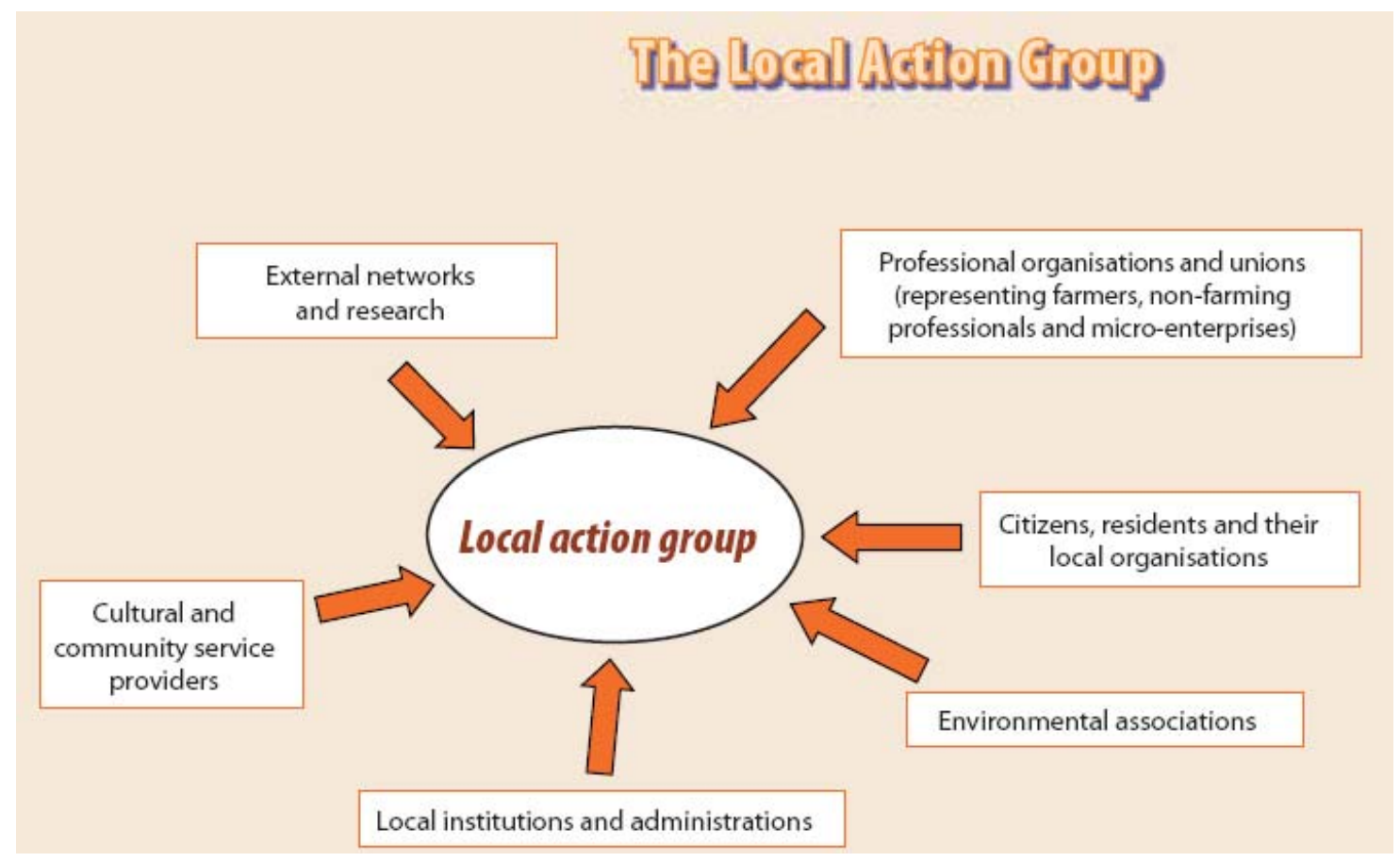

Figure 6: Exemplary composition of LAGs

Source: $\quad$ EC (2006: 12)

\section{$5.2 \quad$ Context factors}

The general decline of agriculture's contribution to rural employment and value-added again serves as an explanation for the governance process at hand. Economically speaking the allocation of funds within the CAP is enormous. A shift in spending patterns from traditional agricultural investments and subsidies towards more integrated approaches, such as IRD can be observed at EU level due to e.g. WTO negotiations and trade liberalisation (Delbrück 2006, Interview). This shift may have facilitated the evolution of the LEADER approach. Likewise one could ague, that the LEADER experiences eased the shift of financial spending. Certainly, however the good experiences under LEADER I and II led to the improvement and continuation of the approach under LEADER+ .

For quite some time now the debate on agricultural policy in general has been demonstrating a strong effect on rural development policy concepts. This is caused by the far reaching structural changes in rural areas, and by the fact that the challenges of the modern state manifest themselves very strongly in rural regions: The reduced importance of agriculture as central source of income especially in highly developed countries like Germany has caused an increased unemployment rate in many rural areas, followed by a migration of the younger and more highly educated part of the population. The role of agriculture is shifting from the mere production of food to multifunctionality including nature conservation and cultural functions (Knickel 2002). Under these conditions smaller agricultural holdings have no chance of securing their existence 'only' with the production of food. Rural areas therefore have to make use of other potentials for development, e.g. their recreational value for the urban population or the natural beauty of their region as touristy value. The discussion also focuses on the demand for sustainable regional development, which harmonizes the ecological functions of a region with the economic and social needs of the population (Bergmann 2000).

Scandals or catastrophes (such as mad-cow as well as hove-and-mouth disease have caused a change in the public demand of quality standards for agricultural products and put a stronger competitive 
pressure on agriculture. They also led to a more sensitive and consumer-oriented policy approach to agriculture as being only one among multiple target groups for financial assistance. This trend is reflected in the LEADER+ programme. Likewise, international trade liberalisation and pressure from WTO for limiting EU agricultural assistance to trade-neutral measures facilitated the LEADER+ programme as a programme testing such modulation (Delbrück 2006, Interview).

\subsection{Governance practices under LEADER+}

\subsubsection{Participation}

\section{Rhetoric}

As mentioned earlier a participatory approach at the regional and local level is a core part of the IRD philosophy and hence it is a core element of the LEADER+ programme. As regards the rhetoric of participation as a constituting element, the EU Commission in a publicity paper on EU rural development policies states that LEADER I marked the beginning of a new approach to rural development policy, which is "territorially based, integrated and participative" (EU Commission 2003:14). Subsequently, LEADER II further elaborated the participatory nature of the LEADER method by applying a far-reaching bottom-up approach. LEADER+ is supposed to maintain this successful approach to participation through safeguarding and guaranteeing that the local citizens and actors are being involved into rural development efforts (Deutsche Vernetzungsstelle LEADER+ 1999a). Consequently, the LEADER tradition and good experiences since 1991 in applying a participatory approach can be seen as one rationale for participation. Even though the two forerunner programmes have not been as sophisticates regarding participation, they are a necessary prerequisite for understanding the process at hand.

The EU Commission's guidelines for LEADER+ call for "cooperation in the broad sense of the term" and "quality partnership" between the various actors as fundamental components of the Community initiative (EU Commission 2000: 6). The document further suggests that the rural development strategies to be elaborated and implemented in the course of the LEADER+ process could be assessed in terms of inter alia "original forms of organisation and involvement of the local population in the decision-making process and in implementing the project" (EU Commission 2000: 8). The Federal Ministry of Consumer Protection, Food and Agriculture (BMVEL) in cooperation with leading environmental NGOs proposes to apply a bottom-up approach and hereby ensuring a broad and well organised participation of individuals and local groups. However, the authors acknowledge that achieving this must be seen as a major challenge (BMVEL et al. 2002). Likewise, BMVEL as one of the core strengths of LEADER+ mentions the involvement and mobilisation of local actors such as relevant private sector-, civil society- and public administration representatives as well as individuals (Deutsche Vernetzungsstelle LEADER+ 1999a). This is where the EU Commission identifies the strengths of the initiative. LEADER+ in many ways is seen to epitomise the EU's approach to rural development policy as it "involves [...] a bottom-up approach with rural stakeholders designing rural development measures, at local level, that best suit their requirements" (EU Commission 2003: 15). Hence, the assumption that participatory approaches better suit local and regional requirements and thus may address problems in partnership in a more effective and efficient manner is one rationale for their use. The German NNU gives other reasons for participation, based on the advantages associated with such an approach. The authors state that "acceptance" for policy measures was higher, if actors concerned with the policy issue were directly involved. In addition a minor rationale for participation may be seen in the free labour which results from voluntary work and contributions by different stakeholders (DVS unknown b). 


\section{Practice}

\section{Central bodies for institutionalised participation}

The EU Commission's guidelines on LEADER+ are the central and binding legal basis for participation in the process under study. At the EU level the guidelines necessitate a steering committee, chaired by the Commission. It meets twice a year in Brussels, and is made up of representatives from the Leader+ Observatory, the Managing Authorities from the different federal states, and National Network Units from the different Member States. It monitors the implementation of the Community Initiative and may amend the programme if necessary. The LEADER+ guidelines further require the establishment of a monitoring committee for each programme under the initiative (i.e. for each of the federal states implementing LEADER+); its composition and role must be defined and will be subject to subsequent inquiry (EU Commission 2000: 8). Within the Committee the different representatives have the opportunity to negotiate with the EC in a more informal and quite influential manner (Swoboda 2006, Interview).

According to the EU Commission a distinctive as well as mandatory feature of LEADER+ is the implementation of integrated development concepts for rural areas, drawn up and implemented by broad-based local partnerships, called Local Action Groups (LAGs) (EU Commission 2003: 14). In order to be supported under LEADER+, such groups are required to organise the local development process by common planning, implementation and evaluation of a rural development concept (Deutsche Vernetzungsstelle LEADER+ 1999b:2). It is crucial to point out that according to the EU guidelines LAGs must consist of a balanced and representative selection of partners drawn from the different socioeconomic sectors in the territory concerned. At the decision-making level the economic and social partners (non-state actors) must make up at least $50 \%$ of the local partnership (EU Commission 2000: 7; Deutsche Vernetzungsstelle LEADER+1999a, b:2).

The LEADER+ guidelines further oblige the members of a LAG to demonstrate that they are able to devise and implement a development strategy for the territory in partnership. The members of the LAG shall be locally based and must either select an administrative and financial leader with the ability to administer public funds or, come together in a legally-constituted common structure (EU Commission 2000: 7). Hence, participation processes are required to be institutionalised to a certain degree. In most of the cases it can be observed that LAGs comprise private, civic and official actors and are legally constituted as e.g. associations, charities or private companies (Deutsche Vernetzungsstelle LEADER+ 1999b:2). The EU Commission may be interpreted as the original initiator of the participatory processes under LEADER+. To deliver an impression of the "typical" constitution of a local action group Table 5 shows the members of the LAG "Rügen", a German island in the Baltic Sea, and their affiliations. 
Table 5: Exemplary constitution of a Local Action Group under LEADER+, the example of the LAG "Rügen" (Federal State of Mecklenburg-Western Pomerania)

\begin{tabular}{|l|l|}
\hline Institution & Name \\
\hline District's farmers association & Mr Püschel \\
\hline "Rügenprodukt e.V." Marketing association & Mr Rock \\
\hline Tourism association & Dr Gelshorn \\
\hline District's Handicraft association & Mr Ambrosat \\
\hline District administration & Ms Kassner \\
\hline Sparkasse (mutual savings bank) & Mr Reimers \\
\hline Regional clubs & Mr Weiß \\
\hline Federal employment office & Ms Meyer-Heßmann \\
\hline Social, Youth, and Churches & Ms Dost \\
& Mr Kordes \\
\hline National Park Office & Mr Hartmann \\
\hline Nature Conservation Associations & Ms Hartmann \\
\hline Regional public transport & Mr Lamp \\
\hline Forest economics & Mr Däumler \\
\hline Arts and Culture & Mr Klötzer \\
\hline Cities and municipalities association & Ms Burmester \\
\hline
\end{tabular}

\section{Participants and non-participants}

Empirical data suggests that LEADER+ processes are mainly driven and managed by representatives of collective actors, rather than by non-organised individuals or citizens respectively (Vogelgesang 2006, Interview). Environmental-NGOs as well as public agencies in general seem to be well represented in most regional processes (Güthler 2006, Interview; Swoboda 2006, Interview). Private or corporate actors, however, are perceived to be less represented in most LAGs. ${ }^{12}$ This especially holds true for farmers and forestry actors (Ortner 2004; Hemmerling 2006, Interview; Schubert 2006, Interview). Farmers may become active as individuals or under the umbrella of the regional farmer associations (e.g. Kreisbauernverband KBV), rural women's associations (Landfrauenverbände), etc. However, the highly influential German Farmers' Association (DBV) has been reluctant to actively participate in the Leader programme ever since the programme offered funds for integrated rural development activities in 1991. Some individual farmers may be engaged in LAG work and LEADER+ projects in specific regions, especially if they are representing alternative forms of farming, e.g. organic farming. The political representative (DBV) of the farmers, however, stated that the association as well as their members have never been excited about LEADER+ and merely played a restraining role in LEADER+ (Hemmerling 2006, Interview). The same holds true for forestry actors. While in many regional processes state forest administration is represented by the regional forest agency, political representatives so far have been passive in participating in LEADER+ (Seeling 2006, Interview). The

12 In a subsequent chapter and under the analysis of REGIONEN AKTIV this weakness of private enterprise representation will be referred to as ,structural exclusion'. The term does not imply a purposeful exclusion, but draws on programmatic characteristics of the funding scheme, which are not suitable for firms and companies. 
empirical material indicates that programmatic qualities of a more technical character are the reason for such groups not to participate. The programme's rather progressive aims and objectives are given as one reason for more traditional farmers not to feel addressed by LEADER+ (Schubert 2006, Interview) as well as LEADER+ does not represent strong sectoral funding policy for agriculture and delivers just a relatively small funding amount in the eyes of the organised farmer's association. The Leader approach in addition is perceived to be far from economic demands, as it is not measure-oriented, but rather focused on common regional strategies and embedded projects. Under LEADER+ a lot of effort would be made at the meta-level of cooperation and networking. Private firms (such as e.g. farmers and foresters) would not see the direct benefit of such work (Hemmerling 2006, Interview). Hence, such cooperative IRD-processes, which are triggered by funding programmes, are a challenge for private sector actors. The design of LEADER+ in this regard may be interpreted as a mechanism of accidental but systematic exclusion of private actors (Schubert 2006, Interview; Hemmerling 2006, Interview).

For the different actor groups various "hidden interests" may be cited for their (non-) participation in LEADER+ activities. The more traditional farmers and DBV may want to obstruct all different processes, by which financial resources especially at EU level are transferred from the $1^{\text {st }}$ to the $2^{\text {nd }}$ pillar of the CAP, which emphasises integrated approaches to support agriculture and also other beneficiaries (Seeling 2006, Interview). E-NGOs may strive for ways of gaining influence through "new" public policies, in order to position themselves and offer cooperation with other actors (Güthler 2006, Interview). Public agencies, especially at the regional and local level, may have an interest in acquiring public funds from outside their budgets. They may also fear the loss of competencies due to an increasing informality of regional bottom-up processes (DVS unknown b). Such "hidden interests", however, are based on empirical indications rather than solid evidence.

\section{Patterns of participation in the policy cycle}

In order to be supported under LEADER+, LAGs are required to organise the local development process by common planning, implementation and evaluation of the rural development concept (Deutsche Vernetzungsstelle LEADER+ 1999b: 2). Hence, a continuous involvement of the relevant LAG-actors throughout the process can be assumed. In practice, however, participation in such groups does not appear in linear forms though naturally, all LAG have general meetings at regular intervals. Often consultation with few central actors at the phase of process initiation (actor formation to propose a new LAG to the EU, best described as actor formation and agenda setting) is followed by a phase of broad participation for generating visions, ideas and projects (formulation). Implementation of the common strategies and projects, however, was observed to be dealt with in smaller groups of engaged actors again. The underlying logic of such patterns was described as follows: In times where capacity to act is crucial, more "narrow forms of participation" will emerge (Swoboda 2006, Interview).

\section{Supporting and impeding factors}

The necessity (EU guidelines) of establishing LAGs as participatory groups in the LEADER+ process is the central feature supporting participation. Likewise, the empowerment of LAGs to decide upon public funds encourages participation. Especially for NGOs it is a novel having decision-making powers in publicly funded policy measures (Walter 2006, Interview).

The administrational structure for LEADER+ within the federal states differs significantly. Since regional co-financing shares under LEADER+ in the Western part of Germany in general are higher (50\%) than in the Eastern federal states (25\%) due to their classification in objective 1 areas, the administrational design tends to be more sophisticated and de-centralised. I.e. that LEADER+ authorisation agency in 
western federal states are located at lower levels, while in the Eastern part they tend to be more centralised. Empirical results indicate that social as well as physical vicinity to public agencies seems to ease participation and mutual understanding (Hinrichs 2006, Interview; Swoboda 2006, Interview). Hence, a centralised design of LEADER+ administration may impede participation.

Communal agencies and administration in some instances are perceived to be reluctant to cooperate with LEADER+ initiatives. Power struggles and questions of which actors and/or administrations are responsible for special issues are presented as potential reasons for ignoring the bottom-up initiatives . (DVS unknown b) Böcher (Böcher 2007: 382) gives another reason: In general, EU funds as LEADER+ have to be co-financed from state funds. Concerning these principles, conflicts in regional and local politics can be observed: On the one hand, local politicians are interested in bringing EU financial support to the region through co-financing. On the other hand, they fear a loss of decision control of democratically legitimated organs in the distribution of funds due to the aforementioned LAG structure. They see their power endangered from two sides: from the EU, which, with LEADER+, is forming new institutions and which can bind budget funds, but on the other hand from the LAG themselves, who can take important decisions even against elected politicians and the local administration. As a consequence, non-cooperative behaviour may be a result of these aspects.

In reality spatial overlaps exist between various regional bottom-up initiatives such as LEADER+, local Agenda21 processes, REGIONEN AKTIV groups, and the like. Such thematic overlap often also brings overlap in actors and representatives who engage in a process. Such overlap, interpreted as 'experience of the actor', may of cause facilitate participation and mutual understanding. It may, however, also constrain participation in that the 'usual suspects' are perceived as the only relevant stakeholders, or at least are the ones who have information about certain processes. It may lead to established and to a certain degree institutionalised regional networks which are not much open for new actors or new ideas (Böcher 2008). Other stakeholders may be passively excluded by such practice. In addition, the emergence of ever more regional processes initiated through different political programmes of different ministries and state-levels with slightly different emphases, which can be observed in German current regional policy may also lead to excessive demands of especially the honorary actors as well as an increasing difficulty to coordinate different policies for rural areas (policy coordination problems) (Spöring 2006, Interview).

In general excessive demands have been reported as a major challenge at the LAG level where the work of honorary people is essential to the LEADER+ process. Such demands may simply be a result of lacking financial reimbursements for materials or time dedicated to the process. Excessive demands, as observed under LEADER+ may also be a result of bureaucratic and administrational requirements set be the EU, which are usually carried out by the volunteers themselves. Finally, heavy work loads as result of budgetary constraints for honoraries were reported to lead to excessive demands as well. As an observed consequence, such volunteers opted out from the respective LAGs and withdraw their engagement in the process (DVS unknown b). A problem connected with this is that honorary people are not able to overview all legal constraints resulting from LEADER+ especially if volunteers are involved in concrete LEADER+ projects. Here, more training activities are often demanded by LEADER groups for their members. ${ }^{13}$

13 Interviews with different actors in the LAG Isenhagener Land, Lower-Saxony. 


\subsubsection{Inter-sectoral coordination}

\section{Rhetoric}

According to the EU Commission LEADER I marked the beginning of a new approach (in 1991) to rural development policy, "which is territorially based, integrated and participative". The term integrated describes a shift from mere sectoral perspectives to more holistic and inter-connected approaches to development policy (EU Commission 2003: 14). Among various actors (BMELV and leading eNGOs in a joint paper on LEADER+) it is common sense that individual sectoral approaches to rural development are not capable of adequately addressing the complex problems of rural regions. Hence, under LEADER+ they call for coordinated and collaborative planning and action for safeguarding dynamic development in rural areas (BMVEL et al. 2002: 10). BMELV concludes that a central strength of the LEADER approach lies within its capability to bring together different sectors. In conducting crosssectoral planning and implementation of the development strategy synergies and potentials for development could be realised, which formerly have been undiscovered (Deutsche Vernetzungsstelle LEADER+ 1999a).

Cooperation and inter-sectoral planning amongst e.g. agriculture and forestry as the sectors primarily managing lands and sectors such as trade, craft, and tourism are called for in order to stimulate regional development and to exhaust synergetic effects (BMVEL et al. 2002: 11). The sectors referred to are agriculture, forestry, trade, craft and tourism. However, no attempt has been made to provide complete lists of sectors, which may cooperate in LEADER+. This again depends on the regional context to be examined later. Instead of further elaborating the interaction between sectors the guidelines demand the strategies "in all cases [...to] demonstrate that it is not just a collection of projects or a mere juxtaposition of sectoral measures (EU Commission 2000: 8).

\section{Practice}

$\underline{\text { ISC only at regional level }}$

Within the LEADER+ method the LAGs as well as the rural development strategies are the core features for the realisation of ISC. In accordance with the LEADER+ guidelines the "development strategy proposed by the LAGs in their development plans must be integrated, in the sense that it adopts a global approach based on the interaction between actors, sectors and projects" (EU Commission 2000: 8).

With respect to evaluation of the success of LEADER+ as regards links and cooperation across sectors, the guidelines suggest to assess "the combination of and links between economic sectors which are traditionally separate" (EU Commission 2000: 8).

Sector definition was observed to be based on two different schemes: On the one hand actors referred to 'public', 'private' and 'civil society' as sectors. On the other hand the guidelines as well as all other sources avoid even giving a rough definition of 'sectors' and 'ISC'. The most suitable programmatic statement in this matter calls for 'links between economic sectors which are traditionally separate.' As regards sector delineation the few explicit programmatic statements do not suffice to make any judgement. It seems that the statements refer to implicit or commonly acknowledged sector boundaries. However, it can be assumed that actors cooperating in LAGs and LEADER+ processes for a common vision on rural development in fact share similar believes or stakes. Eventually the overall endeavour of integrated rural development provides for an own boundary of an 'inter-sectoral community'. The design of German ministries and subordinate departments within ministries, usually along 'traditional' sector 
boundaries, may represent such sector boundaries, which have the potential of constraining ISC (Schubert 2006, Interview).

The issue of ISC is high on the LEADER+ agenda, both in the framework documents' requirements and in day-to-day processes of the LAGs, whose task it is to integrate various sectoral perspectives into a strategy. The latter, however, are responsible for actually implementing IS activities, while the EU merely sets the standards with little own effort of ISC (Swoboda 2006, Interview). ISC-outcomes should appear at the local level in each of the LAGs. Each partnership is supposed to develop a genuine strategy of integrating various sectors based on the region's conditions and requirements. The inability of large administrations, such as national and provincial governments and the EU Commission to cooperate among 'sectors' (ministries or departments) is perceived to be the reason for obliging the regional actors to engage in ISC (Schubert 2006, Interview). Consequently, the EU took the lead by requiring an inter-sectoral approach in its funding regime. However, it did it at a relatively low degree of own costs. In regional contexts different actors may have taken the lead.

The material indicates that ISC not only is an issue of including different sectors, but also to pay attention to the actors representing the sectors. Strong parallels could be found to the element of participation. ISC at the LAG level was perceived also as an issue of power relations, individual preferences and reluctance to change (Swoboda 2006, Interview). Hence, under LEADER+ sector exclusion parallels the exclusion of actors under Participation. As empirical findings show, private sector actors and especially forestry as well as agriculture do not actively participate in LEADER+ processes. Programmatic reasons, especially at the federal states' level are perceived to narrow the ISC potential and seem to obstruct farmers' participation, which may also apply to forestry actors (Seeling 2006, Interview). However, forestry actors carefully judge whether to engage in LEADER+ processes and besides programmatic obstacles have their own reasons not to participate (Giessen et al. 2006; Schubert 2006, Interview).

\section{Dynamics of ISC}

As elaborated under P13, LEADER+ processes are characterised by a rather narrow approach to collective action, followed by more open phases of consultation. This pattern also applies to different intensities of ISC at the different stages of the process. Under LEADER+ inter-sectoral coordination is explicitly called for in the programmatic statements. Under the funding programme ISC is also backed with financial support and manifests in LAGs and their respective joint development strategies. The degree, to which comprehensive ISC is being realised, however, depends on the specific conditions. ISC should not be exercised for its own sake, but must benefit all actors/sectors involved; the aim is to build up win-win situations (BMELV 2005a; Hemmerling 2006, Interview, Schubert 2006, Interview). The dynamics of ISC in the governance context of LEADER+ are closely related to participation dynamics. Such patterns show stages of intense coordination among a variety of interests, followed by phases of focussing. Assuming LEADER I and II as points of reference, we can observe an increase of the role of ISC. While under LEADER I single development projects have been conducted, LEADER II focused on the inter-linkage of such projects within a target region. Not until LEADER+ ISC has been addressed explicitly and supported by one of the central instruments, namely the common development strategy, where the inter-sectoral character of the regional approach should be grounded. In addition, LEADER+ also requires projects to be inter-sectoral. Hence, ISC actions at the programmatic level over time increased significantly and became more sophisticated (Hahne 2004: 199).

As the LAGs and their development strategies are the central component for both, participation and ISC, the findings under 'Participation' also apply for ISC. Non-state interests within the LAG shall make up at least $50 \%$ at the decision-making level. Hence, a quite substantive contribution to ISC of non-state 
actors can be deduced from this requirement. This feature has been in place ever since LEADER+ started. Assuming LEADER I and II as points of reference, we can observe an increase of the role of civic actors (Hahne 2004, 199). Thus, a clear linkage and positive correlation between ISC and Participation could be shown.

In its LEADER+ guidelines the EU Commission prescribes an inter-sectoral approach to rural development and requires LAGs and integrated development strategies as instruments for coordinating different actors from various sectors. Hence, ISC standards to be realised at the local or regional level have been set at the international level. The task of actually coordinating different sectors, however, has been assigned to the regions, consciously leaving out the sub-national level. Empirical material indicates that at the sub-national level, through e.g. the federal states' operational programmes, ISC in some cases even has been constrained (Güthler 2006, Interview). Also, at the national as well as the sub-national level authorities were unable to address ISC issues within their institutional frames and hence dispersed the task to the regional level, where less institutional and traditional sector boundaries constrained ISC (Schubert 2006, Interview). This trend of devolution of ISC tasks to the local level can be observed over the LEADER programming periods from 1991 onwards (Hahne 2004: 199). A problem within the ISC concept of integrated rural development in general might be that the sectors which are forced to cooperate on the sub-national and regional level are still represented by highly sectoral administrational bodies and ministries - the state's organisation is still sectoral so it is still demanding to coordinate the different sectors on the superior levels of the state.

\subsubsection{Multi-level coordination}

Besides the already existing public administrations at different levels, the EU Commission with its LEADER+ programme established a thorough system of MLC analogous to the general European Union's system of multi-level governance. This includes public administrations as well as the European observatory, national networking units in each Member State and LAGs. These actions have also to be seen as a result of the overall constituting partnership principle of the EU structural funds policy which has been reformed in 1999 and of which LEADER+ is one part (Benz/Eberlein 1999). According to the authors the principle is characterized by 4 central attributes:

1. It aims at implementing an integrative approach to policy-making by improving co-ordination of different Structural Funds.

2. It is supposed to improve vertical intergovernmental co-ordination and partnership with regional actors. Grants to selected regions are allocated on the basis of development plans and operational programmes, which are to be elaborated on the national and regional levels and have to be integrated into the Commission's Community Support Framework.

3. All projects to be supported by the EU need to be co-financed by national or regional governments. EU regional policy can be characterized as a system of joint finance linking budgetary policies of different levels of government.

4. Finally, regional administrations are requested to include public and private actors in the decision-making process in order to achieve broad support for policy goals and comprehensive information on development potential." (Benz/Eberlein 1999: 335.

\section{Rhetoric}

The EU Commission in its guidelines on LEADER+ articulates the need for and rationale of MLC as follows: For rural areas "developing their specific resources in an integrated approach that forms part of 
a territorial strategy which is tailored to the local context seems increasingly to be the route that will have to be taken if rural areas are to create and maintain competitive and sustainable products and services. [...] Such an approach will become more effective, however, if it forms part of a Community policy and national and regional policies which are able to provide the framework, tools and impetus necessary for ensuring that the rural areas, and the people who live in them, are in a position to grasp development opportunities and translate them into practice using appropriate resources and arrangements" (EU Commission 2000: 6). The assumption that the involvement of EU, national and regional policies were most effective in terms of rural development can be seen as the central argument for an active approach to MLC. The levels referred to are Community, national, sub-national and regional, with the latter being defined by the regional actors themselves after a constituting process within LAGs.

\section{Practice}

Under LEADER+ only EU, sub-national and local levels are actively involved in the process which refers to the general partnership principle of the EU (see Figure 7). While the EU Commission sets out framework standards in its guidelines, these shall be further elaborated in so-called operational programmes, which in Germany have been elaborated by 13 federal states. The programmes define an administrational structure and appoint authorisation agencies at the appropriate level (e.g. at federal state or district level), which shall guarantee the alignment of LEADER+ measures with EU and other relevant regulations. Based on the operational programmes LAG were supposed to apply for funding.

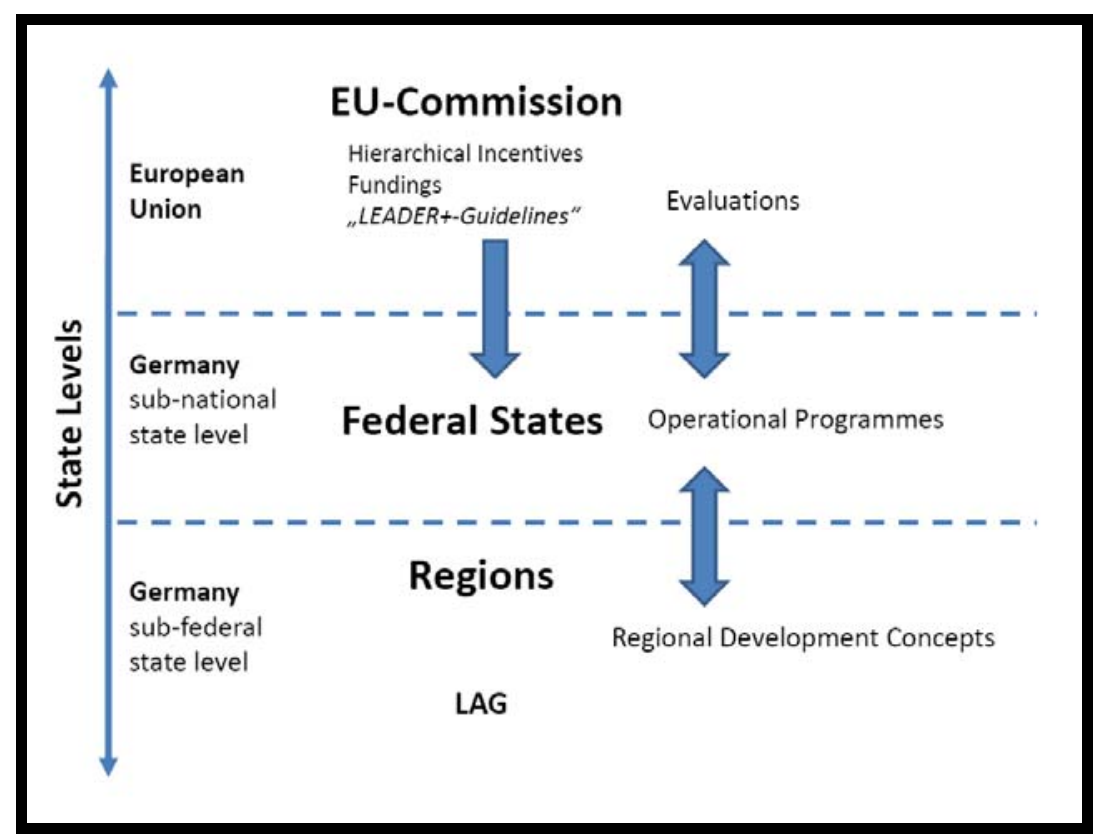

Figure 7: Multi-level coordination under the EU Community Initiative LEADER+

The EU's approach for LEADER+ of providing a framework legislation which focuses on minimum requirements and core topics is a central feature of MLC in the context of LEADER+. As an example, the LEADER+ guidelines propose four fields of action to be further elaborated by the sub-national operational programmes (EU Commoission 2000: 8; Deutsche Vernetzungsstelle LEADER+ 1999b):

- the use of new know-how and new technologies 
- improving the quality of life in rural areas,

- $\quad$ adding value to local products

- making the best use of natural and cultural resources

This ensures a maximum of partnership and subsidiary local adaptation of the initiative. Additionally the LEADER+ Observatory serves as facilitating organisation regarding MLC, networking and provision of information in all EU languages (Swoboda 2006, Interview). At the sub-national level operational programmes are supposed to fill the framework regulation according to specific conditions of the different federal states. Also LEADER+ coordinators may be eligible under LEADER+ at the provincial level, facilitating cooperation and networking. They also serve as mediator between the LAGs and the provincial authorities in some federal states (EU Commission 2000: 11; Plätzer 2006, Interview). LAGs are to be established at the regional level with a minimum of 10.000 and not more than 100.000 inhabitants per region (average about 70.000) (Schubert 2006, Interview; Augustin 2006a, Interview). The programme aims at promoting collective action at this very level.

At the national level the LEADER+ guidelines establish the so-called National Network Units (NNU, Germany: www.leaderplus.de). They play a crucial role in addressing MLC. They coordinate between the different regions and facilitate the exchange of experiences across regions and federal states' borders. It furthermore serves as a training institution and provider for information and services related to LEADER+ (Swoboda 2006, Interview). As mentioned earlier networking among rural areas within the EU is a vital component of LEADER+. Inter-territorial exchange of experiences, transfer of know-how and information exchange and dissemination from national levels to the LAGs are considered vital in replacing central steering bodies and detailed procedural rules. Hence, the NNU plays an active role in the MLC under LEADER+ as well (EU Commission 2000: 9; EU Commission 2003: 15). The national government, however, plays a less important role than e.g. the federal states' level. It merely represents the federal states' positions and interests at EU level and supervises the NNU (Swoboda 2006, Interview); its role can be neglected.

Formally, competencies among the different levels involved in LEADER+ is characterised by subsidiarity. The EU lines out a framework legislation leaving as many competencies at the regional level as possible, whilst setting central minimum requirements. Reducing the role of intermediate authorities (here the national level) can be seen an innovation of the LEADER approach. Even though overlaps can be identified a more or less clear distinction can be made with regard to different levels' competencies at different stages of the policy cycle. Whilst the EU-level is more involved in the overall design phase, the federal states' level is important to further elaborate and formulate the programme reflecting their specific situation. Regional actors are put in charge for the implementation. Monitoring and evaluation have been required by the framework regulation, but are addressed at the regional level and have to be organised and commissioned by the federal states. The principle of EU co-financing of eligible measures under LEADER+ also illustrates the rules and competencies among levels. As mentioned above, EU through structural funds' resources finances up to $50 \%$ of eligible measures in Western and up to $75 \%$ in Eastern federal states as Objective 1 areas. The co-financing shares of 50\% and $25 \%$ respectively have to be covered by either the federal states, the districts or the municipalities (Deutsche Vernetzungsstelle LEADER+ 1999b).

Except for the LAGs all actors playing a central role in MLC, namely the NNU, the European Observatory, EU Commission, the Federal Ministry of Agriculture and the responsible Federal states ministries can be characterised as state actors or at least as 'closely related' to public authorities. For LAGs no such general statement can be made. No deductions can be made with regard to informal roles and interests of MLC. 
The LEADER+ approach to MLC led to an increase in actors concerned with this issue. Fist, the establishment of the Observatory with about 40 employees under LEADER II at EU level put a strong emphasis on the issue. In 2004 there was an open invitation to tender for the Observatory again. Actually about 7-8 staff members work on aforementioned MLC issues (Swoboda 2006, Interview). Consequently, the matter of MLC has lost momentum. Secondly, NNUs present 'new' actors concerned with MLC. Their work is currently highly valued and in Germany the NNU will be expanded for coordinating all rural development processes in the future (BMELV 2006). Thirdly, some federal states employ so-called LEADER+ coordinators at provincial level as an intermediate level between the NNU and the LAGs, also facilitating MLC. A fourth component illustrating the increasing range of actors can be seen in the involvement of the regional level (LAGs) in inter-level networking and learning. The institutions of NNUs, provincial LEADER+ coordinators and the European Observatory are direct results of the LEADER+ initiative and have been established to support inter alia MLC.

The EU plays a prominent role in promoting, supporting and requiring networking activities among different levels. The actual work associated with MLC remains a task of the NNUs and the Observatory. No actor could be identified impeding MLC.

The system of EU framework legislation implies certain legal competencies, procedures and level interdependencies among all levels involved. However, LEADER+ aims at reaching the regional level more or less directly from the EU level, with as little interference at intermediate levels as possible. Direct interdependence only occurs between the EU level and the federal states, and between the federal states and the regions (LAGs) respectively. The national level, as regards formal interdependencies, does not play a major role.

The mode of interaction between the different levels concerned varies between hierarchy and competition. Certainly among the EU and national and sub-national level hierarchical modes and implications prevail. This manifests in the LEADER+ guidelines as well as the operational programmes. However, the LEADER+ approach employed a competitive mode during the selection process of single LAGs for LEADER+ funding, where the operational programmes shall elaborate selection criteria for funding the most promising strategies (EU Commission 2000: 10). Hence, competition triggers the LEADER+ process in the respective federal states. The logic of interaction within the work of the NNU and the Observatory can be assumed to be based on negotiation, if legal provisions do not narrow alternatives.

\section{Problems with MLC}

Empirical results suggest that the EU framework guidelines in some instances may have been too strict or too concrete for an adequate implementation of the programme. For instance the maximum number of 100.000 inhabitants per 'region' as stated in the LEADER+ guidelines, led to problems in the design of regions. It was observed that during the formation phase certain areas, communes or the like have been actively kept out of the process in order to comply with the maximum numbers. Even if for historical of geographic reasons certain areas were perceived as integral parts of a region, people stated 'we can not take them on-board - we will not get funding if we do not comply' (Schubert 2006, Interview; Augustin 2006a, Interview). A new policy paper of the accompanying research team under REGIONEN AKTIV suggests that - to stimulate flexible strategies of region-building - not any prescription of maximum numbers of inhabitants should be made by the EU in future rural development policies (Team der Begleitforschung Regionen Aktiv 2006). 
Operational programmes in the different federal states under LEADER+ in Germany amount to 13. This diversity of programmes and respective experiences constrain the vertical as well as the horizontal exchange.

Although the decision competency over the eligibility of projects lies formally within the competencies of the LAG, provincial authorities have often the last say in whether financial resources are being allocated for respective projects (Güthler 2006, Interview; Schubert 2006, Interview, Böcher 2008). The MLC design of involving and even empowering regions shows deficits in the design of operational programmes and may obstruct innovations as well as the bottom-up approach.

Another shortcoming of some operational programmes seems to be a focus on more traditional rural development measures. Some regulations seem to narrow eligible measures under the programme to the standard EU mainstream measures (Güthler 2006, Interview; Hemmerling 2006, Interview).

By applying a competition approach to funding policy the EU with the LEADER+ programme introduced a completely new paradigm into German rural development policy. This may have caused problems (Augustin 2006c, Interview). However, the approach has been reinforced by REGIONEN AKTIV and hence emergent problems may be observed there.

\subsubsection{Accountable expertise}

\section{Rhetoric}

With regard to AE only few programmatic statements could be identified in the field of LEADER+. It is acknowledged that in complex situations, such as rural development processes under LEADER+, require inter alia a competent management, good public relations and sophisticated networking abilities. Such features describe the kind of expertise which is necessary for a successful management of locally driven rural development processes. However, this statement does not refer to a single kind of expertise. It rather calls for all actors involved to contribute such expertise (BMVEL et al. 2002: 13). The LEADER+ guidelines as well as the guidelines for LEADER+ evaluations call for the use of expertise for conducting ex-ante, mid-term and ex-post evaluations (EU Commission 2002:28). The former further establish the European Observatory as well NNUs as expert bodies with thematic foci. However, no link could be identified at the rhetorical level as regards the accountability of expertise.

\section{Practice}

Concerning the use of expertise the LEADER+ programme establishes a thorough system of expert involvement at all territorial levels and allows for many additional ways for further integrating expertise into the overall and regional processes.

\section{A system for expert involvement}

At the EU level the Observatory is led by the EU Commission, which contracted out all assignments of the Observatory to external consultants. Their main services are publishing experiences e.g. in a journal, promoting trans-national cooperation and offering training courses (EU Commission 2000: 12; Swoboda 2006, Interview). The NNUs are the Observatory's national counterparts. However, the assignment has not been contracted to external experts, but has been integrated into a federal agency (Bundesanstalt für Ernährung und Landwirtschaft) and is being supervised by BMELV (BMELV 2005b: 6; Walter 2006, Interview). Both institutions on the one hand deliver expert advice and services (e.g. 
training courses and seminars, moderation of LAG cooperation, translation and interpretation services, etc) and hence are actively involved in the process as experts. On the other hand, they may consult external experts, if the expertise required can not be delivered by the organisation (Swoboda 2006, Interview). This feature hence has not been set up by the EU and should be considered under b). Lastly, the EU requires a sophisticated system of external evaluations, through which expertise enters into the process. Detailed guidelines exist for the mandatory ex-ante, mid-term and ex-post evaluations. These require evaluators to be "independent [...] from bodies without direct involvement in the implementation, management and financing of the programmes." Such experts should be "aware of the state-of-the-art evaluation practice" and have expertise in the field of rural or local development issues. The latter includes knowledge of participatory methods and bottom-up approach evaluation (EU Commission 2002: 28). The guidelines necessitate the use of external expertise for conducting evaluations. For external evaluations impartial, independent and experienced evaluators fulfil the prerequisites of a suitable (accountable?) expert.

\section{Additional ways for integrating expertise}

The EU through its funding programme under each LAG established LEADER+ Managements, usually 1-2 staff per region. The LEADER+ guidelines further require LAGs to "demonstrate the transferability of the proposed methods. The promoters of the project must make what they learn about methodology and the results they achieve available to the network" (EU Commission 2000: 8). Hence project promoters are perceived as experts on this very project issue. Managers and other experienced regional actors may be considered as experts in two ways. Firstly, they posses competent management, good public relations and sophisticated networking skills. However, such qualities are a necessary prerequisite and day-to-day business and will not be further considered as special kind of expertise. Secondly, individual regional managers or project leaders quite often are consulted by the NNU for contributing their expertise in a certain issue area to e.g. seminars, workshops or the LEADER+ journal (Swoboda 2006, Interview). The same applies for external expertise, which may be consulted by the NNU as described above or at the regional level. Besides the LEADER+ managers, external moderation and facilitation of LAG work is eligible under LEADER+. The financing of such services is perceived as having 'a very high potential for improving process quality'. However, such services in most LAGs are not valued throughout the process but are only accepted in the initial phases of the process (Plätzer 2006, Interview). Lastly, the facultative self-evaluations are a point of access for expertise. In the processes of self-reflection regional actors may become experts on their specific situations and processes. The eligibility of such exercises under LEADER+ shows an increasing attention towards such expertise. In its guidelines on evaluation the EU Commission points out the possibility of programme authorities to "encourage and assist the LAGs in self-evaluation activities". Even though this matter has not been further elaborated it again indicates that under LEADER+ genuine local and evolving modes of expertise seem to play an increasing role (EU Commission 2002: 29). Additionally, some operational programmes even require self-evaluations from the LAGs (Walter 2006, Interview). Actually, the German NNU organised two workshops for LEADER+ actors concerning self-evaluation methods: the first regarding different methods, the second regarding one special self-evaluation method which had been developed before during the implementation of LEADER+ in 8 regions in cooperation between scientists, a consultant, and the regional managers of the involved regions. ${ }^{14}$ The use of expertise, namely the Federal Research Agency for Agriculture (FAL), also occurred during the programming phase of the operational

14 Information available at DVS' website under:

http://www.leaderplus.de/index.cfm/0008B03D1D33125D97D96521C0A8D816 
programmes at federal states' level. At least three federal states had the FAL designing their respective programmes (Swoboda 2006, Interview).

The different kinds of expertise mentioned above may be characterised in 3 types of expertise:

- $\quad$ inherent expertise which was formally established within the governance process as an integral part of the programme design. I.e. the Observatory, NNUs and external evaluations

- $\quad$ external expertise which may be contracted or consulted from outside the LEADER+ community. I.e. moderation and facilitation services, FAL and other experts.

- $\quad$ evolving expertise as result of the regional learning and reflection processes. I.e. self-evaluations and expertise contributed by LEADER+ managers.

The different sources of expertise are mobilised for quite different types of problems. Assuming a distinction between rather 'technical' and 'procedural/processual' problems clearly expertise under LEADER+ mainly is used for the latter. Technical consultation only occurred in some cases. However, when looking at the use of expertise regarding 'process' and 'content' a more diverse picture results. While external evaluations, the FAL and LEADER+ management have been consulted on content issues, external moderation serves for improving the process quality. Self-evaluations as well as the Observatory and the NNU may be consulted on both types of problems.

Likewise, for the stage of consultation no universal answer may be presented. Regarding the 'stage' of the policy cycle it has to be recalled that different cycles have been passed through at different territorial levels under LEADER+. What at the macro-level is the stage of policy implementation may at a regional level be the whole process from problem ID to evaluation. Table 6 lists different kinds of expertise and its utilisation throughout the policy cycle. 
Table 6: Kinds and types of expertise employed under LEADER+ in Germany

\begin{tabular}{|c|c|c|c|c|c|}
\hline Expert & Expertise delivered ${ }^{15}$ & $\begin{array}{l}\text { Stage at which } \\
\text { employed }\end{array}$ & $\begin{array}{l}\text { Level at which } \\
\text { applied }\end{array}$ & $\begin{array}{l}\text { Type of } \\
\text { expertise }\end{array}$ & $\begin{array}{l}\text { Main } \\
\text { addressees }\end{array}$ \\
\hline FAL & $\begin{array}{ll}\begin{array}{l}\text { Design } \\
\text { programmes }\end{array} & \text { operational } \\
\end{array}$ & Formulation ${ }^{16}$ & Some federal states & External & federal states \\
\hline Moderators & $\begin{array}{l}\begin{array}{l}\text { External } \\
\text { moderation }\end{array} \\
\end{array}$ & Formulation ${ }^{17}$ & LAG & External & LAG \\
\hline $\begin{array}{l}\text { External } \\
\text { experts }\end{array}$ & $\begin{array}{l}\text { Presentation on specific } \\
\text { issue }\end{array}$ & All & National, LAG & External & LAG, Managers \\
\hline \multirow{5}{*}{ NNU } & Information & All & National & Inherent & LAG \\
\hline & Networking, cooperation & All & National & Inherent & LAG \\
\hline & Exchange of expertise & all18 & National & Inherent & LAG \\
\hline & $\begin{array}{l}\text { Moderation transnat. } \\
\text { Coop. }\end{array}$ & Initiation ${ }^{19}$ & Trans-national & Inherent & LAG \\
\hline & Self-evalu tools & all & LAG & Inherent & LAG \\
\hline \multirow{4}{*}{ Observatory } & Information & All & EU & Inherent & LAG \\
\hline & Networking, cooperation & All & & Inherent & LAG \\
\hline & Exchange of expertise & All & & Inherent & LAG \\
\hline & Draw lessons for EC & Evaluation & & Inherent & EC \\
\hline \multirow{3}{*}{ Ext. evaluators } & Ex-ante assessment & Formulation & $\begin{array}{l}\text { EU, national, federal } \\
\text { states }\end{array}$ & Inherent & EC \\
\hline & Mid-term a. & Implementation & $\begin{array}{l}\text { EU, national, federal } \\
\text { states }\end{array}$ & Inherent & EC \\
\hline & Ex-post a. & Evaluation & $\begin{array}{l}\text { EU, national, federal } \\
\text { states }\end{array}$ & Inherent & EC \\
\hline $\begin{array}{l}\text { Regional } \\
\text { Actors }\end{array}$ & $\begin{array}{l}\text { Self-evaluation } \\
\text { Self-reflection and } \\
\text { assessment }\end{array}$ & All & LAG, national & Evolving & LAG \\
\hline Reg. Manager & Experience shared & all & national & Evolving & LAG \\
\hline
\end{tabular}

The question of expert selection may only be relevant for external moderators and evaluators as well as for the role of FAL and others, since other kinds of expertise are already in place. FAL may often be observed in assisting federal states' authorities. The high degree of expertise as well as its affiliation with the public administrational system may explain its selection in the instance at hand. External moderators and evaluators are selected according to the specific requirements, but must be based on an open invitation to tender. ${ }^{20}$ The NNU for instance seeks experts primarily through universities. However, this does not result in using scientific expertise only. Rather besides science private consultants or LEADER+ manager are subsequently hired as experts (Swoboda 2006, Interview). For making expert selection easier for regional actors the NNU has set up a searchable online expert

15 Based on information derived from interviews, may deviate from programmatic or actual expert services.

16 Swoboda 2006, Interview

17 Plätzer (2006), Interview

18 EU Commission (2000: 10)

19 Swoboda (2006), Interview

20 Schubert (2006), Interview 
database where private consultants present their skills relating to regional development tasks. This platform may be interpreted as a pre-decision tool regarding expert selection. However, it can neither be estimated if the tool is used frequently nor if the tool represents an adequate number of experts since experts have to register themselves for the database - there has been no systematic inquiry which lead to the database.

The addressees or potential users of the evaluations are manifold. The EU Commission needs documentation of its programmes. Policy makers at EU, national and sub-national levels use the expert knowledge to further improve future policies (Jäger 2006, Interview). But also local actors can benefit from the outside perspectives in a process of self-reflexivity. Finally, the results of the evaluations as a form of expertise, are supposed to feed into the public debate on how to address rural development issues in respective policies. (see Table 2). Besides public administrations LAGs are the main addressees of expertise under LEADER+. Moderation services were perceived to have great impact regarding the process quality and output. Moderated working groups and LAGs had ,the potential to generate something new and sustainable ... and facilitate discovering common potentials for collective action'. 'Still, many LAGs fight external advice tooth and nail and stew in their own grease, refusing the evolution of innovations' (Plätzer 2006, Interview).

Expertise in the form of suitable evaluators seems to be recognised by the central actor, namely the EU Commission, as being accountable. However, features such as "evolving, genuine or local expertise" as referred to earlier, more and more seems be recognised as AE as well. In conjunction with the rhetoric statement on abilities necessary for regional actors and development processes one can conclude that much of the required expertise is supposed to be "produced" in the regions and in processes themselves. This genuine kind of "evolving expertise" may show a high degree of transparency and credibility at local level and hence be perceived as accountable. Contrary to these observations and assumptions the LEADER+ guidelines establish a "monitoring committee for each programme under the initiative; its composition and role must be defined". In addition, a "steering committee chaired by the Commission and comprising representatives of the administrations and the national and regional networks" will be set up (EU Commission 2000: 11). The establishment of monitoring and steering bodies has implications for the utilisation of expertise. However, in this case accountability seems to stem from the official status of the bodies' members (predominantly representatives from public agencies). This finding must be seen in contrast to the aforementioned observation as regards genuine forms of expertise under LEADER+.

Under LEADER+ all evaluations must be carried out by experts 'independent [...] from bodies without direct involvement in the implementation, management and financing of the programmes' (EU Commission 2002: 28). Evaluation document shall be made publicly available upon request (EU Commission 1999: 33). Also evaluation procedures are transparent as requirements set by the EU are also available to the public.

The use of expertise in IRD can be best described as increasing. Under LEADER+ the use of expertise seems to be at a peak, reinforcing this trend. However, a tendency towards complementing scientific expertise by other kinds of knowing can be observed.

A trend of pluralisation on the demand side can be observed under LEADER+. Lower levels and nonstate actors increasingly become addressees of such advice. Subsequently, we may identify a pluralisation on the supply side, where former 'addressees' in the new sense (LAG member or managers) now are requested to share their expertise. 


\subsubsection{Adaptive and Iterative planning}

\section{Rhetoric}

LEADER+ as an EU funded programme has been conducted in accordance with EU planning and programming periods, which call for seven year periods of programme duration (EU Commission 1999b: 4). LEADER+ is operational since 2000 until the end of 2006. Measures under LEADER+, e.g. the work and support of the LAGs, are eligible during this time-span only. Besides the basic functioning of EU planning and programming mentioned above, the evaluation strategy of the EU represents a formal/legal requirement for general evaluation, i.e. IP. Furthermore, the LEADER+ guidelines necessitate additional, more programme-specific assessments and evaluations (EU Commission 2000: 8; EU Commission 2002: 9). The guidelines further require a competition approach in selecting regions eligible under the programme. Operational programmes must contain procedures which are ,transparent and guarantee satisfactory competition between the LAGs' (EU Commission 2000:10).

\section{Practice}

The LEADER+ initiative has evolved from two preceding programmes, namely LEADER I and II. As an argument for the further development of LEADER II the former EU Commissioner for agriculture, Fischler stated: 'We do not have to re-invent the wheel, proven remedy should be continued (... such as) the more than successful implementation of LEADER' (Fischler, c.f. Schoof 2002). As a consequence, this iterativity caused adaptations of the programmes over time contributing to the improvement of the approach over time (Table 7) (Hahne 2004: 199).

Based on the requirements mentioned under rhetoric we may conclude that LEADER+ as a programme is designed in an iterative manner, allowing for adaptations based upon the recurrent steps of the process. Especially between LEADER II and LEADER+ there are some important changes which can be interpreted as results of iterative planning procedures and learning from former programme periods and evaluations (see Table 3). 
Table 7: $\quad$ Programme adaptations from LEADER II to LEADER+

\begin{tabular}{|l|l|l|}
\hline \multicolumn{2}{|c|}{ Differences between LEADER II and LEADER+ } \\
\hline LEADER II & LEADER+ & Reason for adaptations \\
\hline $\begin{array}{l}\text { Funding is only possible in } \\
\text { objective } 1 \text { and 5b regions }\end{array}$ & Funding is possible in all rural areas & $\begin{array}{l}\text { Reform of the EU's structural funds policy in } 1999 \\
\text { (AGENDA 2000) }\end{array}$ \\
\hline $\begin{array}{l}\text { No competition } \\
\text { Competition between rural regions to get funding, } \\
\text { only the best concepts should be supported }\end{array}$ & $\begin{array}{l}\text { Inefficient funding (shot gun principle" should be } \\
\text { Critical mass of resources should be available for } \\
\text { an individual LAG }\end{array}$ \\
\hline $\begin{array}{l}\text { LAG not obligatory, no } \\
\text { restriction concerning the } \\
\text { proportion of public and private } \\
\text { actors }\end{array}$ & $\begin{array}{l}\text { degree of political and administrative actors within } \\
\text { a LAG is restricted to up to 50\% of the members }\end{array}$ & $\begin{array}{l}\text { Avoidance of too strong top-down structures } \\
\text { Activation of participation and communication } \\
\text { processes }\end{array}$ \\
\hline $\begin{array}{l}\text { LAG just as "friendship of } \\
\text { convenience" possible }\end{array}$ & $\begin{array}{l}\text { Should be avoided since LAG have to formulate an } \\
\text { integrated development strategy in advance and to } \\
\text { build up cooperation }\end{array}$ & $\begin{array}{l}\text { LEADER is not a classic subsidy but an instrument } \\
\text { of promoting strategy development }\end{array}$ \\
\hline $\begin{array}{l}\text { Funding of individual projects } \\
\text { possible }\end{array}$ & $\begin{array}{l}\text { projects can only be funded if they contribute to the } \\
\text { goals of the development concept }\end{array}$ & $\begin{array}{l}\text { LEADER wants to promote long term strategies for } \\
\text { the whole region rather than individual lighthouse } \\
\text { projects }\end{array}$ \\
\hline
\end{tabular}

Source:

EU-Commission (2000), Augustin (1999), Stöhr/Schenk (1997)

EU programming periods of 7 years under the structural funds as an AIP aspect are based on Council Regulation 1260/1999 and hence apply to all programmes under the funds. Competition was required for LAG selection in an initial phase of the operational programmes. The federal states were requested to design and conduct the selection process and come up with selection criteria (EU Commission 2000: 10). Ex-ante, mid-term, updated mid-term and ex-post evaluations are obligatory for all Community structural assistance. Under LEADER+ additional evaluation guidelines describe how evaluations shall be conducted (EU Commission 1999b: 33; EU Commission 2002). Contrary to the aforementioned features, self-evaluations according to the guidelines are neither mandatory, nor must they follow detailed rules (EU Commission 2002: 29). However, they are eligible under LEADER+. External consultants or self-assessment tools provided by the NNU may assist regions in carrying out selfreflexive exercises. ${ }^{21}$ In some federal states, however, self-evaluations have been taken up by the operational programmed and have been made mandatory as well (Walter 2006, Interview). Hence, in some federal states rules concerning self-evaluations exist, while in others regional actors hold all responsibilities including the decision whether to undergo such exercises.

AIP as described above has been initiated almost exclusively by the EU Commission as programme provider. Only in very few instances the federal states necessitate self-evaluations as just one feature of AIP. However, the actual impetus for self-evaluations in federal states where these are not obligatory must come from regional actors themselves. Empirical material indicates that most regions did not make use of these opportunities so far (Plätzer 2006, Interview).

21 Swoboda (2006), Interview; http://www.leaderplus.de/index.cfm/0008B03D1D33125D97D96521C0A8D816 
From an AIP perspective the LEADER+ process is designed into three main stages, which equal the reference periods for the compulsory evaluations. These stages, however, merely exist under the EU evaluation strategy and do not structure the process as such. More important for the structuring of LEADER+ are the different programming levels, where EU framework programming was followed by provincial programming and regional implementation. These steps are interdependent in a linear manner. I.e. the subsequent step may only follow, if the previous one has been completed. Delays in programme implementation have been observed due to this step-wise approach (Hahne 2004: 203).

EU Commission in its guidelines set out 'objectives' of a very general nature. These were then further elaborated into 'goals' in operational programmes. However, each process at regional level sets out own emergent objectives and goals to be met in the regions. In the former cases usually not quantifications have been made and goals are of a rather wide and qualitative nature.

The time frame set for the programming of LEADER+ is 7 years. Competition among LAG intentionally should have lasted throughout the process, but lost momentum after the selection processes (Schubert 2006, Interview). Thus, competition occurred only in punctiform. Mid-term reviews are to be submitted 3 years after publishing the framework regulation (here the LEADER+ guidelines) and 5 years respectively for the update, followed by ex-post evaluations no later than three years after programme completion (EU Commission 1999b: 34, 35). Consequently, evaluations occur at the stages of initiation, implementation and evaluation.

The mandatory evaluations shall serve as basis for preparing plans (ex-ante), show if targets are attained and how financial resources are being used (mid-term) and must examine programme efficiency, effectiveness, impact as well as draw conclusions (ex-post) EU Commission (1999: 34, 35) (EU Commission 1999: 34, 35). Hence, the evaluations almost exclusively focus on results rather than process criteria and are 'not intended to improve LAG processes' (Swoboda 2006, Interview).

The LEADER+ guidelines formally require external evaluations by independent bodies. At the same time the evaluation guidelines point out the possibility of conducting internal self-evaluations to be used in conjunction with the external activities.

LEADER+ evaluations as imposed by the EU make use of a criteria and indicator (C\&l) system. The elaboration of C\&ls besides the common questions used in the EU evaluation strategy is being left to the programme authorities in the Member States (EU Commission 2002: 20).

Evaluations shall focus on impacts and results of the interventions (Figure 8). The European evaluation strategy includes the monitoring and evaluation of "hard facts" such as physical, financial and human resources (EU Commission 2002: 5, 8). Without precluding the evaluation of the impact of LEADER+ in terms of actual realisations for rural development, by encouraging a bottom-up, integrated approach, the Commission wishes to bring up the contributions from all actors involved in the programme up to the European level. Hence, all levels and actors involved shall be potential subjects to evaluation (EU Commission 2002: 8). 


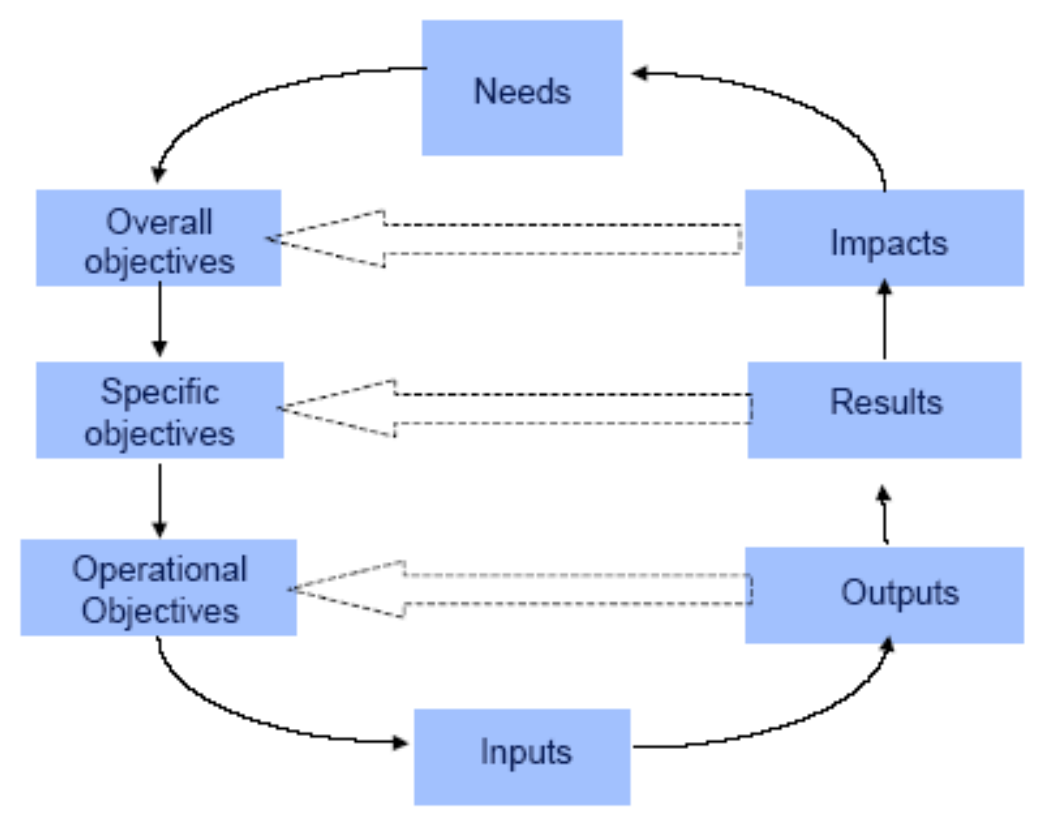

Figure 8: Relations between objectives and impacts in the programming cycle Source: $\quad$ EU Commission (2002)

In general the evaluation results produced under the EU monitoring system are questioned by individual decision-makers regarding their usefulness. In many instances evaluators had chosen 'model cases' which were not representative of the overall situations (Augustin 2006, Interview). The results of the mid-term review were perceived as being not content full, since delays in the programming phase had caused postponements at subordinate levels. Thus, implementation at the stage of mid-term review had not caused many effects yet (Swoboda 2006, Interview). However, the update of the mid-term review has been more appreciated as it was intended to help 'preparing for subsequent assistance operations' (EU Commission 2002: 23; Swoboda 2006, Interview). Ex-post evaluations were recognised as being less helpful for the actual programme, since results were only available some time after programme termination (Walter 2006, Interview). Whether or not and even how the results of the evaluations are fed back into the policy process, both at EU and provincial levels, could not be dealt with here. There is some evidence that evaluations of the former periods of LEADER (LEADER and LEADER II) lead to a change in some important aspects of the programme so that to a certain degree LEADER+ can be understood as a reaction to the experiences of former programme periods (Augustin 1999; EUCommission 2000; Hahne 2004: 199). The mandatory evaluations certainly must be seen as an integral part of the process. Self-evaluations under LEADER+, however, may be characterised as 'add-ons'. Learning effects due to the mandatory evaluations could not be detected. This, however, may not be interpreted in a way that no learning was caused by the evaluations. Still, the rather technical evaluation obligations were perceived as an impeding factor to learning and self-reflexivity. The perception of 'yet another evaluation' could hinder the evolution of a constructive evaluation culture among actors involved (Swoboda 2006, Interview). For self-evaluations a high value-added could be identified as regards learning (Plätzer 2006, Interview). 


\subsection{Effects of LEADER+ as a governance process}

\subsubsection{Impact}

LEADER+ caused a variety of e.g. behavioural changes. First and foremost, however, 'with a small amount of financial resources it changed a lot! The approach may not replace agricultural mainstream funding. But one will not get rid of the idea any more - it is too lively and vigorous' (Schubert 2006, Interview).

The pilot project of LEADER+ increased the visibility and the profile of EU rural development policy for rural actors and even in non-Leader regions is 'quite well known' (Walter 2006, Interview). It changed the attitudes of several regional actors in a way that they 'became cooperative actors' (Swoboda 2006, Interview). The programme furthermore is being actively discussed in the scientific community, nationally and internationally (see e.g. Hahne 2004; Böcher 2005; Ray 2000). And even within the political realm LEADER+ caused actors which traditionally had little in common to jointly research and publish (See e.g. BMELV et al. 2002). BMVEL, in cooperation with leading environmental NGOs, calls for the inclusion of the successful LEADER+ features into national rural development policies, nature conservation and agricultural policy. Such successful components are (BMVEL et al. 2002:14):

- area-based approach with a high degree of local autonomy

- multi-sectoral approaches to development

- participation and mobilisation of local actors

Supported by the LEADER+ programming, actor networks evolved through LAGs and LEADER+ networking efforts. This process is supported by EU observatory which will continue work also past LEADER+ programming (Land Use Policy Group 2005). The formation of such fora of networking can be interpreted as a positive impact on social capital.

The good experiences with the LEADER+ approach encouraged some actors to further engage in IRD activities, such as the federal programme REGIONEN AKTIV (Güthler 2006, Interview; Seibert 2006, Interview). For BMELV the LEADER+ experiences were even the impetus for promoting the idea of IRD within the GAK, finally establishing an new funding principle 'IRD' under the national mainstream policy for rural development (see separate Chapter) (Augustin 2006c, Interview).

However, LEADER+ also caused negative impacts. Due to its experimental character, resulting nonstandardised procedures and the enormous administrational effort associated with LEADER+, the programme was an 'unloved child' within many provincial administrations (Walter 2006, Interview).

\subsubsection{Output}

At the national level the LEADER+ experiences fed into the national strategy for rural development 2007-2013 which has been required by the EU (Reimer 2006; BMELV 2006: 25). As mentioned earlier the LEADER+ experiences led to a revision of the GAK. Here, regional management and development strategies (two IRD instruments successfully applied under LEADER+) have been made eligible under a new funding principle. The instruments have not been completely novel to the programme (Vogelgesang 2006, Interview; Jäger 2006, Interview). Even though the revision may not be tremendous content-wise, it may be seen as a 'significant signal' 'lending the approach a new quality' (Gehrlein 2006, Interview; Jäger 2006, Interview). 
The LEADER+ experiences also to a certain degree caused BMELV to deliver a public funding programme called REGIONEN AKTIV. Frequently referred to as a 'copy of LEADER+' REGIONEN AKTIV builds on many experiences made under the initiative and further elaborated the Leader principles. The standards set by LEADER+ encouraged different actors to develop an even more ambitious programme. 'We successfully implemented what has been intended under LEADER+' (Güthler 2006, Interview; Schubert 2006, Interview; Hinrichs 2006, Interview). Especially LEADER+ experiences concerning participation and self-evaluations (they became mandatory under REGIONEN AKTIV) served as impetus for the initiators of REGIONEN AKTIV (Augustin 2006a, c, Interview).

\subsubsection{Outcomes}

The experiences of LEADER+ had quite far-reaching implications for EU rural development policy. The EC's second Rural Development Conference in Salzburg in November 2003 endorsed the use of the LEADER approach and recommended that it should be integrated or 'mainstreamed' into EU rural development policy to build on its success (Land Use Policy Group 2005: 3). From 2007 onwards the LEADER approach will be 'mainstreamed' as an integral part of the recent "EAFRD Regulation" on rural development programmes 2007-13 developed through the European Agricultural Fund for Rural Development (EAFRD) and delivered through locally agreed local development strategies. To reflect the importance given to the LEADER approach, the EAFRD Regulation states that at least $5 \%$ of co-funded expenditure is reserved for funding through the LEADER approach. ${ }^{22}$ Mainstreaming the approach allows for an area-wide application and the combination of EU rural development measures for achieving synergies, which has not been possible before (Hemmerling 2006, Interview; Augustin 2006c, Interview). However, mainstreaming also had narrowing and hence negative effect. LEADER+ measures were financed by three different structural funds, which allowed for different combinations of activities to be funded (Augustin 2006c, Interview).

As a result of LEADER+ impact in the national strategy for rural development 2007-2013 the NNU will be expended to a 'national network for rural development' accompanied by the employment of more personnel staff (Reimer 2006; BMELV 2006: 25).

Furthermore positive impacts of LEADER+ such as the establishment of new forms of cooperation and participation or support of innovative inter-sectoral development projects are interpreted as result from the special design of LEADER+ and the necessary combination of top-down steering through hierarchical incentives (LEADER+-guidelines, the available funds etc) and self-coordination on the regional level. Participation of local actors under LEADER+ led to self-sustained projects (Walter 2006, Interview).

It seems that LEADER+ is a good example for a successful combination of hierarchical incentives and self-coordination (Böcher 2005: 17).

All relevant actors as well as all documents conclude that the effects achieved under LEADER+ are a result of the Leader approach, which is specified in the introduction. Hence, the bottom-up partnership approach involving various and especially non-state actors (participation) and the inter-sectoral and territorially based (not sector oriented, but focussing on one specific area) character of LEADER+ have been the driving forces behind most effects.

22 Land Use Policy Group (2005: 3); Deutsche Vernetzungsstelle LEADER+ (2005); Reimer (2006). Currently, 1\% of the EU structural funds are spent for LEADER+. 


\subsection{Conclusions on LEADER+ as governance process}

The LEADER+ example shows how IRD ideas have been applied in a rather advanced pilot programme delivered by the EU. On the one hand we found some structural or systematic exclusion of private firms and enterprises and overcharge of honorary actors as weaknesses of the participatory approach taken at the regional level of implementation. On the other hand, the formalised forums for broad participation (LAGs) as a novel have been introduced by LEADER+. Likewise, the requirements and minimum standard of having at least $50 \%$ social and economic partners at the decision-making level of the LAG, is a novel and innovation in rural development policy. At a central level (EU) participation did not play a significant role.

The task of ISC has been observed to be shifted from more central levels (EU, national and even from sub-national) to the regional level, which may be explained by a certain incapability of more centralised levels of appropriately dealing with this issue. This in turn may be a result of the highly institutionalised character of central levels, exemplified through sectoral Directorate Generals and Ministries. The positive correlation between good practices in participation and ISC at the regional level allows us to assess the ISC approach at regional level as innovative.

LEADER+ established a thorough system of MLC, in which the NNUs play a central role. By largely ignoring the national level the EU tried to apply a regionalised approach to rural development. It did so by setting the federal states (which in the understanding of the EU are regions) in charge of formulating operational programmes for LEADER+. Such programmes were found to be a bottleneck for governance practices. They sometimes constrained ISC by narrowing eligible measures, which have been formulated quite generally by the EU, resulting in the re-enforcement of a sectoral strategy. The operational programmes were also observed to constrain the regionalised approach to MLC, which aimed at giving far-reaching responsibilities to the regions, such as content responsibility in strategy and project design as well as financial responsibilities. The latter has been largely avoided by setting some kind of federal states' authorities (rather than regional ones) in charge of administering the funds and granting projects, while the content responsibilities were limited for the same reason. Hence, for the EU's objectives of having a regionalised programme and mobilising endogenous potentials in regions, prominently including the federal states has not been an appropriate strategy.

Expertise was shown to play a very significant and increasing role. Multiple sources and addressees of expertise were observed. We may distinguish between inherent, external and evolving or endogenous expertise used under LEADER+. The latter for the first time in rural development policy plays an explicit role and raises new questions about the concept of accountability (accountable to whose standards? Democratic qualities of social context?). For other sources of expertise the official status of the expert institution was found as being decisive for its accountability.

Several elements contribute to LEADER+ as being an iterative and based on that also a highly adaptive programme. The competition approach combined with recurring programming periods and different mandatory evaluations all contribute to this character. Evaluations however were of a rather technical format, bearing the risk of tiring regional actors and resulting in a mentality of 'oh, yet another evaluation...' The instrument of voluntary self-evaluations may have counterbalanced this development, but has not been applied by regional actors.

As regards the effects we were surprised about the concrete and far-reaching outcomes of the process. LEADER+ seems to have significantly altered the political landscape (mainstream policy and IRD discourse) in regional (very well known also in non-LEADER+ regions) as well as in national and EU contexts. 


\section{The REGIONEN AKTIV Case Study - Federal model and demonstration project}

\subsection{Introduction to REGIONEN AKTIV}

REGIONEN AKTIV - Land gestaltet Zukunft (English translation: 'Active Regions - Shaping rural futures') is a pilot programme initiated by the BMVEL. It aims at contributing to an efficient and goal oriented development of rural areas, based on cooperative problem-solving and regional distribution of decisions and responsibilities (BMVEL 2004a: 8). To a certain degree the programme serves as a model for future improvements of the national GAK policy as well as the EU Common Agricultural Policy (CAP) and more specifically the EU rural development policy (BMVEL 2004A: 13).

In 2001 a competition took place in which 206 German regions applied for REGIONEN AKTIV funding with their visions for a specific strategy of sustainable regional development. These visions contained a "definition" of their region, visionary goals and details of how to establish regional partnerships (BMVEL 2004a: 10). In a second round of the competition, an independent jury chose 33 regions which were invited to prepare regional development concepts (RDC). All regions' visions and their RDC had to be in line with the overall goals as formulated by the BMVEL. Finally in March 200218 regions were chosen and the funding began. Until December 2005, 45 mio. € have been spent on regional management and regional development projects within REGIONEN AKTIV. In 2005 the BMVEL decided to prolongate the programme with different changes until 2007 ('phase II') - in this current second phase especially the building of regional value chains is in the centre of the BMELV's interest. Hence, we are looking at a time frame of six years starting in 2001.

The model project builds upon the following principles (BMVEL 2004a: 12f):

- Competition (among different regions and within a region for funding)

- Regionalisation (decision-making powers as well as financial accountability are shifted to the local actors)

- Integration (of different interests and different sectoral perspectives)

- Partnership (on the regional horizontal level between all relevant actors, on the vertical level between the BMVEL and the regions)

- Know-how and its transfer (continuous mutual learning of actors; learning in policy process through different forms of evaluations and incentives)

- New approach to governance (integration of hierarchical steering, market based incentives and negotiated rules) 


\subsection{Context factors}

\subsubsection{Where REGIONEN AKTIV comes from - The initial context}

The development of REGIONEN AKTIV must also be interpreted against the background of a macropolitical shift in German agricultural policy, known as the abovementioned "Agrarwende" (Agrarian Turnaround). This development in the political culture was triggered after the scandal of "mad-cow disease" and the election of a "social-green" federal government in September 1998, when a more consumer-oriented and ecologically responsible policy was called for (UFZ 2005: 10; Böcher 2005: 8; Güthler 2006, Interview). After mad cow disease became a controversially discussed public issue the red-green government reacted to critics by replacing the social democratic Minister of Agriculture in January 2001 by the green Minister Renate Künast. This can be interpreted as symbolic act of the government for the demonstration of political will to change agricultural policy. For illustrating the 'Agrarwende' as one of the Green party's political flagship issues, Künast needed a 'symbolic project'. REGIONEN AKTIV was initiated in those days and i.e. served this purposes (Güthler 2006, Interview; similar: Vogelgesang 2006, Interview; Observation 2006b).

The evolution of the national pilot programme REGIONEN AKTIV must also be seen and interpreted in the light of the LEADER+ initiative. The EU's area-based, participative and integrated approach to rural development has served as a model for REGIONEN AKTIV. One can, however, distinguish between the desire among REGIONEN AKTIV fathers of a) 'copying' the successful parts of LEADER+ and b) the attempt made to also learn from LEADER + shortcomings and to further develop the Leader method (Schubert 2006, Interview; Güthler 2006, Interview). Hence, the making of REGIONEN AKTIV occurred in the context of experiences made under LEADER+. Contrary, rural development issues traditionally have been dealt with under the GAK regime. Within this framework participatory and inter-sectoral approaches have been largely unknown. BMVEL as the central actor in REGIONEN AKTIV thus acted in the context/ tense environment between the very progressive LEADER+ programme and GAK mainstream policy.

Furthermore, a coalition of actors who prior to REGIONEN AKTIV have already worked with or towards more integrated approaches to agricultural and rural development policy, stimulated the idea of having a federal programme and facilitated its formulation. ${ }^{23}$

Lastly, REGIONEN AKTIV is one concrete project within the German national sustainability strategy, which was announced by the German Federal Government in April 2002 as the first occasion on which German policy has been formulated around the concept of sustainable development. ${ }^{24}$ The strategy focuses on four dimensions: equity across the generations, quality of life, social stability and international responsibility. REGIONEN AKTIV shall demonstrate the practical meaning of the strategy for concrete policy fields, here namely the agricultural policy. Thus, REGIONEN AKTIV must also be interpreted in light of the sustainability strategy as a rather new policy style, showing a consensusoriented anticipatory style of policy making.

23 Such coalition included (based on Güthler, 2006 and 2007, Interviews; possibly list not complete) actors from the organic farming movement, Federal Agency for Nature Conservation (BfN), representatives of the Ministry of Agriculture, Department 525 (BMELV), German Landcare Association (DVL) as well as an eNGOs (NABU) and a private consultant for rural development issues (nova)

24 Bundesregierung 2002 


\subsubsection{The context of major adaptations - Phase II and re-elections in 2005}

In this section we consider the structural changes which came with the election of a new federal government in September 2005 and the 'coincident' extension of REGIONEN AKTIV at that time. In doing so, we intend to explain changes or non-changes in the governance process after significant political transformation. It seems interesting to study the influence a supportive federal government (or rather such a minister) actually has. Since after the past federal elections the present Minister is associated with the conservative party, subsequent developments as regards the follow-up and experiences from REGIONEN AKTIV are highly interesting for studying context factors of governance processes.

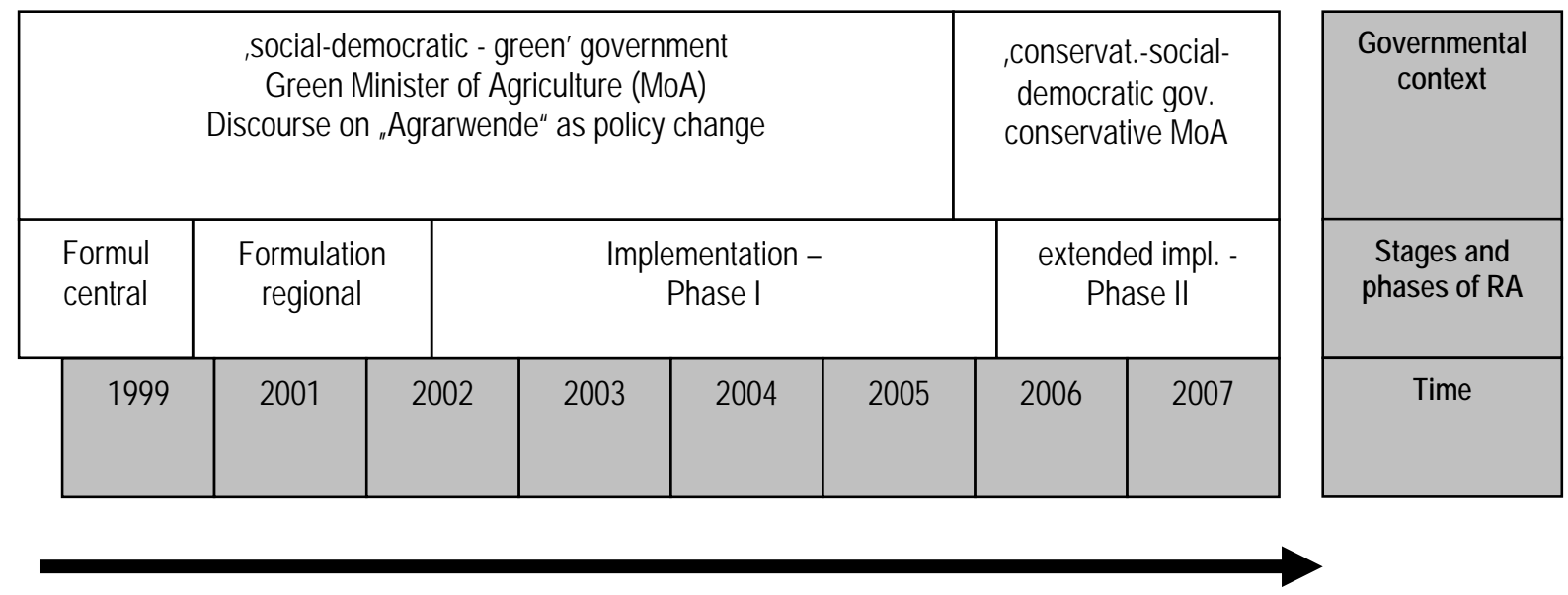

Figure 9: Chronology of REGIONEN AKTIV phases and its governmental context

After the election of a 'conservative-social democratic' government and the resignation of Minister Künast (Green party), the new Minister Seehofer did not reject REGIONEN AKTIV as merely being a 'green programme'. This was due to two reasons. On the one hand, Seehofer seemed to have a personal interest in new approaches to rural development policy. This indication is backed, since it is not common for conservatives endorsing approaches to rural development which discriminate agriculture. Hence, holding up a 'green flagship' which in content also contests conservative convictions would 'require political backbone' (Güthler 2006, Interview; similar: Augustin 2006, Interview, Vogelgesang 2006, Interview; Delbrück 2006, Interview, Hinrichs 2006, Interview). On the other hand, the extension of REGIONEN AKTIV to the period past 2005 had already been strategically decided upon in the last days of Minister Künast. The subsequent conservative Minister did not want to enter into "battle" with the in-house advocates for REGIONEN AKTIV, especially because the positive results of the approach had been too popular and because not much financial resources were bound to the project (Hemmerling 2006, Interview; Hinrichs 2006, Interview). However, the change in government as a context factor resulted in several significant changes (one may argue that the institutional frame was the driving factor here. However, in our opinion the political opportunity structures in this case have mostly been influenced by actor-related factors). Thus, the traditional central role of agriculture in rural development has been reinforced (Observation 2006a, Delbrück 2006, Interview), i.e. through re-inviting the Farmers' Association into the Accompanying Council. Encouraging the participation of the federal states in this very board may also be interpreted as adaptation, which was due to the change in governmental context (Schubert 2006, Interview) and continuous pressure from the federal states, which had to be considered in a way or another for subsequently transferring the lessons and experiences into mainstream policy. Consequently, the programmatic adjustment which occurred under REGIONEN AKTIV may be best 
explained by combination of the institutional context and preferences of individual actors (here: Ministers).

\subsection{Governance practices under REGIONEN AKTIV}

\subsubsection{Participation}

In the relevant documents concerning REGIONEN AKTIV three rationales for participation could be identified: (a)The achievement of integrated, region-specific solutions to complex and diverse problems in rural areas (BMVEL 2004A: 12); (b) since the REGIONEN AKTIV approach empowers local actors to decide upon public funds, a broad participation in relevant decision processes is perceived as lending this practice a certain degree of democratic legitimacy (BMVEL 2004A: 28); (c) REGIONEN AKTIV employs a new approach in rural development policy. This approach as such aims at the mobilisation and encouragement of local people and actor groups in order to exploit the region's potentials and to use synergies (BMVEL 2004A:32).

The area-based, integrated and participatory approach employed by REGIONEN AKTIV to a large degree builds upon ideas, activities and resources contributed by regional actors. In the programme documents such engagement and the manner of interaction among a diverse set of actors (state and non-state) is paraphrased with 'partnership principle'. This principle formally applies to the two territorial levels involved: At the federal level BMELV to a certain degree 'obliged' itself to cooperate with societal actors during programme formulation, namely in the Jury and in the subsequent Accompanying Council' (hereafter Council) (Elbe 2006, 88). At the regional level REGIONEN AKTIV encourages regional actors to collaborate in a PPP called 'Regional Partnerships', where public, private and civic actors deliberatively design the development process. In addition, participation issues gain importance in the context of the programme's initiation, when the partnership principle did not play a prominent role.

\section{Policy-formulation of REGIONEN AKTIV in partnership}

\section{Informal initiation by a 'circle of friends'}

In a rather informal context the initial idea of setting up an integrated federal rural development programme, and also some first programmatic deliberations, have been 'concretely discussed' and decided by a group of allied actors at the federal level (Güthler 2006 and 2007, Interviews). This group has previously been described as a coalition of actors stemming from the organic farming movement, the Federal Agency for Nature Conservation (BfN), representatives of the Ministry of Agriculture, Department 525 (BMELV), German Land care Association (DVL) as well as an eNGOs (NABU) and a private consultant for rural development issues (nova). Interviewees metaphorically described this coalition as 'the obstetricians of the programme' (Güthler 2006, Interview) and 'a circle of friends' (Schubert 2006, Interview). Their intention was to deliberatively design an idea/a programme, under which the successful Leader approach could be employed and even be further developed and improved. The small size and the exclusive character of the group was perceived as 'making perfect sense' as otherwise 'visions will not emerge but will be torn apart' (Güthler 2007, Interview). Also trust among the allies at this stage was perceived as a necessary resource (Güthler 2006, Interview).Thus, through informal consultations and planning processes the idea of REGIONEN AKTIV was born and 
fundamental decisions on programme formulation, such as granting a global budget to the regions as a central instrument, already have been taken. ${ }^{25}$

From a political scientific point of view this "circle of friends" can be interpreted as advocacy-coalition supported by very good windows of opportunity due to a change in the Minister - longer existing ideas could be achieved with support from the green Minister and the underlying discourse of the "Agrarwende".

\section{Jury and Council as formal opportunities for participation}

After this informal phase of agenda setting and programme initiation, the technical programme formulation has mainly been executed by BMELV. However, two substantial options for formal participation of societal groups in formulating REGIONEN AKTIV have been provided by BMELV: 26

Firstly, a Jury has been convened to assist BMELV in the selection of applicant regions to the programme. This board consisted of representatives from a wide range of different actors who in a broad sense were concerned with issues of sustainable rural development (Tränkner 2006: 213; Elbe 2006: 88) (see Table 8). The Jury has been announced as being responsible for a 2-stage selection process of applicant regions (BMVEL 2001: 8f). However, by looking at the decision process at this first participatory phase it becomes obvious, that true decision powers have not been handed over to the societal groups. Firstly, the decisions of the board largely followed preliminary decisions taken by the GS, which was in charge of pre-assessing the application documents (Elbe 2006: 185). Secondly, BMVEL informally added political principles, such as the 'right ratio' between Eastern and Western regions, to the list of pre-defined and objective selection criteria. ${ }^{27}$ Thus, a free selection of regions by independent expert participants, which was based on objective criteria, has been contested by BMVEL's interventions. Lastly, the composition of the Jury has not been very transparent. Only the rules of procedure of the Jury itself gives detailed information on participants, whilst none of the brochures handed out by BMVEL lists the represented organisations in detail.

After the selection phase the Accompanying Council emerged from the Jury and attended its assignments from 03/2002 to 12/2005, accompanying the implementation process of the programme. The number of participants was reduced from 14 to 7 for making or keeping the board operational and able to act under actual programmatic conditions (Güthler 2006, Interview). For Elbe (2006) this reduction in interests represented in the Council strengthened environmental interests and at the same time, weakened the integrated and participatory approach at the formulation level. But the most important negative result seems to be the opportunities foregone as regards dissemination of positive experiences through participants as multipliers (Elbe 2006: 89f). The reduction of participants parallels the increase in responsibilities assigned to the Council. According to its extended rules of procedure the tasks include (BMVEL 2002c; Elbe 2006; 89):

25 On this whole section see Güthler (2006 and 2007), Interviews. We however, cannot estimate the degree to which such preliminary decisions actually have been taken and which actors in detail have been involved.

26 Here the distinction between programme formulation and its implementation becomes blurry and may be contested, especially because some formulation aspects took place continuously and paralleled the implementation process. However, we primarily do not want to study at which stage in the policy cycle such activity occurs, but we want to analyse it as a participatory feature of the programme.

27 Elbe $(2006,185)$; see BMVEL $(2001,17 f)$ on the objective criteria 
- assessment of regions' progress based on the development strategies and the reports compiled by the regions

- granting performance-dependent extra funds

- deciding on changes in regional integrated development strategies

- give general advice to BMVEL

With reference to our interviewees we may say that the tasks especially under the fourth bullet have been vague enough for leaving leeway for interpretations. Hence, we investigated on the tasks and also partly on objectives of this board as perceived by its members, which can be summarised as follows. ${ }^{28}$

- steering the process of implementation, laying down rules of the game

- inclusion of expertise and different points of view into formulation of REGIONEN AKTIV

- reaching higher acceptance

- less steering responsibilities because trust in organisers

- communicating experiences to wider rural development community

- making results comparable

It was interesting to observe that the subjective importance of the Council and of the active participation to it varies between actor groups. While BMELV perceives it as being of 'central importance' into the process (Hinrichs 2006, Interview; Augustin 2006, Interview), members of the inner circle (coalition) assign lower significance to it, because they trust in the organisers (Güthler 2006, Interview).

As mentioned earlier, REGIONEN AKTIV programming period was extended until 12/2007, hence the Council's duties were also extended until 04/2008 (BMVEL 2005a). The timely extension of the board was followed by an opening up or the process for additional participants, namely the Farmers' Association (DBV), Central Association of German Craft (ZDH) as well as representatives of the federal states. Representatives from tourist associations have been inquired, but did not enter into the process (Hinrichs 2006, Interview). The former two actors have already been active in the Jury, while the federal states so far have not been involved into REGIONEN AKTIV. The inclusion of further interests has been a result of different pressures: On the one hand the Federal States continuously had shown their resentment about their exclusion from REGIONEN AKTIV (Spöring 2006, Interview; Vogelgesang 2006, Interview). Likewise, DBV has been outraged about being 'excluded' from the board after the Jury's reduction (Güthler 2006, Interview). On the other hand, some Council members throughout the process argued for the inclusion of other interests (namely Federal States, partly also DBV) (Schubert 2006, Interview; Seibert 2006, Interview; Güthler 2006, Interview). Finally, the new power relations within BMVEL and the new conservative Minister played a decisive role in the extension of the board (Schubert 2006, Interview).

At the national level of programme formulation we observed another relevant actor group as not being represented, neither in the Jury nor in the subsequent Council. As only associations operating at the national level DBV and individuals, such as University Professors have been considered for participation, actors who lack national representation also were structurally excluded (Güthler 2006,

28 We may not have captured all of the tasks assigned to the Council. However, this qualitative deduction shows which tasks actually have been significant to the experts involved and where they perceived to have a say in the process. 
Interview). The de-centralised organisation of Chambers of Crafts may serve as an illustrative example here, as REGIONEN AKTIV rhetorically claims to also address this branch of economy. ${ }^{29}$

\section{The example of the Federal States and DBV - Participants or non-participants?}

With regard to participation in the Jury and Council two interest groups play a significant role. Firstly, DBV as member to the Jury has been excluded from the subsequent Council due to two main reasons: discrepancies between BMVEL staff and DBV on the one hand (Hemmerling 2006, Interview) and DBV's negative attitude towards the programme on the other (Güthler 2006, Interview; Seibert 2006, Interview). Here the strategic interest of DBV to keep former agricultural funds within the agricultural sector and not to distribute it to an ever wider circle of beneficiaries comes into play, which may explain DBV's ambivalent attitude towards the programme (Seeling 2006, Interview). After the election and the taking-over of the conservative party in BMELV, DBV has been high on the list of potential new members to the Council (Schubert 2006, Interview). Even though the ex-post inclusion of DBV among Council members has been perceived as 'good and important' (Seibert 2006, Interview) it, however, merely had symbolic meaning and served DBV for prestige reasons (Güthler 2006, Interview; Hemmerling 2006, Interview).

In contrast, the Federal States as constitutional stakeholders in rural development policy have neither been invited into the Jury nor into the first Council. Two reasons could be identified for this strategy by BMVEL: Firstly, the federal dilemma ${ }^{30}$, i.e. a huge number of states with different interests, would have made the board incapable of action. Secondly, individual states were known not to be supportive for the fundamental ideas upon which REGIONEN AKTIV is built (Hinrichs 2006, Interview). Hence, the approach of leaving out the federal states at sensitive stages of REGIONEN AKTIV served BMVEL for strategic reasons, implying a 'well calculated collateral damage of the exclusion' (Güthler 2006, Interview; similar Hinrichs 2006, Interview). After the elections, at a relatively late stage of programme implementation, 3 representatives of the federal states have been included into the extended Council, having only little influence on the process (Spöring and Kleinfeld 2006, Interviews). For example, the performance-dependent extra fund has been decided upon by the first Council and the extended board did not have similarly far reaching responsibilities. ${ }^{31}$ The main task of the Council at that stage was to evaluate the results of REGIONEN AKTIV and to disseminate and transfer the knowledge gained. Besides some states that were in favour of the approach taken by REGIONEN AKTIV, many federal states have been 'indignant' and 'not very amused' about the federal government's interferences with federal states constitutional responsibilities (Vogelgesang 2006, Interview; Spöring 2006, Interview; Hinrichs 2006, Interview; Schubert 2006, Interview). Yet, some accept BMVEL's approach and the fact, that such a progressive 'programme would have been impossible with the federal states having a say in it' (Vogelgesang 2006, Interview). Hence the programme initiator summarises his past options as 'either acting against the resistance of the federal states or to come up to nothing in cooperation' (Augustin 2006, Interview; similar also Vogelgesang 2006, Interview; Hinrichs 2006, Interview).

29 BMVEL (2004a: 9); One may argue that the inquiry of ZDH to participate in the extended Council at least offered participation to this branch. However, as ZDH as an umbrella organisation also represents other groups and as ZDH did not show much interest in REGIONEN AKTIV (anonymous Interview 2006) we can assume that the Chambers of Crafts would not have been represented by ZDH properly and no deductions can be made, whether their interests would have been met.

30 Scharpf (1976) describes interdependencies between the different levels of a federal state as a dilemma called "joint decision trap"

31 comparison of main tasks as laid down in the rules of procedure for both boards (BMVEL 2002C amd BMVEL 2005a); similar also Kleinfeld (2006), Interview 


\section{Actors' strategies for dealing with participation and non-participation}

These examples and previous illustrations show which strategies to participation are employed by different central actors and actor groups :

- BMVEL as the central actor, initiator and rhetoric advocate for participation at both, formulation and implementation level, conducted an active management of the project environment. Owing to its power resources as federal ministry (personnel, finances, programme formulation monopoly) it could strategically include and also exclude actors to/from meaningful participation in the formulation phase. It did so with e.g. the federal states (strategic exclusion but later also strategic inclusion), DBV (strategic inclusion in Jury with limited influence, strategic exclusion from Council until new Minister strategically included DBV again) and with ZDH (strategic inclusion in Jury with limited influence, exclusion and later inclusion in Council II for concealing that the Council extension has merely been due to macro-political interests of the conservative Minister, for who DBV and federal states probably have been the most important interests to be included). According to interviewees the agenda during the participation process has been primarily set by BMVEL but discussions have been open, collaborative and also controversial (Güthler 2006, Interview; Seibert 2006, Interview).

- DBV employed a merely symbolic strategy to participation in REGIONEN AKTIV. Being publicly recognised as supporter of a bottom-up rural development initiative certainly served the image of DBV more than openly act for its particular interest of objecting the distribution of agricultural funds among various actors (Hemmerling 2006, Interview). This behaviour, however, cannot ignore that fundamentally DBV can not be in favour of the approach taken by REGIONEN AKTIV (Seeling 2006, Interview).

- The coalition of collaborating actors took a rather informal approach in attaining their interests in REGIONEN AKTIV (Güthler 2006, Interview). Trust among the closely connected actors supported this informal strategy, which in turn resulted in the formal inclusion of all these actors in the participation boards (Güthler 2006, Interview; Schubert 2006, Interview).

- Federal states in this case must be interpreted as being merely passive and exposed to the power play produced by BMVEL. However, in other arenas than REGIONEN AKTIV we may assume that federal states will reinforce their responsibility for rural development issues and may obstruct innovations proposed by BMVEL. ${ }^{32}$

\section{Formulation through participation - conclusions}

Participants to the Jury, the first Council and the extended version of the board all are listed in Table 8. Besides their professional or institutional orientation we may also discriminate three participant groups based on their weight/ importance in the process.

- Central actors: includes the coalition mentioned above showing 'a significant overlap in believes' (Güthler 2006, Interview), E.g. DVL, nova, AbL, BfN, DLKrT and FH Weihenstephan

\footnotetext{
32 Here GAK negotiations can be interpreted as an arena where federl states' interests can be best contrasted with federal
} interests and where latter will in the future be contested by the federal states. 
extensively joined the process of REGIONEN AKTIV formulation (see light grey background in Table 8)

- potential central actors (excluded central actors): Interests that from a rather objective point of view ${ }^{33}$, would have had a substantial stake in the issues dealt with and hence, from a normative viewpoint had to be included continuously in the process. This group includes the federal states as well as DBV and the Chambers of Crafts, who all did not affect the process much

- alibi and strategic actors: Actors which certainly enriched the board's view and contributed to the breadth of societal control over the programme, but who did that only in punctiform and with limited influence on the decisions. The group includes Kassel University; Tegut, dlv, vzbv and $\mathrm{ZDH}$. In punctiform here refers to the 2-stage selection of regions by the Jury. Limited influence of each actor may be deduced from the greater number of actors (lower relative weight) as well as from the fact that BMVEL also intervened in the board's decisions by setting additional politically driven selection criteria. Another reason for the limited influence was reported by an interviewee: The limited interest of the actor in issues dealt with under REGIONEN AKTIV led to an 'alibi participation' for lending the process 'notable names of actors' (anonymous Interview 2006).

Elbe $(2006,89 f)$ also finds that the reduction from the Jury to the much smaller Council represents a major drawback in the programme's credibility in being integrated and designed in partnership. However, the approach allowed BMVEL through mainly involving the coalition members to retain maximum control over the programme, while at the same time publicizing the application of a participatory approach at all programme stages.

33 For drawing this ,objective point of view', which certainly does not exist, one may consider the continuous calls of Council members towards BMVEL to include such interests. Likewise, the notion of Hinrichs (2006, Interview), that under today's circumstances one would consider the inclusion of the federal states from the outset and Güthler's statement (2006, Interview) on the 'political importance' of including DBV show, that in retrospect the exclusion of these interests is being reappraised. 
Table 8: Participants in the formulation of REGIONEN AKTIV

\begin{tabular}{|c|c|c|c|c|c|}
\hline \multicolumn{2}{|c|}{ Actors taking part in the ... } & \multicolumn{4}{|c|}{... Participatory phases under REGIONEN AKTIV's formulation at national level } \\
\hline $\begin{array}{l}\frac{0}{0} \\
5 \\
\overline{0} \\
\overline{0} \\
\end{array}$ & $\frac{n}{\frac{0}{8}}$ & 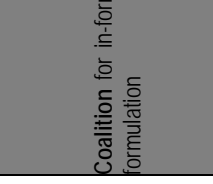 & 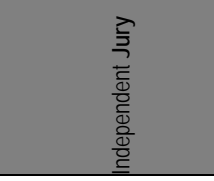 & 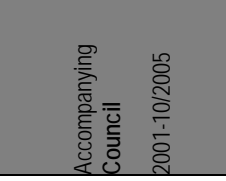 & 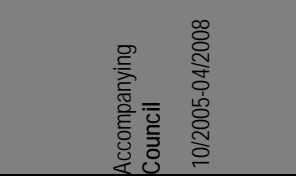 \\
\hline & Main formal tasks in respective phase & -- & $\begin{array}{l}\text { - 2-stage selection of } \\
\text { applicant regions }\end{array}$ & $\begin{array}{l}\text { - Control reporting } \\
\text { - granting additional } \\
\text { funds } \\
\text { - accept changes in } \\
\text { regional strategies }\end{array}$ & $\begin{array}{l}\text { - Control reporting } \\
\text { - accept changes in regional } \\
\text { strategies }\end{array}$ \\
\hline & $\begin{array}{r}\text { Main informal tasks in respective } \\
\text { phase } \rightarrow\end{array}$ & $\begin{array}{l}\begin{array}{l}\text { Informal } \\
\text { decisions, } \\
\text { setting }\end{array} \\
\text { agenda }\end{array}$ & & & $\begin{array}{l}\text {-'assessing and transfer rather } \\
\text { than steering and decisions' }\end{array}$ \\
\hline $\begin{array}{l}\text { Federal } \\
\text { government }\end{array}$ & BMVEL/ BMELV & $\mathrm{BMVEL}^{* *}$ & BMVEL & BMVEL & BMELV*** \\
\hline \multirow{3}{*}{$\begin{array}{l}\text { Federal } \\
\text { states }\end{array}$} & Lower Saxony & & & & $\mathrm{x}$ \\
\hline & Rhineland-Palatine & & & & $\mathrm{x}$ \\
\hline & Mecklenburg-Western Pomerania & & & & $\mathrm{x}$ \\
\hline $\begin{array}{l}\text { Traditional } \\
\text { agriculture }\end{array}$ & German Farmers' Association (DBV) & & $\mathrm{x}$ & & $\mathrm{x}$ \\
\hline \multirow{2}{*}{$\begin{array}{l}\text { Organic } \\
\text { agriculture }\end{array}$} & $\begin{array}{l}\text { Working Group Peasant Farming } \\
(\mathrm{AbL})\end{array}$ & $\mathrm{x}$ & $\mathrm{x}$ & $\mathrm{x}$ & $x$ \\
\hline & $\begin{array}{l}\text { Working Group Organic Agriculture } \\
\text { (AGÖL) }\end{array}$ & $\mathrm{x}$ & $\mathrm{x}$ & & \\
\hline \multirow{4}{*}{$\begin{array}{l}\text { Nature } \\
\text { conservation }\end{array}$} & $\begin{array}{l}\text { Umbrella Organisation of German } \\
\text { Environmental Associations (DNR) }\end{array}$ & & $\mathrm{x}$ & & \\
\hline & $\begin{array}{l}\text { German Association for Land care } \\
\text { (DVL) }\end{array}$ & $\mathrm{x}$ & & $\mathrm{x}$ & $\mathrm{x}$ \\
\hline & $\begin{array}{l}\begin{array}{l}\text { Federal Agency for Nature } \\
\text { Conservation (BfN) }\end{array} \\
\end{array}$ & $\mathrm{x}$ & & $\mathrm{x}$ & $\mathrm{x}$ \\
\hline & $\begin{array}{l}\text { Federation for Nature Conservation } \\
\text { (NABU) }\end{array}$ & $\mathrm{x}$ & & & \\
\hline \multirow{2}{*}{$\begin{array}{l}\text { Regional } \\
\text { authorities }\end{array}$} & $\begin{array}{l}\text { German Association of Counties } \\
(\mathrm{DLKrT})\end{array}$ & & $\mathrm{x}$ & $\mathrm{x}$ & $\mathrm{x}$ \\
\hline & $\begin{array}{l}\text { German Association of Communes } \\
\text { (DStGB) }\end{array}$ & & $\mathrm{x}$ & & \\
\hline \multirow{2}{*}{$\begin{array}{l}\text { Agricultural } \\
\text { science }\end{array}$} & University Weihenstephan & & $\mathrm{x}$ & $\mathrm{x}$ & $\mathrm{x}$ \\
\hline & University Kassel & & $x$ & & \\
\hline Craft & $\begin{array}{l}\text { Umbrella Organisation of German } \\
\text { Crafts (ZDH) }\end{array}$ & & $x$ & & $\mathrm{x}$ \\
\hline Trade & Tegut Itd. & & $x$ & & \\
\hline Women & $\begin{array}{l}\text { German Association of Rural Women } \\
\text { (Dlv) }\end{array}$ & & $x$ & & \\
\hline Consumers & $\begin{array}{l}\text { Federation of Consumer Advice } \\
\text { Centres (Vzbv) }\end{array}$ & & $x$ & & \\
\hline Consultant & Nova Institut & $\mathrm{x}$ & $x$ & $\mathrm{x}$ & $\mathrm{x}$ \\
\hline
\end{tabular}

Source: $\quad$ BMVEL (2001), (2002c), (2005); ( Elbe (2006: 88); Tränkner (2006); pers. correspondence nova Institute (2006); Güthler (2006 and 2007, Interviews); Spöring (2006, Interview). 


\section{Regional partnerships for participatory implementation}

The partnership principle also and foremost applies to the implementation of the programme at regional level. The establishment of regional partnerships as the central features for participation at the implementation level was a prerequisite in the invitation to the competition (BMVEL 2001:12, 14). Consequently, participation has not been imposed hierarchically but by using market-based incentives. The composition of RPs to a minor degree had been subject to programmatic requirements. RPs had to be institutionalised in some legal way (e.g. association, $\mathrm{GmbH}$, etc.), but all turned out to be formalised as associations (Augustin 2006a). At the decision-making level public actors must not exceed $50 \%$. This given standard can be seen as a result of the LEADER+ experiences, where the $50 \%$ limit for public actors also has been applied. 'All relevant and willing actors' (private and public) should bee included into the process (BMVEL 2001:14; similar Elbe 2006: 97). The central responsibility of this PPP was to select projects through which the funds dedicated to each region have been retrieved. Hence, the RPs responsibility was to fill the regional initiative with action through commonly agreed joint projects (Elbe 2006: 56).

Despite the clear rule about the maximum participation of public actors and the representation of all relevant interests, the composition of these RPs largely varies among the 18 model regions, with potential under-representation of different actor groups (Schubert 2006, Interview). The task of stakeholder identification and involvement intentionally has been left to the regional context and hence, individual differences may be expected. However, some structural over- and under-representation could be observed as well. 'The strong representation of communal and semi-communal actors (public actors) was complemented by a weak mobilisation of private sector actors' (Hemmerling 2006, Interview. Elbe reports (Elbe 2006: 101) that public actors with sufficient personnel and financial resources were found to be easily involved into RP activities. He also finds civic actors (individuals and collective actors) being equipped with limited funds and to largely rely on honorary actors' contributions. Their capabilities to participate hence are largely linked to honorary resources, which have been observed to often be overextended (Elbe 2006:101; DVS unknown a,b; Spöring 2006, Interview). While these two actor groups can be viewed as being differently privileged for participation to the process (the former more the latter less), private sector actors, such as private enterprises especially from the non-agricultural sector can be interpreted as to a large extend being 'under-represented' and even structurally excluded from the programme. ${ }^{34}$ This finding does not imply a purposeful exclusion, but draws on programmatic characteristics of the funding scheme, which are not suitable for firms and companies. Elbe explains this with differences in the logic of (inter)action, where private firms necessarily need to achieve monetary benefits and may not align their action with the public or regional good (Knieling et al. 2001:200; c.f. Elbe 2006:101; Hemmerling 2006, Interview; Schubert 2006, Interview).

After Phase I of the programme these trends became obvious and BMVEL through soft measures of intervention tried to counteract this development. Such measures included the notification of the respective regions through the Administrative office and the announcement (threat), that if no corrections in RP composition were undertaken, funding for Phase II could not be guaranteed (Hemmerling 2006, Interview).

Only few further impediments to participation could be identified at the regional level. Besides some structural exclusion of private sector actors (see above) and the large dependency of the processes on honorary workers, duplications of regional initiatives, such as Agenda21, REGIONEN AKTIV, LEADER+, etc, were found to in a way or another, constrain participation (Hemerling 2006, Interview; Spöring 2006, Interview). On the one hand parallel bottom-up initiatives tend to 'always attract the same

34 'Structural exclusion' has not been formulated by any interviewee, but was deduced from i.a. Schubert (2006);

Hemmerling (2006); Seeling (2006); Vogelgesang (2006), Interviews 
actors, yes even the same people' leading to a rather closed circle of actors. On the other hand, a variety of initiatives also heavily draws on honorary workers, whose work load thus may be multiplied (Spöring 2006, Interview). Administrative borders may also hinder a true bottom-up process as may time constraints which come with funding programme such as REGIONEN AKTIV (Hinrichs 2006, Interview).

These bottlenecks regarding participation at the regional level should, however, not mislead us as to ignore one of the central positive effects and innovations of REGIONEN AKTIV: '.. for the first time actors in the regions were empowered to actually decide ...' on the use of public funds. This empowerment amazed regional actors, as now they were the ones deciding on the realisation but also refusal of ideas deliberated by other regional actor or even themselves (Hinrichs 2006, Interview). From the regional actors' point of view the most appreciated effects of RPs were to mutually learn about each others interests and the inclusion of rather small or weak actors, who usually would not have been heard (Elbe 2006:104). Finally, regional actors observed that 'cooperation and networking occurred which, for different reasons, had not occurred before' (Knickel et al. 2005:XIII; c.f. Elbe 2006:104). Early results of the PPP as well as professional moderation (external or internal delivered through the regional management) were perceived as facilitating participation at the regional level (Hinrich 2006, Interview).

\section{Conclusion - Empowering approach implemented at the regional level}

Despite the fact of structural exclusion of private enterprises, the participatory approach applied for programme implementation can be interpreted as an incentive-triggered bottom-up approach with genuine opportunities for participation throughout the whole regional process of implementation, which itself must be seen as a policy process on its own. Given the fact that REGIONEN AKTIV as a funding programme has also had its limitations and its primary addressees, the under-representation of private sector actors does not reflect the programme's incapacity in applying a participatory approach to rural development.

For fully understanding the mechanisms of in- and exclusion at the national level, we also have to take into account that the Council also serves as an expert panel (at least partly, see section on expertise). Therefore, selection criteria for experts constrain the normative claim of having a 'broad and representative' participation process.

\subsubsection{Inter-sectoral coordination}

The issue of ISC in Ra shows strong parallels to the element of participation. This is mainly due to the fact that for both issues the Council at the national and the RPs at the regional level have been interpreted as being relevant. Hence, we largely referred to ISC issues under the section on participation.

The need for ISC can be deduced from the understanding that sustainable development requires the integration of different dimensions (economic, ecologic, and social aspects) and hence, different sectors more or less associated with one of these dimensions and their interests also need to be harmonised (Bundestagsdrucksache 15/4801 2005: 51). Consequently, a holistic approach to rural development is needed instead of mere agricultural subsidies (BMVEL 2002: 8; BMVEL 2004A: 8). According to BMVEL, who together with its programme allies put ISC on the agenda in the formulation process, the rural development process in REGIONEN AKTIV should include as many different sectors as possible and practicable. Key regional interest groups representing fields such as consumer protection, agriculture and forestry, environment, retail, crafts and trades, commerce, health, municipalities and public administrations, education and science are perceived to also represent different sectors involved in the development process (BMVEL 2002: 6; BMVEL 2004A: 18). From the above listing we can 
conclude that the underlying definition of sectors refer to two fundamental assumptions regarding the delineation of sectors. Firstly, sectors are often referred to as economic sectors or, where the term economic does not apply we may replace it with 'functional sectors'. This is reflected by the above fields of e.g. agriculture, forestry, environment, etc. Secondly, the distinction between 'public' and 'private sector' is quite common and can be supplemented with the 'civic sector'. This delineation criterion is reflected by the role of municipalities and public administrations.

In general it is remarkable that besides its rhetoric focus on all relevant sectors in a given rural area REGIONEN AKTIV primarily is built around actors and networks in favour of environmentally sound and organic agriculture. ${ }^{35}$ In deed the original intention had been to design an even more integrative programme ${ }^{36}$, but after the crisis of mad cow disease the former Minister Künast needed to demonstrate successes in Agrarwende (alternative agricultural policy), hence REGIONEN AKTIV subsequently was focussed on organic agricultural networks.

\section{Symbolic coordination of 'sectors' during programme formulation}

The Jury was described as representing a wide range of societal actors (Tränkner 2006, 213; Elbe 2006, 88), implying that also different sector concerned have been involved. It consequently was acknowledged that different sectors need to be addresses if the programme was to follow the idea of IRD. However, the need for active coordination has neither been addresses (rhetorically) nor practiced in the Jury. Even though the subsequent Council has not been called for serving ISC purposes, it was found to be the only feature for analysing inter-sectoral issues during programme formulation. As mentioned earlier, our findings regarding participation also serve for explaining the (non-) coordination of different sectors under REGIONEN AKTIV formulation. While the Jury at least acknowledged that different sectoral views and interests had to be brought together, the following reduction of the board to the Council seemed to ignore this opinion. Environmental representation was strengthened (Elbe 2006) whereas DBV as the most important actor for agriculture has been excluded. Agriculture henceforth was represented by a relatively small actor only. Hence, the Council did not serve the coordination of sectors concerned, but as a mechanism for including useful and excluding threatening actors with their particular interests. The segregation of trade and craft representatives underpins this finding, as these fields/sectors were explicitly mentioned in the rhetoric of documents (BMVEL 2002: 6; BMVEL 2004A: 18) but not represented in the Council at all.

From the above findings we can conclude that ISC at the national level has neither been actively called for nor has it been addressed in policy practice. ${ }^{37}$ This absence of active coordination may be rooted in 'different portfolios/ministries having their own agendas and interests' (Observation 2006b) and was perceived as a fundamental lack of coordination. According to interviewees there is a need for such action especially at the national level for two reasons: Firstly, coordination among different ministries would 'make political objectives and (funding) programmes more consistent'. Secondly, practicing ISC at the level of programme providers 'would lend the idea of ISC credibility' (Hemmerling 2006, Interview). The quest of actually practicing ISC in a ministerial setting was reported to be 'one of the most urgent

35 Under this ,interest group' we subsume environmental interest groups as well as organic or alternative farming associations and associated research institutions. Schubert, Hinrichs (2006), Interviews

36 More integrative' here refers to addressing more sectors and including wider issues, goals and objectives. Schubert, Hinrichs (2006), Interviews

37 Some interviewees mentioned the Council as a forum for ISC. Such statements now must be seen as being merely symbolic. 
future challenges regarding integrated approaches to rural development policy' (Schubert 2006, Interview; similar Observation 2006b).

Still, following the idea of IRD, ISC is called for and required. This is reflected by programmatic statements that 'REGIONEN AKTIV is a completely new approach to national promotion and funding schemes. The focus will switch from individual sectors and promotional activities (e.g. agriculture, economy, infrastructure) - the norm in most "more traditional" promotional schemes - to specific regions themselves (BMVEL 2002: 8)'. The fact that in the first phase of the competition key regional interest groups - 'consumers, agriculture and forestry, environment, retail, crafts and trades, commerce, health, municipalities, education and science' - were asked to develop a joint vision for the future development of their regions as a basis for the development process, can serve as an example for this shift (BMVEL 2002: 6). Thus, necessitating ISC at the regional level of implementation, while ignoring this attitude during formulation at national level illustrates how the difficult task is being shifted and dispersed from one level to another. In a regional context, however, REGIONEN AKTIV triggers individual regional policy processes, where ISC plays a prominent role especially during the stage of formulation of the joint strategies. Onwards in the regional process ISC remains an important issue as projects of an intersectoral nature are continuously proposed and decided upon by RPs.

\section{Regions left with ISC responsibilities}

During programme implementation REGIONEN AKTIV intensely focuses on the coordination of different sectors in a regional context. Here, the regional development concept (negotiated joint planning document) serves as the central instrument for coordination (Hinrichs 2006, Interview). As mentioned earlier the document has been a result of negotiation processes among participating regional actors in the RPs. Here questions of ISC parallel aspects dealt with under participation, as the in- and exclusion of certain interest also immediately affects the representation of sectors. It was, however, stated that the joint strategy alone would not be able to properly function as ISC-tool. The regional management facility as organisational core (Benz 2003) of the development process is needed for moderation and continuous motivation of the diverse actors to also follow common interests, as negotiated in the strategic document (Hinrichs 2006, Interview). Hence, ISC was only possible through the instruments of a joint strategic document in conjunction with an intermediary organisation explicitly dedicated to ISC (or networking) tasks.

Under REGIONEN AKTIV a relatively broad spectrum of sectors was addressed (rhetoric). During implementation the following sectors, as perceived by an interviewee, have played a central role in different regional contexts: ${ }^{38}$

- Agriculture

- Nature conservation

- Tourism

- Renewable energy

- Forestry only marginally

38 Hinrichs (2006), Interview, sequence of sectors refers to their perceived importance. The information is of a rather qualitative nature and must be seen as the perception of the interviewee, who in turn as BMVEL's managing officer for REGIONEN AKTIV has had extensive insights into the regional processes. 
This widening of addressees in a programme provided by the Ministry of Agriculture in conjunction with responses of successful regional cooperation between sectors which have traditionally been separate ${ }^{39}$ is fairly new in German rural development policy. This significant increase in ISC at the regional level is directly linked to the territorial approach taken be REGIONEN AKTIV, rather than focussing on sectors, and a natural, yet innovative consequence of the approach.

In phase II of REGIONEN AKTIV we observed some significant changes in focus of the programme. Regions were appealed to centre their activities around value-chains for obtaining maximum economic effects (Figure 10) (Elbe 2006: 165). The basic ides of these value-chains is based on experiences from forestry and the wood-value-chain (Gothe and Hahne 2006). However, IRD is 'more than economic development, it aims at sustainable regional development. Under REGIONEN AKTIV this approach currently is being narrowed by focussing on value-chains, where the general economic perspective is becoming even more restricted, leading to a neglect of potential synergies between value-chains and sectors' (Hahne (2006, Interview). Thus, the focus on value-chains bears the risk of neglecting synergies among different chains and sectors and solely focussing on sectoral strategies again.

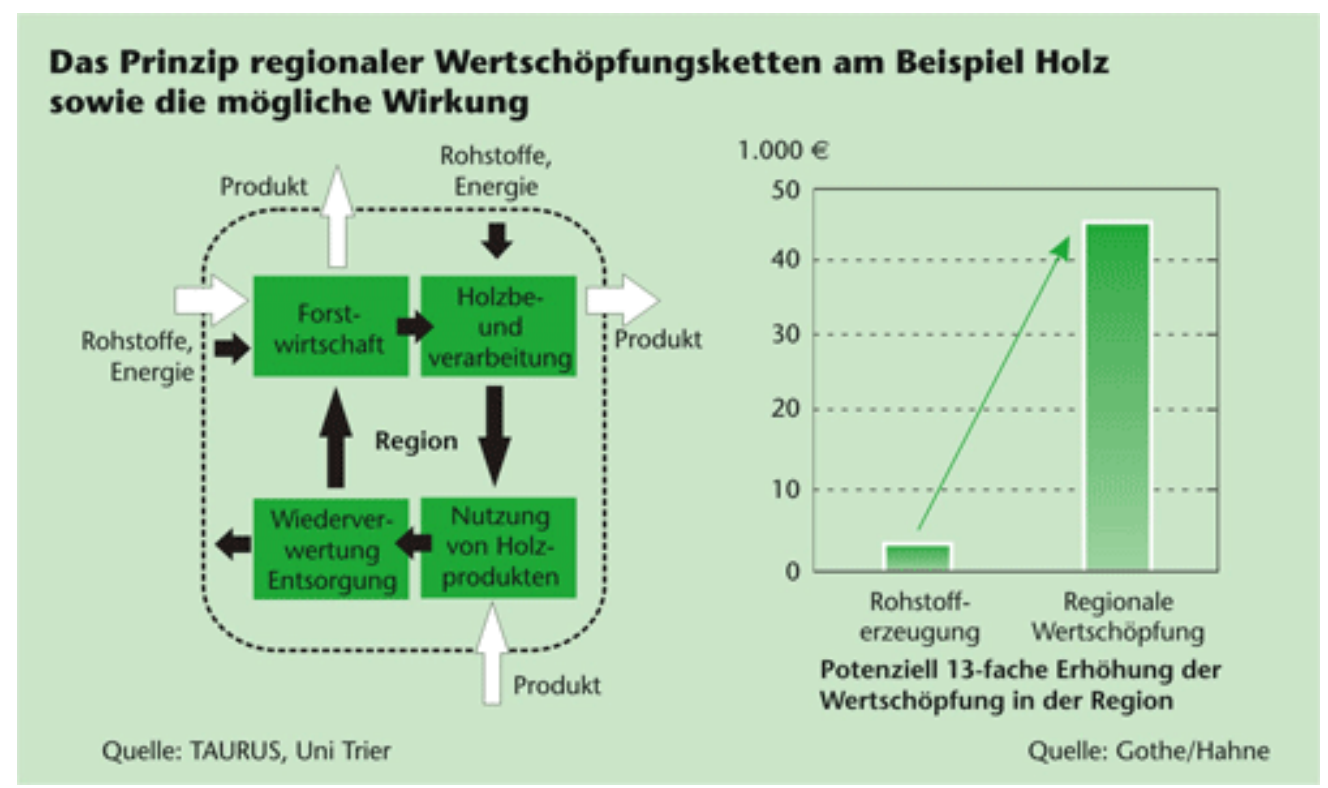

Figure 10: $\quad$ The regional value-chain approach taken in phase II of REGIONEN AKTIV illustrated by the wood value-chain (left part) and its potential benefits in terms of regional value-added

Source: $\quad$ Taurus Trier; c.f. nova (2007)

Additional research shows, however, that despite the rhetoric claim of addressing all relevant sectors in rural regions, some sectors are not adequately represented in the programme, e.g. the forestry sector. In-house research by BMVEL staff showed a relatively low degree of forestry participation at the implementation stage (Schwörer 2006, Interview, Hinrichs 2006, Interview). Other analyses support this finding for the forestry sector (Ortner 2004, Giessen et al 2006, Giessen 2007, 2008).

39 Nature conservation and agriculture have frequently been reported to unexpectedly cooperate under REGIONEN AKTIV. Schubert, Güthler (2006), Interviews; Augustin (2006c), Interview 


\section{Successful ISC at its costs- conclusions}

We can conclude that three aspects are decisive for successful ISC at the regional level. Firstly, the composition of RPs as the place for negotiating the joint strategy; secondly, the joint strategy as result of negotiations and base for ISC and lastly, an intermediate organisation for actively coordinating and moderating different interests of the sectors represented. The combination of all three elements, its full eligibility and the obligatory nature of requiring the strategy, RP and regional management under REGIONEN AKTIV resulted in the active and successful coordination of different sectors at the implementation level. The IS approach taken by the programme, however, has been limited after phase I and was constrained by the value-chain approach taken in phase II for maximising economic effects.

The challenge of ISC has not been addressed during formulation and at national level respectively, but it has been shifted to the regional level. We can not identify reasons, why shifting the task from one stage of the policy cycle to another would have eased the challenge of ISC. Hence, we must assume that the underlying reason for the shift is grounded in the territorial level at which ISC actually is executed. ISC is being executed, however, not at the sub-national level, which in our federal context would be the states, but even below at a regional or local setting. From our material we may suppose that the degree of institutionalisation of different sectors, where ministerial structures play a crucial role, negatively affects the political opportunity structure for ISC. Thus, the task can only successfully be addressed at levels, where formalised and institutionalised sectoral structures do not prevail. As another result of our analysis we observe that non-state actors play a prominent role in ISC under REGIONEN AKTIV. We could also say that at least in the regional contexts state-actors only play a marginal role for ISC. Before the background of the abovementioned 'inability to ISC' at levels where sectors are highly institutionalised and knowing that at regional level state-actors play a minor role we could come up with the hypothesis that ISC may effectively bee addressed only in a rather 'non-state setting' where a single central and powerful actor is lacking.

Lastly, we observe the element of ISC being inter-related with most of the other elements, especially with participation, as the Council and RPs served for analysing both aspects. The Council includes various societal and public actors from different sectors, who have been invited due to their respective expertise and who even represent different territorial levels. Likewise, the RPs represent societal and state-actors stemming from different sectors . For participation and ISC we found that 'ISC is needed for cross-cutting issues dealt with in REGIONEN AKTIV. But ability to act has been the central question in the Council'. Thus, we can conclude that if both elements constrain each other, ISC is residual in priority (Güthler, Hinrichs 2006, Interviews).

\subsubsection{Multi-level coordination}

\section{Simplifying MLC through devolution}

REGIONEN AKTIV aims at a low degree of interdependencies among levels. The coordination among different levels under REGIONEN AKTIV is characterised by a high degree of devolution of responsibilities into regions (Hinrichs 2006, Interview), which explicitly are smaller then a federal state and larger than just a commune or a small group of communes. The need for "regionalisation" especially of decision-making competences is being articulated as a key element in rural development policies (BMVEL 2004A: 8). With REGIONEN AKTIV the federal ministry put an emphasis of helping people help themselves, which implies a re-distribution of competencies to the regional level This empowering approach is represented by four 'anchors of regional responsibility' (Elbe 2006: 20):

- content responsibility $\rightarrow$ regional selection of projects 
- procedural responsibility $\rightarrow$ regional partnership in combination with the professional regional management

- financial responsibility $\rightarrow$ regional budget for funding projects in the region

- administrative responsibility $\rightarrow$ handling of funds by regional authority

The devolutionary approach is also reflected in the legal base of REGIONEN AKTIV, the notification text, which roughly replaces more detailed guidelines. Elbe finds that such guidelines would have made necessary much more detailed specifications on measures etc. than did the mere notification (Elbe 2006: 51). As a consequence of shifting decision-making competencies to the regions, such competencies need to be withdrawn from elsewhere. In the case of REGIONEN AKTIV elsewhere refers to the federal states (Hinrichs 2006, Interview). Hence, BMVEL actively tried to admit a maximum degree of freedom for the regional level while cutting back responsibilities of intermediate territorial levels.

\section{Two levels having distinct competencies}

Before this background and having in mind that BMVEL to a large extend ignored the federal states, it becomes obvious that only two levels play a meaningful role under REGIONEN AKTIV. Programme documents refer to 'programming level' (national) and 'implementation level' (regional), the first being in charge of the so called 'framework steering', while the later in a regional context is supposed to execute 'detailed steering' (Figure 11) (Elbe 2006: 61; BMVEL 2004a: 15). Thus, active coordination across a minimum of territorial levels (2) is being pursuit. In the context of maximum devolution, framework steering may be paraphrased as management by objectives with relatively open ends. In particular it refers to fundamental programming tasks by BMVEL and its service provider GS, region selection by the Jury and accompanying advice by the Council. Detailed steering includes proposal of projects, decision on proposals by RPs, the usage of external advisors, control of legal alignment by managing authority as well as the actual handling of public funds and networking by the regional management (BMVEL 2004A: 14f, 26; Augustin 2006, Interview; Hinrichs 2006, Interview). The two levels are legally interconnected with each other through the regional development strategy document, which serves as contractual base between BMVEL and the regions (Elbe 2006: 61). As regards communication and the flow of information the two levels are also connected by the GS, which in a literal sense must be assigned to the programming level (Schubert 2006, Interview; Augustin 2006, Interview). Thus, all institutions established under REGIONEN AKTIV (in bold) are actively involved in the MLC with the Administrative office having an outstanding role in facilitating MLC. The Administrative office serves as a mediator between the regions and the ministry, having the role of a secretariat for managing the day-today work of the programme and at the same time functioning as an expert consultancy. In the regions, however, the Administrative office has been perceived as 'the right hand' of BMVEL, while among actors at the programming level

The number of actors integrated into MLC hence increased by a significant number. The majority of new actors in MLC now is stemming from the regional level, which formerly either has not been institutionalised or did not have far reaching decision and implementation responsibilities.

The modes of interaction and interdependencies between the two levels vary to a certain degree. Bearing in mind that REGIONEN AKTIV is a funding programme, where a central authority provides public funds for beneficiaries, who in turn have to align with the programme objectives and requirements and have to enter into competition with other applicant regions, it becomes clear that market forces are employed. However, these objectives at the programming level have been set hierarchically by BMVEL 
(Schubert 2006, Interview; BMVEL 2004a: 13). Furthermore, aims and objectives at the regional level were supposed to be the result of negotiation processes among regional actors. Thus, all three modes of interaction are combined under the approach (BMVEL 2004a: 13). Interdependencies result from the need of BMVEL to inform beneficiaries about programme requirements and details. This must be seen as a significant dependency, since REGIONEN AKTIV can not be interpreted as a standard programme, under which every single detail has been laid down in specific guidelines. Many issues of programme governance, such as the 2-stage region selection, the performance-dependent extra funds, requirements for evaluation (Augustin 2006, Interview) had to emerge in an adaptive and iterative manner and subsequently had to be communicated 'downwards'. Likewise, money is being transferred downstream. On the other hand BMVEL declared to count on (not rely on) knowledge and lessons generated in the regions for being a learning programme. Thus, BMVEL to a certain degree depends on an upstream flow of information through regional focus groups, evaluation and reporting mechanisms. The latter dependency, however, must be interpreted as an add-on or optional relationship, which has been chosen by BMVEL itself.

\section{Complicating MLC through simplification}

Problems with MLC occurred at the national level, where the federal states have been actively ignored by the programme provider, even though they have the constitutional responsibilities concerning rural development issues. This approach led to 'diplomatic irritations' and was perceived as politically not being correct, but reasonable and understandable (Vogelgesang 2006, Interview; Güthler 2006, Interview; Schubert 2006, Interview). The BMVEL was definitely able to overcome "normal" federal structures by one strong power resource: financial means helped certainly to weaken the resistance of the federal states. The later inclusion marked a 'considerable change in the multi-level approach taken by REGIONEN AKTIV' (Hinrichs 2006, Interview) and finally benefited BMVEL the most. It helped to overcome the implementation dilemma which BMVEL was facing, i.e. that implementation of the progressive ideas under the pilot scheme probably had been impossible with the states, while the transfer of results (implementation into mainstream policy for rural development) without the federal states de facto is unattainable (Schubert, Hinrichs, Güthler, Vogelgesang 2006, Interviews). The approach taken by BMVEL consequently allowed the national level to intervene at regional level (Spöring 2006, Interview), while at the same time demonstrating and testing the new approach to rural development policy for improving mainstream policy.

Furthermore, REGIONEN AKTIV in some cases led to parallel regional governance structures resulting from various regional initiatives (Spöring 2006, Hemmerling 2006, Interviews). This may serve as an indicator for problems at the national level, showing a lack of coordination between different ministries or departments (Reimann 2006, Interview).

\section{Illustrations of the approach to MLC}

The procedure of how BMVEL intervened after phase I may serve as one illustrative example for MLC in REGIONEN AKTIV, when it became clear that in many regions the composition of the decision-making organs (RPs) was heavily biased towards public and underrepresented private sector actors. Then the ministry through the intermediate institution of the Administrative office urged regions to improve the situation by including lacking actor groups into the development strategies which were to be handed in for the application for phase II. This soft and flexible way of management by objectives can be seen as one way for MLC under REGIONEN AKTIV. However, also harder and more hierarchical modes could be identified. The thorough system of reporting and sometimes 'excessive evaluation obligations' 
(Seibert 2006, Interview) established under the funding scheme shows that management by objectives also was applied in a more rigid way, necessitating e.g. certain reports for regions to obtain further funds (Augustin 2006b, Interview).

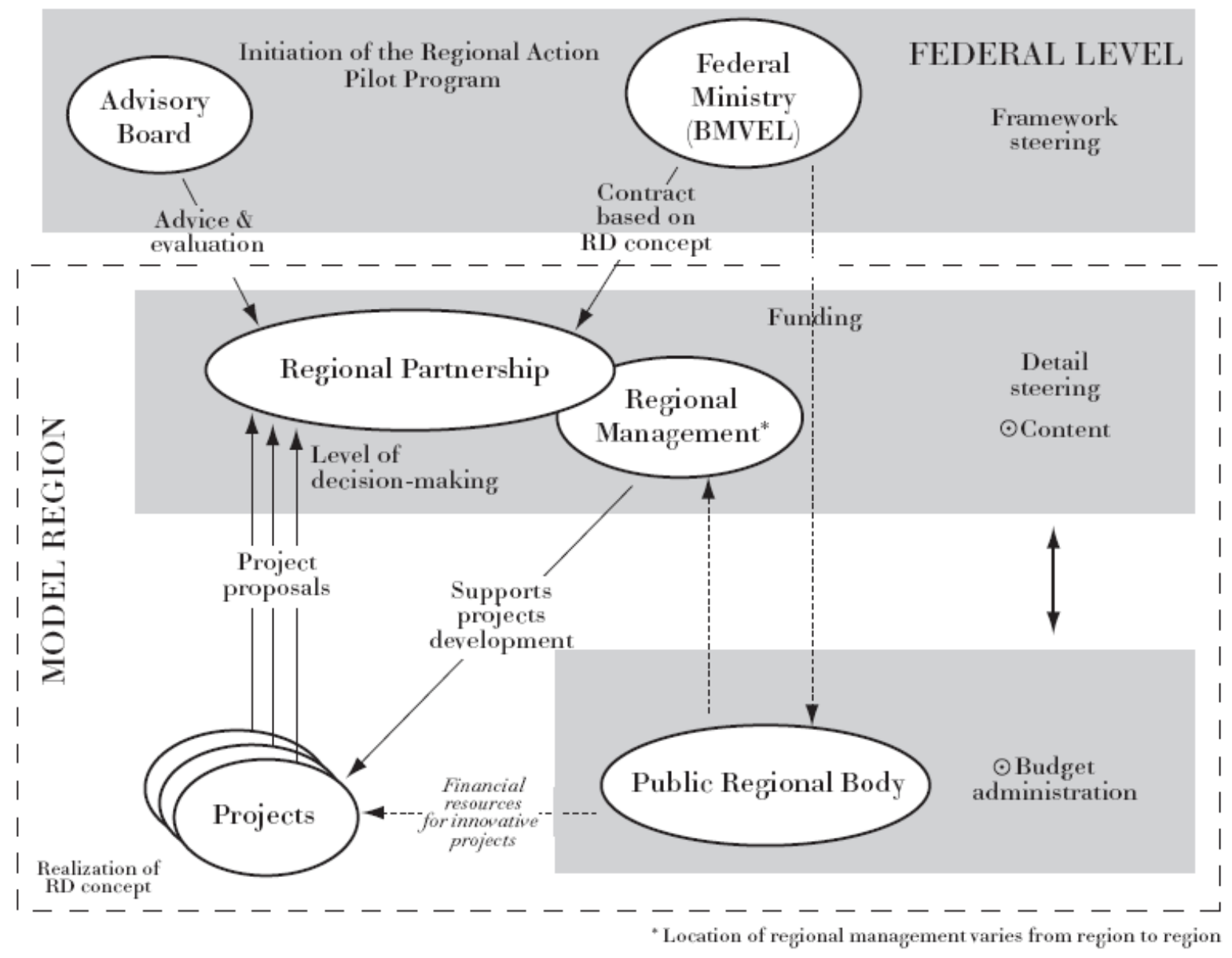

Figure 11: Governance system established under REGIONEN AKTIV distinguished between framework steering at the national (upper) and detailed steering at regional level (lower part)

Source: $\quad$ Peter and Knickel (2006: 18).

\section{Only two levels in a federal country - Does it work?}

From the above illustration we can conclude that in a federal context with the states having a constitutional stake in rural development issues, the federal ministry by delivering REGIONEN AKTIV made a provocative move. It did so because including the level of the federal states would have caused the approach taken under REGIONEN AKTIV to fail for different reasons. The example of LEADER+ with its existing variety of different implementation structures and operational programmes among all federal states shows that negotiations with the federal states upon REGIONEN AKTIV would not have been very easy and could lead to a diminishment of the BMVEL's aims with the programme as well as a delay in implementation. Given the fact that the programme was designed as a temporary pilot project for testing the new approach, federal states can accept (reluctant or in favour of the approach) this solo run of BMVEL. However, as soon as it comes to mainstream policy for rural development, federal states will not accept the federal government to intervene in this manner. Moreover, it needs to be shown if the 
'diplomatic irritations' will be offset by the successful results of the programme or if, at least for some states, they will affect future relations to the federal ministry.

\subsubsection{Accountable expertise}

\section{Experts consulted during formulation}

BMVEL in cooperation with different actors and experts in their fields designed, planned and finally delivered REGIONEN AKTIV. We, however, can not clearly delineate to which degree such cooperation can be interpreted as actual expert advice asked for by the ministry.

\section{The right hand of BMVEL - the administrative office (Schubert 2006, Interview)}

BMVEL contracted nova Institut (private consultancy firm) for arranging an administrative office for REGIONEN AKTIV. This task included the delivery of scientifically grounded expert advice on IRD issues as well as running the website of "Regionen Aktiv" (www.modellregionen.de) (Seibert 2006, Interview; Augustin 2006c, Interview; Hinrichs 2006 ;Interview). BMVEL selected nova as described by the selection model of experts mentioned earlier (see case on IRD philosophy section expertise) (Augustin 2006c, Interview). Nova assisted BMVEL in the actual formulation of REGIONEN AKTIV through joint planning discussions and has been in charge of further developing the ideas towards implementation. In turn, nova itself 'extensively consulted external expertise in form of other consultants on more detailed issues' (Hinrichs 2006, Interview). However, nova has not been consulted for giving expert advice only. Throughout the programming period they also served as secretariat for coping with day-to-day work and nova organised large parts of the knowledge transfer process. Thus, the consultant plays three roles: Firstly, it functions as a secretariat during programme implementation coping with dayto-day work. Secondly, it organised the knowledge transfer as an expert during policy implementation as well, through e.g. organising seminars etc. And lastly, nova continuously contributed to the formulation of the programme with its distinct expertise, as e.g. in the case of the performance-dependent extra funds. Hence, their role can not be seen as being an expert only. ${ }^{40}$ This assumption is backed by the fact that for BMVEL having an external secretariat allows the sourcing-out of extensive administrative tasks (Schubert 2006, Interview). This would have bound enormous ministry resources for personnel, which might have been difficult to argue for under tight budgetary conditions. The solution of having a private consultant (expert) doing this job combined with other, more demanding and pretentious tasks could have eased the putting through of the whole programme. Also, this arrangement enhances BMVEL's ability to act (Hinrichs 2006, Interview) through providing an intermediary institution between BMVEL and the regions, hence reducing social distances and hierarchical structures and by simply having a service provider.

\section{Experts in a participatory setting - The Council}

Besides its function as a forum for including various societal interests the Council also is perceived and serves BMVEL as a way of embracing experts into the programme formulation (Güthler 2006,

40 Schubert (2006), Interview, who understands the concept of ,expertise' as rather problem-centred, while a secretariat would handle day-to-day work. According to him the latter has been the case in programme implementation. One should, however, not underestimate how nova formally (as contractor) as well as informally (during informal formulation as mentioned under participation section) affected the process by acting as an expert. 
Interview). This board also served BMVEL for another function. As an external authority for contested decisions, such as the granting of performance-dependent extra funds for the regions, the Council allowed BMVEL to 'out-source' contested decisions and at the same time legitimising them through the participatory nature of the body.

The selection of participants represented in the Council has been based on two criteria. Firstly, the expertise one has in a certain field of interest to the programme's goals (BMVEL's goals) played a role. Secondly, the person's attitude towards the IRD concept (values) directed the composition of the board (Güthler 2006, Interview). This finding corresponds with results from participation and from expertise, namely the selection model of experts. Before the background of changes in Council composition, we can not appraise all Council members as being 'invited experts'. The initial composition of the Council, as a result of the immediate joint interests of BMVEL and its coalition, may be interpreted as an 'expert panel based on expertise and values' (Güthler 2006, Interview). All other interests have been included due to political pressure..$^{41}$

More generally speaking during formulation expertise has been consulted for process-related issues as well as for content-related ones (e.g. joint discussions of BMVEL and nova, where many central ideas of how to programme REGIONEN AKTIV such as the performance-dependent extra funds have been generated). Scientific expertise was perceived as being necessary and playing a 'very important role' among other sources of expertise (Augustin 2006c, Interview; Seibert 2006, Interview; Hinrichs 2006, Interview).

As regards impact of expert advice we found that even though (scientific) expertise through the accompanying research and the Administrative office is mobilised, its results and 'conclusions then are discussed in the Council' (Hinrichs 2006, Interview). Hence, scientific findings and conclusions are subsequently filtered in a board, which has been (at least partly) stocked for political reasons.

\section{Different level focus groups for enhancing the emergence and transfer of expertise}

A very important and unique aspect of the role expertise plays during the implementation period of REGIONEN AKTIV is the establishment of so-called regional and national focus groups. These focus groups have been installed in cooperation with the accompanying research to serve inter alia as a forum for the exchange of expertise, and the transfer of implementation experiences from the regional actors to administrational actors, the accompanying research, and the BMELV. Focus groups should gain and deliver "knowledge from inside" to science and the ministry42. During REGIONEN AKTIV, 27 meetings of regional focus groups and 2 meetings of the national focus group took place (Lukesch/Payer/Rabenau 2007). The focus groups were an integral part of the accompanying research and the central instrument for the flow of information in two directions (from the regional actors to the researchers and vice versa). Every focus group consisted of actors from different sources (participants of the regional partnerships, regional managers, project officials, relevant administrational actors) and served as a forum of discussion. The focus groups were organised and moderated by one partner of the accompanying research. The discussion in the focus groups should help to activate the expertise of the regional actors themselves (endogenous expertise) and to secure that their experiences can play a bigger role for the analyses of the accompanying research and the further development of integrated

41 As mentioned in the participation section, federal states have been included due to own pressure and the preference of the new Minister. The latter also caused the inclusion of DBV, while embracing ZDH and Tourist Associations has been symbolic coordination (alibi function).

42 See for the theoretical and methodological background of applying the concept of focus groups to Regionen Aktiv Lukesch, Payer, Rabenau (2007). 
rural development policies, especially by asking the actors for descriptions and estimations of the influences of political-administrational framework conditions. All in all, the focus groups should help to make important insider knowledge usable for the accompanying research and to formulate political recommendations. The latter have been developed in cooperation between the focus groups and the accompanying research. One main result of the work of the focus groups has been the design of an imaginary "ideal" funding programme for future policies of integrated rural development (some kind of a "list of wishes" of rural development actors). This draw (see Lukesch/Payer/Rabenau 2007 for documentation) has been added by important research results and the knowledge of the researchers of the accompanying research in order to formulate central policy recommendations, which genuinely integrate the ideas, experiences, and suggestions of the actors involved in integrated rural development policy. After different circles of discussion between the researchers and in the national focus groups the final version of the policy recommendations has been published (documented in Elbe, Kroes et al 2007). The focus groups are a very interesting example for the institutionalisation of emergence and exchange of different forms and sources of expertise by including all relevant actors in an equal way.

\section{A wider range of experts at implementation levels}

In the regional contexts different sources for expertise could be identified. External moderators and other consultants as well as external evaluators enter the processes from the outside (BMVEL 2004A: 15, 51). Regional management facilities and self-evaluation procedures contribute to the evolution of endogenous expertise, which is also demanded within and outside the REGIONEN AKTIV context (Hinrichs 2006, Interview).

Under REGIONEN AKTIV the use and consultation of external expertise (Universities, consultants, moderators, etc.) has been facilitated and even called for on ample occasions. This call is backed through the eligibility of regional management and external experts for REGIONEN AKTIV funds. ${ }^{43}$ The use of external advice was perceived to highly correlate with regions' success. 'The most clever and successful regions are the ones who do not hesitate spending enormous amounts of money for high quality consultancies. Too many regions, however, stew in their own juice and think they themselves can manage everything' (Schubert 2006, Interview).

One kind of such external advice were external evaluators. It has been reported, that some regions, e.g. the region "Lübecker Bucht" in Schleswig-Holstein and Mecklenburg-West Pomerania, even though they were not obliged to, had evaluations conducted (RALB 2005). Besides the positive effects from an iterative point of view, evaluation results have also been instrumentalised for arguing against critiques in the region and for illustrating progress made by the initiative (Hinrichs 2006, Interview). External evaluations dealing with the REGIONEN AKTIV programme, its implementation and impacts on the regional level have in addition been institutionalised in form of the granting of an accompanying research. The first team of three partners ${ }^{44}$ was altered after a first phase of research. The current team consists of 4 partners and has been contracted by BMVEL after a competition between different research proposals which have been evaluated by the BMVEL. The former team had been replaced with a group, where private consultants now play a more prominent role. This seems to be due to the perception that private consultants may serve as 'important linkages between science and practice (Augustin 2006c, Interview). Vast parts of these external evaluations have been based on the regions'

43 While regional management has been eligible to $100 \%$ it was not supposed to exceeded $20 \%$ of the region's budget. 'Information, training and consulting services', however, were eligible to $100 \%$ and have not been limited. Thus, in theory a region could have spent its whole budget on external advice.

44 Knickel et al. (2003); The team consisted of 1 University partner (IfLS), 1 public research institute (ZALF) and 1 semiprivate consultant which has been associated with a University (TUM-Tech $\mathrm{GmbH}$ ). 
self-evaluations. Hence, the scientific and semi-scientific consultant's expertise contributed by the partners has been enriched with regional types of expertise.

The self-evaluations by RPs, which have been a mandatory feature under REGIONEN AKTIV, are based on scientific methods explained in detail in Böcher (2006) and Böcher and Krott (2007) and were externally interpreted (by adding the knowledge of external analyses) by one module of the accompanying research (see for results Böcher and Tränkner (2007)). The system of self-evaluations was established in order to facilitate learning processes among regional actors and contributed to the evolution of regional or endogenous expertise (Hinrichs 2006, Interview). This type of expertise may be seen as mere experience or routine. However, it has been used and demanded by clients within the REGIONEN AKTIV community and even outside it. 45

The regional management facilities, which was supposed to organise and guide the regional process, on the one hand certainly function as a kind of secretariat (like GS) in the regional context. On the other hand organisational talent and the ability to moderate and mediate are all-important, lending the facility the function of a process expert.

All types of expertise employed at the regional level are rather process-oriented (Augustin 2006c, Interview; Hinrichs 2006, Interview) and were applied more or less continuously throughout the process. The variety and increase in the types of expertise employed in the regional contexts also was perceived as decreasing regions' dependency on scientific expertise only (Augustin 2006c, Interview).

Rules for open tendering also applied in the regional context, as public funds were spent (Schubert 2006, Interview). Hence, these rules again had an impact on expert selection or at least had to be considered. It, however, seems likely that expert selection was conducted independently from these rules and was matched to them subsequently (Schubert 2006, Interview).

\section{The accountability of expertise - accountable to whose standards?}

It is remarkable, that at both, formulation and implementation levels various kinds of expertise are mentioned. Arising from this fact it becomes obvious that different expectations are associated with the different kinds of expertise. The term 'accountable' consequently needs to be adjusted to each specific circumstance and associated expectations towards the experts. Roughly, we may discriminate accountability at the national and at the regional level. In the latter, accountability is likely to stem from social qualities of the expert, such as trust, social relation to expert, social acceptance and credibility, contributing to some sort of accountability in a region's own and individual sense. On the formulation level the 'democratic qualities' may play a more prominent role. Here, transparency has been a criterion. All materials have been published online, which also served justification of the programme against the parliament (Augustin 2006c, Interview). Legitimacy largely and primarily seems to stem from the 'scientific groundedness' of the expert (Hinrichs 2006, Interview), which does not exclude other sources of legitimacy.

Most interviewees' responses could not be interpreted in light of the concept of accountability. It was suggested to assess accountability (theoretical concept, deductive) in light of the criteria for expert selection (obtained inductively from empirical materials) (Schubert 2006, Interview). Primarily, the selection of experts was expected to support and promote the initiator's ideas, showing that expertise is

45 Under REGIONEN AKTIV several network meetings, workshops and training courses have been organised where regional actors (often regional managers) were asked to report on best practices, good experiences, etc. Similarly, regional REGIONEN AKTIV actors have been consulted on other IRD issues, e.g. a joint workshop together with the German LEADER+ Network Unit on possibilities of mainstreaming the Leader approach under the new EU EAFRD regulation (LEADER+ Contact Point Newsletter June 2007) 
being used for individual 'goal achievement' and 'illustrating and legitimising ones own ideas' (Augustin 2006c, Interview; Schubert 2006, Interview). This may lead to the conclusion that expertise has been instrumentalised. But as one interviewee correctly stated regarding the role and selection of experts: 'what do I need?' This statement makes clear that the first and foremost objective for consulting expertise is ones own goal achievement. Hence, the instrumentalisation here either has not been that obvious or it can be assumed as being inherent to the use of expertise and consequently did not have an impact on the experts' credibility.

Nevertheless, against the background of the concept of accountable expertise it can be stated that the implementation of Regionen Aktiv reflects some important aspects of accountability: Regarding transparency all information on Regionen Aktiv (that means every report, the self-evaluations of the regions, programme documents, all documents of the accompanying research, etc) are free to access via www.modellregionen.de. The synthesis report will be published on- and offline - its online version can be downloaded for free ("open access policy"). Regarding democratic and fair procedures in the use of expertise it is important that with the instrument of the focus groups an institution has been established for the bi-directional exchange and delivery of information between science and actors as well as a chance for regional actors to formulate their demands and problems with the programme and the accompanying research. Concerning the self-evaluation method, regional actors were asked to deliver their experiences with the first use of the method to reformulate the method for the next use. Regional actors were also asked to comment on drafts of this re-formulation in the forum of the internet page.

\section{Conclusions}

We observe an increase in the use of external expertise at both, the regional and national level as well as at all stages of the policy process (Table 9). At the latter expert selection processes get intermingled with requirements and standards for stakeholder inclusion as relevant for participation, as the Council serves both purposes (elements) and expert advice is exclusively addresses towards BMVEL. At the regional level RPs are primary addressees. However, external advice plays a very prominent role under REGIONEN AKTIV, unlike in the tradition of traditional rural development policy. As a consequence of the increase in expertise we observe a diversification in the types, resulting in the employment of regional endogenous expertise also outside the governance process. The role of science by interviewees was re-confirmed but not re-enforced. 46 Other sources of expertise gain importance, namely private consultants as link between science and practice as well as endogenous experts are increasingly acknowledged.

46 Science still plays a crucial and outstanding role. However, it did not increase its importance, but now exists parallel to other sources for expertise. 
Table 9: $\quad$ Significance of different sources for expertise at different stages of the process and different levels of action

\begin{tabular}{|c|c|c|c|c|}
\hline & Formulation (central level) & Implementation (regional level) & Evaluation & Re-formulation \\
\hline $\begin{array}{l}\text { Accompanying scientific } \\
\text { research }\end{array}$ & & $\mathrm{x}$ & $\mathrm{x}$ & $\mathrm{x}$ \\
\hline Focus groups & & $\mathrm{x}$ & $\mathrm{x}$ & $\mathrm{x}$ \\
\hline Science (general) & $\mathrm{x}$ & $\mathrm{x}$ & & \\
\hline Federal states & & $\mathrm{x}$ & & $x$ \\
\hline GS & $\mathrm{x}$ & $\mathrm{x}$ & $\mathrm{x}$ & $\mathrm{x}$ \\
\hline Council & $x$ & & $x$ & \\
\hline Business rep's & & $\mathrm{x}$ & & \\
\hline Private consultants & $\mathrm{x}$ & $\mathrm{x}$ & $x$ & $x$ \\
\hline Donors (BMELV) & $\mathrm{x}$ & $\mathrm{x}$ & $\mathrm{x}$ & $\mathrm{x}$ \\
\hline Endogenous regional expertise & & $\mathrm{x}$ & $\mathrm{x}$ & $\mathrm{x}$ \\
\hline
\end{tabular}

Source: $\quad$ Hinrichs (2006), Interview; Augustin (2006c), Interview

\subsubsection{Adaptive and Iterative planning}

In REGIONEN AKTIV we identified several features which can be interpreted as lending the process an iterative and/or adaptive character. In general, BMVEL's approach of delivering a pilot programme and testing new approaches in rural development, which then were supposed to inform mainstream policy such as GAK (BMVEL 2004A: 30, 48; Bundestagsdrucksache 15/4801 2005: 20; Augustin 2006c, Interview), itself can be seen as an iterative and adaptive process in the field of rural development policy. The pilot character of REGIONEN AKTIV is expected to lead to adaptations of mainstream policies (BMVEL 2004A: 30, 48; Deutscher Bundestag 2000: 20). However, the programme itself contains ample mechanisms relevant under this section.

\section{Regions vs. regions - Competition facilitating AIP}

REGIONEN AKTIV initially has been designed as a 3-stage programme, including 2 stages for competitive selection of model regions by the Jury. Based on the regions' proposed development strategies 33 candidates out of 206 applicants were accepted for stage 2. The final selection of 18 model regions by the Jury was followed by a 3-year stage of actual implementation (Elbe 2006: 13). The different stages allowed applicant regions as well as the Jury to reconsider, refine and reformulate their proposals and decision criteria respectively. Besides the selection procedure BMVEL offered the distribution of performance-dependent extra funds at two different moments. This special grant was linked to the relative degree of regional learning and goal attainment in individual regions, based on the self-evaluations and measured against the region's own goals and targets (see below under evaluations). ${ }^{47}$ Furthermore, regions on a monthly basis competed for 'the project of the month', which did not lead to significant increase in the adaptiveness or iterativity of the process. The competitive

47 The LGR has been granted as on-top financial allowance for regions based on the relative degree of the attainment of their own goals. In a first round 100.000 Euro per region could be acquired by each region, while in round 290.00 Euro could potentially be granted to each region. Elbe (2006: 187); Schubert, Tränkner (2006), Interviews 
approach taken under REGIONEN AKTIV has been fairly new in German rural development policy and touched upon the foundations of public funding policy (Augustin 2006c, Interview).

\section{Public with private partners - Partnership facilitating AIP}

The collaboration among public and private partners and periodic exchange was observed to facilitate the adaptiveness of REGIONEN AKTIV. Here the collaboration between BMVEL and nova Institut (GS) may serve as an example, where in continuous discussions the creation and development of innovations and ideas about how to further and continuously optimise and adapt the programme have emerged (Augustin 2006b, Interview). Similar processes may be assumed under regional conditions in the respective PPPs.

\section{An annoying duty - Reflexivity through reporting}

A thorough system of reporting obligations has been established which had to be accomplished by all model regions (Table 6). It comprised several reports at different stages of the process with different aims/intentions. Table 10 summarises in a wider sense all reporting duties under RA. Such a system was perceived as being necessary for triggering reflexivity and forcing regional actors to make conscious the way on which they want to arrive at goals. As beneficiaries refused doing so, BMVEL centrally selected instruments, such as uniform procedures for self-evaluation and the SMART method, for facilitating this reflexivity (Augustin 2006b, Interview). As a consequence, some regions sourced the tasks of reporting out to private consultancies, adding another potential loop for reflexivity to the process (Hinrichs 2006, Interview). The system of reporting especially in the model regions was perceived as being excessive and burdening. This view is shared with members of the Council and has also been revealed by Elbe (2006: 157) (Seibert, Hinrichs 2006, Interview). However, besides some common refusal among regional actors no one really obstructed reporting, evaluations or other elements of AIP initiated by the programme level (BMVEL, Council, GS), as all activities have been eligible for $100 \%$ funding and have been clear from the outset of the programme. However, reports were found to have limited impact only. Whilst the $1^{\text {st }}$ interim report revealed an imbalance in RPs composition and, as a result of this BMVEL together with the Administrative office and the Council counter acted this development (Hinrichs 2006, Interview), 'reporting does not serve as the primary source of information for subsequent programme adaptations' (Augustin 2006c, Interview). Hence, reporting must be assumed to also or even primarily serve for legitimising the spending of public funds, rather than for programme adaptations. Still, the reports, which included self-evaluation components, to a large degree have been the base for external evaluations. 
Table 10: Obligatory and necessary reporting under REGIONEN AKTIV requested from model regions

\begin{tabular}{|c|c|c|}
\hline Report & When & Aims of report (not complete) \\
\hline $\begin{array}{l}1^{\text {st }} \text { competition stage: } \\
\text { Visions for regions }\end{array}$ & $11 / 2001$ & Criterion for region selection to $2^{\text {nd }}$ stage \\
\hline $\begin{array}{l}2^{\text {nd }} \text { competition stage } \\
\text { Development strategy }\end{array}$ & $\begin{array}{l}\text { Application to REGIONEN } \\
\text { AKTIV 02/2002 }\end{array}$ & Criterion for final region selection \\
\hline $1^{\text {st }}$ annual report & After $1^{\text {st }}$ year of implementation & Initial successes \\
\hline Interim report I & 31.01 .2004 & $\begin{array}{l}1^{\text {st }} \text { self-evaluation exercise as base for ext. evaluations and } \\
\text { PERFORMANCE-DEPENDENT EXTRA FUNDS }\end{array}$ \\
\hline Progress report & 31.01 .2005 & $\begin{array}{l}\text { Incl. SMART method for goal re-formulation as base for ext. evaluations } \\
\text { and for granting extra funds }\end{array}$ \\
\hline Final report & 24.10.2005 and 31.01.2006 & Assessing and documenting impacts in regions \\
\hline $\begin{array}{l}\text { Updated development } \\
\text { strategy }\end{array}$ & Re-application for phase II & Improve participation in RPs and focus on value chains \\
\hline
\end{tabular}

Source: $\quad$ Tränkner, Schubert (206), Interviews; Elbe (2006:chapter 3); Elbe (2006a: 5)

\section{Combining evaluations methods for learning}

Under REGIONEN AKTIV at least two different evaluation schemes have been employed. Firstly, the accompanying research as external evaluator has been contracted by BMVEL for assessing the approach in light of scientific discussions, b) analysing practical experiences and lessons learned and c) for actively facilitating and designing knowledge-transfer and learning processes (Elbe unknown). Hence, the task of this team has not been a mere technical output evaluation, but rather a process oriented external multi-disciplinary analysis and assessment of the implementation and the effects of Regionen Aktiv as well as securing of knowledge-transfer (focus groups, conference, publications) (Böcher 2006, Interview). External evaluations have also been eligible for REGIONEN AKTIV funding and were conducted in some regions (Lübecker Bucht, Ostfriesland, Mecklenburgische Seenplatte, list may not be complete) in addition to the obligatory evaluation exercises prescribed by BMVEL (Hinrichs 2006, Interview).

More interesting from a learning and adaptive perspective are the mandatory self-evaluations in the regions. These served as a central tool for visualising regional learning effects and for maximising regional self-reflexivity, but were not intended for rigorous assessments or the like (Hinrichs 2006, Interview). RPs in their initial development strategies have been requested to design a region-specific system for evaluation (BMVEL 2002d). After it became obvious that this task has not been addressed adequately by most regions ${ }^{48}$, BMVEL took the lead and formulated binding central guidelines for two evaluations. These were carried out together with the half-time reports and a subsequent progress report. Both self-evaluations were based on the method of 'success factors' (Böcher and Tränkner 2007, Böcher and Krott 2007), which has been developed as a method for participatory self-evaluations. Thus, a decentralised and customised regional system for evaluations failed and was replaced by a central scheme of uniform evaluation. The 'added value of such self-evaluation techniques has not been clear to everybody' and apparently could not be carried out without the pressure of making them an obligatory component of the programme by BMVEL. Still, some regions even conducted voluntary self-evaluations after they made good experiences with this tool (Hinrichs 2006, Interview).

48 Elbe (2006: 144) finds that only two regions proposed an own and decentralised evaluation system. 
The evaluation system employed under REGIONEN AKTIV, including both, internal and external evaluations, itself has evolved in an adaptive manner. No detailed plan for evaluations existed from the outset and the procedures evolved over the programming period (Augustin 2006c, Interview; Elbe 2006: 157). External evaluations by the accompanying research were focussed on inputs and their effects ${ }^{49}$, while internal evaluations by the regions aimed at assessing and reflecting process quality and potentials for improvement. Some external review of the development strategies in the phase of region selection by the Council may also be interpreted as evaluation (ex-ante (Elbe 2006: 142); A12) and focussed on issues of process design. Hence, the distinct system of evaluations covers ex-ante, accompanying (intermediate) as well as ex-post assessments.

The abovementioned features for evaluation have been applied throughout the implementation phase of REGIONEN AKTIV focussing mainly on the regional level. The processes of formulation and especially processes at the national level have not been subject to evaluations.

\section{Focus groups as loops for policy learning}

The focus groups described under the section on expertise also are relevant for AIP, as experiences gained at the regional level were reflected in the focus groups and in a two-way communication approach were fed back to the level of programme formulation. This feature has been an idea of the second team of accompanying research and consequently has not been planned from the outset. It certainly was intended, however, the idea emerged during the process of implementation.

\section{Unintended iterativity and adaptiveness}

While the above elements have largely been of an intended nature, also unintended features facilitated AIP. As an outstanding event the extension of the whole programme beyond 2005 and until the end of 2007 into phase II shall be mentioned. This has not been intentional from the outset and has been decided upon under the old Minister (sometime before September 2005; Hinrichs 2006, Interview). Thus, instead of running for 4 years the programming period was extended to lasting 6 years. This lends the process a certain degree of cyclical macro-design. This is supplemented by a cyclical approach to programme formulation. 50

Two reasons led to the extension of the programme. First, the regional initiatives and especially the regional management facilities should be stabilised, as they had not been self-sufficient. Secondly, no much so-called hard effects (job creation, subsequent investments, etc) had been achieved or visible yet. Hence, the extension of REGIONEN AKTIV can be seen as a learning process within BMVEL, who underestimated time needed for formation and initiation processes in the regions and for effects to occur (Schubert, Hinrichs 2006, Interviews). BMVEL used this discontinuity for making several fundamental adaptations in the programmatic framework. For phase II the representation deficit in the Council has been addressed by integrating the federal states, DBV and ZDH into the board (see participation). Furthermore, after having realised that during the original programme period (phase I) participation in

49 Kroes et al (2006) evaluated the relation between inputs (funding by BMVEL) and effects (soft effects referred to as 'intangibles', as well as hard effects on job creation and subsequent private and other public investments).

50 BMVEL together with the Jurry/Council and the Adninistrative office throughout the programme period intervened in a flexible manner, e.g. by selecting regions in a 3-staged process, by deciding on the LGR and by formulating detailed guidelines on uniform evaluations after implementation deficits occurred. Thus, we observed loops programme formulation parallel to programme implementation which gives the process a cyclical character 
the RPs also has not been as broad as intended51 BMVEL together with the Administrative office and the Council urged respective regions to counter-act this development. Lastly, for phase II all regions have been requested to apply for funding again. The proposals this time were supposed to include an updated development strategy which should be focussed on value chains for maximising economic effects. Thus, the unintended loop of programme extension encouraged BMVEL to reformulate the programme and to intervene with regard to participation at national and regional level.

Another unintended feature was observed in conjunction with goals and objectives. While at the programme level three qualitative objectives have been prescribed by BMVEL from the outset, a fourth one emerged during the process. All objectives were of a rather vague nature, poorly operationalised and no indicators have been developed, which led to problems in measuring the degree of achievement (Schubert 2006, Interview). The programme objectives have been kept general intentionally because BMVEL 'wanted to obtain visions from regions without too much guidance by pre-defined goals' (Augustin 2006b, Interview). Another reason can be seen in the highly politicised environment in which REGIONEN AKTIV has evolved. As it was a high profile project for the highly contested Green Minister Künast, clear and measurable objectives could have made the responsible BMVEL staff vulnerable to opponents' critique. In addition vague objectives lend the programme a certain degree of political flexibility, as political goals had also been subject to change in the meantime from once consumer protection and mad cow disease to rural development, employment and regional value added (Schubert 2006, Interview).

At regional level initially no realistic and operationalised goals were formulated (Schubert, Tränkner 2006, Interviews; Elbe 2006: 148). The competitive instrument of performance-dependent extra funds, however, was directly linked to the relative degree of goal attainment in the regions. But consistent target systems with criteria and indicators were necessary and had been an integral part of the programme's learning approach (Augustin 2006c, Interview). Hence, BMVEL intervened based on suggestions by the Administrative office and prescribed a specific method for goal formulation to all regions. The method is referred to as SMART goals ${ }^{52}$ and subsequently served as base for measuring regions' relative success.

The discrepancy between the call for and finally the enforcement of a target system in the regions on the one hand and the national level's inability for arriving at something comparable is remarkable and parallels rhetoric and practice described under ISC.

\section{Certain and not complex}

High degrees of uncertainty have been reported to constrain AIP. E.g. major political changes, as they occurred after the 2005 federal elections, were associated with uncertainty about new political directions and goals. The extension of REGIONEN AKTIV as a Green flagship project beyond the legislative period has been decided under the Green Minister. However, uncertainty about the actual implementation of this decision under the new Minister was high (Hinrichs 2006, Interview). As regards the overall programme design one has to say that the degree of uncertainty for regional actors intentionally has actively been kept low. The concise structures of REGIONEN AKTIV (this includes the leaving-out of the federal states as an intermediary level) was intended for offering a high degree of certainty and thus, 'enable regional actors daring to experiment more, other than under e.g. GAK, where

51 some processes have either been dominated by administrative actors or private sector actors have not been represented.

52 Goals should be formulated in a SMART manner, while SMART stands for S-specific and concrete; M-measurable; Aambitious; R-realistic; T-timely. (Kanatschnig/Schmutz 2000. c.f. Elbe 2006: 148) 
often unpredictable compromises were the result' (Hinrichs 2006, Interview). The same applies to the question of complexity. While building up new governance structures, which certainly lead to more complex political environments in a regional context, the programme/process as such has not been complex.

\section{Is REGIONEN AKTIV an iterative and adaptive programme?}

REGIONEN AKTIV in its rhetoric only occasionally called for iterativity and adaptiveness. We find hints for being 'reflexive' at both national but more importantly at regional level. The accompanying research, however, to a large extent focussed on issues of reflexivity (Elbe 2006: chapter 3). Hence, the rhetoric of REGIONEN AKTIV creates much lower expectations towards programme iterativity and adaptiveness, than does the conceptual frame around which REGIONEN AKTIV is built and which actually has been a guiding principle.

The above findings show that REGIONEN AKTIV, as compared to other programmes in the field of rural development, can be characterised as being highly adaptive, which in some cases has been due to an iterative approach. This iterative approach throughout the programme has been applied intentionally and is reflected by a) the step-wise approach taken to region selection and subsequent implementation, b) the periodic system of reporting including recurrent self-evaluations by the regions and finally, c) the 2-phased design of programme implementation beyond the original programming period. These three elements of iterativity exclusively have been of an intentional nature..$^{33}$ In addition, all three features also allowed for and resulted in various adaptations, such as improved regional development strategies, the re-formulation of regions' target systems and focussing on a value-chain approach after phase I of the programme. The latter example has been the only incidence, where such adaptations may be characterised as unintentional. ${ }^{54}$ Hence, all intended features of iterativity also lend the process an adaptive character. However, adaptive features also have been found independently from iterative ones. Informal discussions between BMVL and nova allowed for programmatic adaptations, as did the contracting of the accompanying research and the conduct of the focus groups with experts. Likewise, improper formulation of goals and target systems allowed for subsequent adaptations in the process, such as the formulation of uniform guidelines for evaluation, reporting and goal formulation. This, however, only holds true for the regional level, where SMART target systems have been established and consequently led to an unintended adaptation. At the national level this did not happen. Even though the programme goals have been known to be imprecise, no adaptations could be observed. This lack of adaptiveness has been fully intentional, as elaborated above.

53 One may argue that prolonging REGIONEN AKTIV beyond 2005 has occurred spontaneously due to a lack of hard effects (impact) and a low degree of continuity. However, extending the programme has originally been seen as an option by BMVEL (Hinrichs, 2006, Interview). The moment at which the decision for the extension occurred, yet my have been influenced by macro-political changes in the leadership of BMVEL (elections in late 2005 with the prospect that the socialist-green government will not be re-elected again). Hence, the actual decision has been part of the master plan and thus must be interpreted as intentional action.

The rules regarding iterativity as described here, have been laid down in the text of notification as well as in detailed guidelines on evaluation and reporting and can not be described in detail here (see BMVEL undated).

54 At least we can not provide evidence that the value-chain approach has also been pre-decided from the outset of programme implementation and thus been intentional. 


\subsection{Effects of REGIONEN AKTIV as a governance process}

REGIONEN AKTIV has been initiated as a programme for testing new approaches to rural development policy with special emphasis on alternative ways of farming. The goals of the programme have changed over time now addressing employment and regional value added.

The Federal Ministry for Agriculture together with a private consultant and societal groups formulated REGIONEN AKTIV. Implementation is supposed to occur at regional level in voluntary (Regional Partnerships, RPs) between public, civic, and private sector actors. Regional funds which are decided on by RPs shall finance the implementation of regionally agreed projects

REGIONEN AKTIV as a governance process already has shown effects in both, the programme environment (national and regional level) as well as in rural development policy.

\subsubsection{Output}

Public funding by REGIONEN AKTIV triggered processes of endogenous regional development in all applicant (206) and especially in 18 model regions which are based on multi-stakeholder boards for decision-making (RPs) and formulated in development strategies. Hence, the strategy for regional actors to cooperate and be awarded with public funds is relatively new at both, regional and national level in rural development policy. ${ }^{55}$

Under REGIONEN AKTIV new instruments have been applied, which have been tested under LEADER+ already. Regional management facility, the funding for formulating negotiated development strategies and the allocation of global regional funds all are new instruments in rural development policy, and were shown to be applicable and also successful in a rural development context.

During the original programming period of 2001-2005 REGIONEN AKTIV has been extended until the end of 2007. Phase II as a quasi-new programme (alternations in formulation, extra budget) has been an effect of a) the good experiences made so far and b) the lack of hard effects until 2005 (Hemmerling, Augustin 2006c, Interviews).

\subsubsection{Impact}

The impact most frequently reported was attitudinal change towards rural development policy. At regional levels actors, who formerly did not cooperate or even opposed each other, were observed to jointly implement the development strategies through joint projects. At national level the issue of an activating area-based approach to endogenous rural development policy has been prominently set on the agenda (Augustin 2006c, Interview) and led an uptake into some federal states' programmes. ${ }^{56}$ Some central associations at national level also altered their attitudes towards the approach, such as DBV who initially opposed the approach and now was perceived approving it. Likewise, some federal state officials would now also support the general idea, even though they would never publicly state this

55 LEADER+ also followed this approach as well as some preceding programmes of specific federal states. However, BMVEL by supporting this approach, also launched a broad discussion about rural development funding at the national and more importantly at the sub-national level.

56 Tränkner and Giessen (2007) exemplarily show Schlegwig-Holstein's rural development programme 2007-2013 as an example for taking up the general idea of REGIONEN AKTIV and formulating an initiative called 'AktivRegion'. This initiative takes an area-based and participatory approach as tested under REGIONEN AKTIV. 
(Güthler 2006, Interview). Finally, extension of the programme beyond its original period 57 and the use of REGIONEN AKTIV results by the new Minister Seehofer may also be interpreted as some kind of attitudinal change of the conservative Minister, who was expected to focus more on traditional sectoral strategies for rural development (Observation 2006a; Vogelgesang, Delbrück 2006, Interviews). However, all these attitudinal changes must be seen as assumptions and empirical indications. We were not able to test these changes against strong evidence. Hence, these changes in attitude may well be of a symbolic or strategic character only.

The extension of REGIONEN AKTIV into phase II illustrates a revised strategy taken by BMELV. Adaptations in formulation as regards regional value-chains and the inclusion of the federal states and partly also DBV are central components of this change in strategy of programme implementation. Contrary to the aforementioned changes in attitude this change in BMELV's strategy can be reconstructed in different documents.

The creation of regional identities as base and starting point for the evolution of social capital in the regions also was observed as an impact. Regional identities were revealed to be fundamental in endogenous regional development and social capital evolved through (obligatory) networking and cooperation. Hence, capacities were built for endogenous development processes (Schubert 2006, Interview).

Lastly, a negative impact was observed. The approach of leaving out the federal states resulted in some serious 'diplomatic irritations' (Vogelgesang 2006, Interview). 'This marks the one great disadvantage of REGIONEN AKTIV, namely leaving out the federal states of the programme' and lead to major disgruntlements between the federal government and the states. In Bavaria, as the most extreme example, the Minister of agriculture refused cooperation with the green project, whereupon the Farmers' Association (DBV's regional organisation) in Bavaria refused participation in REGIONEN AKTIV regions (Hemmerling 2006, Interview). However, as mentioned earlier the 'collateral damage has been well calculated' (Güthler 2006, Interview) and as a positive effect, this strategy has caused significant discussions on experiences with the approach between federal states and the federal government.

\subsubsection{Outcome}

REGIONEN AKTIV resulted in the setting-up and formation of numerous regional groups engaged in rural development of their own regions. Most effects have been described and evaluated within the final selection of 18 model regions, However, it was reported that regions which have not been selected, continued operations (OECD 2006: 95). Such mobilisation effects as well as an increase in social capital can also be attributed to the innovative nature of REGIONEN AKTIV. The joint planning and implementation of these projects was perceived to cause a 'cooperativisation' of actors, especially those who have not been used to work together (Schubert 2006, Interview).

Economically speaking regions as an average had a net benefit of 2.3 mio. Euro, which results in some 3.4 mio. at an internal rate of return of 4\% (Kroes, et al 2006: 5). Until the end of 2005 some 1000 projects, with a financial volume of 73 mio. Euro, have been implemented under REGIONEN AKTIV at regional level, some of which became self-sufficient and now may operate independently from public funds (Vogelgesang 2006, Interview). Of these 73 mio Euro about 50 mio. were granted by BMVEL, while 4 mio. originated from other public and another 20 mio. from private co-financing sources. In

57 The extension already has been decided under the former Minister. The new Minister, however, could have easily cancelled the pilot with minor efforts, as the financial equipment for phase II had not been decided on. Still, he did not want to enter into battle about some 7 mio. Euro for phase II and hence executed the extension (Hemmerling 2006, Interview). 
addition to these funds spent on implementation, REGIONEN AKTIV also had effects on subsequent investments of approx. 83 mio. Euro, of which 25 mio. come from private sources (Böcher et al. 2006: 31-35).

Job effects have also been observed. About 700 jobs (full-time-equivalent) could be maintained, while 760 new jobs have been created. The job effects as an average amount to 39 maintained and 42 newly created jobs per region. The costs for the creation of one job amounted to 49.000 Euro, which in comparison with other funding schemes REGIONEN AKTIV performs better than other schemes (Böcher et al 2006: 34). Interviewees, however, stated that they were critical and sceptical towards the economic effects and would not 'overextend' successes at the cost of their credibility and acceptance among experts (Vogelgesang 2006, Interview).

The most far reaching outcome of REGIONEN AKTIV in a rather political sense must be seen in its contribution to the re-formulation of various mainstream policies. The GAK as national mainstream policy, certain federal states' rural development programmes and partly also the EU's EAFRD policy (Augustin 2006c, Interview; OECD 2007: 116) have been affected by REGIONEN AKTIV.

- Experiences gained in REGIONEN AKTIV were supposed to stimulate the consideration of certain governance features into the national mainstream policy GAK (see chapters below). The positive practice of REGIONEN AKTIV had two effects: It was a reason for and an argument against critiques against the inclusion of integrated rural development measures into the GAK; (Augustin 2006c, Interview; Hinrichs 2006, Interview) I.e. regional management facilities as well as the formulation of integrated rural development strategies by regional actors which are now eligible for national co-funding under the GAK regime (Böcher 2005: 9; BMVEL 2004A: 21; Deutscher Bundestag 2005: 52). This first uptake of the new funding principle and area-based elements into the sectoral oriented GAK will support inter-sectoral approaches to a certain degree (Jäger 2006, Interview) and can be interpreted as 'a great deal politically speaking, but only a stone's throw regarding the content' (Gehrlein 2006b, Interview).

- OECD finds that the pro-active role of BMVEL under REGIONEN AKTIV as service provider rather than donor only, has been innovative at a European level (OECD 2007: 116). With regard to EU rural development policy the effects of REGIONEN AKTIV can be assumed. However, as being a national programme in the philosophy on IRD, or in the international arena more precisely an area-based approach to rural development, REGIONEN AKTIV among other such policies discursively contributed to the mainstreaming of the approach (Tränkner and Giessen 2007; Augustin 2006c, Interview).

Individual federal states' rural development programmes have been influenced by the experiences gained in REGIONEN AKTIV. Even though some federal states' representatives would not state this officially (Güthler 2006, Interview) the impact on such policies exemplarily has been described (Tränkner and Giessen 2007). E.g. the federal state of Schleswig-Holstein formulated an initiative called 'AktivRegion' around the main ideas of LEADER+ and REGIONEN AKTIV (Thoben 2006, Presentation; Tränkner and Giessen 2007).

Interestingly, for nature conservation policy, Regionen Aktiv-similar features are currently applied by the German "Federal Agency for Nature Conservation" (BfN). Here the since 1979 existing and wellestablished funding of the "Naturschutzgroßprojekte" (Large scale nature conservation projects with importance for the whole federal state) has been currently changed for optimisation tasks. In this optimisation phase a 2-stage-competition of regions will be started in 2007, in which regions have to formulate firstly a vision and - if well-evaluated - in the second stage will have to develop a concept for the valorisation of nature conservation for regional development until the end of 2008. This competition is supported by an external support administrative office (nova) and shall also lead to a cooperation 
between the BfN/Environmental Ministry and the BMELV. This competition is nearly completely new for German nature conservation policy and is - without doubt - inspired by the success of Regionen Aktiv.

\subsection{Conclusions on RA as a governance process}

REGIONEN AKTIV established genuine and outstanding mechanisms for participation at regional level. At national level, however, this element did not play such prominent role and was even constrained by other elements, namely the selection of experts for the same board (the Council).

ISC was addressed as an essential issue, but instead of applying this principle also in programme formulation at national level, the task has been shifted to the regions. We must assume that certain levels with varying degrees of institutionalisation of sectors are more capable of addressing this issue than others.

Similar conclusions can be drawn for MLC, as the leaving out of one territorial level (here it was the level which constitutionally was responsible for the policy issues at hand!) eased the application of REGIONEN AKTIV as a governance-like programme.

An increase in the use of external expertise includes a diversification on the demand and the supply side especially at regional level. The role of endogenous evolving expertise is acknowledged and was even further promoted than under LEADER+. The case of REGIONEN AKTIV, however, illustrates that a narrow consideration of the terms 'expertise' as well as 'accountable' may not lead us to a comprehensive understanding of this respective element of governance. Under REGIONEN AKTIV we, similar to LEADER+, found endogenous and evolving expertise partly fulfilling some requirements of accountability as playing an important role in the processes. We should therefore re-articulate our understanding of accountable, i.e. not just include for instance "democratic qualities" but also considering the social contexts and circumstances under which expertise is perceived as being accountable.

We also found that if one board (here council) is relevant for diverse elements of governance, conflicts among the theoretical claims as regards the different elements occur. In our case the selection of appropriate experts for the Council limited and even constrained proper participation mechanisms.

It is remarkable that under REGIONEN AKTIV the rhetoric on AIP made us expect less than what we found. Ample opportunities (intended and unintended ones) for reflexivity existed at both, regional and national levels. Yet, AIP at regional level has been given greater attention as the example of proper formulation of target systems with criteria and indicators nicely illustrates.

Summing up we may conclude that under REGIONEN AKTIV all governance elements have been actively touched upon. The regional level here plays a more prominent role than did the national level. Hence, we observed more far-reaching governance commitments and elements at regional level. We thus may assume that the governance elements under REGIONEN AKTIV have primarily been applied for overcoming implementation deficits and addressing political goals more effectively than for sharing power and empowering people. However, the focus and rigid inclusion of regional goals and objectives is a novel in rural development policy. 


\section{$7 \quad$ The 'GAK' Case Study - IRD-uptake by an Instrument of Mainstream Funding}

\subsection{Introduction to the Joint Task, Improvement of Agricultural Structures and Coastal Protection' (GAK)}

\section{The GAK traditionally}

In 1969, the German Federal Government based on Article 91 of the constitution (Grundgesetz, GG)58 initiated the so-called Joint Task "Improvement of Agricultural Structures and Coastal Protection" (Gemeinschaftsaufgabe zur Verbesserung der Agrarstruktur und des Küstenschutzes, GAK) promoting the continued existence of efficient and sustainable agricultural and forestal production in order to ensure Germany's competitiveness in the European common market as well as the improvement of coastal protection. This includes, e.g., measures to improve the production and working conditions, to make production more efficient, to compensate natural environmental restrictions, and land consolidation (UFZ 2005: 9).

According to the subsidiarity principle; responsibility for all policy fields not mentioned by the constitution lies within the federal states. Constitutionally, the federal states are responsible for agriculture, rural development, environmental and nature conservation. The federal government relating to the above topics only has competencies regarding agricultural structures and in promoting agricultural and forestry production. ${ }^{59}$ No such competency can be deduced for rural development measures, except for fields closely related to agricultural structures in a wide sense (Delbrück 2006, Interview; Vogelgesang 2006, Interview). This legal pre-condition is a core aspect which seriously has to be taken into account when studying the GAK.

The term 'Joint Task' illustrates that the federal government together with the federal states provide for funding opportunities concerning the 'Improvement of Agricultural Structures and Coastal Protection'. Funding shares usually amount to $60 \%$ of eligible costs stemming from the federal government and $40 \%$ from federal states respectively. ${ }^{60}$ In a system of joint framework planning, measures which are eligible for federal co-financing under the GAK are negotiated. The resulting framework plan contains measures, which may be taken up by federal states' programmes (e.g. rural development programmes, agricultural programmes ...) and which then will be co-financed by the federal government to $60 \%$. Such measures are grouped around thematic issues and bundled in so-called funding principles. The federal states' programmes make use of the GAK measures and federal co-financing in quite different way and widely vary in scope and content. Yet, the federal states for measures they want to offer are requested to further elaborate the measures through own guidelines (BMELV unknown: 4). However, the federal share of co-financing throughout all states is seen as a strong incentive for including respective measures into the states' programmes (Vogelgesang 2006, Interview). Implementation as well as

58 Article 91 defines the general possibility of the cooperation between the federation and the Federal states in Germany: "the Federation shall participate in the discharge of responsibilities of the Länder, provided that such responsibilities are important to society as a whole and that federal participation is necessary for the improvement of living conditions" (GG Art 91a), 1.

59 Article 91GG through the GAK and Article 74, 17GG

60 Shares may vary depending on the measures and eligibility under EU funds. 
monitoring and enforcement lies with the agricultural administrations of the federal states UFZ (2005: 9) (see Figure 12).

The GAK framework plan is being negotiated and decided within the so-called Planning Committee for Agricultural Structures and Coastal Protection (Planungsausschuss für Agrarstruktur und Küstenschutz - PLANAK), which comprises representatives from the federal government and federal states. Although the framework plan is being negotiated on an annual basis, planning periods amount to 4 years (e.g. framework plan 2000-2004) for complying with general requirements for public financial planning. The significance of this 4 year planning period, however, may be neglected (Jäger 2006, Interview).

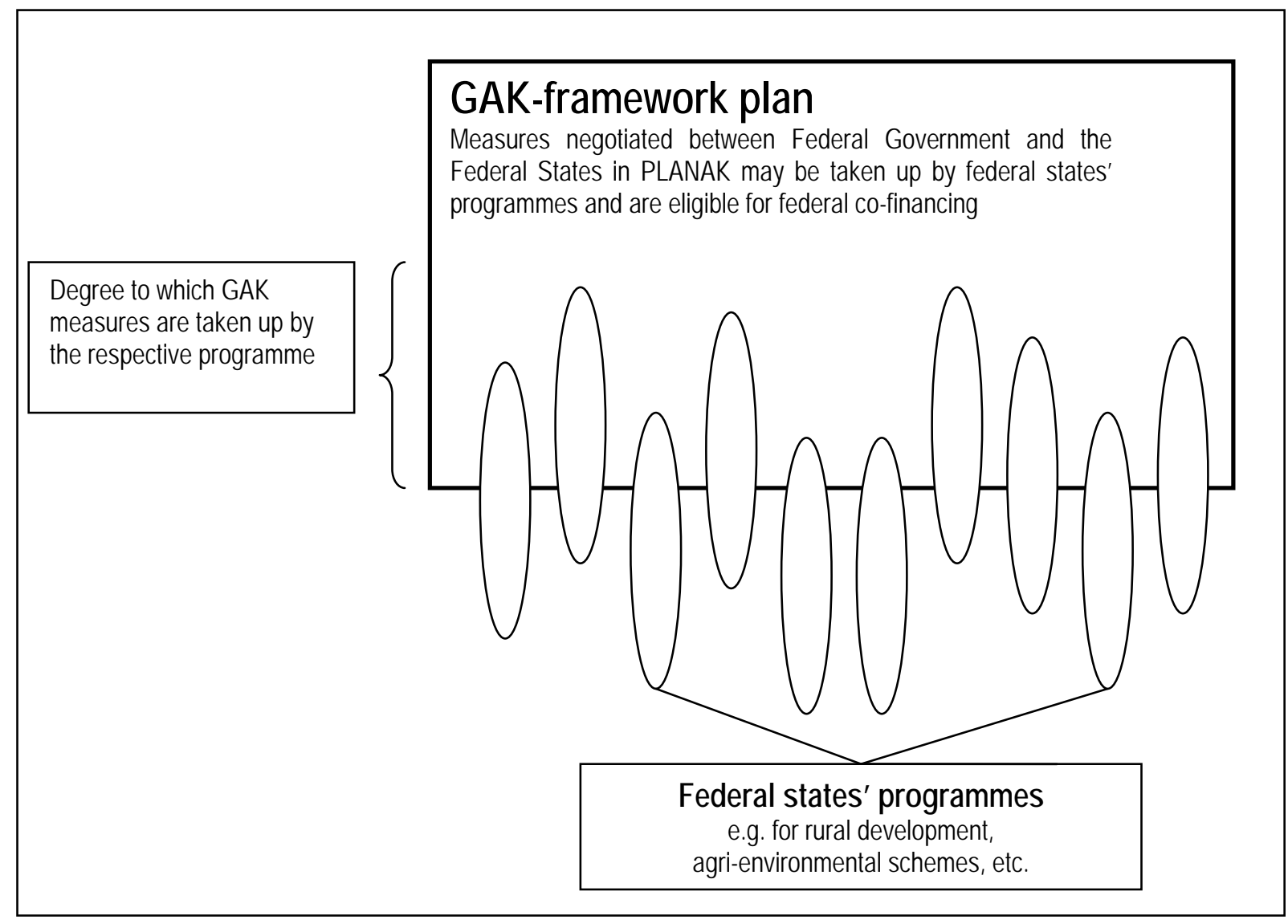

Figure 12: The GAK framework plan's role for the design of federal states' funding programmes

In 2003, the introduction of the new funding principles 'IRD' made essential elements of the approach part of the GAK, subsuming pre-existing 'spatial-relevant measures' as well as regional management and rural development concepts as 'new' instruments (Künast, c.f. BMVEL 2003: 2). Hence, the approaches for modern regional development described above were made an element of mainstream funding (BMVEL 2005: 5).

The GAK framework plan also serves as central instrument for the implementation of the EU structural agricultural policy and rural development policy. It serves as national framework regulation, as the federal states' programmes build upon the GAK measures. It replaces the approval of the individual programmes by the EU Commission and hence facilitates approval procedures significantly. This design has enabled the national co-financing of selected measures within the Rural Development Regulations of the EU. 
For the purpose of studying 'IRD' under the GAK and before the background of the LEADER+ case study different developments within the GAK framework plan need to be considered (see Figure 13). The introduction of the new funding principle in a mere national context plays a key role in this regard. In addition, the EU Rural Development Regulation, formerly known as Council Regulation (EC) No $1257 / 1999$, has been replaced by regulation No1698/2005 on support for rural development by the European Agricultural Fund for Rural Development (EAFRD; programming period 2007-2013). As an integral part of this new regulation for rural development the Leader-approach as one of four programme axis is being mainstreamed. Due to the GAK's functioning as national framework regulation for EU rural development policy, EAFRD will be made available to federal states' programmes through the GAK. Hence, for studying GAK dynamics regarding IRD as well as for investigating effects of the LEADER+ programme the GAK case study is being split into two parts: a) focussing on the IRD funding principle (2004-2007) and b) examining the effects of EAFRD concerning IRD aspects (2007-2013) as a kind of outlook study for the future of IRD in mainstream policy. For the former it seems also necessary to sometimes get back to the pre-IRD period for comparison.

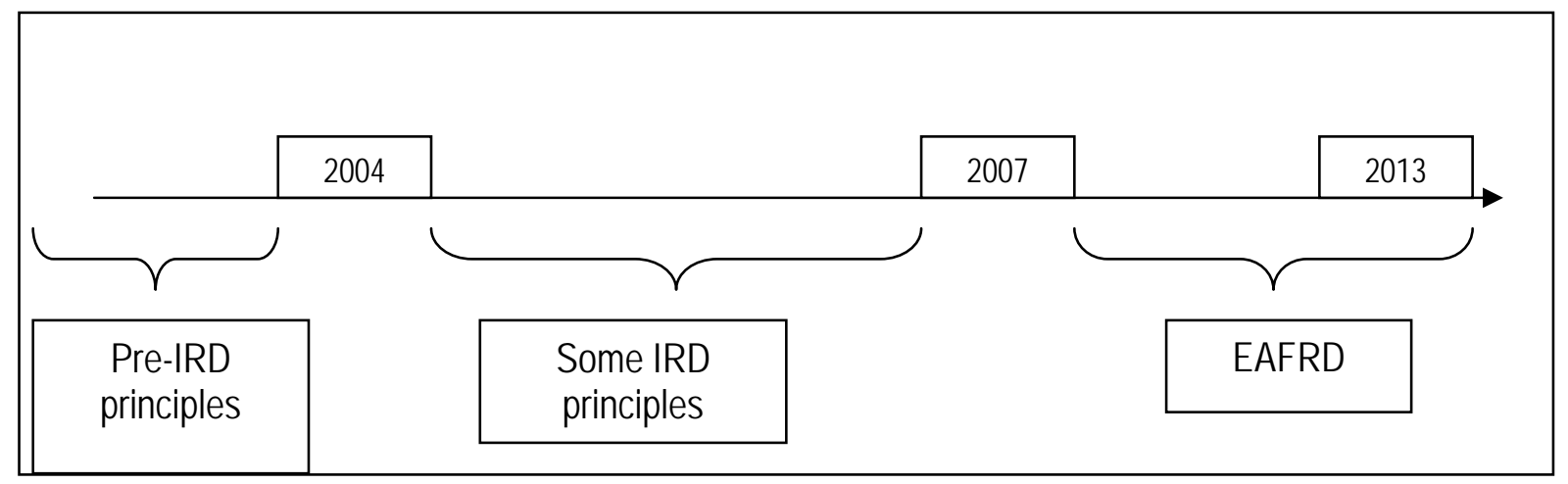

Figure 13: Dynamics of the GAK framework plan as regards 'IRD'-relevant changes

\subsection{Context factors}

The GAK adaptations towards IRD must be seen in the light of the former political setting, especially with regard to BMVEL. After the mad cow disease the green Minister Künast put 'Agrarwende' (Agrarian Turnaround) on the agenda and needed political success for demonstrating changes and adaptations in agricultural policy. In the light of the good experiences of LEADER+ and REGIONEN AKTIV in demonstrating this change, Künast pusher towards adaptations of the purely sectoral GAK. Due to this political pressure from the federal Minister and the in-house advocates for a more integrated approach to rural development, the GAK was amended in 2004.

The context of GAK adaptation, however, can not be seen in light of federal pressures only. Different federal states at that moment already applied the IRD principles within their respective rural development programmes. To a large degree these federal states' programmes used GAK co-financing for two specific measures, which can be seen as the forerunners of the IRD measures introduced in 2004: Firstly, agri-structural development programmes served as area-based, yet merely sectoral measures. Their limited scope and a lack of implementation soon was realised by federal states, who wanted to offer more integrated features. They, however, were bound to the GAK framework, which to a large degree constrained such innovations (Vogelgesang 2006, Interview). The federal state of Rhineland-Palatine for example already in the 1990s adapted this measure to the so-called 'Land- 
development moderation' 61 for facilitating implementation of the programmes. This innovation then was taken up by GAK as an accompanying measure for implementing the agri-structural programmes, the forerunner of the regional management facility, which was introduced as a IRD measure. ${ }^{62}$ In the federal state of Schleswig-Holstein these programmes have been implemented by so-called 'structure and development analyses for rural areas' 63 , which have been known for their progressive character (Hahne 2006, Interview). Thus, some federal states' demands regarding IRD measures and elements within the framework of GAK also serve as an explanatory context factor for GAK amendments as a governance process.

\subsection{Governance practices under GAK $2004-2006$}

Regarding the rhetoric and practices under the GAK one may distinguish two levels: on the one hand the process of framework planning may be considered as relevant, as funding principles and measures eligible for federal funding are negotiated and decided upon. On the other, measures at the implementation level may be researched for their effects regarding the 5 elements.

\subsubsection{Participation}

\section{Rhetoric}

The Arge Landentwicklung (a working group of representatives of relevant ministries of the federal states and the federal government legitimised due formal law) proposes a re-allocation of responsibilities among citizens and state. They call for an activating public administration and active participation of groups and citizens at all stages of the process (Arge Landentwicklung unknown: 16). WWF calls for more participation of societal groups in the planning and implementation of the GAK and their consultation in PLANAK decision-making (WWF et al. 2003: 3).

\section{Practices}

At the planning level, the PLANAK, only ministers from the federal states and the federal government are participating in the decision-making process, who appoint their representatives (Deutscher Bundestag 2005b: 8). According to the GAK-Act PLANAK comprises representatives from the federal government (Ministry of Agriculture, BMELV and Ministry of Finances, BMF) as well as one representative from each federal state's government. Usually federal states set in charge their Minister for agriculture or his/her representatives (Delbrück 2006, Interview). Hence, only state representatives are directly involved in the decision-making process as set out be legal pre-conditions. The formal exclusion of NGOs is determined by formal rules of the PLANAK.

Participation under the GAK framework planning regime is characterised by a high degree of informality (Hemmerling 2006, Interview). Formalised procedures for non-state actors to express their views and interests only exist in punktiform (Jäger 2006, Interview). NGOs are 'welcome to address their concerns to the PLANAK members', who in turn are perceived as being 'horizontally integrated into networks, which guarantee the influence of external interests'. Some NGOs such as DBV 'frequently and regularly

\footnotetext{
61 Landesentwicklungsmoderation

62 Umsetzungsbegleitung. Vogelgesang (2006), Interview

63 ländliche Struktur- und Entwicklungsanalyse LSE
} 
took influence in this way' (Jäger 2006, Interview), while others complain about the lack of involvement (WWF et al. 2003: 3). Besides directly contacting PLANAK members, informal influence in the highly hierarchical system of public administrations also can be achieved by consulting disciplinarians (e.g. the Under-secretary of State), who then may instruct the respective PLANAK representative to act in a certain way. ${ }^{64}$ It can not be fully estimated, which actors take influence in informal ways. However, DBV (farmers' association) has been reported frequently, while eNGOs seem not to be influential in this way (Hemmerling 2006, Interview; Jäger 2006, Interview; Seeling 2006, Interview; WWF et al. 2003: 3). DBV perceives itself as being 'close to the ministry' and as having 'a strong lobby' (Hemmerling 2006, Interview), OECD (2007) finds that especially two interest groups are prominently considered in GAK formulation. Firstly, and in line with our findings, organised farmers' interests take influence through their associations. Secondly, environmental associations gain importance. According to Schubert and Todt (2000) play an important role in giving advice to policy makers.

One reason has been provided for the strict exclusion of non-state actors from negotiations and decision-making: PLANAK negotiations often were about 'political trade-offs and solution packages, where one would not want to state why in particular a decision has been taken at which costs.' The decision-making process is kept confident 65 'for not making transparent who won and who lost' (Jäger 2006, Interview). These practices of (non-)participation were perceived to rest upon the fact, that GAK framework plans are passed by respective authorities without having to consult the parliament (Hemmerling 2006, Interview).

Formal forms of participation under GAK did not appear until the introduction of the new funding principle 'IRD' in form of a hearing of associations concerned. Additionally, more formalised forms of $P$ have been exercised under GAK during the formulation of a national rural development strategy, as required by the EU's EAFRD (Jäger 2006, Interview).

At the implementation level the reform of the GAK framework plan also has effects concerning participation. The funding of rural development strategies necessitates the involvement of 'citizens and relevant regional actors by appropriate means' (Deutscher Bundestag 2005b: 14). Here, the communal level was reported as being decisive for participation aspects (Hemmerling 2006, Interview). In contrast to REGIONEN AKTIV and LEADER+ requirements regarding participation, the framework plan defines communes and local associations of communes as beneficiaries for regional management and development concepts (Deutscher Bundestag 2005b: 13). 'The question now is, whether a meaningful dialogue with economic and social partners was the result of funding the measure' (Hemmerling 2006, Interview). Consequently, the fear of 'communal domination' of IRD processes has been reported frequently, even though practical examples for such trends are yet lacking (Güthler 2006,Interview; Hemmerling 2006, Interview; Gehrlein 2006b, Interview). Experts fear that 'less private funds and private engagement will be mobilised' by this approach (Gehrlein 2006b, Interview). The GAK framework plan merely requires communes to 'include the relevant actors of the region by appropriate means' during the formulation of the concepts and to document the process (Deutscher Bundestag 2005b: 14).

One interviewee stated, that while through IRD participation was promoted, the approach de-toured democratic principles such as the involvement of parliaments for legitimising spending of public funds. Deficits in the legitimacy of such practices were the results, along with a potential over-extension of honorary actors in the regions, who had to decide upon and be accountable for the approval of significant public funds. Such deficit in legitimacy, however, would apply to the whole practice of GAK framework planning (Hemmerling 2006, Interview).

64 Theoretical example given by Augustin (2006a), Interview

65 Minutes of the PLANAK sessions in general are confident; see BMELV (2005: 10) 


\subsubsection{Inter-sectoral coordination}

\section{Rhetoric}

So far the GAK had been an instrument for sectoral support only (Deutscher Bundestag 2000: 8). With the GAK "reform" in 2003 a new funding principle of "Integrated Rural Development" was created. Measures such as integrated rural development strategies and regional management are now eligible for federal funds (Deutscher Bundestag 2004: 1; Deutscher Bundestag 2005b: 53). Through this the 'sectoral approach' of GAK measures was perceived to be 'replaced by a more spatial approach' (BMVEL 2003: 1).

An official working group on land development urges the GAK to support integrated rural development approaches to make best use of the EU framework regulation on rural development and for being able to integrate different sectors in planning processes (Arge Landentwicklung unknown :11; 14).

\section{Practices}

In the general discussion on the GAK attempts are made to merge the policy into some kind of 'Joint Task Rural Development'. The former Minister Künast stated that the integration of IRD into the GAK was a milestone for 'further developing the GAK into an instrument for the development of rural areas'. The issue also seems to be high on the agenda of the present Minister (Künast; c.f. BMVEL 2003: 2; Vogelgesang 2006, Interview). This includes opening the circle of addressees from mainly agricultural actors to the wider range of rural actors, implying a shift from sector-oriented to inter-sectoral support. The introduction of IRD as a funding principle may be interpreted as one such 'tentative attempt' (Jäger 2006, Interview). Such opening of the GAK is being preferred by the BMELV as well as by some, but this is important - not all federal states (Vogelgesang 2006, Interview). It is, however, impeded by two main forces: firstly, the Federal Ministry for Finances (hereafter BMF) may have an interest in obstructing inter-sectoral application of the instrument and thus the widening of federal governments' responsibilities for limiting additional financial needs (Vogelgesang 2006, Interview). Secondly, federal states with a significant interest in classic sector-oriented agricultural funds also block a wider focus of the instrument (Vogelgesang 2006, Interview; Delbrück 2006, Interview).

Within the system of framework planning ISC to some extend is being exercised in the PLANAK. While the position of the federal government is subject to a customary procedure of inter-portfolio coordination ${ }^{66}$, the federal states usually do not follow this approach, but present only their rather sectoral positions (Delbrück 2006, Interview). Hence, ISC within the PLANAK may only be observed at federal level, where different portfolios (Ministries) represent different sectors ever since 1970.

The influence of other Ministries on the process is very little during PLANAK negotiations, but may be larger at the preparation stage during internal consultations within the federal government. The actual influence of different sectoral interests under GAK planning would not so much depend on the power of the sector/Ministry, but on the question if the federal states would agree to a certain issue. This, however, largely depends on the current power-relations in politics (Delbrück 2006, Interview). If, however, agreement may not be achieved at the level of representatives, 'one will climb up the hierarchical ladder' (Jäger 2006, Interview).

The bundling of pre-existing GAK measures and the introduction of two new IRD measures under the IRD principle was perceived as a 'political signal towards inter-sectoral approaches' (Vogelgesang 2006,

66 Portfolios concerned with issues dealt with under the GAK; Delbrück (2006), Interview 
Interview). However, the measures prioritise the need for strategies at regional level, but they do not facilitate sectoral integration. 'GAK hopes that (inter-sectoral) integration emerges in the regions' (Gehrlein (2006b). Thus, inter-sectoral planning may be facilitated by GAK funding, but ISC is not applied throughout the process of implementation as e.g. under LEADER+ and REGIONEN AKTIV (Hemmerling 2006, Interview). ISC under the GAK regime occurs at the formulation stage only for the federal actors and at the implementation stage, depending on the openness of IRD processes as lined out under. ISC hence takes place at the national and regional level. An increase of ISC actions, however, can be observed at the regional level during policy implementation, where rural development strategies have the potential of integrating diverse sectoral interests.

\subsubsection{Multi-level coordination}

Within the GAK the framework plan serves as legally based coordinating instrument between the federal government and the federal states. The plan is in effect for four years and subject to annual revisions allowing for continuous adaptations. For PLANAK to decide upon GAK issues, the federal government together with the majority of federal states (i.e. at least 9 of the 16 states are needed) have to agree. This distribution of decision-making powers within PLANAK leads to a certain interdependence among the two levels and all actors involved, as alliances for decisions are needed. ${ }^{67}$ Between the two levels negotiation is the prime logic of interaction. However, if consensus can not be reached, negotiations are complemented with hierarchical modes, i.e. if consensus can not be reached the issue is being communicated to the superior level of hierarchy, which then is in charge of finding solutions through negotiation. In addition, within each level hierarchy may play a crucial role in the pre-determination of positions and negotiation strategies (Jäger 2006, Interview). In 2003 the idea of integrating IRD into the GAK has 'been initiated and promoted by the federal government' and the Minister Künast (Green Party) against pre-occupations by some federal states (Augustin 2006c, Interview; Vogelgesang 2006, Interview; Jäger 2006, Interview).

The EU plays a 'very important role' in rural development policy delivered by GAK, as 'it involves a lot of money' (Vogelgesang 2006, Interview). This influence, however, is of a rather indirect nature as EU is not formally concerned (Jäger 2006, Interview). In accordance with Article 40(4) of the former rural development regulation (RDR) the GAK framework plan serves as national framework regulation for EU rural development policy (EU Commission 1999: 95). This frame integrates rural development plans, set up by the Federal states, mobilises funds at federal and federal state level and thus facilitates programme approval under the EU rural development regulation, since only the framework plan is subject to EU authorization instead of all programmes of the 16 federal states (Deutscher Bundestag 2004: 3; BMELV unknown: 5).

The framework plan makes regions, in form of communes, communal associations or registered associations (in German: e.V.) including communes, eligible for federal co-financing of rural development strategies, thus involving another territorial level into the process. As a consequence, regional delineation almost exclusively coincides with administrational boundaries (Augustin 2006a, Interview). Although the approach of recognising communes as beneficiaries (instead of farmers only) 'is not completely new to the GAK (...) with the introduction of IRD it has reached a new quality' extending the circle of actors involved in the governance process (Jäger 2006, Interview).

The system of GAK planning is characterised by a high degree of stability regarding the distribution of financial resources over federal states as well as measure-wise. It also is very stable as significant innovations and adaptations only occur rarely (Jäger 2006, Interview). Hence, the system's quality of

67 See Rudolph (2005) for different szenarios of decision-making and blockades 
being adaptive in the GoFOR sense must be neglected due to the over-stabilising (stagnating) effects of the multi-level design.

Due to the complex system of GAK planning the idea came up among PLANAK members (sometime in the past...) to directly transfer financial aid from e.g. the EU to the regions, without limiting their use to the measures mentioned in the framework plan (i.e. empowering the regions/communes). 'This would have led to a significant simplification of (rural development) funding. However, it was difficult for us to leave subordinate levels so much freedom' (Jäger 2006, Interview).

\subsubsection{Accountable expertise}

\section{Rhetoric}

No indications were found explaining the role of AE in the GAK context before the 2003 "reform". However, after the amendments made in the framework plan for the period of 2004-2007 a new funding principle "integrated rural development" with two new measures was introduced in the GAK. One new element is the eligibility of regional management which is characterised by organisational talent and the ability to moderate and mediate the development process. Statements do not call for accountability.

\section{Practices}

Within the system of framework planning external expertise only rarely plays a role. The degree to which joint planning under the GAK rests upon external expertise is extremely low. Internal expertise is perceived to suffice for the functioning of the system (Jäger 2006, Interview). Still, two kinds of external expertise could be identified:68 Firstly, evaluators are presented as the main source of 'intentional expertise'. The Federal Agency for Agricultural Research (FAL) as well as the Federal Research Agency for Forestry and Timber Trade (BFH) were the only sources of expertise consulted by the board. Ministry representatives responsible for a certain issue area within the GAK would consult the organisations if required and define questions to be addressed by the agencies. Secondly, the public feed-back by NGOs upon changes in the GAK framework was identified as rather 'unintended external expertise'. Hence, external expertise (intended and unintended) is mobilised at the stage of evaluation for issues of a rather technical nature. The former is associated with the federal administration system, lending the organisations democratic legitimacy and is perceived as accountable by PLANAK members. The latter may be interpreted as 'checking expertise', gaining legitimacy from the wide range of actors who potentially may comment on GAK changes.

Expertise in form of evaluations is being used indirectly in the discussion process of framework planning only if 'analogue and significant results' were presented. However, evaluations were also recognised as being occasionally instrumentalised in the political process of GAK planning. 'If results from evaluations conform with the own interests they are used, otherwise, if they contradict the own position the results are criticised.' This behaviour can be observed more frequently, at higher hierarchical levels (Jäger 2006, Interview). Yet, even though evaluations have been instrumentalised the evaluators (FAL and BFH which both are part of the Federal research system) do not seem having lost their credibility.

Regional management funded under GAK is supposed to help develop the regional strategy, operate financial management, facilitate networking among actors concerned, etc. The tasks associated with regional management in most regions were contracted-out to external service provider or communal corporations (Gehrlein 2006b, Interview). It hence serves the regional process 'in the generally

68 Based upon information provided by Jäger (2006), Interview 
acknowledged manner', as e.g. under REGIONEN AKTIV. Thus, it qualifies as a meaningful kind of inherent expertise delivering advice and other services throughout the implementation phase. It includes the processing of technical as well as processual problems of regional actors participating in the development process.

\subsubsection{Adaptive and Iterative planning}

The legal design of the GAK is very interesting as regards IP. As mentioned above, the framework plan is being negotiated for a 4-year interval by PLANAK and reviewed on an annual basis and may hence be characterised as a mandatory iterative process allowing for annual adaptations (BMELV UNKNOWN : 3; BMELV 2005b: 5). The practical significance of 4-year plans may be neglected as regards AIP, since it merely reflects a legal requirement for complying with general regulations on public financial planning (Jäger 2006, Interview). The GAK regime in general may be characterised by a low degree of uncertainty, as innovations/novels rarely take significant forms (Jäger 2006, Interview; Rudolph 2005). However, decision-making processes within the PLANAK may become highly complex, which they usually do not seem to be.

Annual programming or at least revision of the framework plan has a content-related as well as a financial aspect. Even if no adaptations are foreseen content-wise, the negotiation of finances among the federal states needs to be addressed (Jäger 2006, Interview). The procedure bears the advantage that financial needs for funding the measures are predictable.

Evaluations only play a minor role under the GAK. In the past few external evaluations have been conducted in form of case studies. They were used 'from time to time and sporadically'. Recently, however, evaluations had been commissioned by PLANAK on 4 GAK measures which were 'homogenously applied in all federal states', examining rather technical issues focussing on input and output. These evaluations were conducted by FAL and BFH (see Expertise) but will not be continued after 2007 due to 'problems in their implementation' (Jäger 2006, Interview). National and sub-national administrations were not interested in evaluations and they are not integrated into PLANAK's work culture. However, due to the involvement of the GAK into EU agricultural policy, evaluations as imposed by EU played an increasing role, and EU evaluations 'will always contain something useful for the GAK also'. The EU was also seen as the steward for more 'client-independent' assessments (Jäger 2006, Interview). Hence, no evaluation culture exists under the GAK, but is perceived as being 'in progress'.

Evaluations have been observed to be instrumentalised occasionally, especially 'at higher hierarchical levels' (see Expertise) and 'evaluations and political decisions do not always go along with each other' (Jäger 2006, Interview). Likewise, learning effects were perceived to occur 'rarely due to evaluations', as insights and findings were known form the representatives' own practice (Jäger 2006, Interview). Lastly, evaluations were perceived as being costly while the effort was high.

Aims and objectives under GAK are 'so broad, that they satisfied even the most different political nuances over time', hence functioning as 'a kind of tool for all purposes under different political constellations' and 'holds-out something for each of the EU objectives'. The broad goals also allow for adaptations without compromising or even having to amend the GAK-Act (Jäger 2006, Interview). As the GAK only serves as a framework plan, federal states' programmes are the level at which operationalised aims may be most appropriate. However, data indicates that also at sub-national level no operationalised aims are formulated for IRD measures (Augustin 2006a, Interview). Operationalisation of aims was perceived as 'problematic' as this does not allow for (political) flexibility and adaptability. 
IRD funding, however, requires the formulation of goals and criteria and indicators for goal attainment within the regional development concepts (BMELV 2005: 14, 15). The GAK did neither introduce competition elements, nor evaluation and reporting obligations, as has been executed under REGIONEN AKTIV and LEADER+ (Augustin 2006a, Interview).

\subsection{Effects of GAK as a governance process}

Effects of the GAK as a case were observed at two levels. At the level of federal states the joint GAK framework plan, which now included IRD measures subsumed under the IRD funding principle, has been the base for several rural development programmes. 10 of 13 states included the IRD measures into their post 2004 programmes. ${ }^{69}$ However, different 'intensities of integration' of the IRD approach into the federal states' programmes could be observed. Thus, no uniform effect could be deduced. Nevertheless, as of 2007 the EU's EAFRD regulation has been in effect, which as an integral part of EU rural development policy employs the Leader approach, which is based on the same IRD philosophy as the new GAK funding principle. ${ }^{70}$ Hence, federal states were expected to consolidate their funding programmes regarding these two options. Three options for doing so were identified by Gehrlein (Gehrlein 2006: 58):

- mainly focussing on and employing the Leader approach (expected in i.e. Schleswig-Holstein)

- employing both approaches, while the Leader approach will serve as an umbrella and guide both types (expected i.e. in Hesse and Lower Saxony)

- parallel existence of both types with different scope (expected e.g. in Rhineland-Palatine)

Even though the final decisions had not been taken in all states we may assume that the Leader approach will be employed in most states, replacing the GAK measures and even making them superfluous (Schubert 2006, Interview).

At the national level of joint GAK framework planning only limited effects were observed. The uptake of the IRD funding principle has been 'a great deal politically speaking, but only a stone's throw regarding the content' (Gehrlein 2006b, Interview). The adaptations under study should not be interpreted as 'new orientation'. However, due to the past political pressure the changes, 'which do not show significant substance', were exaggerated as being a reform (Jäger 2006, Interview). GAK in general is known to be rather repellent to significant changes and innovations (Rudolph 2005). In our case only minor effects have been achieved. An 'advancement in thinking' among GAK members has been reported (impact) (Jäger 2006, Interview). Slight changes as regards the content of the framework plan can be interpreted as effects of the process, such as the minimum size of territories eligible for funding and a bonus for GAK investment funds, if these were part of a development strategy (Output). From an IRD philosophy point of view the developments in GAK, in light of the mainstreaming of the Leader approach through EAFRD from 2007 on, have been of relatively low importance, significance and impact. Or as one

69 Germany consists of 16 federal states, of which 13 can be characterised as ,territorial states', while the other three (Bremen, Hamburg and Berlin) are considered city states with no distinct policy for rural areas or rural development.

70 The two approaches can not be seen as identical, because Leader goes far beyond what has been eligible under the GAK funding regime However, they build upon the same core measures of regional management and territorial development strategies formulated by a PPP. 
interviewee put it: 'The GAK funding for IRD is scrap! It was a misstep, an inconsiderate rush job because one did not consider developments at the EU level.' (Schubert 2006, Interview).

In recent years it is proposed to develop a national instrument to harmonise rural development policies and to make them more consistent (Deutscher Bundestag 2004: 3). The above governance trends in GAK towards integrated and place-based approaches to some degree have supported this idea of having a more inter-sectoral approach also at the national level of GAK (Impact).

Consequently, GAK IRD measures showed significant effects only in federal states' programmes. However, in light of the EAFRD Leader axis, which has been available as of 2007, these effects merely lasted from 2004 until the end of 2006, or until the individual states have consolidated their programmes and merged the two different IRD approaches.

\subsection{Conclusions on GAK as a governance process}

It became clear during the analysis of GAK already, that this case in a governance perspective was not so fruitful with regard to the elements. With regard to the difference in governance under pilot programmes and the mainstream policy, however, this case study helps us understand some major impediments for governance features.

GAK planning has been shown to be a state actors' exercise only. Despite some informal lobbying of one interest group only, participation at the national level of joint planning did not occur until the amendments of 2004. These consultations, however, only occurred in punktiorm and only the superior level of the EU was able to introduce some formalised participation through its EAFRD. At regional level participation has be shown to be also weak. In addition the threat of communal domination is likely to occur, as we already observed these trends under the pilot programmes LEADER+ and REGIONEN AKTIV.

The task of ISC institutionally could be addressed at the national level as well. However, agricultural elites of the federal states do not allow for an opening of the scheme by blocking participation to negotiations by other portfolios and by leaving out coordinating meeting among different portfolios at federal states level. At regional level ISC is associated with participation. Concerns about this issue have been raised above.

Regarding MLC it has been interesting that EU plays an important informal role. As being an exclusive affair between the federal government and the states, the GAK was shown to be frequently and significantly influenced by the EU (directly through regulations such as EAFRD and its mandatory evaluation system, through the significant amount of funds, which can not be ignored by GAK, etc). Apart from that, GAK has proven to be a system of MLC among the federal government and the states, which is highly stable. Thus, active coordination among levels is replaced by stagnation resulting from the 'joint decision trap' (Scharpf 1976).

Under the GAK no regularly or common use of external expertise could be identified. Evaluations under the regime occurred once, and were perceived as not being successful or even a waste of resources (Jäger 2006, Interview). The expertise of participants was reported as sufficing which was supplemented with public feed back as a sort of 'uninvited external expertise'. Only at regional level the support of regional management facilities may be interpreted in the light of external expertise and again adds to the notion of evolving endogenous expertise, which plays an important role under the IRD practices. 
The GAK regime can be described as being highly iterative, but no adaptiveness results from that, as GAK did not show major change over more than 35 years. ${ }^{71}$ Evaluations are not welcomed in this highly politicised environment. Likewise, clear goals and target systems are not appreciated. The EU, however, functions as a steward for reflexivity as e.g. by requiring evaluations of its funding programmes.

Only very limited effects have been caused by the GAK amendments. If one interprets the effects, e.g. the uptake of IRD funding into federal states' programmes, in light of the EU's EAFR with its support for the Leader approach, the effects of the GAK are even diminished. Consequently, the GAK amendments must be interpreted as a minimum giving-in of a well-established mainstream policy to political pressures stemming from the green Minister Künast and the in-house advocates for IRD.

Summed up, we may interpret GAK as a system being reluctant of including new actors and sectors in various forms. Non-state actors as well as non-agrarian actors are excluded and external experts and evaluators are being left out of the process. OECD doubts that GAK has the capacity to addressing rural development issues in Western Germany while its focus in Eastern federal states merely includes agricultural structures. Hence, 'eastern and western federal states [...] follow different strategies in GAK, which however, are not focussed on the wider rural context' (OECD 2007: 109).

71 One may contest this point of view as regards the term 'significant'. Based on Jäger (2006, Interview), we may consider adaptations in 1975 (on disadvantaged areas), at the end of the 1980s (a special plan on extensive land use), in the early 1990s (supplementing the GAK's objectives) and finally the mid 1990's adaptations on altered use of agricultural facilities as being of a rather significant nature. Changes in the GAK framework plan such as the expansion of agrienvironmental schemes in 2004, the integration of 'facultative modulation' and the uptake of the IRD funding principle, however, are considered as politically driven and desired changes of little substance content-wise. 


\section{$8 \quad$ Linkages between IRD and forestry}

Forestry as a sector is perceived as playing a significant role and having a great potential in rural development efforts (Elands and Wiersum 2004). The rhetoric of IRD also calls for the inclusion of forestry into integrated development attempts (BMVEL 2005: 7). However, in the context of IRD forestry is being cited not nearly as often as agriculture, but always in conjunction with agriculture. Hence, the explicit calls for addressing forestry can be interpreted as mere rhetoric, as the combination 'agriculture and forestry' almost is a figure of speech. Likewise, calls for making rural development policy more integrated also use this phrase (e.g. '...must go beyond the sectors of agriculture and forestry ...'). Consequently, forestry is perceived as being included automatically and even above average, and subsequent tendencies of opening up funding programmes largely ignore the sector.

This notion is backed by findings regarding the role of forestry in IRD programmes. Ortner (2004) finds a 'high potential for forestry actors' at the regional level of LEADER+ implementation (Figure 14). This potential, however, is not being 'tapped' by forestry and forest owners andbesides some success stories of forestry participation to IRD programmes, Giessen et al. (2006) find only limited participation at the regional level.

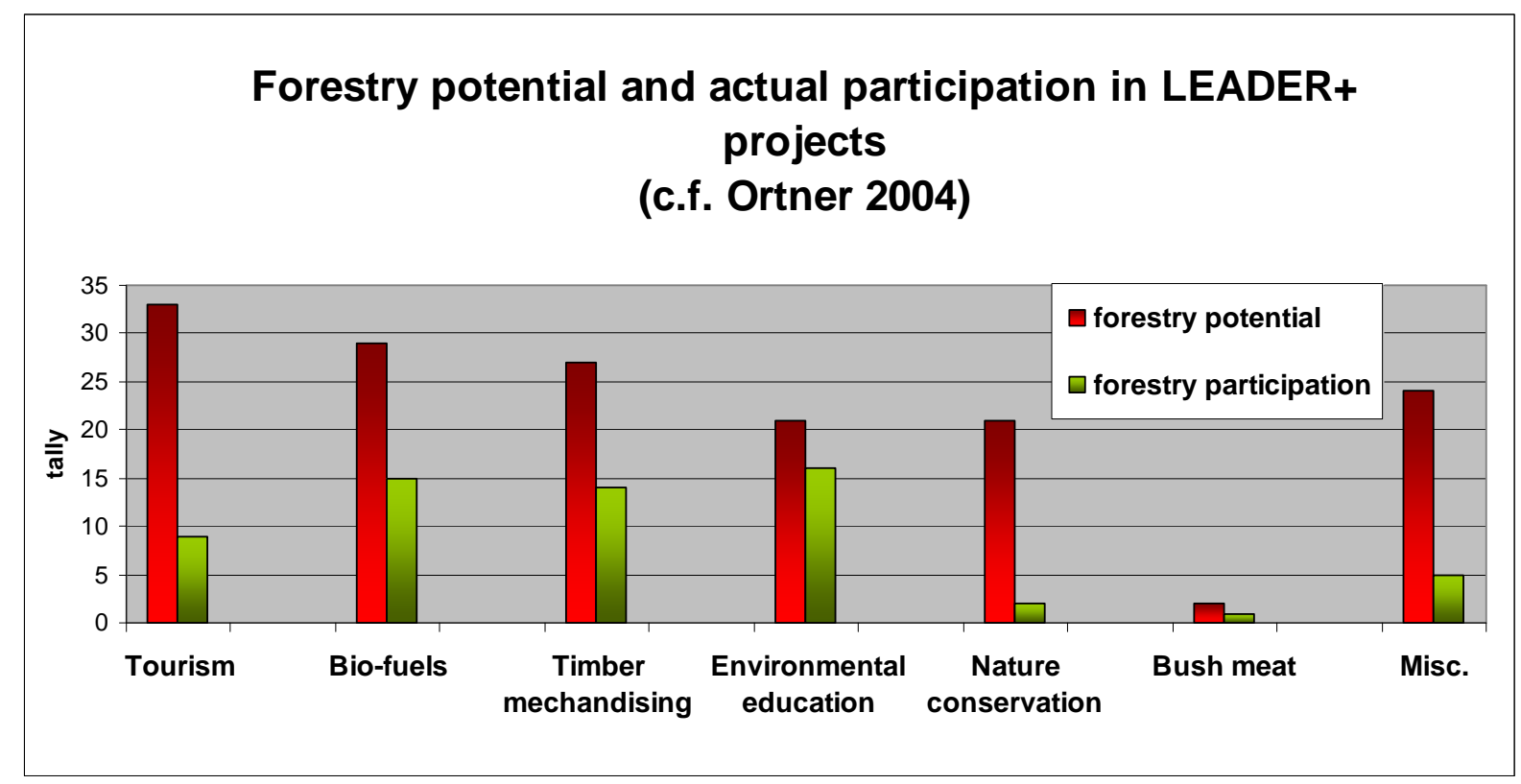

Figure 14: Forestry potential and actual participation at the regional level of LEADER+ implementation

Source: $\quad$ Giessen et al. (2006).

Similar to a low degree of participation at regional level, we observe forestry as being marginally affected at an institutional level (i.e. in ministries, associations, etc.). This was shown to be the case, even though broad and innovative potentials for and of forestry were perceived to exist (Giessen 2007). Different reasons for the discrepancy between the potential and the actual participation in IRD implementation are given by the author (Table 11): 
Table 11: Reasons for low degree of forestry participation to IRD programmes

\begin{tabular}{|l|l|}
\hline Reason & Example \\
\hline Institutional & Forestry as explicit business of federal states, no institutional capacities at other levels (national, EU) \\
\hline \multirow{3}{*}{ Sector-inherent } & Lack of information on programmes \\
\cline { 2 - 2 } & Lack of own resources for deliberations \\
\cline { 2 - 2 } & Traditional caginess of the sector \\
\hline \multirow{3}{*}{ Programmatic } & IRD programmes show high agricultural focus \\
\cline { 2 - 2 } & Lack of specific benefits for forest owners \\
\hline
\end{tabular}

Source: $\quad$ Giessen $(2007,2008)$

Besides such critical analyses and its bottom-line conclusion of incompatibilities between the sector and IRD programmes (Giessen/Krott 2009), regional level success stories show that content-wise this cooperation may be fruitful.

Under REGIONEN AKTIV the very successful region called 'Eifel' inter alia focussed its operations on forestry aspects. Under a regional umbrella brand also forest products such as timber and even furniture are traded (OECD 2006: 158). Thus, the region established its own regionalised certification system, whilst in parallel still applying FSC and PEFC schemes (Giessen 2006). In the further course of the regional development process in the Eifel region, the so-called "network future initiative Eifel", one special field of competencies is devoted to wood and forest economics (Böcher/Tränkner 2007: 91). The forestry sector is here one very important brick within the rural development process. In the $2^{\text {nd }}$ phase of REGIONEN AKTIV the wood value chain plays an important role for the development of the Eifel region and the specific goal of further establishing the regional "umbrella brand" Eifel.

Under the LEADER+ initiative also ample regional projects can be found where forestry actors significantly contribute and benefit from cooperation with other regional actors. In a LEADER+ publication of 100 selected projects of the Germany implementation of the programme ${ }^{72} 18 \%$ were found being of immediate and high relevant to forestry and respective actors (Table 12). Based on the contribution made by forestry these projects mainly address four categories. The share of $18 \%$ forestry participation under an IRD programme may not be overwhelming. However, these are best practice examples showing a high degree of quality. This finding supports result presented by Ortner (2004, see Table 12) of forestry participation to IRD programmes, yet underachieving its potential

Many other examples exist, where forestry successfully used IRD programmes for achieving their traditional or even re-formulated goals and interests. Giessen et al. (2006) as well as Ortner (2008) both present some of these success stories and in addition provide forestry actors with recommendations on how to cope with the challenges attributed to IRD programmes.

72 The selection did not take and evaluative or assessing approach following rigorous criteria. However, such an assembly of cases may well be interpreted as a selection of best or successful practices as the publication of these examples creates public attention as well as control. Moreover, within the LEADER+ community successful projects anyways seem to be well known. 
Table 12: Best practice examples of forest-related projects under LEADER+, sorted after categories and dimensions of sustainability

\begin{tabular}{|c|c|c|}
\hline Dimension & Category & Example \\
\hline \multirow{7}{*}{ Social } & \multirow{4}{*}{ Recreation activities } & Forest-experience centre \\
\hline & & Oasis of senses - Nature experience trail \\
\hline & & Network for nature experiences \\
\hline & & Barrier-free nature experience \\
\hline & \multirow{3}{*}{ Social integration } & Migrant integration through environmental education \\
\hline & & Forest-located day care \\
\hline & & Integration of unemployed youth through re-cultivating woodlands \\
\hline Ecological & Nature conservation & Network land care in wetlands \\
\hline \multirow{10}{*}{ Economic } & \multirow{10}{*}{ Wood products and marketing } & Bundling wood supply from small private forest owners \\
\hline & & Regional umbrella brand for wood and other regional products \\
\hline & & Valorisation and conservation of White Fir \\
\hline & & Lignin from regional timber subsisting oil \\
\hline & & Competence centre wood \\
\hline & & Self-sufficient on bio-energy - Jühnde \\
\hline & & Wood chips for a school \\
\hline & & Initiating a regional market for fuel wood \\
\hline & & Fuel wood for reducing CO2-emissions \\
\hline & & Fuel wood as core part of a region's energy strategy \\
\hline
\end{tabular}

Source: $\quad$ Based on DVS (2006). 


\section{$9 \quad$ Closing the frame: IRD as New Mode of Governance?}

\subsection{Overall effects of the IRD philosophy as a governance process}

\subsubsection{Impact}

For OECD a common effect of place-based IRD policies is that, 'even if they do all yet involve significant funding, they contribute to important culture changes with respect to rural policy' (OECD 2006: 18).

The local and institutional actors benefit from the interactive learning process which is initiated by Leader-like approaches. 'The authorities comprehend and perceive that cross-coordination and horizontal and vertical interface management constitute an effective method to manage the public resources. This is conceived as a gain in quality in regional governance and influences positively the know-how pool of the public administrations' personnel'. Moreover, LEADER-type programmes produce synergies with other regional development measures (ÖIR 2004: X).

\subsubsection{Output}

The IRD philosophy as the most tangible effects has produced several programmes for funding rural development activities. The LEADER+ and REGIONEN AKTIV programmes, having a pilot character, were shown to be among the most advanced IRD programmes. Mainstream policies, such as EAFRD and GAK, can be described as being more reluctant of taking up IRD elements. However, as the policy change has proven under both policies, also these systems have taken up IRD features. Hence, the outputs generated by the IRD process can be described and even being measured in terms of funding programmes based or at least strongly influenced by the philosophy. The EU Community Initiative LEADER+ as well as the German pilot project REGIONEN AKTIV have to be mentioned in this regard. IRD elements have even entered into most of contemporary approaches to rural development. In a German context IRD currently is entering a phase of more wide-spread application and mainstreaming because of the GAK amendments and the new EU regulation EAFRD 2007-2013, under which the Leader approach will be mainstreamed and strengthened (EU Commission 2006). ÖIR (2004: VIII) finds different degrees or intensities of mainstreaming of 'Leader-like approaches'. Strong and full mainstreaming e.g. in the federal state of Hesse was followed by weak and light mainstreaming (e.g. in most other federal states of Germany). As one additional example of 'strong mainstreaming' Tränkner and Giessen (2007) find the rural development programme of the federal state of Schleswig-Holstein. 


\subsection{Conclusions on IRD as a governance philosophy}

\subsubsection{Comparison of programmes' practices with programmatic rhetoric}

Our overall case-study design (having 3 concrete policy processes and one umbrella case on the overall rhetoric in IRD) allows for two different analyses as regards the comparison of rhetoric and practice. Firstly, we will investigate on the different programmes' alignment with its own programmatic rhetoric on the governance elements (Table 13). In the subsequent chapter, we make an attempt in comparing governance practices under the three different cases with the overall IRD rhetoric as outlined above (Table 14).

In Table 13 we analyse the degree to which the programmes conform to their own rhetoric as regards the governance elements. A lack in some programme's rhetoric concerning certain elements is conspicuous. This lack to a certain degree makes it difficult for us to really compare the different degrees to which the rhetoric of programmes is achieved. However, we may also interpret this lack as a programmatic strategy. Issues which due to capacity reasons can not be dealt with by a political (sub-) system are likely not to be addressed by the system. Hence, such lacking rhetoric may be interpreted as hints for non-addressing these governance elements by the respective programme. In the case of the use of expertise under LEADER+ at central level, we can not hold this hypothesis upright, due to a lack of information on this issue. The same holds true for the regional importance of MLC under GAK. However, for all other instances showing a lack of rhetoric, we may assume that the respective programme did not deal with the issue in practice and if there was rhetoric on this very issue, the programme would not have conformed to it. Hence, under this assumption, we may insert '-' (no conform with rhetoric) for most instances of '?' (lack of rhetoric) in Table 13.

Consequently, the most remarkable finding here is that on our continuum from a national pilot project (REGIONEN AKTIV) to a more established and continued EU-driven initiative (LEADER+) to mainstream policy (GAK) we observe a continuously decreasing degree of the programme's conformity with its own governance rhetoric. ${ }^{73}$ Or, the other way round, the more pilot character a programme has, the higher was its conformity with its own rhetoric.

Comparing LEADER+ with REGIONEN AKTIV we find that REGIONEN AKTIV shows no 'lacks of rhetoric', leading us to the conclusion that here policy makers dared to actively addressing all governance elements in the programmatic documents. As compared to LEADER+ this pro-active strategy in two cases resulted in negative alignment with the own rhetoric (Participation -central; ISC central). In a third instance, however, REGIONEN AKTIV by actively addressing the issue of Expertise at central level even exceeds its own rhetoric in this regard.

Additionally, under REGIONEN AKTIV two more instances of programme's 'over-achievements' of its rhetoric were observed (Expertise - regional; AIP - regional). We may take this as an indication that REGIONEN AKTIV, as being an ambitious programme governance-wise, performed very well in the comparison of rhetoric and practice.

\footnotetext{
73 For drawing this conclusion we include the indicator of lacking rhetoric as illustrated in Table 13 and assume that in most
} instances lack of rhetoric may equal non-alignment with potential rhetoric. 
Table 13: Comparison of governance rhetoric (as stated in the respective policy documents) and practices (as analysed in the case studies)

\begin{tabular}{|c|c|c|c|c|}
\hline Governance element & Level of reference & LEADER+ & REGIONEN AKTIV & GAK \\
\hline \multirow{2}{*}{ Participation } & Central & $?$ & - & $?$ \\
\hline & Regional & + & + & - \\
\hline \multirow{2}{*}{ ISC } & Central & $?$ & - & - \\
\hline & Regional & + & + & + \\
\hline \multirow{2}{*}{$M L C$} & Central & - & - & + \\
\hline & Regional & + & + & $?$ \\
\hline \multirow{2}{*}{ Expertise } & Central & $?$ & ++ & $?$ \\
\hline & Regional & ++ & ++ & ? \\
\hline \multirow{2}{*}{ AIP } & Central & + & + & - \\
\hline & Regional & + & ++ & $?$ \\
\hline
\end{tabular}

Legend: +: practice conforms with rhetoric; ++: practice exceeds rhetoric; - : practice does not conform with rhetoric; ?: no rhetoric exists against which to measure practice.

\subsubsection{Comparison of programmes' practices with the overall IRD rhetoric}

After having shown the programmes' relative alignment with own rhetoric, we now 'measure' conformity with some general IRD rhetoric derived from the IRD philosophy case study. Findings in Table 14 reinforce and even make clearer the above conclusion on the correlation between pilot character and the programme's alignment with governance rhetoric.

Here we also made two other finding. Cells in Table 14 with a grey background illustrate these findings. Firstly, we did not identify rhetoric (i.e. programmatic statements and other normative claims) regarding two elements, i.e. participation at the central level of programme formulation and the use of expertise at the same stage. Of cause we may have missed particular parts in the detailed discussions in this regard. We, however, assume that no much scientific or political discussion has been going on so far on the two issues and hence, may be intensified in the future. Secondly, we observe that REGIONEN AKTIV exceeds the IRD rhetoric twice, which stresses our above finding of a programme which overachieves its own and more general rhetoric. 
Table 14: Comparison of governance rhetoric (as lined out in IRD philosophy) and practices (as analysed in the case studies)

\begin{tabular}{|c|c|c|c|c|}
\hline Governance element & Level of reference & LEADER+ & REGIONEN AKTIV & GAK \\
\hline \multirow{2}{*}{ Participation } & Central & ? & $?$ & $?$ \\
\hline & Regional & + & + & - \\
\hline \multirow{2}{*}{ ISC } & Central & - & + & - \\
\hline & Regional & + & + & + \\
\hline \multirow{2}{*}{$M L C$} & Central & - & + & - \\
\hline & Regional & + & + & - \\
\hline \multirow{2}{*}{ Expertise } & Central & $?$ & $?$ & $?$ \\
\hline & Regional & + & ++ & - \\
\hline \multirow{2}{*}{ AIP } & Central & + & ++ & - \\
\hline & Regional & - & + & - \\
\hline
\end{tabular}

Legend: +: practice conforms with rhetoric; ++: practice exceeds rhetoric; - : practice does not conform with rhetoric; ?: no rhetoric exists against which to measure practice; grey background: extremes of IRD rhetoric, either lacking (?-cells) or low profile of rhetoric (++-cells).

Against the background of the IRD philosophy the programmes we have investigated in this assessment stand for a typical phenomenon of integrated rural development politics. The national pilot programme Regionen Aktiv, formulated and implemented without being coordinated with the typical "veto players" of Germany's political system, the federal states, reflects the IRD philosophy at the most. This shows that the BMELV is at the forefront of political actors implementing IRD. LEADER+ as multi-level system between the EU and the German federal states reflects major aspects of IRD as well, nevertheless there are quiet some weaknesses due to administrational and bureaucratic reasons and problems due to the different implementation procedures in the responsible federal states. The GAK has just been complemented with some aspects of IRD - it is in no way an ideal programme of IRD due to its origin and tradition as central sector-oriented agricultural funding instrument and its shared responsibilities between the federal state and the LAENDER - all actors with different interests in IRD policies. Another important aspect is that the programmes with the highest level of "IRD-reflection" are still programmes without being that much important measured against their financial funding. LEADER+ has just a proportion of $1 \%$ of the whole EU structural funds (2000-2006). So the IRD philosophy represents rather a small part of the whole rural development policy, even if we take into account the new funding period with a $5 \%$ proportion of LEADER measures in the $2^{\text {nd }}$ pillar (EAFRD). Therefore we can conclude that the normative frame of integrated rural development and regional governance on the one hand ideally reflects the constituting elements of the current governance debate. The concept of governance plays a dominant role for designing normative models of policies for rural development. On the other hand the practical political programmes that really implement this normative frame are still rare and - if available - represent only a smaller percentage in the policy field. Nevertheless, it seems that in future this percentage will increase - and this tendency is one of the most important results of our assessment: we have the European EAFRD with an increased LEADER part, we have a continuous process of German conferences on rural development maybe leading to new funding programmes, we have a completely new but very similar political competition in the field of nature conservation, and we even can observe a slightly change in the very persistent GAK during the last years. Without overestimating these phenomena we can conclude that Governance in the policy field of integrated rural development is 
much more than just rhetoric - it is a well accepted and currently further developing normative-laden approach that finds its equivalence more and more in political practice, too. 


\section{List of references}

Agrarbündnis (2002): Perspektiven für eine integrierte Entwicklung von Landwirtschaft und Natur- und Umweltschutz in den Regionen - Positionspapier des Agrarbündnis.

Arge Landentwicklung - Bund-Länder-Arbeitsgemeinschaft Landentwicklung (unknown): Landentwicklung - Antworten auf aktuelle und künftige Herausforderungen im ländlichen Raum. Mainz.

Augustin, T. (1999): Der Diskussionsstand zu LEADER+ aus Sicht des Bundesministeriums für Ernährung, Landwirtschaft und Forsten. In: Deutsche Vernetzungsstelle LEADER II (Hrsg.): Regionale Entwicklungskonzepte planen und realisieren (Seminarbericht 5/1999): S. 14-19.

Augustin, T. (2007): Vorwort, in: Böcher, M./Krott, M./Tränkner, S. (2007): Regional Governance und integrierte ländliche Entwicklung, Wiesbaden: VS Verlag f. Sozialwissenschaften, in press.

Benz, A. (2003): Regional Governance mit organisatorischem Kern - Das Beispiel der Region Stuttgart. In: Informationen zur Raumentwicklung, 8/9 2003. Hannover.

Benz, A., D. Fürst, H. Kilper, and D. Rehfeld (2000) Regionalisation. Theory, Practice and Prospects in Germany. Stockholm.

Benz, A.; Meincke, A. (2007): Analyse der Governance Strukturen. Abschlussbericht der Module 3 und 4 zur Begleitforschung Regionen Aktiv 2004-2006. Available under URL www.regionenaktiv.de. Accessed 05.09.2008.

Bergmann, E. (2000) Nachhaltige Entwicklung im föderalen Kontext: Die Region als politische Handlungsebene. Pp. 215-239 in K. Bizer, B. Linscheidt, and A. Truger eds., Staatshandeln im Umweltschutz (Berlin: Duncker \& Humblot)

BMELV, Bundesministerium für Ernährung, Landwirtschaft und Verbraucherschutz (2006): Nationaler Strategieplan der Bundesrepublik Deutschland für die Entwicklung ländlicher Räume 2007 2013. Bonn.

BMVEL (2001): Regionen Aktiv - Land gestaltet Zukunft - Informationen zum Wettbewerb. Bonn.

BMVEL (2002a): Regionen Aktiv- Land gestaltet Zukunft - Dokumentation zu den Gewinnern des Wettbewerbs. Bonn.

BMVEL (2002b): Active Regions- Shaping Rural Futures - Competition Winners. Bonn.

BMVEL (2002c): Geschäftsordnung Beirat Regionen Aktiv. Bonn.

BMVEL (2003): BMVEL - Informationen Nr. 51. Bonn.

BMVEL (2004a): Regionen Aktiv - Land gestaltet Zukunft. Zwischenbericht zum Wettbewerb. Bonn.

BMVEL (2004b): Tagungsband Zukunft der ländlichen Entwicklung in Deutschland- Bausteine des erfolgreichen Wandels. Bonn.

BMVEL (2005): Actively shaping rural development - Guidelines for integrated rural development. Bonn.

BMVEL (2005a): Geschäftsordnung für den Beirat zum Modell- und Demonstrationsvorhaben "Regionen aktiv - Land gestaltet Zukunft". Bonn.

BMVEL (2005b): Aktualisierung Endbericht - Halbzeitbewertung des operationellen Programms Nationale Vernetzungsstelle Deutschland. Bonn.

BMVEL (unknown b): Notifizierungstext Regionen Aktiv. Bonn. 
BMVEL) (2002d): 1.Zuweisungsbescheid vom 17.06.2002. Bonn.

BMVEL, BUND, BN, DVL, GRÜNE Liga, NABU, WWF (2002): Naturschutz und ländliche Entwicklung Standpunkte zur ländlichen Entwicklungspolitik. Gießen.

BMVEL, Bundesministerium für Verbraucherschutz, Ernährung und Landwirtschaft (unknown): Gemeinschaftsaufgabe „Verbesserung der Agrarstruktur und des Küstenschutzes" Erläuterungen zu Rechtsgrundlagen und zur Funktionsweise.

Böcher, M. (2005): The concept of Regional Governance in different national funding programmes, paper presented to the international workshop "Regional Governance for Sustainable Development", Hagen: FernUniversität, Oktober 28-29.

Böcher, M. (2006). "Participatory policy evaluation as an innovative method to improve processes of sustainable rural development." Agricultural Economics Review 7(1): 49-62.

Böcher, M. (2007): The Concept of "Regional Governance" and the Promotion of Sustainable Rural Development Processes in Germany. Insights from the implementation of "Active Regions" and "LEADER+". Proceedings of the 1st COST Action E 51 Joint MC and WG Meeting 12-14 October 2006 Großpetersdorf, Austria. E. Rametsteiner. Vienna, Department of Economics and Social Sciences University of Natural Resources and Applied Life Sciences: 49-66.

Böcher, Michael (2008): Regional Governance and rural development in Germany - the implementation of LEADER+, in: Sociologia Ruralis, Volume 48 (4/2008), 372-388.

Böcher, M., Krott, M. (2007). Politikberatung durch autonome Diskurse - das Beispiel Erfolgsfaktoren für nachhaltige Regionalentwicklung. In: Krott, M. and Suda, M. (eds.) Macht, Wissenschaft, Politik? Erfahrungen aus der wissenschaftlichen Politikberatung im Politikfeld Wald und Umwelt. Wiesbaden, VS Verlag für Sozialwissenschaften: 175-202.

Böcher, M.; Elbe, S.; Langguth, F.; Lukesch, R.; Payer, H.; Rabenau, J.; Tränkner, S. (2006): Übergreifende Auswertung Teil 2 der Abschlussberichte REGIONEN AKTIV. Darmstadt.

Böcher, M.; Krott, M.; Tränkner, S. (2007): Regional Governance und integrierte ländliche Entwicklung, Wiesbaden: VS Verlag f. Sozialwissenschaften, in press.

Böcher, M.; Tränkner, S. (2007): Regionen Aktiv - Land gestaltet Zukunft Begleitforschung 2004 bis 2006. Endbericht des Moduls 5 - Erfolgsfaktoren und Rahmenbedingungen. Göttingen, University Press, in press.

Boehmer-Christiansen, S. (1995). "Reflections on scientific advice and EC transboundary pollution policy." Science \& Public Policy 22(3): 195-203.

Bruckmaier, K. (2000): LEADER in Germany and the Discourse of Autonomous Regional Development, in: Sociologia Ruralis Vol. 40, No. 2, April 2000, pp 220-227.

BTG - Bundesverband für Teilnehmergemeinschaften (2003): 10 Thesen zur nachhaltigen Entwicklung des Ländlichen Raums.

Bundesregierung (2002): Perspektiven für Deutschland. Unsere Strategie für eine nachhaltige Entwicklung, Berlin.

CEPF - Confederation of European Forest Owners (2005): Draft Position on COM (2004) 490 final. Brussels.

Deutsche Vernetzungsstelle LEADER+ (1999a): Die neue Gemeinschaftsinitiative LEADER+. Online under URL

Deutsche Vernetzungsstelle LEADER+ (1999b): LEADER+ - Die Europäische Initiative für den ländlichen Raum. 
Deutsche Vernetzungsstelle LEADER+ (2005): Die Zukunft von LEADER (ELER-Verordnung). Online under URL

Deutsche Vernetzungsstelle LEADER+ (2006): LEADER+ in Deutschland - Ausgewählte Projekte. DVS, Bonn.

Deutscher Bundestag (2000): Politik für ländliche Räume - Ansätze für eine integrierte regional- und strukturpolitische Anpassungsstrategie. Bundestagsdrucksache 14/4855. Berlin.

Deutscher Bundestag (2005): Agrarpolitischer Bericht 2005 der Bundesregierung. Bundestagsdrucksache 15/4801. Berlin.

Deutscher Bundestag (2005b): Unterrichtung durch die Bundesregierung - Rahmenplan der Gemeinschaftsaufgabe „Verbesserung der Agrarstruktur und des Küstenschutzes" für den Zeitraum 2005 bis 2008. Bundestagsdrucksache 15/5820. Berlin.

Douglas, David J.A. (2005): The restructuring of local government in rural regions: A rural development perspective. In: Journal of Rural Studies 21 (2005) 231-246.

DVS, Deutsche Vernetzungsstelle LEADER+ (unknown a): Aspekte der Partizipation - DVD. Bonn.

DVS, Deutsche Vernetzungsstelle LEADER+ (unknown b): Vom Umgang mit Ehrenamtlichen der Partizipation - DVD. Bonn.

EC (2006): Steering Committee. Online available under: http://ec.europa.eu/agriculture/rur/leaderplus/steercom/index_en.htm

Elands, B.H.M.; Wiersum, K.F (2003): Forestry and Rural Development in Europe - Research Results and Policy Implicationsof a Comparative European Study. Wageningen.

Elbe, S. (2006): Abschlussbericht des Moduls 2 - Einordnung des Steuerungsansatzes Regionen Aktiv. SPRINT. Darmstadt

Elbe, S. (2006a): Übergreifende Auswertung der Teil 2 der Abschlussberichte REGIONEN AKTIV. SPRINT. Darmstadt

Elbe, S. (unknown): Vorstellung der Begleitforschung REGIONEN AKTIV 2004-2006. Presentation held on several occasions.

Elbe, S. (2007): Die Voraussetzungen der erfolgreichen Steuerung integrierter Ansätze durch Förderprogram. Untersucht am Beispiel des Modellvorhabens Regionen Aktiv (Dissertation). Aachen.

Elbe, S./Günter Kroës/Arthur Benz/Robert Lukesch/Katrin Weiß/Michael Böcher/Max Krott/Anna Meincke/Ute Middelmann/Harald Payer/Jutta Rabenau/Sebastian Tränkner (2007): Begleitforschung "Regionen Aktiv" Synthesebericht und Handlungsempfehlungen, Göttingen, University Press.

EU Commission (1999): Council Regulation (EC) No 1257/1999 of 17 May 1999, on support for rural development from the European Agricultural Guidance and Guarantee Fund (EAGGF) and amending and repealing certain Regulations.

EU Commission (1999b): COUNCIL REGULATION (EC) No 1260/1999 of 21 June 1999 laying down general provisions on the Structural Funds.

EU Commission (2000): Commission Notice to the Member States of 14 April 2000 laying down guidelines for the Community initiative for rural development (LEADER+), 2000/C 139/05.

EU Commission (2002): Guidelines For The Evaluation Of LEADER+ Programmes.

EU Commission (2003): Fact Sheet Rural Development in the European Union. Luxembourg. 
EU Commission (2006): Fact Sheet The Leader Approach. Luxembourg.

Gehrlein, U. (2006): Integrierte ländliche Entwicklung in Deutschland. Bestehende Ansätze in den Bundesländern. und Entwicklungsperspektiven. In: AGRA-EUROPE 43/06.

Giessen, L. (2006): Integrated Rural Development Policies as Pathway for Innovations - An unexploited potential for forestry. Presentation held at the joint MCPFE - EFI conference on Policies Fostering Investment and Innovation in Support of Rural Development in Zvolen, Slovakia from 27.-29. March 2006.

Giessen, L. (2007): Forstliche Anschlussfähigkeit an sektorfremde Governance? Das Beispiel der integrierten ländlichen Entwicklung (ILE)-. Presentation to the 39th Forstpolitikertreffen held in Praque 2007.

Giessen, L. (2008): Forstwirtschaft zurückhaltend bei Programmen zur integrierten ländlichen Entwicklung -Analyse der politischen Ursachen. In: Forstarchiv, 79/3, 116-121.

Giessen, L.; Böcher, M.; Ortner, M.; Tränkner, S. (2006): Integrated Rural Development as pathway for innovations - an unexploited potential for forestry -. In: MCPFE (Eds.) Policies Fostering Investments and Innovations in Support of Rural Development, Zvolen, Slovakia, March 27-29 2006.

Giessen, L. and Krott, M. (2009): Forestry Joining Integrated Programmes? A question of willingness, ability and opportunities. In: Algem. Forst- $u$. Jagdzeitung. (in press).

Goodwin, M. (1998): The Governance of Rural Areas: Some Emerging Research Issues and Agendas, in: Journal of Rural Studies. Vol. 14, No, I, pp. 5-12, 1998

Gothe, D.; Hahne, U. (2006): ... und regionale Wertschöpfung lohnt sich doch! Arbeitsplätze und Einkommen durch regionale Wertschöpfungsketten im Holzbereich. In: Der kritische Agrarbericht 2006, p. 165.170. Agrarbündnis. Kassel.

Hahne, U. (1984) Ökologische Regionalentwicklung. Informationen zur Raumentwicklung 1/2, pp. 53-62

Hahne, U. (2004): Ländliche Regionalentwicklung mit LEADER+. In: Raumplanung 116, 199-204.

Hogl, Karl, Nordbeck, Ralf, Nussbaumer, Eva, Pregernig, Michael (eds) (2008): Synthesis Report. Deliverable to the European Commission (D12), Project No. 6447GoFOR "New Modes of Governance for Sustainable Forestry in Europe. Vienna, $279 \mathrm{p}$.

Knickel, K. (2002) Die Bedeutung multifunktionaler Landwirtschaft im Rahmen nachhaltiger Regionalentwicklung. Pp. 35-52 in K. Müller et al. eds., Wissenschaft und Praxis der Landschaftsnutzung (Weikersheim: Margraf-Verlag)

Knickel, K.; Siebert, R.; Ganzert, C.; Dosch, A.; Peter, S.; Derichs, S. (2003): Wissenschaftliche Begleitforschung des Pilotprojektes "Regionen Aktiv - Land gestaltet Zukunft" - Ergebnisse der Begleitforschung 2003 - Abschlussbericht. Frankfurt.

Kroes, G., Middelmann, U., Weiß, K. (2006): Abschlussbericht des Moduls 6 - Die ökonomische Analyse des Regionen Aktiv-Ansatzes. Dortmund.

LAG Rügen (2002): Lebensraum Rügen - Verantwortung für eine lebendige Heimat Bewerbung der Lokalen Aktionsgruppe Rügen zur Europäischen Gemeinschaftsaufgabe LEADER+

Land Use Policy Group (2005): European Agricultural Fund for Rural Development - Making the most of the Leader approach to deliver environmental priorities in European and UK rural development programmes.

Leader+ Contact Point (2007) Flash News June 2007. Brussels. 
Lukesch, R.; Payer, H.; Rabenau, J. (2007): Wissen von innen - Regionale Fokusgruppen in der Begleitforschung zu Regionen Aktiv. In: Böcher, Michael/Krott, Max/Tränkner, Sebastian (2007): Regional Governance und integrierte ländliche Entwicklung, Wiesbaden: VS Verlag für Sozialwissenschaften, in press.

Marsden, T.; Murdoch, J. (1998): Editorial: The Shifting Nature of Rural Governance and Community Participation, in: Journal of Rural Studies Vol 14, 1, 1-4.

Moseley, M. J. ed. (2003): Local Partnerships for Rural Development. The European Experience (Wallingford et al.: CABI publ.)

Nds., Land Niedersachsen (2002): LEADER+ in Niedersachsen - Konzeptskizze. Online available under : http://www1.ml.niedersachsen.de/leaderplus/leader-plus.pdf

nova (2007): Regionen Aktiv 2006-2007. Online available under URL: http://www.novainstitut.de/modellregionen/text.php?fid=300\&mexp=3\&click=500\&PHPSESSID=5da7b515611 $18 \mathrm{cb60c18c55a4cd5c884}$

OECD (2006): The new rural paradigm: Policies and governance. Paris.

OECD (2007): OECD Prüfbericht zur Politik für ländliche Räume - Deutschland. Paris.

ÖIR Österreichisches Institut für Raumplanung (2004): Methods for and Success of Mainstreaming Leader Innovations and Approach into Rural Development Programmes.

Ortner, M. (2008): Politische Stärkung der Forstwirtschaft durch Beteiligung an der integrierten ländlichen Entwicklung - Beispiel EU- Förderprogramm LEADER+. Dissertation Uni Göttingen, in press.

Ortner, M. (2004): Zusammenarbeit zwischen Forstwirtschaft und Leader+. In: LEADERforum (2004), Nr. 2, p 41.

Peter, S. and Knickel, K. (2006): Empowerment of regional partnerships - The example of the Regional Action Pilot Programme in Germany. In: disP 42 (2006), 3, pp 16-25.

Pregernig, M. (2007). Zwischen Alibi und Aushandlung: Ein empirischer Blick auf die Interaktion zwischen Wissenschaft und Politik am Beispiel der österreichischen Umwelt- und Ressourcenpolitik. Macht Wissenschaft Politik? Erfahrungen wissenschaftlicher Politikberatung im Politikfeld Wald und Umwelt. M. Krott, Suda, Michael. Wiesbaden, VS Verlag für Sozialwissenschaften: 43-79.

Ray, Ch. (2000): The EU LEADER Programme: Rural Development Laboratory, in: Sociologia Ruralis Vol. 40, No 2, April 2000, pp. 163-171.

Regionalpartnerschaft Lübecker Bucht e.V. (RALB 2005): 3 Jahre Region Aktiv Lübecker Bucht - Lust auf Mehr!, Lübeck.

Reimer, W. (2006): Die Rolle des Bundes in der ELER-Förderung über die Gemeinschaftsaufgabe „Verbesserung der Agrarstruktur und des Küstenschutzes". Presentation to the DBV conference ,EU-Förderung der Ländlichen Entwicklung', 06.10.2006. Berlin.

Rudolph, M. (2005): Agrarstrukturpolitik im vereinten Deutschland. Eine Analyse der Gemeinschaftsaufgabe "Verbesserung der Agrarstruktur und des Küstenschutzes" im Lichte der Neuen Politischen Ökonomie. Shaker.

Scharpf, F.W.; Reissert, B.; Schnabel, F. (1976): Politikverflechtung: Theorie und Empirie des kooperativen Föderalismus in der Bundesrepublik. Cornelsen.

Schoof, U (2002): Die Reform der EU-Strukturfonds von 1999 Zur Einfluss- und Entscheidungslogik in der Europäischen Strukturpolitik. Osnabrück. 
Schubert, D. and Todt, A. (2000), "Actors, Institutions and Attitudes to Rural Development: The German National Report", Forschungsbericht für den World-Wide Fund for Nature und die Statutory Countryside Agencies for Great Britain, Dezember 2000.

SRU (Der Rat von Sachverständigen für Umweltfragen) (1996) Sondergutachten Konzepte einer dauerhaft-umweltgerechten Nutzung ländlicher Räume, Berlin: Erich Schmidt.

Stöhr, L., and W. Schenk (1997) Die Umsetzung des EU-Förderprogramms LEADER. Raumforschung und Raumordnung 55 (6) pp. 421-431.

Team der Begleitforschung Regionen Aktiv (2006): STANDPUNKTE-PAPIER: Handlungsempfehlungen an Politik und Verwaltung (EU, Bund, Länder), www.regionenaktiv.de.

Thoben, H-J. (2006). Ländliche Entwicklung in Schleswig-Holstein - Initiative „AktivRegion“. Presentation online available under URL: http://www.leaderplus.de/data/0009EDE1B11F1538A6636521C0A8D816.0.pdf

Tränkner, S. (2006): Regional Governance und integrierte ländliche Entwicklung - Begleitforschung zum Bundesmodellvorhaben Regionen Aktiv. In: Raumforschung und Raumordnung 3 (2006) pp. 213-221.

Tränkner, S. and Giessen, L. (2007): Four paths of mainstreaming Leader in Germany. In: Soto, P. (Ed.) Which direction for Rural Development? - A report on certain innovatory features in the Rural Development Programmes of 11 Member States. Critica.

UFZ, Umweltforschungszentrum (2005): Promoting the Multifunctionality of Agriculture, Forestry, and Rural Areas - Design and Implementation of Public Policies in Germany. UFZ Discussion Papers 12/2005. Leipzig.

Wissenschaftlicher Beirat für Agrarpolitk beim BMELV (2006): Empfehlungen zur Weiterentwicklung der Politik für die ländlichen Räume (übergeben am 11.10.2006).

Woods, M. (1998): Advocating Rurality? The Repositioning of Rural Local Government, in: Journal of Rural Studies 14, 1, 13-26.

WWF (2002a): Auf dem Weg zu einer nachhaltigen Entwicklung ländlicher Räume in Europa - Studie Deutschland. Frankfurt.

WWF (2002b): Eckpunkte einer Weiterentwicklung der Politik für ländliche Räume - Fragenkatalog des BMVEL vom 13.02.2002. Frankfurt.

WWF (2003): For People and Nature - The Future of Rural Development in Europe. Frankfurt.

WWF, NABU, BUND, DNR, Euronatur, DVL (2003): Reform der Gemeinschaftsaufgabe Verbesserung der Agrarstruktur und des Küstenschutzes. 


\section{Interviews and Observations}

Anonymous (2006): Member to the Regionen Aktiv Council. Interview from 08.12.2006

Augustin, Theo (2006a): Head of Division "Rural Development", BMELV and Head of the Regionen Aktiv Council. Interview from 12.12.2006 by Tränkner

Augustin, Theo (2006b): Interview from 12.12.2006

Augustin, Theo (2006c): Interview from 08.03.2006

Böcher, Michael (2006): Research Assistant, Institute of Forest Policy, Göttingen University and Member to the Accompanying Research Team 2004-2006. Interview from 20.10.2006

Delbrück, Kilian (2006): Head of Division "Agriculture, Forestry and Rural Development", Federal Ministry for the Environment. Interview from 29.08.2006

Eberlein, Annika (2006): Technical Officer for Strategic Matters, BMELV. Interview from 27.10.2006

Gehrlein, Ulrich (2006): Senior researcher. Institut für ländliche Strukturforschung. Interview from 14.07.2006

Gehrlein, Ulrich (2006b): Interview from 14.11.2006 by Tränkner

Güthler, Wolfram (2006): Director of the German Landcare Association (DVL) and Member to the Regionen Aktiv Council. Interview from 20.12.2006

Güthler, Wolfram (2007): Interview from 11.06.2007

Hahne, Dr. Ulf (2006): Professor for Economy of Urban and Regional Development, University Kassel. Interview from 28.09.2006

Hemmerling, Udo (2006), Deutscher Bauernverband (DBV), Division on Economic and Regional Policy. Interview from 05.10.2006.

Hinrichs, Thorsten (2006): Technical Officer for REGIONEN AKTIV, BMELV. Interview from 04.07.2006

Jäger, Dr. Georg Ludwig (2006): Technical Officer for GAK, BMELV. Interview from 04.07.2006

Kleinfeld, Volker (2006): Ministry of Agriculture, Federal State of Mecklenburg-West Pomerania, Division on Land Development 340. Interview from 07.12.2006

nova Institut (2006): personal Email correspondence and Interview from 20.10.2006.

Observation (2006a): BMELV Conference on "The future of rural regions". 05.10.2006. Berlin.

Observation (2006b): Panel discussion of the focus group (NAP). November 2005. Göttingen.

Plätzer, Kerstin (2006): LEADER+ Coordinator, Federal state of Saxony. Interview from 16.11.2006

Reimann, Thomas (2006): Ministry of Agriculture, Federal State of Mecklenburg-West Pomerania, Division on Land Development 340. Interview from 07.12.2006

Schubert, Dirk (2006): nova Institut and Administrative Office of Regionen Aktiv. Interview from 25.09.2006

Schwörer, Matthias (2006): Head of Division "Sustainable Forestry", BMELV. Interview from 04.07.2006.

Seeling, Dr, Ute (2006): Executive Director, Working group of German Forest Owners Associations (AGDW). Interview from 09.10.2006. 
Seibert, Otmar (2006): Professor University of applied sciences Weihenstephan and Member to the Regionen Aktiv Council. Interview from 08.12.2006

Spöring, Helma (2006) Technical Officer for "Integrated Rural Development", Federal state of Lower Saxony and Member to the Regionen Aktiv Council. Interview from 30.11.2006

Stöppler (2006) Head of Division "Strategic Matters", BMELV. Interview from 02.11.2006

Swoboda, Jan (2006): Head of the LEADER+ National Network Unit Germany. Interview from 25.07.2006

Thomas, Frieder (2006): Director of the Working group of peasant agriculture (AbL). Interview from 12.06.2006

Vogelgesang, Heinz (2006): Technical Officer for "Integrated Rural Development", Federal state of Rhineland-Palatine and Member to the Regionen Aktiv Council. Interview from 22.12.2006

Walter, Norbert (2006): Technical Officer for LEADER+, BMELV. Interview from 14.04.2006 


\section{POLICIES FOSTERING} INVESTMENT AND

INNOVATIONS IN SUPPORT OF RURAL DEVELOPMENT

Taking into account forest owners perspective on enhancing economic viability through cooperation and innovation

PROCEEDINGS OF SEMINAR 27-29 March, 2006

Zvolen - Sielnica, Slovakia 


\title{
International Seminar on Policies Fostering Investments and Innovations in Support of Rural Development, held on 27-29 March, 2006 in Zvolen - Sielnica, Slovakia
}

\author{
Organized by: \\ MCPFE Liaison Unit Warsaw \\ European Forest Institute \\ EFI-INNOFORCE Project Centre, Austria \\ Ministry of Agriculture of the Slovak Republic \\ National Forest Centre, Slovakia \\ Slovenská lesnícka spoločnost', Slovakia \\ Confederation of European Forest Owners \\ Union of Foresters of Southern Europe
}

Edited by: Ilpo Tikkanen, Olga Zyrina, Ewald Rametsteiner, Oscar Barreiro \& Roman

Michalak

\section{Prepared by:}

Ministerial Conference on the Protection of Forests in Europe

Liaison Unit Warsaw

ul. Bitwy Warszawskiej 1920 r. Nr 3

00-973 Warsaw, POLAND

Tel: +48 2233170 31, +48 223317039

Fax: +4822331 7032

E-mail: liaison.unit@lu-warsaw.pl

\section{Disclaimer}

This publication comprises the presentations and outcome of the International Seminar on Policies Fostering Investments and Innovations in Support of Rural Development, held on 27-29 March, 2006 in Zvolen - Sielnica, Slovakia. They reflect the views of the authors, which do not necessarily correspond to those of the Ministerial Conference on the Protection of Forests in Europe (MCPFE). Neither the authors, editors, the MCPFE, nor any person acting on their behalf are responsible for the use, which might be made of the information contained in this publication.

(C) Ministerial Conference on the Protection of Forests in Europe, 2006 


\section{CONTENTS}

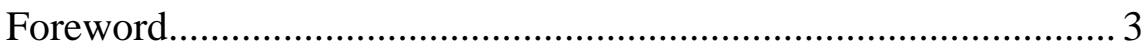

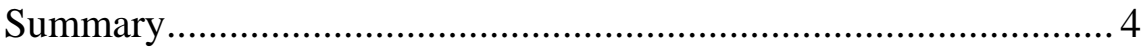

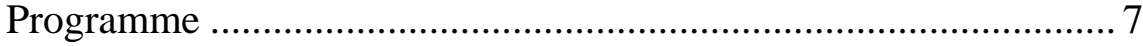

List of Participants.................................................................... 11

Z. Simon

Welcoming Address ................................................................. 14

J.-L. Martres Perspectives and Objectives of the Forest Owners of the

South of Europe ............................................................................ 16

M. Lazdinis EU Rural Development Strategy and Emerging Policy

Issues in Forestry ...................................................................... 20

E. Rametsteiner, Forest-Related Innovation and Investment Policies and

A. Bauer $\quad$ Rural Development Strategies - Key Issues .................................. 26

C.-G. Beckeman Fostering Innovations Through the Forest Technology

Platform ....................................................................................... 36

L. Giessen, Integrated Rural Development as Pathway for Innovations

M. Böcher, M. Ortner, - An Unexploited Potential for Forestry ........................................ 38

S. Tränkner

C. Pinaudeau

Fifteen Years of Co-Operation of the Forest Owners of Southern Europe ...................................................................... 57

A. Whiteman Policy Co-Ordination in Support of Rural Development:

Role of Forestry Investments....................................................... 61

F. Borlea Approaches to Integrating Investment Incentives into

National Forest Policies - A Regional View and

Experiences from Romania

I. Korsbakken Forest-Based Tourism as an Example of Developing the Full Economic Potential of Forest Holdings .................................. 73

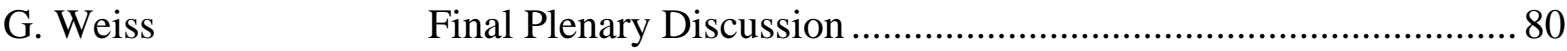





\title{
Integrated Rural Development as Pathway for Innovations - An Unexploited Potential for Forestry
}

\author{
Lukas Giessen, Michael Böcher, Maximilian Ortner, Sebastian Tränkner \\ Institute of Forest Policy and Nature Conservation, \\ University of Göttingen, Germany
}

\begin{abstract}
In this paper we argue that 'Integrated Rural Development' (IRD) may serve as a facilitating political framework for innovations in rural areas, which opens up windows of opportunity for forest related activities and unexploited forestry potentials.

Rural development issues have been on the policy agenda for many years. However, a lack of sufficient impact of traditional sectoral policies addressing rural areas as well as decreasing public funds and the demand for sustainability triggered a shift towards more integrated and multifunctional policies. In this paper IRD is presented as an approach, which implies a wide understanding of rural development, especially of the role of agriculture and forestry as being multifunctional. For implementing IRD, concepts of Regional Governance are suggested, in which hierarchical incentives are supplemented by regional self-coordination and networksteering amongst regional actors. In an empirical section we analyse German rural development policies with regard to whether IRD is being facilitated by means of Regional Governance. Furthermore, we identify conditions under which IRD policies may be most successful. We subsequently present successful cases where forestry contributed to rural development within the German implementation of the EU Community Initiative LEADER+. The examples show that participation of forestry in LEADER+ may create innovative opportunities for the forest-based sector. Regarding forestry actors we highlight that not every cooperation under IRD programmes per se is beneficial. The importance of judging the potential of forestry actors within regional IRD processes is being stressed. We conclude our discourse with recommendations for both, policy-makers and regional forestry actors on how to cope with new challenges attributed to integrated policies in general and IRD policies in particular.
\end{abstract}

Keywords: Integrated Rural Development, Regional Governance, Success Factor Approach, LEADER+ and forestry.

\section{Introduction}

Issues of sustainable rural development have been high on the political agenda for quite some time. With over half of the population of the EU-25 living in rural areas covering $90 \%$ of the territory, rural development policy must be seen as a priority area.(Agenda 21, 14.6; EU Commission 2004a, 20). Out-migration and non-viable age structures, lack of alternative employment as well as poor access to public services are only some of the problems rural areas are facing (EU Commission 2004b). Lacking impact of traditional, mono-sectoral policy approaches led to more integrated and regionalised policies, addressing rural problems. Integrated Rural Development (IRD) approaches are becoming more prominent, in order to overcome the shortcomings of former policy. However, ORTNER finds that despite a high potential, the forest-based sector abstains from actively participating in IRD programmes. He concludes that forestry actors and owners do not tap the full potential of such cooperation (Ortner 2004). Figure 1 identifies a gap between forestry potential and actual participation under the EU programme LEADER+. 


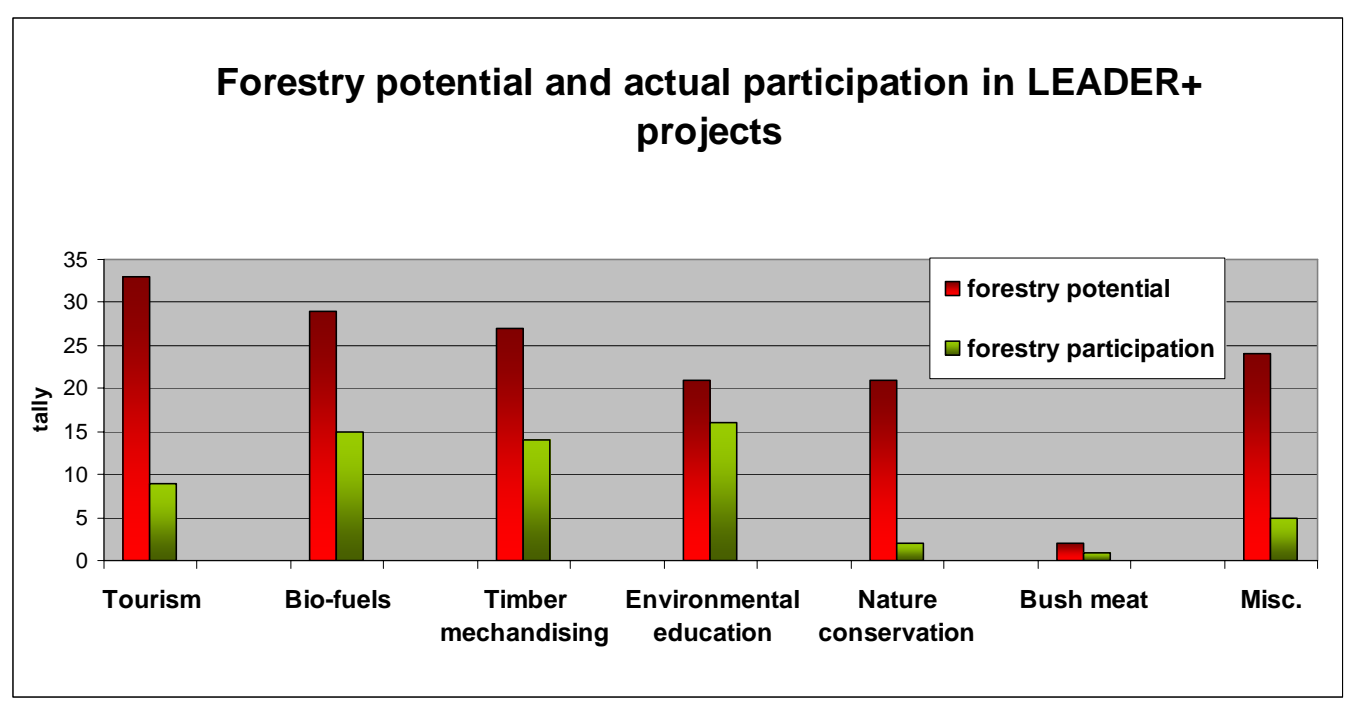

Figure 1. Forestry potential and participation in German LEADER+ projects by disciplines; c.f. Ortner (2004).

In this paper we will address 3 questions: (i) how to promote innovations and development in rural areas through means of IRD policy; (ii) what are the factors of success for Integrated Rural Development policies and (iii) how may forestry actors benefit more from Integrated Rural Development programmes. We commence with a theoretical reflection upon the concept of IRD and present Regional Governance as a way of facilitating this concept. In an empirical part we study to which extent IRD has been taken up by German rural development policies. A subsequent discourse on success factors identifies conditions under which IRD may be most successful. Subsequently, empirical examples of successful forestry cooperation within the EU LEADER+ programme are presented. The materials also reveal success factors of IRD which are most important in the context of forestry. We conclude our discourse with recommendations for policy-makers as well as regional forestry actors and owners on how to cope with new challenges attributed to IRD policies.

\section{Integrated Rural Development}

\subsection{The concept of IRD}

For some time now the concept of “Integrated Rural Development” has been widely discussed as promising approach in achieving sustainable development of rural areas in Europe. Classical approaches of funding regions by merely spreading subsidies among different relevant sectors (agriculture, forestry, nature conservation, etc) are widely regarded as not being effective and efficient anymore. The specific endogenous and cross-sectoral potentials of rural regions and its utilization are seen as essential for the development of region-specific approaches to regional development (van der Ploeg et al 2000). Rural development policy should incite the local and regional actors to help themselves. In such concepts a region is no longer determined by its administrative or geographical borders but by its whole functions as a region for forestry, for tourism, for nature protection, or intensive as well as organic farming. The building up of networks and cooperation between all relevant actors within a rural region represents the organising principle of Integrated Rural Development: rural partnerships have to devise and organise their specific development process in an individual and democratic manner (Ray 2000; Moseley 2003). Table 1 shows key characteristics of Integrated Rural Development. 
The main organising principles of Integrated Rural Development are a multifunctional understanding of the role of different sectors in rural areas (i.e. agriculture as relevant for food production as well as for nature conservation) and a general cross-sector approach (different sectors shall build up cooperation in order to establish win-win coalitions for example between forestry and tourism). The whole development process should be organised in a collaborative approach between rural actors, who build partnerships and formulate individual strategies for the development of their regions. Integrated Rural Development is also conceptualised as long-term approach. Development strategies are rather oriented towards facilitating long-term effects than just achieving short term goals such as the quick creation of outputs like new jobs which are highly dependent on the flow of subsidies. For the concept it is important that the whole process is being further developed by external evaluation and the evaluation of the regional actors themselves at regular intervals. Within Integrated Rural Development a new understanding of the role of agriculture and forestry as serving multifunctional purposes in rural areas can be observed.

Table 1: Characteristics of Integrated Rural Development; c.f. Böcher (2005a).

\begin{tabular}{|ll}
\hline \multicolumn{1}{c}{ What is integrated rural development? } \\
\hline $\begin{array}{l}\text { Region-specific approach } \\
\text { Cross-sector approach }\end{array}$ & $\begin{array}{l}\text { Looks at regions rather than individual sectors } \\
\text { Focused on synergies between different areas of } \\
\text { government and industry }\end{array}$ \\
\hline Partnership approach & $\begin{array}{l}\text { People form partnerships, set up and implement joint } \\
\text { programmes }\end{array}$ \\
\hline Dynamic approach & $\begin{array}{l}\text { The process is continually evaluated and further de- } \\
\text { veloped by the network of actors }\end{array}$ \\
\hline Long-term approach & Focused on medium and long-term potentials \\
\hline
\end{tabular}

\subsection{IRD as a facilitating framework for innovations in rural areas}

The concept of Integrated Rural Development has also to be understood as an idea of how to facilitate innovations in rural areas. In 1939 Schumpeter already argued that the key process for economic change and development is the introduction of innovation which is facilitated by combining existing production factors in a new way (Schumpeter 1939, 88; McDaniel 2000, 278). Within the concept of Integrated Rural Development the process of innovation is not limited to economic product innovations within enterprises. Innovation is rather understood as a process, which contains organizational and/or technological innovations that not necessarily have to be just economic goods (see Rametsteiner and Kubetzcko 2003). Innovation within the concept of Integrated Rural Development can mean that one region is able to produce goods or services better than other regions - here the aspect of competition between different regions (no longer competition merely among different enterprises or sectors) plays an important role. Another meaning would be that through an innovative cross-sectoral cooperation new services or goods can be produced which would not have been able to be produced without the innovative cooperation. Provided that the cooperation among forestry, agriculture and tourism creates an innovative service for tourists in rural regions, this process can be understood as innovation, which refers to the concept of Integrated Rural Development. Integrated Rural Development aims at finding such new innovative cooperation as well as strengthening a region in comparison with others. Consequently, Integrated Rural 
Development has also to be understood as a facilitating framework for innovations in rural areas.

\subsection{Governance for Integrated Rural Development}

The concept of Integrated Rural Development also reflects the current scientific discussion on new forms of Regional Governance. It highlights the importance of regional cooperation and networks as preconditions for successful regional development, stimulating policy-learning of regional actors (Benz et al., 2000; Benz and Fürst, 2002). Analogous to other fields of politics, this increased use of the term "governance" goes hand in hand with the realisation, that earlier political coordination procedures are no longer able to adequately solve regional problem situations under altered general conditions. Fürst gives globalisation, the rise of the neo-liberal paradigm, the state's financial crisis and the increasing meticulous organisation of society combined with the corresponding fragmentation of societal coordination as examples of such altered general conditions (Fürst 2004, 46). One especially observes the limits of state-hierarchical intervention abilities within regional policy. Müller points out that structural regional particularities locally can hardly ever be coordinated "from above", neither by regulatory nor be financial means (Müller, 1998). This diagnosis recently has become much clearer due to the more heated public debate about the problems caused by the development of former East Germany or the development of Eastern European rural areas within the process of EU-enlargement. So what does Regional Governance actually mean? It is important for the further discussion to emphasize that Regional Governance nowadays is used in normative as well as analytical ways. The concept suggests supplementing hierarchical steering not only with market mechanisms, but also with horizontal and cooperative modes of coordination. Consequently, it may be interpreted as new understanding of a modern form of regional policy. Table 2 illustrates characteristics of Regional Governance (see Benz/Fürst, 2003; Löwis/Wiechmann/Müller, 2005, 16 ff.; Fürst, 2004; Diller, 2004; Knieling, 2004 as well as Böcher, 2003 and Böcher, 2005b).

Regional Governance as a concept is highly discussed in political science and as a blueprint in concepts on Integrated Rural Development. However, it is still in question if the characteristics described by the concept are represented by actual rural developmental policies. In the subsequent chapter we take a look into current policies for rural development against the background of its implementation in Germany.

Table 2: Characteristics of Regional Governance; c.f. Böcher (2005b).

\section{Characteristics of Regional Governance}

\begin{tabular}{|l|ll|}
\hline $\begin{array}{l}\text { Increase in significance of } \\
\text { the region as a level of } \\
\text { political coordination }\end{array}$ & $\begin{array}{l}\text { - } \\
\text { - }\end{array}$ & $\begin{array}{l}\text { Fe-central self coordination } \\
\text { - Use of endogenous potentials }\end{array}$ \\
\hline $\begin{array}{l}\text { Replacement of the } \\
\text { territorial principle by the } \\
\text { functional principle }\end{array}$ & - & „Region“ determined by density of social relations \\
\hline $\begin{array}{l}\text { Inter-sectoral cooperation } \\
\text { through } \\
\text { institutionalised regional } \\
\text { reglionion of a region is central, not (just) geographical or }\end{array}$ & - $\begin{array}{l}\text { Networks and cooperation through private and public } \\
\text { actors }\end{array}$ \\
\hline
\end{tabular}




\begin{tabular}{|c|c|}
\hline networks and partnerships. & $\begin{array}{ll}\text { - } & \text { Elaboration of regional development concepts } \\
\text { - } & \text { Inter-sectoral collaboration }\end{array}$ \\
\hline $\begin{array}{l}\text { Steering of incentives } \\
\text { through various } \\
\text { instruments and forms }\end{array}$ & $\begin{array}{l}\text { - Competition as an instrument to identify and support } \\
\text { „best practices“ } \\
\text { - Financial incentives through funds with preconditions } \\
\text { - Steering through regional management as organizational } \\
\text { core } \\
\text { - Increase of the importance of evaluations }\end{array}$ \\
\hline
\end{tabular}

\section{IRD in German policies}

The present chapter aims at empirically analysing to which extent elements of IRD have been taken up by German rural development policies. In addition, we will examine to what degree aspects of the Regional Governance approach are abundant within these political programmes as governance means for facilitating the endeavour of IRD.

The empirical material used for the present analysis has been compiled in conjunction with a research project called "GoFOR- New Modes of Governance for Sustainable Forestry in Europe". ${ }^{1}$ Other results are based on empirical findings of an earlier study by Böcher (2005b). Document analyses as well as expert interviews have been employed for the collection of data.

\subsection{Identification of IRD related policies in Germany}

In the German context a wide range of policies exists at EU, national and sub-national (= Laender) levels, which have implications for rural development. However, here we will merely focus on national and EU-level policies stemming from the agricultural realm and directly relating to the philosophy of IRD.

At the EU level we identified two policies as being relevant in the light of IRD. Firstly, the EU Rural Development Regulation (RDR), consisting of EC regulation 1257/99, which has recently been replaced by Regulation EC 1698/2005, was taken into account. Secondly, as a structural measure, the Community Initiative LEADER+ comprises aspects which lie within our research focus. Its approach is characterised by high levels of local stakeholder and community involvement, by partnership and cooperation, and by the encouragement of innovative approaches to rural development (Land Use Policy Group 2005, 5). At the national level two policies with vital importance as regards IRD have been identified. Firstly, the national Joint Task "Improvement of Agricultural Structures and Coastal Protection" (GAK, German acronym) plays a key role in rural development issues. It provides for a national framework, based upon which the different Laender design more specific rural development programmes. The GAK also serves as national framework plan for selected measures of the RDR and provides support through co-financing Laender programmes. ${ }^{2}$ In 2004, the introduction of the new funding principle "Integrated Rural Development” made essential

\footnotetext{
1 The GoFOR research project involves partners from 10 European countries in studying governance approaches in forestry. It is coordinated by the BOKU University, Vienna and financed within the 5th Framework Programme of the EU Commission.

2 Constitutionally, only measures having implications for agricultural structures and coastal protection may be considered under the federal GAK-policy (see UFZ 2005, 9)
} 
elements of the concept part of the policy. ${ }^{3}$ Measures included in the GAK are eligible for national co-financing. However, they are subject of further specifications in Laender policies. As a second programme, the pilot project "REGIONEN AKTIV", launched by the Federal Ministry for Food, Agriculture and Consumer Protection (BMELV, German acronym) in 2001, will also be considered here. Similar to LEADER+, it also serves for testing and demonstrating integrated approaches to rural development. In our analysis REGIONEN AKTIV as well as LEADER+ are considered as pilot programmes, whereas the GAK including the EU RDR is referred to as mainstream policy.

\subsection{IRD in selected rural development policies}

LEADER+ as well as REGIONEN AKTIV both take a region-specific approach to rural development. Through funding perspectives both programmes encourage regionally managed, so-called integrated 'bottom-up' development processes in rural areas (Land Use Policy Group 2005, 5; BMELV 2004, 12f). In such processes regional actors, who themselves are engaged in the process, define "their" region according to subjective criteria and based upon socially negotiated regional identities. The delineation of a region and its acknowledgement under both programmes do not necessarily coincide with administrative boundaries (Böcher, 2001; EU Commission 2000, 7). In both cases a partnership approach is being encouraged. Networks of regional actors are functioning as central decision-making bodies within the regional development initiative. In both programmes such networks are beneficiaries, who autonomously decide upon the allocation of financial resources provided by the central authorities (EU Commission 2000, 7; BMELV 2002, 8). Both, LEADER+ as well as REGIONEN AKTIV require substantive participation of non-state actors within these decision-making bodies. ${ }^{4}$ Such public-private partnership networks are supposed to guide the whole development process from common agenda-setting to planning, implementation and even evaluation (EU Commission 2003, 14; Deutscher Bundestag 2005a, 52). In order to safeguard a strategic development process, both pilot policies encourage the elaboration of socalled Integrated Rural Development strategies by the regional networks. They must be integrated, in the sense that they adopt a global approach based on the interaction between actors, sectors and projects (BMVEL 2002, 6; EU Commission, 2000, 8). This procedure highlights the significance of cross-sectoral approaches at the implementation level in both programmes. A dynamic approach is taken, as evaluation exercises are central features of LEADER+ as well as REGIONEN AKTIV. The latter employs external and internal selfevaluations at the implementation level for continuously improving analytical skills of regional actors (BMVEL 2002, 9). Under LEADER+, however, external evaluations are used rather at the programming level, intending to further develop policy over time (EU Commission 2002, 5,8). Finally, both programmes aim at achieving long-term effects and utilise regional long-term potentials by funding of both, Regional Management as organisational core as well as for regional networks for the runtime of the programmes (approx. 5 years).

Recent amendments of the GAK suggest a growing significance of IRD also within the national mainstream policy. A 2004 revision of the GAK resulted in the uptake of the new funding principle "IRD", under which two novel measures were established. Firstly, the elaboration of Integrated Rural Development strategies amongst a wide range of rural stakeholders in individual regions is now eligible for GAK funding. Secondly, the set up of a so-called "Regional Management” can be supported under the regime (Deutscher Bundestag

3 The GAK does not address rural development issues only, but mainly structural issues and can be best described as multifunctional policy (UFZ 2005).

4 Within the frame of LEADER+ private actors must make up at least $50 \%$ of local partnerships (EU

Commission 2000, 7), whereas REGIONEN AKTIV does not make specifications (Böcher 2005b, 10). 
2005b, 12). ${ }^{5}$ Both measures highlight the increased significance of individual regions and genuine development approaches within these. In addition, they also reflect a partnershiporiented approach, as both instruments aim at facilitating negotiation processes among diverse actors and foster collective action. However, the GAK does not explicitly call for an intersectoral approach for the elaboration of commonly agreed development strategies. Furthermore, the 2004 amendments do not address issues such as continuous process improvement, mandatory evaluations or regional impact assessment. Thus, a dynamic learning perspective on regional development processes is not being encouraged. The longterm alignments of development processes as well as the long-term potentials of the regions on the one hand are being facilitated through Regional Management as enduring core of the development process. On the other hand, however, the one-shot character of funding the elaboration of a development strategy contradicts this approach.

\subsection{Regional Governance to achieve IRD}

Table 3: Regional Governance in IRD policies.

(+ policy aligns with aspects of Regional Governance; -- does not align, even constraints Regional Governance; n.s. not specified in GAK framework)

\begin{tabular}{|c|c|c|c|}
\hline \multirow[t]{2}{*}{ Aspects of Regional Governance } & \multicolumn{2}{|c|}{$\begin{array}{l}\text { Pilot policies } \\
\text { (c.f. Böcher 2005b) }\end{array}$} & \multirow{2}{*}{$\begin{array}{l}\begin{array}{l}\text { Mainstream } \\
\text { policy }\end{array} \\
\text { GAK } \\
\text { (IRD section) }\end{array}$} \\
\hline & $\begin{array}{l}\text { REGIONEN } \\
\text { AKTIV }\end{array}$ & LEADER+ & \\
\hline \multicolumn{4}{|c|}{ Significance of regions as level of political coordination } \\
\hline De-central self-coordination & + & + & -- \\
\hline Free-will principle & + & + & + \\
\hline Use of endogenous potentials & + & + & -- \\
\hline \multicolumn{4}{|c|}{ Replacement of the territorial principle by the functional principle } \\
\hline $\begin{array}{l}\text { „Region“ determined by density of social } \\
\text { relations }\end{array}$ & + & + & n.s. \\
\hline $\begin{array}{l}\text { Function of a region is central, not (just) } \\
\text { geographical or administrative delimitation }\end{array}$ & + & + & + \\
\hline \multicolumn{4}{|c|}{ Inter-sectoral cooperation through weakly institutionalised regional networks and partnerships } \\
\hline $\begin{array}{l}\text { Networks and cooperation through private and } \\
\text { public actors }\end{array}$ & + & + & n.s. \\
\hline Joint visions & + & + & n.s. \\
\hline Elaboration of regional development concepts & + & + & + \\
\hline Inter-sectoral collaboration & + & + & n.s. \\
\hline \multicolumn{4}{|c|}{ Steering of incentives through various instruments and forms } \\
\hline $\begin{array}{l}\text { Competition as instrument to identify and } \\
\text { support „best practices“ }\end{array}$ & + & + & -- \\
\hline $\begin{array}{l}\text { Financial incentives through funds with } \\
\text { preconditions }\end{array}$ & + & + & n.s. \\
\hline $\begin{array}{l}\text { Steering through regional management as } \\
\text { organizational core }\end{array}$ & + & + & + \\
\hline Increase of the importance of evaluations & + & + & -- \\
\hline
\end{tabular}

Böcher finds that LEADER+ as well as REGIONEN AKTIV both reflect all key aspects of Regional Governance (Böcher 2005b, 13). Therefore, we now will only highlight important differences between pilot and mainstream policies as well as shortcomings of the GAK as

5 In the context of IRD „Regional Management“ refers to a facility, where professional staff is taking on information, communication and facilitation responsibilities within a regional development initiative. 
concerns Regional Governance aspects (Table 3). Within the GAK some aspects of Regional Governance are either not addressed explicitly (see Table 3 "n.s.") or are even constrained by the regime (see Table 3 "--"). In the former case, such aspects are likely to be addressed in subsequent Laender policies (Augustin 2006). However, within the GAK four lacking aspects of Regional Governance have been identified, which inhibit it from effective functioning (Augustin 2006; Deutscher Bundestag 2005b). Continuous de-centralised self-coordination is being obstructed by the GAK regime, since common decision-making and collective action is only funded in the initial phase of a development process. Likewise, the lack of institutionalised fora for continuous discussion and decision-making leads to an underutilisation of endogenous potentials over time. Thirdly, GAK support for IRD does not take a competition approach. Again, this may cause respective regional actors not to unfold their full potentials of performance. Finally, the issue of evaluations does not yet play a meaningful role under the regime, which again narrows opportunities for learning and reflexivity.

\subsection{Critical assessment in the light of innovations}

It becomes obvious, that in both pilot programmes the concept of IRD is well and comprehensively integrated into policy. This partly holds true for the national mainstream policy, where only selected IRD features have been realised. It is likely that Laender, who build upon the GAK framework, add such IRD aspects to their programmes. Still, the GAK does not provide for a comprehensive integrated approach to rural development. It consequently foregoes the innovative potential of continuously institutionalised regional networks, external evaluations as well as internal self-assessments, as applied under the pilot plans.

The fragmented appearance of Regional Governance elements within the GAK may not lead to optimal results. Especially issues such as self-coordination, competition and evaluations can be assumed to have a high potential regarding creativity and reflexivity within regional processes. These matters must be seen as essential parts in innovation policy and should not be left out. However, until the 2004 amendments no such approaches could be identified within the GAK at all. Hence, we can observe a clear trend towards IRD and Regional Governance approaches in German policies in support of rural development.

We have empirically shown the appearance of the IRD concept as well as the application of Regional Governance mechanisms at the programmatic level of relevant policies. However, based on our data we can not predict whether conditions are favourable for a thriving application of the concept. Consequently, in the following chapter we will present factors, which are crucial in setting the scene for a successful performance of IRD in practice.

\section{Success factors of IRD and cooperative forest policy}

\subsection{Background to the Success Factor Approach}

The question which factors are responsible for the success of cooperative policy processes has a long tradition in policy evaluation. In response to measurement failures of traditional evaluation methods which normally follow linear input-output models at the beginning of the 1990s, new approaches and instruments were developed in regional policy research. They focus on e.g. the exploration of complex policy processes, on the involvement of stakeholders and addressees, and on the consolidation of cooperation (Sedlacek 2004, 11-26; Benz and Fürst 2002). 
The Success Factor Approach (SFA), as a tool for evaluating complex governance processes, aims to contribute to this discussion. The crucial question is how regional partnerships initialize regional development processes, continue cooperation and realise long-term and sustainable outcomes in spite of existing conflicts and obstacles. The main objective is to identify central determinants of success of regional cooperation (partnerships) in the framework of IRD. Such procedural and institutional success factors are not used for assessing the success of measures (outputs or outcomes), but for the identification of conditions and causes, which lead to success of cooperative processes in regional development (Böcher and Tränkner 2005). Consequently, the success factors of cooperative regional development are strategic indicators for the quality of regional development processes and hence may serve as a tool for policy evaluation and policy advice.

From a political scientists view, rural development partnerships are policy networks on a regional level. A policy network, consisting of actors from different social sectors, can be defined as a negotiation system, because negotiation is the dominant modus of decision making and problem solving in actors networks within a framework of institutions (Scharpf 1993). In spite of multi-causality and multi-dimensionality of influence factors and their different contribution to success it is supposed, that success of regional partnerships is reducible to a manageable number of central success factors (Böcher 2001, 12; Hoffmann 1986).

For policy evaluation, the path to cooperation and the successful consolidation are the most important research objectives. According to this, practical indicators have to be identified which measure the value of success factors based on empirically verified theories (Böcher 2002). Depending on the concrete context, an adequate heuristic reference framework has to be designed in which an appropriate set of theories and indicators have to be integrated for measurement of success factors. In this regard the actor-centered-institutionalism has to be tested as suitable reference frame. It integrates both theories of institution, describing the framework, and theory of individual and organisational action. According to this scholar, actions of actors are not pre-determined, but influenced by the institutional framework they are embedded in. Therefore success factors depend on institutional framework, on negotiation and on both, actors as well as their interactions. Thus success factors preliminary can be divided into procedural factors of action and institutional factors. Procedural factors may be directly influenced, while factors of institution may not or only indirectly be influenced by actors of a partnership (Scharpf2000).

Regional development is characterised by high complexity and no sole theory is available specialised on cooperative regional policy. Therefore a set of theories from political science and sociology is needed. In the case of regional partnerships acting in institutional framework theories e.g. social network theory, negotiation theory, organisation theory and institution theory are used for building the theoretical background. The research design follows the interpretative paradigm and aims to picture the complexity of political processes of regional partnerships. Interpretative case studies, in depth analysis and success stories are used for identifying success factors (Brendle and Krott 1999; Lijphart 1971).

\subsection{Success factors of IRD}

The success factors mentioned in Table 4 are being used as the analytical matrix for evaluating Integrated Rural Development processes. Originally, the Success Factor Approach was developed for analysing the driving political forces behind the success of nature conservation projects. These factors were further adopted for analysing the general political conditions in the field of integrated rural policy in the frame of the EU initiative for rural 
development (LEADER+). Recently, these success factors were further specified for the evaluation of integrated policy processes of 18 regional partnerships participating in the German funding program REGIONEN AKTIV (Brendle and Krott 1999; Böcher 2001; Böcher and Tränkner 2005; Böcher (2006).

Table 4: Success factors for IRD

\begin{tabular}{|c|c|}
\hline Success factor & Explanation \\
\hline $\begin{array}{l}\text { Need for action } \\
\text { willingness to solution }\end{array}$ & $\begin{array}{l}\text { Certain pressure of problems is necessary to stimulate } \\
\text { collective action. Commonly perceived problems can be } \\
\text { transformed into solutions, if actors are willing to work } \\
\text { together. }\end{array}$ \\
\hline $\begin{array}{lr}\text { Visions } & \text { and } \\
\text { Rural } & \text { Integrated } \\
\text { Concept } & \end{array}$ & $\begin{array}{l}\text { Common visions and goals discussed in a broad circle of } \\
\text { actors and fixed in an integrated regional development } \\
\text { concept are guidelines of action for partnerships and reduce } \\
\text { the number of possible choices of actions to a feasible and } \\
\text { realistic level. }\end{array}$ \\
\hline $\begin{array}{l}\text { Opportunities of linkage } \\
\text { and manageable } \\
\text { structures }\end{array}$ & $\begin{array}{l}\text { Transactions costs decrease and chances for realization } \\
\text { increase, if structures of projects are transparent and } \\
\text { comprehensible and if number of actors involved as well as } \\
\text { number of themes in process are limited. Success for regional } \\
\text { development processes increases, if the process ties up with } \\
\text { existing structures in the region or existing funding programs. }\end{array}$ \\
\hline $\begin{array}{l}\text { Win-win situations and } \\
\text { coalitions }\end{array}$ & $\begin{array}{l}\text { on of } \\
\text { more }\end{array}$ \\
\hline Ma & $\begin{array}{l}\text { Actors are motivated, sceptics are convinced and acceptance } \\
\text { is stimulated inside and outside the partnership by achieving } \\
\text { fast partial success and its effective communication and } \\
\text { marketing. }\end{array}$ \\
\hline $\begin{array}{l}\text { learning and } \\
\text { ge of knowledge }\end{array}$ & $\begin{array}{l}\text { Exchange of information inside and among partnerships is } \\
\text { important for building trust, for initiating learning processes } \\
\text { and stimulating innovation. A common base of knowledge } \\
\text { and trust is a condition to consensus oriented negotiations and } \\
\text { to overcome conflicts. Self-evaluation is a useful instrument } \\
\text { for self-reflection and helps to adjust regional development } \\
\text { strategies. }\end{array}$ \\
\hline $\begin{array}{l}\text { Transparency, Openness, } \\
\text { Flexibility }\end{array}$ & $\begin{array}{l}\text { Regional cooperation is not formally legitimized. Continuous } \\
\text { transparency and openness are necessary prerequisites for } \\
\text { acceptance. Structures and processes have to be } \\
\text { comprehensible, flexible as well as open for interested } \\
\text { outsiders. }\end{array}$ \\
\hline $\begin{array}{l}\text { Promoters as } \\
\text { entrepreneurs }\end{array}$ & $\begin{array}{l}\text { Policy entrepreneurs e.g. advocate for innovations, broker the } \\
\text { ideas among the many policy actors and mobilize public } \\
\text { opinion. Promoters invest personal costs for pushing the } \\
\text { process and play a crucial role in the initial phase of } \\
\text { cooperation regarding mobilization, integration and } \\
\text { conviction of potential participants. }\end{array}$ \\
\hline $\begin{array}{l}\text { Powerful interceders an } \\
\text { allies }\end{array}$ & $\begin{array}{l}\text { Werful and influential interceders and partners, such as } \\
\text { cal or regional politicians or entrepreneurs with financial, }\end{array}$ \\
\hline
\end{tabular}




\begin{tabular}{|l|l|}
\hline Broad participation & $\begin{array}{l}\text { personal, informational or political resources, are important to } \\
\text { support regional development initiatives. }\end{array}$ \\
\hline $\begin{array}{l}\text { Regional cooperation is based on actor networks. Higher } \\
\text { legitimization and acceptance is attained and the evolution of } \\
\text { exclusive elites can be prevented, if actors of different sectors } \\
\text { have a fair chance to participate. }\end{array}$ \\
\hline management & $\begin{array}{l}\text { Competent process management means to develop adequate } \\
\text { regional development strategies and a foresighted view on } \\
\text { situations in change. It requires flexibility, willingness to } \\
\text { compromise and learning aptitude, social and communicative } \\
\text { skills. }\end{array}$ \\
\hline $\begin{array}{l}\text { Sufficient/adequate } \\
\text { resources }\end{array}$ & $\begin{array}{l}\text { Especially in the initial phase of cooperation actors taking } \\
\text { part in regional cooperation need sufficient amounts of } \\
\text { resources regarding time and money , information and } \\
\text { voluntary engagement. }\end{array}$ \\
\hline $\begin{array}{l}\text { Subsidiary and cooperative } \\
\text { program implementation }\end{array}$ & $\begin{array}{l}\text { Partnerships act in the shadow of hierarchy. This means, state } \\
\text { authorities define the global context (e.g. memorandum of } \\
\text { understanding, management by objectives), act as mediator } \\
\text { and facilitate networking at the regional level. }\end{array}$ \\
\hline
\end{tabular}

We presented the SFA as a promising means for policy evaluation in the field of IRD. As a tool, the approach is capable of identifying major aspects to be considered and addressed by policies in order to set the scene for a successful performance of IRD in practice. If applied for forest policy analysis, certain success factors become less relevant, while others gain momentum. The subsequent chapter presents empirical examples on the potentials of forestrelated innovations within IRD policies. The German implementation of LEADER+ as a facilitating framework for innovative forestry projects has been chosen to practically illustrate the importance of certain factors of success in the field of forestry.

\section{IRD as an opportunity for forestry ${ }^{6}$}

\subsection{LEADER+ and the forest-based Sector in Germany}

Until the end of 2006 LEADER+ continues its role as a laboratory which aims to encourage the emergence and testing of new approaches to integrated development (EU, 2000). In future the LEADER-principles gain importance since the new EU Rural Development Regulation 1698/2005 will contain a fourth "axis" based on experiences with the overall LEADERapproach introducing possibilities for locally based bottom-up approaches to rural development.

The LEADER programme is not designated as a forestry programme. It rather addresses all relevant public and private rural actors. This is reflected by a low degree of visibility and political support for forestry in LEADER+. For this reason the majority of forestry actors have little experience in new integrated programmes and are not well informed about their opportunities to participate in LEADER+.

In Germany one third of the land area is covered by forests and owned by both public and private actors. Due to their defined rural character many LEADER+ regions show a forest

6 Chapter author: Maximilian Ortner; The research project is sponsored by the Ministry for Science and Culture of Lower Saxony and the Georg-Ludwig-Hartig-Foundation 
cover, which is above-average. In account of this LEADER+ should provide opportunities for forest-related activities. For this reason in 2004 a written survey about LEADER+ and forestry opportunities was carried out by the Institute of Forest Policy. Managers of all current 148 LEADER+ regions in Germany were queried about the potential for forestry actors taking part in LEADER as well as their actual participation. However, as mentioned in Figure 1 "forestry actors do not tap the full LEADER potential - still many more opportunities left to use”. Forest-related cooperation was found in about 30 Regions. Non-cooperation despite high forest potential was also detected. The majority of running forestry activities is found in the field of nature related education, renewable energy and measures promoting and developing timber sales (Ortner 2004). At present forest policy makers and forest policy scientists stress the rising importance for the forest sector playing a strong role in the Integrated Rural Development process (Böcher and Gießen 2006; Setzer 2006; Fürst 2006). Furthermore, EU policy makers see the recent EU RDR as one of the key instruments for implementing the future EU Forestry Strategy by midyear 2006 (Encke 2006; EU 2005). In the run up to the next period the forest sector has the opportunity to get it self established as an important actor of Integrated Rural Development by participating in present LEADER+ activities. For this reason the following analysis has been carried out, to find new strategies for forestry actors to successfully take part in the LEADER Programme.

\subsection{Success factors for forestry and LEADER}

Since 2005 in-depth research was conducted in a selected sample of all LEADER+ regions. The main objective is to develop strategies for forestry actors how to enter into cooperation within IRD programmes in order to achieve subjective benefits. The research project is conducted by qualitative forest policy analysis via expert interviews and document analysis (cf. Krott 2005). Assuming a subjective cost benefit analysis by the actor (considering time, money, social prestige etc.) the forestry actors' choice for, against and runtime of LEADER+ related cooperation is explained using relevant models of negotiation theory.(Benz 1994; Scharpf 2000). The Success Factor Approach (SFA) is employed to identify processes of regional IRD cooperation, where forestry cooperation is promising. The success factors in focus of the project tie in with the SFA described above and are adapted for the forestry sector with data from prior empirical finding (Ortner 2005, 2006).

Assuming sufficient prerequisites of money and time successful cooperation for the forestry sector was defined in preposition to the forest policy analysis as follows:

\section{a) Gain political support for forestry actors \\ b) Policy learning of forestry actors}

As a preliminary result the most relevant success-factors for forest-related LEADER+ projects are described in the following. It has to be mentioned that the success factors are seen to be independent of each other. They are described in groups for better understanding only.

- Gain support of society, politics, and industry for forestry actors through cooperation: Attract "strong interceders" and "strong allies" (powerful forest and especially non forest stakeholders) to achieve a common purpose: “win-win-situating”. Utilise public relations.

- Increase the "demand for forest products (timber and non timber forest products) and forestry expertise". The new partner and project should utilise forestry expertise.

- "Need for action" to solve a forest-related problem e.g. decline of timber sales. Initiated by a "strong forestry promoter" LEADER is realised as a means of forestry-problem-solving based on innovative "integrated forest-related ideas" (i.e. the forest project was made compatible to the LEADER-programme) 
- "Policy-Learning": Institutionalise the "lesson learnt" e.g. at new job descriptions and via new regulations. Forestry operating plans are reviewed and adapted. The network with the new cooperative actors is institutionalised.

\subsection{Empirical findings on LEADER+ forestry projects}

In the following paragraphs some striking examples for successful forest-related LEADERProjects are described. In-depth research in these projects is still in progress. The cases have been analysed using the abovementioned success factors.

\subsubsection{The „Wood competence centre”-case}

Declining timber sales in a specific region reflected the "Need for action". The vice chief district forester had the idea to build a wooden house made of regional pine (Pinus sylvestris). His consultations with the regional LEADER manager lead to an "integrated forest-related idea”. Provided that regional timber and labour could be used, a wooden house, trend-setting in design and energy-balance was constructed. The LEADER manager convinced an architect specialised in timber construction and building-biology to design the house. The architect turned out to be a "strong promoter" of the project. He achieved sustained success in monetary terms as well as for nature conservation. In 2005 this prototype house was constructed and has been used as an educational show-room promoting wood as a renewable resource.

"Strong allies" could be won for the project. The co-financier and builder is a small city in the LEADER region represented by its mayor utilising the project for his region. There is a "win-win situation" for both the region and the forestry actors. Forestry actors benefit from timber valorisation, tending of woods as well as benefiting from public relations for forestry and wood processing. The new house is located on the property of the local youth hostel which uses this attraction for educational purposes. The house is a fundament for increasing tourist trade and improving the quality of life in the region. Furthermore it increases the awareness of wood for next generations of home buyers. Serial production for national sales is intended.

The positive project development was greatly influenced by "strong interceders". Early in the process the local agency for rural development realised the potential of the project for the region. It supported the LEADER-management in applying for EU project funds. The president of the state forest service, Members of EU-Parliament and members of the State parliament (officials living this electoral district) used the houses' opening ceremony to be associated with this project. In return of this public marketing all officials gave good feedback about the project in their comity.

A regional company sponsored the fitted kitchen for the house. Up to now there are two follow-up projects (non-LEADER projects) to mention. The kitchen company plans a new kitchen made of the regional pine. Another company producing urban furnishing products plans to built benches and other furniture from this provenience.

\subsubsection{The trans-national congress on regional timber}

"Need for action": The chief district forester was looking for appropriate action to improve the situation of for local forest and timber industry. The consultation with the LEADER management showed that LEADER could be a way to implement e.g. public relations as a needed action. Due to a forest cover of $80 \%$ the forest sector in this LEADER-region is a factor of high economic and political significance (approximately 10-20\% forest-related voters). For this reason the project is headed by the district administrator as one co-financier. 
Furthermore, members of State Parliament act as "strong interceders". "Forest related idea" as a LEADER-project: A trans-national timber promoting symposium as initial start-up for further action was accomplished successfully. To date there is a high number of follow-up LEADER and non-LEADER projects. For instance the symposium was designed as a transnational annual event. A glossy brochure was published and internet presence promoting regional wood was initiated by the following: local handcraft, trans-national LEADERRegions, the German Timber Promotion Fund, Ministry of Forest and forest research institutes as "win-win" partners and co-financiers. Furthermore, a new LEADER-project cofinanced by private architects is doing a comparative study comparing conventional house versus timber house construction.

"Policy Learning": Background: Due to a reform of the state forest service, where 7 forest offices were closed down, the head of the district authority became the new manger in line of the chief district forester and now works as a political entrepreneur on behalf of forestry. In spite of the radical forest administrative reform the chief district forester took advantage of the successful forestry projects described above to stress the necessity for a regional wood promoter. As a consequence, a permanent position has been institutionalised by a new official job description. The position is being financed by the district authority.

\subsubsection{Airport utilises forest for bio energy}

"Need for action": The entry lane of an airport had to fulfill certain provisions concerning the maximum tree heights. The airport as private forest owner is responsible to meet these requirements. Former practices of clear-cutting caused the owner high costs and created conflicts with nature conservation interests. "Integrated forest-related ideas": Co-financed by LEADER+, both, the airport management and the local forester commissioned a feasibility study. As a result a simple coppice system combined with allotment method was recommended as being the most feasible means. "Win-Win-Situation": The timber is utilised for bio energy by regional companies. The successful implementation runs cost-covering and has prospect of yielding returns.

\subsubsection{LEADER co-operation against cut-backs in forest administration}

LEADER was one decisive element in the negotiation about the closure of a forest district office. Supported by LEADER+ the forest office enhanced its core segment by nature related education. A "strong interceder" informed the Ministry of Education about this new business segment. Due to the "strong demand for forestry expertise" in the new segment especially by regional schools the Ministry of Education successfully vetoed against the closure of the forest office as a new "strong ally".

\subsection{Summary of findings for forestry actors and policy makers}

As to the preliminary results forestry actors should try to take advantage of Integrated Rural Development. They should inform themselves about the IRD programmes running in their region via internet and public agencies. As a first step it is recommended to participate in the regular meetings of local IRD initiatives in order to get a general idea of the "making of projects" and the new actors as possible partners for integrated forest related projects. In spite of that one should keep in mind that successful LEADER projects are not an advantage for forestry in every case. Forestry actors should consider the expenditure of time and all consequences of the cooperation, such as the common-pool-problem: A recreation-related project providing short-term advantages for the forestry actor could lead to increased litter and wild game disturbance despite long-term advantages for other non-forestry actors. Summing up LEADER + can be used as a stage to establish new powerful allies - especially non forestry stakeholders - and innovative business segments. Furthermore, the sector gains the advantage 
of better connectivity to the forthcoming EU programming period (2007-2013). Projects which serve the common good will gain in importance. The forestry actors should consider the monetary incentives as well as the political advantages e.g. new allies in integrated forestry projects.

\section{Conclusions}

We theoretically as well as empirically demonstrated the potentials of Integrated Rural Development as a concept, to serve as a facilitating framework for innovations. A trend towards more integrated and cooperative rural development policies could be identified. Also, the philosophy of IRD often is being realised by a Regional Governance approach. The Success Factor Approach may serve as a promising means for the analysis and evaluation of integrated policies. It helps identifying conditions under which IRD may be most successful. However, IRD does not per se bring benefits for forestry actors. They should consider the expenditure of time and all consequences of the cooperation. In some instances cooperation may not be favourable, while in other cases innovation potentials may be harnessed. The Success Factor Approach may assist forest-based actors in identifying promising IRD processes.

So far, forestry and forest owners do not tap the full potential of IRD programmes. Cooperative behaviour of forestry actors within the frame of IRD (e.g. under LEADER+) under certain conditions however, was shown to be highly promising. Engagement of forestry actors in IRD processes must be seen as an investment. Thus, we call upon forestry actors to enter into IRD-related cooperation in order to judge whether respective processes are promising in their individual respect.

\section{Recommendations}

- $\quad$ Sectoral approaches to rural development should be complemented with IRD policies to facilitate innovations, especially in forestry

- $\quad$ Regional Governance arrangements are promising for regionalised approaches to rural development

- $\quad$ Even though not each and every cooperation under IRD may be beneficial, we encourage forestry actors to enter into integrated and cooperative rural development processes in order to:

- judge on potential benefits

- tap the full potential of such programmes

- increase their visibility through networking with other relevant actors in rural policy

- create win-win situations and benefit from synergies

- $\quad$ Engagement in such processes should be seen as an investment. The return on investment, however includes uncertainty

- $\quad$ Without such cooperation both at the management and the policy-making level future developments will happen with a low degree of forestry participation.

\section{Literature}

Augustin, T. (2006): Interview from March, 8th 2006 by Böcher and Giessen. Bonn. 
Benz, A. (1994): Kooperative Verwaltung: Funktionen, Voraussetzungen und Folgen, Nomos, Baden-Baden. 418 pp.

Benz, A., Fürst, D. (2002): Policy Learning in Regional Networks, in: European Urban and Regional Studies 9 (1): 21-35.

Benz, Arthur / Dietrich Fürst (2003): Region - Regional Governance - Regionalentwicklung, in: Adamaschek, Bernd / Marga Pröhl (Eds.): Regionen erfolgreich steuern, Gütersloh: Bertelsmann-Stiftung, p 11-66.

Benz, Arthur, Dietrich Fürst, Heiderose Kilper, Dieter Rehfeld (2000): Regionalisation. Theory, Practice and Prospects in Germany. Stockholm.

BMVEL (2002): Active Regions- Shaping Rural Futures - Competition Winners. Bonn.

BMVEL (2004): Regionen Aktiv - Land gestaltet Zukunft. Zwischenbericht zum Wettbewerb. Bonn.

Böcher, M. (2001): Politikwissenschaftliche Ex-Ante-Analyse zur Entwicklung und Implementierung eines Beratungs- und Managementmodells zur Integration von Naturschutzaspekten in Prozesse einer nachhaltigen Regionalentwicklung, Göttingen.

Böcher, M. (2002): Evaluation of the implementation of success factors for a sustainable rural development within the scope of the EC Initiative for Rural Development (LEADER+), Göttingen.

Böcher, M. (2003): Die politische Steuerung nachhaltiger Regionalentwicklung. Das Beispiel der EU-Gemeinschaftsinitiative LEADER+. In: Edgar Grande / Rainer Prätorius (Eds.): Politische Steuerung und neue Staatlichkeit (Staatslehre und politische Verwaltung Bd. 8), Baden-Baden: Nomos, p 235-258.

Böcher, M. (2005a): Actively shaping rural development. Federal Ministry for Consumer Protection, Food and Agriculture, Rural Development Division (525), Bonn 50 pp.

Böcher, M. (2005b): The concept of Regional Governance in different national funding programmes, Paper presented at the international workshop "Regional Governance for Sustainable Development”, Hagen 28.-29.10.2005. http://www.fernunihagen.de/POLALLG/pdf-files/Regional_Governance_Boecher_Hagen.pdf

Böcher, M. (2006): Participatory policy evaluation as an innovative method to improve processes of sustainable rural development. In: Agricultural Economics Review, Vol 7, 1, forthcoming.

Böcher, M., Tränkner, S. (2005): Regionen Aktiv - Land gestaltet Zukunft Begleitforschung 2004 bis 2006. Zwischenbericht des Moduls Erfolgsfaktoren und Rahmenbedingungen, Göttingen.

Böcher, M.; Giessen, L. (2006): Forst als Partner in der integrierten ländlichen Entwicklung. In: AFZ-Der Wald (2006), Nr. 5, p 263. 
Brendle, U. Krott, M. (1999): Musterlösungen im Naturschutz - Politische Bausteine für erfolgreiches Handeln, Bonn-Bad Godesberg.

Deutscher Bundestag (2005a): Agrarpolitischer Bericht 2005 der Bundesregierung. Bundestagsdrucksache 15/4801. Berlin.

Deutscher Bundestag (2005b): Rahmenplan der Gemainsachftsaufgabe „Verbesserung der Agrarstruktur und des Küstenschutzes“ 2005-2008. Bundestagsdrucksache 15/5820. Berlin.

Diller, Christian (2004): Regional Governance im "Schatten der Hierarchie". In: Raumforschung und Raumordnung 4-5, 2004, p 270-279.

Encke, B. (2006): In der Forst- und Holzwirtschaft muss Europa an einem Strang ziehen! In: AFZ-Der Wald (2006), Nr. 5, p 260-262.

EU (2005): Council Regulation (EC) No 1698/2005 of 20 September 2005 on support for rural development by the European Agricultural Fund for Rural Development (EAFRD)

EU Commission (2000): Commission Notice to the Member States of 14 April 2000 laying down guidelines for the Community Initiative for rural development (Leader+) 2000/C 139/05.

EU Commission (2002): Guidelines For The Evaluation Of LEADER+ Programmes.

EU Commission (2003): Fact Sheet Rural Development in the European Union. Luxembourg.

EU Commission (2004a): The Common Agricultural Policy Explained. Brussels.

EU Commission (2004b): Planting Seeds for Rural Futures - Rural Policy Perspectives for a Wider Europe. Second European Conference on Rural Development - Salzburg 2003. Brussels.

Fürst, Ch. (2006): Forstliche Förderung im Umbruch? In: Forst und Holz (2006) Nr. 2, p 5052.

Fürst, Dietrich (2004): Regional Governance, in: Arthur Benz (Hg.): Governance - Regieren in komplexen Regelsystemen, Opladen: Leske \& Budrich, p 45-64.

Hoffmann (1986): Kritische Erfolgsfaktoren - Erfahrungen in großen und mittelständischen Unternehmungen, in: ZS f. betriebsw. Forschung 38(1986)10, p 831-843.

Knieling, Jörg (2004): Good Governance in der Regionalentwicklung - vom Vollzug zur aktiven Gestaltung. In: BMVEL (Ed.): Zukunft der ländlichen Entwicklung in Deutschland, Bonn: S. 108-117.

Krott, M. (2005): Forest policy analysis; Dordrecht; 323 pp.

Land Use Policy Group (2005): European Agricultural Fund for Rural Development Making the most of the Leader approach to deliver environmental priorities in European and UK rural development programmes. 
Lijphart, A. (1971): Comparative Politics and the Comparative Method; in: The American Political Science Review, Nr. 3 (65. Jg.), p 682-693

Löwis, Sabine von/Thorsten Wiechmann/Bernhard Müller (2005): Regionale Agenden in Deutschland - Akteure, Institutionen und Strategien nachhaltiger Regionalentwicklung am Beispiel der "Regionen der Zukunft", in: Wiechmann, Thorsten/Sabine von Löwis/Johann Kaether (Eds.): Das Modellvorhaben "Regionen der Zukunft", Dresden (IÖR-Schriften 45), $13-78$.

McDaniel, Bruce A. (2000): A Survey on Entrepreneurship and Innovation, in: The Social Science Journal Vol. 37, No.2, p 277-284.

Moseley, Malcolm J. (Ed.) 2003: Local Partnerships for Rural Development. The European Experience, Wallingford.

Müller, Bernhard (1998): Regionalpolitik, Regionalmanagement und die Rolle der Raumordnung, in: Arthur Benz / Everhard Holtmann (Eds.): Gestaltung regionaler Politik, Opladen: Leske \& Budrich, p 33-40.

Ortner, M. (2004): Zusammenarbeit zwischen Forstwirtschaft und Leader+. In: LEADER forum (2004), Nr. 2, p 41.

Ortner, M. (2005): „Die Region als forstliche Chance“, Poster, Forstpolitikertreffen bei der Bundesforschungsanstalt für Forst- und Holzwirtschaft, Hamburg.

Ortner, M. (2006): „Die Region als forstpolitischer Erfolg“, Poster, Forstpolitikertreffen bei der Technischen Universität München, Lehrstuhl für Forstpolitik, Freising.

Rametsteiner, E. and Kubetzcko, K. (2003): Innovation und Unternehmertum in der Forstwirtschaft in Zentraleuropa. Paper presented at Forstpolitikertreffen 2003. Gent.

Ray, Christopher (2000): The EU LEADER Programme: Rural Development Laboratory, in: Sociologia Ruralis Vol. 40, No 2, April 2000, p 163-171.

Scharpf, F. W. (1993): Positive und negative Koordination in Verhandlungssystemen, in: Hèritier, A. (Ed.), Policy-Analyse (PVS-Sonderheft 24). Opladen.

Scharpf, F. W. (2000): Interaktionsformen: akteurzentrierter Institutionalismus in der Politikforschung. Opladen.

Schumpeter, Joseph (1939): Business Cycles, New York and London.

Sedlacek, P. (2004): Evaluation in der Stadt- und Regionalentwicklung; in: Sedlacek, P. (Ed.); Evaluation in der Stadt- und Regionalentwicklung, 1. Aufl., Wiesbaden.

Setzer, F, (2006): Verlangt die Europäische Union einen Paradigmenwechsel in der forstlichen Förderung? In: Forst und Holz (2006) Nr. 2, p 47-50.

UFZ, Umweltforschungszentrum (2005): Promoting the Multifunctionality of Agriculture, Forestry, and Rural Areas - Design and Implementation of Public Policies in Germany. UFZ Discussion Papers 12/2005. Leipzig. 
United Nations (1992): Agenda 21. Online under URL: http://www.un.org/esa/sustdev/documents/agenda21/english/agenda21chapter14.htm.

Van der Ploeg, JD et al (2000): Rural Development: From Practices and Policies towards Theory; in: Sociologia Ruralis, Vol 40, No 4, 391-408. 


\title{
Forestry Joining Integrated Programmes? A question of willingness, ability and opportunities
}

\author{
Chair of Forest and Nature Conservation Policy, University of Göttingen, Germany
}

By LUKAS GIESSEN ${ }^{1)}$ and MAX KROTT

(Received June 2008)

\section{KEY WORDS - SCHLAGWÖRTER}

Integrated programmes; policy integration; forestry; forest sector; sectors; integrated rural development.

Integrierte Programme; Politikintegration; Forstwirtschaft; Forstsektor; Sektoren; Integrierte Ländliche Entwicklung

\section{POLICY INTEGRATION AS A CHALLENGE FOR FORESTRY}

For quite some time now issues relating to policy integration such as environmental policy integration, inter-sectoral coordination as well as cross-sectoral approaches and respective integrated programmes, are being discussed in political as well as scientific discourses. ${ }^{2)}$ Two main reasons can be identified why policy integration receives attention: Firstly, the structure of political issues changed in a way, that 'cross-cutting issues transcend the boundaries of once well established policy fields' (MEIJERS, 2004: 9; similar JÄNICKE, 2006: 63 and BRIASSOULIS, 2005: 1). Secondly, political approaches to tackle such complex issues have also been subject to change. While 'barely satisfactory results of regulatory policy' (LENSCHOw, 2002: 3) and 'sectoralized, uni-dimensional, uni-disciplinary and uncoordinated policies' (BRIASSOULIS, 2005:1) may not contribute to the societal endeavour of sustainable development, policy integration is supposed to enhance policy efficiency and efficacy (see MeIJers, 2004: 9).

However, besides these rationales of the concept, policy integration in practice experiences severe challenges. ${ }^{3)}$ JÄNICKE (2006: 68) mentions two main political impediments to the approach. Firstly, policy integration contradicts the logics of highly specialised public administrations and sectoral institutions, which have evolved following the logic of the Weberian model of rational and effective public administration. The approach secondly often challenges massive economic interests of the industrial clientele surrounding these administrations. ${ }^{4)}$ However, the bulk of policy integration literature often is of a problem-oriented nature largely dealing with procedural aspects of integration, while only few scholars tackle interests (individual and sectoral ones) and power relations as determinants for the success of policy integration. ${ }^{5)}$

In this article we seek answers to the fundamental question of why forestry actors only play a minor role in such integrated programmes, yet programmatic statements call upon forestry to partic-

\footnotetext{
1) Corresponding author: LuKAS GIESSEN.

E-Mail: 1giesse@ uni-goettingen.de

2) On the political discourse see OECD $(1989,1996)$, on the scientific discourse see a literature review by MEIJERS (2004); LENSCHOW (2002); BRIASSOULIS (2005) and JÄNICKE (2006).

3) see e.g. LENSCHOW 2002: 4-5; JÄNICKE (2006: 68); JÄNICKE and JÖRGENS (2004: 316) and BRIASSOULIS (2005: 37).

4) Similar and in more detail on impediments see MEIJERS (2004) or BRIASSOULIS (2005)

5) Exemplary exceptions from this are JÄNICKE (2006); Scientific Council for Government Policy (2002) and PETERs (1998). More sector-oriented exceptions for forestry are Hogl (2002); VerbiJ and Schanz (2002), ShanNon and Schmidt (2002) and Hubo and Krott (2007a,b), who are affiliated with the forest sector, and thus may better perceive, interpret and accept existing sectoral interests.
}

ipate? The concept of 'sectors' becomes paramount in explaining this phenomenon, leading to the more detailed research question of why sectors in general and forestry in particular resist attempts of integrated programmes? Given significant differences between diverse sectors, the article further asks whether individual sectors with their differences regarding institutions, procedures and actors, actually are able to participate in integrated programmes. Finally, following the logics of the sector concept the question is being raised, if integrated programmes also are subject to sectoral influences and consequently such schemes entail a sectoral bias, discriminating other addressees of an integrated programme who stem from other sectors?

To answer these questions the concept of 'integrated rural development ${ }^{6)}$ (IRD) in Germany shall serve as a case study for exemplification. ${ }^{7)}$ From an integration perspective IRD mainly stands for an area-based approach and refers to a shift in focus from sectoral support to funding of rural areas as functional units (GIESSEN and BÖCHER, 2007: 6). In the form of funding programmes, IRD addresses the 'different demands on rural regions [...] jointly and across sectors $[\ldots$ by] integrating the different sectors in one joint development strategy'. Hence it takes a cross-sectoral approach, focussing on 'synergies between different areas of government and industry' (BMVEL 2005: 4-5, similar EC 2006: 8, 10, 13 and DVS, 1999). Respective programme documents call upon the forest sector $^{8)}$ in particular to participate in IRD activities (e.g. BMVEL, 2005: 7, 28). Forestry as an economic sector is represented in most rural areas of Europe and may contribute to rural development with a higher utilisation of wood- and non-wood forest resources and services (HytTINEN et al., 2000: 221; similar HytTinEN et al., 2002). This especially applies to integrated strategies, where networking and cross-sectoral cooperation are discussed as promising approaches unfolding additional synergetic benefits to all participants. Lastly, a trend in public funding from sector-oriented to more integrated patterns shows that related programmes become more and more interesting for forest owners. ${ }^{9)}$

So far only few studies have addressed the role of forestry within cross-sectoral programmes. In the field of IRD forestry can be described as being relatively passive. ${ }^{10)}$ ORTNER (2008) and GIESSEN et al. (2006) find forestry actors not to play a prominent role under these funding schemes, even though a high potential for participation has been attributed to the forest sector. GIESSEN (2007,

\footnotetext{
6) BMVEL (2005); In the scientific discourse similar approaches are discussed under 'neo-endogenous' (RAY, 2000, 2006) and 'autonomous' (HAH$\mathrm{NE}, 1984)$ rural development.

7) See GIESSEN and BöCHER (2007), who provide a case study on IRD within the EU funded research project 'New Modes of Governance for Sustainable Forestry in Europe' (http://www.boku.ac.at/GoFOR/).

8) The term forest sector is used here, referring to aspects and activities relating to forestry. In the present context this term is preferred over 'forest-based sector' which is closely related to the Forest-Based Sector Technology Platform (FTP) and covers several sectors which are dependent on forest resources.

9) KRUL and OzINGA (2005: 9-16) outline how EU rural development funds may benefit forests, and forest owners.

10) See e.g. Ortner (2008); GIESSEN and BÖCHER (2007); GIESSEN (2007, 2008); GIESSEN et al. (2006); BöCHER and GIESSEN (2006).
} 
2008) again stresses the potential benefits of cooperation under IRD for forestry as perceived by sector-internal as well as -external actors. The authors, however, also provide examples of successful cooperation which benefits forestry actors. All in all, a few examples of successful cooperation across sectors by individual forestry actors in integrated programmes contrasts to a general refusal of the sector to cooperate.

In the subsequent chapters we will describe the methodology applied and will position the concept of sectors in theory. For the above research questions we will formulate three hypotheses on why forestry as a sector only plays a minor role in IRD-programmes. Each assumption will be followed by empirical evidence on the very hypothesis. We will conclude with suggestions on how to improve the situation from the point of view of integrative programmes.

\section{CONCEPTUALISING SECTORS}

The concept of 'sectors' may largely contribute to answering the above research questions. Taking a system-theoretic viewpoint, sectors may basically be seen as 'closed and self-referential social systems' which create and maintain differences between themselves and their environment. ${ }^{11)}$ Sectors may further be described using the Advocacy Coalitions Framework by Sabatier and JenkinsSmith. Within a policy sub-system different 'advocacy coalitions' may form based on shared 'belief systems'. ${ }^{12)}$ Following Sabatier's approach, belief systems are organised in three hierarchical spheres: deep core beliefs, referring to basic normative and ontological assumptions, which are followed by policy core beliefs, representing normative commitments and causal perceptions. The former may be shared across policy sub-systems, while the latter cover all aspects of the sub-system. Lastly, at the lowest level so-called secondary aspects include e.g. policy preferences covering only parts of the policy sub-systems (SCHNEIDER and JANNING, 2006: 195f.). Policy core beliefs may be seen as 'the fundamental glue of coalitions $[\ldots]$ within the domain of specialisation of policy elites' (SABATIER and JenKins-Smith, 1999).

HogL adds to this view by describing sectors as 'relatively autonomous decision-making structures' (PETERS, 1998: 297; cf. Hogl, 2002: 78). From this we may conclude that boundaries, delineating the space of relative autonomy from its environment, play a central role in the social construction of sectors. Actors are assumed 'to define, to structure, to identify and to distinguish' (VERBIJ and SCHANZ, 2002: 98) sector boundaries. Such 'boundary behaviour' ${ }^{13)}$ may be explained by beliefs and/or interests and in addition comprises ensuring, defending or even maximising a given degree of autonomy sectors have (SHANNON, 2002: 21; HUBO and KROTT, 2007a). Such sectoral boundary behaviour can be observed in day-to-day political practice, where different interests, represented by sectoral advocates, compete for scarce resources (HuBO and KROTT, 2007a; Peters, 1998; JäCKERING, 1994).

Still, autonomous decision-making structures which are delineated by boundaries and based on shared believes alone do not allow for a full account of a sector in empirical practice, as 'they do not go beyond the level of actors, organisations or networks. [...] the concept of a sector comprises more than the classical understanding of actors in networks' (VerbiJ and Schanz, 2002: 96). Consequently, Нuвo and Квотт (2007b: 3-4) propose that besides

\footnotetext{
11) See LUHMANN (1996); WiLLKE (1996); SHANNON/SCHMIDT (2002: 19f).

${ }^{12)}$ SABATIER (1988: 139) describes advocacy coalitions as 'people from a variety of positions [...] who share a particular belief system - i.e. a set of basic values, causal assumptions, and problem perceptions - and who show a non-trivial degree of coordinated activity over time'.

13) The term does not refer to physical sciences, but describes some sort of 'territorial behaviour'.
}

(i)actor-related elements (advocacy coalitions, interests or belief systems, etc.) sectors are constituted by (ii) political programmes and (iii) institutional and related procedural compounds. Programmes are described as forming a sector content-wise and at the same time contributing to its institutional constitution, while the institutional design of a sector and associated procedures determine a sector's ability and potential to act (ibid.).

In light of these theoretical reflections we assume as a fundamental hypothesis, that sectors tend to show boundary behaviour in order not to be coordinated by integrated, sector-external programmes. Following this fundamental assumption we further may hypothesise that forestry is a sector in the above sense and hence resists attempts of being coordinated by integrated, sector-external programmes. In the course of this article we will address the abovementioned hypothesis as well as two further assumptions, accruing from it.

\section{METHODOLOGY}

Following the empirical-analytical approach the study takes the phenomenon of low forestry participation in IRD-programmes and tries to analyse its causes. In doing so it takes a qualitative research perspective. This seemed especially appropriate because a previous study by ORTNER (2004) took a quantitative approach in estimating forestry participation under an IRD-programme. We consequently have been interested in complementing Ortner's findings by investigating on potential reasons explaining the phenomenon of low forestry participation, rather than in its relative frequency. Since causes may occur at different levels of aggregation (from the individual forest owner's behaviour up to national forest owners' association's interests, etc.), the study addresses mostly collective actors at an institutionalised level. Employing a case study design on the role of forestry within IRD-programmes three funding programmes - the EU Community Initiative LEADER+, the Federal Ministry's Regionen Aktiv as well as the 'Joint Task for the Improvement of Agricultural Structures and Coastal Protection' have been studied as IRD-programmes. In this case study we carried out 11 qualitative expert interviews with specialists active in the field of IRD (referred to as externals/ext.) and others active in forestry (internals/int). ${ }^{14)}$ The interviews were of a semi-structured nature (JONES, 1996), also comprising narrative elements (RosENTHAL, 2005) on individual experiences with forestry in cooperative programmes. In addition, two focus group discussions (PARKER, 2006) comprising five group members in each discussion round have been conducted involving experts from the same two groups. Lastly, qualitative document analysis (JONES, 1996) was used for eliciting programmatic aspects of abovementioned IRD funding schemes and for validating interview data. All qualitative data has been processed using the coding functions of MaxQDA software.

\section{RESULTS}

\subsection{Sectoral resistance to integrated programmes}

GANE (2007: 25) conceptualises the 'forest sector' as consisting of three components: sector resources, activities and outputs. He pays special attention also to the interactions between those compounds by analysing which actors or organisations undertake sectoral activities (ibid.: 32) and how the institutional framework provides for a 'sectoral infrastructure' (ibid.: 211). This approach to understanding the sector concept rather aims to cover 'sector' in its political as well as economic terms. For the purpose of this

\footnotetext{
14) Survey at an institutionalised level comprising forestry and non-forestry representatives from associations, Federal (national) and Länder (subnational) authorities, scientific bodies and private consultants. Distinction between sector-internal and external actors based on membership to the German Forestry Council (DFWR 2001).
} 
study, however, it seems appropriate conceptualising the forest sectors in a more narrow sense, by focussing on the aforementioned three aspects relevant to policy analysis and political theory.

Forestry as an economic human activity not per se qualifies as a sector. However, in Germany political programmes on forestry exist. We define a forest policy programme as statements by forest stakeholders which are made in a societal context and which concern the utilisation and/or protection of forests (KROTT, 2005). ${ }^{15}$ ) Corresponding laws and regulations are important components of such a programme. In Germany the Federal Forest Act and 16 different Federal States' Forest Acts provide for a legal basis (KROTT, 2005: 23). Respective Federal State's forest programmes further contribute to a political programme on forestry. Together with the legal framework they are the first constitutive components (i.e. political programmes) of forestry as a sector by providing for content forming the sector and give meaning to shared policy core beliefs such as the (sustainable) management of forests. Actors build advocacy coalitions around such a core belief. WIERSUM (1999) elaborates a disciplinary matrix of forestry as the science and practice of forest management, suggesting that in forestry 'shared perspectives on problem situations and problem solving' prevail. Such coalitions with shared perspectives/beliefs in a German context manifest e.g. in the German Forestry Council and are supported by the profession and educational background, which in the case of forestry still plays an important role (HoGL, 2002: 79). From an institutional point of view, public administrative units exist at national, sub-national and local level, showing decreasing, yet pertaining degrees of autonomy over time. ${ }^{16)}$ These units are in strategic interaction with other actors of the advocacy coalition, sharing a set of normative and causal beliefs, defining problems and formulating policy. Together with their established procedures, such as e.g. the distribution of information within sectoral networks, their actors and programmes they constitute forestry as a sector.

In the context of IRD-programmes forestry was observed to resist such external coordination attempts in two ways. First, sector-external interviewees perceived resistance at a rather abstract level which is reflected in their hetero representation of the sector of 'forestry only rarely engages in such [integrated] approaches' ${ }^{17)}$ This abstract resistance is also reflected by the perception that 'forestry has its completely own world' in which sectoral actors are seen as the only entities 'being responsible for forests'. In this micro-cosmos "no one is supposed taking a hand in our business [i.e. forest-related issues] and in turn we [i.e. forestry actors] will also leave others alone'. ${ }^{18)}$ This finding is backed by forestry actors' auto representation, according to which forestry is 'reserved towards IRD' and shows a strong 'identity as an independent sector' ${ }^{19)}$

15) We do not refer to the National Forest Programme here. In addition to domestic forestry programmes several similar compounds emerge at the international level as result of e.g. UNFF and MCPFE negotiations (see e.g. Humphreys, 2006)

16) Public forestry institutions in Germany exist at the national level within the Ministry of Agriculture (BMELV, Dept. 53) and the Federal Research Centre for Forestry and Forest Products (BFH). Due to the federal character of Germany these national institutions are weak because responsibility for forests lies within the Federal States. At this sub-national leve sectoral discretion largely persists (InterviewFedGov-2ext; similar HoFMANN 2002), even though public sector reforms tend to decrease the autonomy of units concerned with forestry issues especially at the regional level (see e.g. recent reforms of state forest administration in the Federal State of Baden-Wuerttemberg where the regional forest offices have been mandated to the general regional administration).

17) Interview Assoc-3ext, similar FedGov-2ext, FedSt-1ext, Sci-1ext.

${ }^{18)}$ Interview Assoc-6int, Assoc-5ext, FedGov-2ext, FedSt1ext, Sci-1ext.

19) Interviews Assoc-1int, Assoc-2int.
Secondly, also active modes of sectoral refusal to go along with IRD were detected. External respondents state that 'the forest sector tries to keep other sectors and their funding programmes out of the forest ${ }^{2}{ }^{20)}$ In addition forestry was perceived as refusing IRD because these programmes were a manifest of the outflow of former agricultural and forestry funds into integrated approaches. ${ }^{21)}$ Perceptions of sectoral actors support the observation of active resistance. Property rights and the freedom of action play a crucial role among private forest owners. While this precondition is acknowledged in sectoral arrangements, integrated strategies bear the risk of underestimating this point at the cost of the owners' control over forest resources. Collective action viewed from such point of view first and foremost presents a limitation of these options, thus causing rejection among most owners. This especially holds true for the eastern part of Germany, where owners experienced the dark side of 'collective action' during the communist era and now fear an 'indirect expropriation' through integrated programmes. The economic instrument of public funding also is looked at critically by private forest owners, as it largely depends on unstable public budgets' and is 'perceived as the forerunner of regulatory hard law'. The described pre-conditions lead to active sectoral resistances at two different stages of the policy cycle. During implementation forest owners and their associations largely avoid participation to IRD-programmes, while in the past 'their respective efforts [in the formulation of programmes] very much was focused on traditional forestry [funding] aspects'. ${ }^{22)}$

Consequently, in order to retain a maximum control over the sector's resource base as well as to defend vested rights in public policies the forest sector resists the integrative IRD-approach by nonparticipation during implementation and conservative sectoral strategies in the formulation process of political programmes. Such demonstrated sectoral resistance, however, does not imply that no one individual private forest owner ever collaborates in IRD activities. Indeed we found several indications even for successful participation. ${ }^{23)}$ Still, at an aggregate level and in more general sectoral boundary behaviour of collective forestry actors partly explains the low degree of forestry involvement in integrated programmes.

\subsection{Forestry's inability to cooperate}

Integrated programmes are delivered by entities from outside most addressee sectors. This has implications for the compatibility of the programmes with the different sectors, their respective institutional design and procedures. According to CzADA (1991:153) public administrative units are in a strategic interaction with a specific societal segment - the other elements of the sector, through which their degree of organisation, their influence and power develop their virtue (HUBO and KROTT, 2007b). For functioning properly such strategic interaction must be based on commonly agreed rules and procedures. For example patterns and practices of disseminating information within sectoral networks, which may be of relevance to some segments of a sector, can be seen as one such procedure. Supposing that the provider of an integrated programme tries to reflect on own sector particularities and to minimise sectoral bias of the resulting programme, we still may assume that this provider may not anticipate the institutional design and relating procedures of all addressee sectors. We consequently hypothesise that institutional design as well as relating procedures between the system delivering an integrated programme and the addressee sectors

\footnotetext{
20) Interview Assoc-5ext.

21) Interview FedGov-2ext.

${ }^{22)}$ Interview Assoc-1int on all citations under sector-internal perception of active resistance.

${ }^{23)}$ see e.g. GIESSEN et al. (2006); GIESSEN and BÖCHER (2007); ORTNER (2008).
} 
differ and are not fully compatible with each other. ${ }^{24)}$ Thus the ability of the forest sector to participate in IRD-programmes is low.

Taking an inductive approach the empirical materials suggest that there are at least three aspects to be taken into account when assessing the compatibility of forestry with IRD-institutions and procedures and vice versa. These results have been derived from sector-internal as well as from external experts, lending them a high degree of validity and reliability.

Communicative aspects were observed playing a role. Extensive participation processes disadvantage private enterprises, such as farmers and forest owners and entail high transaction costs for goal attainment. ${ }^{25}$ ) While agro-sectoral actors already anticipated the necessity to publicly argue for support and hence are equipped with communication skills for doing so, forestry actors are perceived as not fulfilling these requirements. ${ }^{26)}$ This handicap of the forest sector is also reflected by weak lobbying activities in integrated programmes at all levels ${ }^{27}$ as well as by poor availability and dissemination of information on the respective programmes. ${ }^{28)}$

Secondly, managerial aspects in form of lacking resources find consideration. The prospect of proceeds has a significant influence on forest owners (KROTT, 2005: 48). Thus, forest owners possibly will only invest resources in IRD activities if early monetary benefits may be expected. In addition 'when business largely depends on capital-intensive machines, one may not expect from forest owners to engage in lengthy discussions in the afternoon'. Public forest administrations currently suffer from severe cut-backs. Under such circumstances organisations tend to focus on their core-business. 'How are you ought to do participation [in IRD-processes] when you are tied-up with maintaining your basic functions?' A lack of human resources (personnel) compatible with IRD-procedures (i.e. capable of dealing with open networks, complex communication processes, etc.) in all types of forest ownership was perceived as resulting from a 'general climate hostile to innovation [... where] innovators within the forest sector often are regarded as exotic. IRD is exactly about such Ideas, which may supply niche markets' ${ }^{29)}$

Thirdly, institutional aspects were perceived to play the most prominent role in determining how compatible the integrated programmes may be with sectoral procedures and vice versa. Institutions of forestry and IRD (i.e. a specific segment within the agricultural sector) in a multi-level system do not correspond with each other. While IRD is being delivered through public agricultural institutions, which are well established at local, sub-national, national as well as EU level ${ }^{30}$, public forest institutions are represented at sub-national and local levels only. This leads to a lack of political engagement at national and EU-level of both, public as well as private forestry actors. The claim of sectoral actors that forestry is an absolute responsibility of the Federal States ${ }^{31)}$ in this regard must be seen as hindering compatibility even more.

24) We are aware of the one exception where the programme provider addresses its sector of origin, which probably holds true for most integrated programmes.

25) Assoc-1int, Cons-1ext; GIESSEN and BöCHER (2007: 16).

26) Assoc-5ext, Sci-1ext making reference to a conference on communication in forestry.

${ }^{27)}$ FedSt-2int, Sci-1ext, Assoc-1int, Assoc-5ext.

${ }^{28)}$ For poor availability of information especially for small and medium private forest owners see Interview Assoc-1, while ORTNER (2008) reveals that distribution of information by and within forest administration does not occur.

29) Sci-1ext on whole section on 'managerial aspects', similar Assoc-1int.

${ }^{30)}$ At local level the influence of public agricultural agencies may vary. However, at all other levels, e.g at national level within the 'Joint Task' GAK, their prominent role and political influence may not be neglected.

31) Sci-1ext.
Hence, in our case we observe a lack of an institutional 'level of fit' (LENSCHOW, 2002: 17) between a potential addressee sector (here: forestry) and the sector providing the funds (agriculture). This institutional non-fit results in procedural dissonances as well. Guidelines of EU funding programmes, for example, have entailed accounting systems ranging over 20 years and requiring a high degree of accuracy regarding area delineation. Such standard have been known from agriculture, where they may be applicable. 'Among forest owners such incidents resulted in the attitude that measure-oriented EU funding is crap'. ${ }^{32)}$ Thus, an institutional non-fit and the resulting procedural dissonances among IRD and forestry support the assumption of an institutional incompatibility of the two systems as one additional reason why forestry only plays a marginal role in IRD-programmes.

\subsection{Limited opportunity to participate in biased 'integrated' programmes}

The rhetoric behind integration states that programmes have to be well balanced among all participants. But strong sectors could try to influence the programmes in order to adapt them to the specific interests of the respective sector. We consequently may ask whether isolation of forestry is the only sectoral mechanism in place in this case. From the above we may state that under integrated programmes also other sectors, including programme providers show boundary behaviour and consequently, integrated programmes delivered by sectoral entities can be assumed showing a high degree of sectoral influences and thus, such biased integrated' programmes would not be attractive for other sectors to join.

In the case study also other sectors were observed showing boundary behaviour. After taking a closer look, the IRD rhetoric of being a cross-sectoral programme seems to entail sectoral interests as well. While our introductory chapter illustrated that forestry was a direct addressee of IRD-programmes, a more focussed document analysis revealed that forestry as a sector has not been addressed explicitly. It rather is mentioned in composite phrases such as '[...] actors from agriculture and forestry', or '[...] products from agriculture, fisheries and forestry'. ${ }^{33)}$ In the programme documents the sector almost exclusively was mentioned as an add-on, paraphrased as 'something ... and forestry'.

In fact the IRD-programmes considered under this study have all been delivered by public administrations from the agricultural domain. ${ }^{34)}$ Significant sectoral (i.e. agricultural) influences in IRDprogrammes have been revealed by our empirical results from both expert groups. High agreement was found on the perception that IRD-programmes 'show a strong bias towards agriculture ${ }^{35)}$ and rather may be considered as 'agro-structural programmes [...] currently offering limited benefits for forestry actors' ${ }^{36)}$ These agro-

\footnotetext{
32) Assoc-1int.

${ }^{33)}$ Exemplary BMVEL (2005: 11, 15), BMVEL (2001: 7-8); In German language this triple compound shows a considerable degree of stereotypic character, as the terms for all these three land uses are somewhat similar (i.e. Landwirtschaft, Forstwirtschaft und Fischereiwirtschaft) and often are mentioned in sequence of appearance strating with agriculture. This linguistic reality mirrors a significant political imbalance among the land uses in favour of agriculture.

34) Providers of the programmes under consideration were European Commission's DG Agriculture and Rural Development, the German Federal Ministry of Consumer Protection, Food and Agriculture as well as different Federal States' Ministries, which apart from one exception (Schleswig-Holstein, see TRÄNKNER and GIESSEN (forthcoming)) all comprise responsibilities for agriculture (see BMVEL 2005: 65ff), which show a strong bias and persistence towards agricultural interests (Interview FedGov-2ext)

35) Sci-1ext, similar Assoc-1int, Assoc-3ext, Asoc-4ext, FedGov-1int, FedGov-2ext

36) Assoc-3ext, similar Assoc-1int.
} 
sectoral influences of IRD policies may be explained by the sector concept as well, as in light of a decreasing role of agriculture and WTO and GATT trade liberalisations agriculture faces enormous alternations in the way and amount the sector receives public support. The ongoing shift in EU support for agriculture from direct payments $\left(1^{\text {st }}\right.$ pillar of CAP) to rural development measures $\left(2^{\text {nd }}\right.$ pillar) may serve as an example here. Consequently, by trying to internalise the policy field of (integrated) rural development, the agricultural sector outwards seeks to expand its influence (or more drastically: secure 'organisational survival' ${ }^{37}$, while inwards it obstructs such integration tendencies by designing integrated programmes in a non-integrative fashion or by merely opting-out, i.e. refusing its implementation. ${ }^{38)}$

Taking a look at the role agriculture plays in IRD-programmes, we may approach the above hypothesis even in more detail. Following the assumption that IRD-programmes show a high degree of agricultural bias, the respective agricultural sector must be expected to benefit in a privileged way from such funding. Indeed under the Regionen Aktiv programme farmers were observed being the primary beneficiaries, receiving about $30 \%$ of the project funds (BMELV 2006: 15). ${ }^{39)}$ This finding also supports the former hypothesis, showing that the compatibility between integrated programmes and their respective sectors of origin results in a privileged access to funding resources for sectoral actors.

Historical developments in the EU may serve as an explanation here. While the Treaty of Rome (and in particular Annex 2) excludes forestry from common policy, the sector as a whole has not been faced with major changes in respective policy and subsequent adaptations of its strategies. With the Common Agricultural Policy, however, agro-sectoral actors and institutions needed to adapt to major changes. Thus, processes of policy learning could take place, e.g. in the field of integrated bottom-up approaches of funding policy.

If IRD-programmes contain only limited potential benefits for forestry, and if then they are not just delivered by the agriculture sector but even formulated and designed to its predominant benefit, we conclude that IRD-programmes must be interpreted as biased toward agriculture. Consequently such faked 'integrated' programmes are of minor advantage for forestry.

\section{CONCLUSION: Strengthening willingness and ability to create real opportunities for integration}

We could show theoretically that sectors are a social construct, which benefit elites in a given policy domain, and hence are flexible and context-dependent. Our empirical findings show that the forest sector resists integration and does not develop the ability for cross-sectoral cooperation. Furthermore, there is no opportunity to genuinely join the integrative programme, but a threat by an agricultural biased 'integrated' programme. Nevertheless, we can identify a few integrative projects which produce profits for specific forestry actors, leading to win-win solutions for all participants. But the individual solutions are not copied frequently to become a strategy changing the basic isolationisms of forestry.

The factors identified explain the lack of forestry participation, but simultaneously show how integrated programmes could be more successful in the future. Firstly, the lack of willingness to

\footnotetext{
37) Peters (1998: 308).

38) The latter point could be observed in one case, where agricultural actors (a Federal State's Minister for Agriculture as well as the highly influential Farmers' Association (DBV) publicly refused participation in an IRD-programme for strategic reasons (Assoc-6int).

39) HemmerLing (2006) takes up this fact on behalf of the German Farmers' Association (DBV) and concludes that agriculture was the primary beneficiary under the funding scheme.
}

open up is inherent to the forest sector and will probably not be changed by good arguments about advantages of networking only. The threat of an anticipated crisis touching upon the material interests of forestry in the future would be a strong driver shaking up the sector for reaching out for allies outside the sector. Up to now such a strong threat may not be expected. Secondly, the ability to cooperate can be improved by numerous instruments e.g. success stories of pilot projects or guidelines for cooperation (see GIESSEN et al., 2006; ORTNER, 2008). Such empowerment would help the sector meeting parts of the integration challenges in the future. Thirdly, the lack of unbiased integrative programs cannot be changed by the forest sector. Making progress in integrative programs is a core task of all innovators and policy-makers who lobby for the advantages of integrated policies. Analysing their driving factors, however, is beyond the forestry focus of this paper.

\section{ABSTRACT}

Policy integration and cross-sectoral programmes are discussed as means to better achieve the endeavour of sustainable development. Lately, political programmes, such as integrated rural development (IRD) funding schemes emerge taking an integrated, intersectoral approach. In Germany forestry, however, so far has been observed to only play a minor role in IRD. In this article we seek an answer to the fundamental question of why forestry actors only play a minor role in such integrated programmes? The article theoretically reveals that sectors tend to avoid being coordinated by sectorexternal entities and programmes. Our case study indicates that forestry as a sector, shows abstract as well as active resistance against external attempts of integrated coordination. In the rare cases where the sector opens up towards integrated programmes, however, forestry actors lack the ability, resources as well as institutional preconditions for cooperation. Lastly, the agricultural bias of formally integrative programmes causes refusal among forestry actors. These findings lead us to the conclusion that forestry participation in integrated programmes is a question of willingness and specific utility as well as of ability in terms of institutions and resources. However, the existence of truly integrated programmes is a prerequisite, which policy makers still need to deliver.

\section{Zusammenfassung}

Titel des Beitrages: Die Beteiligung der Forstwirtschaft an integrierten Programmen - eine Frage der Bereitschaft, der Fähigkeit und der Möglichkeiten.

Politikintegration und sektorübergreifende Programme werden als moderne Strategie für Nachhaltige Entwicklung diskutiert. In den letzten Jahren nehmen solche Programme in Deutschland an Bedeutung zu. In der Förderung um eine ,integrierte ländliche Entwicklung" (ILE) spielt die Forstwirtschaft jedoch bisher nur eine geringe Rolle. Dieser Artikel geht der Frage nach, warum forstliche Akteure in solchen integrierten Programmen lediglich gering vertreten sind. Wir zeigen theoretisch, dass integrierte Programme den einzelnen Sektoren generell widersprechen. Unsere Fallstudie zeigt, dass die Forstwirtschaft als Sektor sich gegen integrierte Koordination durch ILE-Programme bewusst abgrenzt. In den seltenen Fällen, in denen sich der Sektor öffnet, fehlen den forstliche Akteure die Fähigkeiten, Resourcen und institutionellen Voraussetzungen an integrierten Programmen teilzuhaben. Schließlich schreckt auch ein landwirtschaftlicher Bias der ILE-Programme die forstliche Beteiligung ab. Diese Befunde führen uns $\mathrm{zu}$ dem Schluss, dass die Beteiligung der Forstwirtschaft an integrierten Programmen einerseits eine Frage des Willens bzw. des spezifischen Nutzens, andererseits der Fähigkeiten sektoraler Akteure ist. Allerdings ist das Vorhandensein von tatsächlich integrierten Programmen eine Erfolgsvoraussetzung, die von der Politik bislang nicht angeboten wird. 


\section{Résumé}

Titre de l'article: La participation de la foresterie à des programmes intégrés- Une question de disponibilité, d'aptitude et de possibilités.

On discute d'intégration politique et de programmes plurisectoriels en tant que stratégie moderne pour permettre un développement durable. Au cours des dernières années de tels programmes ont pris de l'importance en Allemagne.Pourtant, la foresterie n'a joué jusqu'à présent qu'un rôle restreint dans l'avancement d'un «développement rural intégré» (ILE). Cet article pose la question de savoir pourquoi les acteurs forestiers sont très peu représentés dans de tels programmes intégrés. Nous montrons en théorie que des programmes intégrés sont en général incompatibles avec les secteurs particuliers. Notre étude de cas montre que la foresterie en tant que secteur, se démarque délibérément d'une coordination intégrée dans le cadre de programmes ILE. Dans les rares cas dans lesquels le secteur s'ouvre, il manque aux acteurs forestiers les aptitudes, les ressources et les conditions institutionnelles pour prendre part aux programmes intégrés. Finalement une tendance «agricole» des programmes ILE décourage la participation forestière. Ces observations nous amènent à la conclusion que la participation de la foresterie à des programmes intégrés est une question, d'une part de volonté, d'avantage spécifique pouvant en être tiré, et d'autre part d'aptitudes des acteurs sectoriels. Sans doute, l'existence de véritables programmes intégrés est une condition préalable de réussite, que la politique n'offre pas jusqu'à présent.

R.K.

\section{Acknowledgement}

We would like to thank our colleague MichAEL BöCHER for his valuable input.

\section{Literature cited}

BMVEL, German Federal Ministry of Consumer Protection, Food and Agriculture (2001): Regionen Aktiv - Land gestaltet Zukunft - Informationen zum Wettbewerb. Bonn.

BMVEL (2005): Actively shaping rural development - Guidelines for integrated rural development. Bonn.

BMVEL (2006): So haben ländliche Räume Zukunft. Regionen Aktiv: Ergebnisse 2002-2005 und neuer Ansatz bis 2007. Bonn.

Böcher, M. und L. GIESSEN (2006): Forst als Partner in der integrierten ländlichen Entwicklung. In: AFZ - Der Wald, 5/2006, pp. 263-264.

Briassoulis, H. (2005): Policy integration for complex environmental problems - The example of mediterranean desertification. Ashgate, Burlington.

CzadA, R. (1991): Regierung und Verwaltung als Organisatoren gesellschaftlicher Interessen. In: Hartwich, H. H., Wewer, G. (Eds.): Regieren in der Bundesrepublik III. Systemsteuerung und "Staatskunst“". Theoretische Konzepte und empirische Befunde. Opladen, pp. 151-173.

DFWR, Deutscher Forstwirtschaftsrat (2001): Satzung des Deutschen Forstwirtschaftsrates e.V. (DFWR)

DVS, Deutsche Vernetzungsstelle LEADER+ (1999): LEADER+ - Die Europäische Initiative für den ländlichen Raum.

EC, European Commission (2006): The Leader Approach - A basic guide. Brussels.

Gane, M. (2007): Forest Strategy - Strategic management and sustainable development for the forest sector. Springer. Dordrecht.

GIESSEN, L. (2007): Forst gering vertreten in integrierten Programmen Gründe dafür am Beispiel der integrierten ländlichen Entwicklung. In: PrKnova, H. (Hg.): 39. Forstpolitikertreffen - Sammelband. Prag.

GiesseN, L. (2008): Die Zurückhaltung der Forstwirtschaft in der integrierten ländlichen Entwicklung - Analyse der politischen Ursachen. Forstarchiv 79 (3): 116-121

GIESSEN, L. and M. Böcher (2007): New Modes of Governance in Integrated Rural Development Policies. Final report within the research project 'New modes of governance for sustainable forestry in Europe'. Göttingen.

Giessen, L., M. Böcher, M. ORTNer and S. TrÄNKNER (2006): Integrated Rural Development as pathway for innovations - an unexploited potential for forestry -. In: MCPFE (Ed.) Policies Fostering Investments and Innovations in Support of Rural Development, Zvolen, Slovakia, March 27-29 2006

HaHNE, U. (1984) Ökologische Regionalentwicklung. Informationen zur Raumentwicklung 1/2, pp. 53-62.
HemmerLinG, U. (2006): „Regionen Aktiv“ nutzt auch der Landwirtschaft. In: Deutsche Bauern Korrespondenz, 5/06, p. 26.

Hofmann, F. (2002): Globale Waldpolitik in Deutschland - Eine Untersuchung über die Wirkung internationaler Regime in föderalen Strukturen. Dissertation. Freiburg.

HoGL, K. (2002): Reflections on inter-sectoral co-ordination in national forest programmes. In: TiKKANEN, I., GLÜCK, P., PAJUOJA, H. (Eds.): Cross-sectoral policy impacts on forests. EFI Proceedings No. 46. Joensuu.

Hubo, Christiane und Max Krott (2007a): Politiksektoren als Determinanten von Umweltkonflikten am Beispiel invasiver gebietsfremder Arten. In: FeINDT, P. H., SARETZKI, Th. (Eds.): Umwelt- und Technikkonflikte, VS Verlag für Sozialwissenschaften. Wiesbaden.

Hubo, Christiane und MAX KrotT (2007b): Umsetzungsstrategien für integrative Politikansätze am Beispiel invasiver gebietsfremder Arten. In: Zeitschrift für angewandte Umweltforschung, 18/2, pp. 216-226.

HuMPHREYs, D. (2006): Logjam. Deforestation and the crisis of global governance. Earthscan. London.

Hyttinen, P., A. NisKanen and A. Otitsch (2000): New challenges for the forest sector to contribute to rural development in Europe. In: Land Use Policy, 17, pp. 221-232.

Hyttinen, P., A. NisKanen and A. OtTitsch (2002): Forest related perspectives for regional development in Europe. Leiden. Boston. $129 \mathrm{pp}$.

JÄCKERING, W. (1994): Verwaltung und öffentliche Aufgaben. In: MATTERN, K.-H. (Ed..): Allgemeine Verwaltungslehre, $4^{\text {th }}$ edition. Berlin, Bonn, Regensburg, S. 15-31.

JÄNICKE, M. (2006): Politikintegration im Mehrebenensystem: das Beispiel der deutschen Umweltpolitik. In: Koch-Baumgarten, S., RüTtgers, P. (Eds.): Pluralismus und Demokratie: Interessenverbände - Länderparlarmentarismus - Föderalismus - Widerstand: Siegfried Mielke zum 65. Geburtstag. Bund Verlag, Frankfurt. pp. 63-73.

JÄNICKE, M. and H. JöRGENS (2004): Neue Steuerungskonzepte in der Umweltpolitik. In: Zeitschrift für Umweltpolitik und Umweltrecht, 3/2004, pp. 297-348.

JONES, R. A. (1996): Research Methods in the Social and Behavioral Sciences. $2^{\text {nd }}$ Edition. Sinauer, Sunderland.

KROTT, M. (2005): Forest Policy Analysis. Springer. Dordrecht.

KRUL, L. and SASKIA OzINGA (2005): Funding Europe's Forests - How to use EU funds for sustainable forest management and nature protection. FERN and Taiga Resource Network. Brussels.

LENSCHOW, A. (2002): Environmental Policy Integration - Greening Sectoral Policies in Europe. Earthscan, London.

Luhmann, N. (1996): Soziale Systeme: Grundriss einer allgemeinen Theorie. Frankfurt. Suhrkamp. 674p.

Meijers, E. (2004): Policy integration: A literature review. In: Stead, D., GeErlings, H., MeIJers, E.. (Eds.): Policy integration in practice. The integration of land use planning, transport and environmental policy-making in Denmark, England and Germany. DUP, Delft. pp. 9-24.

OECD (1989): Agricultural and Environmental Policies - Opportunities for Integration. OECD, Paris.

OECD (1996): Building policy coherence - Tools and tensions. Public Management Occasional Papers No. 12. OECD, Paris.

ORTNER, M. (2004): Zusammenarbeit zwischen Forstwirtschaft und Leader+ In: LEADERforum (2004), No. 2, p 41

ORTNER, M. (2008): Erfolgsfaktoren für die Beteiligung forstlicher Akteure an der integrierten ländlichen Entwicklung - Beispiel: LEADER+ Programm der EU-Strukturpolitik. Dissertation. Universitätsverlag Göttingen. (in press)

PARKER, A. (2006): Focus group method and methodology: current practice and recent debate. In: International Journal of research and method in education, No. 29, pp. 23-38.

Peters, B. G. (1998): Managing horizontal government - The politics of coordination. In: Public Administration 76, pp. 295-311.

RAY, CH. (2000): The EU LEADER Programme: Rural Development Laboratory. In: Sociologia Ruralis Vol. 40, No 2, April 2000, pp. 163-171.

RAY, CH. (2006): Neo-endogenous rural development in the EU. In: CloKE, P., Marsden, T. and Mooney, P. (eds.): Handbook of Rural Studies, pp. 279-91. London.

Rosenthal, G. (2005): Interpretative Sozialforschung - Eine Einführung Juventa. Weinheim.

SABATIER, P. A. (1988): An advocacy coalition framework of policy change and the role of policy-oriented learning therein. Policy Sciences 21. pp. 129-168.

Sabatier, P. A. and H. C. Jenkins-Smith (1999): The advocacy coalition framework. In: SABATIER, P. (Ed.): Theories of the policy processes. Westview Press. pp. 117-166.

Scientific Council for Government Policy (2002): Sustainable Development. Administrative Conditions for an Activating Policy. Reports to the Government No. 62. Sdu, The Hague.

SCHNEIDER, V. und F. JANNING (2006): Politikfeldanalyse - Akteure, Diskurse und Netzwerke in der öffentlichen Politik. VS Verlag. Wiesbaden. 
Shannon, M. A. and C. A. Schmidt (2002): Theoretical approaches to understanding intersectoral policy integration. In: TIKKANEN, I., GLÜCK, P. PAJuoJa, H. (Eds.): Cross-sectoral policy impacts on forests. EFI Proceedings No. 46. Joensuu.

TRÄNKNER, S. and L. GIESSEN (forthcoming): Four paths of mainstreaming the LEADER approach in Germany. In: SOTO, P. (Ed.): Which direction for Rural Development? (in press).
VerbiJ, E. and H. SchanZ (2002): Inter-sectoral co-ordination: State of the arts and beyond. In: Tikkanen, I., Glück, P., Pajuoja, H. (Eds.): Cross-sectoral policy impacts on forests. EFI Proceedings No. 46. Joensuu.

WIERSUM, K. F. (1999): Social Forestry: Changing perspectives in forestry science or practice? Thesis Wageningen Agricultural University. Wageningen.

Willke, H. (1996): Ironie des Staates: Grundlinien einer Staatstheorie polyzentrischer Gesellschaft. Suhrkamp, Frankfurt. 389p. 


\section{Sebastian Elbe (Hrsg.)}

\section{Land-Stadt Kooperation und Politikintegration für ländliche Räume}

Zentrale Ergebnisse und Handlungsempfehlungen der Begleitforschung Regionen Aktiv 2007 bis 2008

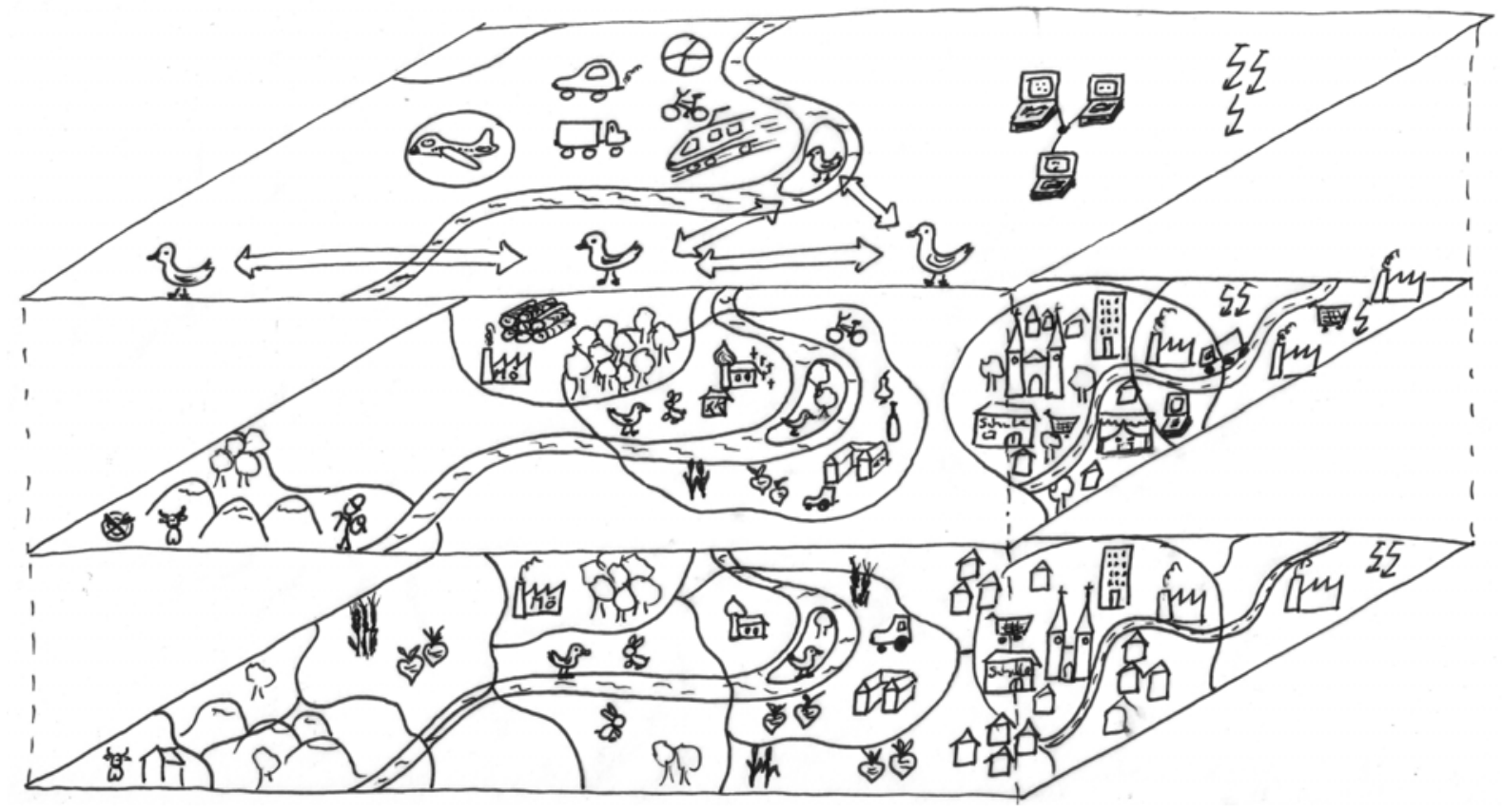


Hinweis: Der Bericht gibt die Auffassung und Meinung der Verfasser wieder und muss nicht mit der Auffassung des Auftraggebers übereinstimmen. 
DANK

HINTERGRUND BEGLEITFORSCHUNG REGIONEN AKTIV 2007 BIS 2008........ VI

\section{FOKUS LAND-STADT KOOPERATION: ZWISCHEN GRABENKÄMPFEN UND KONZEPTIONELLEN ANSÄTZEN}

1. EINFÜHRUNG

2. ZUR NOTWENDIGKEIT VON LAND-STADT KOOPERATIONEN .................... 3

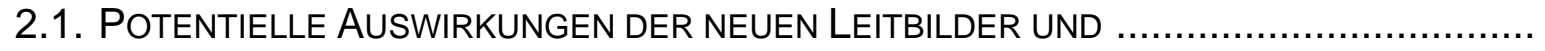
HANDLUNGSSTRATEGIEN AUF LÄNDLICHE RÄUME........................................ 4

2.1.1. Auswirkungen auf metropolnahe ländliche Räume........................... 5

2.1.2. Auswirkungen auf ländliche Zwischenräume................................... 6

2.1.3. Auswirkungen auf periphere ländliche Räume .................................. 7

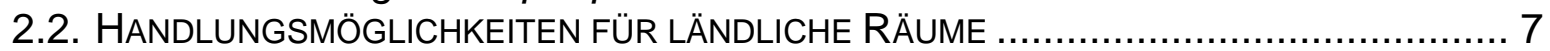

2.3. Programmatische RahmenBedingungen FÜr LAND-STADT-KoOPERATIONEN.... 9

2.3.1. Europäische Ebene: Leipzig Charta und Territoriale Agenda ................. 9

2.3.2. Bundesebene......................................................................... 12

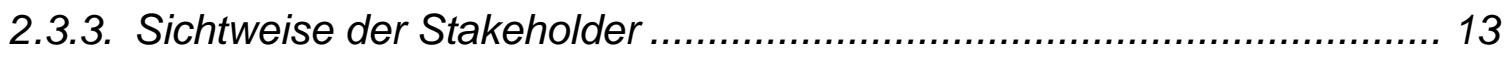

2.3.4. Zwischenfazit ................................................................... 16

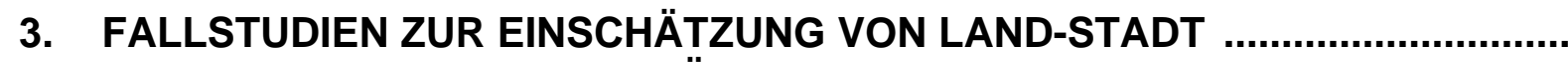
KOOPERATIONEN IN EUROPÄISCHEN METROPOLREGIONEN ................. 17

3.1. EINSCHÄTZUNG DER AUSDEHNUNG UND DER POLYZENTRALITÄT ...................... 17

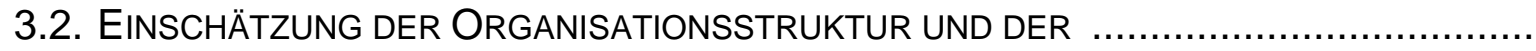

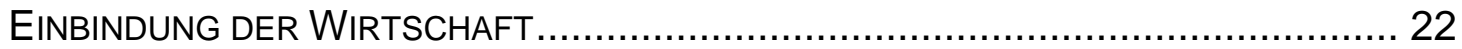

3.3. EINSCHÄTZUNG DER KOOPERATIONSFELDER …........................................ 25

3.3.1. Einschätzung hierarchiebezogener Themenfelder........................... 26

3.3.2. Einschätzung marktbezogener Themenfelder ................................ 28

3.3.3. Einschätzung verhandlungsbezogener Themenfelder....................... 32

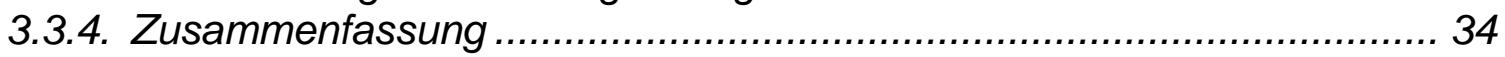

3.4. EINSCHÄTZUNG ZUR FINANZIERUNG VON KOOPERATIONEN ........................... 36

4. ERGEBNISSE UND HANDLUNGSEMPFEHLUNGEN ............................... 38

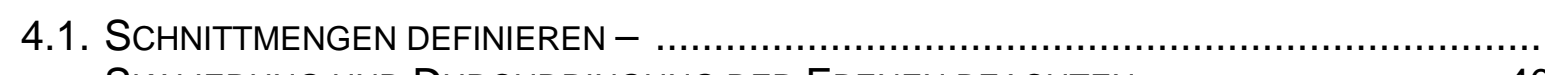

SKALIERUNG UND DURCHDRINGUNG DER EBENEN BEACHTEN ....................... 40

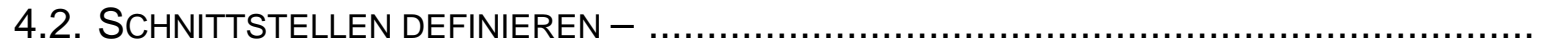

PERSONEN UND ENTSCHEIDUNGSSTRUKTUREN ETABLIEREN ......................... 41

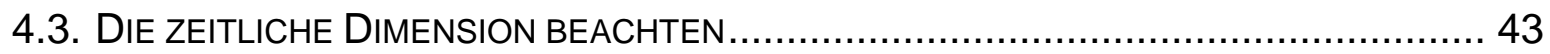

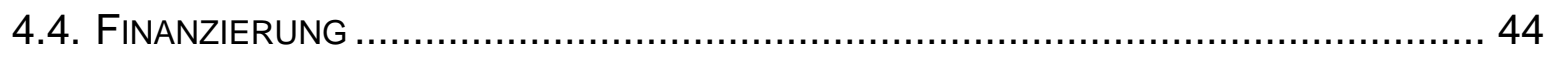

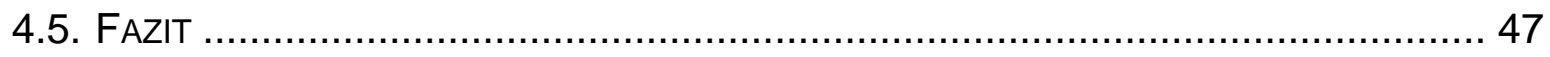

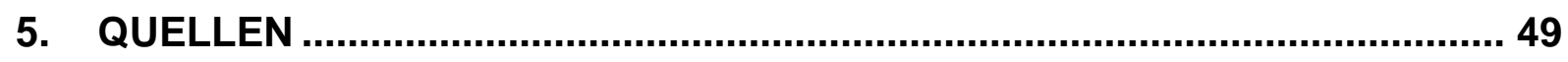

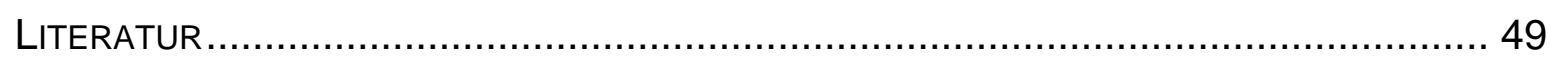

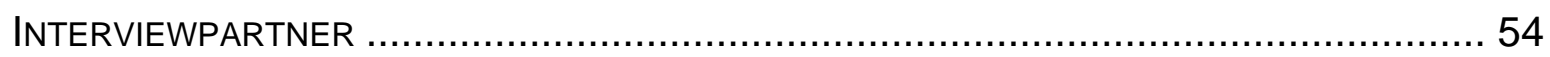




\section{POLITIKINTEGRATION FÜR LÄNDLICHE RÄUME? DIE (NICHT-) KOORDINATION DER FÖRDERUNG}

1. POLITIKINTEGRATION ALS ANSATZ EINER LÄNDLICHEN POLITIK 57

2. THEORIE DER POLITIKINTEGRATION ..................................................... 58

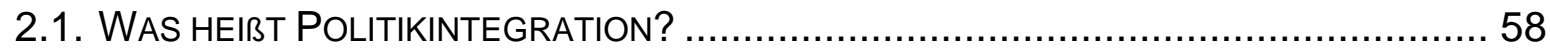

2.2. HORIZONTALE, VERTIKALE UND PUNKTUELLE POLITIKINTEGRATION ..................... 60

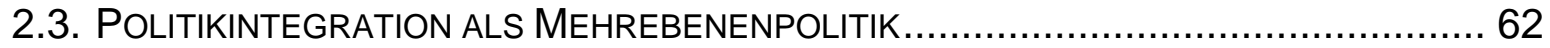

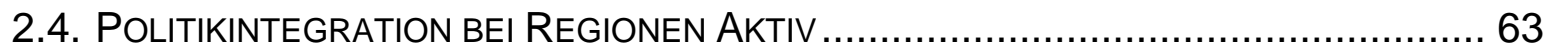

3. POLITIKINTEGRATION IN DER FÖRDERUNG FÜR LÄNDLICHE RÄUME .. 64

3.1. Formale Politikintegration BEI DER FÖRDERUNG PROGRAMMATISCHE GRUNDLAGEN DER STRUKTURFONDS

3.2. INFORMALE WIRKLICHKEIT -

AUF DER SUCHE NACH MECHANISMEN ZUR KOORDINATION ........................... 71

3.2.1. Koordinationsmechanismen auf Landesebene................................. 71

3.2.2. Koordinationsmechanismen auf regionaler Ebene ............................. 85

3.2.3. Fördernde und hemmende Faktoren einer Politikintegration .................. 88

3.2.4. Mängel und Lücken in der Koordination von Förderung ........................ 93

3.3. LICHTBLICKE - GUTE BEISPIELE DER KOORDINATION VON FÖRDERPROGRAMMEN .. 95

3.3.1. Koordination auf der Ebene der Programmgestaltung:

Das Beispiel Sachsen. 96

3.3.2. Koordination auf der Ebene der Programmumsetzung: Das Beispiel Tirol.

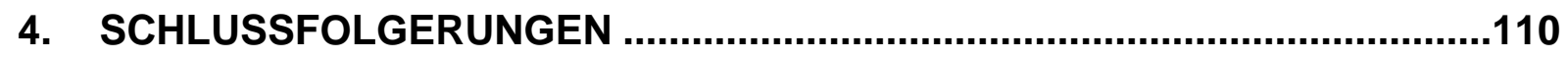

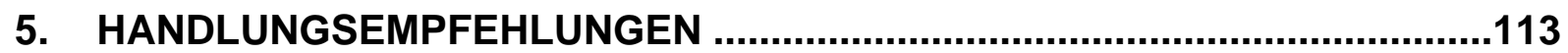

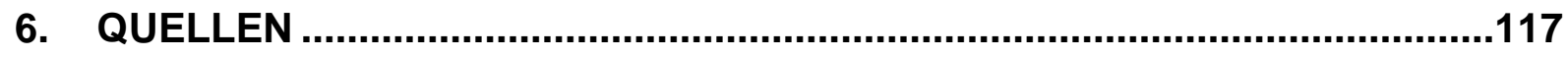

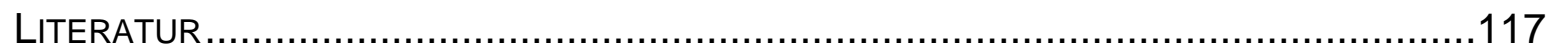

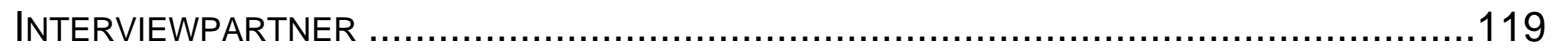




\section{Politikintegration für ländliche Räume? Die (Nicht-) Koordination der Förderung}

von Lukas Gießen, Robert Lukesch, Michael Böcher und Sebastian Elbe

\section{Politikintegration als Ansatz einer ländlichen Politik}

Der Förderpolitik wird im Zusammenhang mit der Entwicklung ländlicher Räume generell eine hohe Bedeutung beigemessen. In diesem Zusammenhang werden verschiedene Politiksektoren bzw. deren Förderinstrumentarium diskutiert, die zu diesem politischen Ziel beitragen könnten. Neben dem Komplex der Wirtschaftsförderung in strukturschwachen Räumen (z.B. EFRE- und GRW-Förderung) kommt dem landwirtschaftlichen Sektor ebenfalls eine prominente Rolle in diesem Zusammenhang zu (ELER- und GAK-Förderung). Zu diesen Instrumenten der sektoralen Regelförderung gesellen sich zeitweise auch Modellvorhaben, die im Fall der ländlichen Politik eher einen Querschnittscharakter aufweisen (Regionen Aktiv, Leader, etc.). Der Ansatz der Regelförderung, gezielt auf sektorale Zusammenhänge Einfluss zu nehmen, kann als fähig gesehen werden, detailgenaue Lösungen für Probleme eines spezifischen Politikfeldes zu fördern. Dabei erfüllen öffentliche Stellen die Anforderungen an eine rationale Verwaltung durch hochgradige Spezialisierung und Abgrenzung zu anderen Bereichen. Bei Querschnittsproblemen hingegen scheinen integrierte, sektorübergreifende Lösungsansätze geeigneter. Solche wurden im Bereich der ländlichen Politik durch die oben genannten Modellvorhaben getestet und in die Debatte um die Anpassung der Regelförderung eingebracht. Dabei war die Suche nach Synergien in der Förderung verschiedener Sektoren ein erklärtes Ziel. Diese Suche nach Synergien im Hinblick auf Querschnittsprobleme wird unter dem Begriff der „Politikintegration“ debattiert. Generell ist die Integration von gewissen politischen Zielen (wie z.B. ländliche Entwicklung, Wirtschaftswachstum oder Umweltbelange) bei allen Arten der politischen Instrumente denkbar (bei Regularien, Anreizsystemen oder Informationsinstrumenten). Im Folgenden wird im Bereich der Förderpolitik als ökonomisches Anreizinstrumentarium untersucht, inwieweit sich die verschiedenen Förderpolitiken unterschiedlicher Politiksektoren wirklich aufeinander abstimmen und mit Blick auf das Ziel der ländlichen Entwicklung koordinieren lassen. In aufeinander folgenden Arbeitsschritten wurden die folgenden Teilfragestellungen behandelt: 
- Welche Erkenntnisse hält die Wissenschaft zum Thema Politikintegration bereit? ${ }^{82}$

- Welche programmatischen Ansprüche an die gegenseitige Integration und Abstimmung von Förderinstrumenten mit Relevanz für ländliche Räume besteht in der politischen Praxis? ${ }^{83}$

- Welche Mechanismen zur Abstimmung und Koordination können in der Verwaltungspraxis angetroffen werden und wie werden diese umgesetzt? Welche fördernden $u$ hemmenden Faktoren bestehen in der Förderpraxis? Lassen sich darunter gute Beispiele finden ${ }^{84}$

Die folgenden Kapitel beleuchten zunächst die theoretischen Grundlagen und zentralen Erkenntnisse aus der Politikintegrationsforschung, bevor in der empirischen Analyse die Politikintegration am Beispiel der Förderpolitik für ländliche Räume untersucht wird. Der Beitrag schließt mit Schlussfolgerungen zu den Ergebnissen und darauf basierenden Handlungsempfehlungen für Politikgestalter, die einen integrierten Mitteleinsatz zur Förderung ländlicher Räume verfolgen.

\section{Theorie der Politikintegration}

\subsection{Was heißt Politikintegration?}

Der Begriff der Politikintegration reflektiert, dass sich Natur und Wahrnehmung politisch zu lösender Probleme dahingehend verändert haben, dass diese zunehmend einen Querschnittscharakter aufweisen und die sektoralen Grenzen traditioneller Politikfelder überschreiten ${ }^{85}$ (Meijers 2004: 9; ähnlich Jänicke 2006: 63 und Briassoulis 2005: 1). Andererseits haben sich auch die politischen Lösungsansätze geändert, da eindimensionale, sektorale, disziplinäre und unkoordinierte Ansätze nicht mit dem derzeitigen Verständnis einer Nachhaltigen Entwicklung zu vereinbaren sind (Lenschow 2002: 3, Briassoulis 2005: 1). Letztendlich ist mit Politikintegration die Hoffnung verknüpft, hinsichtlich veränderter politischer Problemlagen eine Effizienz- und Effektivitätssteigerung von Politik zu erreichen (vgl. Meijers 2004: 9). Auch wenn Politikintegration angesichts des Querschnittsaspekts vieler aktueller politischer Probleme nahe liegt, heißt das jedoch nicht, dass Politikintegration leicht zu verwirklichen wäre. Vielmehr sprechen zwei zentrale Gründe dafür, dass Politikintegration auf Hemmnisse stößt (Jänicke 2006: 68, Jänicke/Jörgens 2004: 316, Briassoulis 2005: 37, Giessen/Krott 2008):

82 Siehe auch Gießen/Böcher (2007)

83 Siehe auch Gießen et al. (2007)

84 Siehe auch Gießen (2007) und Lukesch/Gießen (2008).

85 Man denke z.B. an das Postulat der Nachhaltigkeit, das schon materiell mehrere Sektoren und Politikfelder betrifft. 
- Das Integrationsprinzip läuft der Eigenlogik hochgradig spezialisierter Staatsverwaltungen zuwider. Diese entwickelten sich nach dem Weber'schen Modell der rationalen und effektiven öffentlichen Verwaltung zu relativ autonomen Verwaltungssektoren, die funktionale (=sektorale) und vertikal organisierte Politik liefern.

- Das Integrationsprinzip entspricht nicht dem wirtschaftlichen Interessenumfeld eben dieser Sektoralverwaltungen. Politikintegration betrifft nicht selten massive Interessenlagen deren „industrieller Klientel“. Wenn Integrationsforderungen auch Eingriffe in die Substanz der Sektoren, ihrer Märkte, aber auch ihrer gesellschaftlichen Funktionen bedürfen, ergeben sich deutliche Hemmnisse (vgl. Jänicke/Jörgens 2004: 316).

Tabelle 1: Kategorien und erklärende Faktoren für Politikintegration am Beispiel von Environmental Policy Integration (EPI)

\begin{tabular}{|c|c|}
\hline $\begin{array}{l}\text { Kategorie der } \\
\text { Faktoren }\end{array}$ & Individuelle Faktoren \\
\hline \multirow{6}{*}{ Normativ-ideelle } & Verpflichtung und Engagement auf hoher politischer Ebene \\
\hline & Gesellschaftliche Unterstützung \\
\hline & Vorhandensein eines politischen Rahmens für EPI/SD \\
\hline & fundamentaler Paradigmenwechsel in politischer Tradition \\
\hline & Zeitliche Perspektive \\
\hline & Verwenden von Wissen(schaft) \\
\hline \multirow{6}{*}{$\begin{array}{l}\text { Institutionell- } \\
\text { organisationale }\end{array}$} & $\begin{array}{l}\text { Änderungen in der Regierungsstruktur zum Überwinden von } \\
\text { Kompartimentierung }\end{array}$ \\
\hline & Rechenschaftsmechanismen \\
\hline & Koordinations- und Kommunikationsmechanismen \\
\hline & Restrukturierung von öffentlichen Haushaltsprozessen \\
\hline & Fort- und Weiterbildung und Informationskampagnen \\
\hline & Interaktion mit Externen Akteuren \\
\hline \multirow{2}{*}{$\begin{array}{l}\text { Institutionell- } \\
\text { prozedurale }\end{array}$} & Implementation eines EPI-Systems \\
\hline & Änderungen in Routineprozeduren \\
\hline \multirow{4}{*}{$\begin{array}{l}\text { Akteurs- } \\
\text { abhängige }\end{array}$} & Macht- und Einflusspotentiale der Akteure auf Entscheidungen \\
\hline & $\begin{array}{l}\text { Verpflichtung und Engagement der unterschiedlichen Sektoren } \\
\text { getrennt nach Ebenen }\end{array}$ \\
\hline & $\begin{array}{l}\text { Verpflichtung und Engagement getrennt nach gewählten und } \\
\text { permanenten Verwaltungsakteuren }\end{array}$ \\
\hline & Druck zu EPI durch politische Führung oder bottom-up Bewegung \\
\hline
\end{tabular}

Quelle: synthetisiert nach Persson 2004:36; Lenschow 2002: 16-18; Lafferty und Knudsen 2007:13). 
Da Politikintegration nicht der Tagesordnung unseres sektoral organisierten politischen Mehrebenensystems entspricht, werden in der Politikwissenschaft verschiedene Aspekte für eine erfolgreiche Politikintegration diskutiert (Lafferty/Knudesn 2007, Persson 2004:36, Lenschow 2002:16-18). Tabelle 1 zeigt die daraus resultierenden wichtigen Erfolgsfaktoren für Politikintegration, welche zum großen Teil aus dem empirischen Bereich der Forschung um „Environmental Policy Integration“ (EPI) stammen.

\subsection{Horizontale, vertikale und punktuelle Politikintegration}

Die Literatur unterscheidet zwischen horizontaler, vertikaler und punktueller Politikintegration (Briassoulis 2005, Persson 2004, Jänicke 2006, Jänicke/Jörgens 2004, Hubo/Krott 2007). Unter horizontaler Politikintegration verstehen wir die Behandlung von Querschnittsaufgaben auf einer territorialen Ebene, die die etablierten Grenzen von Politikfeldern überschreiten und die nicht den Zuständigkeiten einzelner Institutionen entsprechen (Definition basierend auf Meijers 2004: 10). Unter vertikaler Politikintegration verstehen wir eine Behandlung von Querschnittsaufgaben auf mehreren/allen territorialen Ebenen, die die etablierten Grenzen von Politikfeldern (und u.U. politischen Ebenen) überschreiten und die nicht den Zuständigkeiten einzelner Institutionen entsprechen (Definition basierend auf Meijers 2004: 10 und Jänicke und Jörgens 2004: 318). Abbildung 1 verdeutlicht dieses Verständnis von Politikintegration am Beispiel der Umweltpolitik. 


\section{Abbildung 1: Von der horizontalen zur vertikalen Politikintegration am Bei- spiel der Umweltpolitik}

Horizontale Politikintegration

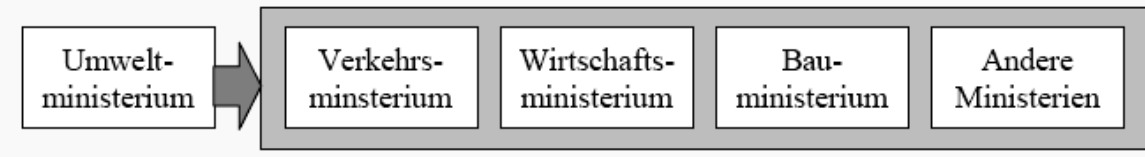

Vertikale Politikintegration

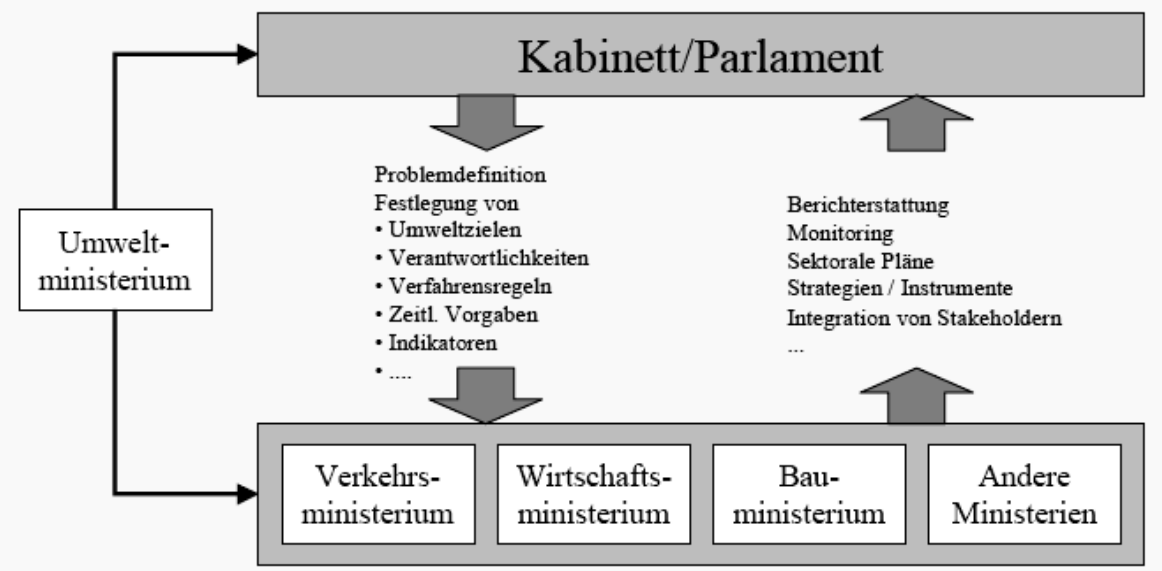

Quelle: Jänicke/Jörgens 2004: 318, verändert

Zur Ergänzung der Diskussion um Aspekte horizontaler und vertikaler Politikintegration schlagen Hubo und Krott (2007: 223-4) einen dritten Ansatz vor, welcher die Defizite der beiden etablierten Ansätze berücksichtigt. Demnach sollte auf die eher unrealistische - Vorstellung eines Gesamtkonsenses aller Sektoren hinsichtlich der Verwirklichung von Politikintegration verzichtet werden und Politikintegration als „dauerhaft konfliktreiche Aufgabe“ verstanden werden. Es kommt dann darauf an, für die zu integrierenden Belange (hier: integrierte sektorübergreifende ländliche Entwicklung) alle politischen „windows of opportunity“ zu nutzen und somit eine „punktuelle Integration“ zu leisten. Das Modell der „punktuellen Integration“ reflektiert somit die tatsächlichen Macht- und Interessenkonstellationen in Politikfeldern, die eine dauerhafte horizontale und vertikale Politikintegration erschweren. In bestimmten Konstellationen können jedoch „windows of opportunity“ zu einer punktuellen Politikintegration führen, z.B. wenn grundlegende agrarpolitische Problemlagen dazu führen, dass punktuell integrierte Programme wie Regionen Aktiv angestoßen werden. 


\subsection{Politikintegration als Mehrebenenpolitik}

Zwischen Politikintegration und Mehrebenenpolitik besteht ein inhärenter Zusammenhang, da meist mehrere politische Ebenen durch integrierte Politiken miteinander verwoben sind und dabei mitunter auch politische Probleme gelöst werden sollen, die sowohl sektor- als auch mehrebenenübergreifend sind. Der Begriff der Mehrebenenpolitik (oder „Multilevel Governance“) wurde dabei vor allem für den Bereich der Europaforschung sowie der internationalen Politik geprägt. So findet sich Mehrebenenpolitik nicht nur im Verhältnis von Innen- und Außenpolitik, sondern auch in vertikal gegliederten Staaten, wie Bundesstaaten, regionalisierten Staaten oder dezentralisierten Einheitsstaaten (Benz 2007: 297). Mehrebenenpolitik bedeutet, dass an der Politikumsetzung meist mehrere staatliche Ebenen beteiligt sind und (z.B. im deutschen Föderalismus) durch das politische System zudem ein hoher Konsens- und Abstimmungsbedarf zwischen den Ebenen existiert, infolgedessen politische Entscheidungen tendenziell nur im Konsens zwischen diesen Ebenen zustande kommen.

Der Mehrebenen-Ansatz betont grundsätzlich das Mit- und Nebeneinander von Politikprozessen auf verschiedenen Regierungsebenen (Heinelt 1996: 17). Besonders zur Analyse der Regionalpolitik in der Europäischen Union hat sich das Konzept der Multilevel Governance als fruchtbar erwiesen, da die Regionen als sub-nationale Ebene in einem „Europa der Regionen“ an Bedeutung und Einfluss gewannen (Marks 1993: 392, 407; Benz 2007: 301; Heinelt 1996: 9). Ingesamt verbirgt sich hinter Mehrebenenpolitik (Multi-Level-Governance) ein Ansatz, die Politikverflechtung zwischen mehreren Ebenen, also deren Interdependenzen, zu beschreiben und zu erklären. Mehrebenenstrukturen liegen immer dann vor, wenn Befugnisse und Mittel zur Implementation auf territorial abgegrenzte, zentrale und dezentrale Organisationen aufgeteilt sind. Im Kern erfasst Multi-Level-Governance die Tatsache, dass „in einem institutionell differenzierten politischen System Akteure unterschiedlicher Ebenen aufeinander angewiesen sind und ihre Entscheidungen koordinieren müssen“ (Benz 2007: 297). Dabei ist keine Ebene alleine in der Lage, die bestehenden Konflikte zu lösen. Innerhalb von Politikintegration „kann (daher, die Autoren) Mehr-Ebenen-Steuerung als übergreifender Steuerungsaspekt nicht ausgeklammert werden“ (Jänicke/Jörgens 2004: 323). Allerdings besteht hier die Gefahr einer „Auflösung der Verantwortungsstrukturen aber auch die (Möglichkeit einer, die Autoren) Eröffnung von Ausweichmöglichkeiten bei hoher Intransparenz der Willensbildungsstrukturen“ (ebd.) In der Verbindung zwischen Politikintegration sollten höhere politische Ebenen strategische, berichtspflichtige Zielvorgaben definieren, während die Umsetzung auf unteren Ebenen möglichst Spielräume für flexibles Handeln und vor allem für Wettbewerb eröffnen sollte (vgl. ebd.). Abbildung 2 illustriert den Zusammenhang zwischen Poli- 
tikintegration und Mehrebenenpolitik als dreidimensionalen Würfel, um zu verdeutlichen, dass Politikintegration mehrere Ebenen (z.B. national, regional, lokal), Politikfelder (Tourismus, Bau, Landwirtschaft) und Akteure (Zivilgesellschaft, Staat, Unternehmen) betrifft.

\section{Abbildung 2: Dimensionen der Umweltpolitik als komplexes Handlungsfeld für Politikintegration}

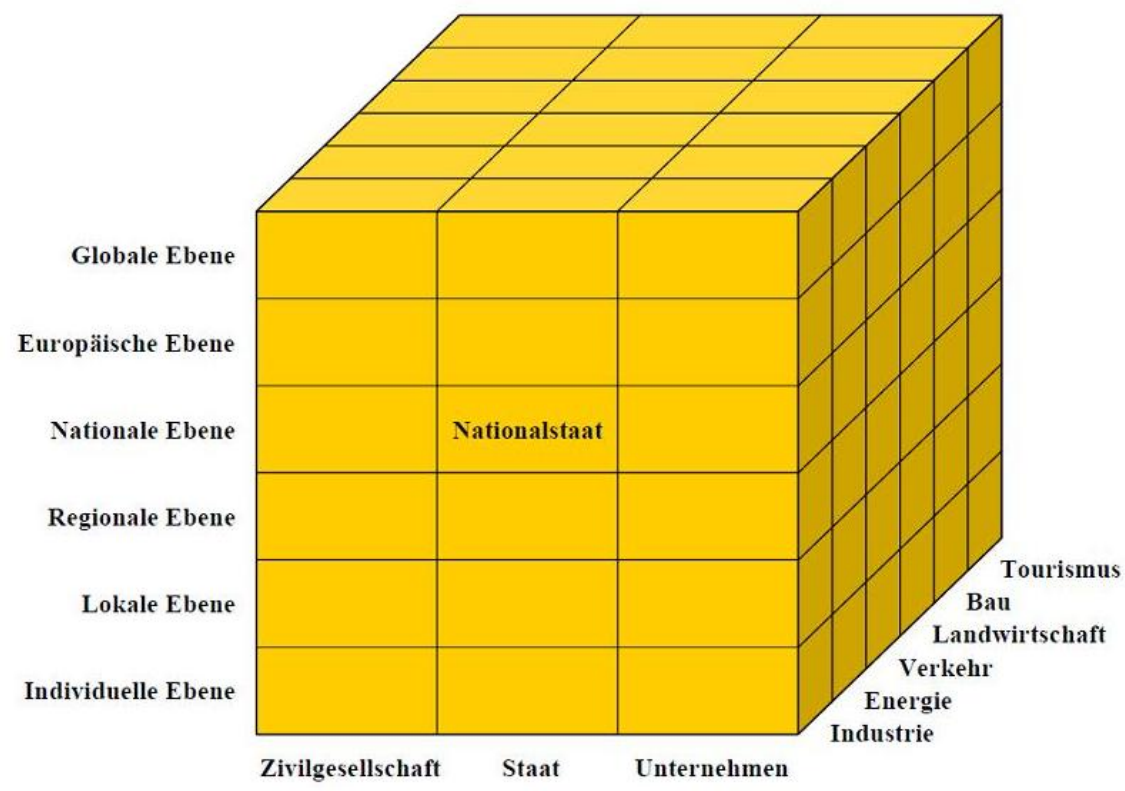

Quelle: Jänicke 2006: 67

\subsection{Politikintegration bei Regionen Aktiv}

Bei Regionen Aktiv handelt es sich um ein integriertes Förderprogramm (Elbe 2007), das somit Elemente von Politikintegration beinhaltet. In den Regionen sollen gleichzeitig verschiedene Aspekte integrierter ländlicher Entwicklung (z.B. Landwirtschaft, Soziales, Arbeitsmarktpolitik, etc.) vor dem Hintergrund des Leitbildes nachhaltiger Entwicklung umgesetzt werden. Die genannten allgemeinen Aspekte, Erfolgsfaktoren und Hemmnisse von Politikintegration sind daher für die empirische Analyse der Umsetzung von Regionen Aktiv fruchtbar. Außerdem handelt es sich bei Regionen Aktiv um Mehrebenenpolitik, da eine höhere politische Ebene (Bund) vor dem Hintergrund europäischer Strukturpolitik und internationaler Politikziele (Nachhaltige Entwicklung) versucht, nachgeordnete politische Ebenen (Regionen) hinsichtlich agrarpolitischer Ziele zur Umsetzung von integrierter ländlicher Entwicklung zu bewegen und dabei auch die Bundesländer - ohne direkt beteiligt zu sein - versuchen, Einfluss auf die Umsetzung von Regionen Aktiv auszuüben. Ähnliches gilt ebenfalls für Programme der Regelförderung. Da vermehrt 
Ansätze einer umfassenden, integrierten ländlichen Politik („rural policy“) gefordert werden (OECD 2006), können die theoretischen und empirischen Erkenntnisse zur Politikintegration nun auch fruchtbar auf die Förderpolitik angewendet werden. Es bleibt zu zeigen, ob hier eine Politikintegration für ländliche Räume gelingt.

\section{Politikintegration in der Förderung für ländliche Räume}

Im Folgenden werden Förderprogramme mit Relevanz für eine integrierte Entwicklung ländlicher Räume empirisch dahingehend analysiert, in wieweit diese aufeinander abgestimmt sind, sich also eine ländliche Politikintegration in der Förderpolitik vollzieht. Dabei spielen die EU-Strukturfonds eine gewichtige Rolle, das diese nicht nur erhebliche Finanzströme mit sich bringen, sondern durch den Anspruch auf nationale und sub-nationale Kofinanzierung im Mehrebenensystem der Förderpolitik ihre Wirkung entfalten und ihren Koordinationsanspruch programmatisch, d.h. formal erklären. Im Folgenden geht die Analyse dieses formalprogrammatischen Anspruchs der Identifikation von Koordinierungsmechanismen auf Landesebene voran. Letztere betont hingegen, dass nationale Programme bei der Betrachtung von ländlicher Politikintegration nicht außer Acht zu lassen sind.

\subsection{Formale Politikintegration bei der Förderung Programmatische Grundlagen der Strukturfonds}

\section{Programmatischer Integrationsanspruch auf EU-Ebene}

Grundlage für die Anforderungen an die Koordination zwischen den Strukturfonds ist die EU VO 1083/2006 mit den allgemeinen Bestimmungen über die Strukturfonds. ${ }^{86}$ Artikel 9 benennt die hierfür geltenden Grundsätze:

„Komplementarität, Kohärenz, Koordinierung und Konformität:

(1) Die Fonds ergänzen mit ihren Interventionen die nationalen Aktionen, einschließlich der Aktionen auf regionaler und lokaler Ebene, und integrieren so in diese Maßnahmen die Prioritäten der Gemeinschaft.

(2) Die Kommission und die Mitgliedstaaten sorgen für die Kohärenz der Förderung aus den Fonds mit den Tätigkeiten, Politiken und Prioritäten der Gemeinschaft und für Komplementarität mit anderen Finanzierungsinstrumenten der Gemeinschaft. Auf diese Kohärenz und Komplementarität wird insbesondere in den strategischen Kohäsionsleitlinien der Europäischen Union, im nationalen

86 Rat der Europäischen Union (2006): Verordnung (EG) Nr. 1083/2006 der Rates vom 11. Juli 2006 mit allgemeinen Bestimmungen über den Europäischen Fonds für regionale Entwicklung, den Europäischen Sozialfonds und den Kohäsionsfonds und zur Aufhebung der Verordnung (EG) Nr. 1260/ 1999 
strategischen Rahmenplan und in den operationellen Programmen hingewiesen."

Artikel 9 ist damit der zentrale Bezugspunkt für die systematische Koordination der Förderinstrumente auf den unterschiedlichen Ebenen. Der von jedem Mitgliedstaat vorzulegende Nationale Strategische Rahmenplan (NSRP) liefert dafür den Rahmen.

Analog zu den Strukturfonds gestaltet sich die Koordination im Geltungsbereich des Europäischen Landwirtschaftsfonds zur Entwicklung des ländlichen Raums (ELER) auf der Grundlage der EU-Ratsverordnung 1698/2005. ${ }^{87}$ Artikel 11 des ELER stipuliert die systematische Koordination der Förderinstrumente auf den unterschiedlichen Ebenen:

„Der nationale Strategieplan gewährleistet die Kohärenz zwischen der Gemeinschaftshilfe für die Entwicklung des ländlichen Raums und den strategischen Leitlinien der Gemeinschaft sowie die Koordinierung zwischen den gemeinschaftlichen Prioritäten und den einzelstaatlichen und regionalen Prioritäten. ${ }^{88 .}$

Daraus wird deutlich, dass die Aufgabe der Koordination zwischen Programmen nicht nur als Aufgabe auf EU-Ebene besteht, sondern auch an die nachgeordneten Ebenen gestellt wird.

Eine wichtige Weichenstellung auf EU-Ebene war die durchgängige Einführung des Monofonds-Prinzips für die Haushaltsperiode 2007 bis 2013. Jedes Operationelle Programm kann nur mehr aus einem EU-Fonds (EFRE, Kohäsionsfonds, ESF, ELER, EFF) kofinanziert werden. Auch die Gemeinschaftsinitiativen Interreg, Urban, Equal und Leader wurden in die Hauptprogramme (Konvergenz, Wettbewerbsfähigkeit und Beschäftigung, Europäische Territoriale Zusammenarbeit und Ländliche Entwicklung) integriert. Mit der Demarkation der Zuständigkeiten hoffte man, auch die Gestaltung von Schnittstellen und Klärung von möglichen Überlappungsbereichen transparenter und effizienter gestalten zu können.

87 Rat der Europäischen Union (2005): Verordnung (EG) Nr. 1698/2005 des Rates vom 20. September 2005 über die Förderung der Entwicklung des ländlichen Raums durch den Europäischen Landwirtschaftsfonds für die Entwicklung des ländlichen Raums (ELER).

88 Artikel 11, Absatz 2 des ELER 


\section{Koordinationsmechanismen auf EU-Ebene}

Auf EU-Ebene konnten folgende Mechanismen identifiziert werden, die einen Einfluss auf die Koordination relevanter Förderprogramme haben können:

- Interservice-Verfahren innerhalb der Europäischen Kommission zur Vorbereitung von Kommissionsvorlagen für Rats- und Parlamentsbeschlüsse: Hier werden auch nicht-staatliche Akteure (Stakeholder, Wissenschaft) im Vorfeld der Politikgestaltung einbezogen.

- Konsultationen zwischen EU-Parlament und Rat in der Beschlussphase; dabei sind zu unterscheiden:

- Mitentscheidungsverfahren: Rat und Parlament teilen Legislativgewalt. Dieses Verfahren ist wegen der Sistierung des Reformvertrags („Vertrag von Lissabon") nach der Abstimmungsniederlage in Irland am 12. Juni 2008 für Fragen der Agrar- und Strukturpolitik nicht relevant.

- Zustimmungsverfahren: Zustimmungspflicht des Parlaments. Das Verfahren wird bei besonders wichtigen Beschlüssen, wie zum Beispiel dem Beitritt neuer Mitglieder angewandt.

- Anhörungsverfahren: Der Rat ersucht das Parlament um Kommentare zu einem Vorschlag; dieses kann zustimmen, ablehnen oder Änderungen vorschlagen. Dieses Verfahren betrifft die Fragen der Agrar- und Strukturpolitik. Das Parlament kann dabei mittels Verzögerung zumindest indirekt Macht ausüben.

- Komitologie (Comitology): Ausschusswesen zur Unterstützung der EUKommission in der Umsetzung der Beschlüsse. Auf Comitology-Ebene werden nicht unerhebliche Beschlüsse gefasst, die helfen, den Vollzug der EU-Rechtsvorschriften den vielschichtigen realen Bedingungen in den Mitgliedsländern anzupassen.

Bereits in der ersten Umsetzungsphase der Strukturfondsprogramme und Programme für ländliche Entwicklung wurde allerdings klar, dass auf EU-Ebene trotz der identifizierten Mechanismen zur Koordination nicht von Politikintegration und effektiver Koordination gesprochen werden kann. Das Monofonds-Prinzip verstärkt eher die sektorale Perspektive. Die serielle und parallele Bearbeitung von Vorschlägen in unterschiedlichen Gremien schleift den substantiellen Kern derselben häufig $a b$, so dass am Ende eher nicht ein Pareto-Optimum ${ }^{89}$, wie anzustreben wäre, sondern der kleinste gemeinsame Nenner herauskommt.

89 Gemäß dem nach Vilfredo Pareto (1848-1923) benannten Kriterium wird damit ein Zustand bezeichnet, in dem es nicht mehr möglich ist, den Nutzen für einen Akteur A zu verbessern, ohne den Nutzen für einen anderen Akteur B zu vermindern. Als erweitertes Modell wird häufig auch Bezug auf das Kaldor-HicksKriterium (aus 1939) genommen, wonach die Nutzenminderung des Akteurs B durch Umverteilung aus dem Nutzengewinn von A kompensiert wird, sodass am Ende noch ein Mehr an Nutzen bei A herauskommt. 
Agrarpolitik, Politik für den ländlichen Raum und Strukturpolitik: Einschätzung der weiteren Entwicklungen

Trotz der formalen Angleichung der Strukturen und Mechanismen, die für die Politik für den ländlichen Raum auf der einen Seite und für die regionale und soziale Strukturpolitik auf der anderen Seite gelten, sind sie sehr unterschiedlich verfasst. Der Zuständigkeitsbereich für die Gemeinsame Agrarpolitik ist von hoher interner Kohärenz gekennzeichnet, die Akteure haben hohe fachliche Kompetenz und sind innerhalb und zwischen ihren Institutionen (GD Landwirtschaft, Landwirtschaftsministerien der Mitgliedsstaaten, AgrarverterterInnen) gut vernetzt. Demgegenüber sind die Zuständigkeiten in der Strukturpolitik nicht nur breiter gestreut (GD Beschäftigung, GD Regionalpolitik, GD Verkehr und Energie...), sondern auch weniger stark auf EU-Ebene aggregiert. ${ }^{90}$ Daher konnte die Landwirtschaft gegenüber den anderen, im Ringen um Budgetmittel konkurrierenden Bereichen (regionale und soziale Strukturpolitik) auf EU-Ebene bisher als „Kontextgeber“ auftreten: Die entsprechenden politischen Festlegungen und Budgetpakete waren schon fertig geschnürt, bevor die anderen Akteure sich über alternative Überlegungen verständigen konnten ${ }^{91}$. Der Austausch zwischen den einzelnen Sektoren wird zudem durch einen Mangel an Kontinuität und Tiefe der wechselseitigen Beziehungen zwischen den Einheiten der EU-Kommission erschwert.

Daraus wird deutlich, dass bisher die agrarpolitischen Interessen die sektorübergreifende Perspektive der ländlichen Entwicklung (die zweite Säule der Agrarpolitik) allein aufgrund der institutionellen Einbettung dominiert haben. Das heißt, eine sektorübergreifende und gebietsorientierte Perspektive innerhalb der Gemeinsamen Agrarpolitik (GAP) ist dort möglich, wo sektorübergreifende Maßnahmen zweifelsfrei komplementäre oder sogar verstärkende Wirkungen auf die agrarischen Maßnahmen ausüben. Wenn dies nicht klar zu sein scheint, verzichtet man lieber auf einen gebietsorientierten Ansatz: „In dubio pro agricultura“.

90 Zum Beispiel gilt das Europäische Raumentwicklungskonzept (1999) nur als Orientierungsrahmen. Auch gibt es keine explizite europäische Politik für städtische Räume.

91 Man denke an das Chirac-Schröder-Abkommen im Jahr 2002, das die Budgetmittel für die erste Säule der Agrarpolitik bis 2013 festschrieb. 
Mit der Revision der finanziellen Perspektiven des EU-Haushalts bis (2008 bis 2010) zeichnet sich eine Verschiebung des institutionellen Machtgefüges zuungunsten der Landwirtschaft ab, da

- einerseits der Druck auf die EU-Verhandler im Hinblick auf eine mögliche Wiederaufnahme der WTO-Verhandlungen steigen wird, den globalen Partnerländern mehr entgegen zu kommen;

- die Agrarpreise sich zumindest im Getreidesektor wohl langfristig auf einem höheren Niveau einpendeln werden;

- die derzeitige Präsidentschaft im EU-Reformprozess eine stärkere Position innerhalb der Kommission wahrnimmt als frühere. Von ihr sind eher Akzente in Richtung Wettbewerbspolitik und territorialen Zusammenhalts zu erwarten als in Richtung einer Weiterführung der bisherigen Landwirtschaftspolitik.

Diese sich abzeichnenden Entwicklungen können im Hinblick auf eine zukünftige verbesserte Koordination des EU-Förderinstrumentariums als „window of opportunity" gedeutet werden.

\section{Identifikation vorläufiger Koordinationsmechanismen auf Bundes-Ebene}

Der programmatische Integrationsanspruch auf Bundesebene gleicht sich den Vorgaben der EU-Ebene an. Demgemäß können die durch die EU geforderten nationalen Strategiepläne für die Strukturfonds sowie für den ELER als vertikale und teilweise auch horizontale Koordinationsmechanismen betrachtet werden. Die Wirtschafts- und Sozialpartner sind als nicht-staatliche Akteure daran beteiligt und können im begrenzten Maße Einfluss nehmen. Jedoch werden die Begleitausschüsse in der Praxis (noch) eher als administrative Verpflichtung denn als Koordinationsmechanismus verstanden.

Als zweiter Ansatzpunkt für eine übergreifende Koordination wurde die nationale Vernetzungsstelle gesehen. Gremien wie z.B. der $\mathrm{PLANAK}^{92}$, ressortübergreifende Abstimmungen auf Bundesebene, Bund-Länder ${ }^{93}$ sowie HuK ${ }^{94}$ - oder PKR ${ }^{95}$ Besprechungen finden unter den Interviewpartnern auf Bundesebene zwar Erwähnung, gelten aber nicht als signifikante Koordinationsmechanismen. ${ }^{96}$ Es lässt sich zwar argumentieren, dass zumindest im PLANAK verbindliche Absprachen getroffen werden. Jedoch wird der GAK-Rahmenplan jeweils so weit gefasst, dass für die Bundesländer programmatischer Spielraum bleibt, welcher meist nicht in Richtung einer Politikintegration ausgelegt werden dürfte, da die Länder die wohl

\footnotetext{
92 Planungsausschuss für die Gemeinschaftsaufgabe Agrarstruktur und Küstenschutz

93 z.B. aktuell zum Thema Breitbandvernetzung im ländlichen Raum (BMF, BMWi und BMELV).

94 Haushalts- und Koordinierungs- (Referenten)

95 ProgrammKoordinierungsReferenten

96 Bühner, Tetsch, Schreckenberger,
} 
konservativere (im Sinne von sektoral und koordinationsfeindlich) Grundhaltung im GAK-Regime innehaben. ${ }^{97}$ Vielmehr ist zu erwarten, dass Koordinationsansätze des PLANAK im Vollzug der Bundesländer auf die realen Hürden und sektoralen Abgrenzungen stoßen und somit nur eine geringe Koordinationswirkung entfalten können. Auf Bundesebene wurde zudem auf die Operationellen Programme der Länderebene, sowie auf regionale Entwicklungskonzepte und Regionalmanagement in den Regionen als Hauptmechanismen zur Koordination verwiesen.

\section{Andere zentrale Erkenntnisse auf Bundesebene}

Betrachtet man die o.a. zusammenfassenden Aussagen, so wird deutlich, dass Synergien bzw. Kooperationsgewinne an zweiter Stelle stehen: Im Vordergrund steht die Vermeidung von Doppelförderung und Überschneidungen zwischen den Fonds. Strukturelle Unterstützung erfährt dieser Punkt durch das Monofondsprinzip. Hoffnungsträger im Bereich Synergien sind die Vernetzungsaktivitäten durch die Begleitausschüsse auf nationaler und Länderebene. ${ }^{98}$ Betrachtet man jedoch die Erfahrungen aus den Begleitausschüssen der abgelaufenen Förderperiode und den Tagungsturnus (halbjährlich), so sollte man die Erwartungen nicht zu hoch ansetzen. Insgesamt ist festzuhalten, dass

- der Anspruch der systematischen horizontalen und vertikalen Koordination der Förderprogramme auf der programmatischen Ebene (EU und Bund) formuliert ist

- die Erzielung von Synergien gefordert wird, jedoch auf Bundesebene durchgehend die inhaltliche Abgrenzung der Förderprogramme (Negativ-Koordination; Monofonds-Ansatz) und weniger die Suche nach Kooperationsgewinnen (Positiv-Koordination) im Vordergrund steht und die Verantwortung der Koordination auf die Länderebene weiterverlagert wird.

- auf Bundesebene neben den klassischen Abstimmungsinstrumenten im Wesentlichen auf die Instrumente „Begleitausschuss“ und „nationale Vernetzungsstelle", die eine Informationsfunktion erfüllen sollen, gesetzt wird.

- insgesamt die konkrete Umsetzung der horizontalen und vertikalen Koordination von der EU- auf die nationale und von dort auf die Ebene der Bundesländer und die regionale Ebene (als Ebene unterhalb des Bundeslandes) weiterverlagert wird.

- es in Bezug auf die Schaffung von Synergien somit entscheidend ist, wie vor Ort in der Region die Fördermöglichkeiten gebündelt werden (können!).

\footnotetext{
97 Jäger, Delbrück

98 Schreckenberger
} 


\section{Programmatischer Integrationsanspruch auf Landes-Ebene}

Wohl übersetzt sich der programmatische Integrationsanspruch von der EU- über die Bundesebene auch auf die jeweilige Landesebene, es ist jedoch möglich, Unterschiede im Koordinationsanspruch verschiedener Bundesländer wahrzunehmen. Das Team der Begleitforschung hat die Ex-Ante-Bewertungen der Operationellen Programme zu den Strukturfonds und dem ELER, vor allem die Kapitel zu Kohärenz und Komplementarität, daraufhin analysiert. ${ }^{99}$ Diese Analyse ermöglichte zumindest eine grobe Einschätzung des programmatischen Integrationsanspruchs der Länder und der wesentlichen Mechanismen zur Koordination ihrer Förderprogramme.

\section{Identifikation vorläufiger Koordinationsmechanismen auf Landesebene}

Auf Ebene der Bundesländer wurden verschiedene Mechanismen zur Koordination der Förderung identifiziert (Tabelle 2). Die einschlägigste Wirkung dürften einer ersten Einschätzung zufolge die programmatischen Mechanismen haben.

Tabelle 2: Beispielhafte Koordinationsmechanismen

\begin{tabular}{|c|l|}
\hline $\begin{array}{c}\text { Art des } \\
\text { Mechanismus }\end{array}$ & \multicolumn{1}{|c|}{ Beispielhafte Mechanismen } \\
\hline $\begin{array}{c}\text { Programmati- } \\
\text { sche }\end{array}$ & $\begin{array}{l}\text { Fondsübergreifende Landesstrategie zur Mittelverwen- } \\
\text { dung durch z.B. Staatskanzlei/Kabinett }\end{array}$ \\
\cline { 2 - 3 } & $\begin{array}{l}\text { Dachrichtlinie zur Verwendung von Mitteln unterschiedlicher } \\
\text { Herkunft }\end{array}$ \\
\hline \multirow{2}{*}{$\begin{array}{c}\text { Personell- } \\
\text { institutionelle }\end{array}$} & $\begin{array}{l}\text { Gegenseitige Beteiligung der Fondsverwalter in Begleit- } \\
\text { ausschüssen }\end{array}$ \\
\cline { 2 - 2 } AK Fondsverwalter im Vorfeld der Programmierung \\
\hline \multirow{2}{*}{$\begin{array}{l}\text { Planerisch- } \\
\text { prozedurale }\end{array}$} & Ressort- bzw. referatsübergreifende Abstimmung \\
\cline { 2 - 3 } & Regierungsberatungen über Mittelverwendung \\
\cline { 2 - 3 } & Prüfung auf Doppelförderung durch Bewilligungsstellen \\
\hline
\end{tabular}

Quelle: basierend auf der Analyse aller Ex-Ante-Bewertungen der Operationallen Programme der Bundesländer zu den EU-Strukturfonds und ELER.

99 Aus Gründen der Übersichtlichkeit wird hier darauf verzichtet, jedes der offiziellen Dokumente zu zitieren. Es handelt sich dabei um die zu veröffentlichenden Versionen der Ex-Ante_Bewertung der Operationellen Programme zu EFRE, ESF und ELER eines jeden Bundeslandes, soweit diese die Dokumente nicht zusammengefasst haben. 
Auf Ebene der Bundesländer hat sich die Forschungshypothese, dass Programmabgrenzung vorherrschend und die Suche nach und Schaffung von Synergien höchstens zweitrangig sind, verfestigt. Jedoch konnten in einzelnen Bundesländern programmatische Grundlagen und Mechanismen identifiziert werden, die sich positiv auf das Zusammenwirken der Förderprogramme auswirken. Einschränkend sei gesagt, dass man nur anhand der Auswertung der Ex-Ante-Evaluierungen der Operationellen Programme nicht definitiv auf den Integrationsanspruch des Landes bzw. seine programmatischen Grundlagen schließen kann.

\subsection{Informale Wirklichkeit - Auf der Suche nach Mechanismen zur Koordination}

Basierend auf der Analyse der programmatischen Grundlagen wurden deshalb Bundesländer ausgewählt, in denen regionale Fallstudien durchgeführt wurden. Der folgende Analyseschritt befasst sich mittels regionaler Fallstudien im Kontext der Rahmenbedingungen der Förderpolitik des jeweiligen Landes mit sog. Koordinationsmechanismen. Dazu wurden die Länder Bayern (BY, Region Chiemgau), Baden-Württemberg (BW, Region Reutlingen), Sachsen-Anhalt (ST, Region Altmark), Schleswig-Holstein (SH, Region Lübecker Bucht), MecklenburgVorpommern (MV, Region Lübecker Bucht) sowie Sachsen (SN, ohne Region) ausgewählt. Die vertiefenden Ergebnisse zu Mechanismen der Koordination von Förderung, deren fördernden und hemmenden Faktoren sowie Mängel in der Koordination werden im Folgenden dargestellt.

\subsubsection{Koordinationsmechanismen auf Landesebene}

Auf Landesebene konnten verschiedenen Mechanismen der Koordination von Förderprogrammen identifiziert werden. Diese sind hier in ihrer summarischen Vielfalt dargestellt, in der sie in den 6 untersuchten Bundesländern beobachtet wurden. Auf regionaler Ebene sind die Befunde nicht annähernd so divers. Tabelle 3 gibt einen Überblick über die identifizierten Mechanismen. Im Folgenden sollen diese Mechanismen beschrieben werden, ohne dabei einen Vergleich der Bundesländer, in denen diese beobachtet wurden, oder eine abschließende Bewertung ihrer Integrationswirkung anzustreben. 
Tabelle 2: Mechanismen zur Politikintegration in der Förderpolitik auf Landesebene und in Regionen

\begin{tabular}{|c|c|c|c|}
\hline $\begin{array}{c}\text { Ebe } \\
\text { ne }\end{array}$ & $\begin{array}{c}\text { Art des } \\
\text { Mechanismus }\end{array}$ & Mechanismus & Beispiel \\
\hline \multirow{15}{*}{ 임 } & \multirow{4}{*}{$\begin{array}{l}\text { Personell- } \\
\text { institutionelle }\end{array}$} & $\begin{array}{l}\text { Arbeitskreis EU- } \\
\text { Förderung }\end{array}$ & $\begin{array}{l}\text { Netzwerk aller beteiligter Stellen zu } \\
\text { EU-Förderung in BW }\end{array}$ \\
\hline & & $\begin{array}{l}\text { Kontinuierliche Konsul- } \\
\text { tationen }\end{array}$ & $\begin{array}{l}\text { Gegenseitige Beteiligung in Begleit- } \\
\text { ausschüssen, ,jour fix“, große und } \\
\text { kleine Besprechungen zw. Fondsver- } \\
\text { waltern, etc. }\end{array}$ \\
\hline & & $\begin{array}{l}\text { Staatssekretärsaus- } \\
\text { schuss „ländlicher } \\
\text { Raum“ }\end{array}$ & Lediglich in BY beobachtet \\
\hline & & $\begin{array}{l}\text { Treffen der Programm- } \\
\text { koordinierungsreferen- } \\
\text { ten }\end{array}$ & PKR auf Bundesebene \\
\hline & \multirow{4}{*}{$\begin{array}{l}\text { Planersich- } \\
\text { prozedural }\end{array}$} & Externe Prüfungen & $\begin{array}{l}\text { Prüfung auf Komplementarität bei ver- } \\
\text { wendeten Landesmitteln oder Prüfstel- } \\
\text { len für Fonds bei Finanzministerium }\end{array}$ \\
\hline & & $\begin{array}{l}\text { Moderierte Workshops } \\
\text { zwischen den Häusern }\end{array}$ & $\begin{array}{l}\text { Abgrenzung und Synergiesuche zwi- } \\
\text { schen Wirtschafts- und Arbeitsministe- } \\
\text { rium BW unter Hilfe externer Moderati- } \\
\text { on }\end{array}$ \\
\hline & & $\begin{array}{l}\text { Ressortkoordinatoren zu } \\
\text { Strukturfonds in partizi- } \\
\text { pierenden Häusern }\end{array}$ & Lediglich in ST beobachtet \\
\hline & & $\begin{array}{l}\text { Genehmigungsverfah- } \\
\text { ren der EU-Kommission }\end{array}$ & $\begin{array}{l}\text { Starke Einflussnahme auf OP-Entwürfe } \\
\text { bei Genehmigung }\end{array}$ \\
\hline & \multirow{7}{*}{$\begin{array}{l}\text { Programma- } \\
\text { tische }\end{array}$} & $\begin{array}{l}\text { Integration mehrerer } \\
\text { Fonds in ein Ministerium }\end{array}$ & $\begin{array}{l}\text { ELER u. EFRE im Ministerium f. Ern. } \\
\text { u. ländl. Raum BW }\end{array}$ \\
\hline & & $\begin{array}{l}\text { Gemeinsame Verwal- } \\
\text { tungsbehörde für alle } \\
\text { Strukturfonds } \\
\end{array}$ & $\begin{array}{l}\text { Fondsverwaltung ESF, ELER u. EFRE } \\
\text { bei Staatskanzlei in MV }\end{array}$ \\
\hline & & $\begin{array}{l}\text { Partizipation mehrerer } \\
\text { Häuser an einem Struk- } \\
\text { turfond }\end{array}$ & $\begin{array}{l}\text { Gegenteiliger Trend z.B. in BY, wo zur } \\
\text { Vereinfachung weniger Häuser betei- } \\
\text { ligt werden }\end{array}$ \\
\hline & & $\begin{array}{l}\text { Integriere, querschnitts- } \\
\text { orientierte Landespro- } \\
\text { gramme und -richtlinien }\end{array}$ & $\begin{array}{l}\text { Entwicklungsprogramm ländlicher } \\
\text { Raum in BW, welches sich verschie- } \\
\text { dener Quellen bedient }\end{array}$ \\
\hline & & $\begin{array}{l}\text { Regionalisierung der } \\
\text { Förderung/ Abkehr vom } \\
\text { Maßnahmenansatz }\end{array}$ & $\begin{array}{l}\text { ESF-Förderung in BW, wo regionale } \\
\text { Gremien über Förderwürdigkeit eige- } \\
\text { ner Projektvorschläge entscheiden; } \\
\text { Harmonisierung der Förderung in SN }\end{array}$ \\
\hline & & \begin{tabular}{|l} 
Fondsübergreifende \\
Landesstrategie zu \\
Strukturfonds
\end{tabular} & $\begin{array}{l}\text { Verschiedene Reichweiten in SH, ST } \\
\text { und MV }\end{array}$ \\
\hline & & Zielintegration & $\begin{array}{l}\text { Landesstrategien und Zusammenfüh- } \\
\text { rung v. Ziel } 2 \text { und } 3 \text { auf EU-Ebene }\end{array}$ \\
\hline
\end{tabular}




\begin{tabular}{|c|c|c|c|}
\hline $\begin{array}{l}\text { Ebe } \\
\text { ne }\end{array}$ & $\begin{array}{c}\text { Art des } \\
\text { Mechanismus }\end{array}$ & Mechanismus & Beispiel \\
\hline \multirow{4}{*}{ 등 } & \multirow[t]{3}{*}{$\begin{array}{l}\text { Personell- } \\
\text { institutionelle }\end{array}$} & $\begin{array}{l}\text { Beratung zu Regelförde- } \\
\text { rung }\end{array}$ & $\begin{array}{l}\text { Besondere Rolle von Regierungspräsi- } \\
\text { dien o.ä., Landwirtschaftsämter, Wirt- } \\
\text { schaftsförderung }\end{array}$ \\
\hline & & $\begin{array}{l}\text { Integrierte Förderbera- } \\
\text { tung }\end{array}$ & $\begin{array}{l}\text { Strategie, erworbenes Förderwissen } \\
\text { zur integrierten Förderung zu nutzen }\end{array}$ \\
\hline & & Personelle Konstanz & $\begin{array}{l}\text { Strategie, erworbenes Förderwissen } \\
\text { zur integrierten Förderung zu nutzen }\end{array}$ \\
\hline & $\begin{array}{l}\text { Planersich- } \\
\text { prozedural }\end{array}$ & $\begin{array}{l}\text { Gegenseitige Beteili- } \\
\text { gung regionalen Gre- } \\
\text { mien }\end{array}$ & $\begin{array}{l}\text { Beteiligung von Wirtschaftsförderern in } \\
\text { den Leader-LAGs und umgekehrt }\end{array}$ \\
\hline
\end{tabular}

Quelle: Eigene Zusammenstellung

\section{Vorbemerkung: Die Rolle der Staatskanzleien ${ }^{100}$}

Den Staatskanzleien können in der inhaltlichen Koordination der Förderung für ländliche Räume sehr unterschiedliche Rollen zukommen. Gemein ist allen Staatskanzleien, dass sie im europäischen Bereich zunächst formaler Ansprechpartner für die EU sind. ${ }^{101}$ Allerdings ergibt sich für die Staatskanzleien der untersuchten westlichen Bundesländer eher eine passive Rolle bei der Koordination der Förderung (ggf. ist NRW eine Ausnahme), während in Ostdeutschland ein aktiveres Verständnis der Staatskanzlei als Koordinierungseinheit bei der Strategieentwicklung und Programmplanung vorherrscht. ${ }^{102}$ Im Falle Westdeutschlands kommt ihr eine „strategische Koordinations- und Kommunikationsrolle zu. Solange sich die Programmierung noch im europäischen Willensbildungsprozess befindet" werden überwiegend "massive“ Landesinteressen wie Rückflüsse von EU-Mitteln auch in Innovationsregionen wie BW; Begrenzung des Gesamtmittelvolumens der Strukturpolitik als Anliegen eines Nettozahlers; sowie der Bürokratieabbau vertreten. ${ }^{103} \mathrm{Im}$ Hintergrund stehen für die Staatskanzlei somit bei der (Re-) Formulierung der europäischen Rahmendokumente Fragen nach der detaillierten Ausgestaltung einzelner Programme und Maßnahmen, obwohl sich ggf. eine Zuständigkeit der Staatskanzlei oder des dort angesiedelten EU-Ministers (im Falle von BY) für die Strukturfonds ableiten ließe. Inhaltlich schalte sich die Staatskanzlei erst im

\footnotetext{
${ }^{100}$ Der Begriff Staatskanzlei wird hier und im Folgenden synonym für alle Entsprechungen wie z.B. Staatsministerium verwandt. Der Begriff Kabinett wird ebenfalls für seine Entsprechungen wie z.B. Ministerrat verwandt.

${ }^{101}$ Zoller (im Folgenden werden Referenzverweise auf Interviews mit Experten durch Nennung von deren Nachnamen in einer Fußnote gemacht. Die Affiliation der genannten Personen ist im Kapitel "Quellen" erwähnt.

102 Wohlgschaft, ähnlich Moser

${ }^{103}$ Zoller
} 
Rahmen einer Kabinettsvorlage (Ministerratsvorlage) ein ${ }^{104}$ oder aber, „wenn Interessenkollisionen zwischen den Häusern absehbar sind“ oder bei „Hilferuf" eines Hauses. ${ }^{105} \mathrm{Im}$ ersten Falle assistiert sie, die Eckpunkte zwischen den Häusern zu verhandeln („wer ist an welchen Strukturfonds beteiligt, mit wie viel, etc“). ${ }^{106}$ Somit kommt den Staatskanzleien in Westdeutschland eine eher passive Rolle in der inhaltlichen und organisatorischen Koordination der Förderprogramme sowie der Strategie- und Programmentwicklung $\mathrm{zu}^{107}$ (ggf. mit Ausnahme von NRW ${ }^{108}$ ).

In Ostdeutschland stellt sich deren Rolle jedoch anders dar. Nach 1990 habe es dort einen Neustart gegeben, welcher mit großen EU-Fördermitteln einherging. Die Staatskanzleien haben diese Mittelflüsse gerne kontrollieren wollen. Zudem nehme die EU-Förderung in diesen Bundesländern einen relativ gesehen wesentlich höheren Stellenwert ein, als bspw. in BY oder BW. Darauf begründe sich der Anspruch der Staatskanzlei, diese Mittel kontrollieren zu wollen, ebenfalls. ${ }^{109} \mathrm{Zu}$ dem sei an die Verfügung über die Strukturfonds-Mittel auch eine politische Verantwortung für die Abwicklung verbunden (z.B. bei Rückerstattungsskandalen). Dieses Risiko lohne sich, bei gegebenem EU-Fördervolumen in BY oder BW für einen Ministerpräsident oder EU-Minister nicht. ${ }^{110}$ Als Mechanismus, um als Staatskanzlei bzw. Ministerpräsident/EU-Minister über die Verwendung der Mittel (mit)verfügen zu können, könnte die Zuständigkeit für die Strukturfonds formell der Staatskanzlei übertragen werden, die Verwaltung dieser aber zu den entsprechenden Ministerien als zwischengeschaltete Stellen delegiert werden. Ein solcher Trend sei in Ostdeutschland vorzufinden. ${ }^{111}$ Somit könne die Staatskanzlei Einfluss auf die Verwendung der EU-Mittel nehmen und deren Verwendung, z.B. mittels einer fondsübergreifenden Landesstrategie, an übergeordnete Landesziele koppeln.

\footnotetext{
104 Wonka, Müller

105 Reimann, ähnlich Wohlgschaft

106 Müller

${ }^{107}$ Moser, Göttler, Wohlgschaft, Zoller

${ }^{108}$ Wohlgschaft

${ }^{109}$ Wohlgschaft

${ }^{110}$ Moser

${ }^{111}$ Moser
} 


\section{Arbeitskreis EU-Förderung bei der Staatskanzlei in BW}

Einen aktiveren Ansatz zur möglichen Koordination zwischen den Fördersträngen stellt die Einberufung des „Arbeitskreises EU-Förderung“ durch die Staatskanzlei in BW dar. Dabei handelt es sich um ein eher informales Netzwerk aus ca. 30 Mitgliedern aus öffentlichen Stellen, die an der Strukturfondsförderung beteiligt seien. ${ }^{112}$ Dieser wurde nach der letzten Landtagswahl als Teil der Koalitionsvereinbarung durch die Staatskanzlei eingesetzt. ${ }^{113}$ Dieses Gremium tage „unregelmäßig und in großen Abständen" und sei bisher zwei Mal zusammengetreten. ${ }^{114}$ Der AK dient dem besseren Informationsaustausch, ermöglicht das leichtere Auffinden von Ansprechpartnern zu einzelnen Fragen und soll somit gegenseitige Hilfe ermöglichen. Zudem sei somit auch ein Vergleich von „best practice Beispielen“ zwischen den Häusern möglich. Erstaunlich ist, dass dieser hochrangig angesiedelte Mechanismus zur Koordination von keinem der Fondsverwalter als solcher erwähnt wurde. ${ }^{115}$

\section{Koordination in den Häusern}

Ein Haus - zwei Fonds

In BW findet sich eine „EU-weite Besonderheit“. ${ }^{116}$ Hier werden zwei EU-Fonds innerhalb eines Ministeriums abgewickelt. Im Ministerium für Ernährung und Ländlichen Raum (MLR) werden sowohl ELER als auch EFRE verwaltet. Dies hat zum Hintergrund, dass das EFRE-Volumen in BW aufgrund der wirtschaftlichen Stärke des Landes relativ gering sei und sich das Gründen einer eigenen EFREVerwaltung im Verhältnis zu aufwendig gewesen sei. Da bereits eine Fondsverwaltung sowohl beim MLR als auch beim Arbeitsministerium (für ESF) bereits bestand, sich EFRE jedoch aus dem alten Ziel-2 Programm entwickelt habe, dessen Abwicklung damals bereits beim MLR lag, wurde auch dieser Fonds hier angesiedelt. Generell sei anzumerken, dass die Förderung aus dem landwirtschaftlichen Bereich derart aufwendig sei und somit „eine eigene Welt" darstellt, die wesentlich schwerer in andere Fondsverwaltungsstrukturen zu integrieren sei, als anders herum. ${ }^{117}$ Diese Konstellation im MLR sei anfangs wenig problematisch gewesen. Jedoch habe die EU-Kommission spätestens bei Vorlage der OPs 2007-13 festgestellt, dass das EFRE-OP „sehr ländlich geprägt“ sei. ${ }^{118}$ Es sei der EU-

\footnotetext{
112 Vertreter der Kommunen, Landesbank, Fondsverwaltungen, Vertreter aller an den Fonds Beteiligter Ressorts, Regierungspräsidien, Staatskanzlei durch EU-Abteilung und Spiegelreferate

113 Debach, CDU-BW/FDP-BW (2006: 77).

114 Zoller, Debach

${ }^{115}$ s. Interviews Dr. Ris und Hausen.

${ }^{116}$ Debach meint damit, dass EU-weit der ELER nirgends mit einem SF zusammen verwaltet wird. In ST werden nach Müller EFRE und ESF in einem Haus abgewickelt.

${ }^{117}$ Dr. Ris

${ }^{118}$ Debach
} 
Kommission ein "Dorn im Auge“, dass sich die EFRE-Verwaltung im Landwirtschaftsbereich befinde, jedoch biete dieser Sachverhalt allein noch keinen ausreichenden Grund zur Intervention. ${ }^{119}$

Konstellationen, bei denen zwei Fonds in einem Haus verwaltet werden, finden sich auch in ST, wo EFRE und ESF in einem Ministerium verwaltet werden. ${ }^{120}$ In MV ist dies auch der Fall. Jedoch existiert hier entsprechend der VO 1260/99 der Europäischen Gemeinschaft für die Intervention der europäischen Strukturfonds eine gemeinsame Verwaltungsbehörde durch Kabinettsbeschluss der Landesregierung. Diese wurde zunächst beim Wirtschaftsministerium eingesetzt (Landesregierung Mecklenburg-Vorpommern 2000: 243), jedoch in der Periode 2007-2013 zur Staatskanzlei verlegt (Landesregierung Mecklenburg-Vorpommern 2006: 134). Die gemeinsame Verwaltungsbehörde sorgt mit der Unterstützung der an der Strukturfondsförderung partizipierenden Landesministerien für eine effiziente und korrekte Umsetzung der integrierten Intervention im Verlauf der Förderperiode. Der gesamte Programmvollzug obliegt gemäß Art. 60 der Verordnung (EG) Nr.1083/2006 der Verantwortung der „Gemeinsamen Verwaltungsbehörde“.

\section{Prüfungen durch externe Stellen (Landesrechnungshof, Finanzministerium)}

Die Prüfungen des Rechnungshofes wurden ebenfalls als eine Art Mechanismus zur Koordination angesehen. ${ }^{121}$ Dieser Prüfe für Landesmittel, ob Doppelförderung vorliege und ob die Förderung kohärent sei. Die externe Prüfung und Bescheinigung bei den Fonds durch Stellen außerhalb des zuständigen Hauses bietet ebenfalls die Möglichkeit, die Programminhalte besser aufeinander abzustimmen. Dies trifft allerdings nur solange zu, als eine externe Stelle mehr als nur einen Fond prüft. $^{122}$

\footnotetext{
${ }^{119}$ Dr. Ris, ähnlich Debach

120 Müller

${ }^{121}$ Dr. Ris

${ }^{122}$ Pitzke
} 


\section{Koordination zwischen den Häusern}

Moderierte Workshops der Fondsverwaltungen

Anlässlich der Erstellung der OP-Entwürfe zu ESF und EFRE wurd in BW ein externer Beratungsdienstleister hinzugezogen, um mittels Workshoptechniken Schnittstellen, Überschneidungen und Synergien zwischen den Programmen zu identifizieren. In einem ersten Treffen haben sich die jeweiligen Fondsverwaltungen dann positioniert, ihr OP präsentiert und sich gegen die anderen abgegrenzt. In einem 2. Treffen seien dann eher technische Details der Abgrenzung besprochen, verhandelt und geklärt worden. ${ }^{123}$

\section{Kontinuierlicher Austausch der Verwalter}

Der wohl trivialste Mechanismus zur Koordination und Abstimmung der Förderung sind persönlicher Austausch der Fondsverwaltungen. Hierzu zählen die routinemäßige gegenseitige Einbeziehung in die jeweiligen Begleitausschüsse, wie auch ein „jour fix“ oder „große“ und „kleine Besprechungen“ zwischen den Verwaltungen. ${ }^{124}$ Bezüglich der gegenseitigen Beteiligung der Verwalter in allen Begleitausschüssen (BGA) lässt sich sagen, dass dies ein Novum zumindest für den landwirtschaftlichen Bereich ist. ${ }^{125}$ Zuvor seien lediglich die Häuser in den BGA vertreten gewesen, die auch am jeweiligen Fonds partizipiert hatten. Die neuerliche Pflicht, alle Verwaltungen in alle BGA zu entsenden führe zu einer besseren Informiertheit der Verwaltungen sowie einer höheren Intensität der Zusammenarbeit, die vorher im Abstecken von Eckpunkten und einem anschließenden getrennten vorgehen bestanden habe. ${ }^{126}$ Nach wie vor und trotz der kontinuierlichen Einbindung Aller in die BGA kommt wohl den Konsultationen zwischen den Verwaltern zu Beginn der Programmierung bezüglich des Koordinationsergebnisses ein hoher Stellenwert zu, da „das Abstecken von Eckpunkten“ und die Verhandlung von Zuständigkeiten nicht nur ein fortwährender Mechanismus verwaltungsinterner Koordination ist, sondern als grundlegendes Charakteristikum einer rationalen Verwaltung zu sehen ist. ${ }^{127}$ Als weiterer kontinuierlicher Mechanismus können interministerielle Arbeitsgruppen (IMAG) gesehen werden. Unter anderem in ST findet dort ein relativ institutionalisierter Austausch zwischen allen an der Förderung beteiligten Referaten und unter Vorsitz der jeweiligen Fondsverwaltung statt. ${ }^{128}$ Jedoch ist hier anzumerken, dass diese IMAGs jeweils nur zu einem Fond tagen und somit eine Integration der verschiedenen Stränge nicht zwangsläufig begünstigen.

\footnotetext{
123 Hausen

${ }^{124}$ z.B. Balduhn, ähnlich zahlreiche Andere

${ }^{125}$ Wohlgschaft

${ }^{126}$ Wohlgschaft, ähnlich Müller

127 z.B. Müller, Hausen

${ }^{128}$ Dr. Rosner, Dr. Herbert
} 


\section{Beteiligung mehrerer Häuser an den Fonds}

Die Beteiligung mehrerer Ministerien an den Landes-OPs der Strukturfonds kann als weiterer Mechanismus gesehen werden, durch den eine Integration und Koordination herbeigeführt werden könnte. Der Verwaltungsaufwand, als das maßgebliche Argument in der Diskussion um die Beteiligung mehrerer Partner an einem Topf, steigt drastisch mit steigender Anzahl an Partnern. Daher lässt sich andersherum der Aufwand deutlich minimieren, wenn möglichst wenige Partner beteiligt sind. Genau dieser Trend findet sich bspw. in BY, wo die Reduktion des Aufwandes explizit begrüßt wurde. ${ }^{129}$

\section{Ressortkoordinatoren zu einzelnen Strukturfonds in partizipierenden Häusern}

In ST ist es Praxis, dass sowohl für den ESF als auch für den EFRE (beide Fonds werden hier vom gleichen Referat am Finanzministerium verwaltet) sogenannte Ressortkoordinatoren in den partizipierenden Häusern etabliert werden. Diese kooperieren eng mit der Fondsverwaltung und sollen die Kommunikation und Koordination zwischen der Verwaltung und allen am Fonds partizipierenden Förderreferate (solche, die für die Umsetzung einzelner Maßnahmen verantwortlich sind) der anderen Häuser sicherstellen, um der Fondsverwaltung einen höheren Einflussgrad auf „aushäusige“ Referate zu gewährleisten. ${ }^{130}$ Diese Stellen werden aus Mitteln zur technischen Hilfe finanziert. Für den ELER sei dieses Vorgehen nicht notwendig gewesen, da nahezu alle partizipierenden Förderreferaten in dem Haus angesiedelt sind, in dem sich die ELER-Verwaltung befindet und somit auf den „kleinen Dienstweg“ zurückgegriffen werde. ${ }^{131}$

\section{Staatssekretärsausschuss ländlicher Raum}

In BY wurde im Herbst 2007 ein "Staatssekretärsausschusses ländlicher Raum“ als ein neuer Koordinationsmechanismus durch das Kabinett einberufen. Dieser tage anlassbezogen und sei durch die GAK-Breitbandinitiative des Bundesministers Seehofer ausgelöst worden. In deren Zuge habe sich „erstmals die Anforderung zur Koordination untereinander" gestellt. ${ }^{132}$ Ziel sei es, bei überlappenden Fragen eine Abstimmung zu erreichen. Dazu seien alle Ressorts einbezogen worden. Diese Art der Koordination im Politikfeld „ländlicher Raum“ stellt zumindest in BY ein Novum dar. ${ }^{133}$

\footnotetext{
${ }^{129}$ Müller

${ }^{130}$ Dr. Herbert

${ }^{131}$ Dr. Herbert

132 Reimann

133 Reimann
} 


\section{Das Kabinett}

Als höchstrangiges Verhandlungssystem stellt das Kabinett eine wichtige Instanz bei der Koordination und Integration von Förderung und deren Zielen dar. Diese Rolle kann allgemein in zweierlei Ausprägungen ausgefüllt werden:

- Das Kabinett gibt lediglich „grobe informelle Richtlinien und die Verteilung der EU-Mittel auf die Häuser" vor. ${ }^{134}$ Somit kommt dem Kabinett in diesen Fällen eine eher strategische jedoch inhaltlich passive Rolle zu, indem es vorab ausgehandelte Abgrenzungen und Zuständigkeiten zwischen den Häusern lediglich absegnet, nicht aber inhaltsreich zur Koordination beiträgt.

- Im Falle einer fondsübergreifenden Strategie (s.u.) jedoch wird dessen Rolle deutlich aufgewertet. Nach Kabinettsbeschluss zur integrierten, fondsübergreifenden Verwendung der Strukturfonds-Mittel durch eine übergeordnete Landesstrategie (so der Fall in ST) beauftragt dieses die Staatskanzlei mit der Koordination der daraus resultierenden Koordinations- und Verteilungsaufgabe. ${ }^{135}$ Diese hochrangige Beauftragung selbst beinhaltet zwar noch keine Koordination, jedoch folgt diese einem solchen Mandat automatisch nach und zwar genau soweit, wie die Kompetenzen, die in diesem Falle teilweise auf das Votum des Kabinetts zurückgehen, der Staatskanzlei reichen. ${ }^{136}$ Im Falle von MV hingegen wurde das Bestreben nach einer Landesstrategie zur StrukturfondsVerwendung von der Staatskanzlei an das Kabinett herangetragen, ohne dass dieses einen solchen Vorschlag je gemacht hätte. ${ }^{137}$ Jedoch spielte dieses Votum eine sehr wichtige Rolle in der strategischen Planung des Vorgehens, wobei eine inhaltliche Koordination lediglich auf Arbeitsebene (Staatskanzlei und Häuser) betrieben werde. ${ }^{138}$ Hier ist sozusagen eine niederrangig initiierte hochrangige Beauftragung zu beobachten, welche auf einem breiten Landesinteresse beruht und Ressortinteressen in den Hintergrund drängt.

\footnotetext{
${ }^{134}$ Göttler, ähnlich Wohlgschaft

135 Dr. Rosner

136 Mattner

137 Mattner

${ }^{138}$ Mattner
} 


\section{Programmatische Koordination}

Landeseigene, integrierte (querschnittsorientierte) Förderprogramme und Richtlinien

Als Mechanismus zur inhaltlichen Verschneidung verschiedener Förderstränge können landeseigene Programme und Richtlinien dienen. Als solche gelten Programme, die sich mehrerer Quellen bedienen, um ein Maßnahmenspektrum anzubieten, welches über den oft eng definierten sektoralen Zusammenhang der einzelnen Strukturfonds hinausgeht. In BW kann das „Entwicklungsprogramm Ländlicher Raum" (ELR) als solches gesehen werden, in dem Mittel unterschiedlicher Herkunft (EFRE, Leader aus ELER, GAK-Breitbandförderung sowie Landesmittel) inhaltlich nebeneinander verwendet werden und somit die Ziele unterschiedlicher Förderprogramme parallel bedient werden. ${ }^{139}$ Hier ist zu bemerken, dass wegen des Monofondsprinzips die ELER-geförderten Maßnehmen von jenen, die der EFRE kofinanziert klar voneinander abgegrenzt sind. Für potentielle Antragsteller sind die verschiedenen Herkünfte der Mittel jedoch nicht mehr erkennbar, für inn stellt sich die Förderung als „ELR“ dar.

Beim ELR sind Gemeinden die Hauptadressaten und aufgrund der langjährigen Erfahrungen wüssten alle Bürgermeister über diese Förderung Bescheid. Somit trage eine Richtlinie dazu bei, dass der „Förderdschungel“ eigentlich keiner sei. ${ }^{140}$

\section{Regionalisierung der Förderung - Verzicht auf Maßnahmenansatz}

Die Abkehr von förderfähigen Maßnahmen hin zu projektbasiertem Vorgehen und die Planung und Umsetzung dieser Projekte durch regionale public-privatepartnerships auf Landkreisebene stehen stellvertretend für den regionalisierten Ansatz in der ESF-Förderung. Als einziges Bundesland setze BW auf die Arbeit sog. ESF-Arbeitskreise auf Landkreisebene, in denen alle beschäftigungspolitischen Akteure einer Region vertreten sind. ${ }^{141}$ „Maßnahmen“ werden in Form von Projekten in der Region ausgestaltet (vorgeschlagen) und durch den Arbeitskreis inhaltlich bewertet (und quasi selektiert). Dabei basiert die Entscheidung auf übergeordneten ESF-Zielen und förderfähigen Themenfeldern. Nach Prüfung der Anträge bewilligt die Landesbank die Projekte formell. Dieses Modell werde in BW unter anderem daher angewendet, um (a) die diversen regionalen Bedarfe besser erfassen und somit die Förderung bedarfsorientiert gestalten zu können und (b) weil demnach ein gewisser Anteil an Kofinanzierungsmitteln von den regionalen Partnern bereitgestellt werden muss. In BW übernehme das Land lediglich 10$15 \%$ des Mittelvolumens als Kofinanzierungsmittel, was sich in Ländern mit zent-

\footnotetext{
${ }^{139}$ Dr. Ris; s. auch MLR (2008)

${ }^{140}$ Dr. Ris

${ }^{141}$ Hausen zum gesamten Abschnitt „Regionalisierung“
} 
ralistischem ESF-Ansatz wie z.B. Hessen auf 50\% belaufe. ${ }^{142}$ Dieser Ansatz leistet zwar per se noch keinen nennenswerten Beitrag zur inhaltlichen Koordination mit anderen Fördersträngen. Bei inhaltlichem Anlass und Gelegenheit bietet dieser Ansatz den Vorteil, dass, angepasst an die regionalen Bedarfe und flexibel, Synergien zwischen den Förderbereichen zu erzielen sind.

Ein eher standardisiertes Vorgehen in der Koordination verschiedener Förderstränge auf regionaler Ebene wurde in BY beobachtet. Hier existiert Regionalmanagement sowohl nach ELER-Leader als auch nach EFRE auf Landkreisebene. Gewissermaßen als Verabredung zwischen den beiden zuständigen Häusern (Wirtschaft, Landwirtschaft) gilt, dass im Falle konkurrierender Förderanträge das RM nach EFRE Vorrang genießt. ${ }^{143}$ Dieses eher standardisierte Vorgehen in der Koordination von Förderprogrammen weist jedoch auf fehlende inhaltliche Koordination hin.

Um eine solche Überschneidung von strategischen Fördertatbeständen (wie Regionalmanagements oder ILEKs ${ }^{144}$ ) zu vermeiden, wurde in SN eine „Harmonisierung der Planungsinstrumente“ unter besonderer Berücksichtigung solcher informeller Instrumente und dadurch getragenen Projekten durchgeführt. ${ }^{145} \mathrm{Im}$ Zuge der EU-Anforderungen an Abgrenzung und Synergien zwischen den Strukturfonds wollte die Staatskanzlei dies nicht nur inhaltlich (an einzelnen Maßnahmen) vorgenommen wissen. Vielmehr sollte auch eine strategische Abgrenzung unter der Vielzahl der in den verschiedenen Häusern existierenden Planungsinstrumente vorgenommen werden. Dieser folgte dann die Selektion je eines strategischen Instrumentes (z.B. ILEK, zuvor gab es eine Vielzahl solcher strategischer Instrumente verschiedener Häuser, die alle in gleichen Raum wirken sollten) für drei verschiedene territoriale Ebenen (Gemeinde, Kleinregionen von 5.000 bis 150.000 EW, Großregionen). Dieses Vorgehen wurde durch die Staatskanzlei initiiert und nach Beschluss einer entsprechenden Kabinettsvorlage wurde das MLU mit der Planung dazu beauftragt. Die weitere Erarbeitung und Umsetzung dieses Masterplanes wurde in der IMAG „Regionale Entwicklung“ durchgeführt. Als Folge dieses Ansatzes ist in allen Richtlinien aller Häuser ein Vorrang für Maßnahmen vorgesehen: a) bevorzugte Beratung, b) schnelle bevorzugte Bewilligung, c) bis $10 \%$ höhere Fördersätze, welche über ein „strategisches Instrument“ eingebunden sind. In der Richtlinie zur ILE ist eine Förderung nur noch möglich, wenn ein solches regionales Votum vorliegt. Diese Richtlinie vereint nahezu 50\% der ELER-Mittel in SN. Zudem wurden hier im Rahmen der ILE-Richtlinie auch quasi regionale Budgets

\footnotetext{
142 Hausen

${ }^{143}$ Wohlgschaft

144 Integrierte ländliche Entwicklungskonzepte

145 Grieß
} 
eingerichtet. Die formale Prüfung und Bewilligung von Anträgen obliegt zwar nach wie vor einer zentralen bewilligenden Behörde, die Förderwürdigkeit hingegen wird durch das regionale Votum festgestellt. Diese Dezentralisierung wird in SN über alle Fördermittel durchgeführt. ${ }^{146}$

\section{Fondsübergreifende Landesstrategie}

Als am weitesten reichende programmatische Koordinierung wurden sogenannte fondsübergreifende Landesstrategien zur Verwendung der Strukturfonds-Mittel identifiziert, von denen hier drei Typen beobachtet wurden:

\section{Das Modell Schleswig-Holstein}

Das „Zukunftsprogramm Schleswig-Holstein“ (ZP) muss als wenig weit reichend gesehen werden. Dieses wurde durch die Fondsverwalter initiiert und an die Staatskanzlei herangetragen. ${ }^{147}$ Es stellt zwar ein Dach für die vier nachgeordneten Programme dar, welche jedoch als „völlig unabhängige Programme“ dastünden. ${ }^{148}$ Dafür spricht, dass die Teilprogramme (zu den Themen Arbeit, Wirtschaft, Landwirtschaft und Fischerei in Anlehnung an die Strukturfonds) auf je einzelnen Auftaktveranstaltungen dem jeweils nur an Einzelprogrammen interessierten Publikum (Klientel) vorgestellt wurden und es bei der Staatskanzlei keinen direkten Ansprechpartner für das ZP gebe. ${ }^{149}$ Das ZP formuliert ferner keine eigenen (Landes-) Ziele, welche den Ressortprioritäten übergeordnet werden müssten. ${ }^{150}$ Es erfolge keine inhaltliche Einflussnahme, da sich letztlich kein Ressort reinregieren lasse. $^{151}$

\section{Das Modell Sachsen-Anhalt}

In ST wird eine „allgemeine Förderstrategie“ zur Verwendung der StrukturfondsMittel praktiziert. Diese formuliert für die Verwendung der Strukturfonds drei sogenannte Oberziele (Landesziele) als Strategieschwerpunkte, welche als Landesinteressen (-ziele) den Ressortprioritäten bei der Verwendung übergeordnet sind. ${ }^{152}$ Dieser Strategieprozess wurde in ST nach Beschluss des Kabinetts initiiert und der Auftrag zur Erarbeitung und Moderation der Strategie an die Staatskanzlei ge-

\footnotetext{
${ }^{146}$ Grieß

147 Bayer, Elers

148 Elers, Balduhn

149 Ewald

150 Stangenberg

${ }^{151}$ Balduhn, ähnlich Elers

152 Nach Landesregierung ST (2006), ähnlich Dr. Rosner: Bildung; Forschung, Entwicklung und Innovation; Investitionsförderung und Abbau von Finanzierungshemmnissen
} 
geben. ${ }^{153}$ Diese habe die Moderation bis zur Genehmigung der OPs durchgeführt, sich danach jedoch inhaltlich raus gehalten und die operative Koordination den Verwaltungen überlassen. ${ }^{154}$ Somit kommt ihr eine Koordinationsfunktion gröberer, strategischer Natur zu. ${ }^{155}$ Nach der Formulierung der Strategie wurde zunächst eine Bedarfsabfrage unter allen Häusern durchgeführt, die an den einzelnen Fonds partizipieren wollen und Maßnahmenvorschläge entgegen genommen. Diese lagen in ihrer Gesamtheit weit über den zur Verfügung stehenden Mitteln und wurden deshalb dahingehend bewertet, wie viel sie zu einem der 3 Landesziele beitrügen. Dieses „Maßnahmen-Scoring“ wurde durch einen externen Berater durchgeführt, worauf die Staatskanzlei dem Kabinett einen Vorschlag zur Mittelzuteilung unterbreitete. Nach der Maßnahmenpriorisierung und der Mittelzuweisung sei eine Koordination der Staatskanzlei lediglich bei wenigen, sehr übergreifenden Maßnahmen und bei gravierender Änderung der Ausgangslage nötig. ${ }^{156}$ Die Verwaltung der einzelnen Fonds verbleibt in ST bei den zuständigen Häusern (ELER Landwirtschaft, EFRE/ESF bei Wirtschaft).

\section{Das Modell Mecklenburg-Vorpommern}

Ein „integrierter Einsatz der EU-Strukturfonds“ wird in MV praktiziert. Dieses Modell ist dem aus ST sehr ähnlich, unterscheidet sich dennoch in wenigen zentralen Punkten. Die übergeordnete Landesstrategie ${ }^{157}$ verfolgt dabei ebenfalls übergeordnete Ziele. ${ }^{158}$ Die Staatskanzlei initiierte und formulierte hier die Strategie und hat diese an das Kabinett als Vorlage herangetragen. Nach deren Verabschiedung fand die Koordination und Planung durch die Staatskanzlei statt, wobei inhaltliche Detailfragen und Abwicklung bei den jeweiligen Häusern verblieben. Die Verwaltung der Fonds wurde jedoch in einer Gemeinsamen Verwaltungsbehörde (GVB) an der Staatskanzlei zentralisiert. Dieser obliegen die wenigen eher strategischen Aufgaben der Verwaltungsbehörden, die sich aus den jeweiligen Fonds-VO ergeben. Die operativen Aufgaben wurden an die jeweiligen Häuser als zwischengeschaltete Stellen delegiert (ELER bei Landwirtschaft; ESF/EFRE bei Finanz). Die Verteilung der Aufgaben sei bei allen Fonds sehr ähnlich gestaltet. ${ }^{159}$ Anhang 1 zeigt diese drei Modelle schematisch auf.

\footnotetext{
${ }^{153}$ Dr. Rosner

154 Dr. Herbert, Dr. Rosner

155 Dr. Rosner

${ }^{156}$ Dr. Rosner

${ }^{157}$ Vgl. Landtag Mecklenburg-Vorpommern (2005)

158 Verbesserung der Wettbewerbsfähigkeit des Landes; Verbesserung der Infrastruktur; Entwicklung von Forschung, Entwicklung und Humanressourcen; Teilhabe an sozialen Standards.

${ }^{159}$ zum gesamten Abschnitt Mattner
} 


\section{Koordination durch die EU (programmatisch)}

Genehmigungsverfahren der EU - Steuernde Eingriffe in Richtung Koordination? Im Genehmigungsverfahren der OPs lassen sich ebenfalls Möglichkeiten zur Koordination finden. So habe man in BW relativ große inhaltliche Freiräume beim Entwurf der ELER-OP gehabt. Im Genehmigungsverfahren hingegen habe die EUKommission „mit einem Verwaltungshandeln, das wir hier nicht kennen [...] sehr stark eingegriffen". ${ }^{160}$ Jedoch sei es der EU-Kommission dabei weniger um das Auffinden und die Nutzung von Synergien gegangen. Vielmehr wurde in folgenden Konsultationsgesprächen der Abgrenzung einzelner Maßnahmen voneinander und der Ausschluss von Doppelförderung ein sehr hoher Stellenwert beigemessen. ${ }^{161}$

\section{Zielintegration auf EU-Ebene}

Auf EU-Ebenen erfolgte eine Zielintegration der Ziele 2 und 3 zum Ziel „Wachstum und Beschäftigung". Für die Koordination der verschiedenen Finanzinstrumente der EU lässt sich somit vermuten, dass sich daraus ebenfalls eine inhaltliche Integration über die Ziele/das Ziel ergibt. In der Verwaltungspraxis ist jedoch zu beobachten, dass die Zielintegration zwar auf politischer Ebene erfolgt sei, sich in der Praxis jedoch nichts geändert habe. Die Ziele seien auch vorher schon ähnlich gewesen. ${ }^{162}$

\section{Koordination der Länder auf Bundesebene}

Eine Besonderheit stellen die Treffen der Programmkoordinierungsreferenten (PKR; analog der HuK-Treffen bei GAK) auf Bundesebene dar. Als Koordinationsmechanismus, der vorrangig den gegenseitigen Austausch zum Zwecke hat, wird hier jedoch weniger inhaltliche Koordinierung als vielmehr gegenseitige Unterrichtung praktiziert. Da sich die Referenten dabei außerhalb der landespolitischen Bühne bewegen, ist bei diesem Mechanismus eine besonders geringe Verbindlichkeitswirkung zu erwarten. ${ }^{163}$

\footnotetext{
160 Schlotterbeck

161 Hausen

162 Moser, ähnlich Hausen

${ }^{163}$ Wohlgschaft zum gesamten Absatz.
} 


\subsubsection{Koordinationsmechanismen auf regionaler Ebene}

Auf regionaler Ebene wurden überwiegend Anlauf- und Beratungsstellen für Förderangebote als Koordinationsmechanismen identifiziert. Dieser Umstand ist wohl der Tatsache zu schulden, dass hier die Förderpolitik nicht mehr maßgeblich formuliert und beeinflusst werden kann und somit auch die Kerninteressen von Verwaltungseinheiten und deren Klientel nicht mehr zu verteidigen sind, sondern hier mit dem gesetzten Rahmen zu leben ist.

\section{Sektorale Fördereinrichtungen und deren Beratung}

Den Ämtern für Landwirtschaft kommt in allen untersuchten Regionen eine wichtige Rolle in der Beratung und Abwicklung landwirtschaftlicher Förderung zu, auch wenn diese gelegentlich als nicht innovativ oder wenig aktivierend empfunden wird. ${ }^{164}$ Gleiches gilt für Ämter der Wirtschaftsförderung bei Kommunen und Landkreisen und deren Entsprechungen. ${ }^{165}$ Hier ist jedoch ein Unterschied zwischen Ost und West zu beobachten, da in den neuen Ländern dieser Art der Förderung und ihrer Förderinstitutionen eine große Bedeutung beigemessen wird. ${ }^{166}$ So spielen die Ämter für Wirtschaftsförderung in der Beratung und Koordination zum Gesamtthema „Förderung für den ländlichen Raum" eine überragende Rolle, was in westdeutschen Regionen nicht vorzufinden war. Hingegen ist das Verhältnis zwischen RALB und der dortigen Wirtschaftsförderung als eher disjunkt zu beschreiben. ${ }^{167}$ Neben den genannten Einrichtungen wurde auf viele weitere Anlaufstellen zum Thema Regelförderung verwiesen. ${ }^{168}$

\section{Koordinierung der Regelförderung durch Regierungspräsidien}

Da ein Großteil an Landesförderprogrammen in BW und BY bei den Regierungspräsidien abgewickelt werde, komme diesen Verwaltungseinrichtungen eine besondere Bedeutung in der Koordination der Förderung zu. ${ }^{169}$ Allerdings haben diese keinerlei Einfluss mehr auf die Ausgestaltung der Programme, sondern können lediglich der informationellen Verbreitung und Beratung zu den fertig formulierten Programmen dienen. Jedoch ist auf regionaler Ebene zu beobachten, dass die Zuständigkeiten zwar hier gegeben sind, deren Aufgabenwahrnehmung aber als eher passiv und verwaltend beschrieben wird. ${ }^{170}$ Zudem findet eine Beratung

\footnotetext{
${ }^{164}$ Remmelberger

${ }^{165}$ Hagen, Reppenhagen, Badge, Weible, Friemel

${ }^{166}$ s. Badge, Paetow

${ }^{167}$ Hagen

168 U.a. IHK, Handwerkskammern, Arbeitsagenturen, Investitionsbanken der Länder o.ä., wissenschaftliche Einrichtungen (hier: ,TU Weihenstephan), EUREGIO-Büro

169 Dr. Ris, Müller, Leicht

${ }^{170}$ Friemel
} 
durch die zuständigen Sachbearbeiter statt, welche wiederum lediglich in ihrem engen Förderbereich ausreichend Informationen hätten, nicht aber zu übergreifenden Projektideen.

\section{Integrierte Förderberatung}

Auf regionaler Ebene kommt den Regionalmanagements (RM) eine überragende Rolle in der Bewältigung der Beratungsaufgabe zu verschiedensten Förderangeboten zu. Dies trifft in allen Regionen zu, wenngleich die Aufgabenverteilung basierend auf den jeweiligen Fähigkeiten und Engagement zwischen RM und Abwicklungspartner (siehe unten) variieren, stellen die RM, die unter Regionen Aktiv geschaffen wurden, die wichtigste Anlaufstelle für integrierte, d.h. die Förderstränge übergreifenden Projektideen dar. Sie dienen als Schnittstelle zu den Institutionen und Kollegen der „Regelförderung, ${ }^{171}$ welche durch Modellansätze niemals ersetzt werden kann und wird“. ${ }^{172}$ Daher kommt der Anbindung und dem Verhältnis zwischen integrierter Förderberatung und dem System der Regelförderung samt seinen sektoralen Eigenarten eine zentrale Rolle zu. ${ }^{173}$ Die Rollenverteilung zwischen diesen beiden „Fördersystemen“ und ihrer Vertreter scheint jedoch klar zu sein. Integrierte und übergreifende Förderberatung als „Neuling“ ist aufgerufen, ein aktives Networking und persönliche Kontakte zu den zuständigen Stellen zu betreiben. $^{174}$

Diese wichtige Schnittstellenrolle wird teilweise auch von anderen RMs auf anderen territorialen Ebenen übernommen. So wird als gutes Beispiel eines effektiven, umfassend informierten und bedarfsorientierten RM das Bundesland Oberösterreich zitiert. ${ }^{175}$ Dieses sei dort auf Bundeslandsebene angesiedelt und sei in den vier Themenfeldern Leader, EUREGIO, Dorfentwicklung und Energie tätig. Je ein Regionalmanager befasse sich mit einem Themenbereich. Gemeinsam sitze man in einem Büro und stelle somit eine relativ große Organisationseinheit, die sich umfassend mit finanzieller Förderung befasse, zudem aber die sektorale Förderlandschaften mit ihren Besonderheiten im Blick habe. Als weitere wichtige Institution wurde im Falle vom Chiemgau und RALB beobachtet, dass neben dem RM den Abwicklungspartners (AP) eine zentrale Rolle in der Förderberatung zukommt. Beiden APs ist gemein, dass sie über mehrjährige Erfahrungen im Bereich Förde-

\footnotetext{
${ }^{171}$ z.B. Landesförderinstitute, Wirtschaftsförderung, Landkreis, Regierungspräsidien, Amt f. Landwirtschaft u.v.m.

${ }^{173}$ Man vergleiche hier die Verwaltungsanbindung des RM an den Landkreis Reutlingen und deren überragend gute Erfahrungen in der Kooperation mit „der Regelförderung“ (Leicht, Weible)und die eher lose Einbindung von Regionen Aktiv in den politisch-administrative Struktur im Chiemgau und deren überwiegend negative Einstellung der Regelförderung gegenüber (Wiedauer, Remmelberger, Friemel). 
rung verfügen und diese in Festanstellung bei Verwaltungsbehörden erlangten. ${ }^{176}$ Zudem brachten sie sich aktiv und gestalterisch in die Erarbeitung von Projektideen ein. Dies belegt u.a. die Rolle des ehem. APs der RALB als Vorsitzender der dortigen neuen LAG. ${ }^{177}$

\section{vereinzelte innovative „Mechanismen“}

\section{Langjährigkeit zur Professionalisierung der Koordination}

Die Kombination einer langjährigen Erfahrung im Bereich der Förderung, kombiniert mit dem Auftrag oder Selbstverständnis zum aktiven, auch inhaltlich gestaltenden Einbringen in Projektideen lokaler Antragsteller, kann hier als effektiv wirkender „Mechanismus“ gesehen werden, der viel Potential für eine Integration der Förderung vor Ort birgt. „Der so genannte Förderdschungel ist nur für den Ungeübten ein Dschungel. Für diese Art der Expertise braucht man 3 Jahre Einarbeitung plus 3 Jahre extra für die Strukturfondsförderung und EU-Recht". ${ }^{178}$ Hinzu komme, dass man nach dieser Zeit nicht nur über das spezifische Wissen verfüge, sondern man habe erst dann ein „Netzwerk aus Leitern der Bauämter, Bürgermeistern, Landräten, etc. und die Bevölkerung kennt dann ihren Ansprechpartner.“179 Diese Voraussetzungen können (wie oben gezeigt) sowohl RM als auch AP mit sich bringen. Eine Gefahr hingegen birgt die Ausschreibung solcher strategischer Stellen auf Zeit und außerhalb der Verwaltungsstrukturen. ${ }^{180}$

\section{Gegenseitige Beteiligung in förderrelevanten Gremien}

Eine institutionelle Zusammenarbeit zweier zentraler förderungsrelevanter Institutionen wurde in $\mathrm{SH}$ beobachtet, wo Vertreter der regionalen Wirtschaftsförderung zwingend Mitglieder der dortigen LAG sind und andersherum. ${ }^{181}$

\footnotetext{
${ }^{176}$ anders als dies z.B. bei ILE-RM zu erwarten ist, welche z.T. öffentlich ausgeschrieben werden müssen und somit eine Kontinuität und ein stetig wachsendes „Förderwissen“ nicht zu gewährleisten sind (s. Paetow, auch Reppenhagen).

177 Reppenhagen

${ }^{178}$ Reppenhagen, ähnlich Friemel

${ }^{179}$ Reppenhagen

180 Paetow, s. FN108

${ }^{181}$ Dr. Bayer
} 


\subsubsection{Fördernde und hemmende Faktoren einer Politikintegration}

Auf Landesebene wurde eine Vielzahl fördernder und hemmender Ausprägungen von Determinanten beleuchtet, die den Erfolg der Politikintegration und somit der Koordination der Förderung mitbestimmen. Diese werden im Folgenden aufgelistet und den Institutionen zugeordnet, welche am meistem Einfluss auf den jeweiligen Faktor haben dürften.

\section{Die EU-Kommission}

Als fördernd wirkt der verbindliche Programmierungsrahmen, der von der EU für die Verwendung der Strukturfonds vorgegeben wird. Hier sind besonders zu nennen die Pflicht zur Beschreibung der Abgrenzung und Synergien zu anderen Fonds in den OPs, die zu einer „Vergegenwärtigung“ dieser Ziele bei den handelnden Verwaltungsakteuren geführt hat ${ }^{182}$, wobei die fehlende Durchsetzung und Kontrolle der Synergieanforderungen im Genehmigungsverfahren der OPS durch die EU-Kommission ${ }^{183}$ als die inhaltsreiche Koordination hindernd angesehen werden muss. Die Ausgestaltung der Fonds-Verordnungen wirkt sich ebenfalls auf die Koordinierbarkeit aus. Während der EFRE eher großzügige Handlungsspielräume lasse ${ }^{184}$, beschränke der ELER z.B. durch die Minimalverwendungsvorgaben in den vier Schwerpunkten dessen Integrationsfähigkeit. Das Monofondsprinzip wirkt gleichsam negativ auf die inhaltsreiche Koordination der Förderung. ${ }^{185}$ So lege die EU-Kommission das Monofondsprinzip derzeit dahingehend aus, dass nicht nur inhaltlich lediglich ein Fonds für die Förderung bestimmter Maßnahmen zuständig ist, sondern leitet daraus auch ab, dass für jeden Fonds dessen Verwaltungsstrukturen (Fondsverwaltung, Bewertung und Begleitung, BGA, etc.) getrennt sein müssten. ${ }^{186}$ Nach ihrem früheren Monofondsansatz der 1990er Jahre habe die EU in der vergangenen Periode einen eher integrierten Ansatz gewählt, um diesen nun wieder durch das Monofondsprinzip zu ersetzen. Als einzig plausibler Grund dafür wurde bisher das Autonomiestreben bzw. -erhalt der verschiedenen Generaldirektionen identifiziert. ${ }^{187}$ Dieses sei während der Koordination der Strukturpolitik durch die DG Region zwischen 2000 und 2006 durch deren „Reinregieren“ in die jeweils anderen DGs diese Autonomie verletzt wurde. Das den einzelnen Bundesländern aus Brüssel zur Verfügung stehende Mittelvo-

\footnotetext{
182 Elers, Hausen

183 Hausen

${ }^{184}$ Dr. Herbert

185 Müller, Dr. Ris

186 Mattner

187 Mattner
} 
lumen wurde ebenfalls als einflussreiche Größe genannt. ${ }^{188}$ Die absolute Höhe der Kofinanzierungsmittel sowie besonders deren relativer Anteil am Landeshaushalt seien bestimmend dafür, ob sich hochrangige und signifikante Koordinationsinterventionen politisch lohnten. ${ }^{189}$

\section{Die Landesministerien}

Als genereller und relativ weit reichender Faktor wirken sich sog. „Ressortegoismen" auf die Koordination aus, die auf den hoch spezialisierten Aufbau der Verwaltungen und deren Zuständigkeitsbereicht zurückzuführen sind. Traditionelle (sektorale) Schwerpunkte der Förderpolitik und Präferenzen einzelner Häuser sind generell nur schwer dem Ziel der Politikintegration für eine (integrierte) ländliche Entwicklung unterzuordnen. Somit wirken die Ressortegoismen als Kerninteressen der Organisationen und ihrer Teile (Ministerien, Abteilungen und Referate) generell hemmend auf eine Politikintegration. ${ }^{190}$ Als ebenfalls hinderlich zeigten sich die sehr unterschiedlichen verwaltungstechnischen Anforderungen bei der Abstimmung und Koordination von Fördermitteln. Mittel aus verschiedener Herkunft (Landes-, Bundes- und EU-Mittel) unterliegen dabei teilweise einer Jährlichkeit, teils dem 7-Jahres-Zyklus der EU-Planung, was eine inhaltsreiche Abstimmung sehr erschwere. ${ }^{191}$

Der extrem hohe Verwaltungsaufwand in den Landwirtschaftsfonds wird ebenfalls als hinderlich gesehen, diese an anderer Stelle zu integrieren. ${ }^{192}$ Letztlich kann es passieren, dass es aufgrund dieser Diskrepanzen im Verwaltungsaufwand zu einer Zerstückelung einzelner Maßnahmen(Pakete) kommt, ${ }^{193}$ welche einem integrierten Vorgehen diametral entgegenstehen. Das Partizipieren mehrerer Häuser an der Umsetzung eines Fonds kann hingegen als förderlich gesehen werden, da somit verschiedene (Ressort)Ziele und -präferenzen koordiniert werden müssen. Genau diese Tatsache aber führt zunehmend zu einer „Verschlankung der Fonds “'194, um den Verwaltungsaufwand zu minimieren und den Vollzug zu vereinfachen, was der Integration wieder entgegensteht.

\footnotetext{
${ }^{188}$ Mattner

${ }^{189}$ Moser

${ }^{190}$ Debach, Dr. Herbert, Hausen, Dr. Reimann, Göttler, Wonka, u.a.

${ }^{191}$ Schlotterbeck

192 Dr. Ris

${ }^{193}$ Wohlgschaft

194 Müller, i.S. einer Reduktion der partizipierenden Ministerien.
} 
Die Integration verschiedener Förderbereiche in eine Organisation (Ministerium oder noch konkreter in eine Abteilung) wurde ebenfalls als förderlich beobachtet. So wirkt die Ansiedlung von ELER und EFRE im MLU in Baden-Württemberg sehr koordinierend. ${ }^{195}$ Ähnliches ist für die Ansiedlung von EFRE und ESF im gleichen Haus mancher ostdeutsche Länder festzuhalten. Letztlich kann die klare definitorische Abgrenzung verschiedener Förderbereiche und -maßnahmen ebenfalls, entgegen unserer Erwartungen, positiv auf eine Koordination wirken. Die klare Abgrenzung ist im Rahmen der Programmierung besonders bei den Strukturfonds sehr zentral, um eine (finanzielles) Risiko für das Land zu minimieren. ${ }^{196}$ Zudem erlauben klare Abgrenzungen auch klarere Handlungsanweisungen, wie im Falle von inhaltlichen Überschneidungen zu verfahren ist. Jedoch darf in diesem Zuge das Suchen nach möglichen Synergien nicht ausgelassen werden, da der Koordinationseffekt sonst sehr gering ist.

\section{Die Staatskanzleien}

Die hochrangige Rolle der Staatskanzleien als zentrales Koordinierungsorgan kommt in verschiedenen Politikbereichen je unterschiedlich zum Tragen, wirkt sich aber auf Integrationsbemühungen generell positiv aus. Bei Themen, die „erklärte Chefsache" sind, reichen ihre Kompetenzen und Einflusspotentiale meist weiter als in anderen Bereichen. Somit kommt der relativen, landesspezifischen Bedeutung der Förderung für den ländlichen Raum (bzw. der Gemeinschaftsaufgaben und der Strukturfonds) eine große Bedeutung in der Mobilisierung der Staatskanzlei und des Ministerpräsidenten in diesen Politikfeldern zu. Somit lässt sich auch erklären, dass trotz „Ressortsegoismen“ eine übergeordnete Landesstrategie mit eigenen Zielen politisch durchsetzbar ist. ${ }^{197}$ Dafür sind jedoch die oben genannten Einflusspotentiale der Staatskanzlei entscheidend ${ }^{198}$ die zwischen Ländern und Politikfeldern variieren.

\footnotetext{
195 Debach

196 Debach

${ }^{197}$ Dr. Herbert

198 Mattner
} 


\section{Das Kabinett}

Da Entscheidungen über das Kofinanzierungsvolumen des Landes zu den Strukturfonds im Kabinett getroffen werden, kann dieses sowohl förderlich als auch hinderlich wirken. ${ }^{199}$ Eine Entscheidung in Richtung sehr geringer Kofinanzierungsanteil des Landes z.B. am ESF in BW hatte zur Folge, dass weitere Kofinanzierungsmittel durch regionale Partner aufzubringen waren. Daher wurde hier ein regionalisierter Ansatz der Projektförderung gewählt, um diesen finanziellen Beteiligungen auch Entscheidungskompetenz nachfolgen zu lassen. ${ }^{200}$

Im regionalen Kontext konnten weitere fördernde und hemmende Faktoren einer inhaltsreichen Koordination der Förderprogramme beobachtet werden.

\section{Parallelstrukturen}

Als generell hinderlich für die effektive Koordination verschiedener Fördermöglichkeiten in den Regionen wurden Parallelstrukturen beobachtet. So hat die parallele Abwicklung von Regionen Aktiv und Leader+ in der Altmark ein großes Potential, einen fokussierten und professionellen Aufbau einer einzigen kompetenten Anlaufstelle für übergreifende Förderung zu behindern. ${ }^{201}$ Aber nicht nur diese Konkurrenzsituation integrierter Beratungsstrukturen wirkt hindernd. Die Institutionen der integrierten Förderung (wie z. B. Regionen Aktiv) werden bis zur Eingliederung oft als Konkurrenz zum politisch-administrativen System gesehen. Eine effektive integrierte Förderberatung wie sie in Reutlingen möglich war $^{202}$ steht dem Versuch, als solche zu fungieren, im Chiemgau diametral gegenüber. ${ }^{203}$

\section{Zentralisierung und Dezentralisierung}

Die Ausgestaltung des programmatischen Landesförderrahmens spielt hier ebenfalls eine wesentliche Rolle für den Erfolg von Koordination. Während zentralisierte Ansätze (über detaillierte Richtlinien) und deren Maßnahmen im regionalen Kontext häufig unflexibel und daher schwer anschlussfähig an andere Interventionen wirken, befördert ein dezentraler, regionalisierter und projektbasierter Ansatz der Förderpolitik die Integrationsfähigkeit einzelner Interventionen eher. Diese Art der Dezentralisierung soll hier vertikale Dezentralisierung genannt werden (engl. devolution), im Gegensatz zu einer Dezentralisierung auf einer Ebene (horizontale). Bei horizontaler Dezentralisierung werden eine Vielzahl von Förderbereichen und -kompetenzen an unterschiedliche Organisation abgegeben, was etwaige Ko-

\footnotetext{
199 Zoller

200 Hausen

201 Badge

202 Leicht

203 Hier wurden Vertreter der integrierten Förderung von der Politik und Verwaltung „ins Leere laufen gelassen“ (Wiedauer, ähnlich Remmelberger).
} 
ordinationsbemühungen erschweren dürfte. Im Sinne einer Koordination der Förderpolitik wäre es sehr sinnvoll, einen Mittelweg zwischen beiden Konzepten zu wählen: Eine formelle Zentralisierung von Kompetenzen wäre hier aus den oben genannten Gründen nicht ratsam, wohl aber die Orientierung an übergeordneten (Landes)Zielen, die strategische Ausrichtung der Förderinstrumente, die wiederum eine stringente Führung durch die Staatskanzleien erfordert.

\section{Ausgestaltung der Stellen zur Förderberatung}

Eine Ausgestaltung der Stellen zur Förderberatung (integriert und Regelförderung) kann in zweierlei Hinsicht positiv auf die Koordination wirken. Das Aufgabenfeld bzw. die Arbeitsauffassung der zuständigen Sachbearbeiter auf der einen Seite wirkt dann förderlich, wenn dieses über das Abwickeln und Verwalten der Förderprogramme hinausgeht und innovatives und kreatives Vorgehen in Antragsprozessen honoriert werden. Auf der anderen Seite sind ein langjähriges Förderwissen und Netzwerke zentral für die Professionalisierung der Förderberatung und wirken positiv auf die Integration verschiedener Fördermöglichkeiten.

\section{Das Angebot Integrierter Modellvorhaben}

Letztlich soll die Rolle bzw. das Vorhandensein von integrierten Förderprogrammen kritisch auf die Koordination von Fördermitteln beleuchtet werden. Zwar stellt ein Programm wie Regionen Aktiv eine große Leistung im Hinblick auf Politikintegration dar, welche jedoch aufgrund des Modellcharakters nicht von Dauer ist. Im System der Regelförderung, die entsprechend der funktionalen Ausdifferenzierung der Verwaltungen ebenfalls sehr divers ist, führt das Vorhandensein von Fördermöglichkeiten wie unter Regionen Aktiv eher dazu, dass eine effektive Koordination und Beratung zu Möglichkeiten der Regelförderung überflüssig ist. Gerade Fördersätze von 100\% veranlassen die Antragsteller dazu, bestehende Fördermöglichkeiten nur dahingehend zu durchleuchten, zu zeigen, dass diese eigentlich nicht bestehen (in der Hoffnung, keine andere Möglichkeit zu finden). ${ }^{204}$ Sollte es diese jedoch geben, kann dies dazu führen, dass die Anträge so umgeschrieben werden, dass sich in der entsprechenden Regelförderung nicht mehr förderfähig erscheinen, um die höheren Fördersätze der integrierten Programme zu erhalten. ${ }^{205}$ Als weiteres Resultat ergibt sich ein eher geringer bis nicht vorhandener Anteil an mischfinanzierten Projekten unter Regionen Aktiv. ${ }^{206}$ Somit wirkt eine große Diskrepanz in Fördersätzen von integrierten und Regelprogrammen hinderlich auf die Integration verschiedener Förderbereiche.

\footnotetext{
${ }^{204}$ Friemel

${ }^{205}$ Leicht, Friemel, Remmelberger

${ }^{206}$ Leicht, Weible, Badge, Paetow, Hagen, Wiedauer, Friemel.
} 


\subsubsection{Mängel und Lücken in der Koordination von Förderung}

Auf Landesebene wird das Fehlen einer inhaltlichen Koordinationsstelle als Mangel gesehen. ${ }^{207}$ Diese sollte sich, anders als der bestehende Arbeitskreis EUFörderung es tut, auch inhaltlicher Fragen annehmen und diese koordinieren. Eine solche Stelle hätte zum Vorteil, dass a) der Mittelrückfluss bei Bundes- und EUKofinanzierungen optimiert werden könnte, b) das Risiko von Anlastungen aus schlecht koordinierten Strukturfondsförderungen minimiert würde und c) inhaltliche Potentiale und Synergien genutzt werden könnten. ${ }^{208}$ Die komplette inhaltliche Trennung zweier Quellen innerhalb eines Förderbereichs (Sektors), wie sie zwischen ELER und GAK beobachtet wurde, ${ }^{209}$ ist ebenfalls zu bemängeln. Als weiterer Mangel wurde von regionalen Akteuren fehlende bzw. schlecht aufbereitete Information zu bestehender Förderung angeführt. Dies treffe besonders auf die Landesprogramme zu, deren Internetauftritte bzw. Landessuchmasken nur technisch sehr schwache Suchoptionen böten. ${ }^{210}$

Die fortwährende Trennung verschiedener Beratungsinstitutionen wie der Wirtschaftsförderung bei Kommunen und Landkreisen vom Regionen Aktiv RM wurde ebenfalls bemängelt. ${ }^{211}$ Als größter Mangel in der Koordination der Förderung wurde einhellig das Fehlen einer zentralen Anlauf- und Beratungsstelle zum Thema „Förderung ländlicher Raum" angeführt. ${ }^{212}$ Diese sollte einen Überblick über eine Vielzahl von Themenfeldern (s.u.) haben und an geeigneter Stelle angesiedelt werden. Als geeignet wurden angesehen Regierungspräsidien (wo vorhanden), die Planungsregion (bestehend aus 5 Landkreisen) sowie das Bundesland (mit Verweis auf das o.g. Modell Oberösterreichs). Gemein ist den Vorschlägen, dass ein Kreis meist nicht die kritische Masse an Fördervolumen bringe, um eine solche recht aufwendige Beratungsinstitution zu tragen/rechtfertigen. Dies variiert jedoch stark zwischen Regionen und Bundesländern.

Bei aller gebotener Vorsicht, nicht in einem Wunschzettel der Regionen zu münden, sollen nun einige wenige und zentrale Vorstellungen der regionalen Akteure zu sinnvollen Förderideen dargestellt werden (sog. Förderlücken). Modellvorhaben wie Leader+ und Regionen Aktiv seien sehr hilfreich gewesen, um zu Projektideen z.B. Machbarkeitsstudien durchzuführen und sich beratende Expertise einzukaufen. Diese Möglichkeiten seien in der Regelförderung selten möglich. Diese ergänzende Funktion der Modellvorhaben könnte stärker als bisher in die Regel-

\footnotetext{
207 Debach, Müller

208 Debach

${ }^{209}$ Schlotterbeck

${ }^{210}$ Paetow, Friemel

211 Hagen

${ }^{212}$ Paetow, Remmelberger, Wiedauer, Friemel, Hagen, Reppenhagen, Leicht.
} 
förderung aufgenommen werden. Ferner erfüllten die Modellvorhaben die Koordinationsaufgabe zu übergreifender Förderberatung, welche ebenfalls sinnvoller Weise flächendeckend förderfähig sein sollte. Ein regionales Budget bzw. ein Globalzuschuss bleiben bei den regionalen Akteuren und besonders bei RM und AP ein anzustrebender Fördertatbestand. Programme zu Umweltbildung sowie Erwachsenenbildung allgemein und erweiterter/alternativer Landwirtschaftsberatung seien nur unzureichend vorhanden. Letztlich entstehe eine Förderlücke im Zusammenhang mit EU- und nationalem Wettbewerbs- und Vergaberecht. So seien die EU-Anforderungen bei Förderung von Existenzgründern an einen überregionalen Absatz sehr hinderlich. Ähnliches findet sich für die sog. Anhang 1 Produkte (Produkte bis zur ersten Verarbeitungsstufe) bemängelt. Somit werden sehr innovative Ideen im Keim erstickt. 


\subsection{Lichtblicke - gute Beispiele der Koordination von Förder- programmen}

Für die Auswahl der Beispiele guter Praxis ging das Team der Begleitforschung von einem Modell aus, das hohe Integrationsleistung (horizontale Koordination) und Subsidiarität (vertikale Koordination) miteinander in Beziehung setzt. Die Wahl fiel auf ein deutsches und ein österreichisches Beispiel.

Das deutsche Beispiel, die Integration von Förderprogrammen auf Regierungsebene betreffend, kommt aus dem Freistaat Sachsen. Die Harmonisierung der regionalen Förderinstrumente in Sachsen steht für viele Ansätze erfolgreicher Politikintegration, die durch politische Weichenstellungen auf der Gestaltungsebene ihren Ausgang nahm. Das Beispiel verdeutlicht vor allem die günstige Wirkung von Politikintegration auf höchster, das heißt Regierungsebene und die ordnende Kraft der Selbstorganisation, die wesentlich durch regionale Identität geformt wird.

Das österreichische Beispiel, die Integration von Förderprogrammen auf der Regionsebene betreffend, kommt aus dem Land Tirol. Die Organisation und Integration des Regionalmanagements in Tirol steht für viele Ansätze erfolgreicher Politikintegration auf der Umsetzungsebene, die allerdings ohne wesentliche Unterstützungsleistungen der Gestaltungsebene schwer vorstellbar ist. Das Beispiel verdeutlicht die segensreiche Wirkung einer professionellen Haltung der Verwaltungsbehörde, die man mit „Allparteilichkeit“ umschreiben kann, und zeigt darüber hinaus eine differenzierte Vorgehensweise, die wohl durch die Integration der Informations- und Raumbeobachtungsfunktion in die koordinierende Verwaltungsbehörde begünstigt wird.

Hinter beiden Beispielen stehen ansehnliche Steuerungsleistungen der Landesregierung, der innen nachgeordneten Verwaltungsstellen und der regionalen Partnerschaften bzw. Regionalmanagements. Es ist verfehlt zu glauben, die beiden Beispiele stünden für "top down“ versus „bottom up“. In jedem dieser Beispiele geht es darum, eine "homöostatische“ Balance zwischen der zentralen Koordinationsfunktion und der dezentralen Verantwortungsübernahme zu finden, unter starker Einbindung und (Selbst-) Verpflichtung aller beteiligten Partner, was nicht zwangsläufig starke Eingriffe in das regionale Handlungssystem bedeutet. Das Gegenteil ist oft der Fall: Das Gute fällt leicht. 


\subsubsection{Koordination auf der Ebene der Programmgestaltung: Das Beispiel Sachsen}

\section{Hintergrund}

Sachsen ist mit $18.414 \mathrm{~km}^{2}$ und knapp 4,3 Mio. EinwohnerInnen (2006) ein deutsches Bundesland mittlerer Größe. Der 1990 wieder begründete Freistaat ist mit einer Bevölkerungsdichte von 233 Einwohnern pro $\mathrm{km}^{2}$ das bevölkerungsreichste und - abgesehen von Berlin - dichtest besiedelte neue Bundesland. Im gesamtdeutschen Vergleich liegt es hingegen eher im Schnitt. Seine Wirtschaft erarbeitet $3,8 \%$ des deutschen Bruttoinlandsprodukts, seine Exportquote ist mit $33,4 \%$ relativ hoch, da es viele Standorte im Hochtechnologiesektor beherbergt. Ein großes Problem stellt die demografische Entwicklung dar. Im Jahr 1990 betrug die Bevölkerung fast 5 Mio. Menschen. Bis 2020 wird ein Rückgang auf 3,8 Mio. EinwohnerInnen prognostiziert.

Die Lage an der Grenze zu den neuen Mitgliedsländern der EU, die Rekonversion alter Braunkohle- und Industriereviere und die Wandlungsprozesse nach der Vereinigung mit der Bundesrepublik stellten die Verantwortlichen für die Landesentwicklung - und damit der Regionalentwicklung - vor große Aufgaben, für die sie bereits in den neunziger Jahren die heute noch gültigen und wirksamen gesetzlichen Grundlagen schufen. Aus den seit 1993 gesammelten Erfahrungen aus der Förderung gemeindeübergreifender Initiativen wurde im Jahr 1997 die Förderrichtlinie „Erstellung und Umsetzung Regionaler Entwicklungs- und Handlungskonzepte und Modellvorhaben der Raumordnung (FR-Regio)" erarbeitet, die die Förderung der Erarbeitung und Umsetzung von Regionalen Entwicklungskonzepten (REKs) regelt. Nach und nach entstanden aus diversen Förderinstrumenten (EUStrukturfonds, GAK, GRW) verschiedene Initiativen, die durch die im Folgenden dargestellte „Harmonisierung“ zu einem kohärenten und klar abgestuften, vor allem aber überschaubaren und steuerbaren Konzept zusammengeführt wurden.

Der Anstoß zur Koordination der Förderprogramme, die hier "Harmonisierung“ heißt, kam von den strengen Anforderungen nach Abgrenzung der Fördertatbestände und Gebietskulissen, die die ELER-Verordnung 1698/2005 an die programmverantwortlichen Behörden stellte. Die Entscheidungsträger in der sächsischen Regierung fragten sich, ob die strengen Abgrenzungserfordernisse nicht für alle Förderinstrumente in gleichem Maße gelten sollten. Und wenn schon passive Abgrenzung, warum dann nicht gleich aktive Integration? ${ }^{213}$ 
Die wesentlichen Akteure in der Harmonisierung sind die Staatskanzlei (in führender Rolle), das Kabinett (das die Regierungsbeschlüsse fasst), sowie die Interministerielle Arbeitsgruppe (IMAG) „Regionale Entwicklung“, in der die Staatskanzlei sowie die Staatsministerien für Inneres, für Wirtschaft und Arbeit, sowie für Umwelt und Landwirtschaft (SMUL) vertreten sind. Dem SMUL wurde die koordinierende Rolle in der Umsetzung der harmonisierten Förderpolitik übertragen.

Neben den fünf gesetzlich verordneten Planungsregionen gibt es die freiwilligen Zusammenschlüssen von Gebietskörperschaften und Partnern aus Wirtschaft und Gesellschaft, die für sich ein REK oder ein Integriertes Ländliches Entwicklungskonzept (ILEK) erarbeitet haben und entsprechende Förderung bekommen.

\section{Die Integration der Förderprogramme seit 2007}

\section{Gesamtstrategie}

Die gemeinsam (im Kabinett und in der IMAG) getroffenen und von der Staatskanzlei überwachten strategischen Festlegungen werden, was die Regionalentwicklung betrifft, vor allem von drei Fachministerien in konkrete Handlungen umgesetzt: vom Staatsministerium für Inneres, das für den Landesentwicklungsplan (2003) verantwortlich zeichnet, vom Staatsministerium für Wirtschaft und Arbeit, das die Mittel der Strukturfonds EFRE und ESF steuert, und vom Staatsministerium für Umwelt und Landwirtschaft (SMUL), das die Förderungen für den gesamten ländlichen Raum koordiniert (sowie die EU-Fonds ELER und EFF), der 83,5\% der Fläche des Freistaats umfasst und wo 48\% der Bevölkerung leben.

\section{Der Landesentwicklungsplan 2003 und das Prinzip der Harmonisierung}

Der Landesentwicklungsplan (LEP) 2003 hat zwei wichtige Impulse geliefert, die die Sächsische Regionalentwicklung entscheidend prägten:

- Das Prinzip der ressortübergreifende Strategien: die Vereinheitlichung der Förderinstrumente sowohl horizontal (ressortübergreifend) als auch vertikal (zwischen den territorialen Ebenen);

- Das Prinzip der Harmonisierung auf regionaler Ebene: die Verlagerung der Förderentscheidungen auf die regionale Ebene im Sinne des Subsidiaritätsprinzips. 
Im LEP 2003 wurde das Konzept der Zentralen Orte straffer ausdefiniert. Zentrale Orte gliedern sich nunmehr in drei Typen: Grund-, Mittel- und Oberzentren ${ }^{214}$. Neben den ordnungspolitischen Festlegungen fordert der LEP ausdrücklich eine prozess-, akteurs- und umsetzungsbezogene Planungskultur. Kooperation und Vernetzung wird als Partnerschaft von Stadt und Land verstanden. Der Erarbeitung des Landesentwicklungsplanes ging ein umfangreiches Beteiligungsverfahren, unter erstmaliger Einbeziehung der Öffentlichkeit mittels einer Reihe öffentlicher Veranstaltungen, voraus.

\section{Die harmonisierten regionalen Entwicklungsinstrumente}

\section{ILEKS und REKS}

Im Zuge der EU-Anforderungen an Abgrenzung und Synergien zwischen den Strukturfonds wollte die Staatskanzlei dies nicht nur inhaltlich (an einzelnen Maßnahmen) vorgenommen wissen. Vielmehr sollte auch eine strategische Abgrenzung unter der Vielzahl der in den verschiedenen Ministerien existierenden Planungsinstrumente vorgenommen werden. Dieser folgte dann die Selektion je eines strategischen Instruments für drei unterschiedliche territoriale Ebenen, und zwar: (i) Gemeinde, (ii) Kleinregion von 5.000 bis 150.000 Einwohnerlnnen und (iii) „Großregionen“ mit mehr als 150.000 EinwohnerInnen. ${ }^{215}$

Hinsichtlich der Unterscheidung zwischen ILEKs und REKs ist hier eine Begriffsklärung angebracht:

- Die integrierten ländlichen Entwicklungskonzepte (ILEKs) sind aufgrund der EU- und Bundesvorgaben auf Gebiete mit maximal 150.000 EinwohnerInnen begrenzt (wobei die ELER-Verordnung 1698/2005 der programmverantwortlichen Behörde das Recht zugesteht, begründete Ausnahmen zuzulassen, was auch in einem Fall in Sachsen gemacht wurde). Die Integration von Städten und die Zusammenarbeit zwischen Stadt und Land werden von den verantwortlichen Stellen ausdrücklich gewünscht.

- Räume, die höhere EinwohnerInnenzahlen umfassen - urbane oder urbanisierte Räume - waren in den vergangenen Jahren mit dem Instrument der GRW und Landesmitteln gefördert worden. Gebietskonzepte in diesen „Großregionen“ werden Regionalentwicklungskonzepte (REKs) genannt. REKs diesen Zuschnitts entstehen zumeist als branchenspezifische Wirtschafts- oder Tourismuskonzepte, werden aber zusehends anspruchsvoller bezüglich multisektoraler Vernetzung ${ }^{216}$. Die Wirtschaftskraft der betreffenden Regionen bedingt,

\footnotetext{
214 Plauen, Zwickau, Chemnitz, Dresden, Leipzig und der „oberzentrale Städteverbund Bautzen-GörlitzHoyerswerda".

${ }^{215}$ Die Metropolregion „Sachsendreieck“ (Der Raum zwischen Chemnitz-Zwickau, Dresden und Leipzig-Halle, der fünf der sechs Oberzentren umspannt), wird durch diese Einteilung nicht tangiert.

216 „Im Idealfall“, so Grieß, „bilden sie alles ab.“
} 
dass sie in der Regel keiner spezifischen Förderung - von Anschubfinanzierung abgesehen - bedürfen, um nach Konstituierung nachhaltig zu wirken. Sie schöpfen aus eigenen oder EU-Strukturfondsmittel, um ihre Projekte umzusetzen und können ihrerseits als Koordinierungsinstrument für ihre Teilregionen dienen.

Die ILE-Richtlinie als „Master-Richtlinie“

Die Abgrenzung und Abstufung der Gebietskulissen war, wie erwähnt, durch die Staatskanzlei initiiert und in der IMAG ausdiskutiert worden. Nach Beschluss einer entsprechenden Kabinettsvorlage wurde das Staatsministerium für Umwelt und Landwirtschaft mit der Planung dazu beauftragt. Die 2007 verabschiedete Richtlinie zur "Integrierten Ländlichen Entwicklung“ (ILE) ist als "Master-Richtlinie“ zu verstehen, die ressortübergreifende Prozesse regelt und alle anderen Förderrichtlinien des Freistaats betrifft, „sofern eine regionale Prioritätensetzung sinnvoll ist" ${ }^{217}$

So hat der Freistaat Sachsen die LEADER-Methode mittels ILE in die Regelförderung überführt, wie dies auch im GAK-Rahmenplan festgelegt ist; die Bedingungen zur Förderung unter LEADER sind in Artikel J der ILE-Richtlinie festgelegt. Das ILEK hat dieselbe Form und Funktion wie die in Achse 4 des ELER geforderte lokale Gebietsstrategie. Weiters ist laut ILE-Richtlinie eine Förderung nur noch möglich, wenn ein regionales Votum auf ILEK-Ebene, das heißt eine Willensbekundung durch die regionale Partnerschaft, vorliegt. Projekte werden nur dann gefördert, wenn sie regional vernetzt und relevant im Sinne der Gebietsstrategie sind. „Isolierte Projektförderung“ gehört hier der Vergangenheit an.

Diese Richtlinie vereint nahezu 50\% der ELER-Mittel in Sachsen. Die „Vorrangregel“ (d.h. Vorrang für Maßnahmen, die in ein ILEK eingebunden sind) gilt auch für alle anderen mit der ILE-Richtlinie "harmonisierten" Richtlinien. In diesen Richtlinien verweist jeweils ein Passus auf den „Fördervorrang“, der in der ILE-Richtlinie festegelegt ist. Somit ist Kohärenz im Vollzug gesichert. Dieser Akt der Dezentralisierung bringt in Sachsen alle relevanten Fördermittel, basierend auf derzeit 14 Landesrichtlinien aus 5 Fachressorts bei Einhaltung der einschlägigen Fachanforderungen unter einen - den regionalen - Hut.

${ }^{217}$ Richtlinie „Integrierte Ländliche Entwicklung“ (http://www.smul.sachsen.de/foerderung/85.htm) 
Das ILEK stellt in jedem Fall eine integrierte, regionale Entwicklungsstrategie dar, bei der die Förderung einzelner Projekte an ein regionales Votum gekoppelt ist. Die Finanzmittel der Strukturfonds (EFRE, ESF), des ELER, des EFF, der GAK und weitere Landesmittel werden in dieser Form regional gebündelt und eingesetzt.

\section{Abbildung 2: Aufbau und Inhalte eines regionalen Entwicklungskonzeptes}

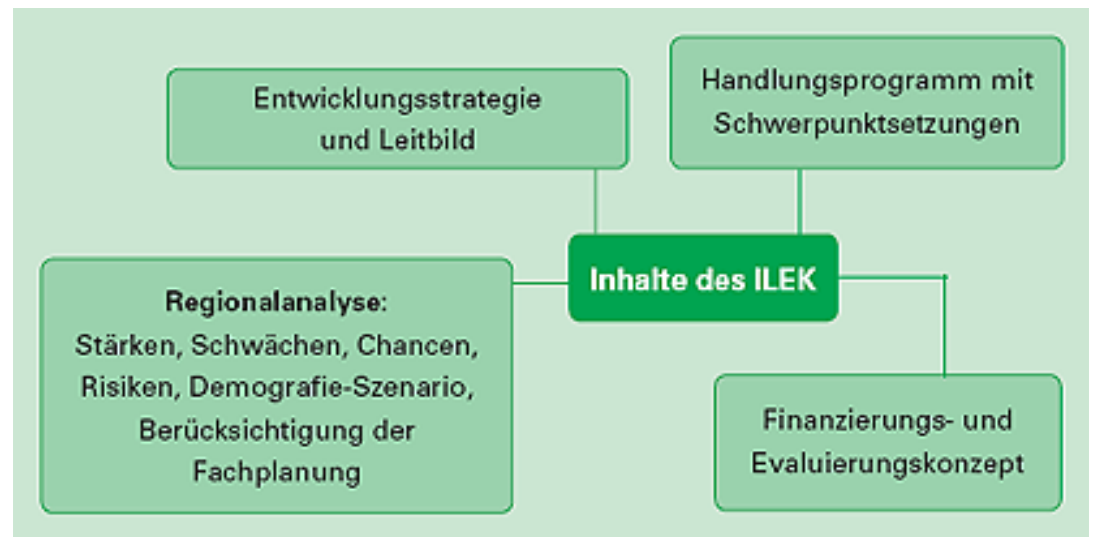

Quelle: Landesregierung Sachsen

Die detaillierte Ausarbeitung und Umsetzung des Masterplans zur Harmonisierung der Förderungen wurde bereits auf Regierungsebene - und das ist entscheidend in der IMAG „Regionale Entwicklung“ geleistet. Als Folge dieses Ansatzes ist in allen relevanten Richtlinien aller Ministerien ein Vorrang für Maßnahmen vorgesehen (das heißt: bevorzugte Beratung, sowie schnelle, bevorzugte Bewilligung und bis zu $10 \%$ höhere Fördersätze ${ }^{218}$ ), welche über das „strategische Instrument“ eines ILEK eingebunden sind. „Relevant“ heißt in diesem Zusammenhang, dass zusätzlich zu den fachlichen Anforderungen ein regionaler Mehrwert absehbar sein sollte. Denn wo der nicht möglich scheint, würde die Regionalisierung auch keinen Sinn machen.

\footnotetext{
${ }^{218}$ Durch den GAK-Rahmenplan ermöglicht.
} 


\section{Emergente Regionsbildung}

Gebiete, in denen sich die regionalen Akteure zu keiner regionalen Prioritätensetzung durchgerungen haben (die also kein REK oder ILEK vorgelegt haben), werden „Basis-Gebiete“ genannt. AntragstellerInnen in Basis-Gebieten werden entsprechend geringer gefördert. Wohlgemerkt sind all diese Formen des Zusammenschlusses freiwilliger Natur und beruhen auf entsprechenden Willensbildungen und Beschlüssen der beteiligten Gebietskörperschaften. Wegen der Freiwilligkeit war zu Beginn der Ausschreibung auch keinerlei Garantie gegeben, wie die Regionen das Angebot aufnehmen würden. Die Überraschung bei den Regierungsverantwortlichen war groß, als schließlich klar wurde, dass die bereits bestehenden und die neu entstehenden ILE- bzw. LEADER-Gruppen etwa 99\% des ländlichen Raumes abdecken würden - und das ohne Einmischung "von oben“ in Bezug auf Antragstellung oder wechselseitige Gebietsabgrenzungen. Es stellte sich heraus, dass sich - wie von „unsichtbarer Hand“ geleitet - alte Identitätsräume neu formierten. Die 150.000 Einwohner-Schwelle bildete dabei kein Hemmnis. Nur in einem Fall wurde sie leicht überschritten, was durch eine Ausnahmegenehmigung gelöst wurde.

\section{ILE und LEADER}

ILE-Regionen (ländliche Gebiete zwischen 10.000 und 150.000 Einwohner) sind nach einem einmaligen, mehrstufigen Antrags- und Auswahlprozess definiert worden, im Zuge dessen sie zwei Kategorien zugeordnet werden können:

- 22 ILE-Regionen, denen im Rahmen der ILE-Richtlinie mehr Förderbereiche und höhere Fördersätze (+5\%) zur Verfügung stehen und die vorrangig gefördert werden;

- 12 LEADER-Regionen, die als Regionen mit den zukunftsfähigsten Strategien ausgewählt wurden und mit noch höheren Fördersätzen (+10\%) unterstützt werden.

Das Verfahren zur Anerkennung als ILE- oder LEADER-Region ist durch das SMUL ausgeschrieben und bis Oktober 2007 abgeschlossen worden. Die verfügbaren Mittel sollten so verteilt werden, dass etwa ein Drittel der ILEK-Gebiete in den Genuss des LEADER-Programms kommen. Die unter LEADER förderfähigen Gebiete wurden mit 1/3 des ländlichen Raums begrenzt. In den Regionen, in denen weniger als 50\% der EinwohnerInnen dem ländlichen Raum zuordenbar sind, ist das Staatsministerium des Inneren für die Umsetzung der Förderungen zuständig.

Die Dezentralisierung war also mit einer Regionalisierung der Mittelzuteilung verbunden. Im Rahmen der ILE-Richtlinie wurden somit quasi regionale Budgets eingerichtet. In ILE- und LEADER-Gebieten entscheidet der Koordinierungskreis (KK) 
als zentrales Lenkungs- und Arbeitsgremium der LEADER-Aktionsgruppe bzw. des ILE-Fördervereins über die Mittelvergabe. Die formale Prüfung und Bewilligung von Anträgen wird nach einer jüngsten Verwaltungs- und Funktionalreform nicht mehr durch staatliche Ämter in den drei Regierungspräsidien abgewickelt, sondern den 13 Kreisämtern übertragen. Die Förderwürdigkeit hingegen wird durch das regionale Votum festgestellt.

\section{Abbildung 3: Anerkannte LEADER und ILE-Gebiete in Sachsen}

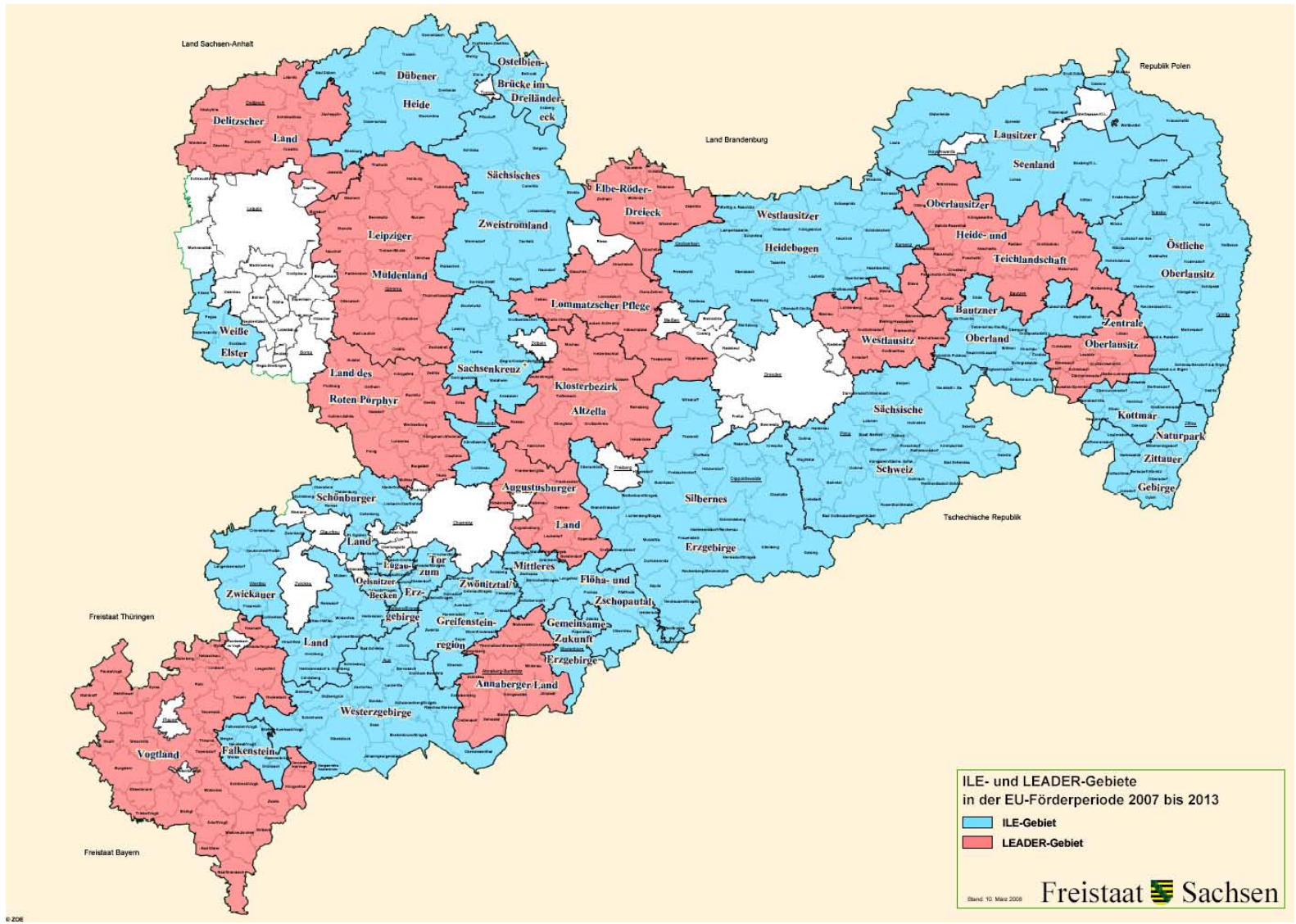

rot: LEADER; blau: ILE

Quelle: Landesregierung Sachsen 


\section{Validierung}

In der „Harmonisierung“ der Förderungen im Freistaat Sachsen finden sich einige Faktoren, die kreativ miteinander verknüpft wurden:

- Die Existenz einer starken zentralen koordinierenden Kraft in Form der Staatskanzlei, die auch in der IMAG Regionale Entwicklung mitwirkt und die entsprechenden Kabinettsbeschlüsse strategisch vorbereitet und trägt. Sie ist geprägt durch ein Selbstverständnis von "gestaltender Verwaltung“ und durch die Erfahrung im Umgang mit großen Volumina an unterschiedlichen Fördermitteln seit der Wende und der Vereinigung mit der Bundesrepublik.

- Die Vorgaben der EU-Fonds in Bezug auf Kohärenz, Komplementarität und die Schaffung größtmöglicher Synergien in Zeiten relativ geringer werdender Fördermittel.

- Der in vollem Schwung befindliche Prozess der Verwaltungsreform und Dezentralisierung, der auch eine Neuausrichtung der Förderadministration unabdingbar machte, als temporäre Rahmenbedingung („window of opportunity“).

- Der Erfahrungsschatz, den regionale Akteure und Beamte der programmverantwortlichen Behörden und Bewilligungsstellen mit partnerschaftlichen und gebietsorientierten Instrumenten der EU (LEADER), des Bundes (GAK/ILE, Regionen Aktiv) und des Landes (Regionalmanagements) gesammelt haben und zu nutzen wussten.

Trotz ihrer komplexen Struktur stellt die Harmonisierung eine Vereinfachung gegenüber früheren Förderstrukturen dar, weil in ihr drei Ordnungskriterien zusammenwirken:

- Eine genau definierte vertikale Abstufung und Abgrenzung der Förderinstrumente (von der Großregion über die ILE-Region bis zur Gemeinde);

- eine horizontale Bündelung der Förderungen unter die formalen Kriterien einer Master-Richtlinie (der ILE-Richtlinie) mit entsprechender Koordinierungskompetenz der programmverantwortlichen Behörde (SMUL);

- eine Abgrenzung der strategischen Entwicklungsschwerpunkte und der dazugehörigen Gebietskulisse durch ein Anreizsystem der freiwilligen Gebietszusammenschlüsse.

Hier scheint es gelungen zu sein, die Integrations- und Koordinationsmacht der Staatsregierung bei gleichzeitig dezentralisierten Entscheidungsbefugnissen nicht nur intakt zu halten, sondern auch im Sinne effektiver und demokratischer Fördergebarung zur Wirkung zu bringen. 


\subsubsection{Koordination auf der Ebene der Programmumsetzung: Das Beispiel Tirol}

\section{Hintergrund}

Das österreichische Bundesland Tirol nimmt mit etwa $12.648 \mathrm{~km} 2 \mathrm{ca}$. zwei Drittel der Fläche von Sachsen ein, hat aber mit knapp über 700.000 Einwohnerlnnen nur ein Sechstel seiner Einwohnerzahl. Die Bevölkerungsdichte $\left(55 \mathrm{Ew} . / \mathrm{km}^{2}\right)$ ist im Vergleich noch geringer als die von Mecklenburg-Vorpommern, aber aus anderen Gründen, nämlich aufgrund der inneralpinen Lage. Die eigentlichen Siedlungsräume, die Täler und die begleitenden Terrassen, sind dicht besiedelt (469 EW/ $/ \mathrm{km}^{2}$ Dauersiedlungsraum) und geben ob der auftretenden Nutzungskonflikte den Raumplanerlnnen schwierige Nüsse zu knacken. Das gesamte Inntal von Landeck bis Kufstein - von wenigen Zwischenräumen abgesehen - bildet einen Verdichtungsraum, in dem Stadt und Land teilweise zu einer „Talstadt" verschmelzen. Hinzu kommen die großen Tourismuszentren in den Seitentälern. Es gibt aber auch entlegenere Landesteile mit geringerer Entwicklungsdynamik, wie z.B. Osttirol (Hauptort Lienz). Die großen Herausforderungen, die das Gebirgs-, Transit- und Tourismusland an die Raumordnung stellt, haben in Politik und Landesverwaltung ein hohes Bewusstsein über die Verantwortung in diesem Bereich wachsen lassen, das sich in einer kompetenten und mit den entsprechenden Ressourcen ausgestatteten Abteilung Raumordnung-Statistik niederschlägt, in der auch die Steuerungsfunktionen für die Raumentwicklung und die entsprechenden regionalen Strukturen angesiedelt sind ${ }^{219}$.

Vor dem Hintergrund der herannahenden Förderperiode 2007-2013 entschloss sich die Tiroler Landesregierung im Jahr 2004, eine Evaluierung der Steuerungsstrukturen für regionale Entwicklung in Auftrag zu geben. Gegenstand der Evaluierung war die Tätigkeit und Wirkungsweise aller damals 11 Regionalvereine des Bundeslandes Tirols. Dazu zählten drei Regionalmanagements, die für Regionalentwicklungsverbände tätig waren, fünf lokale Aktionsgruppen der Gemeinschaftsinitiative LEADER+ und drei EUREGIOs, das heißt die österreichischen Teilzusammenschlüsse der grenzüberschreitenden Strukturen. Die 11 Regionalvereine waren im Laufe der Zeit entstanden, teils basierend auf nationalen Entwicklungen (wie die Regionalmanagements) oder in Reaktion auf europäische Förderprogramme (LEADER, INTERREG).

\footnotetext{
${ }^{219}$ Bis heute sind trotz der Einbettung von Leader in die ländliche Entwicklung, die Kompetenzen für Leader (ELER-Achse 4) in dieser Abteilung geblieben. In allen anderen österreichischen Bundesländern haben diese Kompetenzen immer schon die Agrarabteilungen innegehabt oder sind spätestens seit 2007 dorthin gewandert.
} 
Als Ergebnis der erwähnten Evaluierung wurde ein breit angelegter Diskussionsprozess geführt, der in ein neues Modell mündete, mit dem die regionalen Steuerungsstrukturen vereinheitlicht und die Förderprogramme gebündelt werden sollten. Dieses Modell existiert seit 2006 und heißt „Konzept zur Weiterentwicklung der Regionalmanagement-Strukturen in Tirol“. Seinerseits wurde dieses Konzept in die 2007 fertig gestellte Landesentwicklungsstrategie ZukunftsRaum Tirol eingebettet. Damit wurden die freiwilligen und keineswegs flächendeckend konzipierten Regionalentwicklungsverbände mit den flächendeckend an administrativen Einheiten orientierten Planungsverbänden und den bedeutsamen Tourismusverbänden in Beziehung gebracht.

Die politische Verantwortung für die EU-kofinanzierten Regionalförderungen und damit auch für die regionalen Umsetzungsstrukturen liegt unmittelbar beim Landeshauptmann („Chef“ der Tiroler Landesregierung); zudem kommen dem für die Raumordnung zuständigen Regierungsmitglied wesentliche Aufgaben in diesem Kontext zu. Der aktive Gestaltungs- und Umsetzungswille der politisch Verantwortlichen war und ist die Grundvoraussetzung für die Entwicklung und den Erfolg des Tiroler Modells der Regionalentwicklung.

Die Koordination auf Landesebene konzentriert sich in der Abteilung Raumordnung-Statistik, einer von mehreren Abteilungen der „Gruppe Wirtschaft, Gemeinden und Finanzen" des Amtes der Tiroler Landesregierung und zuständig für Regionalentwicklung, Raumordnung und Informationswesen (einschließlich der Landesstatistik). Ihre zentralen Steuerungsaufgaben des Landes bestehen in Leitungsaufgaben, Netzwerkaufgaben (teilweise extern beauftragt) und in der Betreuung von Gebieten, die keine eigene Regionalmanagement-Einrichtungen haben. Die Koordination mit der ländlichen Entwicklung erfolgt gemeinsam mit der Gruppe „Agrar" des Amtes der Tiroler Landesregierung, die für alle Förderungen im Rahmen der Gemeinsamen Agrarpolitik (1. Säule und Achsen 1 bis 3 der zweiten Säule) zuständig ist. Weitere Bereiche, mit denen starker Koordinationsbedarf besteht (z.B. Tourismus, Finanzen, Wirtschaft und Arbeit) sind in derselben Gruppe angesiedelt, oder wie etwa der Straßenbau, die Verkehrsplanung und der Umweltschutz in anderen der insgesamt acht Gruppen. Für die formale Koordination (z.B. zwischen Gruppen/Fachabteilungen und Bezirkshauptmannschaften) ist die Landesamtsdirektion (LAD) zuständig. 
Die wichtigsten Säulen der Regionalentwicklung bilden die RMs, die

- in regionale Trägervereine (privat-öffentliche Partnerschaften auf freiwilliger Basis) eingebettet sind;

- nach Zusammenführung der bisherigen unterschiedlichen Grundtypen (RM, Leader, Euregio) einem einzigen konsistenten Strukturmodell folgen, das alle relevanten Bereiche überschneidungsfrei abdeckt;

- EU-Strukturfondsprogramme und die ländliche Entwicklung (ELER) strukturell und inhaltlich zusammenführen, wobei auf Landesebene eine laufende Abstimmung zwischen der Raumordnungs- und Agrarabteilung erfolgt;

- sich verpflichtend der Leader-Methode (strategische Fundierung der Projekte, innovativer Gehalt, Übertragbarkeit, Zusammenarbeit) ${ }^{220}$ zu befleißigen haben.

Die RMs sollen vier Hauptfunktionen erfüllen: Akteursvernetzung, Strategieentwicklung, Projektentwicklung bzw. -begleitung sowie Dienstleistungen: für regionale Planungsverbände, Gemeinden und sonstige Projektträger bei regional bedeutsamen Projekten. Es existieren klare Schnittstellen und Kooperationsvorgaben zwischen den Regionalentwicklungseinrichtungen und anderen regionalen Einrichtungen, vor allem solchen, für die ein Regelungs- oder Steuerungsanspruch des Landes besteht. Dazu zählen vor allem die 36 Regionale Planungsverbände und Tourismusverbände (verpflichtend laut Tiroler Raumordnungs- ${ }^{221}$ bzw. Tourismusgesetz und Schutzgebietsbetreuungen (für die eine landesweite Schutzgebietsplattform geschaffen wurde). Dazu kommen lokale/regionale Agenda 21Gruppierungen, regionale Impuls- und Kompetenzzentren und die Bezirksorganisationen der Interessenvertretungen (Sozialpartner).

Die laufende fachliche Betreuung der Planungsverbände erfolgt durch die räumlich zuständigen Sachverständigen für Örtliche Raumordnung der Abteilung Raumordnung-Statistik. Das Regionalmanagement steht dort, wo ein solches besteht, den Planungsverbänden in bestimmten Fragen (Leitbildentwicklung, Standortentwicklung...) zur Seite. Um eine optimale Vernetzung zu gewährleisten, ist auch verpflichtend vorgeschrieben, dass die Obleute der Planungsverbände in den Vorständen der dort wirkenden Regionalmanagements sitzen.

Gebiete, in denen keine Regionalmanagements tätig sind - in der Regel ressourcenstarke Gebiete - müssen die entsprechenden Beratungsleistungen zu Marktbedingungen vergeben und können, wie alle Planungsverbände, auch auf die Unterstützung der Landesverwaltung zählen.

\footnotetext{
${ }^{220}$ In der Erläuterung zur LEADER-Methode wird explizit nicht „bottom-up“ genannt, das sonst primär mit dieser Methode in Verbindung gebracht wird, allerdings wird die Verknüpfung von top-down und bottom-up ausführlich in dem Konzeptdokument erläutert (Amt der Tiroler Landesregierung (2006))

${ }^{221}$ In innen sind 278 Gemeinden Tirols (ohne Innsbruck) zum Zweck der gemeindeübergreifenden Planung und Zusammenarbeit vereint. Zusätzlich gibt es den Stadtregions-Planungsverband Innsbruck und Umgebung, der sich seinerseits aus der Landeshauptstadt und sechs Planungsverbänden des Umlandes zusammensetzt.
} 


\section{Die Integration der Förderprogramme}

Die Abteilung Raumordnung-Statistik steuert als programmverantwortliche Stelle und teilweise auch als Förderstelle den Fördermittelfluss aus vier EUkofinanzierten Programmen, wodurch eine optimale Abstimmung und gegenseitige Ergänzung der Programme gewährleistet ist. Insgesamt koordiniert die Abteilung Raumordnung-Statistik für die EU-Strukturfonds in Bezug auf die genannten Programme vier Kofinanzierungs-Förderstellen des Bundes und zumindest sechs des Landes, fungiert zusätzlich als programmverantwortliche Landesstelle für die LEADER-Achse und ist selbst Förderstelle für INTERREG und Teile von LEADER. Auf Regionsebene haben sich acht Regionalvereine konstituiert, die auch als lokale Aktionsgruppen gemäß Leader anerkannt wurden. Da die im Grunde freiwillig, also bottom-up, konstituierten Regionalvereine und ihre Regionalmanagements bestimmten Qualitätskriterien unterworfen sind, um als solche anerkannt zu werden, haben die Landesbeamten bzw. der Servicebeauftragte vor allem neue Gruppierungen in ihrer Aufbauphase gecoacht, um sie an die Qualitätsvorgaben der LEADER-Methode und an die mit dezentraler Steuerung im Rahmen der regionalen Governance verbundenen Aufgaben heranzuführen.

Die Finanzierung der RM-Einrichtungen gliedert sich in Basisfinanzierung und Projektfinanzierung. Die Basisfinanzierung dient der Deckung der Personal- und Bürokosten und ermöglicht ein Tätigwerden der RM im strategischen Bereich bzw. die Besorgung von Aufgaben im gemeinsamen „öffentlichen“ Interesse, die nicht über Projekterlöse finanziert werden können. Die Basisfinanzierung erfolgt durch Eigenmittel (Mitgliedsbeiträge der Vereinsmitglieder, vor allem der Gemeinden), Landesbudgetmittel und EU-Kofinanzierungen (Interreg, Leader-Achse des ELER $^{222}$ ).

Monitoring und Evaluierung erfolgen zweistufig, zunächst in Eigenverantwortung der einzelnen Organisationen und weiters im Rahmen der Wahrnehmung der Steuerungsfunktion durch das Land.

${ }^{222}$ Deren finanzielle Abwicklung obliegt der Agrarabteilung („Gruppe Agrar“). 


\section{Validierung}

Die Koordination der Förderprogramme im Land Tirol bot den für Raumordnung und Regionalentwicklung zuständigen Stellen Gelegenheit, ein mehrstufiges Governance-Modell zu implementieren, das in hohem Maße die Vorteile dezentraler, gebietsbezogener Förderzuschnitte mit denen zentraler Gesamtsteuerung verbindet, ohne die mit dem jeweils einen oder anderen verbundenen Nachteile „einzukaufen“. Angesichts der sehr kleinteiligen Gemeindestruktur in Tirol ist dabei die Stärkung der regionalen Ebene (mit Regionalmanagements ausgestattete LEADER-Regionen und Planungsverbände) von zentraler Bedeutung, wobei die Gemeinden als aktive (Mit-)Träger dieser Strukturen in Erscheinung treten. Nicht minder wichtig sind die koordinierte Besorgung der einschlägigen Aufgaben auf Landesebene und die Verknüpfung der Aktivitätsebenen Land - Region - Gemeinde in einem gut funktionierenden Netzwerk, das die positiven Effekte von Bottomup-Initiativen mit Top-down Impulsen verbindet. Die Orientierung an abgestimmten strategischen Grundlagen (die Landesstrategie ZukunftsRaum Tirol, einschlägige Förderprogramme auf Landesebene, regionale Strategiepläne der LEADER Regionen) schafft hierfür eine gemeinsame Basis. Letztlich „lebt“ dieses System von den Schlüsselakteuren, die es entwickeln und betreiben.

Die Freiwilligkeit des regionalen Zusammenschluss muss hier als wesentliches Element zur Verankerung des bottom-up-Ansatzes betrachtet weden (,regionale Eigenverantwortung“). Das Land versteht sich dabei als Unterstützer des „regionalen Systemaufbaus“, als Mitgestalter in den Netzwerken regionalpolitischer Akteure und als Instanz, die das Gesamtsystem steuert. Die freiwilligen Zusammenschlüsse werden durch Regierungsbeschluss zu Umsetzungspartnern, die klaren Zielvorgaben und Erfolgskriterien zu entsprechen haben. Die Leader-Methode wird als „Fertigteil“ in das Governance-Instrumentarium eingebaut.

Bleibt die Frage zu klären, wie eine unscheinbare Abteilung der Landesverwaltung sich zu einer koordinierenden Rolle im Steuerungssystem für die gesamte regionale Entwicklung aufschwingen konnte. Um das zu verstehen, gibt der historische Entwicklungsprozess Aufschluss. In Tirol sind Raumordnung und Regionalentwicklung bereits seit 1972 (erstmaliges Inkrafttreten des Tiroler Raumordnungsgesetzes) eng miteinander verknüpft, da dies vom damaligen Landeshauptmann so gewollt wurde. Die damalige Landesplanung und heutige Abteilung RaumordnungStatistik war daher stets auch mit regionalwirtschaftlichen Planungen und Prozessen befasst. Das in der Abteilung vorhandene Know-how führte dazu, dass die Abteilung im Vorfeld des österreichischen EU-Beitritts mit der Programmierung für die Programme 1995 -1999 beauftragt wurde. Zugleich hatte sie bereits seit Anfang der 90er Jahre aus Eigeninitiative mit Billigung der Politik die Entwicklung der Regionalmanagements in Gang gesetzt. 
Diese Aufgabenzuweisung war eine wichtige Weichenstellung für die künftige Entwicklung. In der ersten Programmperiode war die Umsetzungskoordination der Programme noch schwierig gewesen, da Erfahrungen mit solchen Instrumenten fehlten und erst das Vertrauen für kompetenzübergreifende Koordinierungen entwickelt werden musste. ${ }^{223} \mathrm{Im}$ Lauf der Jahre ist es gelungen, dieses Vertrauen Schritt für Schritt aufzubauen, wobei den verantwortlichen Beamten ihre Erfahrung in der Raumordnung geholfen hat: Integrierte Sichtweisen und der Umgang mit divergierenden Interessen sind ein Kernbestandteil ihrer Arbeit.

Zusammenfassend können als Erfolgsfaktoren festhalten werden:

- Die Output-Legitimation, die darin besteht, den sektoralen Akteuren Reibungsverluste und politische Querelen zu ersparen, indem die Abteilung dafür sorgt, Koordination auf eine sachlich-technische Ebene und vor allem dorthin zu verlagern, wo die jeweilige Aufgabe am besten gelöst werden kann. ${ }^{224}$

- Die Vernetzungsdichte, die auch dadurch hergestellt wird, dass die Landesstatistik, und das geografische Informationssystem in dieser Abteilung verknüpft werden.

- Die handelnden Personen bilden ein gut eingespieltes und solides Team, das bereits über mehrere Förderperioden an dieser Stelle wirkt. Die informellen Vernetzungszusammenhänge und „gutes persönliches Einvernehmen“ sind im Land Tirol wohl noch bedeutsamer als die formalen Strukturen. Die Interventionen der Landesbehörde sind von der Haltung der „Allparteilichkeit“ geprägt.

\footnotetext{
223 "Starke Regionen bedeuten starkes Land....aber....es hat eine Menge Zeit gebraucht, bis der Nutzen des Systems richtig herauskam." (Rauter).

${ }^{224}$ Der Verantwortliche beschreibt das mit den Worten: „Wir stiften allen Nutzen.“ (Rauter). Ein Beispiel für eine „allparteiliche“ Haltung.
} 


\section{Schlussfolgerungen}

Zunächst lässt sich festhalten, dass nur sehr wenige systematische Ansätze einer Koordination der Förderpolitik beobachtet werden konnten. Punktuelle Ansätze und Mechanismen sind wohl vereinzelt und ad-hoc auszumachen. Sie folgen keinem Masterplan zur Integration der Förderziele. Ausnahmen bilden hier die landesweiten Strategien aus Mecklenburg-Vorpommern und Sachsen-Anhalt, sowie der Harmonisierungsansatz in Sachsen.

Als eine zentrale Schlussfolgerung aus den Ergebnissen lässt sich daher festhalten, dass eine Organisation sich erst dann inhaltsreich mit anderen koordiniert und somit einen realen Verlust an Autonomie hinnimmt bzw. riskiert -, wenn sie dies tun muss (aufgrund des Problemdrucks, durch Budgetknappheit, zwingende Vorgaben oder viel versprechende Chancen bei Kooperation). Das Autonomiestreben der Organisationen und ihrer Teile steht solchen Bemühungen grundsätzlich entgegen. Diese Hypothese lässt sich auch auf EU-Ebene belegen, wo das Monofondsprinzip und dessen strikte Auslegung eine frühzeitige Koordination behindern.

Jedoch konnten innerhalb eines Bundeslandes gleichgerichtete Interessen der einzelnen Organisationen (Häuser) gegenüber der EU-Kommission identifiziert werden, auf deren Basis und hervorgerufen durch hohen Problemdruck ein übergeordnetes „Landesinteresse“ Gestalt annehmen kann. Hier kommt der hochrangigen Beauftragung (durch Ministerpräsidenten, Kabinett oder Staatskanzlei) eine zentrale Rolle zu, da dadurch die gesamte Hierarchie entsprechend auf Linie gebracht werden kann. Die oben genannten Landesstrategien stellen einen solchen Ansatz dar, variieren aber in ihrer Reichweite. Definitive Ergebnisse dieser Koordinationsbemühungen im Sinne einer vollständigen vertikalen Politikintegration (d.h. durch den gesamten Apparat des Programmvollzugs) waren jedoch noch nicht zu beobachten, da diese Bemühungen überwiegend auf die Anforderungen der EU-Programmplanung 2007 bis 2013 zurück zu führen sind und sich erst etablieren müssen.

Als zentraler Akteur tritt dabei die Staatskanzlei in Erscheinung (auch im umgekehrten Sinne, um eine solche Koordination durch De-Thematisierung bzw. Nichtentscheid zu verhindern). Hier war ein deutlicher Unterschied zwischen west- und ostdeutschen Staatskanzleien zu beobachten. Bei gleichem Aufbau kann man im zweiten Fall davon ausgehen, dass der Transformationsprozess nach 1990 besonders in Politikfeldern wie Regional- und EU-Politik noch nicht abgeschlossen ist (Häußer 1995: 232-4). Um diesen Wandel zu bewältigen „obliegt ihr zwingend eine zentrale Steuerungsfunktion“, aus der heraus sich ein sich fortsetzendes zentralistisches Selbstverständnis ergeben hat, welches die oben genannten Ko- 
ordinationsanstrengungen begünstigt. Ein solches Vorgehen, die Koordination der Förderung zentral zu steuern bedeutet aber zugleich und automatisch auch die Ausrichtung der Förderung auf die partikulären Ziele und Interessen der begünstigten Organisationseinheit. Gestützt wird diese Erkenntnis durch die Tatsache, dass es einen negativ korrelierten Zusammenhang zwischen inhaltlicher Nähe von Förderprogrammen und deren Abstimmung aufeinander zu geben scheint. Eine unserer Hypothesen zu Anfang der Analyse war, dass Programme innerhalb eines Politiksektors (z.B. Landwirtschaft) eher und intensiver miteinander koordiniert werden, als mit sektorfremden Instrumenten. Die Ergebnisse zeigen jedoch, dass nicht die sektoralen Charakteristika (also inhaltliche Nähe der Förderung) eine Koordination bewirken, sondern diese vielmehr zwischen den verschiedenen Strukturfonds und dem ELER auftritt. Dies ist alleine auf die starken finanziellen Anreize der EU, ihrem Programmplanungsverfahren Folge zu leisten, zurückzuführen.

Auf regionaler Ebene allein ist eine weitreichende Koordination nicht zu erreichen, da hier lediglich die Implementierung des Förderrahmens vorgenommen wird. Der Begriff der regionalen Koordination besagt in unserem Kontext lediglich, dass bzw. wie man sich mit diesem Rahmen mit dem Ziel der Nutzenmaximierung aus Fördermitteln arrangiert. Dafür benötigen regionale Akteure Kenntnisse (Informationen) und Fertigkeiten (Netzwerke, etc.) zu je verschiedenen Fördermöglichkeiten. Die integrierten Modellvorhaben stellten dafür die Ressourcen des Regionalmanagements und des Abwicklungspartners zur Verfügung. Zwar werden diese Ressourcen nun auch in vielen Mainstream-Programmen gefördert, deren strategische Koordination und Abstimmung aufeinander ist jedoch selten (Ausnahme: Sachsen). Folglich stehen für potenzielle Antragsteller zumeist keine Beratungsstrukturen zu themen bzw. sektorübergreifender Förderung wie das Regionalmanagement in „Regionen Aktiv“ zur Verfügung..

Die Ergebnisse zeigen auf, dass in den verschiedenen Regionen und Bundesländern eine Vielzahl verschiedener Koordinationsmechanismen zum Einsatz kommt. Betrachtet man jedoch lediglich die zentralen und eigentlich wirksamen Mechanismen, so lässt sich zwischen Ländern unterscheiden, die eine hochrangige übergeordnete strategischen Zielvorgabe (wie die „Harmonisierung“ der Programme in Sachsen) durchgesetzt haben und solchen, die dies nicht tun. Unter den Ländern, die eine solche Strategie verfolgen, stellt die in MecklenburgVorpommern gewählte Variante das stärkste Maß an zentraler Intervention dar. Wie bereits erwähnt, geht diese Art der zentralisierten Koordination mit der Verengung der Förderung auf die partikulären Ziele und Interessen der begünstigten Organisationseinheit einher. 
Die beiden Beispiele guter Praxis zeigen hingegen, dass hochkomplexe Steuerungsleistungen möglich sind, die horizontale Koordination von Förderprogrammen und dezentralisierte Entscheidungsabläufe miteinander in Einklang bringen, und zur Zufriedenheit der Akteure funktionieren. In beiden Beispielen

- verzichtet der Staat teilweise darauf, exekutive Macht auszuüben, um den Selbstorganisationskräften der Zivilgesellschaft Raum zu geben;

- werden bestehende Förderinstrumente, namentlich der europäischen Ebene, kreativ und sinnvoll genutzt, um die eigenen Strukturen zu verbessern.

- tritt die Bedeutung des Sozialkapitals (das Produkt aus Vernetzungsdichte und der Fähigkeit, zu vertrauen) klar hervor;

Natürlich ist auch zu bedenken,

- dass alte und neue Strukturen oft im Widerstreit zueinander stehen, woraus Reibungsverluste resultieren (fachspezifische vs. sektorübergreifende Perspektive);

- mit neuen Instrumenten (z.B. der EU) auch neue Restriktionen mit eingekauft werden (z.B. der überbordende Kontrollapparat);

- dass die langfristigen Umsetzungsergebnisse zeigen müssen, dass sich der Umbau auszahlt.

In dem Maße, in dem Regionen neue Bedeutung im globalen Kontext erlangen ob als politisch-institutionell definiertes Territorium, als ökonomisches Wirkungsgefüge oder als soziales Konstrukt - wird die Verantwortungsübernahme durch die Zivilgesellschaft, die mit den Begriffen Subsidiarität, Dezentralisierung und Devolution verbunden sind, zu einem Schlüsselthema der Weiterentwicklung von gesellschaftlicher Steuerung und Demokratie. In diesem Sinne sind Regionen die Grundbausteine und Laboratorien der Weltgesellschaft. 


\section{Handlungsempfehlungen}

Um die Politikintegration im Bereich der Förderpolitik mit dem Ziel der ländlichen Entwicklung voranzutreiben, ergeben sich aus den hier präsentierten theoretischen Überlegungen sowie den Ergebnissen und Schlussfolgerungen einige zentrale Handlungsempfehlungen. Diese richten sich an alle Politikgestalter auf EU-, Bundes-, Landes- und Regionsebene, die durch integrierte Politik- und Förderansätze zur Lösung komplexer Problemlagen im ländlichen Raum beitragen möchten. Dabei betrachten wir Politikintegration keineswegs als Selbstzweck. Vielmehr schlagen wir eine Betrachtungsweise vor, die die Förderung von Entwicklungsansätzen im ländlichen Raum in den Mittelpunkt stellt. In Anlehnung an den gängigen Begriff der Umweltpolitikintegration geht es hier also um Politikintegration für ländliche Entwicklung. Da sich Organisationen wie Ministerien aus den oben genannten strukturellen Ursachen schwer tun, sich inhaltsreich mit anderen Organisationen zu koordinieren, sehen wir im Hinblick auf die Politikintegration für ländliche Entwicklung folgende Aspekte als besonders bedeutsam:

Problem- bzw. Finanzdruck unterstützen Politikintegration: Wird der Problemdruck (z.B. Arbeitslosigkeit in manchen ostdeutschen Regionen; oder Reduktion der Finanzmittel aus der Gemeinsamen Agrarpolitik) in der öffentlichen und politischen Wahrnehmung besonders groß, werden verschiedene Politikinstrumente, die zunächst anderen Zielen gedient haben, auf eben diese Probleme hin ausgerichtet. Da die entsprechenden Problemlagen weder gewünscht noch geplant werden, lassen sich hierfür auch keine weiteren Empfehlungen aussprechen.

Verpflichtungsfähigkeit bzw. hochrangige Beauftragung sind wichtigstes Mittel: Um verschiedene Förderprogramme und -politiken aufeinander abzustimmen, bedarf es eines strategischen und zentral koordinierten Vorgehens. Dieses lässt sich in der Hierarchie öffentlicher Verwaltungen lediglich durch Anordnung von höherer Stelle gewährleisten. Letztlich kommt der hochrangigen Beauftragung zur Koordination von Förderpolitik wohl die zentralste Rolle zu. Diese kann durch Parlamente, das Kabinett oder den Ministerpräsidenten angeregt werden, wobei deren politische Reichweiten differieren dürften. Da die meisten (zumindest die westdeutschen) Staatskanzleien eine eher passive Rolle in der Koordination der Förderpolitik zu spielen scheinen, lassen sich hier Handlungsspielräume identifizieren, um eine Integration voranzutreiben. Eine aktive, koordinierende Rolle der Staatskanzlei in strategischen Fragen bei gleichzeitigem Verbleib aller inhaltichen Kompetenzen bei den Häusern scheint hier am ehesten Erfolg zu versprechen. Das Beispiel der Harmonisierung der Planungsinstrumente in Sachsen kann hier 
als Modell mit moderatem Interventionscharakter gesehen werden. Grundsätzliche Überlegungen, die hinter diesem Vorgehen stehen, ließen sich im Sinne einer Politikintegration für ländliche Räume auch andernorts umsetzen. Ein intensiverer Ansatz, dieses Ziel zu verfolgen, stellen die sog. (fondsübergreifenden) Landesstrategien zur Fördermittelverwendung dar. Hier sei empfohlen, nicht symbolische Ansätze wie in Schleswig-Holstein, sondern eine inhaltsreiche Koordination der Förderpolitik zu verfolgen. Beispiele hierfür liefern u.a. die Bundesländer Mecklenburg-Vorpommern und Sachsen-Anhalt. Zu bedenken bleibt hier, dass solche Landesstrategien im Hinblick auf eine effektive Koordination nur dann Erfolg versprechend sind, wenn der Vollzug der Landesstrategien durch alle Politiksektoren hindurch vertikal gewährleistet werden kann. Dem Monitoring solcher Interventionen kommt hier eine zentrale Rolle zu.

Monitoring der Kooperation, um vertikale Integration zu gewährleisten: Um die Politikintegration auf oberer Eben nicht nur zu formulieren, sondern deren Vollzug im Mehrebenenspiel auch zu gewährleisten, werden Kontrollmechanismen etabliert, wie zum Beispiel die Berichtspflicht für entsprechende Maßnahmen. Berichtspflichten und andere Kontrollmechanismen für Politikintegration konnten zum jetzigen Zeitpunkt zwar noch nicht beobachtet werden; sie sollten jedoch Gegenstand künftiger Diskussionen und Analysen sein. Wir empfehlen deren Einrichtung im Zuge einer strategischen Abstimmung von Förderprogrammen, um die konsistente Bündelung der Förderangebote für ländliche Räume aus unterschiedlichen Programmen bzw. durch unterschiedliche Verwaltungen voranzutreiben.

Anreize zur Kooperation I Integration schaffen und nutzen: Um Kooperationsbarrieren abzubauen, braucht es neben formalen Weisungen auch Anreize. Ein gutes Beispiel dafür ist die Kopplung großer Fördersummen an inhaltliche und organisatorische Qualitätsanforderungen für die Programmplanung, wie das bei den Strukturfonds und dem ELER der Fall ist. Einschränkend sei zu bemerken, dass in Verhandlungssystemen wie dem GAK-Regime die Politikverflechtung das zentrale Setzen von Anreizen in eine bestimmte Richtung erschwert. Trotzdem sollte man sich bemühen, solche zu schaffen, um den Preis der Kooperation zu reduzieren. Das Beispiel der EU-Programmplanung zeigt auf der einen Seite, dass Anreize günstig auf die Koordinationsleistung einwirken. Andererseits wirkt die gängige Interpretation des Monofondsprinzips dieser Errungenschaft entgegen. Daher sei Bund und Ländern empfohlen, ihre Interpretationen des Monofondsprinzips offensiv in Richtung einer integrierten, fondsübergreifenden Programmierung und Mittelverwendung weiter zu entwickeln. Dabei sollten alle Häuser eines Landes das Monofondsprinzips gleichsinnig interpretieren und zum Gegenstand von Verhandlungen mit Bund und EU machen. 
Bestehende Ansätze der Dezentralisierung nutzbar machen: Im Sinne des europäischen „Good Governance“-Prinzips kommen Subsidiarität, Dekonzentration, Dezentralisierung oder Devolution immer wieder auf die politische Agenda. Diese Reformbemühungen können von Förderverwaltungen zum Anlass genommen werden, das Mehrebenensystem der Politikgestaltung und -umsetzung in ihrem Bereich weiter zu verbessern. Es gibt gute Beispiele, dass Politikkoordination, die auf höchster Ebene gewollt und organisiert ist, bis auf die regionale Ebene "hinunter" orchestriert werden kann und dabei den Regionen ein großes Maß an Gestaltungsspielraum und Verantwortungsübernahme bleibt. Neben den beschriebenen Beispielen guter Praxis können wir auch auf andere Beispiele aus der ländlichen Entwicklung verweisen (LEADER in Irland, bzw. die aus verschiedenen Quellen finanzierten lokalen Aktionsgruppen in einigen spanischen Regionen oder Finnland). Voraussetzung dafür ist eine ermöglichende, unterstützende Rolle der zentralen Verwaltung und ihrer regionalen Behörden und die Fähigkeit, zwischen Verwaltungsstellen bzw. Verwaltungsebenen und mit VertreterInnen der Zivilgesellschaft, die in regionalen Partnerschaften involviert sind, sowie intermediären Organisationen wie z.B. Regionalmanagements, wirkungsvolle Netzwerkbeziehungen aufzubauen und zu pflegen.

Regionale Akteure ermächtigen, Strukturen bzw. Agenturen zur Integration der Förderprogramme einzurichten: Damit können sie unabhängig davon, ob Politikintegration auf höherer Ebene erzielt werden kann, die bestehenden Spielräume zur Politikintegration nutzen. Der themenübergreifenden und umfassenden Beratung potenzieller Projektträger im ländlichen Raum kommt angesichts des vielfältigen und teilweise verwirrenden Förderangebots eine besonders wichtige Funktion zu. Diese Funktion könnten Anlaufstellen zur „Förderung des ländlichen Raums“ übernehmen. Solche Clearinghäuser wüssten über verschiedenste Förderangebote mit direktem oder indirektem Bezug zum ländlichen Raum Bescheid, hätten einen expliziten und kundenorientierten Beratungsauftrag und wären je nach Gegebenheit auf der Ebene von Regierungspräsidien, Planungsregionen oder Landkreisen angesiedelt. Als Modell sei hier auf das Beispiel der Tiroler Regionalmanagements verwiesen, bei dem sich zentral hierarchisch gesetzte Impulse zur inhaltlichen Koordination von Förderprogrammen mit Gestaltungsspielraum auf Implementierungsebene ergänzen. Ein solches Vorgehen sollte im Hinblick auf eine ländliche Politikintegration in der Förderpolitik auch andernorts verfolgt werden. 
Sektoraler Abgrenzung entgegenwirken - Mehrwert rechtfertigt höheren Aufwand: Sowohl auf EU- als auch auf Bundes- und Landesebene wurden Tendenzen beobachtet, die Beteiligung unterschiedlichster Häuser (oder Generaldirektionen) an einem Fonds auf eine überschaubare Anzahl zu reduzieren. Die derzeitige Interpretation des Monofondsprinzips ist Ausdruck eben dieses Trends, der als starker Mechanismus wirkt, die Förderprogramme zunehmend voneinander zu isolieren. Bei der Suche nach Synergien und an komplexe Problemlagen ländlicher Räume angepassten Lösungen ist die Beteiligung mehrerer Häuser an einem Förderprogramm als sinnvoll zu betrachten. Daher sollte dem Argument, man reduziere lediglich den Verwaltungsaufwand, indem man die Zahl der Partizipierenden reduziere, inhaltsreich und entschlossen entgegengetreten werden.

\section{Politikintegration realistisch betrachten}

Letztlich empfehlen wir all jenen, die einen integrierten Förderansatz verfolgen (möchten), die ländliche Politikintegration als „dauerhaft konfliktreiche Aufgabe“ zu verstehen. Sie lässt sich entweder punktuell und inkremental - also in kleinen Schritten, von denen jeder einzelne aufs neue ausgehandelt werden muss - erfüllen, oder im umfassenden Sinn, wenn es gelingt, die politische Unterstützung der höchsten Entscheidungsebene dafür zu gewinnen. Letztere Option ist dabei jedoch als ein Ideal anzusehen, welchem man in seiner Reinform in der Realität selten begegnen dürfte. 


\section{Quellen}

\section{Literatur}

Amt der Tiroler Landesregierung, Raumordnung-Statistik 2006: Konzept zur Weiterentwicklung der Regionalmanagement-Strukturen in Tirol ab 2007. Innsbruck.

Amt der Tiroler Landesregierung, Raumordnung-Statistik 2007: ZukunftsRaum Tirol. Strategien zur Landesentwicklung. Innsbruck.

Benz, A. (2007): Multilevel Governance. In: Benz, A.; Lütz, S.; Simonis, G. (Hg.): Handbuch Governance - Theoretische Grundlagen und empirische Anwendungsfelder.

Briassoulis, H. (2005): Policy integration for complex environmental problems The example of mediterranean desertification. Ashgate, Burlington.

Elbe, S. (2007): Die Voraussetzungen der erfolgreichen Steuerung integrierter Ansätze durch Förderprogramme. Untersucht am Beispiel des Modellvorhabens Regionen Aktiv (Dissertation). Aachen.

Gießen, L. (2008): Koordination von Förderprogrammen: Regionale Fallstudien vor dem Hintergrund landesspezifischer Rahmenbedingungen. AS4 der Begleitforschung des Modellvorhabens Regionen Aktiv - Land gestaltet Zukunft (2007/08). Göttingen.

Gießen, L., Elbe, S.; Lukesch, R. (2008): Synthese der Teilberichte zum programmatischen Integrationsanspruch und zu Koordinierungsinstrumenten. AS2 der Begleitforschung des Modellvorhabens Regionen Aktiv - Land gestaltet Zukunft (2007/08). Göttingen.

Gießen, L.; Böcher, M.: (2007): Politische Koordination unterschiedlicher Förderprogramme zur Entwicklung des ländlichen Raums - Theoretische Grundlagen zur Mehrebenen- und sektorübergreifenden Koordination. AS1 der Begleitforschung des Modellvorhabens Regionen Aktiv - Land gestaltet Zukunft (2007/08). Göttingen.

Giessen, L.; Krott, M. (2009): Forestry Joining Integrated Programmes? A question of willingness, ability and opportunities. In: Algem. Forst- u. Jagdzeitung (im Erscheinen).

Häußer, O. (1995): Die Staatskanzleien der Länder. Aufgaben, Funktionen, Personal und Organisation unter Berücksichtigung des Aufbaus in den neuen Ländern. Baden-Baden.

Heinelt, H. (1996): Politiknetzwerke und europäische Strukturfondsförderung - Ein Vergleich zwischen EU-Mitgliedstaaten. Leske + Budrich, Opladen.

Hubo, Ch.; Krott, M. (2007): Umsetzungsstrategien für integrative Politikansätze am Beispiel invasiver gebietsfremder Arten. In: Zeitschrift für angewandte Umweltforschung, 18/2, S. 216-226. 
Jänicke, M. (2006): Politikintegration im Mehrebenensystem: das Beispiel der deutschen Umweltpolitik. In: Koch-Baumgarten, S; Rüttgers, P. (Eds.): Pluralismus und Demokratie: Interessenverbände - Länderparlarmentarismus - Föderalismus - Widerstand: Siegfried Mielke zum 65. Geburtstag. Bund Verlag, Frankfurt. public participation. 63-73.

Jänicke, M. und Jörgens, H. (2004): Neue Steuerungskonzepte in der Umweltpolitik. In: Zeitschrift für Umweltpolitik und Umweltrecht, 3/2004, 297-348.

Lafferty, W. M. und Knudsen, J. (2007): The issue of 'balance' and trade-offs in environmental policy integration: How will we know EPI when we see it? EPIGOV Papers No. 11. Ecologic. Berlin.

Lenschow, A. (2002): Environmental Policy Integration - Greening Sectoral Policies in Europe. Earthscan, London.

Lukesch, R.; Gießen, L. (2008): Gute Beispiele der Koordination zwischen Förderprogrammen. AS5 der Begleitforschung des Modellvorhabens Regionen Aktiv Land gestaltet Zukunft (2007/08). Hirzenriegl.

Marks, G. (1993): Structural Policy and Multilevel Governance in the EC. In: Carfuny, A; Rosenthal, G. (Hg.): The State of European Community, 2. Aufl. Lynne Rienner Publishers. S. 391-410.

Meijers, E. (2004): Policy integration: A literature review. In: Stead, D.; Geerlings, $\mathrm{H}$.; Meijers, E. (Hg.): Policy integration in practice. The integration of land use planning, transport and environmental policy-making in Denmark, England and Germany. DUP, Delft. pp. 9-24.

OECD (2006): Das neue Paradigma für den ländlichen Raum: Politik und Governance. Paris.

Persson, A. (2004): Environmental Policy Integration: An Introduction. Diskussionspapier zum Projekt „Policy Integration for Sustainibility (PINTS)“. Stockholm Environment Institute.

Sächsisches Staatsministerium des Inneren (2003): Landesentwicklungsplan Sachsen. Dresden.

Sächsisches Staatsministerium des Inneren (2004): Raumordnung und Landesentwicklung in Sachsen. Dresden. 


\section{Interviewpartner}

- Badge, Frau: ehem. Abwicklungspartnerin Region Altmark, jetzt Amt für Wirtschaftsförderung, Landkreis Stendal (ST).

- Balduhn, Herr: Fondsverwaltung EFRE, Ministerium für Wissenschaft, Wirtschaft und Verkehr Schleswig-Holstein.

- Bayer, Herr Dr.: Fondsverwaltung ELER, Ministerium für Landwirtschaft, Umwelt und ländliche Räume Schleswig-Holstein.

- Burghardt, Frau: Fondsverwaltung ESF, Ministerium für Arbeit und Soziales Baden-Württemberg.

- Debach, Herr: Prüfbehörde der Strukturfonds, bescheinigende Stelle der Landwirtschaftsfonds, Finanzministerium Baden-Württemberg.

- Delbrück, Herr: Referatsleiter Landwirtschaft, Forstwirtschaft und Ländliche Entwicklung, Bundesministerium für Umwelt, Naturschutz und Reaktorsicherheit.

- Derpa, Herr Dr.: Abteilung für EU-Politik, Staatsministerium BadenWürttemberg.

- Elers, Frau: Fondsverwaltung ESF, Ministerium für Justiz, Arbeit und Europa Schleswig-Holstein.

- Ewald, Herr: Pressestelle, Staatskanzlei Schleswig-Holstein.

- Friemel, Frau: ehemalige Abwicklungspartnerin Region Chiemgau.

- Göttler, Herr: Spiegelreferent Wirtschaft, Staatskanzlei Bayern.

- Grieß, Herr: Referat ILE, Sächsisches Staatsministerium für Umwelt und Landwirtschaft, Sachsen.

- Hagen, Herr: Regionalmanagement und Regionale Partnerschaft Region Lübecker Bucht.

- Hausen, Frau: Referentin ESF, Ministerium für Arbeit und Soziales BadenWürttemberg.

- Hauser, Herr Dr.: Prüfbehörde der Strukturfonds, Finanzministerium BadenWürttemberg.

- Herbert, Herr Dr.: Fondsverwaltung ELER/EFF, Ressortkoordination EFRE/ESF am MLU, Ministerium für Landwirtschaft und Umwelt, SachsenAnhalt.

- Jäger, Herr Dr.: Referent für GAK, Bundesministerium für Ernährung, Landwirtschaft und Verbraucherschutz.

- Leicht, Frau: Regionalmanagement Regionen Aktiv, Region Reutlingen, Landkreis Reutlingen (BW).

- Mattner, Herr: Leiter Gemeinsame Verwaltungsbehörde, Staatskanzlei Mecklenburg-Vorpommern.

- Moser, Herr: Fondsverwaltung ESF, Staatsministerium für Arbeit, Sozialordnung, Familie und Frauen Bayern.

- Müller, Herr: Fondsverwaltung EFRE, Staatsministerium für Wirtschaft, Infrastruktur, Verkehr und Technologie Bayern.

- Paetow, Frau: Regionalmanagement Regionen Aktiv und angehendes ILEManagement Region Altmark (SA).

- Pitzke, Herr: Bescheinigende Stelle der Landwirtschaftsfonds, Finanzministerium Bayern.

- Rauter F.: Amt der Tiroler Landesregierung, Innsbruck.

- Reimann, Herr Dr.: Spiegelreferent Landwirtschaft, Staatskanzlei Bayern.

- Reitmann, Herr: Bescheinigende Stelle ELER, Finanzministerium Bayern. 
- Remmelberger, Herr: Landwirt, Vorsitzender AbL Chiemgau, Projektträger, Regionale Partnerschaft Region Chiemgau.

- Reppenhagen, Herr: Abwicklungspartner Region Lübecker Bucht, Landkreis Nordwest-Mecklenburg.

- Ris, Herr Dr.: Fondsverwaltung EFRE, Leiter Referat für Strukturentwicklung ländlicher Raum, Ministerium für Ernährung und ländlichen Raum BadenWürttemberg.

- Rölz, Frau: Referat EU-Haushalts- und Finanzpolitik, Staatskanzlei Bayern.

- Rosner, Herr Dr.: Leiter Referat 21, Koordinierungsstelle Förderpolitik, Staatskanzlei Sachsen-Anhalt.

- Schlotterbeck, Frau: Referentin GAK, Ministerium für Ernährung und ländlichen Raum Baden-Württemberg.

- Stangenberg, Herr: Referat für Öffentlichkeitsarbeit, Staatskanzlei SchleswigHolstein.

- Weible, Frau: Abwicklungspartner Region Reutlingen, Landkreis Reutlingen (BW).

- Wiedauer, Frau: Projektträgerin, Regionale Partnerschaft Chiemgau, ehemaliges Regionalmanagement Region Chiemgau.

- Wohlgschaft, Herr Dr.: Fondsverwaltung ELER, Leitung Referat GAK, Staatsministerium für Landwirtschaft und Forsten Bayern.

- Wonka, Herr: Spiegelreferent Soziales und Arbeit, Staatskanzlei Bayern.

- Zoller, Frau Dr.: Leiterin EU-Abteilung, Staatsministerium Baden-Württemberg.

- Bühner, Herr, Lieter Referat 521 Gemeinschaftsaufgabe (GAK) und EUProgramme zur Entwicklung ländlicher Räume, Bundesministerium für Ernährung, Landwirtschaft und Verbraucherschutz

- Tetsch, Herr, Unterabteilungsleiter im Bundesministerium für Wirtschaft und Arbeit, Unterabteilungsleiter: Unterabt. I C: „Strukturpolitik, Neue Länder, Bürokratieabbau"

- Schreckenberger, Frau, Bundesministerium für Wirtschaft und Technologie Referat E B 1 - Koordinierung der EU-Strukturpolitik 


\section{Curriculum Vitae}

\section{Lukas Giessen}

28.06.1997

09/98-07/02

$10 / 02-11 / 04$

06/04 - date

$09 / 97-10 / 98$

$09 / 98-01 / 99$

03/01 - 08/01

$12 / 02-10 / 04$

09/04

$10 / 04$

$12 / 03-12 / 04$

04/04

$01 / 05$ to $07 / 05$

$03 / 05$

Göttingen, March 2010

\section{Formal and Scientific Education}

'Abitur' - Sophie Hedwig-Gymnasium Diez/Germany (Grade: 2.9)

'Dipl.Ing. (FH) Forest Management and Engineering' - University of Applied Sciences (FH) Goettingen/Germany (Grade: 1.7)

Diploma Thesis: 'Food Preference Study of Ursus americanus During First Application of Supplemental Feeding' (Grade: 1.0)

'M.Sc. Sustainable Forestry and Land Use Management' - University Freiburg/Germany (Grade: 1.3)

Master Thesis: 'MCPFE Expert Level Meetings as a means to integrate the concept of public participation into pan-European decision-making - an evaluative approach' (Grade: 1.7)

Completion of a PhD-Thesis on "Regional Forest Governance" and Research Assistant with the Institute of Forest and Nature Conservation Policy, University of Göttingen including diverse teaching, research project development and research project assignments

\section{Practical Experiences}

Civil Service in the field of youth welfare service - 'Landeswohlfahrtsverband Hessen', Idstein/Germany

Internship in forest management - 'Staatliches Forstamt', Idstein/Germany

Internship in forest management - University of Washington's Pack Experimental Forest, Eatonville WA/USA

Junior research assistance - Institute of Forest Growth, Freiburg/Germany

Participation $-12^{\text {th }}$ World Forestry Congress, Québec/Canada

Independent research study on 'Ecological Impacts of Different Logging Systems' - Halliburton Forest Ltd., ON/Canada

Youth welfare service 'Jugendhilfe Suedniedersachsen', Goettingen/Germany

Youth representation at the $4^{\text {th }}$ session of the UNFF, Geneva/Switzerland

DAAD Carlo Schmid-program fellow - affiliated with the Food and Agriculture Organisation of the United Nations (FAO), Rome/Italy

Assignment: Review study on participatory research as a means to development in Central and Eastern Europe

Youth representation - FAO Committee on Forestry 
Die Arbeit befasst sich mit dem regionalisierten und sektorübergreifenden Steuerungsansatz von Regional Governance und der Einbeziehung der Forstwirtschaft als Politiksektor. Am Beispiel der integrierten ländlichen Entwicklung klärt sie einerseits die Frage nach forstwirtschaftlichen Potentialen in Regional Governance-Initiativen und analysiert andererseits allgemeine politische Kräfte, die Regional Governance bestimmen. Es wird gezeigt, dass im Rahmen von Regional Governance-Initiativen konventionelle und innovative Potentiale für die Forstwirtschaft bestehen. Diese können jedoch aufgrund unterschiedlicher Informationsstände, verschiedener Kapazitäten sowie unterschiedlicher Anreizwirkungen nicht von allen Akteursgruppen gleichermaßen realisiert werden. Die vorgefundenen politischen Determinanten von Regional Governance umfassen die Konkurrenz zwischen Regional Governance-Institutionen und demokratisch legitimierten Institutionen, die Strategie höherer politischer Ebenen zur Erlangung von Einfluss auf Regionalpolitik, sowie die Prägung von Regional Governance durch die Interessen von starken Akteuren und deren Koalitionen. In diesem Zusammenhang wird gezeigt, dass der sektorübergreifende Anspruch von Regional Governance aufgrund sektoraler Interessenlagen sowohl in der Formulierung als auch im regionalen Vollzug nicht erfüllt wird und sich lediglich punktuelle Integrationserfolge auf Projektebene erreichen lassen. Diese Ergebnisse lassen sich durch zweierlei Machtstrategien erklären: Einerseits das Bemühen übergeordneter politischer Ebenen, ihren Einfluss auf Regionalpolitik auszuweiten und andererseits die Strategie von konkurrierenden Politiksektoren, ihren Einflussbereich zu verteidigen bzw. zu Lasten anderer Sektoren auszudehnen.

This study addresses the relation between the cross-sectoral steering approach of Regional Governance and forestry as a policy sector. It examines the potentials for forestry and analyses the political driving forces of Regional Governance, using the example of Integrated Rural Development. The study reveals that Regional Governance initiatives offer both, conventional as well as innovative potentials for forestry. However, these potentials may not be realised by all types of forestry actors due to differences in actors' information on Regional Governance programmes, their capacities and how actors are incentivised by Regional Governance initiatives. The identified political drivers of Regional Governance comprise: the strategy of superior political levels for gaining influence in regional politics and over regional policy; the competition between institutions of Regional Governance and traditional regional government; and the influence of powerful actors and their coalitions' interests on Regional Governance initiatives. In this vain, the study shows that Regional Governance does not achieve its cross-sectoral claim due to prevailing sectoral interests both, in the formulation and during the regional implementation. Cross-sectoral integration was only achieved in selected cases at the project level. The study concludes that these results may be explained by power strategies of superior political levels, trying to gain influence at regional levels as well as over regional policy and by power strategies of policy sectors and sub-systems, attempting to expand their influence into the domain of other policy sectors or resisting such efforts respectively. 